UNIVERSIDADE DE SÃO PAULO

FACULDADE DE FILOSOFIA, LETRAS E CIÊNCIAS HUMANAS

DEPARTAMENTO DE SOCIOLOGIA

PROGRAMA DE PÓS-GRADUAÇÃO EM SOCIOLOGIA

\title{
Realismo e redes: dilemas metodológicos na obra de Anthony Giddens
}

Fábio Rodrigues Ribeiro da Silva

Tese apresentada ao Programa de PósGraduação em Sociologia, do Departamento de Sociologia da Faculdade de Filosofia, Letras e Ciências Humanas da Universidade de São Paulo, para obtenção do título de Doutor em Sociologia.

Orientador: Prof. Dr. José Jeremias de Oliveira Filho

São Paulo 


\section{Sumário}

Resumo

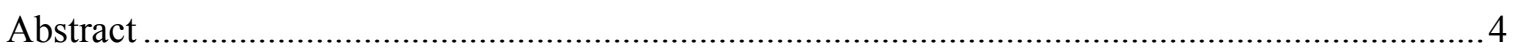

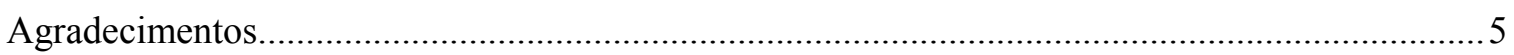

1. Introdução: Dilemas metodológicos na obra de Anthony Giddens ............................................

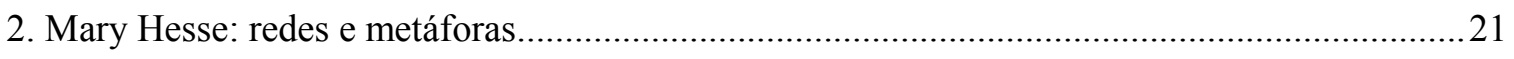

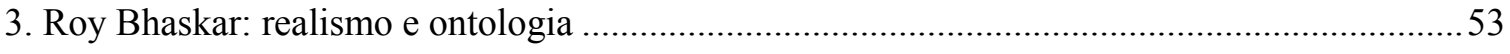

4. Anthony Giddens entre Hesse e Bhaskar - um projeto de reconstrução...................................... 85

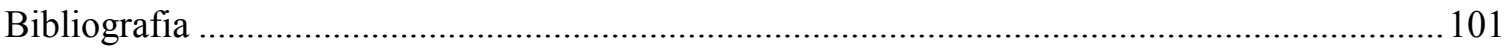

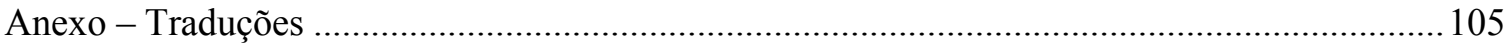

1. Gregor McLennan - Teoria crítica ou positiva? Um comentário sobre o estatuto da teoria

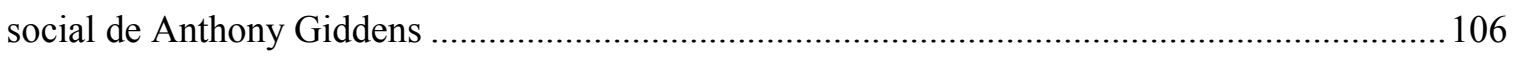

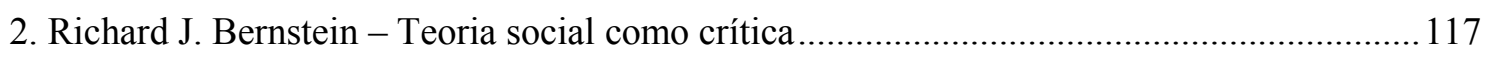

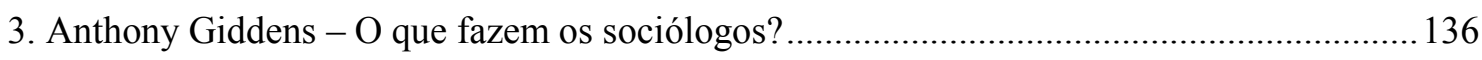

4. Ira J. Cohen - O estatuto da teoria da estruturação: uma resposta a McLennan .....................159

5. Gregor McLennan - Teoria da estruturação e filosofia pós-empirista: uma réplica ...............178

6. Zygmunt Bauman - Hermenêutica e teoria social moderna ................................................... 188

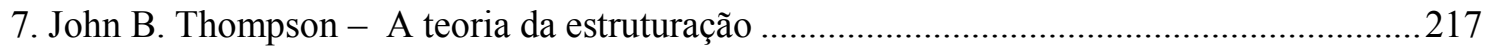

8. Gianfranco Poggi - Anthony Giddens e "os clássicos" ...........................................................243

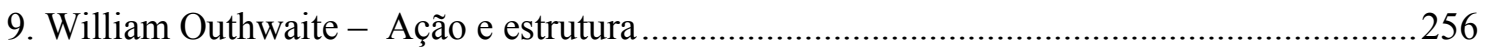

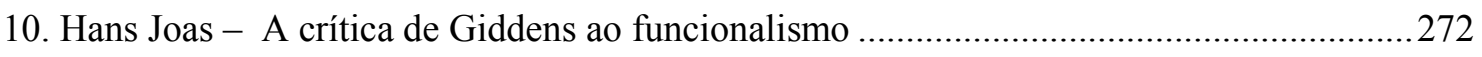

11. Edward Soja - Espacializações: uma crítica da versão giddensiana ...................................289

12. Richard Kilminster - A teoria da estruturação como uma visão de mundo............................311

13. Anthony Giddens - Teoria da estruturação: passado, presente e futuro ...............................359

14. Christopher G. A. Bryant - Sociologia sem filosofia? O caso da teoria da estruturação de Giddens

15. Colin Hay, Martin O’Brien \& Sue Penna - Giddens, modernidade e identidade do eu: o

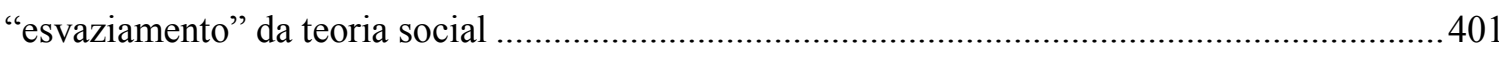

16. Tony Spybey - A constituição da sociedade global ...........................................................434 


\section{Resumo}

Esta obra aponta questões de ordem metodológica e epistemológica na teoria da estruturação de Anthony Giddens, problemas reconhecidos e debatidos por vários de seus comentadores. Seguindo pistas encontradas nos próprios textos de Giddens, ela analisa com maior detalhe alguns livros de Mary Hesse e Roy Bhaskar, em busca de elementos que ajudem numa reconstrução metodológica da teoria de Giddens. Finalmente, ela argumenta em favor de uma maior atenção ao modelo de redes de Hesse, como uma ferramenta muito mais fértil para a análise de Giddens do que o realismo crítico de Bhaskar, para tentarmos resolver os dilemas que Giddens enfrenta. Como anexo, temos traduções de vários textos dos comentaristas mais importantes de Giddens, e também dois artigos do próprio, inéditos em português.

Palavras-chave: Anthony Giddens; Mary Hesse; Roy Bhaskar; metodologia das ciências sociais; epistemologia; ontologia; teoria da estruturação. 


\begin{abstract}
This work raises methodological and epistemological questions regarding Anthony Giddens' theory of structuration, issues that have been acknowledged and debated by several of his critics. Following clues found in Giddens' own texts, it analyses more deeply some works by Mary Hesse and Roy Bhaskar, searching for elements that would help with a methodological reconstruction of Giddens' theory. Finally, it argues for greater attention towards Hesse's network model, as a much more fruitful tool for analyzing Giddens than Bhaskar's critical realism, in order to attempt to solve the dilemmas that Giddens faces. Also included are translations of several articles written by Giddens' most important critics, and two papers by Giddens himself, previously unavailable in Portuguese.
\end{abstract}

Keywords: Anthony Giddens; Mary Hesse; Roy Bhaskar; methodology of the social sciences; epistemology; ontology; theory of structuration. 


\section{Agradecimentos}

Gostaria de agradecer a meu orientador, professor doutor José Jeremias de Oliveira Filho, por seu apoio irrestrito e suas ideias que muito me ajudaram, especialmente nos momentos mais difíceis da produção deste trabalho.

Agradeço aos professores doutores Mário Antônio Eufrasio e Alexandre Braga Massella por seus comentários valiosos durante meu exame de qualificação. Reservo uma gratidão especial ao professor Eufrasio, por sua ajuda e amizade durante todo este período.

Agradeço também ao CNPq pelo apoio financeiro durante parte deste trabalho.

A meus pais, Eliana e Carlos, que me acompanharam o tempo todo, não sem uma certa apreensão, fica uma gratidão maior do que palavras podem expressar.

E o mesmo vale para minha esposa, Daniela. Sem ela, este trabalho não teria sequer começado, quanto mais terminado.

Christy Pato e Daniel Fanta compartilharam comigo as agruras da pósgraduação, e sem eles este caminho teria sido bem menos agradável. Obrigado, amigos.

Agradeço a Sônia Cristina Matsuyama, pelo carinho e cuidado, em todos os momentos deste trabalho.

E registro aqui minha gratidão também a meus queridos amigos de além-mar, Kat Devlin, Dan Stansens, Carrie Ingalls e Kevin Hutchins, que tanto me ajudaram não só pela companhia, mas também esclarecendo dúvidas de tradução e me ajudando a localizar itens mais obscuros da bibliografia. 
Finalmente, gostaria de agradecer a Fábio Villares, Adalton Oliveira e aos outros colegas do Instituto de Estudos Econômicos e Internacionais, pelo tempo valioso que passamos juntos, e também por seu apoio.

Eu dedico este trabalho à memória do professor Gilberto Dupas. 


\section{Introdução: Dilemas metodológicos na obra de Anthony}

\section{Giddens}

I

As ciências sociais não estão livres de modismos. Esta é uma questão menos simples do que parece: de um extremo ao outro, seria talvez possível escrever uma história da filosofia da ciência no século XX centrada neste tema. Em uma ponta, a rigidez positivista afirmando que não há espaço algum para o contexto interpretativo na ciência, e todos os critérios de formulação de teorias e de decisão entre teorias rivais considerados completamente livres de influências contextuais e de quaisquer considerações não racionais - a ciência nos leva à verdade, ou, ao menos, à melhor aproximação possível dela. No outro lado, a consideração oposta, de que ideias como "racionalidade" e "verdade" são inatingíveis, ou, pior, máscaras ocultando o jogo sujo por trás da atividade científica. Tudo o que interessa seriam considerações estratégicas, instituições e pessoas manipulando umas às outras com objetivos de curto ou longo prazo - a ciência completamente à mercê das marolas do contexto social, econômico, político, envolta numa trama inescapável de poder e ideologia.

A resposta, como costuma ser o caso, está em algum lugar no meio. Não precisamos ignorar as dimensões estratégica e social envoltas na ciência e nos cientistas - elas certamente existem e são importantes. Mas também não é particularmente necessário aderir à noção de que, por causa disto, a pesquisa científica não pode (nem deve) proceder de forma racional em busca de algo que possamos chamar de "verdade", ou "conhecimento". 
Talvez esta não seja uma resposta totalmente satisfatória (eu nem sequer toquei no velho problema das supostas diferenças e incompatibilidades entre as ciências sociais e naturais, que teima em não desaparecer), mas serve para reforçar a afirmação inicial. Modismos estão presentes nas ciências sociais, como em quase todas as áreas da atividade humana. E isto para dizer: a obra de Anthony Giddens esteve em moda durante os anos 90. Hoje isto não ocorre mais, e pouco se fala deste autor. Há motivos para isto. Alguns estão ligados a problemas e deficiências em seu trabalho, mas outros me parecem mais prosaicos, todavia não menos importantes.

Giddens foi, entre outras coisas, um dos principais teóricos da globalização. “Globalização" também foi um dos termos mais em voga nos anos $1990^{1}$. Depois da queda do bloco comunista, o termo, certamente bastante complexo, recebeu uma conotação esperançosa (para alguns), significando o triunfo do capitalismo e da modernidade, que se espalhariam inevitavelmente para todos os cantos do planeta. Giddens certamente não defende uma noção tão ingênua, mas isso não impediu que ele fosse levado pela onda da globalização - e seus escritos se tornaram mais conhecidos por isto, sem dúvida alguma. O segundo fator que alçou a popularidade de Giddens foi, obviamente, sua teoria da "terceira via" na política, entre o capitalismo e o socialismo. Adotada explicitamente por Tony Blair na Inglaterra, e não tão explicitamente por governos tão díspares quanto o de Bill Clinton nos EUA, Gerhard Schröder na Alemanha, e mesmo Fernando Henrique Cardoso no Brasil, num primeiro momento ela pareceu realmente indicar um caminho possível para uma nova socialdemocracia no mundo ocidental. A proximidade de Giddens a Tony Blair aumentou sua visibilidade (assim como o cargo de diretor da famosa London School of Economics, onde hoje Giddens é professor emérito, que ele ocupou durante boa parte dos anos 90).

\footnotetext{
${ }^{1}$ Depois da crise financeira mundial de 2008-2009, o termo voltou a aparecer com certa frequência, mas numa conotação quase sempre mais negativa.
} 
E, como hoje sabemos, nada disto durou muito. Politicamente, a terceira via sofreu um baque bastante significativo com os atentados de 11 de setembro, que diminuíram consideravelmente a euforia com a globalização em todos os cantos do mundo. Os anos que se seguiram, com as guerras no Afeganistão e no Iraque, e o ressurgimento da direita em grande parte da Europa $^{2}$ (para não falar do governo de George W. Bush nos EUA), aliados ao discurso cada vez mais triunfalista do neoliberalismo econômico, colocaram a terceira via (e praticamente todo o pensamento de esquerda) na defensiva. Giddens, neste meio tempo, tem escrito mais sobre questões europeias e britânicas, e aparentemente se retirou do palco global ${ }^{3}$. Isto se reflete em sua influência no Brasil, onde seus livros não são traduzidos desde 2001 (com exceção de suas obras didáticas), e seu nome raramente é mencionado em debates públicos.

Estes são os principais fatores extra-acadêmicos, por assim dizer, do declínio de Giddens enquanto intelectual público. Mas também há fatores mais específicos. O mais óbvio é que ele simplesmente não publica mais obras teóricas de sociologia desde 1994. Por mais importante que estas obras sejam, depois da torrente inicial de trabalhos secundários de análise, é de se esperar que o interesse diminua. Isto, de qualquer forma, não é de preocupar, pois a história da sociologia e da teoria social está repleta de eventos cíclicos, onde autores crescem e mínguam em diferentes períodos. É bastante possível que Giddens apenas esteja em sua primeira fase minguante, depois de um crescimento quase ininterrupto desde o início dos anos 1970.

\footnotetext{
${ }^{2}$ A Grã-Bretanha realizou eleições gerais em maio de 2010, e o Partido Trabalhista foi derrotado depois de mais de uma década no poder. É interessante notar que a retórica da campanha desse partido passou longe dos principais temas da terceira via.

${ }^{3}$ Entretanto, num dos artigos mais recentes de Giddens [2008] que consegui localizar, para o jornal inglês The Guardian, ele se aproveita da atual crise financeira global para reafirmar os valores da terceira via. Seu último livro trata de problemas do meio ambiente [Giddens, 2009], o que poderá ajudá-lo a voltar a ter uma exibição maior globalmente.
} 
Ou talvez existam motivos mais profundos. Como tentei argumentar em minha dissertação de mestrado [Ribeiro da Silva, 2004], apesar da obra de Giddens ser obviamente instigante e relevante, há certos problemas teóricos e metodológicos que, em minha opinião, limitam seu apelo e sua aplicabilidade nas próprias ciências sociais. E, infelizmente, o fato de Giddens nunca mais ter abordado tais questões desde meados dos anos 1990 significa que esses problemas continuam em aberto.

E quais são estes problemas? Um dos principais, creio eu, é o do estatuto da teoria da estruturação. Giddens, apesar de sempre exaltar a relação íntima que deve existir entre as ciências sociais e a filosofia, tende a evitar discussões epistemológicas mais aprofundadas. Uma interpretação não muito caridosa desta situação diria que Giddens não se acanha em lidar com problemas filosóficos quando se sente bastante seguro de sua posição, mas que quando se depara com questões mais espinhosas, ele as evita com a justificação de que no fundo é um sociólogo, e não um filósofo. De qualquer forma, o problema do estatuto existe. Em termos breves: em algum momento de sua elaboração, Giddens passou a afirmar que a teoria da estruturação é uma ontologia social, e não propriamente uma teoria. Enquanto ontologia, seus conceitos não teriam mais poder explicativo, e serviriam apenas como "dispositivos sensibilizadores" para o pesquisador social. Mas isto sempre me pareceu estranho. O objetivo declarado de Giddens é evitar que sua teoria da estruturação se torne uma "grande teoria" nos moldes parsonianos (risco que ele identifica em Habermas) - ou seja, um amontoado de conceitos que pretendem explicar e determinar toda situação possível no mundo social.

É evidente que minha sentença anterior é hiperbólica, mas ela simboliza os temores de Giddens. Ele carrega toda a bagagem da filosofia da ciência pós-positivista, todos os debates sobre generalizações, leis, explicações, hermenêutica, etc. Neste contexto, ele certamente não pode elaborar uma teoria rígida e determinista como a de 
Parsons $^{4}$, nem ter a ilusão de que a relação entre teoria e o mundo é simples e nãoproblemática.

O que Giddens faz, então, é pender para o polo oposto, o que de certa forma é surpreendente num autor que quase sempre, quando se depara com duas alternativas, busca o caminho do meio. Durante a passagem de Novas regras do método sociológico [Giddens, 1993, publicado originalmente em 1976] e Problemas centrais na teoria social [Giddens, 1979] para A constituição da sociedade [Giddens, 1984], a teoria da estruturação passa a ser chamada de "ontologia". Com isso, Giddens pretende escapar de qualquer determinismo: os conceitos de sua teoria servem apenas para orientar pesquisadores, e ajudá-los a entender (num sentido fraco) as práticas que eles encontram e descrevem, mas a realidade não é explicada, nem determinada, pelos conceitos da teoria. A intenção é nobre, pois ninguém duvida que uma teoria que engesse a realidade com seus conceitos seja perniciosa. O problema, em minha opinião, é que o tiro de Giddens sai pela culatra. Sua ânsia em evitar os problemas que identifica nas "grandes teorias" faz com que sua teoria se torne "pequena". Fica difícil ver por que qualquer sociólogo ou cientista social utilizaria a teoria da estruturação em seu trabalho, já que seus conceitos e relações, numerosos e complexos, acabariam, para usar uma metáfora econômica, dando muito pouco retorno para o investimento.

O efeito que isto tem na influência da obra de Giddens na sociologia é prejudicial em dois sentidos. Ou o sociólogo simplesmente ignora as invectivas ontológicas de Giddens e continua a tratar a teoria da estruturação como uma teoria "comum", ou ele se depara com uma ontologia tão ampla e complexa que acaba auxiliando muito pouco seu trabalho, pois ele não pode utilizá-la para responder as

\footnotetext{
${ }^{4}$ Isto, é claro, se concordarmos que a teoria parsoniana é tão rígida e determinista como Giddens a apresenta. Não poderei me dedicar a esta questão aqui, mas seria de bom tom não aceitarmos tão prontamente a interpretação de Giddens - que adotarei aqui apenas para seguir sua própria argumentação.
} 
questões que sua pesquisa suscita. Isto leva a uma situação insólita, onde o próprio Giddens admite que os usos mais interessantes que viu da teoria da estruturação são em trabalhos que não a utilizam como um todo ${ }^{5}$.

Este acaba sendo um destino bastante desolador para uma teoria tão promissora e interessante. Acredito que este seja um dos principais motivos para que a teoria de Giddens não tenha alimentado tantos desenvolvimentos quanto se poderia esperar (uma comparação apenas superficial com a enxurrada de trabalhos influenciados por Foucault, Elias, Bourdieu e Habermas, por exemplo, mostra que este é o caso). E acredito também que boa parte do problema aqui é causado pela falta de elaboração metodológica nesta transição de teoria para ontologia. Giddens nunca se importou em analisar as consequências que sua mudança causa neste nível, e normalmente se acanha em expor suas ideias a este respeito, por isso é bastante difícil traçar seu caminho.

O que pretendo fazer neste ensaio é seguir uma pista revelada pelo próprio Giddens, e reforçada por alguns comentadores. Em um trabalho do início dos anos 1970, discutindo o positivismo, Giddens revelou bastante simpatia em relação ao modelo de redes proposto por Mary Hesse (inspirada em Quine). A citação é curta, e aparece em um texto mais periférico, mas está lá. Logo depois, porém, veio a transição para a ontologia. Uma hipótese bastante plausível é que Giddens tenha sido influenciado pela obra de Roy Bhaskar, fundador do que veio a ser chamado de "realismo crítico", que enfatiza bastante preocupações ontológicas. Giddens, até onde eu sei, quase nunca cita Bhaskar diretamente, mas é certo que ele teve algum contato com sua obra.

Esta estratégia me atrai porque permitirá que eu analise em certos detalhes as ideias destes dois autores (Hesse e Bhaskar) que não são muito conhecidos nem

\footnotetext{
${ }^{5}$ Ver Giddens [1990:310-315].
} 
estudados no Brasil (Bhaskar tem seguidores, mas Hesse é praticamente desconhecida fora do círculo de especialistas em filosofia da ciência). Depois deste estudo, pretendo tentar localizar as possíveis influências que Giddens possa ter retirado deles, e, com alguma sorte, tirar conclusões sobre esta "transição ontológica" tão estranha e com consequências tão interessantes na obra do sociólogo inglês. Talvez, assim, eu possa fazer uma contribuição pertinente ao estudo deste autor.

II

Há uma segunda contribuição que eu gostaria de fazer com este trabalho. Giddens, no Brasil, parece ser um autor muito lido mas pouco compreendido. Boa parte de sua obra foi publicada aqui, mas nunca de forma sistemática. Faltam, por exemplo, dois livros fundamentais (Problemas centrais na teoria social [Giddens, 1979] e Uma crítica contemporânea do materialismo histórico [Giddens, 1995, publicado originalmente em 1981]), e muitos de seus artigos mais antigos e importantes. Giddens passou por várias editoras, e seus tradutores nunca se esforçaram em sistematizar a terminologia que ele utiliza. Isto é um problema sério, pois Giddens cria muitos conceitos, e reformula vários outros. Sem um trabalho metódico, é muito fácil cairmos em erros perigosos de tradução.

Assim, minha proposta é sugerir uma terminologia apropriada de forma um pouco indireta, e também apresentar ao leitor brasileiro um material pouco conhecido. Giddens, durante os anos 1980 e 1990, foi o foco de inúmeros artigos e livros, e quase nada destas obras foi vertido para o português. Apresento aqui, então, uma seleção ampla e significativa dos comentaristas da teoria de Anthony Giddens. 
Os textos abrangem praticamente todos os tópicos relevantes da obra sociológica de Giddens (mas quase não tocam sua obra de teor mais abertamente político a partir de meados dos anos 1990). Escolhi alguns autores conhecidos e consagrados, mas também há nomes certamente desconhecidos do público brasileiro, comentaristas mais "puros", por assim dizer, da teoria da estruturação. A maior parte dos textos é generosa em sua avaliação de Giddens, mas sem deixar de apontar problemas, contradições e ambiguidades em sua obra. Os textos são apresentados em ordem cronológica.

O primeiro texto também é a primeira parte do melhor debate sobre questões metateóricas na obra de Giddens. Os participantes são Gregor McLennan [1997a; 1997b], atualmente professor da Universidade de Bristol, e Ira J. Cohen [1997], professor da Universidade Rutgers e um dos autores que mais escreveu sobre Giddens (seu livro Teoria da estruturação [Cohen, 1989] ainda é a obra mais completa existente sobre a teoria de Giddens). McLennan, em seu primeiro artigo, publicado originalmente em 1984, tenta extrair um posicionamento epistemológico da obra de Giddens, que, segundo ele, oscila entre o realismo e a desconstrução. A partir desta (falta de) base, ele questiona o papel da crítica na teoria da estruturação, e aponta que a teoria de Giddens parece desconjuntada, em termos teóricos - suas análises mais empíricas não teriam uma conexão clara com seus trabalhos teóricos.

Passamos para um artigo de Richard Bernstein [1989, publicado originalmente em 1985], grande pensador infelizmente ainda pouco conhecido no Brasil, que analisa, assim como McLennan, mas de forma mais profunda, a relação não muito confortável entre a teoria da estruturação e a crítica. Giddens proclama de forma inequívoca que a teoria da estruturação e a crítica estão inextricavelmente ligadas - mas, segundo Bernstein, fracassa ao tentar explicar o que isso significa, confundindo o impacto prático das ciências sociais com seu impacto crítico. Bernstein aprecia várias das ideias 
de Giddens, mas também se incomoda, de modo não muito diferente daquele que comentei na seção anterior, com as evasões deste em relação a alguns temas mais espinhosos.

Apresento então o primeiro de dois textos do próprio Anthony Giddens, inéditos no Brasil. “O que fazem os sociólogos?” [1987:1-21] foi uma palestra inaugural realizada na Universidade de Cambridge em 1986, e é a melhor introdução que conheço ao pensamento teórico de Giddens como um todo. De forma bastante lúcida e acessível, Giddens discorre sobre várias questões bastante relevantes, desde o estatuto da sociologia enquanto ciência até seu impacto prático, passando por problemas da modernidade, do senso comum e do conhecimento mútuo, da relação da sociologia com o público leigo, a influência de pensadores como Goffman e Garfinkel, e assim por diante. De modo geral, é um pequeno artigo bastante interessante.

Voltando ao debate iniciado por McLennan no primeiro artigo, temos agora a resposta de Ira Cohen [1997, publicado originalmente em 1986], onde ele tenta refutar as críticas de McLennan no nível da epistemologia, da crítica e da teoria. Assim, segundo ele, McLennan estaria caindo numa fantasia objetivista ao pedir coerência entre os diferentes módulos da teoria da estruturação. Cohen também argumenta que a teoria da estruturação estaria firmemente integrada, em termos filosóficos, no campo da filosofia da ciência pós-empirista (mas sem maiores especificações), e acaba reiterando a visão de Giddens sobre o papel crítico da teoria social.

Por fim, em sua curta réplica, McLennan [1997, publicado originalmente em 1988] afirma que a resposta de Cohen, ainda que interessante, não consegue abarcar o essencial de sua crítica - embora reconheça que possa haver valor na tentativa de Giddens de trilhar o caminho do meio entre epistemologia e desconstrução. 
Zygmunt Bauman [1989] é um sociólogo muito conhecido no Brasil. Estudando a relação entre a teoria da estruturação e a hermenêutica, ele percebe uma relação mais íntima do que Giddens gostaria de sua teoria com a de Parsons, e também nota suas semelhanças com as obras de Norbert Elias (que Giddens conheceu pessoalmente nos anos 1970) - mas conclui que a sociologia da figuração de Elias é superior à teoria da estruturação, por enfatizar mais as relações sociais do que a dualidade entre ação e estrutura com a qual Giddens se ocupa. Ainda assim, Bauman (e sua obra é testemunho disto) é bastante atraído pelas reflexões de Giddens sobre a modernidade.

O sociólogo inglês John B. Thompson [1989] destacou-se por seus estudos sobre mídia, mas também publicou obras interessantes sobre teoria social. E debruçou-se sobre a obra de Giddens, editando o livro de onde retirei este e os artigos de Bernstein e Bauman. Seu texto é uma avaliação mais geral dos temas tratados pela teoria da estruturação, mas ele enfoca especialmente o conceito de "estrutura", notando as mudanças pelas quais ele passou durante a obra de Giddens, e também apontando problemas e dificuldades, especialmente em relação à falta de clareza quanto ao uso que Giddens faz do conceito de "regra" (lembremos que, para Giddens, a estrutura é em seu nível mais básico um "conjunto de regras e recursos”). Para Thompson, Giddens não se afastou o suficiente do modelo linguístico em sua elaboração de "estrutura", nem levou em conta todas as implicações da coerção estrutural em seu esquema, apesar de suas tentativas em A constituição da sociedade.

Gianfranco Poggi [1990], sociólogo italiano conhecido por suas obras sobre os clássicos da sociologia, analisa exatamente este aspecto da obra de Giddens. Afinal, o que primeiro projetou Giddens no cenário internacional não foi sua teoria social, e sim sua renovação do tratamento dos "pais fundadores" da sociologia: Marx, Durkheim e Weber. Os textos de Giddens sobre estes autores até hoje são bibliografia básica em 
grande parte dos cursos de introdução à sociologia no mundo. Poggi também discorre sobre a crítica de Giddens a estes autores, notando especialmente que, apesar de Giddens ser normalmente associado com a redescoberta de Durkheim no mundo angloamericano, sua análise acaba reduzindo a importância do mestre francês de forma indevida, em comparação com Marx e Weber.

Em seu artigo "Ação e estrutura", o renomado sociólogo William Outhwaite [1990] mira no coração da teoria da estruturação. Seu relato é uma descrição bastante lúcida e clara do tratamento que Giddens dá a estes conceitos. Ele também rebate dois tipos de críticas que Giddens recebeu: a de Thompson, no artigo mencionado acima, e a de Margaret Archer, baseada em sua teoria da morfogênese. Finalmente, Outhwaite é um dos primeiros teóricos a apontar para a ligação de Giddens com Bhaskar que examinarei melhor posteriormente.

O alemão Hans Joas [1990], por sua vez, toca em outro tema caro a Giddens: a crítica ao funcionalismo (lembremos que o próprio Giddens sintetizou a teoria da estruturação com a expressão "um manifesto antifuncionalista"). Joas aponta que, apesar de Giddens considerar a batalha contra o funcionalismo completamente vencida, não foi isso o que o desenvolvimento posterior da teoria social mostrou. Assim, ele aponta o ressurgimento do funcionalismo nas teorias de Niklas Luhmann, Jeffrey Alexander e, de forma um pouco mais controversa, Jürgen Habermas, e tenta analisar, de modo interessante, se as críticas de Giddens ao funcionalismo "clássico" ainda valeriam contra estas vertentes do novo funcionalismo.

O americano Edward Soja [1997] é um dos teóricos da geografia mais conhecidos no mundo, especialmente por seus trabalhos relacionados à pósmodernidade. Em seu texto sobre Giddens (na verdade um capítulo de seu livro de 
1990, Geografias pós-modernas), Soja naturalmente aborda o tratamento que os conceitos de "espaço" e "tempo" recebem na teoria da estruturação. Apesar da intenção declarada de Giddens de incluir estes conceitos no centro da teoria social, Soja afirma que, como a maior parte dos cientistas sociais, Giddens comete o erro de menosprezar a dimensão espacial e sobrevalorizar a temporal. Ainda assim, ele reconhece avanços no tratamento que Giddens dá ao urbanismo, mas conclui que Giddens fica preso demais ao edifício modernista da ciência, que precisa ser desconstruído - e mostra como a ontologia de Giddens pode ser estendida para dar conta das questões espaciais que preocupam Soja.

Richard Kilminster [1991], sociólogo inglês especializado em teoria social e hoje editor da versão em inglês das obras completas de Norbert Elias, escreveu o texto mais longo desta coletânea, analisando a teoria da estruturação como uma "visão de mundo". A partir daí, ele nos leva a interessantes digressões sobre a relação da sociologia com a pesquisa empírica e a filosofia, a influência de Habermas, Elias e Gadamer sobre Giddens, e o caráter programático (ou não) da teoria da estruturação, finalmente acusando Giddens de esvaziar o conteúdo das teorias rivais que aborda em suas obras.

O segundo artigo de Giddens desta coletânea, “Teoria da estruturação: passado, presente e futuro" [Giddens, 1991], tem caráter menos introdutório mas é uma excelente autoavaliação de Giddens sobre seu projeto de modo geral. Este texto também contém a declaração mais explícita de Giddens sobre sua transição ontológica, o que lhe dá relevância especial, além de discussões metodológicas importantes e raras, ainda que, em minha opinião, insuficientes. 
Christopher Bryant [1997, publicado originalmente em 1992] é outro dos principais defensores de Giddens, e coeditor da coleção Critical Assessments, da editora Routledge, dedicada a ele. No texto que escolhi, ele trata de um tema caro aos metodólogos das ciências sociais: a relação entre sociologia e filosofia. Bryant aceita sem questionar a proposição de Giddens de que a teoria da estruturação deve ser entendida como uma ontologia, mas ainda assim aponta que o fato de Giddens não ter dedicado muita atenção a temas epistemológicos e normativos enfraquece sua posição de modo geral. Mas, especialmente em relação a temas normativos, Bryant acredita que as obras de Giddens voltadas à discussão da modernidade possam preencher esta lacuna (embora seu texto tenha sido escrito antes da guinada política na obra de Giddens).

Os sociólogos ingleses Martin O’Brien, Sue Penna e Colin Hay [1997, publicado originalmente em 1994] escrevem a seis mãos um texto em que discutem as ideias posteriores de Giddens sobre modernidade, autoidentidade e reflexividade. O artigo é uma exposição útil deste período da obra de Giddens, que tende a ser a parte mais conhecida no Brasil. Assim, ele passa por conceitos importantes como a "política da vida", a análise institucional da modernidade, experiência, a "relação pura", e assim por diante. Mas, segundo os autores, apesar de indicar vários caminhos possíveis, Giddens não consegue fornecer as ferramentas necessárias para resolver o problema da conexão entre análises de micropráticas e macroestruturas - ainda que eu acredite que vários pontos de sua crítica a Giddens sejam equivocados.

Encerro a coletânea com um artigo de Tony Spybey [2001], também um sociólogo inglês, que se especializou em questões de sociologia política e globalização. E é sobre este último tópico que discorre seu artigo, desde as primeiras indicações sobre o tema ainda na teoria social de Giddens aos estudos mais diretamente ligados à globalização nos anos 1990. O texto é útil por conter análises sobre a sociologia mais 
política de Giddens, incluindo uma apreciação inicial do projeto da Terceira Via, e das palestras que Giddens realizou sobre o "mundo em fuga", que são o ponto de partida para suas reflexões mais recentes.

Como se pode ver, esta coletânea de artigos, de modo geral, me parece ser uma contribuição bastante relevante para o público brasileiro. Textos escritos no calor dos debates, levantando questões sobre praticamente todos os aspectos importantes da obra de Giddens, e que dificilmente seriam publicados no Brasil de outra forma. E, como no decorrer destes textos praticamente todos os conceitos de Giddens são analisados, ou, ao menos, mencionados, eles serão úteis para me ajudar no trabalho de estabelecimento da terminologia apropriada ${ }^{6}$.

\footnotetext{
${ }^{6}$ Isto também significa que, quando o próprio Giddens é citado pelos comentadores, eu não utilizo as traduções já existentes, escolhendo em vez disso retraduzir todas as citações.
} 


\section{Mary Hesse: redes e metáforas}

I

Antes de iniciar a discussão sobre as obras de Mary Hesse e Roy Bhaskar, é preciso esclarecer um ponto. Meu objetivo aqui não é realizar uma análise exaustiva de sua obra completa, nem de seus comentadores, e sim algo muito mais humilde, por assim dizer: o que me interessa é utilizar estes autores como instrumental de reconstrução (cf. Oliveira Filho [1976]) para o estudo dos dilemas metodológicos de Anthony Giddens. Tendo isto em vista, meu trabalho se concentrará nos livros de Hesse e Bhaskar que poderiam ter sido lidos por Giddens enquanto este elaborava a teoria da estruturação, e não sua obra posterior ${ }^{7}$. Isto também significa que eu ignorei as alterações presentes nas reedições dos livros de Bhaskar. A ideia, então, é descrever o argumento central de Hesse e Bhaskar no período de 1974 a 1981, em que Giddens desenvolveu a teoria da estruturação ${ }^{8}$.

Como eu sugeri no capítulo anterior, a possível influência destes autores é em grande parte indireta. Bhaskar é citado diretamente por Giddens apenas duas vezes [Giddens, 1982:14; 1984:83n68]. A primeira citação, numa conferência cujo texto foi publicado numa coletânea de artigos um tanto obscura em sua bibliografia, reconhece semelhanças ("independentes") em seus projetos, mas a segunda, em sua obra mais importante, se refere apenas a um conceito bastante marginal para ambos os autores ("relações de posição-prática"). Hesse é abordada de forma um pouco mais abrangente,

\footnotetext{
${ }_{8}^{7}$ Com uma exceção no caso de Hesse, onde incluo sua última resposta a Habermas, de 1995.

${ }^{8}$ Uma consequência desta abordagem é que, como não é meu objetivo abordar a fortuna crítica desses autores, eu não reivindico correção, muito menos originalidade, para meus próprios comentários críticos que ficarão evidentes no decorrer do trabalho. É bastante possível que meus argumentos já tenham sido feitos por outros autores, ou que tenham sido rebatidos. Mas, mais uma vez, minha posição pessoal é secundária - meu propósito sendo primariamente descritivo.
} 
e tratando de sua concepção central da teoria de redes [Giddens, 1977:75-80] entretanto, isto ocorre apenas num artigo, ainda que importante, paralelo aos principais livros teóricos de Giddens, onde ela não é mencionada (nem seus conceitos). Ou seja, as pistas são poucas e fracas, mas acredito ser possível extrair daqui argumentos que permitirão que entendamos melhor os problemas (e possíveis soluções) enfrentados por Giddens em seu caminho nos anos 1970 e 1980.

Mary Hesse, nascida em 1924 em Sussex, na Inglaterra, passou quase toda sua carreira acadêmica na universidade de Cambridge, onde é professora emérita de filosofia da ciência. Sua formação ocorreu nas ciências exatas - é bacharel em matemática, e recebeu seu título de doutora com uma tese sobre microscopia eletrônica. O período de sua carreira que analisarei aqui é particularmente interessante, porque ele contém sua principal contribuição à filosofia da ciência, o livro The Structure of Scientific Inference [A estrutura da inferência científica; Hesse, 1974, doravante SSI], e também o início de sua passagem para temas de ciências humanas em Revolutions and Reconstructions in the Philosophy of Science [Revoluções e reconstruções na filosofia da ciência; Hesse, 1980, doravante RRPS]. Seus textos dos anos 1990 e 2000 enfocam, em sua maioria, a relação entre ciência e religião.

Neste capítulo, eu descreverei a argumentação básica dos dois livros mencionados acima, e também reservarei um espaço para falar em mais detalhes dos textos de Hesse sobre Jürgen Habermas, que considero um bom exemplo de como uma filósofa treinada numa tradição específica (no caso de Hesse, a tradição empirista/analítica inglesa) aborda, de forma cautelosa e generosa, uma escola completamente diferente. 
Hesse está diretamente dentro do caldeirão da filosofia da ciência pós-positivista (ou pós-empirista, pós-popperiana, etc.), cuja fervura normalmente é assinalada pela publicação de $A$ estrutura das revoluções científicas, em 1962 [Kuhn, 1996]. Ela não é tão radical quanto alguns dos filósofos mais conhecidos desse período ${ }^{9}$, mas seu livro é muito bem montado e argumentado. Hesse tem dois objetivos principais nesta obra: elaborar sua teoria das redes, estendendo o "modelo Duhem-Quine"; e resgatar o papel da indução na filosofia da ciência, depois de todos os ataques de Karl Popper e seus seguidores - a consequência disto é a adoção de uma teoria da inferência probabilística e finita.

A primeira questão que Hesse se põe a analisar é a distinção tradicional na filosofia da ciência positivista entre "linguagem teórica" e "linguagem de observação", dois níveis utilizados na formulação de teorias e conectados através de "regras de correspondência" ${ }^{10}$. Esta distinção sofreu um pesado ataque em meados do século XX, e Hesse pretende resolver o problema propondo o seguinte:

“(i) Todos os predicados descritivos, incluindo predicados de observação e teóricos, precisam ser apresentados, aprendidos, entendidos e usados ou através de associações empíricas diretas em algumas situações físicas, ou através de sentenças contendo outros predicados descritivos que já foram apresentados, aprendidos, entendidos e usados dessa forma, ou através de ambos juntos. (...) (ii) Nenhum predicado, nem mesmo aqueles da linguagem de observação, pode funcionar apenas através de associações empíricas diretas" [SSI:11].

\footnotetext{
${ }^{9}$ O que lhe rendeu algumas críticas. Ver, por exemplo, Feyerabend [1993:34-35].

${ }^{10}$ Para uma das formulações clássicas do modelo hipotético-dedutivo da ciência, ver Nagel [1979].
} 
Fica claro que isto é uma versão da ideia de "carga teórica" [theory-ladenness] dos predicados, um dos principais postulados da filosofia da ciência pós-positivista na segunda metade do século XX. Em outras palavras, mais diretas: "nenhuma característica na paisagem total de funcionamento de um predicado descritivo está isenta de modificação sob pressão de seu ambiente. (...) qualquer situação ou aplicação 'correta' - mesmo aquela em cujos termos o termo foi apresentado originalmente pode se tornar incorreta para preservar um sistema de leis e outras aplicações" [SSI:16]. Precisamos ser cautelosos e não achar que isto significa que todos os predicados são instáveis e mudam de significado a cada instante, de acordo com qualquer configuração contextual fugidia. Há predicados mais "entrincheirados" que outros, ou seja, menos sujeitos a mudar de função na linguagem ordinária - mas esta é uma questão fatual de sua invariância relativa em relação ao aumento de informações empíricas, e não algo estabelecido a priori como se uma classe de predicados fosse eternamente imutável.

Esta concepção de que não há uma diferença a priori entre enunciados teóricos e de observação, e de que todos podem, a princípio, ser modificados dependendo de seu contexto é a base do que Hesse chama de modelo de redes, ideia que havia sido pressentida por Pierre Duhem, já no início do século XX, e depois retomada por W. V. O. Quine, mais recentemente. A principal diferença aqui é a ênfase de Hesse na possibilidade de modificação também de enunciados de observação, que os outros autores não deixaram muito clara - Hesse nota que Quine hesitava, em seus escritos, em adotar explicitamente as implicações mais revolucionárias desta tese, oscilando para 
posições mais conservadoras relacionadas ao conceito de "definição implícita" da matemática, em vez de especificar o caráter linguístico (e não formal) da rede ${ }^{11}$.

Enquanto aprendemos os predicados de nossa linguagem, aprendemos também as relações de semelhança e diferença intransitivas que se aplicam entre eles (nem todos os termos são aprendidos através de relações de semelhança, mas, segundo Hesse, pelo menos alguns precisam ser aprendidos através de reconhecimentos causais de semelhanças físicas). É preciso notar também a redefinição do termo "lei":

“(...) alguns destes predicados entram em enunciados gerais que são aceitos como verdadeiros e que chamaremos de leis: 'bolas são redondas'; (...) 'comer maçãs verdes causa dor de estômago'. Não importa muito se alguns deles são o que chamaríamos de enunciados analíticos; alguns, talvez a maioria, são sintéticos. Também não é necessário que todas essas leis sejam de fato verdadeiras, apenas que no momento elas sejam aceitas como verdadeiras pela comunidade linguística. (...) Explicitar estas leis gerais é apenas uma continuação e extensão do processo (...) descrito como identificar e reidentificar ocasiões apropriadas para o uso de um predicado através de semelhança física. Pois o conhecimento das leis permitirá que o usuário da linguagem agora aplique descrições corretamente em situações diferentes daquelas em que ele as aprendeu, e mesmo em situações onde ninguém poderia tê-las aprendido na ausência de leis. (...) Em outras palavras, as leis permitem que inferências e predições geralmente corretas sejam feitas sobre estados de coisas distantes ('não-observáveis')" [SSI:14-15].

Para desenvolver a teoria das semelhanças, Hesse adota a ideia de Wittgenstein de "semelhança de família", onde objetos podem formar uma classe cujos membros podem ter um mesmo predicado descritivo aplicado corretamente, mesmo que um par de objetos dessa classe não tenha mais nada de semelhante. Para Hesse, tais

\footnotetext{
${ }^{11}$ Neste modelo, as "regras de correspondência" se tornam apenas enunciados que podem funcionar como postulados, teoremas, inferências, etc.: "não há um único método de preencher uma lacuna lógica entre teoria e observação. Essa lacuna lógica não existe" [SSI:40].
} 
semelhanças são necessárias mas não suficientes para explicar o uso de termos universais. Este processo inclui um postulado de correspondência, necessário para fazermos classificações iniciais, e também condições de coerência para refinarmos essas classificações $^{12}$.

Dadas estas qualificações ao modelo de redes, Hesse afirma que ele agora pode ajudar a esclarecer alguns problemas da epistemologia clássica. Primeiro, é preciso notar que, ao postular uma classificação inicial, Hesse não está capitulando à ideia antiga dos enunciados privilegiados (da linguagem de observação). Ela cita a famosa metáfora da jangada de Otto Neurath - substituímos as tábuas da embarcação uma a uma, mas não todas de uma só vez, e não há nenhum conjunto particular de tábuas que precise ficar intacto. E o fato de usar o termo "inicial" não significa necessariamente que há uma relação temporal de antecedência entre o estabelecimento dessa classificação e o processo teórico subsequente (de acordo com as condições de coerência mencionadas acima). O modelo também não requer paradigmas de termos universais, porque, de acordo com a semelhança de família, o pertencimento de um objeto a uma classe não depende de sua semelhança com um paradigma dessa classe, e sim do complexo de suas relações de semelhança com outros objetos (sempre, mais uma vez, de acordo com as condições de coerência) ${ }^{13}$.

O postulado de correspondência, como já poderíamos imaginar, indica que o conceito de verdade do modelo de redes é um conceito de verdade por correspondência:

\footnotetext{
${ }^{12}$ Hesse não enfrenta, em SSI, o problema de exatamente quais condições de coerência devem ser empregadas, fixando-se apenas na relação entre essas condições e a classificação inicial, e o que fazer com os predicados que não se encaixam. De qualquer forma, ela oferece esta possibilidade: "é provável que as condições de coerência necessárias mais rigorosas venham de princípios metafísicos relativamente a priori e talvez culturalmente condicionados, e também de restrições físicas (por exemplo, estruturas linguísticas profundas) que podem ter sido selecionadas durante a evolução de organismos (...)" [SSI:52].

${ }^{13}$ Podem existir objetos "exemplares" de uma classe, mas eles não precisam ser eternos.
} 
“(...) o postulado de correspondência é a pressuposição básica de que a maior parte de uma classificação corresponde ao mundo, em termos de qualquer linguagem convencional descritiva do mundo que foi aprendida. Esta pressuposição é independente das condições de coerência, ainda que estas condições determinem de vez em quando qual parte de uma classificação é a melhor estimativa de verdade relativa à melhor teoria (...) Que o valor de verdade de um enunciado de observação é relativo a condições de coerência é uma questão de epistemologia, mas o conceito de verdade pressuposto é uma questão de ontologia, ou seja, de uma relação entre existentes. A verdade é uma relação entre o estado do mundo que produz estímulos empíricos e os enunciados de observação expressos na linguagem descritiva atual" [SSI:56-57].

Esta concepção de verdade tem elementos pragmáticos, estando relacionada ao sucesso preditivo dos enunciados - mas, como veremos, ela não significa que possamos confirmar verdades universais e imutáveis.

E como ocorre a "substituição das tábuas", ou seja, como ocorre a mudança de significado no modelo de redes? Para Hesse, a referência extensional não é suficiente, pois as classes não são definidas apenas pelos objetos que contêm - precisamos também do que ela chama de "referência intensional", o "reconhecimento de semelhanças e diferenças na produção da classificação inicial em uma dada linguagem" [SSI:62]. Assim, o significado de um predicado muda quando algumas (ou todas) as situações empíricas que descrevíamos utilizando esse predicado passam a receber, de acordo com regras derivadas das condições de coerência, um outro predicado - ou seja, as relações de semelhança e diferença são modificadas por algum motivo. 
Depois de estabelecer os traços principais do modelo de redes ${ }^{14}$, Hesse parte para seu segundo objetivo no livro - resgatar a indução enquanto ferramenta possível para a inferência científica ${ }^{15}$. O modelo dedutivo herdado de Hume não é apropriado para o modelo de redes - primeiro, por causa da relação entre a distinção das linguagens de observação e teórica com a ordem de dedução lógica; segundo, porque no modelo de redes não há espaço para um ponto de partida dado (e não corrigível) para o argumento modus tollens falseador; terceiro, porque o modelo de Hume permite inferências apenas através de dedução de premissas teóricas para conclusões observacionais, e Hesse quer resgatar inferências indutivas (e analógicas) que possam se mover também da observação para a teoria, do particular para o geral, e do particular para o particular.

Antes de começar a analisar o problema da indução, Hesse precisa definir o que ela quer dizer com "inferência indutiva":

“(...) uma asserção ou argumento sobre o não-observado que tem duas características essenciais:

(i) Ele fornece alguma regra ou conjunto de regras para passarmos de enunciados sobre evidências para generalizações ou predições singulares sobre aquilo que ainda não foi observado.

(ii) Ele carrega alguma reivindicação sobre a verdade de tais generalizações ou predições; isto quer dizer, de forma momentaneamente imprecisa, que há alguma expectativa racional que a conclusão da inferência corresponde a enunciados verdadeiros sobre o não-observado" [SSI:96].

Hesse não tenta elaborar uma teoria da indução "forte" (onde os postulados propostos podem ser justificados independentemente dos próprios processos indutivos)

\footnotetext{
${ }^{14}$ A argumentação de Hesse inclui também uma proposta de solução bastante interessante do "paradoxo do verul" [grue paradox] de Goodman, mas que não precisa ser relatada aqui [cf. SSI:cap. 3].

${ }^{15}$ Adotar a indução não significa descartar a dedução.
} 
- em vez disso, ela propõe que, se os postulados de inferência indutiva formarem uma "boa explicação" das regras indutivas intuitivas (como indução por enumeração, eliminação, implicação inversa, inferência preditiva, e assim por diante), isso já seria uma justificação suficiente.

Esses postulados devem adotar algum tipo de teoria da confirmação probabilística, que deve explicar e sistematizar métodos indutivos realmente utilizados na ciência; sugerir novos problemas de inferência indutiva e novas ideias sobre a estrutura da ciência; e podem até sugerir um isomorfismo entre a inferência lógica e a biológica (relacionada ao aprendizado em organismos).

Depois de estabelecer seu ponto de partida, Hesse começa a desenvolver essa teoria probabilística apropriada para o modelo de redes. Esta discussão é bastante complexa, e eu não a reproduzirei em detalhes aqui, apontando apenas suas conclusões, mas não o processo de argumentação e elaboração. Hesse adota uma interpretação personalista da probabilidade, ou seja, baseada em graus de crença racional, e não em probabilidades objetivas (estatísticas ou lógicas), e nem crenças subjetivas: "a probabilidade personalista é uma mensuração das crenças em proposições, e não uma propriedade das próprias proposições" [SSI:105]. Essa teoria da probabilidade segue um modelo de transformação bayesiano, onde probabilidades iniciais são levadas em consideração (porque não é possível conceber uma crença racional se não houver um estabelecimento da probabilidade inicial das hipóteses em questão durante a inferência).

A partir disto, Hesse tenta mostrar como essa teoria bayesiana pode mudar algumas intuições científicas - especialmente a respeito da universalidade de leis e teorias científicas (porque é muito difícil designar probabilidades iniciais a generalizações supostamente universais). Simplificando bastante a elaboração que 
Hesse desenvolve, ela resolve o problema da indução de forma pragmática - admitindo um universo infinito, a indução realmente não é possível, pois é praticamente certo que em algum momento ou em algum lugar surgirá uma nova instância que falseia a hipótese. Mas se estabelecermos um limite pragmático para o tempo e o espaço, adotando princípios como o da aglomeração de instâncias, podemos gerar inferências indutivas com probabilidades bastante confiáveis ${ }^{16}$.

Para Hesse, teorias científicas têm um caráter analógico. A ideia aqui é que não temos mais um movimento de um enunciado inicial, através da indução, para uma teoria num nível "superior" que depois "desce”, através da dedução, para um enunciado final, e sim uma inferência analógica direta entre o enunciado inicial e o final, e a teoria "não fornece o nível superior de uma estrutura dedutiva, extraindo em vez disso a essência dos [enunciados inicial e final], quer dizer, ela revela nestas leis as analogias relevantes através das quais passamos de uma para a outra indutivamente" [SSI:212].

Como exemplo de seu modelo, Hesse examina a teoria eletrodinâmica de Maxwell. Ele herdou, como paradigma de sua época, uma teoria que interpretava forças elétricas e magnéticas em termos de pequenas partículas de tipos diferentes exercendo tipos específicos de repulsão e atração umas sobre as outras. Estas forças, não observáveis, geraram uma linguagem descritiva cheia de metáforas, como "carga", “corrente", "polarização", "capacidade", etc. Hesse nega que as teorias científicas precisem remover o caráter metafórico dos termos que utilizam com o objetivo de tornálos termos com significado unívoco desconectados de sua história linguística.

A perspectiva de Maxwell, no entanto, era completamente diferente. Em vez de objetos atraindo-se e repelindo-se através de um espaço vazio, temos condensações de

\footnotetext{
${ }^{16}$ Hesse elabora esta proposta nos capítulos 5 a 8 de SSI. Um resumo um pouco mais complexo do que o apresentado aqui pode ser encontrado em SSI:193-195.
} 
massa inercial nos campos de força, realizadas pelas tensões, expansões e contrações das linhas de força no próprio espaço:

"Consequentemente, Maxwell tinha que mudar, de alguma forma, a linguagem com que descrevia os fenômenos, porque a linguagem já interpreta a observação através de algum tipo de teoria. Mas é inconveniente cunhar uma nova linguagem sempre que desejamos modificar uma teoria, e não seríamos compreendidos se o fizéssemos. Então Maxwell fez, de forma bastante explícita, o que sempre é feito tacitamente quando uma mudança de teoria radical ocorre - ele mudou as implicações metafóricas da linguagem existente (...). Metáforas são expressões necessárias da analogia entre modelos e fenômenos, e servem para ligar teorias a experimentos de forma compreensível intersubjetivamente, ainda que não derivável dedutivamente. Argumentos dedutivos proíbem metáforas, e por isso se tornam impossíveis tão logo a própria linguagem na qual os fenômenos são descritos muda seus significados metafóricos. Significados são holísticos: eles dependem de toda a rede de modelos e de suas analogias com fenômenos." [Hesse, 1995:373].

O processo metafórico tem suas próprias regras, obviamente - não é qualquer metáfora que serve num contexto científico. Elas precisam explorar relações de semelhança e diferença conhecidas, o que não é o caso, por exemplo, de metáforas poéticas.

Hesse termina SSI propondo a sua versão de uma interpretação realista da ciência. O realismo tradicional tem três condições: os enunciados teóricos têm valor de verdade; o mundo natural não muda ao sabor das teorias; e nosso conhecimento científico é uma coleção permanente e cumulativa de proposições verdadeiras que correspondem ao mundo. O modelo de redes não tem problemas com a primeira condição (mesmo que o valor de verdade seja probabilístico). Entretanto, as outras 
condições são preenchidas apenas parcialmente pelo modelo de Hesse. Apesar dela admitir que significados podem ser traduzidos de teoria para teoria (de forma que o mundo natural permaneça o mesmo, apenas interpretado diferentemente), isso não se estende a todos os significados - as entidades "primárias" são relativas à teoria (e passíveis de serem superadas e substituídas por outras teorias). As mesmas qualificações se aplicam à condição do caráter cumulativo do conhecimento científico enunciados com alta probabilidade são acumulados, mas identificações de entidades primárias (e suas propriedades essenciais) não necessariamente se acumulam, podendo haver substituições. Ainda assim, Hesse considera isto não uma negação do realismo, mas uma revisão dele.

No final de SSI, Hesse já aponta para seu futuro interesse nas ciências humanas:

"Este modelo reconhece que descobertas são feitas em interação com o mundo usando uma linguagem particular, e que este processo tem seus limites, tanto em relação à verdade teórica, quanto às condições sob as quais o aprendizado ocorre. A inferência nas ciências naturais tem bases racionais, mas estas são de aplicação essencialmente finita e local, e determinadas por condições empíricas de testabilidade e autocorreção. Se quisermos ir além desta forma de racionalidade, precisamos nos voltar para os estudos do homem, da sociedade e da história, (...) cujos métodos e objetivos não são exauridos pelos da ciência natural" [SSI:302].

III

Hesse se desloca para as ciências humanas em RRPS, publicado em 1980. Mas este é um livro diferente - não uma obra integrada como SSI, e sim uma coletânea de artigos publicados de 1965 a 1979 (os textos mais antigos tratam de temas que Hesse 
desenvolveu em seu livro de 1963, Modelos e analogias na ciência, e em SSI). Fica evidente que Hesse é bastante cuidadosa e cautelosa ao se aproximar das humanidades em lugar da autora que se sente completamente a vontade no tema de $S S I$ e propõe ideias novas e inovadoras, dialogando com vários autores em suas elaborações e análises $^{17}$, RRPS tem um caráter claramente de exploração, de alguém que se interessa e se aproxima de uma área que não domina, e começa a desbravá-la até com uma certa humildade. O que não quer dizer, como veremos, que o livro não é interessante e não traz contribuições.

Já na introdução de RRPS percebemos uma mudança de ênfase. Hesse diagnostica, na ascensão de realismos metafísicos na teoria da ciência, um certo descompasso (não sem ironia) entre a filosofia e o mundo. Este realismo abandona questões epistemológicas e enfatiza a ontologia das teorias, pressupondo que a ciência atual chegou (ou está prestes a chegar) à verdade, mantendo também a tese empirista da aplicabilidade da lógica e de uma linguagem científica precisa ao mundo - tese da qual Hesse discorda, pois, como vimos, ela não acredita que possamos alcançar uma verdade universal infinita.

Hesse nota que os fundadores do positivismo lógico não tinham apenas interesses filosóficos. Sua preocupação com aquilo que podemos saber que é verdade, e a rejeição do conhecimento metafísico, estavam ligadas à disputa política entre liberalismo, autoritarismo e socialismo (este últimos influenciados exatamente pela metafísica que o positivismo combatia $)^{18}$. A filosofia analítica de hoje em dia, em contraste, se divorciou de interesses práticos, "perdendo assim a urgência da pergunta 'Como podemos saber?', contentando-se em pressupor ontologias ideais para as quais

\footnotetext{
${ }^{17}$ Diálogos que infelizmente tive que omitir do presente trabalho - mas qualquer olhadela superficial em SSI é suficiente para provar o que digo.

${ }_{18}$ Para um excelente estudo sobre o contexto histórico e político em que o positivismo do Círculo de Viena se desenvolveu, e da atuação política de seus membros, ver Reisch [2005].
} 
eles não sentem nenhuma necessidade de recorrer para as respostas a questões práticas" [RRPS:xiii].

Insatisfeita com este estado de coisas, Hesse nota que, ao se isolar num discurso exageradamente intelectual, a filosofia analítica perde contato com o resto do mundo filosófico, ou seja, as correntes hermenêutica e dialética. Para os analíticos, estas correntes (e a filosofia da ciência pós-positivista mais radical, inspirada em Kuhn e especialmente Feyerabend) levam apenas a um relativismo inaceitável. Hesse também não concorda com um relativismo extremo em que teorias são apenas sistemas de proposições internas, a verdade se transforma na coerência com o sistema, e o conhecimento se torna crenças institucionalizadas socialmente. Mas, como vimos, sua concepção de teorias finitas e analógicas admite um certo grau de relativismo (que, segundo ela, de qualquer forma é uma consequência inescapável da subdeterminação das teorias pelos fatos). O objetivo de Hesse em RRPS, então, é encontrar um caminho entre os extremos do realismo metafísico e do relativismo - tarefa que requer uma integração da ciência natural num esquema epistemológico que abranja a filosofia das ciências sociais.

Os artigos iniciais do livro tratam de questões relacionadas à história da ciência. A primeira questão com que Hesse se defronta é se os historiadores da ciência devem tentar avaliar a verdade e a racionalidade da ciência do passado. Após analisar o exemplo da influência dos textos herméticos na ciência do século XVII, Hesse discorre sobre três argumentos contra essa possibilidade de avaliação dos historiadores modernos.

Primeiro, afirma-se que, como não existem critérios normativos de racionalidade aceitáveis (já que tanto a história quanto a filosofia da ciência não alcançaram nada que 
se pareça com um consenso sobre esta questão), teríamos um relativismo completo quanto à racionalidade científica. Mas, para Hesse, este não é um problema muito sério. É verdade que não há nenhuma demarcação firme entre a história interna da ciência (uma história que se limita à análise de teorias científicas) e a história externa (que leva em consideração fatores sociais, econômicos, políticos, etc., e sua influência sobre a ciência). Mas isto não significa que um historiador, buscando uma interpretação da ciência do passado, não reconheça que sua própria racionalidade é importante, e consiga realizar uma história interna adequada: "E se isto parece correr o risco de se tornar uma definição circular de história interna como aquilo que é contínuo com nossa ciência de acordo com nossa história interna, a única cura é examinar melhor o registro histórico para ver se a autonomia relativa da história interna pode ser mantida apesar de possíveis fatores perturbadores" [RRPS:21].

Segundo, temos o problema da possível distorção se nos focarmos demais na história interna às custas da externa, e vice-versa. Para Hesse, esta é apenas uma formulação mais específica da questão metodológica mais geral de como o historiador seleciona alguns aspectos e descarta outros para sua descrição. Na história da ciência ela pode parecer mais premente, tendo em vista a ênfase que muitos historiadores da ciência dão à história interna, mas este não é um problema específico desta subdisciplina, e nem impede que possamos obter descrições não distorcidas.

Finalmente, temos a afirmação de que o historiador deve evitar juízos de valor sobre a racionalidade e a verdade de sistemas de pensamento científico do passado. Hesse nota que, embora realmente devamos tomar cuidado com a distinção entre fatos e valores, não devemos nos esquecer que a distinção entre fatos e teoria (em outras palavras, entre a linguagem de observação e a linguagem teórica) deve ser rejeitada assim, é impossível que um historiador da ciência descreva um acontecimento de forma 
completamente "neutra", e seu ponto de vista (e racionalidade) sempre influenciará suas decisões:

"Vejamos, [por exemplo], as tentativas de vinte anos de Ørsted para demonstrar o que qualquer criança agora pode fazer com uma pilha, um pedaço de fio e uma agulha de bússola. Para entendermos as dificuldades de Ørsted, precisamos não apenas saber que ele acreditava numa teoria newtoniana de forças atrativas e repulsivas centrais, e a aplicou para produzir as expectativas erradas neste caso; precisamos também reconstruir o que seu equipamento realmente precisava ser de modo a não revelar imediatamente o que para nós é óbvio sobre a direção da rotação da agulha. Isto (...) é um requerimento do programa de levar os fatos e ideias de um período a sério. E, aliás, um dos testes comparativos de nossa ciência é que ela não apenas pode explicar aquilo que era explicado diferentemente no passado, mas pode explicar por que outras coisas não foram explicadas ou sequer observadas quando deveriam ter sido. Claro que pode-se responder que esta comparação é recíproca, porque nós, sem dúvida, estamos negligenciando coisas que deveríamos estar vendo, e uma racionalidade diferente poderia detectar e explicar esta negligência. Mas em relação à nossa história isto ainda é válido, porque ninguém jamais sugeriu que nós devêssemos escrever uma história aristotélica da ciência do século XX, mesmo se tal projeto fosse concebível, e nós certamente não podemos escrevê-la do ponto de vista de uma racionalidade do futuro" [RRPS:24-25].

$\mathrm{O}$ artigo seguinte discorre sobre a tese forte da sociologia da ciência, dos sociólogos Barry Barnes e David Bloor. A análise completa de Hesse não nos interessa aqui, mas sim suas observações sobre o debate entre racionalistas e relativistas. Os primeiros acreditam que a análise de "nossa" linguagem, racionalidade e ciência revelará as pressuposições de qualquer linguagem, racionalidade e ciência possíveis. Os relativistas, obviamente, consideram que "nossa" linguagem, racionalidade e ciência são limitadas culturalmente. Hesse recoloca isto como um debate entre evolucionistas e 
"teóricos críticos ou hermenêuticos" - os primeiros considerando a ciência atual o ápice de uma longa cadeia evolutiva, e os últimos aceitando que a análise social e histórica pode questionar nossas próprias pressuposições, através do entendimento entre culturas e da crítica autorreflexiva.

Em “A função explicativa da metáfora”, o artigo mais antigo desta coletânea, Hesse propõe o primeiro esboço daquilo que se tornaria seu modelo analógico de teorias, ao propor que a explicação teórica significa a redescrição metafórica do explanandum. Seu artigo é influenciado por Max Black, que trata a metáfora não como uma comparação, mas como uma interação: numa metáfora como "o homem é um lobo", o uso da metáfora muda algumas das ideias associadas com o termo primário ("homem"), mudando assim o significado de sua descrição literal. O mesmo ocorre com o termo secundário ("lobo") - os dois sistemas interagem um com o outro, e se adaptam um ao outro, ao contrário do que acontece na visão tradicional da metáfora como comparação, onde os termos permanecem com o mesmo significado original. É este caráter de interação que mostra como a metáfora pode ser utilizada como uma explicação do termo primário (uma explicação, obviamente, não dedutiva) ${ }^{19}$.

"Modelos de mudança teórica", o artigo seguinte, toca em questões desenvolvidas em SSI, reafirmando a posição de Hesse de que a ciência é, em sua essência, um dispositivo de aprendizado sobre o mundo empírico. Apesar de boa parte do artigo não ser muito diferente do que vimos em SSI, aqui ela explica um pouco melhor as condições de coerência que foram apenas mencionadas naquele livro. Assim, ela menciona três tipos de condições de coerência: normativas, inatas, e determinadas por valores. As normativas são as mais comuns na filosofia da ciência, incluindo a

\footnotetext{
${ }^{19}$ Para uma análise da obra de Hesse com ênfase no uso de metáforas e analogias, ver o excelente trabalho de Jordão Nunes [2005:319-337].
} 
lógica da dedução, da confirmação, critérios de simplicidade, classificação, etc. critérios que parecem, intuitivamente, ser necessários para boas teorias.

A complicação é que sempre há problemas para justificar por que tais critérios seriam necessários, especialmente nesse modelo dedutivo, já que esta é uma questão indutiva (quais são as condições mais bem sucedidas para o aprendizado?). E, além disso, elas parecem não ser suficientes para explicar nossos sistemas cognitivos, comparativamente econômicos (em relação à infinidade de possíveis sistemas compatíveis com essas condições normativas). Daí a passagem para condições de coerência inatas, ou seja, condições genéticas naturais do ser humano - da mesma forma como alguns linguistas sustentam que teríamos estruturas gramaticais profundas inatas. Mas, segundo Hesse, há poucos estudos sobre este tipo de condição.

Condições de coerência determinadas por valores seriam, por exemplo, objeções morais a teorias da seleção natural ou da mente. Supostamente, as ciências naturais estariam cada vez mais distantes deste tipo de condição (ao contrário das sociais), mas isso se mostra discutível - por um lado, a própria escolha de tentar desenvolver ciências "não influenciadas por valores" reflete um valor (a saber, que esse tipo de ciência seria desejável); por outro, embora condições teológicas e/ou metafísicas tenham perdido espaço no decorrer dos séculos, considerações sociais e éticas tornam-se cada vez mais presentes.

É em "A verdade e o crescimento do conhecimento científico" que Hesse começa a se mover além daquilo que estabeleceu em SSI, tentando imaginar um novo conceito de verdade para a ciência que não se afaste do realismo - e também comentando sobre a divisão do trabalho entre filósofos e historiadores da ciência. 
Hesse começa adotando o que chama de "princípio de nenhum privilégio", que afirma que nossas teorias científicas são tão passíveis de sofrer mudanças radicais quanto as teorias do passado. Ela também introduz uma concepção da verdade como consenso, que não estava presente anteriormente, ao discutir como podemos atribuir verdade a sentenças de observação ${ }^{20}$ :

"Há uma resposta mínima com a qual quase todos concordam, a saber, que para uma dada comunidade linguística, sentenças de observação 'verdadeiras' e a aplicação 'correta' de termos de observação gerais são pelo menos aquelas que são reforçadas enquanto tal pelo consenso da comunidade. (...) Não se segue que em tal teoria tudo aquilo que é consensual é verdadeiro, nem que a verdade é completamente dependente da comunidade linguística. Tais objeções se baseiam num mal-entendido, pois as próprias mecânicas do aprendizado linguístico e do reforço da 'correção' dependem da referência externa da linguagem. Não é que vale tudo desde que a comunidade linguística concorde, mas sim que a comunidade linguística concorda ou não de acordo com restrições externas" [RRPS:145].

Esta verdade de uma comunidade se relaciona às verdades de outras comunidades através do "princípio da caridade" - a ideia de que tentamos traduzir as sentenças de qualquer linguagem estrangeira, especialmente as de observação, de forma que o maior número possível delas seja verdadeiro em nossa linguagem. Passando das sentenças de observação para as teóricas, Hesse reafirma sua teoria probabilística, tanto em sua forma ontológica (em domínios infinitos, certamente todas as sentenças têm probabilidade zero, mas isso não ocorre em domínios finitos) quanto na epistemológica

\footnotetext{
${ }^{20}$ Talvez seja útil reforçar que, apesar de Hesse atacar a distinção entre linguagem teórica e de observação, como exposto acima, isto não significa que não existam sentenças teóricas e sentenças de observação - apenas que nenhuma tem prioridade sobre a outra, e que todas podem ser alteradas, dependendo da configuração da rede.
} 
(o grau de crença racional da comunidade científica em questão sobre a verdade das sentenças).

Mas como o princípio da caridade funciona no caso das teorias? Afinal, muitas vezes, quando falamos de teorias, queremos mostrar que as teorias "estrangeiras" não são verdadeiras em comparação com as nossas. Não podemos simplesmente dizer que as teorias estrangeiras são falsas simplesmente porque contradizem as nossas, pois isto iria de encontro ao princípio de nenhum privilégio. A solução, segundo Hesse, é um pouco mais complexa: procuramos afirmar que as teorias estrangeiras têm baixa probabilidade através de boas inferências científicas a partir de suas sentenças de observação. Isto certamente transfere o privilégio de nossas teorias para nossas inferências, mas, para Hesse, isso se justifica porque estamos falando sobre sistemas científicos (e não uma linguagem ordinária), e temos o direito de reconhecer como científicos apenas os sistemas que podem ser submetidos a nossos critérios de testes e padrões de inferência que levam ao sucesso preditivo $^{21}$. Aqui o princípio da caridade significa que utilizamos as regras de tradução que deem às teorias estrangeiras a maior probabilidade possível.

Esta versão da teoria da verdade tem consequências importantes para a questão do significado:

"Como podemos dizer que sentenças teóricas têm valor de verdade, também podemos dizer que elas têm referência da mesma forma que sentenças de observação têm referência, ou seja, se elas forem verdadeiras, existem entidades e propriedades no mundo como elas descrevem. O significado teórico é referencial - ele é dado pelo significado e valor de verdade de sentenças de observação junto com as regras inferenciais que ligam o

\footnotetext{
${ }^{21}$ Para Hesse, esta é uma tarefa para filósofos, e não historiadores: estes podem muito bem aceitar os critérios de cientificidade "estrangeiros", mas aqueles não.
} 
valor de verdade das teorias ao valor de verdade de sentenças de observação. O significado não é, como em teorias da 'variação de significado', dado independentemente de restrições da observação e puramente através do contexto teórico. Assim, dentro do vocabulário observacional de uma dada comunidade linguística não surgem problemas de variação de significado" [RRPS:153].

A partir disto, Hesse consegue conciliar o princípio da caridade e o princípio de nenhum privilégio numa concepção pragmática do crescimento da ciência. O princípio da caridade permite que reconheçamos um acúmulo de sentenças de observação verdadeiras no sentido do aumento de nosso controle preditivo sobre o ambiente natural $^{22}$. E isto se estende a sentenças teóricas mais próximas de testes preditivos pragmáticos. Mas isso não significa que nossas teorias tenham algum privilégio, pois todas elas podem ser alteradas e substituídas.

Hesse reconhece que este critério pragmático funciona como um critério de demarcação entre o que vale como ciência empírica e o que não vale. Mas, para ela, apesar de todas as críticas que essa ideia recebeu, a ciência precisa reivindicar o conhecimento empírico para que possamos distingui-la de cosmologias simbólicas ou metafísicas. Hesse afirma que isto é uma reconstrução filosófica daquilo que conta como ciência - ela precisa espelhar a prática existente razoavelmente bem, mas isso não implica que tudo o que os cientistas fazem se encaixa com ela, nem que não existam motivações não pragmáticas para o desenvolvimento da teoria científica: "nenhum argumento filosófico pode garantir que o critério pragmático compreende a 'essência' da ciência: tais essências não existem, apenas tipos ideais baseados em juízos seletivos" [RRPS:xix-xx].

\footnotetext{
22 "Controle preditivo" não significa necessariamente controle tecnológico. Descobertas sobre quasares, por exemplo, normalmente não melhoram nossa tecnologia. Mas é claro que em muitos casos há uma relação entre predição e tecnologia.
} 
"Teoria e valor nas ciências sociais" é a tentativa de Hesse de analisar a questão metodológica talvez mais básica das ciências sociais: estas devem ser naturalistas (seguindo o mesmo método das ciências naturais), dualistas (seguindo um método completamente diferente das ciências naturais) ou pluralistas (seguindo um método com elementos das ciências naturais, mas também com diferenças $)^{23}$ ?

Hesse volta a defender seu critério pragmático como o melhor candidato a dar conta do fato de que, apesar das revoluções científicas inevitáveis e constantes, há um progresso e acúmulo de conhecimento nas ciências naturais. Mas as ciências sociais apresentam duas características distintas das naturais. Primeiro, o que era de se esperar: não existem teorias gerais nas ciências sociais que satisfaçam o critério pragmático (e talvez elas nunca possam existir). Segundo, e mais interessante: como a própria adoção do critério pragmático é um juízo de valor, é possível decidirmos contra esse critério como objetivo das ciências sociais, adotando outros valores.

Quanto ao primeiro ponto, Hesse é agradavelmente direta quando diz que a melhor resposta que temos é simplesmente: não sei. Pode ser que as teorias das ciências sociais se desenvolvam num sentido de maior generalidade, ou pode ser que o ambiente social simplesmente tenha variáveis demais para permitir qualquer tipo de controle instrumental sofisticado. A segunda característica exige uma discussão mais complexa.

O efeito do critério pragmático nas ciências naturais é exatamente diminuir a importância de outros juízos de valor, e é possível que algo parecido ocorra nos casos em que ele puder ser aplicado nas ciências sociais - mas isto não deve acontecer com grande frequência. E, como isto não ocorre com frequência, precisamos ter cuidado com reivindicações de objetividade total nas ciências sociais, e, portanto, encararmos juízos

\footnotetext{
${ }^{23}$ Para uma análise destas (e outras) posições envolvidas nesta questão antiga, ver Oliveira Filho [1995].
} 
de valor não como um mal necessário, mas como algo a ser examinado crítica e positivamente. É claro que a questão de quais valores devem ser adotados não pode ser resolvida a priori. Mas também fica evidente de que Hesse passa longe de defender o naturalismo e o dualismo, tendendo a uma posição pluralista no que tange à metodologia das ciências.

\section{IV}

Nesta parte final, eu gostaria de analisar com mais cuidado os textos que Hesse dedica à análise de Jürgen Habermas. Este é o principal interlocutor de Hesse nas discussões que ela realiza sobre as ciências sociais ${ }^{24}$, e sua influência já aparece no final de SSI, quando ela nota as propostas de Habermas em Conhecimento e interesse [Habermas: 1987] de postular princípios sociais em lugar do realismo ingênuo que considera as coisas e propriedades como entidades imutáveis - princípios que Hesse não considera incompatíveis com seu modelo de redes, apesar dela não desenvolver esta questão em detalhes ${ }^{25}$.

Hesse nota, junto com vários outros comentadores, que a visão das ciências naturais na obra inicial de Habermas é surpreendentemente conservadora, mantendo intacta a ligação entre a possibilidade de controle técnico do mundo natural e o valor e objetividade da ciência natural. Onde Habermas não é conservador é em sua rejeição de interpretações realistas da ciência, que ele considera ideológicas e/ou dogmáticas. Não

\footnotetext{
${ }^{24}$ Hesse demonstra conhecimento de outros autores clássicos das ciências sociais, como Marx, Durkheim, Weber, Mannheim, Goffman, Garfinkel, Gouldner, Myrdal, entre outros (Giddens, até onde eu sei, é citado apenas uma vez, como veremos abaixo). Mas é Habermas que concentra suas atenções e serve como ponto de entrada para suas reflexões.

${ }^{25}$ Como sabemos, a teoria que Habermas propõe em Conhecimento e interesse sofre imensas modificações durante a década de 1970, até ser substituída no início dos anos 1980 pela teoria da ação comunicativa (que também sofreria grandes transformações com o passar dos anos). Mas os textos de Hesse sobre Habermas tratam, com apenas uma exceção, da fase anterior à teoria da ação comunicativa.
} 
há uma objetividade transcendental, apenas o valor (interesse) das atividades científicas para uma comunidade humana. Hesse menciona depois, com aprovação, a ideia de Habermas do interesse comunicativo como a fonte da objetividade das ciências humanas, através do diálogo em busca de consenso ${ }^{26}$. E, mais uma vez, defende o pluralismo metodológico, afirmando que esta separação de interesses não é uma dicotomia, e sim um continuum, pois uma compreensão hermenêutica do ser humano seria incompleta sem a compreensão de sua natureza biológica, e a concepção de natureza de uma sociedade certamente precisa ser analisada hermeneuticamente. Esta é a principal tese metodologicamente pluralista de Hesse, contra o reducionismo naturalista e o dualismo.

Mas ela percebe que a terceira parte da tipologia de interesses de Habermas, o interesse na emancipação (das coerções naturais e sociais), não é simétrico aos outros. Metodologicamente, o interesse técnico corresponde à escola analítica, o comunicativo à hermenêutica, e o interesse na emancipação à escola crítica (dialética). Epistemologicamente, porém, a simetria se quebra: o interesse técnico está ligado ao conhecimento empírico, e o comunicativo ao conhecimento hermenêutico - mas não há um tipo de conhecimento correspondente ao interesse na emancipação. Assim, a emancipação acaba se relacionando em outro nível com os outros conhecimentos, que precisam se tornar autorreflexivos e críticos para se libertarem de suas coerções.

Analisando em maiores detalhes a teoria da verdade por consenso de Habermas, que, como vimos, a influenciou diretamente, Hesse nota que ele abandona a teoria da verdade por correspondência como consequência das teorias da filosofia da ciência póspositivista - a verdade por correspondência só é plausível dentro de um esquema

\footnotetext{
${ }^{26}$ Mas talvez Hesse utilize esta ideia de Habermas de forma um pouco mais hermenêutica do que este gostaria - ver o seu exemplo de aplicação à questão do debate sobre a história da ciência nos séculos XVI e XVII [RRPS:180-181].
} 
conceitual único, mas isto é impossível quando temos mudanças teóricas radicais e reconhecemos a relevância dos valores nas teorias sociais. Já que até os enunciados de observação mais elementares são expressos em termos de alguma linguagem teórica (e passível de mudança), a verdade não pode ser simplesmente a correspondência destes enunciados com o mundo empírico. Assim, estas linguagens não “descrevem” o mundo, e sim o interpretam de forma mais ou menos adequada. Esta adequação, que supostamente aumenta com o desenvolvimento da ciência, não é medida apenas através de verificação experimental, mas também através de raciocínio argumentativo - pois é isto que permite a comunicação entre a comunidade científica em questão. Em um artigo posterior, Hesse enfatiza este caráter pragmático do significado na obra de Habermas:

“(...) a teoria pragmática do significado garante que termos denotativos se refiram a objetos idênticos no mundo. A ideia de que o significado é completamente dependente do contexto teórico é bastante irreal, porque a linguagem ordinária descritiva é aprendida em condições pragmáticas sob as quais a identidade de referência em casos normais é garantida na prática. (...) Explicações teóricas podem ser traduzidas em conhecimento técnico porque teorias científicas são contínuas com estes significados da linguagem natural. Assim, o significado no nível da observação pragmática é relativamente independente da teoria, e o problema da variação de significado é um pseudoproblema" [Hesse, 1982:103].

Para Hesse, este caráter pragmático do significado é na verdade um resíduo da teoria da verdade por correspondência na obra de Habermas, ainda que, é claro, livre de conotações realistas.

Habermas não fala muito sobre como seria a comunicação entre linguagens diferentes, mas, adotando a noção de "tradição" de Gadamer, ele afirma que toda 
linguagem natural contém os recursos para entender outras linguagens naturais (incluindo o seu próprio passado) - e nenhuma linguagem teórica pode ser construída do nada, sem contato com esta tradição.

Mas como Habermas resolve os principais problemas gerados por uma teoria da verdade como consenso? Para ele, "a verdade de enunciados tanto na ciência empírica quanto em interpretações hermenêuticas deve ser entendida como o consenso ideal de praticantes competentes dessas disciplinas" [RRPS:215]. Os problemas aqui são como descrever esse caráter ideal, e esta competência, para podermos separar consensos falsos de consensos verdadeiros. Esta situação do discurso ideal, para Habermas, depende de uma estrutura livre de coerções, ou seja, onde todos os participantes gozam de uma distribuição de chances simétrica de selecionar e empregar atos de fala. Este é um ideal transcendental que não encontra correlato na realidade humana - assim, nesta teoria, a verdade não pode ser obtida sem a obtenção da liberdade e da justiça.

Habermas também afirma que, nestas condições ideais, o discurso seria universal, o consenso verdadeiro através do tempo e do espaço. A situação do discurso ideal seria uma condição transcendental enquanto compromisso (sincero) de seus participantes com o discurso - e tal compromisso pode ser encontrado na história, ainda que, obviamente, muito longe de qualquer universalidade:

"Toda teoria que faz reivindicações de verdade num esquema conceitual particular inclui suas próprias 'antecipações' da natureza total do mundo enquanto elas forem relevantes para essa teoria. O compromisso com o consenso antecipado é o compromisso com o abandono de posições falseadas, e também de esquemas conceituais que não levem ao consenso. Não há nenhuma última teoria, ou último teórico, no sentido de que a ciência se detém nesse ponto, para sempre congelada em qualquer esquema conceitual que por acaso seja corrente. Mas toda teoria séria e todo teórico sincero é o 
'último', no sentido de que é lá que a responsabilidade diante do consenso ideal opera para ele. Entrar na comunidade científica pressupõe a aceitação dessa responsabilidade” [RRPS:219].

Desta forma, a verdade se torna não um predicado de proposições, e sim um predicado de reivindicações feitas em atos de fala, o que dá a ela um caráter múltiplo: ela varia com a cultura de uma sociedade (e com seus esquemas conceituais), mas não em relação às simetrias e universalidade exigidas pelo discurso ideal. E isto gera uma tensão clara - pois Habermas postula que todas as culturas que existiram, existem e existirão compartilham deste compromisso com a situação do discurso ideal. Isto, obviamente, não pode ser justificado empiricamente - é um juízo de valor sobre o qual podemos dizer que, na teoria de Hesse, substituiria o critério pragmático para as teorias das ciências sociais.

E é este ponto que Hesse questiona - não exatamente a situação do discurso ideal, mas por que deveríamos adotá-la como o padrão da verdade não-empírica. Para Hesse, não parece possível considerar esta ideia como algo que não seja influenciado pelos valores de Habermas (a não ser que pudéssemos provar que ela seria um resultado da evolução biológica humana - naturalismo este que o próprio Habermas rejeita). E se tivermos que tratar a situação do discurso ideal como um valor que orienta a ciência, isto pode muito bem ser válido - mas perde o caráter transcendental que Habermas deseja lhe atribuir ${ }^{27}$. Só que, na opinião de Hesse, o máximo que Habermas alcança em defesa deste transcendentalismo são argumentos circulares (do tipo "a situação do discurso ideal escolheria como sua finalidade a situação do discurso ideal").

\footnotetext{
${ }^{27}$ Habermas tenta refutar este problema em sua discussão da "pragmática universal”, que Hesse não analisa. Para os principais textos sobre este tema, ver Habermas [1998].
} 
Habermas, em sua resposta a Hesse (e outros críticos), rebate vários dos pontos mencionados acima ${ }^{28}$. Mas o mais interessante aqui é que Habermas critica a tentativa de Hesse, em seus próprios escritos, de alcançar uma solução metodologicamente pluralista para as ciências sociais e naturais, afirmando que o dualismo seria mais profundo do que ela imagina:

“[Hesse] não levou suficientemente a sério a ideia central de Dilthey e Rickert. As ciências naturais também têm que lidar com problemas hermenêuticos no nível teórico, e especialmente no nível metateórico; entretanto, elas não precisam antes disso ganhar acesso a seu domínio através de meios hermenêuticos. A diferença entre o acesso do observador a um domínio de objetos fisicamente mensuráveis da perspectiva de terceira pessoa, por um lado, e o acesso a um domínio de objetos pré-estruturados simbolicamente na atitude performativa de um participante na comunicação, por outro lado, tem consequências não apenas para a técnica de pesquisa; ela afeta profundamente a lógica da investigação nas ciências objetivadoras e de compreensão de significado" [Habermas, 1982:274].

Em outras palavras, não seria possível simplesmente postular um continuum metodológico entre as ciências naturais e sociais, com casos em que as primeiras podem adotar alguns métodos das últimas e vice-versa - para Habermas, os cientistas partem de perspectivas diferentes e o acesso a seus objetos de investigação é irredutivelmente diferente $^{29}$.

Em seu último artigo sobre Habermas, Hesse enfoca a questão de qual deve ser o tipo de argumento utilizado na situação do discurso ideal, e o que significa a ideia da "força do melhor argumento", que, segundo Habermas, seria o que direcionaria a

\footnotetext{
${ }^{28}$ Não é necessário entrarmos em detalhes sobre a resposta de Habermas, já que ele não é o nosso principal foco aqui. Para interessados, ver Habermas [1982:274-278].

${ }^{29}$ Esta posição, é claro, tem consequências importantes para a análise da metodologia do próprio Habermas, cujas inclinações dualistas tendem a ser talvez mais ignoradas do que se deveria.
} 
obtenção do consenso nesta situação. Habermas liga sua teoria da argumentação à distinção de Aristóteles entre retórica, dialética e lógica. Mas o problema aqui é que, para Aristóteles, as duas primeiras estavam subordinadas à terceira, e a lógica aristotélica permitia acesso a uma verdade não-problemática através de deduções silogísticas partindo de premissas verdadeiras. Hoje em dia, tal perspectiva é fortemente questionada, como já vimos acima. Habermas reconhece essas dificuldades, mas não as resolve, e isto enfraquece sua teoria de modo geral, como Hesse afirma:

"Habermas nunca se debruçou sobre uma teoria da linguagem e da inferência que forneceria tal substituição [da teoria tradicional], e, sem ela, sua teoria puramente formal de como a racionalidade emerge em forma universal a partir do discurso ideal está vulnerável a ataques relativistas. Um Foucault ou um Derrida podem situar o 'discurso ideal' como um mero fenômeno de superfície ou 'texto' da cultura ocidental, permitindo que a elite estabelecida de mentes treinadas domine todas as conversas intelectuais" [Hesse, 1995:369].

Hesse passa a analisar então quais seriam possíveis candidatos desta forma de argumentação. O primeiro é a própria lógica analítica, mesmo depois das mudanças da filosofia pós-positivista. É neste ponto que Hesse responde à crítica de Habermas mencionada acima. E ela o faz invocando a hermenêutica dupla de Giddens como uma caracterização apropriada da diferença metodológica entre as ciências sociais e as naturais ${ }^{30}$. Entretanto, ela nota que Habermas ainda se atém à distinção entre as ciências naturais monológicas e as ciências sociais dialógicas. Mas, para Hesse, o ataque pós-

\footnotetext{
${ }^{30}$ Para Giddens, a "hermenêutica dupla" representa o fato de que os cientistas sociais, ao contrário dos naturais, precisam lidar com um mundo que já é pré-interpretado por seus sujeitos (os atores humanos). Assim, eles precisam não apenas interpretar seus "fatos" de acordo com teorias sociais, mas também interpretar os esquemas de significado através dos quais os atores conduzem suas vidas - esquemas estes que podem ser alterados como resultado da apropriação de teorias sociais pelos atores em questão. Os cientistas naturais lidam apenas com o primeiro momento hermenêutico (de aplicação de teorias para interpretar fatos que nunca são teoricamente neutros), daí a caracterização de seu método como "hermenêutica simples".
} 
positivista tende a tornar insignificante essa distinção monológico/dialógico (a distinção entre hermenêutica simples e dupla seria mais significativa). Ela identifica o seguinte problema em Habermas:

“(...) Habermas tende a chamar de 'monológicas' duas características distintas da linguagem que não estão necessariamente ligadas. Por um lado, o termo caracteriza a linguagem 'de terceira pessoa' sobre objetos que não participam do diálogo. Dentro desta linguagem, a intencionalidade não está envolvida, exceto quando for redutível a comportamento. Neste sentido, as ciências naturais permanecem no nível da primeira hermenêutica ${ }^{31}$ e, portanto, são monológicas. Mas 'monológico' também é utilizado num sentido bastante independente para caracterizar linguagens com significados unívocos, idealmente sujeitos aos requerimentos da lógica proposicional, e capazes de gerar argumentos dedutivos rigorosos" [Hesse, 1995:371-372].

É este segundo significado de "monológico" que perde seu espaço depois da crítica pós-positivista, e enquanto Habermas não resolver este problema, ele não conseguirá se libertar dos resquícios da filosofia da ciência analítica tradicional.

O segundo tipo de argumento que Hesse analisa é seu próprio argumento metafórico, exposto anteriormente - mas ela admite que ainda não temos uma teoria formal da inferência metafórica comparável às teorias tradicionais da dedução e da indução simples. A questão que Hesse coloca, então, é se seria realmente necessário termos uma teoria formal para a filosofia da inferência, especialmente agora que quase todos admitem que não precisamos de uma para a ciência teórica. Assim, como terceiro argumento, Hesse propõe que o argumento apropriado para a filosofia é "dialógico e dialético", e não monológico e dedutivo. O termo "dialética" aqui é usado "no sentido

\footnotetext{
${ }^{31}$ Aquilo que Giddens chama de "hermenêutica simples".
} 
medieval de argumentos a partir de teses e antíteses, mas sem a ênfase na lógica dedutiva" [Hesse, 1995:375].

Utilizando o exemplo das teorias que pretendem explicar os fenômenos luminosos, Hesse esquematiza o argumento dialético da seguinte forma: primeiro, temos uma tese (no caso, a teoria corpuscular da luz, enquanto interpretação analógica). A esta tese, opõe-se uma antítese (a teoria ondulatória da luz, enfatizando aspectos analógicos diferentes da primeira). Temos então um período de confronto entre a tese e a antítese, mas não focado em confirmações e falseamentos lógicos, e sim em negociações de significados teóricos e interpretações de fenômenos observados. Este debate modifica tese e antítese, mas muitas vezes as duas se deparam com um impasse, pois não chegam a um acordo sobre os limites da interpretação razoável dos dados. Este problema não pode ser resolvido apelando-se a "fatos" neutros, então o próximo passo é examinar as pressuposições compartilhadas por ambos os modelos (o que Hesse chama de "redução sintética"). No nosso exemplo, isto significa as pressuposições mecânicas da física newtoniana - o que está em questão aqui é que tipos de força são admissíveis na teoria. Agora são estas pressuposições que formam uma nova tese sobre a realidade física num nível mais profundo, e surge uma nova antítese contra ela. Se a nova tese num nível mais profundo é a mecânica newtoniana, a nova antítese é a teoria dos campos de Faraday e Maxwell, em que massa, força e movimento são substituídos pela energia elétrica, magnética e gravitacional como elementos básicos. Repetimos então os passos dialéticos com estas duas teorias, eventualmente postulando a física quântica como antítese da teoria dos campos clássica, e a física relativista como antítese da teoria clássica não-relativista, e o processo continua ininterruptamente.

Hesse afirma que este esquema se aplica não só a controvérsias científicas e argumentos cotidianos, mas também ao próprio argumento filosófico (por exemplo, 
partindo do realismo ingênuo dos séculos XVI e XVII, passando pelo positivismo, até chegarmos às diferentes formas de relativismos e realismos mais sofisticados existentes hoje). Hesse admite que seu modelo dialético é essencialmente histórico, esquecendo as pretensões universalistas de Habermas. Mas ela não acha que com isto esteja se aliando a um relativismo mais extremo nos moldes foucaultianos, pois sua dialética tem uma estrutura e se situa numa tradição (assumidamente ocidental), onde existem continuidades - ainda que através de mudanças radicais. Segundo ela, isto é o máximo a que podemos aspirar, já que é impossível admitirmos o universalismo de Habermas, que inevitavelmente está amparado nos valores iluministas ocidentais.

Podemos concluir que Hesse não desenvolve um modelo teórico completo para as ciências sociais. Mas simplesmente seu interesse nelas já revela uma transformação profunda na filosofia da ciência pós-positivista - eram raros os filósofos que se interessavam por estas disciplinas (e quando o faziam, muitas vezes adotavam um naturalismo extremo). Hesse é um excelente exemplo de como realizar abordagens interdisciplinares - de forma aberta e digna, tratando de questões relevantes mas sempre num espírito de diálogo. Talvez seja esta sutileza que tenha impedido uma absorção mais profunda de suas ideias entre cientistas sociais e filósofos que estudam esta área. Sua obra mais decisiva, SSI, é considerada como inacessível demais para as peculiaridades das ciências sociais (Jordão Nunes [2005:337] percebe isto com clareza. Eu exponho uma posição alternativa no capítulo final), mas eu acredito que uma reavaliação mais aprofundada de seus escritos sobre as ciências sociais, e especialmente de seus refinamentos da teoria da metáfora e da argumentação dialética, poderia ser bastante frutífera para estudiosos da teoria e metodologia das ciências sociais. 


\section{Roy Bhaskar: realismo e ontologia}

I

Nascido em Londres em 1944, a formação de Roy Bhaskar é mais estritamente filosófica que a de Hesse. Em Oxford, ele se graduou num curso interdisciplinar de filosofia, política e economia, posteriormente desenvolvendo seu doutorado sobre a relevância da teoria econômica para países subdesenvolvidos (projeto que ele não chegou a completar). Este tema o levou para a filosofia das ciências sociais, sob orientação do filósofo neozelandês Rom Harré.

Bhaskar lecionou nas universidades de Oxford, Edimburgo, Sussex e na City University de Londres. Ele se tornou conhecido como fundador da escola filosófica do "realismo crítico". Os textos básicos desta escola são exatamente os que nos interessam aqui (em relação ao instrumental de investigação para analisarmos Anthony Giddens): $A$ Realist Theory of Science [Uma teoria realista da ciência; Bhaskar, 1997 (a primeira edição é de 1975, doravante $R T S$ )], seu primeiro livro, onde ele propõe sua interpretação da filosofia da ciência; e The Possibility of Naturalism [A possibilidade do naturalismo; Bhaskar, 1979 (doravante $P N)$ ], onde ele estende a aplicação de sua teoria para as ciências sociais. O termo "realismo crítico" é um amálgama criado pelos seguidores de Bhaskar, misturando seu "realismo transcendental", desenvolvido em RTS com o “naturalismo crítico" de $P N^{32}$. Nos anos 1990, seus escritos começaram a enfocar mais a ideia da dialética, um passo que desagradou alguns de seus primeiros seguidores. Mais

\footnotetext{
32 Não me parece coincidência que o amálgama enfatize os termos relativamente não-problemáticos nestes conceitos (ou, talvez, os termos mais vistos como "desejáveis"), descartando as conotações mais negativas associadas com "transcendental" e "naturalismo".
} 
recentemente, Bhaskar parece estar passando por um "giro espiritual", tratando de questões espirituais e teológicas naquilo que chama de "filosofia da metarrealidade".

Bhaskar, diferente da maioria dos filósofos, empenhou-se ativamente na constituição de uma escola ${ }^{33}$, juntando os intelectuais interessados em seus escritos ao redor de si, e promovendo seminários e conferências dedicados à discussão do realismo crítico e sua expansão para outras disciplinas (como a economia, a biologia e a política). Em 1996, ele foi um dos membros fundadores do Centro do Realismo Crítico, e em 1997 também fundou a Associação Internacional do Realismo Crítico (IACR, na sigla em inglês), que edita o Journal of Critical Realism, a revista oficial da escola, e realiza uma conferência anual em universidades ao redor do mundo ${ }^{34}$. Hoje Bhaskar trabalha em tempo integral nestas duas entidades.

II

A distinção mais fundamental que Bhaskar apresenta é entre o que ele chama de dimensões intransitiva e transitiva do conhecimento. O conhecimento intransitivo é aquele que independe dos seres humanos: "os objetos intransitivos do conhecimento são de modo geral invariantes em relação ao nosso conhecimento deles: eles são as coisas e estruturas, mecanismos e processos, eventos e possibilidades reais do mundo, e em sua maioria eles são bastante independentes de nós" [RTS:22]. A dimensão transitiva é aquela da produção do conhecimento realizada por seres humanos, e esta produção depende do conhecimento anterior que possuímos. No fundo, podemos associar a

\footnotetext{
${ }^{33}$ Segundo Bhaskar, isto ocorreu porque seus seguidores eram "marginalizados" no mundo acadêmico. Ver a entrevista de Norris [1999].

34 A Conferência Anual da IACR em 2009 aconteceu na Universidade Federal Fluminense. Ver http://www.uff.br/iacr/ (acessado em 30/03/2010).
} 
dimensão intransitiva de Bhaskar a algo como a sincronia, e a dimensão transitiva à diacronia.

Com isto, Bhaskar pode propor o seu argumento básico em RTS:

“A resposta da pergunta transcendental 'como o mundo precisa ser para que a ciência seja possível?' merece o nome de ontologia. E, ao mostrar que os objetos da ciência são intransitivos (...) e de um certo tipo, a saber, estruturas e não eventos, minha intenção é fornecer uma ontologia para a nova filosofia da ciência (...). Qualquer filosofia da ciência adequada precisa ser capaz de sustentar e reconciliar ambos os aspectos da ciência; quer dizer, mostrar como a ciência, que é um processo transitivo, dependente do conhecimento anterior e da atividade eficiente dos homens, tem objetos intransitivos que não dependem disso. (...) Ela precisa satisfazer (1) um critério da produção nãoespontânea do conhecimento, a saber, a produção do conhecimento a partir e através do conhecimento (na dimensão transitiva), e (2) um critério de realismo estrutural e essencial, a saber, a existência e atividade independentes de estruturas causais e coisas (na dimensão intransitiva" [RTS:23-24].

Segundo Bhaskar, existem três tradições da filosofia da ciência. A primeira é o empirismo clássico de Hume e dos positivistas, onde os objetos do conhecimento são eventos atomísticos, e a ciência é um tipo de resposta automática ao estímulo de fatos dados e suas conjunções, que são consideradas necessárias e suficientes para a operação de uma lei causal. A segunda é o idealismo transcendental de Kant, cujos objetos do conhecimento são modelos ideais, construtos artificiais que não são independentes dos seres humanos, e as conjunções destes modelos ainda são consideradas necessárias, mas não suficientes, para a causalidade. A terceira é o realismo transcendental que Bhaskar propõe. Aqui os objetos do conhecimento são as estruturas e mecanismos que geram fenômenos, e o conhecimento produzido na atividade social da ciência - o empirismo 
não consegue dar conta nem da dimensão transitiva nem da intransitiva do conhecimento, e o idealismo transcendental não inclui a dimensão intransitiva. Para o realismo transcendental, uma conjunção constante de eventos não é nem necessária nem suficiente para pressupormos a operação de uma lei causal.

O empirismo clássico e o idealismo transcendental não conseguem captar a dimensão intransitiva do conhecimento porque eles compartilham da ontologia do "realismo empírico" (que Bhaskar quer negar em favor de seu realismo transcendental $\left.{ }^{35}\right)$ :

"Para o realista transcendental, este conceito incorpora uma sequência de erros filosóficos relacionados. O primeiro consiste no uso da categoria de experiência para definir o mundo. Isto envolve dar uma função ontológica geral a algo que, com efeito, é um conceito epistemológico particular. $O$ segundo consiste na visão que ser experimentado ou experimentável é uma propriedade essencial do mundo, quando isto deveria ser concebido mais corretamente como uma propriedade acidental de algumas coisas (...). O terceiro então consiste na negligência das circunstâncias (socialmente produzidas) sob as quais a experiência é de fato epistemicamente significativa na ciência" [RTS:28].

A partir disto, Bhaskar afirma a impossibilidade da neutralidade ontológica numa teoria da ciência. Este compromisso ontológico é condicional: a questão, mais uma vez, é o que precisa existir para que a ciência seja possível. Assim, "não é necessário que a ciência ocorra. Mas já que ela ocorre, é necessário que o mundo seja de uma de certa forma" [RTS:29]. O papel do realista transcendental, enquanto filósofo, é afirmar que o fato de que o mundo é estruturado e diferenciado pode ser estabelecido

\footnotetext{
${ }^{35}$ Fica claro então que "realismo transcendental" é um termo tanto epistemológico (em oposição ao empirismo clássico e ao idealismo transcendental) quanto ontológico (em oposição ao realismo empírico).
} 
através da argumentação filosófica (mas as estruturas particulares do mundo são questões para a investigação científica).

O principal problema com a ontologia empirista é que ela pressupõe sistemas fechados de experimentação, já que conexões causais só podem ser estabelecidas a partir da experiência. A nova filosofia da ciência já afirmou que nossa interferência ativa na natureza é uma condição das regularidades empíricas que experimentamos mas Bhaskar diz que precisamos ir mais longe e perceber uma distinção ontológica entre a regularidade empírica que produzimos e a lei causal que ela permite que identifiquemos. Reconhecendo isto, podemos admitir que leis causais continuam a operar em sistemas abertos - o que quer dizer, no universo inteiro fora das condições controladas de experimentos científicos. Para Bhaskar, esta ênfase do empirismo na experiência é um exemplo de antropocentrismo.

Bhaskar introduz então o que chama de "falácia epistêmica", a ideia de que “enunciados sobre o ser podem ser reduzidos ou analisados em termos de enunciados sobre o conhecimento" [RTS:36] - fica claro que este é o principal problema com o empirismo clássico. Uma objeção possível a esta posição de Bhaskar seria afirmar que a ontologia depende da epistemologia, porque aquilo cuja existência podemos conhecer é apenas uma parte daquilo que podemos conhecer. Esta é a resposta que ele oferece:

"Esta defesa se aproveita de uma combinação tácita de ontologias filosóficas e científicas. (...) Uma ontologia filosófica é desenvolvida através da reflexão sobre o que precisa existir para a ciência ser possível; e isto é independente de qualquer conhecimento científico efetivo. (...) O conhecimento vem depois da existência, na lógica e no tempo; e qualquer posição filosófica que negue isto implícita ou explicitamente está virada pelo avesso" [RTS:39]. 
Uma consequência do argumento de Bhaskar é que, se é impossível reduzir a ontologia à epistemologia, então mesmo uma epistemologia (como a empirista) que negue a ontologia precisa ter uma ontologia implícita (e um realismo implícito).

Depois de "vingar" a ontologia, como Bhaskar explica sua concepção de "lei causal"? Ele postula entidades que chama de "mecanismos geradores" - para o idealismo transcendental, uma "fantasia irredutível da imaginação" imposta pelo homem sobre o padrão de eventos; para o realista transcendental, algo que pode ser estabelecido como real durante a atividade científica. É preciso pressupor que as "leis causais" analisadas por cientistas experimentais perduram fora do ambiente controlado criado pelo experimento, e para isto elas não podem ser idênticas à conjunção de eventos observada no experimento. Bhaskar introduz aqui uma distinção entre estruturas e mecanismos "reais" [real] que geram padrões de eventos "efetivos" [actual]. Daí sua descrição dos mecanismos geradores:

"O mundo consiste de mecanismos, não de eventos. Tais mecanismos se combinam para gerar o fluxo de fenômenos que constituem os estados e acontecimentos efetivos do mundo. Pode-se dizer que eles são reais, mas é raro que eles se manifestem efetivamente e ainda mais raro que eles sejam identificados empiricamente pelos homens. Eles são independentes dos homens - como pensadores, agentes causais e focos da percepção. É possível conhecê-los, mas o conhecimento deles depende de uma mistura rara de habilidades intelectuais, prático-técnicas e perceptivas. Eles não são construtos artificiais. Mas também não são formas platônicas. Pois eles podem se manifestar aos homens na experiência. Assim, não estamos presos em cavernas (...). Não estamos condenados à ignorância. Mas também não somos espontaneamente livres. Esta é a tarefa árdua da ciência: a produção do conhecimento daqueles mecanismos da natureza persistentes e continuamente ativos que produzem os fenômenos de nosso mundo" [RTS:47]. 
Nossas "leis causais", então, são o resultado da operação destes "mecanismos geradores", enquanto agentes causais. E estes agentes causais possuem tendências que eles podem exercer ou não - é preciso enfatizar que o que importa aqui são estas tendências, e não o poder causal em $\mathrm{si}^{36}$. Bhaskar chama estas tendências de "nórmicas". De qualquer forma, fica claro que para Bhaskar leis não são o que realmente lhe interessa - seu foco é nos "mecanismos geradores". O debate sobre leis serve primariamente para derrubar o empirismo clássico e sua ontologia realista empírica e determinista. E neste caso, é bom notar que Bhaskar não afirma que o empirismo clássico está totalmente equivocado - ele funciona direito quando há o que ele chama de "fechamento", ou seja, um ambiente experimental controlado onde cientistas podem isolar um ou mais eventos que desejam analisar. O problema é que tais fechamentos não ocorrem naturalmente, sendo então uma minoria ínfima do universo, e os empiristas não teriam ferramentas para conseguir transportar satisfatoriamente suas conclusões obtidas em sistemas fechados para os sistemas abertos, onde ocorre a verdadeira prática humana.

Continuando sua "revolução copernicana" da filosofia da ciência, Bhaskar passa para a questão da estratificação do mundo, cuja captura ele considera o movimento essencial da ciência enquanto atividade social. Para isto, ele propõe sua "lógica da pesquisa científica" ${ }^{37}$, que, segundo ele, é dialética:

"Existe assim na ciência um tipo característico de dialética em que uma regularidade é identificada, uma explicação plausível para ela é inventada, e a realidade das entidades e processos postulados na explicação é então conferida. (...) Se a tradição empirista clássica se detém no primeiro passo, a tradição neokantiana enxerga a

\footnotetext{
${ }^{36}$ Outra consequência disto é que leis, para Bhaskar, não são enunciados preditivos, já que se referem apenas a tendências cuja realização ou não é totalmente contingente - mas elas são explicativas, normalmente através de "retrodições".

${ }^{37}$ Em inglês, "logic of scientific discovery", uma referência direta à famosa obra de Karl Popper.
} 
necessidade do segundo. Mas ela ou nega a possibilidade, ou não desenvolve as implicações (realistas transcendentais) completas do terceiro passo. Se e somente se tomarmos o terceiro passo é possível haver uma justificativa adequada para o uso de leis para explicar fenômenos em sistemas abertos (...) ou para o estabelecimento experimental desse conhecimento" [RTS:145].

O segundo passo, tanto para o idealismo transcendental quanto para o realismo transcendental, consiste na construção de um modelo em que imaginamos um mecanismo gerador (ou mais) para o fenômeno em questão. A diferença é que para os idealistas este modelo sempre será imaginário, enquanto para os realistas ele pode ser real, e pode ser estabelecido enquanto tal. Daí a passagem realista para o terceiro passo, que seria a tarefa da ciência: descobrir quais modelos explicativos imaginados são reais.

Para Bhaskar, a filosofia da ciência pós-empirista conseguiu estabelecer a pobreza de uma análise dedutivista da explicação e o fato da mudança científica, mas ela permanece vulnerável a contra-ataques positivistas porque compartilha da mesma ontologia implícita do empirismo:

“A diferença geral entre a filosofia da ciência recente e o realismo transcendental pode ser resumida dizendo que, enquanto a filosofia recente perguntou apenas quais são as condições da possibilidade da experiência individual e encontrou uma resposta no mundo intersubjetivo da ciência, o realismo transcendental pergunta, além disso, quais são as condições da possibilidade da atividade social da ciência, encontrando uma resposta no mundo intransitivo das coisas" [RTS:147].

Ou seja, segundo Bhaskar sua teoria é a única que desenvolve uma "sociologia filosófica" que dá conta do caráter social da ciência. Mas, antes disso, ele precisa explicar o que entende por “estratificação da realidade". Esta estratificação é uma hierarquia de explicações, partindo de eventos observáveis para mecanismos cada vez 
mais profundos. Ele oferece o exemplo da química: uma reação observável expressa através de uma fórmula, como $2 \mathrm{Na}+2 \mathrm{HCl}=2 \mathrm{NaCl}+\mathrm{H}_{2}$, representa o primeiro estrato da realidade, que é explicado através de referência às teorias do número atômico, da valência, e das ligações químicas, que formam o segundo estrato. Estas são explicadas através de teorias eletrônicas da estrutura atômica, o terceiro estrato, que por sua vez é explicado através de várias teorias rivais sobre a estrutura subatômica. É neste ponto que a ciência está agora, tentando estabelecer a realidade de um destes mecanismos (representados pelas teorias divergentes). Quando isto ocorrer, ela passará a buscar um estágio mais fundamental, e assim por diante ${ }^{38}$. Segundo Bhaskar, esta estratificação da realidade é necessária para entendermos a própria estratificação das ciências. E é através deste processo dialético que podemos falar de progresso científico (não indutivo).

O argumento básico de Bhaskar quanto ao caráter social da ciência é que o conhecimento nunca é criado a partir do nada, e sim sempre a partir de conhecimento prévio (na terminologia aristotélica que ele usa, o conhecimento é a causa material do conhecimento $^{39}$ ) - e esta transferência é uma atividade social. Isto é afirmado em contraposição à perspectiva empirista, onde o conhecimento surge a partir da experiência, que pode ser analisada individualmente (e sugere um individualismo epistemológico presente na base do empirismo). Para Bhaskar, a "sociologia filosófica" consiste:

"numa resposta para a pergunta: o que a sociedade precisa ser se a ciência (enquanto um tipo específico de atividade social) quiser ser possível? Ela precisa

\footnotetext{
${ }^{38}$ Ele também afirma que, para este processo ocorrer, as teorias precisam ser compreendidas antes de estabelecermos regras de correspondência entre os estratos, invertendo o procedimento empirista.

39 “Conceber a ciência como trabalho a prepara facilmente para uma esquematização aristotélica. A causa material é o conhecimento, fatos e teorias estabelecidos anteriormente; a causa eficiente é o paradigma metodológico ou teoria geradora em operação na atividade teórica e experimental dos homens; a causa formal é novo conhecimento, fatos e teorias; e a causa final o conhecimento dos mecanismos duradouros (...) da natureza" [RTS:194].
} 
satisfazer os requerimentos de ser uma estrutura irredutível a seus efeitos, mas presente apenas neles. Podemos saber que a sociedade existe, mas não mostrar que ela existe. Ela existe apenas em virtude da atividade intencional dos homens, mas não é o resultado (nem a causa) de sua atividade intencional. (...) A sociedade não se preocupa com massas de indivíduos nem com o comportamento de massas, mas sim com as relações persistentes entre indivíduos" [RTS:195-196].

É isto que Bhaskar chama de "revolução newtoniana" da sociologia. Ele usa a metáfora da linguagem, algo que existe previamente aos seres humanos mas que depende deles para sua reprodução para explicar sua concepção de sociedade ${ }^{40}$. Mas em $R T S$ ele não vai muito além disso - sua teoria das ciências sociais só será desenvolvida mais profundamente em seu próximo livro.

Bhaskar também aplica seu realismo transcendental ao problema da indução. Para ele, a solução é muito simples:

“A indução é justificada porque a natureza é estratificada. Ora, nós não precisamos saber quais são as estruturas para saber que a natureza é estratificada. (Nós não precisamos saber qual é a explicação para saber que há uma explicação.) Nós sabemos que a natureza é estratificada porque sua estratificação é uma condição da possibilidade da ciência-em-geral. E nós sabemos que a ciência é possível porque ela de fato ocorre. Para saber que a indução é justificada, não precisamos saber o que qualquer explicação em particular é" [RTS:219-220].

Ou seja, para Bhaskar a indução é justificada porque a ideia de que alguma observação futura pode mudar a natureza de alguma coisa simplesmente é inconcebível em seu esquema. Como ele próprio diz, se em algum momento do futuro a água congelar ao ser fervida, em vez de esquentar, então esta entidade que congelou não é

\footnotetext{
${ }^{40}$ A mesma metáfora utilizada por Giddens em várias ocasiões, e que causou a ele uma certa dor de cabeça ao precisar explicar que a sociedade não é "como uma linguagem".
} 
mais água (e sim um outro "mecanismo gerador" em algum nível da estratificação do mundo que precisa ser investigado por cientistas).

III

Em A possibilidade do naturalismo, Bhaskar oferece a primeira parte de sua concepção das ciências sociais $^{41}$. O naturalismo, segundo a tipologia de Oliveira Filho [1995:264], é uma subclasse do reducionismo, patologia metodológica que consiste em adotar os procedimentos de um conjunto de disciplinas (ou corrente metodológica) como modelo para todas as disciplinas (e correntes metodológicas). A versão naturalista desta patologia é a mais comum, definida como a afirmação de que os procedimentos das ciências naturais devem ser o modelo também das ciências sociais e formais. Seus defensores mais tradicionais são os pensadores influenciados pelo positivismo. Em oposição a esta patologia, temos uma outra: o dualismo metodológico, que postula que os métodos das ciências sociais não apenas são irredutíveis aos das naturais, mas que também não há nenhuma interseção entre eles. A solução para este dilema, segundo Oliveira Filho, é o desenvolvimento de uma posição pluralista, que consiga dar conta das evidências históricas de interação entre as ciências: "As ciências empíricas naturais, as ciências sociais e as ciências formais possuem regras metodológicas diferenciadas e comuns; características de técnicas e de métodos e características lógicas e epistemológicas que se manifestam na construção e teste das teorias e na geração das diferentes formas de explicação científica, causais e teleológicas" [Oliveira Filho, 1995:268].

\footnotetext{
${ }^{41}$ A segunda parte é o livro Scientific Realism and Human Emancipation, de 1987, fora do escopo deste ensaio.
} 
Bhaskar chama o dualismo simplesmente de "antinaturalismo", e o identifica com a corrente hermenêutica das ciências sociais. Sua definição de "naturalismo" também é diferente:

"O naturalismo pode ser definido como a tese de que há (ou pode haver) uma unidade de método essencial entre as ciências naturais e as sociais. Ele deve ser distinguido imediatamente de duas espécies dele: o reducionismo, que afirma que também há uma identidade efetiva dos domínios de investigação; e o cientismo, que nega que existam quaisquer diferenças significativas nos métodos apropriados para estudar objetos sociais e naturais" $[P N: 3]$.

Para Bhaskar, o problema tanto do naturalismo positivista quanto da hermenêutica antinaturalista é pressuporem uma concepção positivista das ciências naturais, incluindo uma ontologia positivista. O erro básico da hermenêutica é simplesmente inverter o positivismo. Sua proposta, como o próprio título " $A$ possibilidade do naturalismo" já sugere, é:

“(...) um naturalismo antipositivista qualificado, baseado numa visão da ciência essencialmente realista. Tal naturalismo afirma que é possível uma concepção da ciência que abranja os métodos apropriados e mais ou menos específicos tanto das ciências naturais quanto das sociais. Mas ele não nega que existam diferenças significativas nestes métodos, baseadas em diferenças reais em seus domínios de investigação e nas relações que suas ciências entabulam com eles" $[P N: 3]$.

Ou seja, segundo a tipologia de Oliveira Filho, Bhaskar supostamente defende uma posição pluralista. Mais tarde veremos que este não é exatamente o caso. Também é bom notar que, apesar de sua definição, Bhaskar imediatamente transfere o problema 
metodológico do naturalismo para os níveis epistemológico ${ }^{42}$ e ontológico - seu argumento básico em $P N$ é apenas uma variação de seu argumento transcendental em RTS. Se em seu primeiro livro ele pergunta como deve ser o mundo para que a ciência (natural) seja possível, em $P N$ a pergunta é como deve ser o mundo para que a ciência social seja possível - mais especificamente, que propriedades sociedades e pessoas precisam ter para se tornarem objetos do conhecimento para nós.

Ao falar de sociedades, o primeiro ataque de Bhaskar é contra o individualismo metodológico. Sua crítica não difere muito das acusações mais comuns a esta doutrina: ela estaria ligada a uma ideologia liberal utilitarista, pressupondo o ser humano como uma unidade racional em busca da maximização de seus interesses, incapaz de conceber relações sociais ou coletividades. Bhaskar, como vimos anteriormente, afirma que o objeto da sociologia é o estudo de relações sociais. Ele busca, assim, evitar não apenas uma concepção individualista da sociologia (que ele identifica com o utilitarismo e também a tradição weberiana, devido ao conceito de "tipo ideal"), mas também concepções coletivistas, que enfatizam grupos e coletividades (a tradição durkheimiana). Encaixando estes autores numa tipologia que também leva em consideração o "método" empregado por eles, chegamos a este quadro: utilitarismo empirista e individualista; a tradição weberiana neokantiana (idealista transcendental, na classificação anterior de Bhaskar) e individualista; Durkheim empirista e coletivista. A isto, Bhaskar adiciona Marx, que seria o único que anteviu não só uma sociologia relacional, mas também uma ontologia realista ${ }^{43}$.

\footnotetext{
42 "Afirmar uma unidade essencial do método científico é afirmar uma concepção que considera as ciências unificadas na forma em que o conhecimento científico assume" [ $P N: 24]$. Bhaskar está fundindo o nível metodológico e o epistemológico. Mesmo que a forma do conhecimento seja igual, isto não significa que o processo de investigação e as linguagens metateóricas também o sejam.

${ }^{43}$ Bhaskar aqui mistura mais uma vez a metodologia com a ontologia. Ele classifica o método marxiano como realista em sua tipologia, embora afirme que "eu acho que Marx tentou combinar uma ontologia realista e uma sociologia relacional" $[P N: 39]$. Para ele, a ontologia "baseia" a epistemologia.
} 
A partir disto, Bhaskar trata de como a relação entre indivíduo e sociedade é concebida na teoria social. Ele mais uma vez postula duas posições opostas: o "voluntarismo weberiano", onde "objetos" sociais são criados por indivíduos, e a "reificação durkheimiana", onde os objetos teriam vida própria. Ele rejeita ambos estes extremos, mas também rejeita a posição "dialética" surgida mais recentemente, onde se afirma, resumidamente, que a sociedade forma os indivíduos que criam a sociedade (o exemplo que ele utiliza é a teoria de Peter Berger, mas vale notar que a posição de Giddens, nestes termos, é razoavelmente semelhante). Para Bhaskar, apesar deste modelo não conter reificações, seu problema é que ele não escapa de gerar uma objetivação da sociedade (citando Berger, "quando o homem estabelece uma distância de sua produção e de seu produto, para que possa fazer dele um objeto de sua consciência" $[P N: 41])$ - e ao fazer isto ele cai tanto numa interpretação voluntarista da estrutura social quanto numa interpretação determinista das pessoas. Bhaskar deseja afirmar que a sociedade é um objeto que existe antes dos seres humanos, por isso ele nota que não criamos a sociedade, e sim a reproduzimos e transformamos. E toda atividade humana depende de formas sociais pré-existentes. Bhaskar chama isto de "modelo transformacional da atividade social":

“(...) tanto a sociedade quanto a práxis humana precisam possuir um caráter duplo. A sociedade é ao mesmo tempo a condição (causa material) sempre presente e o resultado continuamente reproduzido da ação humana. E a práxis é ao mesmo tempo trabalho, quer dizer, produção consciente, e reprodução (normalmente inconsciente) das condições de produção, quer dizer, sociedade" [PN:44-45].

Bhaskar chama este primeiro eixo de seu modelo de "dualidade da estrutura", invocando explicitamente o conceito de Giddens. O segundo eixo recebe o nome de "dualidade da práxis". 
Com isto, Bhaskar pode conceber as estruturas sociais como os mecanismos geradores da atividade social. Só que imediatamente aparecem limitações à sua analogia com os mecanismos geradores do mundo físico - estruturas sociais não existem independentemente das atividades que governam; não existem independentemente das concepções dos atores daquilo que estão fazendo em suas atividades; e podem ser apenas relativamente duradouras. Estas três condições colocam limites ontológicos ao naturalismo. A estes limites ontológicos, devemos adicionar um epistemológico: é impossível encontrarmos um sistema social fechado, por isso a experimentação em ambientes controlados que encontramos nas ciências naturais não ocorre nas sociais. Para Bhaskar, isto automaticamente invalida qualquer tentativa de aplicação da causalidade humeana às ciências sociais, e também as teorias hermenêuticas que se colocam em contraste a ela. A principal consequência deste limite epistemológico é que as ciências sociais precisam ser explicativas e não-preditivas. $\mathrm{O}$ último limite ao naturalismo que Bhaskar reconhece é metodológico, tratando das possibilidades de mensuração nas ciências sociais, que não se preocupam com uma mensuração precisa, e sim com a precisão dos significados que analisam, um processo linguístico.

Para Bhaskar, seu modelo transformacional da atividade social impõe uma sociologia relacional. Com isto ele quer dizer que o interesse da sociologia está no sistema de mediação da dualidade da práxis - as posições que os indivíduos assumem para a produção e reprodução da sociedade, e as práticas que eles desempenham nestas posições. Este é o "sistema de posições-práticas". Segundo Bhaskar, este interesse relacional da sociologia é a característica que a distingue das outras ciências sociais. Mais uma vez, Marx teria previsto tanto este caráter relacional da sociologia quanto o modelo transformacional da atividade social - com um porém: a premissa do 
materialismo histórico de que a produção material determina o resto da vida social, que Bhaskar rejeita.

Se as ciências sociais não contam com um sistema fechado adequado para experimentos, há algo que preenche, até certo ponto, uma função análoga. Nas ciências naturais, o fechamento serve para os cientistas isolarem os mecanismos geradores em que estão interessados. Nas ciências sociais, períodos de transição ou crise podem tornar as estruturas geradoras mais visíveis para os cientistas: "assim, certamente não é um acidente que o marxismo tenha nascido nos anos 1840, e que tenha definhado sob os efeitos combinados do stalinismo, por um lado, e do fascismo, a Guerra Fria e a expansão de 1945-70, pelo outro" [PN:61]. Mas o fato das ciências sociais não serem preditivas significa que sua teoria é necessariamente incompleta. Esta desvantagem é contrabalançada quando notamos que os cientistas sociais trabalham com atividades sociais dependente de conceitos por natureza, e por isso seus fenômenos quase sempre já estão identificados de antemão. Assim, a questão mais importante para as ciências sociais não é fornecer uma hipótese causal, e sim como chegar a uma definição real do fenômeno em jogo. O procedimento que Bhaskar defende, como era de se esperar, é o uso de argumentos transcendentais - mas, ao contrário dos argumentos filosóficos "formais" que ele apresentou em RTS, aqui tratamos de argumentos transcendentais "substantivos". O exemplo, mais uma vez, é Marx:

“A análise de Marx no Capital ilustra o uso substantivo de um procedimento transcendental. Pois eu acho que a forma mais plausível de enxergar o Capital é como uma tentativa de estabelecer o que deve ser o caso para que as experiências compreendidas pelas formas fenomenais da vida capitalista sejam possíveis; estabelecer, por assim dizer, um esquema puro para a compreensão de fenômenos econômicos sob o 
capitalismo, especificando as categorias que precisam ser empregadas em qualquer investigação concreta" $[P N: 65]$.

Isto, para Bhaskar, confirma a possibilidade do naturalismo para as ciências sociais, já que sociedades também são mecanismos geradores intransitivos que podem ser compreendidos por cientistas sociais. A partir deste ponto, ele se volta para a questão dos valores. Ele deseja negar tanto que os fatos não seriam afetados por valores (o que, obviamente, é um dos principais temas de toda a filosofia da ciência póspositivista), quanto que os valores não seriam afetados pelos fatos (através de uma crítica da ideologia).

É neste ponto que encontramos a principal crítica direta de Bhaskar a Giddens. Bhaskar quer estabelecer que sua visão das ciências sociais não apenas é inerentemente crítica, como também inerentemente anticonservadora. Assim, ele se opõe à noção de Giddens de "conhecimento mútuo", esquemas interpretativos básicos utilizados pelos atores para dar sentido à sua vida social. Enquanto esquemas básicos, para Giddens eles não são corrigíveis pelas descobertas das ciências sociais (já que, segundo a hermenêutica dupla, os cientistas também compartilham deste conhecimento mútuo para poderem fazer parte de suas próprias sociedades) - ao contrário do "senso comum", conhecimento teórico vindo de diversas fontes que é disseminado na sociedade, e que pode ser (e é) revisado. Bhaskar se recusa a aceitar qualquer tipo de conhecimento social que não possa ser mudado através da ciência social. E, segundo ele, isto invalida qualquer pretensão crítica da teoria de Giddens:

"Pois apesar de um escravo que compreende completamente as circunstâncias de sua própria subordinação não se libertar apenas por causa disso, tal entendimento é uma condição necessária para sua autoemancipação racional. Inversamente, seu mestre tem um interesse em que ele permaneça ignorante das circunstâncias de sua escravidão. $O$ 
conhecimento é assimetricamente benéfico para as partes envolvidas em relações de dominação. Além do mais, de forma geral, o conhecimento explicativo aumenta o conjunto de possibilidades conhecidas, e assim, ceteris paribus, altera o 'equilíbrio de forças ideológicas' contra o conservadorismo e o status quo (...). Assim, é bastante incorreto considerar [como Giddens] a ciência social igualmente tanto 'um instrumento potencial de dominação' quanto 'da expansão da autonomia racional da ação'” [PN:98].

No capítulo seguinte, Bhaskar, tendo estabelecido que as sociedades não são reduzíveis a pessoas, e, assim, são objeto de conhecimento possível para nós, passa a analisar as próprias pessoas - ou seja, a ação. Neste caso, ele quer demonstrar a possibilidade da psicologia, e do naturalismo nesta disciplina. Para isto, ele precisa demonstrar que seres humanos também são mecanismos geradores, e, assim, o foco principal de sua investigação é analisar se razões podem ser causas:

"Eu afirmarei que o comportamento humano intencional é causado, e que é sempre causado por razões, e que é apenas porque ele é causado por razões que podemos caracterizá-lo adequadamente como intencional. O ator (...) pode ou não ter consciência das razões que causam seu comportamento intencional" [PN:103].

Bhaskar, como Giddens, caracteriza a ação como um fluxo contínuo de intervenção no mundo, sujeito à monitoração reflexiva, e que só pode ser dividido em "atos" intencionais ou não analiticamente. Seu argumento para justificar que razões podem ser causas afirma que esta é a única forma possível para diferenciarmos as coisas que fazemos das coisas que acontecem conosco, ou seja, distinguir nossa atividade dos efeitos que recebemos passivamente.

Mais que isso, Bhaskar sugere que precisamos distinguir razões reais de razões possíveis para que o discurso seja possível, e que "esta distinção só pode ser explicada em termos da eficácia causal de razões reais" [PN:115]. Razões reais são definidas, não 
sem uma certa circularidade, como "uma razão possuída por algum ator $X$ em $t$ que foi causalmente eficaz na produção do comportamento de $X$ em $t^{\prime \prime}[P N: 117]$. Estas razões, para Bhaskar, precisam ser analisadas como tendências (possuídas pelos atores, mas que podem ser exercidas ou não), assim como a causalidade natural. É por isto que Bhaskar afirma que a psicologia também é naturalista. E se os seres humanos são mecanismos geradores da mesma forma que os mecanismos geradores do mundo natural, isto permite a Bhaskar defender o que chama de "materialismo sincrônico de poderes emergentes" - nós somos coisas providas de crenças (razões) para nossas possíveis ações - em contraposição ao "materialismo de estado central" (que reduz a mente à matéria) e ao behaviorismo.

Com as bases de seu modelo expostas, Bhaskar parte então para a refutação das filosofias da ciência social: o positivismo e a hermenêutica. O positivismo, nas ciências sociais, parte da pressuposição que sua versão das ciências naturais é adequada, e busca aplicá-la de alguma forma para as ciências sociais - o que normalmente leva a um debate sobre como devem ser as explicações nestas ciências. Isto, para Bhaskar, se reflete no enfraquecimento do modelo hipotético-dedutivo de explicação, que os positivistas são forçados a adaptar para uso nas ciências sociais, acomodando explicações estatísticas, indutivas, probabilísticas, parciais, elípticas, e assim por diante. Ou eles podem admitir que as invariâncias empíricas na vida social são complexas demais (ou que elas operam num nível mais básico, normalmente neurofisiológico). Mas nada disto serve para redimir o positivismo, já que ele sempre permanece incapaz de lidar nem com o fato de que o mundo é um sistema aberto, nem com o caráter histórico das leis sociais.

Passando para a análise da hermenêutica, Bhaskar enfoca basicamente um autor: Peter Winch, e seu clássico A ideia de uma ciência social [Winch, 2008], de 1958. 
Como a própria data do livro sugere, a obra de Winch foi uma das primeiras a aplicar uma filosofia de cunho hermenêutico (no caso de Winch, inspirada pelo Wittgenstein das Investigações filosóficas) para a teoria e filosofia das ciências sociais. Como era de se esperar, Winch foi analisado por muitos outros pensadores preocupados em examinar a tradição interpretativa das ciências sociais - incluindo Habermas [1988] e o próprio Giddens [1993]. O tratamento de Bhaskar não difere muito destas análises, tirando, é claro, sua ênfase em caracterizá-lo como um antirrealista: "formalmente, a obra de Winch pode ser considerada como constituída pela conjunção de um idealismo transcendental transposto linguisticamente e elementos de um romantismo ou expressivismo social e epistemológico menos rigoroso" [PN:170]. Se Bhaskar busca um naturalismo, o argumento de Winch vai na direção oposta: para ele, o método das ciências sociais e da filosofia é o mesmo, assim como sua categoria central - um método conceitual para análise do significado, em contraposição às ciências naturais, cujo método empírico analisa a causalidade.

A refutação de Bhaskar segue caminhos familiares: primeiro, ele mostra que a hermenêutica de Winch depende da aceitação tácita de uma ciência natural positivista. Depois, ele rejeita o foco de Winch na ação, reafirmando que o objeto próprio da sociologia são as relações sociais. Bhaskar identifica o problema de Winch em seu critério linguístico de significado - como Bhaskar sempre enfatiza que os objetos sociais são reais e intransitivos, ele não pode aceitar a ideia de que nossa linguagem restringe aquilo que podemos conhecer e interpretar: "não há nem identidade nem homologia entre aquilo que é real e aquilo que é conhecível, ou dizível: os limites da linguagem não são os limites do mundo" [PN:182]. Bhaskar também precisa negar que a causalidade não possa ser aplicada no mundo social, como Winch defende. Assim, ele mostra que o comportamento seguidor de regras (o modelo de Winch) pressupõe a 
causalidade - pois esta é a diferença entre alguém que segue uma regra e alguém que não o faz (seguir uma regra, para Bhaskar, significa que a regra causa a ação).

Depois de despachar Winch, Bhaskar passa para o resto da tradição hermenêutica. Ele reconhece três realizações importantes da hermenêutica: o caráter pré-interpretado da realidade social, o caráter que sempre contém pressuposições da investigação social, e o caráter indéxico das expressões usadas na linguagem ordinária e na linguagem das ciências sociais. Mas os outros pensadores hermenêuticos não recebem muita atenção de Bhaskar:

"Eu já examinei estes temas (positivistas transpostos) operando em Winch. Mas eles são bastante característicos da tradição hermenêutica de modo geral, afetando mesmo suas variantes dinâmicas e quase-materialistas. Assim, para Schutz, o postulado da adequação exige que os conceitos das ciências sociais 'sejam construídos de forma que o ato humano realizado no mundo da vida pelo ator individual seja compreensível pelo próprio ator, assim como por seus colegas, em termos das interpretações de senso comum da vida cotidiana'; para Garfinkel a proposta que fundamenta a etnometodologia 'é que as atividades através das quais os membros produzem e administram ambientes de negócios cotidianos organizados são idênticas aos procedimentos dos membros para tornar essas atividades "responsabilizáveis"; assim como para Winch o domínio de investigação da ciência social é autodefinidor e seus conceitos técnicos precisam estar 'amarrados logicamente' àqueles da sociedade sob estudo. O tema wittgensteiniano de que a filosofia 'deixa tudo como está' e consiste na 'investigação descompromissada' em Winch é espelhado na tradição fenomenológica de modo geral na marca da noção original de Husserl que a filosofia 'apenas explica o sentido que o mundo tem para todos nós, antes de qualquer atividade filosófica, e obviamente recebe apenas de nossa experiência - um sentido que a filosofia pode descobrir mas nunca alterar'. Isto é ecoado no postulado da indiferença etnometodológica, e de forma mais sutil na noção [de Giddens] da 
'incorrigibilidade dos recursos usados para gerar a interação social'. A insistência de Wittgenstein de que "dar a essência de proposições significa dar a essência de todas as descrições, portanto a essência do mundo" é ecoada no dito de Gadamer que 'o ser é manifesto na linguagem', que reflete a posição de Heidegger de que 'a linguagem é a casa do ser’. E a falácia linguística encontra até um deslocamento quase-materialista na reformulação de Habermas do objetivo da emancipação social como 'comunicação livre de dominação' e 'um consenso geral e não forçado"' [PN:198-199].

Tudo isto é rejeitado sumariamente por Bhaskar, devido à "falácia linguística". A hermenêutica se perderia num idealismo irremediável. Assim, depois de rejeitar o positivismo e a hermenêutica, e estabelecer sua própria posição naturalista crítica, Bhaskar conclui o livro apontando para seu próximo projeto - aplicar seu modelo a uma crítica da ideologia. Mas isto está além de meu propósito aqui.

IV

Nesta última seção deste capítulo, eu gostaria de esboçar uma crítica ao projeto de Bhaskar. Este esboço, como eu já advertira anteriormente, será bastante preliminar. Não é meu objetivo me estender demais sobre este assunto, e não abordo nem a obra posterior de Bhaskar, nem sua fortuna crítica - não reivindico originalidade, e é bem possível que alguns dos pontos que levantarei já tenham sido discutidos e/ou refutados por Bhaskar ou seus seguidores. Mas acredito que esta seção será útil para a análise que desenvolverei no próximo capítulo.

No início deste capítulo, sugeri que Bhaskar se empenhou ativamente em constituir a escola que hoje recebe o nome de "realismo crítico". Ao analisar a escola 
sociológica de Chicago, Mário Eufrasio aponta, baseado em Martin Bulmer, nove características típico-ideais para a criação de uma escola ${ }^{44}$ :

"1 - uma figura central em torno da qual se organiza;

2 - a localização numa universidade importante, bem organizada e com boa presença na área de estudos e motivada pela comunidade local;

3 - as características da cidade ou metrópole e a relação da universidade com essa cidade;

4 - a personalidade dominadora da figura central da escola, para inspirar admiração, respeito e lealdade;

5 - o líder da escola deve possuir uma visão intelectual clara e um impulso missionário;

6 - deve haver intercâmbios intelectuais frequentes e intensos entre o líder e os outros membros do grupo: tal 'rede' acadêmica deve ser mais fortemente unida do que normalmente ocorre (através de seminários, publicações, orientações, núcleos de estudos e discussões, etc.);

7 - para desenvolver pesquisa empírica deve existir uma infraestrutura adequada: métodos de pesquisa, boas ideias, ligações institucionais, apoio financeiro externo, etc.;

8 - a escola persiste enquanto permanece atuante a geração de seu(s) fundador(es);

9 - deve haver abertura para ideias e influências de outros campos e boas relações interdisciplinares.” [Eufrasio, 2008:13]

Vários destes pontos se aplicam facilmente ao projeto de Bhaskar. Ele é certamente a figura central do realismo crítico, e uma personalidade dominante - seus

\footnotetext{
${ }^{44}$ Eufrasio nota que estas características se referem a uma escola nas ciências sociais, mas, tendo em vista a ênfase que Bhaskar dá a estas disciplinas, acredito que elas possam ser transpostas sem grandes dificuldades para a suposta escola filosófica do realismo crítico.
} 
seguidores o tratam com grande reverência. Já comentei sobre seu impulso missionário declarado; e as conferências fechadas do realismo crítico, junto com as instituições criadas para organizá-las e editar a revista do grupo, confirmam os pontos 6 e 7 . Bhaskar e os principais membros da escola ainda estão ativos, por isso o ponto 8 é válido. Os problemas, nesta classificação, estão na falta da centralização do movimento numa universidade importante ${ }^{45}$ (o que consequentemente invalida o ponto seguinte, da relação do movimento com sua cidade), e o ponto final, que em minha opinião também não se aplica - embora Bhaskar enfatize que um de seus objetivos é expandir sua abordagem para praticamente todas as disciplinas das ciências sociais, isso só ocorre nos termos do realismo crítico: seu fundador e seus seguidores são bastante fechados a influências de outras escolas e sistemas de pensamento.

Tendo em vista este quadro, minha sugestão é que o realismo crítico constitui uma escola, embora um tanto irregular, devido ao seu caráter mais fechado em comparação com fenômenos similares (a própria Escola de Chicago, e também a Escola de Frankfurt, são bons exemplos de escolas que mantinham um diálogo muito mais fértil com outras perspectivas teóricas). E isto ajuda a explicar uma das características mais peculiares do realismo crítico: se para Bhaskar e seus seguidores simplesmente não existe nenhuma perspectiva filosófica válida que não a do realismo crítico, fora dessa escola seu impacto é quase nulo. Simplesmente não encontramos citações a Bhaskar e seus seguidores nas obras dos principais filósofos das ciências naturais e sociais $^{46}$. Mesmo Giddens, cuja relação com Bhaskar discutirei em maiores detalhes no

\footnotetext{
${ }^{45}$ Embora talvez seja possível argumentar que a própria independência universitária do realismo crítico fortalece sua união enquanto escola fechada, imune a pressões de universidades particulares.

${ }^{46}$ Por exemplo, Jürgen Habermas, Paul Feyerabend, Hillary Putnam, Charles Taylor, Michel Foucault, Richard Bernstein, Larry Laudan, Axel Honneth, Richard Rorty, Pierre Bourdieu, Donald Davidson, Ian Hacking, e a própria Mary Hesse. Obviamente esta seleção não é exaustiva, mas certamente é representativa. Adicionalmente, nenhum dos autores incluídos naquela que é considerada a principal coletânea sobre o realismo científico na década de 1980 (Leplin [1984]) menciona Bhaskar. E no livro
} 
próximo capítulo, o cita muito menos do que poderia, e sempre hesita em declarar seu comprometimento com um realismo do tipo de Bhaskar.

A simples leitura dos textos escritos por Bhaskar nos indica uma possível explicação para este fato. Bhaskar é um autor extremamente incisivo. Como algumas das citações das seções anteriores devem ter indicado, seus textos são uma coleção de frases como " $x$ precisa ser desta forma que defendo", "[minha posição] é a única que faz justiça ao assunto y", "[minha posição] está vindicada depois da refutação da teoria $z$ ", "é difícil acreditar como tantos filósofos puderam aceitar por tanto tempo uma [ideia/teoria/posição] tão equivocada", e assim por diante. Para quem está predisposto a acreditar em Bhaskar, ou considera seus argumentos convincentes, ele soa bastante ousado. Mas quando isto não ocorre, seus escritos transpiram uma arrogância que logo se torna muito cansativa para o leitor (é um tanto difícil levar a sério um autor que chama seu próprio trabalho de "revolução copernicana" na filosofia da ciência e “revolução newtoniana" na sociologia) ${ }^{47}$.

Ao tratar outros pensadores, Bhaskar tem apenas uma atitude: o ataque. Não encontramos nele a fluência das críticas positivas de um Giddens, as análises minuciosas de um Habermas, muito menos a humildade e o respeito que percebi em Hesse. Outros autores, para Bhaskar, existem para ser refutados e desacreditados. Nestes dois livros que analisei, há apenas dois autores que Bhaskar menciona com aprovação: Karl Marx e, surpreendentemente, Michael Scriven. E mesmo assim, ambos são elogiados apenas porque teriam sido realistas críticos avant la lettre, que quase

clássico de Quentin Skinner [1985] sobre o retorno da teoria nas ciências humanas, o único a mencionar Bhaskar, num artigo sobre Gadamer, é William Outhwaite, um de seus seguidores.

${ }^{47}$ Talvez o principal exemplo desta ousadia/arrogância seja exatamente o começo de RTS, onde Bhaskar afirma, sem meias-palavras, que há três grandes tradições na filosofia: o empirismo de Hume, o idealismo de Kant, e seu próprio realismo. 
alcançaram as percepções que Bhaskar obteve posteriormente ${ }^{48}$. Outros autores, no máximo, conseguem chegar a uma ou outra ideia interessante que teria sido desperdiçada por eles não as terem concebido dentro do esquema do realismo crítico.

Tirando estes problemas, que poderíamos chamar de retóricos, eu acredito que a obra de Bhaskar nestes dois livros também tem muitos problemas de natureza mais conceitual. O principal trata do próprio argumento transcendental no qual Bhaskar fundamenta todo o seu projeto. $\mathrm{O}$ argumento transcendental kantiano original procede da seguinte maneira: Kant perguntou como o mundo deveria ser para que o conhecimento (não necessariamente o conhecimento científico) fosse possível. O detalhe, aqui, é que o conhecimento é uma categoria certamente necessária para a vida humana neste mundo (e talvez até para toda a vida em geral). É inconcebível que vivamos sem nenhum tipo de conhecimento. Esta é a força do argumento transcendental: ele se refere a uma categoria necessária, e, neste sentido, imutável, pois também é inconcebível que em algum momento do passado tenhamos vivido sem conhecimento algum, e que em algum momento do futuro vivamos sem nenhum tipo de conhecimento. Mas a ciência, como Bhaskar prontamente reconhece, é uma atividade contingente. O ser humano já viveu em um mundo sem ciência, e certamente é concebível, embora pragmaticamente difícil, que isto possa ocorrer novamente no futuro. Para Bhaskar, este caráter contingente da ciência não é um problema - o argumento simplesmente assume a seguinte forma: "a ciência é contingente. Mas, já que ela existe, como deve ser o mundo para que ela seja possível?’. E ele procede a partir daí.

\footnotetext{
${ }^{48}$ A posição de Bhaskar sobre Marx foi relatada acima - e eu a considero extremamente discutível. Quanto a Scriven, foi dele que Bhaskar retirou o conceito de "proposição nórmica", que ele utiliza para a análise das tendências causais dos mecanismos geradores.
} 
Eu já não tenho tanta certeza de que a situação seja realmente tão simples - eu não acredito que seja possível (ou útil) designar necessidade ontológica para atividades/categorias contingentes. Em outras palavras, em relação à ciência, uma atividade contingente dependente de seres humanos históricos, o mundo não "deve ser" nada - o mundo simplesmente é, e a partir deste mundo dado, desenvolvemos a atividade científica, que assume diversas formas e modelos, sempre mudando com o passar da história. Talvez uma analogia ajude a esclarecer melhor minha posição: tomemos o futebol. Como deve ser o mundo para que o futebol seja possível? Simplificadamente, deve existir uma bola, um campo de jogo, algo que delimite os gols, seres humanos física e psicologicamente capazes de jogá-lo, um conjunto de regras. Tal perspectiva "transcendental" certamente é capaz de sugerir algo interessante sobre a nossa compreensão do futebol enquanto fenômeno contingente que ocorre no universo. Daí a afirmar que ela nos diz algo necessário sobre a constituição ontológica do mundo, porém, há uma grande distância. Ou seja, não é porque existem bolas, campos, jogadores, regras - não é porque o futebol é possível - que estas coisas fazem parte da ontologia necessária do mundo. Bhaskar nunca enfrenta esta questão com profundidade $^{49}$. Mas, se minha argumentação fizer sentido, fica difícil justificar o lugar privilegiado que Bhaskar reivindica para sua ontologia, e também as refutações de outras teorias que ele supostamente realiza com base nela.

De qualquer forma, mesmo que aceitemos a argumentação transcendental de Bhaskar, ainda é possível identificar vários outros problemas em seus textos. Por exemplo, os conceitos básicos de sua ontologia, "mecanismo gerador" e "estrutura",

\footnotetext{
${ }^{49} \mathrm{O}$ máximo que ele faz é afirmar que está tratando de uma ontologia científica, e não filosófica. Este argumento não parece melhorar muito a situação - primeiro, voltando ao meu exemplo, o que haveria de tão especial numa ontologia futebolística? Segundo, seu próprio modo de exposição no decorrer de suas obras revela que esta distinção não é realmente aplicada, e ele sempre argumenta pela necessidade de suas conclusões transcendentais.
} 
nunca recebem uma análise aprofundada. Ele parece utilizar "estrutura" da forma tradicional, ou seja, como um esquema ou arcabouço, semelhante a um esqueleto humano ou às vigas de um prédio - e isto tem várias consequências deletérias que já foram analisadas por muitos autores, especialmente o próprio Giddens. Bhaskar também nunca se incomoda com o caráter claramente metafórico de "mecanismo gerador". O que isto nos diz sobre estas entidades? É impossível evitarmos a associação metafórica com o mecanicismo ${ }^{50}$ - e também impossível chegarmos ao que estas entidades realmente seriam em termos não metafóricos.

Outro problema sério que identifico em Bhaskar é sua própria defesa extrema da ontologia. Grande parte de seu argumento neste ponto se refere à imputação da "falácia epistêmica" às outras correntes de pensamento. Sua intenção é mostrar que existem entidades sem que as conheçamos, ou seja, que nosso conhecimento de uma entidade não é uma condição de sua existência. O problema aqui é como aplicar esta ideia. Se ela simplesmente quer dizer que existem coisas que não conhecemos, ela se torna um truísmo inútil - nenhum filósofo ou cientista sério afirmaria que já conhecemos tudo que existe no universo. Mas se ela quer dizer algo além disso, a situação fica mais complicada. Porque se é verdade que existem entidades que não conhecemos, também é verdade que, até que as conheçamos de algum modo, essas entidades são irrelevantes para nós ${ }^{51}$. De que nos serve algo a que não podemos nos referir, ou que não faz parte de nenhuma teoria, ou que não encontra nenhuma formulação na linguagem ordinária? Num nível mais abstrato: eu não acho que a ontologia consiga ir muito além de uma

\footnotetext{
50 É interessante notar, também, que a própria escolha do termo "mecanismo gerador" parece ser razoavelmente condicionada historicamente. Não há nada que nos impeça, de nossa posição no início do século XXI, de usar um termo como, por exemplo, "algoritmo produtor" em lugar da metáfora de Bhaskar.

${ }^{51}$ Não precisamos, é claro, “conhecer" essas entidades através de observação sensorial direta. Elas podem ser entidades postuladas em teorias.
} 
"listagem" das entidades que existem no mundo. Qualquer peso maior que desejemos dar a ela significa atrelá-la à epistemologia de forma irrevogável.

Isto fica bastante claro nos próprios textos de Bhaskar. Ele não pretende apenas propor uma ontologia de mecanismos geradores. Bhaskar afirma que existe uma estratificação do mundo, ou seja, que alguns destes mecanismos são mais fundamentais que outros. Mas como é possível imaginar tal estratificação sem pressuposições epistemológicas que o ajudem a decidir o que conta como mais "fundamental"? Afirmar que um átomo é mais fundamental que uma mesa é defender implicitamente uma epistemologia científica atomística, e todas as suas pressuposições. Para um leigo sem conhecimento dela, a madeira pode ser mais "fundamental" do que os átomos que a compõem. Ontologicamente, a madeira existe tanto quanto o átomo, ou o ser humano. Qualquer "estratificação" que queiramos impor à natureza precisa passar pelo conhecimento que temos dela, é uma atividade estritamente epistemológica. Este dilema fica ainda mais severo nas ciências sociais, já que grande parte da confusão que motiva inúmeros pensadores há décadas é a da prioridade epistemológica na vida social (normalmente em termos do dualismo ação/estrutura, ou indivíduo/sociedade). Deslocar esta questão para uma ontologia da vida social não nos leva muito longe (ainda que a ontologia das ciências sociais seja mais incerta, por assim dizer, que a das ciências naturais $)^{52}$.

O mesmo tipo de raciocínio se aplica às acusações frequentes de Bhaskar do "antropocentrismo" do empirismo e do idealismo. Para Bhaskar, seu realismo é o único que consegue dar conta de um mundo sem seres humanos. Mais uma vez, isto é ou um truísmo ou uma afirmação inútil. Pois somos seres humanos, e neste sentido, a ciência e

\footnotetext{
${ }^{52}$ Se esta minha argumentação estiver correta, um outro resultado é que o argumento de Bhaskar contra a "falácia linguística" (que para ele é um caso especial da falácia epistêmica) também cai por terra.
} 
a filosofia serão sempre atividades inescapavelmente humanas. Não há nenhuma vantagem, em termos pragmáticos, em martelar este ponto.

Mas, como já afirmei, Bhaskar sempre considera necessário atacar pontos de vista divergentes. O que é curioso quanto a estes ataques é a sua desigualdade. Bhaskar gasta páginas e mais páginas atacando o empirismo e o positivismo - o que é algo relativamente fácil de fazer, especialmente tendo em vista que praticamente todos os filósofos da ciência pós-empiristas realizaram algo semelhante. Mas ele não fala quase nada sobre o idealismo transcendental, a outra tendência supostamente tão maléfica quanto o empirismo. Tudo que Bhaskar tem a dizer sobre esta tradição é que ela é derivada de Kant, afirma que o conhecimento é baseado em modelos idealizados, e que seria incapaz de dar conta da dimensão intransitiva do mundo. É muito pouco. Especialmente quando sua intenção é montar um esquema quase evolucionista, "começando" no empirismo, "passando" pelo idealismo para "terminar" em seu realismo.

Esta fraqueza também atinge Bhaskar em seu tratamento da tradição hermenêutica em $P N$. Como eu disse, ele basicamente discute apenas Winch (que, como os positivistas/empiristas, já fora bastante "surrado" por outros autores). O resto da tradição é sumariamente descartado em apenas um parágrafo (que citei no final da seção anterior), numa simplificação quase inacreditável, que certamente não faz justiça à riqueza dos pensadores hermenêuticos ${ }^{53}$. O único que recebe alguns poucos parágrafos a mais é Gadamer, que é acusado de utilizar uma metáfora exagerada em seu conceito de “fusão de horizontes" - acusação que, como vimos, é involuntariamente irônica, já que

\footnotetext{
${ }^{53}$ De certa forma, Bhaskar faz o mesmo com a tradição empirista, que é praticamente reduzida a Hume e o modelo hempeliano do século XX. Não há uma discussão aprofundada, por exemplo, de Stuart Mill, do Círculo de Viena, de Bertrand Russell, de filósofos analíticos mais recentes, entre outros.
} 
Bhaskar nunca analisa a metáfora dos "mecanismos geradores" no coração de sua própria teoria.

Voltando à questão da relação entre ontologia e epistemologia, outra consequência da separação rígida que Bhaskar deseja propor é que ela permite que ele evite várias questões epistemológicas complicadas. Não vemos, em seus escritos, discussões aprofundadas sobre o conceito de "verdade", a construção de teorias, e mesmo sobre o que caracteriza a ciência (definida apenas como a busca e descrição de mecanismos geradores). Podemos perceber facilmente o resultado disto se compararmos as soluções de Hesse e Bhaskar ao problema da indução. Enquanto Hesse leva o problema a sério e consegue obter, depois de uma análise cuidadosa, uma proposta de solução elegante e inovadora, Bhaskar simplesmente não concebe o problema dentro de seu esquema ontológico, e o dispensa em poucas linhas. Este procedimento se repete com outras questões filosóficas relevantes - Bhaskar está enfeitiçado por sua própria teoria que, para ele, consegue dar conta facilmente de praticamente todos os dilemas filosóficos e científicos existentes.

E tal descuido atinge sua expressão máxima no naturalismo que Bhaskar propõe. Em seu afã de caracterizar os seres humanos como entidades iguais às entidades naturais, Bhaskar ignora a diferença básica entre a ação em sistemas naturais e a ação social. Para ele, não há diferença entre um ser humano e uma molécula de ácido clorídrico, em termos de ação (e de seus potenciais causais). E, da mesma forma que Bhaskar falha ao tentar estabelecer uma separação absoluta entre ontologia e epistemologia, porque tenta varrer rapidamente sob o tapete as questões mais problemáticas, sua proposta de naturalismo também cai por terra porque ele não consegue se livrar das diferenças mais básicas entre entidades naturais e sociais, como ele mesmo admite. 
Os limites ontológicos ao naturalismo, mencionados acima, ficam numa posição um tanto desajeitada, porque Bhaskar também confunde sistematicamente os níveis ontológico e metodológico. Seu naturalismo nunca decide em que nível quer estar. Assim, partes do livro parecem defender um naturalismo metodológico, já que os objetos que queremos analisar, sociais e naturais, são essencialmente os mesmos. Mas às vezes Bhaskar se lembra dos limites que ele mesmo postulara, e analisa diferenças entre eles. De qualquer forma, no final das contas, o fato é que o naturalismo não se sustenta, exatamente por causa das diferenças básicas entre as entidades em questão: o fato de que sociedades e seres humanos não são "dados", como entidades naturais o são, não é um mero detalhe que pode ser convenientemente deixado de lado para falarmos da "possibilidade" do naturalismo. É a base de diferenças ontológicas irrevogáveis. O próprio Bhaskar admite isto, mas não percebe as consequências dessa admissão, quando diz que "indivíduos não nascem como seres sociais: eles são socializados (tornados sociais) e constituídos como sujeitos num processo (...)" [PN:185-186]. Imagino que não seja demais afirmar que, se entidades sociais (como os indivíduos) precisam passar por um processo como o de socialização para se tornarem entidades sociais, esta é uma diferença ontológica extremamente relevante para qualquer concepção teórica que queiramos defender.

Bhaskar falha em sua tentativa de "vingar" o naturalismo. Talvez seja realmente melhor esquecer essa ideia, nos três níveis da ontologia, epistemologia e metodologia, e nos focarmos no que realmente importa: um pluralismo metodológico que permita que compreendamos o mundo como ele é (e não como ele "precisa ser", no realismo desnecessário de Bhaskar). 


\section{Anthony Giddens entre Hesse e Bhaskar - um projeto de}

\section{reconstrução}

I

Nesta parte final do ensaio, é hora de trazer Giddens de volta para a discussão, e mostrar como as obras de Hesse e Bhaskar podem nos ajudar a esclarecer algumas das questões mais complicadas de sua obra ${ }^{54}$.

Hesse, como eu disse, é discutida por Giddens apenas uma vez. Isto ocorre num dos principais artigos de Giddens, "O positivismo e seus críticos” [Giddens, 1977:29$89]^{55}$. Este artigo é essencialmente um grande resumo dos principais conceitos da filosofia da ciência pós-empirista e sua relação com a sociologia, apresentados de forma clara. Giddens começa analisando o positivismo de Comte (e sua influência sobre Durkheim), passando depois para Mach e o Círculo de Viena (com uma ênfase especial nos escritos sociológicos de Neurath), até chegar a Zetterberg, Hempel e Nagel como exemplos da influência do positivismo do século XX na sociologia. Depois, ele discute a transição iniciada por Popper, mostrando suas fraquezas, até chegar em Kuhn, como o responsável pela grande virada na disciplina. Temos então um desvio para a crítica do positivismo da Escola de Frankfurt, focada na polêmica entre Adorno e Popper (e a contribuição do jovem Habermas). Já no final do artigo, Giddens discute duas

\footnotetext{
${ }^{54}$ Neste capítulo, utilizarei durante a argumentação alguns artigos incluídos no anexo de traduções deste trabalho. Quando isto ocorrer, para maior comodidade, as referências bibliográficas remeterão às traduções neste volume, e não aos textos originais.

${ }^{55}$ Vale a pena notar que este artigo foi escrito depois de Novas regras do método sociológico, que é o livro onde Giddens mais se detém em questões metodológicas. Giddens cita o primeiro livro de Hesse, Modelos e analogias na ciência, quando menciona brevemente metáforas nas Novas regras. Esta citação indistinta, onde Giddens apenas lista vários livros sobre o tema, foi removida da segunda edição do livro em 1993 (embora o parágrafo original não tenha sido modificado. Ver Giddens [1993:155]).
} 
perspectivas recentes do debate: a de Lakatos, que ele rejeita pelos resquícios popperianos, e a de Hesse, tratada de forma muito mais favorável.

Giddens trata apenas dos principais traços do modelo de redes, enfocando a distinção pragmática entre enunciados teóricos e de observação, e as leis finitas que resolvem o problema da indução. Ele classifica Hesse como realista, e menciona muito de passagem a questão de metáforas e modelos. Para Giddens, Hesse fornece "uma forma de reconhecer a poética da inovação teórica enquanto ao mesmo tempo oferece um modo de distinguir o sentido e a referência em relação a "paradigmas"” [Giddens, 1977:76]. Giddens considera que o modelo de Hesse pode ajudar a combater os dilemas relativistas que assolam a obra de Kuhn (e também Gadamer e Winch), causados por seu idealismo ${ }^{56}$. Para Giddens, o modelo de redes permite a mediação hermenêutica entre paradigmas, mas esta mediação não é completamente intensional (como no idealismo), já que os termos da rede estão amarrados de forma complexa e variável a predicados extensionais (empíricos). Entretanto, Giddens parece não aceitar o critério pragmático de Hesse para diferenciar a ciência de outras formas de conhecimento, defendendo, neste ponto, a posição da teoria crítica frankfurtiana, com uma separação mais rígida entre fatos e valores. De qualquer forma, Giddens segue todos os passos de Hesse em sua teoria da verdade apresentada em SSI, apoiando a combinação entre uma verdade por correspondência modificada por condições de coerência.

Giddens, porém, reconhece que este modelo não é imediatamente adequado para a filosofia das ciências sociais - embora ele não diga o motivo para isto. Neste ponto, ele parte rapidamente para uma discussão da hermenêutica e sua relação com o positivismo. No final do artigo, entretanto, encontramos esta citação:

\footnotetext{
${ }^{56}$ Que, para Giddens, é diferente da concepção de Bhaskar. Para Giddens, um "paradigma” idealista constitui um mundo de objetos, em vez de ser apenas uma representação ou modo de relação com um mundo de objetos (podemos intuir que isto seja o que Giddens considera "realista") - ao contrário do "idealismo transcendental" de Bhaskar, que seria uma construção puramente mental.
} 
"Podemos representar as teorias na ciência social, assim como na ciência natural, como redes envolvendo leis ou generalizações abstratas. Mas, na segunda destas, a rede não está em interação com o mundo de objetos que ela busca explicar, enquanto na primeira, ela está. As generalizações nas ciências sociais sempre são, a princípio, instáveis em relação a seu 'domínio de investigação' - ou seja, a conduta social e suas formas institucionais - pois sua aceitação altera a relação entre a racionalização da ação e suas bases não-reconhecidas. Isto é diferente das possibilidades de intervenção 'técnicas' na natureza oferecidas pelas leis nas ciências naturais" [Giddens, 1977:88].

Isto sugere que, para Giddens, talvez a hermenêutica dupla seja a chave da aplicação do modelo de redes para as ciências sociais, hipótese que discutirei mais à fundo posteriormente. Hesse é citada uma última vez por Giddens, curiosamente, junto com a primeira citação que Giddens faz a Bhaskar. Isto ocorre num artigo chamado "A hermenêutica e a teoria social" [Giddens, 1982:1-17], uma palestra proferida em 1981. O texto percorre o mesmo caminho de seu irmão mais velho e mais volumoso. Hesse e Bhaskar são citados no final, como exemplos de "teorias da ciência realistas modificadas" que poderiam ajudar a combater o relativismo da posição kuhniana na filosofia das ciências naturais. Giddens repete o mesmo argumento aqui: "as implicações para as ciências sociais ainda não foram exploradas totalmente, mas parecem ser compatíveis com um ponto de vista que utiliza a hermenêutica sem sucumbir ao historicismo de Gadamer" [Giddens, 1982:14]. Então, Giddens menciona que o "modelo transformativo da atividade social" de Bhaskar chegou "independentemente" a uma concepção das ciências sociais que teria muito em comum com a teoria da estruturação. A segunda, e última, referência a Bhaskar ocorre distante de qualquer discussão metateórica, quando, na Constituição da sociedade, Giddens menciona, com aprovação, o conceito de Bhaskar de "relações posição-prática" no começo de sua discussão do posicionamento social, para logo depois passar a uma 
discussão extensa sobre a ideia de "posição social" baseada principalmente em Goffman (ver Giddens [1984:83-92]). E é apenas isto.

\section{II}

Na verdade, fica claro que, ao menos diretamente, Giddens foi uma influência muito maior sobre Bhaskar do que o contrário. A possibilidade do naturalismo aparece depois das Novas regras do método sociológico, e o próprio Bhaskar chama este último livro de "importante" [PN:76n84]. Como eu disse, o conceito de ação de Bhaskar é praticamente igual ao de Giddens, e também sua concepção da relação entre ação e estrutura é parecida (mas com algumas diferenças importantes, que mencionarei abaixo).

Bhaskar se une a vários outros críticos que consideram que a teoria de Giddens não consegue escapar de uma ênfase na ação às custas da estrutura, apesar de todas as suas intenções em contrário ao estabelecer a dualidade da estrutura. Na entrevista com Norris [1999], Bhaskar afirma que "basicamente, a estrutura sempre tende a desmoronar na ação [no modelo de Giddens]", sem maiores elaborações.

Apesar de Bhaskar não se estender nesta questão, há uma diferença bastante fundamental entre sua teoria e a de Giddens que pode nos ajudar a entender esta acusação. Lembremos que Giddens concebe a estrutura como algo virtual, um conjunto de regras e recursos instanciados apenas em traços de memória. Isto, obviamente, é inaceitável para Bhaskar, que se esforça não só para mostrar que estruturas sociais são reais, mas também que são reais como entidades do mundo natural (até certo ponto). Se 
a estrutura, para Giddens, não "existe" nestes termos, então é inevitável, na posição de Bhaskar, que ela tenha que se reduzir aos indivíduos que a "geram" e "reproduzem"57.

Outra diferença básica que poderíamos levantar aqui é que Bhaskar não dedica atenção nenhuma aos conceitos de "tempo" e "espaço", que Giddens, como sabemos, tenta incorporar integralmente à teoria da estruturação - o que é um tanto surpreendente, pois poderíamos imaginar que as categorias do espaço-tempo devessem ser centrais para qualquer tipo de ontologia.

De qualquer forma, há uma certa discussão entre os comentaristas de Giddens sobre até que ponto podemos relacionar sua teoria com a de Bhaskar. Outhwaite é um dos que tenta estabelecer essa aproximação. Ele assume que o conceito de estrutura de Giddens e Bhaskar é essencialmente similar, e afirma que o próprio Giddens se posiciona como um realista em Problemas centrais da teoria social. A citação em questão, retirada da avaliação de Giddens do estruturalismo, é esta aqui:

"Eu argumentarei que a estrutura tem uma 'existência virtual', enquanto instanciações ou momentos; mas isto não é a mesma coisa que identificar a estrutura meramente com modelos inventados por observadores sociológicos ou antropológicos. Eu considero os conceitos que formulo [no resto do livro] compatíveis com uma epistemologia realista, mas não defenderei esta afirmação" [Giddens, 1979:63] ${ }^{58}$.

Para Outhwaite, isto seria uma indicação do compromisso de Giddens com uma ontologia realista à la Bhaskar. O primeiro ponto que salta aos olhos é que Giddens aqui não menciona ontologia, e sim epistemologia (como vimos, esta é uma confusão que o

\footnotetext{
${ }^{57}$ É verdade que Bhaskar, como mencionei acima, usa o conceito de "dualidade da estrutura" em sua própria teoria - mas esta apropriação é um tanto desajeitada, desconsiderando o papel metateórico que o conceito possui na teoria de Giddens e, basicamente, apenas aplicando o rótulo de "dualidade da estrutura" para o modelo de Bhaskar num nível diferente. Basta apenas notar que Bhaskar simplesmente ignora o fato de que a dualidade da estrutura, na verdade, se refere à dualidade entre estrutura e ação. Ele a trata como se o conceito se referisse somente à estrutura, e adiciona sua "dualidade da práxis" para cobrir a parte da ação.

${ }^{58}$ É interessante notar que Outhwaite omite de seu artigo a oração "mas não defenderei esta afirmação".
} 
próprio Bhaskar comete rotineiramente). E fica claro também que Outhwaite deixa de lado o caráter virtual da estrutura que mencionei acima. Sua própria explicação do conceito de "estrutura" em Giddens se resume a repetir a discussão de Bhaskar deste conceito, o que, na minha opinião, é uma estratégia equivocada [ver pp. 266-267 para a argumentação de Outhwaite].

Outro ponto de aproximação entre os dois teóricos seria, para Outhwaite, "um cuidado extremo quanto a qualquer reivindicação existencial particular" [ver p. 269]. Ou seja, Giddens e Bhaskar evitariam postular a existência de entidades particulares $a$ priori, deixando esta tarefa para o trabalho científico empírico. Isto não é exatamente correto em relação a Bhaskar, já que este certamente postula a existência dos seus "mecanismos geradores" (ele não os detalha, mas sua existência é inquestionável para Bhaskar). Quanto a Giddens, um dos problemas metodológicos mais complicados de sua obra é exatamente até que ponto ele consegue preservar a contingência histórica, e qual seria a vantagem disto - mas este é um tópico que discutirei posteriormente.

Ira Cohen é outro comentador que, pelo menos inicialmente, tentou aproximar Giddens e Bhaskar. Assim, em seu debate com Gregor McLennan, ele estabelece a relação entre os dois autores baseada na ideia de potenciais ontológicos, que certamente é um dos pontos mais interessantes da teoria de Bhaskar. Como vimos, para Bhaskar as entidades são mecanismos geradores com poder causal. Mas, e isto é parte integral do ataque de Bhaskar à causalidade humeana, o que conta para Bhaskar não é a operação efetiva dos poderes causais das entidades, e sim seu potencial. $\mathrm{O}$ fato das entidades às vezes não exercerem seus poderes causais não significa que elas não possuam esses poderes, nem que elas percam seu estatuto de mecanismos geradores. 
Cohen tenta argumentar que Giddens trabalha com essencialmente o mesmo conceito:

“(...) seus argumentos analíticos focam de forma similar as práticas sociais e as características das coletividades como potenciais que são realizados de formas diversas na perpetuação e transformação da vida social através de todos os casos historicamente situados. Tanto Bhaskar quanto Giddens se referem a estes potenciais analíticos em termos ontológicos.”[ver Cohen, p. 168 nos anexos]

Ou seja, para Cohen, Giddens não estaria preocupado com as ações efetivas dos atores, e sim com o seu potencial sempre presente de agir de forma situada. A ideia aqui é mais uma vez fortalecer a contingência da história, afirmando que para Giddens não existem ações a priori, apenas o fluxo histórico da ação que ocorrerá de acordo com inúmeras variáveis. Entretanto, este argumento, como o próprio McLennan sugere durante o debate, é um tanto questionável - pelo simples fato de que Giddens nunca menciona potenciais ontológicos de ação em seus escritos. A exposição mais clara (e recente) de Giddens sobre a ação, a causalidade e o poder aparece em $A$ constituição da sociedade:

"Qual é a natureza da conexão lógica entre ação e poder? (...) Ser capaz de 'agir de outra forma' significa ser capaz de intervir no mundo, ou de se abster de tal intervenção, com o efeito de influenciar um processo ou estado de coisas específico. Isto pressupõe que ser um ator é ser capaz de empregar (cronicamente, no fluxo da vida cotidiana) um conjunto de poderes causais, incluindo aqueles de influenciar os poderes empregados por outros. A ação depende da capacidade do indivíduo de 'fazer uma diferença' num estado de coisas ou curso de eventos pré-existente. Um ator deixa de sê-lo se perder a capacidade de 'fazer uma diferença', ou seja, de exercer algum tipo de poder" [Giddens, 1984:14]. 
A linguagem aqui não é de potenciais. E mais, não há nenhuma indicação de que Giddens esteja preocupado com os potenciais da ação, e sim com os atores enquanto exercem estes poderes no fluxo cotidiano. Fica bem difícil entabular a relação desejada por Cohen ${ }^{59}$. E, de qualquer forma, ele mesmo nota uma diferença metodológica básica entre Giddens e Bhaskar que o força a separar os dois: Bhaskar persegue abertamente um naturalismo, enquanto Giddens, através do conceito da hermenêutica dupla, é claramente um pluralista metodológico.

No fundo, não conseguimos tirar muito do próprio Giddens quanto a esta questão. O máximo que temos é esta citação de um artigo de Christopher Bryant, referindo-se a uma entrevista que, até onde eu sei, não foi publicada:

"Giddens se contenta em dizer, como disse para Jary e eu, que ele é um realista ingênuo; há um mundo lá fora, e a facilidade com que podemos dar um encontrão nele é, para Giddens, assim como para Durkheim, confirmação de sua facticidade.” [Bryant, p. 388 nos anexos]

Este é mais um sinal do descompromisso filosófico de Giddens. Se há um ponto em que todos os comentadores dos fundamentos da teoria da estruturação de Giddens concordam, é a estupefação com a falta de informações sobre a fundamentação e as consequências filosóficas da teoria. É óbvio que Giddens não é realmente um realista ingênuo - o que a citação quer dizer é simplesmente que ele não se deu ao trabalho de investigar a questão a fundo.

De qualquer forma, deve estar bastante evidente que eu me incluo entre os comentadores de Giddens que acham que enfatizar uma possível relação com Bhaskar não é uma hipótese frutífera. Giddens teve várias oportunidades para endossar essa

\footnotetext{
59 Que, não obstante, repete o mesmo argumento em seu livro, embora ainda não encontre nenhuma justificativa direta em Giddens [ver Cohen, 1989:16-17].
} 
relação, se ela existisse - ele teve contato com a obra de Bhaskar, mas as citações são esparsas e não nos dão nenhum indício que possa confirmar essa relação. É bom lembrar que Giddens sempre se mostrou arredio a qualquer classificação de sua obra em correntes de pensamento externas: ele se recusa a ser rotulado de marxista, weberiano, hermeneuta, frankfurtiano, etc. Giddens nunca incorpora nenhuma teoria "por atacado", por assim dizer. Seu procedimento é sempre de análise teórica, crítica da teoria sendo analisada, e incorporação dos conceitos dessa teoria que ele julga úteis para seu próprio $\operatorname{programa}^{60}$.

Se aliarmos este fato à própria hesitação de Giddens em mergulhar mais profundamente em questões de fundamentação, fica fácil chegar à conclusão de que é mais provável que Giddens deseje manter distância de Bhaskar e seus seguidores do que se aproximar deles. O que, na minha opinião, é uma decisão acertada. Embora as teorias sociais de Giddens e Bhaskar tenham realmente alguns objetivos em comum, as diferenças básicas são grandes demais para ser ignoradas. E, como tentei mostrar acima, o programa de Bhaskar contém problemas muito sérios para servir como uma orientação teórico-filosófica para as ciências sociais. Enquanto instrumental de reconstrução, de modo geral, Bhaskar na verdade parece ser mais um exemplo de como uma abordagem errônea da filosofia pode condenar um programa de investigação, do que um exemplo a ser seguido e adotado por programas de investigação atuais e futuros. E, enquanto instrumental de reconstrução específico para a metodologia de Anthony Giddens, ele também não nos leva muito longe.

\footnotetext{
${ }^{60}$ Mesmo no campo político, Giddens é arredio aos rótulos. Nos anos 1980, ele professava ser um "socialista libertário", o que certamente era no mínimo curioso para o socialismo inglês tradicional. E, é claro, nos anos 1990 ele desenvolveu a Terceira Via que, supostamente, seria uma alternativa "além" do capitalismo e do socialismo, sem se alinhar definitivamente com nenhum deles.
} 
Hesse, no entanto, pode ser um caminho mais frutífero, ainda que seja bastante difícil traçá-lo. Mas há uma dica muito promissora na própria obra de Giddens, que não foi explorada adequadamente até o momento ${ }^{61}$. Se é verdade que Giddens não se referiu mais a Hesse desde o seu artigo de 1977, ele voltou a mencionar o modelo de redes num contexto bastante diferente - em sua resposta ao texto de Richard Bernstein, questionando o estatuto da teoria da estruturação enquanto teoria crítica.

A principal objeção de Bernstein a Giddens tem a ver, mais uma vez, com a falta de fundamentação do efeito crítico da teoria social, que, lembremos, para Giddens seria uma atividade inerentemente crítica ${ }^{62}$ :

"Giddens pode muito bem achar que qualquer conversa de fundamentar a teoria crítica seja intelectualmente repulsivo e desnecessário. Mas ele precisa, pelo menos, encarar de frente o assunto que tal projeto pretende enfrentar. Qual é a base para nossos juízos e propostas críticas, se é que ela existe? Como devemos fundamentar esses juízos críticos? (E quem é, ou quem deve ser, este 'nós'?)” [Bernstein, p. 134 nos anexos]

A resposta de Giddens começa delineando quatro níveis diferentes de crítica, do menos ao mais problemático: a crítica intelectual; a crítica prática; a crítica ideológica; e a crítica moral ${ }^{63}$. É neste último nível que ele volta a utilizar a ideia de redes. Giddens deseja defender o que chama de "racionalismo moral contingente", o que, como é costumeiro na argumentação dele, representa uma tentativa de evitar os extremos do fundacionalismo ético e do voluntarismo/relativismo moral completo: "o diálogo com

\footnotetext{
${ }^{61}$ Bryant [p. 395 do anexo] farejou este caminho, mas não o desenvolveu.

${ }^{62}$ Há uma diferença entre esse caráter "inerentemente" crítico da ciência social em Giddens, e aquele que mencionei durante minha análise de Bhaskar. Giddens admite que há partes do conhecimento humano que não podem ser modificadas diretamente pela crítica, e também reconhece a possibilidade do uso reacionário/opressor do conhecimento das ciências sociais. Para Bhaskar, como vimos, se o conhecimento é científico, ele precisa ser crítico e necessariamente precisa colaborar para a emancipação.

${ }^{63}$ Para a discussão dos três primeiros níveis da crítica, ver Giddens [1989:288-290].
} 
todo e qualquer ponto de vista moral é possível, e sempre envolve uma fusão de disputas morais e fatuais" [Giddens, 1989:291].

Giddens parece sugerir a ideia de que a divisão weberiana rígida entre observação fatual e juízo moral seria um paralelo da divisão positivista entre a linguagem teórica e a de observação, que Hesse contrataca com a postulação do modelo de redes. Ele não menciona nem Hesse nem a questão da filosofia da ciência, mas o paralelo é bastante aparente:

"Mas já que, [na visão de Weber], observações fatuais e juízos morais são completamente separados logicamente, o trabalho do cientista social não pode de modo algum influenciar diretamente a seleção dos próprios fins. Weber adiciona que os fins existem numa hierarquia, que pode ser seguida até algum tipo de valor ou valores definitivos. Mas este não parece ser o caso. Sempre que examinamos qualquer debate real tratando de questões sociais e juízos relacionados, encontramos redes de juízos fatuais e axiológicos, organizados através da argumentação" [Giddens, 1989:291-292].

Giddens afirma que não existem posições de valor nestas redes discursivas que não tenham conexão alguma com nenhuma outra, e isto indicaria que o diálogo sempre é possível, de alguma forma - o que invalidaria a hipótese weberiana de valores definitivos, já que na rede, nenhum dos nós é imune a mudanças.

Eu considero bastante interessante esta retomada da ideia do modelo de redes, mais de dez anos depois da última vez em que ele foi mencionado, e para tratar de uma questão diferente. Pensando em termos de instrumental de reconstrução metodológica, eu acredito que isto sugira que, apesar de toda a relutância de Giddens em enfrentar diretamente questões epistemológicas e metodológicas, a ideia do modelo de redes ainda pode estar operando num nível, digamos, menos discursivo. Isto me parece fazer sentido porque, de certa forma, o modelo de redes de Hesse se encaixa muito bem com 
o impulso, sempre presente na obra de Giddens, de encontrar um "caminho do meio" para questões relevantes que costumam ser apresentadas como dualismos. Como vimos, no modelo de redes nunca há uma hierarquia definitiva de relações, ou conceitos e teorias que jamais possam ser alterados - o que é bastante significativo para os propósitos de Giddens de retrabalhar conceitos e relações que muitas vezes são considerados fossilizados, ou em oposição completa.

E talvez seja possível demonstrar esta influência do modelo de Hesse em um outro aspecto da teoria da estruturação, ainda mais fundamental do que a discussão da teoria crítica. O conceito de hermenêutica dupla é provavelmente o maior legado de Giddens ao arsenal conceitual metodológico das ciências sociais - ainda que não possamos dizer que Giddens foi o primeiro a sugerir esta ideia, ele certamente foi um dos principais responsáveis por sua popularização entre os intelectuais que discutem a teoria social ${ }^{64}$.

Minha sugestão é que, se nas redes das ciências naturais temos enunciados teóricos e de observação interligados através de inferências, e se nas redes da teoria crítica temos juízos fatuais e axiológicos interligados através da argumentação, podemos conceber as redes das ciências sociais, de forma preliminar, como redes compostas de enunciados leigos e científicos interligados através da hermenêutica dupla.

O conceito exerceria assim seu papel metateórico de mediação entre a linguagem técnica das ciências sociais e a linguagem ordinária cotidiana, e o modelo de redes de Hesse me parece bastante apto a representar o movimento de dupla interpretação típico

\footnotetext{
${ }^{64}$ Cohen [ver anexo, p. 175] nota que o próprio Habermas teria reconhecido a importância da hermenêutica dupla para a teoria social. Curiosamente, Cohen deixa de lado o fato que Habermas, logo depois de mencionar Giddens, nota que a ideia de hermenêutica dupla não é nova nem original [ver Habermas, 1984:110-111].
} 
das ciências sociais, de acordo com esta concepção. Nenhum dos enunciados é incorrigível ou isolado, e a rede permite, a princípio, uma forma de manter a contingência histórica que Giddens tanto preza.

Eu discuti em outra ocasião a questão da contingência histórica como um dos principais dilemas encontrados na teoria de Giddens ${ }^{65}$. Resumindo o problema, Giddens pretende elaborar uma teoria que preserve essa contingência a qualquer custo, ou seja, uma teoria cujos conceitos não engessem o fluxo da história, como costuma ocorrer com teorias evolucionistas e/ou marxistas ortodoxas. O preço que Giddens paga por esta decisão é uma relação ambígua entre seus conceitos teóricos e a atividade empírica dos cientistas. A única posição que ele consegue desenvolver é afirmar que seus conceitos seriam "dispositivos sensibilizadores", utilizados para ajudar na interpretação de resultados de pesquisa, mas que não gerariam programas de pesquisa por si mesmos.

Eu argumentei que isto esvazia os conceitos de Giddens - se, para preservar a contingência histórica, ele precisa retirar qualquer conotação empírica que seus conceitos poderiam ter, então seu arcabouço conceitual se torna um mero sistema complicado de conceitos abstratos que não é muito atraente para os pesquisadores. Este dilema se torna ainda mais complexo quando lembramos que Giddens, depois das Novas regras, realiza seu giro ontológico e afirma que pretende que sua teoria seja uma ontologia do mundo social. E o terceiro fator que se emaranha aqui é o fato de que o próprio Giddens, quando se desloca para temas mais substantivos, não consegue evitar a postulação de conceitos e tipologias que acabam limitando a contingência histórica de qualquer forma: vide a sua tipologia das sociedades, classificadas como sociedades tribais, sociedades divididas em classes e sociedades de classe - tipologia que ele

\footnotetext{
${ }^{65}$ Ver Ribeiro da Silva [2004:157-158].
} 
pretende, apesar de todos os cuidados com a contingência, que tenha aplicação universal $^{66}$.

$\mathrm{Eu}$ creio que seja possível, se pensarmos a teoria da estruturação dentro do modelo de redes de Hesse, imaginarmos essa teoria como um conjunto de enunciados interconectado de forma que possamos conceber conexões entre os enunciados da teoria da estruturação e os enunciados históricos do mundo da vida, mediados pela hermenêutica dupla ${ }^{67}$. Esta mediação não implica numa determinação destes por aqueles, nem vice-versa, mas também significa que a teoria não fica "suspensa" num nível abstrato, incapaz de orientar, criticar e interpretar o mundo da vida.

A grande vantagem de pensarmos desta forma é que, a princípio, esta rede não está isolada das outras - ela se expande até se conectar com as ciências naturais e a filosofia. Podemos dizer que, quando decidimos utilizar este modelo de redes, no fundo estamos escolhendo um modo de pensar. Hesse não nos deu um modelo que tentamos representar no papel como os enunciados $\mathrm{x}, \mathrm{y}, \mathrm{z}$ conectados de alguma forma; seu exemplo da teoria de Maxwell nos mostra como novos enunciados são continuamente adicionados à rede tanto através da reflexão quanto da pesquisa empírica, e como a mudança em um ponto afeta vários outros, até (nesse caso) chegarmos a uma perspectiva que enxerga o universo de modo diferente.

Eu acredito que este modo de pensar pode ser bastante valioso para nós. Em vez de aceitarmos barreiras disciplinares rígidas, ou encarar outras linhas de pensamento como inimigos em potencial, o modelo de redes nos sugere uma certa humildade e aceitação da riqueza do mundo. Eu desconfio de projetos ontológicos como o de

\footnotetext{
${ }^{66} \mathrm{E}$, ainda que não evolucionista, certamente há um sentido de "progressão" histórica do primeiro tipo para o terceiro, passando pelo segundo.

${ }^{67} \mathrm{O}$ outro conceito metateórico fundamental de Giddens, a dualidade da estrutura, também opera na rede, mas entre os conceitos da linguagem técnica das ciências sociais.
} 
Bhaskar porque eles acabam tentando reduzir a existência a algumas categorias, que, pior, seriam "estratificadas" de acordo com um critério que certamente pode ser questionado (e isto antes de levarmos em conta a confusão entre epistemologia e ontologia que mencionei acima). É melhor, em minha opinião, adotarmos a seguinte atitude: o mundo está aí. O que ele é? Do que ele é composto? Como podemos conhecêlo? Estas três perguntas estão inexoravelmente relacionadas.

Voltando a Giddens: o que tentei realizar aqui foi apenas uma sugestão inicial de um caminho a seguir que pode indicar um modo frutífero de tratar os problemas em sua teoria, que certamente existem. Pensar a teoria da estruturação num modelo de redes não resolve automaticamente a tensão entre epistemologia e ontologia em sua obra, nem mesmo as questões da teoria crítica, da contingência histórica e do uso empírico da teoria da estruturação. Mas indica possibilidades.

Minha intenção, em termos de reconstrução metodológica de programas de investigação social, foi mostrar que Bhaskar, apesar de à primeira vista parecer representar um instrumental de reconstrução adequado para a compreensão de Giddens, em muitos aspectos é um beco sem saída. E que Hesse, que costuma ser esquecida nas discussões dos comentadores, na verdade é um caminho possivelmente bem mais interessante para esse projeto. Mas qualquer reconstrução metodológica completa do programa de Giddens precisaria incluir muitos outros fatores de instrumental de reconstrução que não abordei aqui. A saber: a relação de Giddens com os autores clássicos, tanto Marx, Durkheim e Weber, quanto aqueles que ele omite; seu acerto de contas com Parsons e o funcionalismo, tanto nêmese quanto inspiração da teoria da estruturação; a sombra de Habermas sobre todo e qualquer programa na teoria social dos anos 1970 e 80, com quem Giddens tem uma relação ambivalente; o estranho silêncio quanto a Norbert Elias, que Giddens conheceu em seus anos de formação na 
Universidade de Leicester; a influência do mundo acadêmico dos EUA nos anos 1960, quando Giddens passou um período nesse país, incluindo Goffman e Garfinkel $^{68}$; a leitura que Giddens faz de Heidegger e dos teóricos da geografia. E esta lista cobre apenas o período da teoria da estruturação - a teoria da modernidade que Giddens desenvolveu durante os anos 1980 e 90 exigiria um outro conjunto de estudos. Alguns dos textos incluídos no anexo são importantes para a análise de todos estes outros aspectos que não discuti aqui.

Giddens pode não estar mais "na moda", mas ele fez o suficiente para inscrever o seu nome na história da teoria social. Isto significa duas coisas. Primeiro, que é válido o esforço de reconstrução metodológica de sua obra, ao qual este ensaio pretendeu contribuir. Segundo, como acontece com qualquer grande obra intelectual humana, ele serve como uma excelente porta de entrada para um enorme conjunto de questões que afetam a nossa existência em vários níveis diferentes. Apesar de todos os problemas e complicações dessa obra, é impossível não sairmos mais ricos depois de travar um diálogo com ela. Eu espero que este ensaio, e os textos incluídos no anexo, sirvam como um exemplo da riqueza deste diálogo.

\footnotetext{
${ }^{68}$ Alan Sica [1991] tem um artigo muito interessante sobre esta influência, que tende a ser ignorada pela maioria dos comentadores de Giddens.
} 


\section{Bibliografia}

BAUMAN, Zygmunt [1989] "Hermeneutics and Modern Social Theory", in Held, David \& Thompson, John B. (eds.). Social Theory of Modern Societies: Anthony Giddens and His Critics. Cambridge: Cambridge University Press, pp. 34-55.

BERNSTEIN, Richard J. [1989] "Social Theory as Critique", in Held, David \& Thompson, John B. (eds.). Social Theory of Modern Societies: Anthony Giddens and His Critics. Cambridge: Cambridge University Press, pp. 19-33.

BHASKAR, Roy [1979] The Possibility of Naturalism: A Philosophical Critique of the Contemporary Human Sciences. Brighton: Harvester.

BHASKAR, Roy [1997] A Realist Theory of Science. $2^{\mathrm{a}}$ edição (1 $1^{\mathrm{a}}$ edição 1975). London: Verso.

BRYANT, Christopher [1997] 'Sociology without Philosophy? The Case of Giddens' Structuration Theory", in Bryant, Christopher \& Jary, David (eds.), Anthony Giddens: Critical Assessments, vol. 1. London: Routledge, pp. 388-403.

COHEN, Ira J. [1989] Structuration Theory: Anthony Giddens and the Constitution of Social Life. New York: St. Martin's Press.

COHEN, Ira J. [1997] "The Status of Structuration Theory: A Reply to McLennan", in Bryant, Christopher \& Jary, David (eds.), Anthony Giddens: Critical Assessments, vol. 1. London: Routledge, pp. 364-379.

EUFRASIO, Mário A. [2008] "A escola de Chicago de sociologia: perfil e atualidade", in Lucena, C. T. \& Souza Campos, M. Christina de (orgs.), Práticas e representações. São Paulo: Humanitas/CERU, pp. 13-27.

FEYERABEND, Paul [1993] Against Method. $3^{\text {a }}$ edição (1ª edição 1975). London: Verso.

GIDDENS, Anthony [1977] Studies in Social and Political Theory. London: Hutchinson.

GIDDENS, Anthony [1979] Central Problems in Social Theory. Berkeley: University of California Press.

GIDDENS, Anthony [1982] Profiles and Critiques in Social Theory. Berkeley: University of California Press.

GIDDENS, Anthony [1984] The Constitution of Society. Berkeley: University of California Press. 
GIDDENS, Anthony [1987] Social Theory and Modern Sociology. Stanford: Stanford University Press.

GIDDENS, Anthony [1989] "A Reply to My Critics", in Held, David \& Thompson, John B. (eds.). Social Theory of Modern Societies: Anthony Giddens and His Critics. Cambridge: Cambridge University Press, pp. 249-301.

GIDDENS, Anthony [1990] "Structuration Theory and Sociological Analysis", in Clark, Jon, Modgil, Celia \& Modgil, Sohan (eds.) Anthony Giddens: Consensus and Controversy. London: Falmer Press, pp. 297-315.

GIDDENS, Anthony [1991] "Structuration Theory: Past, Present and Future", in Bryant, Christopher \& Jary, David (eds.), Giddens' Theory of Structuration. London: Routledge, pp. 201-221.

GIDDENS, Anthony [1993] New Rules of Sociological Method. 2 edição (1ª edição 1976). Stanford: Stanford University Press.

GIDDENS, Anthony [1995] A Contemporary Critique of Historical Materialism. $2^{\mathrm{a}}$ edição (1 ${ }^{\mathrm{a}}$ edição 1981). Stanford: Stanford University Press.

GIDDENS, Anthony [2008] "New Labour Is Very Alive". London: The Guardian, $1^{\circ}$ de dezembro.

GIDDENS, Anthony [2009] The Politics of Climate Change. Cambridge: Polity.

HABERMAS, Jürgen [1982] "A Reply to My Critics", in Thompson, John B. \& Held, David (Eds.) Habermas: Critical Debates. Cambridge, MA: The MIT Press, pp. 219-283.

HABERMAS, Jürgen [1984] The Theory of Communicative Action, v. 1. Boston: Beacon.

HABERMAS, Jürgen [1987] Knowledge and Human Interests. $2^{\mathrm{a}}$ edição (1 ${ }^{\mathrm{a}}$ edição 1972). Cambridge: Polity.

HABERMAS, Jürgen [1988] On the Logic of the Social Sciences. Cambridge, MA: The MIT Press.

HABERMAS, Jürgen [1998] On the Pragmatics of Communication. Cambridge, MA: The MIT Press.

HESSE, Mary [1974] The Structure of Scientific Inference. Berkeley: University of California Press.

HESSE, Mary [1980] Revolutions and Reconstructions in the Philosophy of Science. London: Harvester. 
HESSE, Mary [1982] "Science and Objectivity", in Thompson, John B. \& Held, David (Eds.) Habermas: Critical Debates. Cambridge, MA: The MIT Press, pp. 98-115.

HESSE, Mary [1995] "Habermas and the Force of Dialectical Argument", in History of European Ideas, volume 21, n 3, pp. 367-378.

JOAS, Hans [1990] "Giddens' Critique of Functionalism" in Clark, Jon; Modgil, Celia \& Modgil, Sohan (eds.) Anthony Giddens: Consensus and Controversy. London: Falmer Press, pp. 91-102.

KILMINSTER, Richard [1991] "Structuration Theory as a World-View", in Bryant, Christopher \& Jary, David (eds.), Giddens' Theory of Structuration. London: Routledge, pp. 74-115.

KUHN, Thomas S. [1996] The Structure of Scientific Revolutions, $3^{\mathrm{a}}$ edição (1 ${ }^{\mathrm{a}}$ edição 1962). Chicago: University of Chicago Press.

LEPLIN, Jarrett (ed.) [1984] Scientific Realism. Berkeley: University of California Press.

McLENNAN, Gregor [1997a] "Critical or Positive Theory? A Comment on the Status of Anthony Giddens' Social Theory", in Bryant, Christopher \& Jary, David (eds.), Anthony Giddens: Critical Assessments, vol. 1. London: Routledge, pp. 318-326.

McLENNAN, Gregor [1997b] "Structuration Theory and Post-Empiricist Philosophy: A Rejoinder", in Bryant, Christopher \& Jary, David (eds.), Anthony Giddens: Critical Assessments, vol. 1. London: Routledge, pp. 380-387.

NAGEL, Ernest [1979] The Structure of Science: Problems in the Logic of Scientific Explanation (1 ${ }^{a}$ edição 1961). Indianapolis: Hackett.

NORRIS, Chris. "Roy Bhaskar Interviewed", in The Philosophers' Magazine, n. 8, 1999, pp. 34-50. Disponível em

http://www.raggedclaws.com/criticalrealism/archive/rbhaskar_rbi.html (acessado em $13 / 05 / 2010)$

NUNES, Jordão Horta [2005] As metáforas nas ciências sociais. São Paulo/Goiânia: Humanitas/UFG.

O'BRIEN, Martin; PENNA, Sue \& HAY, Colin [1997], "Giddens, Modernity and Self-Identity: The 'Hollowing out' of Social Theory", in Bryant, Christopher \& Jary, David (eds.), Anthony Giddens: Critical Assessments, vol. 4. London: Routledge, pp. 85-112.

OLIVEIRA FILHO, José Jeremias de [1976] "Reconstruções metodológicas de processos de investigação social”, in Revista de História, volume LIV, pp. 263-276.

OLIVEIRA FILHO, José Jeremias de [1995] "Patologias e regras metodológicas", in Estudos Avançados, volume 9, nº 23, pp. 263-268.

OUTHWAITE, William [1990] "Agency and Structure", in Clark, Jon; Modgil, Celia \& Modgil, Sohan (eds.) Anthony Giddens: Consensus and Controversy. London: Falmer Press, pp. 63-72. 
POGGI, Gianfranco [1990] "Anthony Giddens and 'The Classics"”, in Clark, Jon; Modgil, Celia \& Modgil, Sohan (eds.) Anthony Giddens: Consensus and Controversy. London: Falmer Press, pp. 11-19.

REISCH, George A. [2005] How the Cold War Transformed Philosophy of Science: To the Icy Slopes of Logic. Cambridge: Cambridge University Press.

RIBEIRO DA SILVA, Fábio Rodrigues [2004] O caminho da Constituição da sociedade: a teoria social de Anthony Giddens. Dissertação de Mestrado. São Paulo: FFLCH-USP.

SICA, Alan [1991] "The California-Massachusetts Strain in Structuration Theory", in Bryant, Christopher \& Jary, David (eds.), Giddens' Theory of Structuration. London: Routledge, pp. 32-51.

SKINNER, Quentin [1985] The Return of Grand Theory in the Human Sciences. Cambridge: Cambridge University Press.

SOJA, Edward [1997] "Spatializations: A Critique of the Giddensian Version", in Bryant, Christopher \& Jary, David (eds.), Anthony Giddens: Critical Assessments, vol. 3. London: Routledge, pp. 110-127.

SPYBEY, Tony [2001] "The Constitution of Global Society", in Bryant, Christopher \& Jary, David (eds.), The Contemporary Giddens: Social Theory in a Globalizing Age. Basingstoke: Palgrave, pp. 147-167.

THOMPSON, John B. [1989] "The Theory of Structuration", in Held, David \& Thompson, John B. (eds.) Social Theory of Modern Societies: Anthony Giddens and His Critics. Cambridge: Cambridge University Press, pp. 56-76.

WINCH, Peter [2008] The Idea of a Social Science and Its Relation to Philosophy. $2^{\mathrm{a}}$ edição (1 ${ }^{\mathrm{a}}$ edição 1958). London: Routledge. 


\section{Anexo - Traduções}

Algumas notas sobre os textos a seguir:

- Todos eles foram traduzidos do original em inglês, com exceção do artigo de Hans Joas, para o qual eu utilizei a versão inglesa do original em alemão, por Jon Clark.

- As referências bibliográficas de todos os artigos foram padronizadas de acordo com o resto deste ensaio.

- As traduções de todas as citações encontradas nos textos também são minhas.

- Eu removi o primeiro parágrafo do texto de Anthony Giddens, "Teoria da estruturação: passado, presente e futuro", que consistia apenas em um curto comentário sobre os artigos de comentadores de Giddens contidos no volume onde o texto apareceu, mas que não teria valor sem o contexto do resto dos artigos. 


\section{Gregor McLennan - Teoria crítica ou positiva? Um comentário sobre o estatuto da teoria social de Anthony Giddens}

\section{Introdução}

O simpósio conduzido sobre a obra recente de Anthony Giddens (em Theory, Culture \& Society, vol. 1, n. 2, 1982) destacou de forma muito instrutiva algumas questões atuais e dilemas recorrentes que teóricos críticos ou sociais enfrentam. $\mathrm{Na}$ verdade, a obra de Giddens como um todo me parece ser uma encarnação de dois dilemas amplos, e isto possivelmente explica sua popularidade relativa em estudos culturais, na sociologia e em seminários de pós-graduação, tanto quanto a teorização positiva que ela contém.

Os principais termos dos dilemas que tenho em mente são:

i) epistemologia/desconstrução

ii) teorização positiva/crítica.

Vários outros problemas ou dicotomias sem dúvida poderiam ser citados ao invés destes. Num debate recente em Theory and Society, por exemplo, Giddens [1982d] condenou, de forma típica, a noção de explicação funcional, mas igualmente se recusou a se comprometer ao individualismo metodológico como algum tipo de alternativa ao funcionalismo. Os dísticos que adotei devem ser vistos como categorias indicativas, e não definitivas, e eu certamente espero que sejam amplos o bastante para incluir o tipo de abstenção quanto à primazia explicativa que Giddens revela no debate sobre marxismo e funcionalismo. Talvez eu deva adicionar que uma motivação por trás desta nota crítica é minha preocupação em preservar uma noção positiva de materialismo histórico. Isto não necessariamente significa defender uma versão explicativa-funcional do marxismo na forma harmoniosa de, digamos, G. A. Cohen [1979]. Na verdade, eu considero que a revisão recente de Cohen de sua posição sobre a primazia do crescimento das forças produtivas na história - sua mudança da ideia de grilhões por crescimento para a de grilhões por uso - constitui uma concessão a algumas das objeções de seus comentadores marxistas e não marxistas, e como tal enfraquece a força do componente "funcional" na doutrina. Ainda assim, eu gostaria de 
dizer que as aspirações da teorização de Cohen, e seu rigor, são em alguns aspectos importantes preferíveis à proliferação de "complexidades" no tipo de perspectiva que Tony Giddens exemplifica, apesar do valor de suas adições à lista duradoura de críticas do materialismo histórico "clássico". Assim, vale a pena apontar as aparentes inconsistências da perspectiva teórica de Giddens (basicamente como ela emerge no simpósio de Theory, Culture \& Society).

\section{Epistemologia ou desconstrução?}

Um grande dilema proposto pelos pronunciamentos de Giddens sobre teoria social é se esta pode ter, mesmo a princípio, uma fundamentação epistemológica sólida. Seus comentários extensos sobre as tradições positivista e idealista na sociologia sugerem sua prontidão em adotar um caminho intermediário entre as duas, mas seus leitores podem perguntar do que consiste exatamente sua síntese. Em Problemas centrais da teoria social, os pontos de vista filosóficos de Giddens se inspiraram muito na obra de Roy Bhaskar, em particular, por isso podemos pressupor que ele adote alguma variante de realismo científico.

Esta posição é apoiada explicitamente em Problemas centrais, e na forte afirmação no simpósio de que, apesar da importância da teoria social para Giddens [1982a:74], disputas teóricas podem ser resolvidas através dos “fatos da questão". Já que Giddens não é um empirista declarado, eu suponho que esta formulação indique seu compromisso com a posição de que, em alguns aspectos empíricos chave, posições teóricas rivais são comensuráveis. Esta é certamente uma afirmação realista. De modo mais geral, a preocupação de Giddens com a existência de estruturas sociais além de interações individuais, e seu reconhecimento de que rejeitar a epistemologia seria "fútil" [Giddens, 1982a:72], dão à sua teorização um molde "objetivista" no sentido mínimo de que uma realidade extra-subjetiva existe e pode ser descrita através da teoria social - e estes novamente parecem ser pontos realistas. Assim, Giddens deseja patrocinar um "diálogo" entre fato e teoria. Este termo lembra proposições similares feitas anteriormente por E. P. Thompson na Miséria da teoria [1978]. E, assim como no caso de Thompson, a "estratégia intermediária" de Giddens na epistemologia às vezes parece ser alguma coisa diferente de "realista". 
Mesmo levando em conta a informalidade de entrevistas, as posições de Giddens na contribuição ao simpósio significam uma hesitação quanto ao realismo em particular, e à epistemologia em geral. De fato, ele suplementa intimações realistas com alguns sentimentos idealistas, produzindo uma mistura um tanto incoerente. Ele explicitamente rejeita a ideia de um "solo firme" para a teoria social, e adota em vez disso uma "multiplicidade de leituras". Isto se encaixa com o teor geral da entrevista, “desconstrutivista" e "descontinuísta" (ver especialmente sua "resposta aos críticos"), e estas são as marcas registradas de uma ortodoxia popular hoje em dia de que a segurança epistemológica é um padrão de juízo obsoleto e um tanto imperdoável. Consequentemente, Habermas é rechaçado por Giddens por reter o projeto de reconstrução teórica em larga escala. Esse projeto implica uma realidade única intratável e a possibilidade de seu abarcamento racional na teoria. É apenas a partir deste tipo de pressuposição que uma ontologia social pode ser proposta, e eu detecto em Giddens uma hesitação também quanto a este salto filosófico. Assim, John Urry [1982] nos engana quando cita (em sua contribuição ao simpósio) a passagem para a ontologia como uma característica da escola "estruturacionista", na qual ele localiza Giddens, Bhaskar, Bourdieu, Berger e Luckmann, e outros.

Assim, as ideias de Giddens sobre o compromisso filosófico apropriado para a teoria social oscilam entre a ideia de que não pode haver uma base epistemológica segura ou coerente para ele, e que é fútil rejeitar a epistemologia. Mas é claro que apesar desta ser uma posição atraente, ela não é sustentável, pois, especialmente em questões epistemológicas, a lei do terceiro excluído parece valer. $O u$ a teoria, a realidade, e a possibilidade de coerência filosófica. $O u$ a desconstrução, leituras múltiplas, e salvas discursivas. Mas não ambas.

O lugar incerto da filosofia em sua obra também indica que Giddens enfrenta um certo dilema quanto ao nível de pensamento apropriado para a teoria crítica. Seus escritos são teóricos e abstratos até certo ponto (eles não são realmente empíricos); mas eles também não são filosoficamente elaborados ou rigorosos. Isto, obviamente, é em parte uma questão de escolha. Ao discutir Habermas, Giddens deixa implícito que a formalidade filosófica não é um guia melhor para a ação do que preceitos do senso comum. Em outras palavras, a teoria social, para Giddens, deve a princípio ser relativamente não-esquemática e empiricamente flexível se quiser ter um propósito prático. 
Podemos fazer mais duas observações sobre este aspecto da "estratégia intermediária". A primeira é que, se a obra empírica e a ação política quiserem ter uma certa coerência e base (que precisam ter para serem úteis), então seus conceitos governantes precisam ser distintivos. Entretanto, podemos dizer que os próprios conceitos distintivos devem se basear em (e ser abertos a) delineações formais e talvez até a arranjos metafísicos (a ação, por exemplo, é um conceito desse tipo). Até o momento, Giddens tem se esquivado de discutir as implicações destas questões básicas para estabelecer o estatuto da "teoria social" como ele a apresenta. Imagino que esta seja uma razão para o desprezo de Paul Hirst [1982:78] no simpósio afirmando que a tentativa de Giddens de reorientar "algo chamado teoria social" não pode ser bemsucedida porque é indeterminada.

\section{Teorização positiva ou crítica?}

Esses comentários sobre o estatuto epistemológico da teoria em Giddens estão ligados à tarefa mais substantiva de avaliar o que os seus conceitos principais efetivamente realizam em termos concretos. Quero sugerir que há uma diferença entre uma orientação crítica na teoria social, e uma descrição positiva completa de quais estruturas, que ações, em que tipo de sequências, acabam compondo o objeto de investigação da teoria social. Não fica claro para mim que Giddens ofereça qualquer ajuda quanto à relação entre estas tarefas, e seus conceitos e comentários também não produziram uma posição coerente ou convincente a partir da qual teoria e prática possam se entrelaçar.

A concepção de teoria social de Giddens [1982a:72] é "disparar salvas críticas na realidade", e sua preferência metodológica é "a concepção contrafatual de o que as pessoas saberiam se estivessem nas circunstâncias em que você está". Além disso, a própria série de neologismos de Giddens atraiu elogios de vários comentadores. Estes conceitos certamente refletem a amplitude e acuidade das leituras secundárias de Giddens: bordas espaço-temporais, distanciamento social, presença, capacidade de armazenamento, a cidade como receptáculo de poder, transições episódicas, e assim por diante. Todos estes termos são positivos num certo sentido, já que Giddens corretamente se preocupa em produzir ferramentas teóricas empiricamente relevantes na ciência social. Mas, em minha opinião, todas as camadas de seu aparato conceitual 
sofrem de uma tendência debilitante de moldar seus conceitos em termos excessivamente figurativos.

Como um slogan, "salvas críticas" funciona - mas o que isto significa, exatamente? Qual é a realidade em questão, e de onde os tiros são disparados? Metodologicamente, Giddens é igualmente críptico. Afinal, esforçar-se para apreciar os motivos e intenções de outros agentes é uma coisa. Mas por que deveríamos privilegiar esta troca "contrafatual" de posições? Como Giddens sabe, há várias críticas danosas que podem ser feitas quanto à "interpretação" sociológica, verstehen, e assim por diante (algumas delas feitas por ele próprio). De fato, há uma objeção lógica séria contra qualquer elevação da empatia contrafatual além do relativamente enfadonho. Se outras pessoas realmente devessem ser concebidas como estando numa posição para saber o que eu, em minha posição, sei (e talvez nem sejamos capazes de caracterizar isso adequadamente), então elas não estariam, ex hypothesi, nas relações e circunstâncias específicas que queremos analisar. Supostamente, por razões como esta, Giddens se contenta em chamar seu método contrafatual de uma concepção "de intervalo", e não uma "base para a teoria crítica".

Eu afirmei que algumas das novas ideias de Giddens são atraentes por causa de sua expressão figurativa e concreta. Mas este processo literário de cunhagem me parece conter tantas armadilhas quanto vantagens, se quisermos avaliar sua contribuição nos termos mais altos reivindicados em seu nome. Afinal, os principais conceitos que ele introduz para compreender a dimensão espaço-temporal da vida social (em sua opinião, subestimada) são metáforas espaciais e temporais. Eu não tenho nenhuma objeção a metáforas, já que todo pensamento significativo requer modelos e metáforas para sua expressão e desenvolvimento. Também não deve haver nenhuma objeção a lembretes de que o espaço e o tempo estruturam relações sociais que por sua vez os organizam - mas eu acho que Giddens exagera o grau em que eles estariam ausentes nas principais tradições, especialmente o materialismo histórico. Mas eu hesitaria em aceitar a noção de uma "borda espaço-temporal", por exemplo, ou "distanciamento social" como uma entrada nova séria na teoria social. Apesar das várias páginas na obra recente de Giddens dedicadas à propaganda destes conceitos, eles me parecem excessivamente metafóricos porque representam características mais completas de sistemas sociais, mais explicadas formal e substantivamente. Resumindo, elas não parecem transmitir proposições sociológicas específicas e distintivas. 
Talvez a ideia mais distintiva de Giddens seja a teoria da estruturação, e seria grosseiro afirmar que, nesta parte de sua obra, Giddens não apresentou uma conjunto de conceitos novo e proposicional para aplicação e desenvolvimento posteriores. Eu diria que mesmo aqui é difícil estimar exatamente do que consiste esta teoria. É claro que Giddens contribuiu positivamente contra a insatisfação intelectual disseminada com uma polarização entre teorias objetivistas e subjetivistas da causalidade social. Ele propõe em vez disso uma "dualidade da estrutura", que não admite nenhuma separação fácil entre fatores estruturais e ações intencionais. Na verdade, o próprio termo "dualidade da estrutura" é levemente enganoso, pois Giddens está efetivamente insistindo quanto à dualidade da estrutura-e-ação. Esta noção é supostamente a pedra de toque da teoria da estruturação, e em termos gerais ela pode ser entendida de forma bastante direta como um entendimento dialético da sincronia e diacronia, coerção e permissão [Giddens, 1979:69]. Enquanto tal, ela compartilha características óbvias com algumas abordagens duradouras de fenômenos sociais, notavelmente nas tradições marxista e da teoria crítica.

Entretanto, a teoria da estruturação parece ser algo mais específico do que a dualidade da estrutura, ainda que esta última seja uma de dez partes componentes, e uma parte "essencial" [Giddens, 1981:27; 1982c:10]. Uma forma de olhar para a teoria mais ampla é enxergá-la como a afirmação da dualidade da estrutura através de uma série de formulações sugestivas, mas variáveis. Por exemplo: "De acordo com a teoria da estruturação, toda ação social consiste de práticas sociais, situadas no espaço-tempo, e organizadas de forma cognitivamente hábil por agentes humanos" [Giddens, 1979:19]. $\mathrm{Na}$ verdade, isto é provavelmente menos definitivo que a dualidade da estrutura, parecendo um tanto banal e indiscriminado. Este modo de afirmação teórica em Giddens inspira enunciados incessantemente repetidos sobre a textura hábil mas frágil da existência humana, e estes sentimentos também parecem fazer parte da teoria da estruturação em sua forma generalizada.

Às vezes a teoria parece ser equivalente à afirmação dos desiderata que a teoria social deve cumprir, surgindo dos "debates atuais na teoria social" [Giddens, 1982c:8]. De modo geral, isto significa a esperança que "a demanda que uma teoria do sujeito que evite o objetivismo não escorregue no subjetivismo" [ibid.]. Mais uma vez, este tipo de relato dificulta que os leitores de Giddens distingam entre a dualidade da estrutura e a 
teoria da estruturação. Mas há formulações mais firmes onde esta última vai além das orientações muito gerais daquela:

"Na teoria da estruturação, a estrutura se refere às regras e recursos instanciados em sistemas sociais, mas tendo apenas uma 'existência virtual'. As propriedades estruturais da sociedade, cujo estudo é básico para explicar o desenvolvimento a longo prazo de instituições, 'existem' apenas em suas instanciações na estruturação de sistemas sociais, e nos traços de memória (reforçados ou alterados na continuidade da vida social cotidiana) que constituem a habilidade cognitiva de atores sociais" [Giddens, 1982c:9].

Nesta caracterização de sua teoria, Giddens não deixa claro se, e até que ponto, a "estruturação de sistemas sociais" difere dos "traços de memória" dos atores ou os inclui, e esta última noção é certamente um conceito vago demais. Além do mais, esta definição da teoria faz com que "propriedades estruturais" e mesmo a própria “estruturação" precisem de explicações adicionais. Até o momento, a viabilidade e conteúdo destes conceitos é pressuposta, e não demonstrada. Finalmente, devemos notar que descrever a estrutura como existindo apenas "virtualmente" convida críticas de vacilação quanto a compromissos ontológicos. Como Urry [1982] e Dallmayr [Giddens, 1982c:22] afirmaram, isso deixa a natureza das conexões entre estrutura virtual e sistema efetivo substantiva e teoricamente nebulosas. Substantivamente nebulosas porque Giddens não especifica os elementos sociais concretos que devem ser considerados predominantemente estruturais. Teoricamente nebulosas porque $\mathrm{o}$ significado de existência "virtual" não é nada óbvio, e por isso não podemos dizer se a relação entre estrutura e sistema é gerativa e causal ou (por contraste) expressiva e lógica.

Por outro lado, é verdade que quando Giddens coloca sua perspectiva geral para trabalhar, ele obtém algumas críticas importantes e avenidas interessantes para pesquisas posteriores. Assim, sua distinção entre recursos de alocação e de autoridade parece ser frutífera, e sua exploração de questões de dominação e legitimação é aguda. Não obstante, já que meus argumentos neste artigo têm a ver principalmente com coerência teórica, eu diria que as contribuições de Giddens a estas questões me parecem ter relativamente pouco a ver com a teoria da estruturação em suas várias formulações. $\mathrm{Ou}$, em outras palavras, essa teoria é esboçada de formas tão diversas, e com tantas ênfases múltiplas, que as diversas considerações de Giddens sobre contradições sociais são facilmente encaixadas sob o rótulo de "estruturação". Desta forma, a questão de se 
as principais coisas substantivas com as quais Giddens está preocupado (poder, recursos) são parte da definição de estruturação, ou se são meramente suas extensões plausíveis não importa muito. A estruturação se refere às "condições que governam a continuidade ou transformação de estruturas, e, portanto, a reprodução de sistemas" [Giddens, 1982c:35]. E a própria estrutura se refere a regras e recursos. Assim, o poder, a alocação e a reprodução precisam ser centrais para qualquer conteúdo que o modelo tenha. E o mesmo vale para o tempo, a outra dimensão favorita de Giddens. Entretanto, há um ponto em que este nexo de conceitos mais uma vez escorrega para uma afirmação de desiderata em vez de relações e proposições explícitas. Para conseguir encaixar tudo, Giddens [1981:4] tem um hábito pernicioso de apelar a quase-tautologias como um meio de definição, como neste enunciado: "na teoria da estruturação, o poder é considerado como gerado na reprodução de estruturas de dominação, e através delas". Este tipo de slogan indica a vacuidade da teoria da estruturação, e não sua força.

Obviamente, é injusto destacar algumas entre muitas formulações deste tipo para depois declarar que a teoria é frouxa. Uma das melhores exposições de Giddens acontece quando ele esboça a ideia de que a ação reflexiva ocorre em condições nãoantecipadas e tem consequências não-intencionais. A superioridade desta elaboração (na minha opinião) reside em sua demarcação clara de elementos lógicos e sociais, e sua preocupação distintamente "objetivista" de enfatizar o caráter confinado da ação. Eu gostaria de fechar esta parte da discussão meramente notando que Giddens chama seu ponto de vista de "modelo de estratificação da ação". Enquanto tal, ele toma sua posição como a sexta parte das dez que compõem a teoria da estruturação [Giddens, 1982c:31; 1981:27-29]. Um dos objetivos de minha discussão foi simplesmente questionar, baseado nas grandes discrepâncias na qualidade, generalidade e extensionalidade das formulações centrais de Giddens, se estamos analisando uma "teoria" aqui, ou em vez disso um amálgama de percepções e exageros pronunciados rapidamente.

Voltamos, então, para a questão chave do estatuto teórico: Giddens parece preso entre a ideia da teoria-como-salvas e a aspiração em desenvolver um relato positivo amplo do mundo moderno. Minha reclamação geral é que Giddens não conseguiu cumprir duas tarefas importantes necessárias para transformar o primeiro tipo de teoria social no segundo - uma elaboração filosófica, e enfatizar aspectos específicos de relações sociais como explicativamente primários. Ele pretende excluir todas as proposições funcionais sem examinar detalhadamente se as falhas do funcionalismo 
estão sempre e necessariamente implicadas nas ideias de funções (papéis, lugares, consequências não-intencionais). Ele declara ser "contra qualquer tipo de teoria evolucionista" [Giddens, 1982a:63] apesar da probabilidade de termos cognatos (gênese, desenvolvimento, transição) de aparecer em qualquer teoria que leve sequências temporais e estruturais a sério. E sua retenção da causalidade na teoria da estruturação é comprometida por algumas trivialidades existenciais (que somos finitos, e que os seres humanos fazem diferença no mundo por causa da autoconsciência). Eu vejo estas opiniões basicamente dogmáticas como grandes obstáculos para Giddens, se ele deseja iniciar uma nova direção poderosa no pensamento social.

Finalmente, e também minha crítica mais substantiva, as contradições sociais identificadas nas principais tradições da teoria social tendem a se dissolver em uma teia complexa de "fatores" nas mãos de Giddens. Mais uma vez, é preciso dizer que ele demonstra percepções sensíveis sobre os problemas do monismo teórico e também sobre o pluralismo do conflito social contemporâneo. Assim, ele enfatiza a saliência contínua da luta de classes contra o funcionalismo, mas usa a guerra, o nacionalismo, o poder, o feminismo e o urbanismo como efeitos polêmicos em sua desconstrução do materialismo histórico. O valor destas salvas críticas é óbvio para todos, exceto os apologistas das várias ortodoxias. Mas será que é apenas um dogmatismo nãodesconstruído que inspira a pergunta do quão convincente e coerente é a alternativa de Giddens, e que sugere uma resposta negativa? Hirst [1982] afirmou persuasivamente que o marxismo foi maltratado por Giddens em seus esforços para apontar suas "ausências" manifestas e múltiplas. Mas mesmo que Giddens esteja certo a este respeito, podemos conjurar uma alternativa viável ao materialismo histórico a partir de um amálgama de ausências? Será que o conceito de poder de Foucault constitui um avanço adequado, ou o conceito do papel da guerra na história de Kiernan, ou as elites construtoras do Estado de Skocpol, ou a "história-delas" ["herstory"] do feminismo, etc.? Para que a nova teoria social seja algo mais do que uma fusão de contradições separadas (por mais importante que cada uma delas seja), é preciso um trabalho construtivo adicional em vários níveis de abstração, e Giddens ainda não me convenceu que seu esquema pode realizar esta tarefa.

Minha discussão foi crítica, mas espero que não inclemente. De fato, eu não ofereço nenhuma perspectiva alternativa inapelavelmente superior à de Giddens. Minha intenção principal foi ajudar a estabelecer que uma concepção da ciência social 
construtivista e objetivista ainda é um objetivo legítimo e desejável, em oposição a posições ecléticas e descontinuístas que são atualmente populares nas ciências humanas. Também, por implicação, me esforcei para enfatizar que o materialismo histórico continua a ser o principal candidato para a teorização positiva, e que ainda é um guia específico, e não nominal, para a prática social. É claro que esta implicação não foi defendida detalhadamente aqui.

Aliás, eu não considero o termo "eclético" (utilizado no parágrafo anterior) como algo ruim em si mesmo. Pelo contrário, ele é um modo preparatório necessário e valioso de análise e crítica, para gerar sínteses positivas e coerentes. Então, apesar de eu ter alguma simpatia com Hirst [1982], que se diverte com o "sincretismo" do empreendimento de Giddens, sua própria resposta não consegue lidar o suficiente com a dificuldade de estabelecer uma perspectiva sintética avançada de forma não-eclética. Além do mais, sua conversão a modos "discursivos" de teorização e problematização enfraquece este ponto de sua crítica. Afinal, é apenas se realmente buscamos uma posição epistemologicamente segura, repleta de conceitos unitários e conexões lógicas, que o sincretismo e a inconsistência parecem insatisfatórios. Meu ponto de vista nesta nota crítica foi defender, contra Hirst e Giddens, a opção "racionalista" na investigação social.

\section{Bibliografia}

COHEN, G. A. [1979] Karl Marx's Theory of History: A Defence. Oxford, Oxford University Press.

GIDDENS, A. [1979] Central Problems in Social Theory. London: Macmillan.

GIDDENS, A. [1981] A Contemporary Critique of Historical Materialism. London: Macmillan.

GIDDENS, A. [1982a] "Historical Materialism Today: An Interview", in Theory, Culture \& Society, v. 1, n. 2.

GIDDENS, A. [1982b] “A Reply to the Critics”, in Theory, Culture \& Society, v. 1, n. 2.

GIDDENS, A. [1982c] Profiles and Critiques in Social Theory. London: Macmillan.

GIDDENS, A. [1982d] "Commentary on the Debate”, in Theory and Society, v. 11, n. 4.

HIRST, P. [1982] "The Social Theory of Anthony Giddens: A New Syncretism?”, in Theory, Culture \& Society, v. 1, n. 2.

THOMPSON, E. P. [1978] The Poverty of Theory. London: Merlin. 
URRY, J. [1982] "Duality of Structure: Some Critical Issues", in Theory, Culture \& Society, v. 1, n. 2. 


\section{Richard J. Bernstein - Teoria social como crítica}

“A teoria da estruturação está essencialmente incompleta se não for ligada a uma concepção de ciência social enquanto teoria crítica.” [Giddens, 1984:287]

A obra extensa de Anthony Giddens já é uma realização notável. Há poucos teóricos sociais e sociólogos contemporâneos cujo pensamento tenha alcance, diversidade e sutileza comparáveis. Giddens está no processo de tentar nada menos que repensar a tradição sociológica moderna. Ele escreveu de forma incisiva e provocadora sobre Marx, Weber, Durkheim, Parsons e Habermas. Ele se engalfinhou com todos os principais movimentos sociológicos, incluindo as variações do estruturalismo, funcionalismo, teoria dos sistemas, etnometodologia, sociologia fenomenológica e interacionismo simbólico. Ele tem um senso agudo da relevância das correntes filosóficas contemporâneas para o pensamento social, passando pela filosofia angloamericana, francesa e alemã. Ele expandiu o campo do pensamento sociológico mostrando a importância de temas tão diversos quanto as reflexões de Heidegger sobre a temporalidade e a significância dos estudos sobre tempo e espaço da geografia humana. Ele sempre está tentando explorar o jogo dialético entre teoria e pesquisa empírica, e enfrentou questões espinhosas - negligenciadas por muitos outros teóricos sociais - como o caráter e papel distintos do nacionalismo e do estado-nação nas sociedades contemporâneas. E tudo isto foi feito com rara habilidade hermenêutica. Giddens combina um talento para exposição simpática judiciosa com uma habilidade incrível de localizar e especificar problemas, forças e fraquezas nas posições e pensadores que ele examina. A característica mais importante e impressionante de sua obra não é seu virtuosismo intelectual, mas o impulso sistemático que está evidente mesmo em seus escritos mais antigos, e que se tornou mais focado e dominante em seus livros recentes. Giddens está engajado no projeto ambicioso de desenvolver uma teoria social estruturada e compreensiva adequada para nosso tempo que simultaneamente incorpora as percepções dos grandes pensadores sociais, rejeita o que é inadequado e errôneo, e pode guiar e esclarecer a pesquisa sociológica empírica. É este projeto sistemático que desejo explorar - um projeto centrado naquilo que Giddens chama de "A Teoria da Estruturação", uma abordagem teórica que reconstrói a dualidade da 
estrutura e ação humanas. Quero investigar a relevância da teoria da estruturação para entender as funções críticas da teoria social.

Dada a diversidade e riqueza dos escritos de Giddens e sua própria ênfase constante na importância do contexto espaço-temporal, o problema inicial é conseguir uma orientação própria. Começarei situando seu projeto ao comparar e contrastar seu livro recente, A constituição da sociedade [Giddens, 1984] com o clássico de Robert Merton, Estrutura social e teoria social [Merton:1949].

A obra de Merton serviu como um manifesto e afirmação do consenso sociológico para uma geração de sociólogos. Uma forma de discernir as mudanças (progresso?) na teoria social durante os últimos trinta e cinco anos é examinar as diferenças entre os dois textos. Não há nenhuma das principais teses propostas por Merton que Giddens não desafia diretamente e/ou qualifica seriamente. Podemos começar a entender o que Giddens está "tramando" ao examinar o que ele combate - e por que ele se opõe a isso tão fortemente. Merton começou seu famoso capítulo sobre "Funções manifestas e latentes" com uma reivindicação ousada:

“A análise funcional é ao mesmo tempo a abordagem contemporânea a problemas de interpretação sociológica mais promissora e possivelmente a menos codificada (...) As realizações da análise funcional são suficientes para sugerir que sua maior promessa será eventualmente cumprida, assim como suas deficiências atuais testemunham a necessidade de reformar periodicamente o passado para construir melhor para o futuro."

Giddens, apesar de admitir que a análise funcional "enfatizou fortemente a importância das consequências não-intencionais da ação", nos diz de forma decisiva que "conceitualmente sua influência foi em grande parte perniciosa" [Giddens, 1984:xxxi]. Os ataques frequentes e multifacetados de Giddens ao funcionalismo (em todas as suas variedades) são apenas a ponta do iceberg de suas desavenças com Merton (e com os sociólogos que compartilham a orientação de Merton) ${ }^{2}$. Merton começa seu livro refletindo sobre a natureza da sociologia enquanto uma disciplina, o caráter lógico da teoria e explicação sociológicas, e a relação entre teoria e pesquisa empírica. Giddens desafia todas as principais afirmações de Merton.

\footnotetext{
${ }^{1}$ Merton [1949:21]. Todas as referências de página a Merton são deste livro.

${ }^{2}$ Giddens critica o funcionalismo em vários de seus livros recentes. Além de suas notas sobre a análise funcional em Giddens [1984], ver "Funcionalism: après la lutte", em Giddens [1977].
} 
Merton compara o desenvolvimento da sociologia com outras ciências naturais como a física, química e biologia. Ele nos diz que é mais "realista" e "psicologicamente mais recompensador" comparar as realizações e potencial da sociologia do século XX com a medicina do século XVII em vez da física do século XX. "Talvez a sociologia ainda não esteja pronta para seu Einstein porque ela ainda não encontrou seu Newton" [Merton, 1949:7]. Merton nunca questiona seriamente se a analogia entre a sociologia enquanto disciplina científica e as outras ciências naturais é apropriada. Ele até sugere que a sociologia pode obter resultados comparáveis à física do século XX quando ela se beneficiar dos "bilhões de horas de trabalho em pesquisa ininterrupta, disciplinada e cumulativa" [ibid.] que foram necessárias para as realizações da física contemporânea. Mas para Giddens a própria analogia entre a sociologia e as ciências naturais é mal concebida. Ele ataca violentamente a tese popular de que a sociologia é uma ciência natural jovem ou "imatura". A sociologia não é e nunca poderá ser o tipo de ciência natural de seres humanos que Merton pressupõe ser seu objetivo e base racional. (Isto não significa que a sociologia não possa ser científica.) Merton distingue nitidamente a "história da teoria" e a "sistemática da teoria". De forma superficial, o próprio Giddens poderia aceitar tal distinção, mas ele se opõe fortemente à forma pela qual Merton a faz. Para Merton, a história da teoria social consiste em "quem disse o quê através de especulação ou hipótese" e inclui "os maus começos, as doutrinas arcaicas e os erros estéreis do passado". A "sistemática da teoria" supostamente consiste da "acumulação altamente seletiva das pequenas partes das teorias anteriores que até o momento sobreviveram aos testes da pesquisa empírica" [Merton, 1949:5]. Para Giddens, esta distinção fácil entre a história e a sistemática da teoria é enganosa. Ela indica o quanto Merton (e outros cientistas sociais de inclinação naturalista) aceitaram de forma nãocrítica uma concepção empirista lógica da ciência natural, hoje desacreditada. Um exemplo adicional é aquilo que talvez seja a parte mais conhecida do manifesto de Merton, sua defesa de "teorias de alcance médio". Merton defendia uma via media entre teorias "grandiosas que tudo englobam" e "hipóteses de trabalho menores", mas sua noção de teoria é essencialmente uma concepção de teoria nomológico-dedutiva. Ele distingue dois tipos de generalização sociológica: a generalização empírica, "uma proposição isolada resumindo uniformidades de relações observadas entre duas ou mais variáveis"; e "leis científicas". "O segundo tipo de generalização sociológica, a assim chamada 'lei científica', difere da anterior por ser um enunciado de invariância derivável de uma teoria" [Merton, 1949:92]. Giddens traz uma bateria completa de 
argumentos contra este entendimento de teoria. Este é o conceito de teoria que era privilegiado pelos empiristas lógicos. Mas a filosofia da ciência pós-empirista mostrou que "ela acabou tendo aplicação bastante limitada mesmo nas ciências naturais" [Giddens, 1984:xviii]. Se é assim que concebemos a teoria, então "qualquer um que pretenda aplicá-la à ciência social precisará admitir que (por enquanto) ainda não há teoria alguma" [ibid.]. Giddens bate mais forte. O próprio caráter sedutor da concepção de teoria e lei científica nomológico-dedutivas se baseia numa suposição errônea: "a ideia de que a 'teoria' na teoria social precisa consistir essencialmente de generalizações se ela quiser ter conteúdo explicativo" [ibid.]. Mas isto é uma ficção. "A maioria das perguntas 'por quê?' não precisa de uma generalização como resposta, nem as respostas implicam logicamente que deve haver alguma generalização escondida em algum lugar que poderia ser invocada para apoiar a resposta" [Giddens, 1984:xix]. Giddens vai ainda mais longe em sua tentativa de demolir e desconstruir o próprio entendimento de teoria, explicação e generalização que Merton defende, e que foi (e continua a ser) aceito em versões mais fracas por muitos cientistas sociais. Merton não apenas mistifica o conceito de teoria social, mas obscurece o caráter e o papel das generalizações empíricas na sociologia. Giddens nos diz que "a descoberta de generalizações não é a tarefa suprema e básica da teoria social" [ibid.]. Além do mais, generalizações empíricas não consistem apenas de proposições "que resumem uniformidades de relações observadas entre duas ou mais variáveis”. Também há generalizações (que são muito importantes na teoria da estruturação de Giddens) que "valem porque os próprios atores as conhecem - em alguma forma - e as aplicam na realização do que fazem. $O$ cientista social observador não precisa 'descobri-las', mas pode dar uma nova forma discursiva a elas" [ibid.].

Além do mais, as reivindicações que Merton faz sobre teoria, lei, explicação e generalização empírica ofuscam o que ele quer esclarecer - a relação entre teoria sociológica e pesquisa empírica. Seu aparato conceitual nos leva a pensar que o papel principal da pesquisa empírica é "descobrir” as generalizações empíricas que confirmam ou refutam leis sociológicas deriváveis de teorias. Mas esta concepção do papel da pesquisa empírica é limitadora demais. Ela insulta as contribuições empíricas do tipo de pesquisa etnográfica que não está preocupada em resumir as uniformidades observadas de relações entre duas ou mais variáveis, mas em fornecer "descrições densas" das formas de vida de atores sociais. 
Poderíamos continuar nesta trilha, mostrando detalhadamente como Giddens desconstrói obstinadamente o edifício da teoria sociológica apresentado por Merton (que foi compartilhado amplamente por sociólogos). O funcionalismo não é a única orientação sociológica atacada por Giddens. Ele é igualmente incansável em sua crítica ao estruturalismo, objetivismo, subjetivismo, naturalismo e evolucionismo. Giddens usa várias táticas de guerrilha ao atacar todos estes "-ismos". Mesmo sua prosa fica mais farpada e lapidar quando ele "vai atrás" dos espectros que ainda assombram a teoria social. Há poucos que podem rivalizar com Giddens enquanto crítico penetrante dos dogmas, metáforas enganosas (por exemplo, as várias metáforas biológicas e sistêmicas) e pressuposições não questionadas que assolam o pensamento sociológico. Mas Giddens não é apenas um "crítico crítico" ou um “crítico negativo". O que baseia suas análises detalhadas e lhes dá tanta força é a forma através da qual ele as usa para elaborar uma abordagem sociológica substantiva alternativa para entender, explicar e criticar a sociedade contemporânea.

Permitam-me ilustrar isto voltando à questão do funcionalismo. Eu já indiquei que Giddens realmente pensa que a análise funcional deu uma contribuição positiva ao enfatizar a importância de "consequências não-intencionais" da ação social. O que ele quer dizer é que podemos apropriar esta ênfase positiva sem usar nenhum conceito funcional. $\mathrm{O}$ que exatamente há de errado com o funcionalismo? Apesar de Giddens listar vários tipos diferentes de objeções ao funcionalismo, sua objeção central é que uma explicação funcional "na verdade não explica nada. Podemos demonstrar isto contrastando os tipos de descrição" [Giddens, 1984:294]:

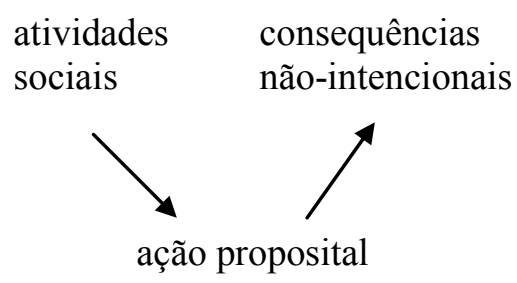
(2) atividades sociais consequências funcionais

A interpretação (2) é o tipo de descrição favorecida pelos funcionalistas. Mas "a interpretação (2) não é uma explicação porque ela não fornece um mecanismo que ligue a afirmação de uma necessidade funcional com as consequências que supostamente ocorrerão para o sistema social mais amplo em que as atividades a serem explicadas estão envolvidas" [Giddens, 1984:295]. 
Consideremos a "interpretação funcional" de Merton do cerimonial da chuva dos hopi. A função manifesta da cerimônia é causar chuva, mas a função latente é reforçar um "sistema unitário de valores" necessário para sustentar uma sociedade tão pequena. Esta pode ser a consequência não-intencional da prática social da cerimônia da chuva, mas podemos afirmar isto sem usar nenhum conceito funcional. (É para isto que serve a interpretação (1).) Ao sugerir que estas consequências ocorrem "por causa" de uma "necessidade funcional”, estamos apenas mistificando a situação. Assim, explicações pseudofuncionais não apenas não fornecem um mecanismo que ligue uma "necessidade funcional" a consequências não-intencionais, mas o próprio conceito de "necessidade funcional" é uma ficção (uma ficção que ganha plausibilidade parcial por causa da apropriação enganosa de metáforas biológicas sobre as "necessidades" de sistemas sociais).

Giddens cava ainda mais fundo. O próprio conceito crucial de "consequências não-intencionais" pressupõe um conceito viável de ação humana. É isto que Giddens busca elaborar. Não podemos falar legitimamente de consequências não-intencionais a não ser que esclareçamos os critérios para distinguir ação intencional de nãointencional. Giddens sabe que esclarecer sistematicamente a natureza da ação humana requer explicar uma série de conceitos inter-relacionados como poder, motivos e razões. (Podemos seguir aqui a apropriação e reconstrução criativa de Giddens da análise filosófica da ação anglo-americana). Além do mais, a ação social humana não pode ser compreendida adequadamente a não ser que entendamos conceitualmente como a própria ação está implicada reflexiva e recursivamente nas estruturas sociais. Resumindo, pensar o que está certo e errado no funcionalismo, investigar e avaliar criticamente o que as interpretações funcionais pressupõem, nos leva ao próprio coração da teoria da estruturação - a teoria que pretende iluminar a dualidade e o jogo dialético entre ação e estrutura ${ }^{3}$.

\footnotetext{
${ }^{3}$ Meu foco na crítica do funcionalismo de Giddens, e em como ela tanto apoia quanto se baseia na teoria da estruturação, pretende ilustrar o que é característico de sua abordagem crítica. Giddens não está meramente preocupado em "marcar" pontos negativos contra as doutrinas às quais se opõe, mas em nos mostrar como pensar sobre as percepções e inadequações destas doutrinas contribui para a articulação e embasamento da teoria da estruturação. Eu sugiro que esta é a forma mais esclarecedora de interpretar suas críticas do evolucionismo, objetivismo, subjetivismo e naturalismo. Neste ponto, a abordagem de Giddens reflete um enunciado afirmado com força pela filosofia da ciência pós-empirista: podemos julgar a adequação de uma teoria - como a teoria da estruturação - através de sua habilidade de explicar o que é válido e inválido em teorias rivais.
} 
O que é, então, a teoria da estruturação? Num enunciado preliminar, Giddens nos diz:

"A estrutura, enquanto conjuntos de regras e recursos organizados recursivamente, está fora do tempo e do espaço, exceto em suas instâncias e coordenação enquanto traços de memória, e é marcada por uma 'ausência do sujeito'. Os sistemas sociais nos quais a estrutura está implicada recursivamente, ao contrário, compreendem as atividades situadas de atores humanos, reproduzidas através do tempo e espaço. Analisar a estruturação de sistemas sociais significa estudar os modos pelos quais tais sistemas, baseados nas atividades com conhecimento [knowledgeable] de atores situados que utilizam regras e recursos em vários contextos de ação, são produzidos e reproduzidos na interação. Crucial à ideia de estruturação é o teorema da dualidade da estrutura (...) A constituição de atores e estruturas não são dois conjuntos de fenômenos dados independentemente, um dualismo, representando, em vez disso, uma dualidade. De acordo com a noção de dualidade da estrutura, as propriedades estruturais de sistemas sociais são tanto meio quanto resultado das práticas que elas organizam recursivamente. A estrutura não é 'externa' aos indivíduos (...) A estrutura não deve ser igualada à coerção, ela é sempre coerciva e permissiva.” [Giddens, 1984:25, itálico meu]

Numa primeira leitura, o resumo acima é extremamente denso. A constituição da sociedade, assim como grande parte dos escritos recentes de Giddens, pode ser vista como uma explicação e elaboração do que isto significa e implica. (para explicações breves das expressões em itálico na passagem acima, ver seu Glossário [Giddens, 1984:373-7]). Os detalhes concretos da teoria da estruturação de Giddens são tão ricos e complexos que, neste contexto, o máximo que posso esperar é indicar seus principais temas, articular as visões centrais que baseiam a teoria. Pois apesar da teoria provocar várias questões e ainda estar num processo de desenvolvimento, já podemos discernir seus contornos. A teoria é poderosa e atraente porque ela exprime um entendimento profundo do que somos enquanto atores humanos reflexivos e hábeis [knowledgeable] que sempre são condicionados por estruturas sociais que constantemente reproduzimos.

Podemos evocar esta visão central de várias perspectivas. Uma forma de acessar a teoria é encará-la contra dois polos extremos que caracterizaram grande parte da sociologia do século XX. Há pensadores sociais que focaram sua atenção principalmente em estruturas, coerções sociais e características sistêmicas da sociedade, e que disseram que este é o domínio apropriado da análise sociológica. Estas estruturas 
impessoais precisam ser descobertas e explicadas se quisermos entender como os seres humanos funcionam na sociedade. Frequentemente, deste ponto de vista, a tarefa do sociólogo é a descoberta destas forças, leis, tendências e "coerções estruturais" que sempre operam "pelas costas" dos atores sociais. Há mesmo aqueles que afirmam que o ator social se dissolve numa série de estruturas ou que deve ser localizado como um mero "genérico" ["place holder"] num sistema impessoal dinâmico. Quando tal orientação estruturalista é pressionada ao extremo, ela causa uma reação desproporcional. Surge uma desconfiança profunda quanto a qualquer conversa sobre estruturas impessoais. A partir deste extremo oposto, tudo isso passa a ser considerado uma reificação ou hipóstase de algo que é sempre fluido e mutável - o que está sempre no processo de ser negociado e renegociado. Não importa se os defensores deste extremo se consideram "individualistas metodológicos" ou etnometodólogos enfocando as interações face-a-face de indivíduos, eles têm pouca simpatia com qualquer coisa que se pareça com estruturas reificadas. Quando estes polos opostos são pressionados a seus extremos, nos deparamos com um "ou... ou" rígido. Ou sobra uma dança de estruturas impessoais, ou um jogo de atores nominalistas.

Claro que a situação não é tão simples e evidente assim. Pessoas atraídas para um destes polos - os polos da estrutura e da ação - dizem ser capazes de acomodar as "percepções" de seus oponentes. Giddens mostra que a maioria destes "compromissos" não funciona. Eles não funcionam porque não podemos simplesmente emendar uma abordagem deficiente adicionando alguns corolários como concessões. Se quisermos escapar desta oposição instável, então precisamos de uma reconstrução dos conceitos de estrutura $e$ ação. Precisamos analisar a estrutura social para podermos discernir claramente como ela requer a ação, e analisar a ação humana de forma que compreendamos como toda ação social envolve a estrutura social. Pois a estrutura social é sempre ao mesmo tempo coerciva e permissiva. Ela limita e determina "a capacidade do indivíduo de 'fazer diferença' num estado de coisas ou curso de eventos préexistente" [Giddens, 1984:14]. Esta é a principal força da reivindicação de Giddens de que "a constituição de atores e estruturas não são dois conjuntos de fenômenos dados de forma independente, e sim representam uma dualidade" [Giddens, 1984:25]. Ambos dependem do outro e implicam o outro.

Outra perspectiva para compreender o que é central para a teoria da estruturação é enxergá-la (como Giddens o faz) como um comentário e elaboração da famosa 
afirmação de Marx que "os homens [digamos imediatamente seres humanos] fazem a história, mas (...) não a fazem sob circunstâncias de sua escolha”. Depois de citar esta passagem, Giddens nota: "Bem, é verdade. Mas que tamanha diversidade de problemas complexos de análise social este pronunciamento aparentemente inócuo revela!" [Giddens, 1984:xxi] São exatamente estes "problemas complexos" que a teoria da estruturação deve iluminar e resolver.

Eu acho que a forma mais clara de entender os pontos centrais da teoria da estruturação é enfocar o conceito de "consciência prática". Giddens nos diz que "a importância da consciência prática é um dos principais temas [de $A$ constituição da sociedade]" [Giddens, 1984:xxiii] e ela é um dos principais temas da teoria da estruturação. Giddens resume (em seu Glossário) o que ele quer dizer com "consciência prática":

"Aquilo que os atores sabem (acreditam) sobre condições sociais, incluindo especialmente condições de sua ação, mas que não podem expressar de forma discursiva; entretanto, nenhuma barreira de repressão protege a consciência prática, como ocorre com o inconsciente" [Giddens, 1984:375].

A consciência prática precisa ser diferenciada da consciência discursiva, por um lado, e do inconsciente, por outro. Quando Giddens fala da habilidade cognitiva que os atores sociais possuem em relação às atividades, ele está se referindo principalmente à sua habilidade cognitiva prática (know-how). Os atores humanos sabem, de forma prática, bastante sobre o que estão fazendo, sobre sua sociedade, sobre as regras dos jogos em que estão envolvidos (e mesmo sobre como burlar tais regras). Os atores sociais estão sempre monitorando reflexivamente sua ação. Nós não somos "patetas culturais", nem somos atores que percebemos de forma transparente o que estamos fazendo. Estamos sempre no processo de fazer a história em circunstâncias que não escolhemos, e não temos consciência total (e nem podemos ter) do que estamos fazendo e criando.

William James comentou uma vez que "qualquer autor é fácil se você pegar o centro de sua visão", e continuou sugerindo que para apreciar os detalhes técnicos do sistema de um autor, era preciso pegar o centro de sua visão. Talvez James tenha sido um pouco otimista, mas sua afirmação é relevante para entender Giddens. Se quisermos compreender os detalhes técnicos das reflexões de Giddens sobre estudos espaço- 
temporais para a análise social, a importância da dualidade de presença/ausência, regionalização, segurança ontológica, etc., então precisamos ver como tais discussões são alimentadas, contribuem e nuançam sua visão central da dualidade entre estrutura e ator.

Eu afirmei que a visão no centro da teoria da estruturação é poderosa e atraente sem justificar totalmente este enunciado. Eu acho que Giddens está no caminho certo quando enfoca o caráter "saltitante" de grande parte da análise sociológica contemporânea. $\mathrm{Na}$ verdade, eu penso que encontramos este mesmo balanço instável para frente e para trás não apenas em todas as disciplinas sociais mas em todas as disciplinas culturais - incluindo a teoria política e a filosofia. Em todas estas disciplinas há uma oscilação instável entre uma obsessão nominalista com atores individuais isolados e uma fascinação com a dissolução de atores em sistemas de sinais, estruturas e epistemes. Pensem, por exemplo, nas formas típicas com as quais filósofos analíticos anglo-americanos abordam a "filosofia da ação", modelando suas análises em atores intencionais isolados, e contrastem isto com a fascinação francesa com a différence, o jogo das estruturas e o "descentramento do sujeito". Ambas as tendências podem ser encontradas em Nietzsche - o que pode ser uma das razões para ele estar tão na moda. Mas depois de toda a conversa chique sobre desconstrução, a necessidade intelectual mais profunda de nosso tempo é a reconstrução. É isto que Giddens está tenazmente tentando realizar. Seu projeto de reconstrução não apenas é importante teoricamente, mas tem significância prática enorme. Pois, sem cair na desesperança de pensar que há uma "lógica da história" que sempre opera pelas nossas costas com necessidade inexorável ou cair numa ilusão voluntarista simplista de que podemos ser mestres completos de nosso destino, Giddens permite que entendamos os limites e as oportunidades para moldarmos nossos destinos. Por estas razões, aquilo que ele já realizou tem uma importância que vai muito além dos domínios da sociologia.

É claro que há muito em Giddens aberto a críticas sérias. Seus vícios intelectuais são o outro lado de suas virtudes. Em seu desejo de abrangência, ele frequentemente escreve como se tivesse uma opinião bem fundamentada sobre virtualmente qualquer tópico ou tema que tenha sido abordado por qualquer pensador social. Consequentemente, suas análises são desiguais. (Por exemplo, seu exame detalhado da natureza e variedades de tipos de coerção social é sutil, perspicaz e esclarecedor, todavia suas afirmações sobre o inconsciente e seu papel na explicação social tendem a 
ser superficiais.) Às vezes a sensação é de que Giddens não está sempre em controle do material que está discutindo. Quando esperamos explicações e justificações detalhadas, muitas vezes encontramos repetições e variações “eloquentes". Giddens tem temperamento de raposa em sua abordagem, apesar de suas ambições sistemáticas exigirem que ele seja como o porco-espinho. Dada a simples variedade de tópicos, temas e pensadores que ele trata, podemos entender por que ele nos diz que "este não foi um livro particularmente fácil de escrever e, em parte, mostrou-se refratário à ordenação normal em capítulos" [Giddens, 1984:xxxv]. Giddens comete um "pecado" comum entre outros sociólogos que pensam de forma ampla. Pois sempre que ele confronta um problema difícil, ele é tentado a introduzir um excesso de distinções e esquemas (Giddens critica Parsons e Habermas por adotarem esta prática, mas ele também é culpado disto). Muitas destas distinções são esclarecedoras, mas frequentemente temos uma sensação desagradável de que muito mais precisa ser dito sobre os critérios de sua aplicabilidade. Giddens reflete sobre o jogo da teoria e a pesquisa empírica. Apesar dele rejeitar a ideia estreita de que a única ou principal função da pesquisa empírica é confirmar ou rejeitar "leis" derivadas de postulados teóricos, e a visão indutiva ingênua de que podemos construir teorias através da generalização de observações empíricas, ele afirma que a teoria pode nos "sensibilizar" à pesquisa empírica.

"Os conceitos da teoria da estruturação, como os de qualquer perspectiva teórica rival, devem, para muitos propósitos de pesquisa, ser considerados como dispositivos sensibilizadores [sensitizing devices], e nada mais. Quer dizer, eles podem ser úteis para pensar sobre problemas de pesquisa e a interpretação de resultados de pesquisas. Mas supor que ser bem fundamentado teoricamente - o que é necessário para qualquer um que trabalhe nas ciências sociais, até certo ponto - significa sempre operar com um tumulto de conceitos abstratos é tão nocivo quanto uma doutrina que sugira que podemos nos virar muito bem sem usar nenhum conceito." [Giddens, 1984:326-327]

O capítulo final de $A$ constituição da sociedade, "Estruturação, pesquisa empírica e crítica social", é um tour de force no qual Giddens mostra como a teoria da estruturação pode servir como um dispositivo sensibilizador crítico para avaliar e mostrar a importância teórica de tipos bastante diferentes de pesquisa empírica. No entanto, dado o caráter elaborado (e o que às vezes parece ser o caráter elaborado demais) dos vários conceitos e distinções da teoria da estruturação, às vezes podemos 
suspeitar que o próprio Giddens é culpado da prática nociva de "operar com um tumulto de conceitos abstratos".

As falhas mencionadas acima são esperadas numa perspectiva teórica tão elaborada e compreensiva como a teoria da estruturação. Muitas das dificuldades podem ser resolvidas sujeitando a teoria da estruturação à crítica rigorosa que ela merece. Giddens, que refina continuamente seus conceitos e distinções, já demonstrou sua habilidade de responder de forma criativa a críticas (ver por exemplo seu refinamento dos sentidos e variedades de "coerção" no capítulo 4 de $A$ constituição da sociedade). Mas eu quero me concentrar numa área em que muitos destes problemas ficam bastante claros, e onde há evidências de confusões sérias e tendências em conflito. Trata-se das reflexões de Giddens sobre a ciência social enquanto crítica - "a teoria da estruturação está essencialmente incompleta se não for ligada a uma concepção de ciência social enquanto teoria crítica" [Giddens, 1984:287]. Entretanto, ao buscarmos o que Giddens quer dizer com crítica e teoria crítica, descobrimos não apenas ambiguidades e vaguidade, mas reivindicações conflitantes e até contraditórias. Para sermos justos com Giddens, devemos notar que ele admitiu francamente não ter "examinado em qualquer detalhe" como ele pretende lidar com os assuntos relevantes ${ }^{4}$. Minha preocupação não é tanto com o que ele deixou de dizer, mas com o que ele diz.

Para localizar as áreas problemáticas específicas, são precisos dois conjuntos preliminares de afirmações. O primeiro trata de como Giddens entende "teoria" quando fala de teoria social, sociológica ou crítica. O segundo lida com o que ele considera ser uma concepção errônea ou inadequada da teoria crítica. Pois Giddens é mais claro sobre o que ele é "contra" do que sobre o que ele é "a favor".

(1) Como referência, voltemos à concepção de Merton de teoria científica - uma concepção que deve muito à análise da teoria científica dos empiristas lógicos. Uma "virtude" desta concepção de teoria é sua clareza relativa sobre o que constitui uma teoria científica "legítima" ou não. Para Merton, uma teoria consiste em conceitos, distinções, postulados e teoremas que formam um sistema dedutivo. Teorias são usadas para explicar fenômenos empíricos porque "leis científicas" podem ser derivadas de teorias; e estas leis, por sua vez, podem ser confirmadas ou refutadas por generalizações

\footnotetext{
${ }^{4}$ Para as reflexões de Giddens sobre a teoria crítica e a função crítica da ciência social, ver Giddens [1982:63-77].
} 
empíricas. Teorias não devem ser entendidas como "consistindo de orientações gerais para os dados, sugerindo tipos de variáveis que devem ser levadas em conta de alguma forma...". A teoria consiste em "enunciados claros e verificáveis de relações entre variáveis especificadas" [Merton, 1949:9, itálico no original]. Não devemos confundir a teoria com a metodologia, ou com uma "análise [miscelânea] de conceitos sociológicos" como estatuto, papel, Gemeinschaft, interação social, anomia, etc. A teoria também não consiste em "interpretações sociológicas post factum" [Merton, 1949:90] que podem explicar quase qualquer dado. A teoria "propriamente dita" é formulada segundo o modelo da explicação hipotético-dedutiva ${ }^{5}$.

Giddens, utilizando as críticas desta concepção de teoria feitas por filósofos da ciência pós-empiristas, a rejeita por ser estreita, restritiva e distorcida demais. Ironicamente, muito do que Merton diz não pertencer à teoria "propriamente dita" está incluído na noção de teoria de Giddens (depois de removidas suas conotações negativas). Para Giddens, teoria ou uma orientação teórica é algo muito mais aberto do que Merton ou os empiristas lógicos sugerem. Giddens faz uma distinção heurística preliminar entre "teoria sociológica" e "teoria social":

“Eu uso o termo 'teoria social' para abranger assuntos que, na minha opinião, são preocupações de todas as ciências sociais. Estes assuntos tratam da natureza da ação humana e do eu atuante; de como a interação deve ser concebida e sua relação com as instituições; e de compreender as conotações práticas da análise social. Eu entendo a 'sociologia', por outro lado, não como uma disciplina genérica que lida com o estudo das sociedades humanas como um todo, mas o ramo da ciência social que enfoca particularmente as sociedades modernas ou 'avançadas'. Tal caracterização disciplinar implica numa divisão de trabalho intelectual, apenas isso. Apesar de existirem teoremas e conceitos que pertencem distintamente ao mundo industrializado, não há como distinguir claramente algo chamado 'teoria sociológica' dos conceitos e preocupações mais gerais da teoria social.

'Teoria social' é um termo que não tem precisão alguma, mas é muito útil por causa disso. Como eu o concebo, 'teoria social' envolve a análise de assuntos que transbordam para a filosofia, mas que não é uma atividade primariamente filosófica (...) A teoria social tem a tarefa de fornecer concepções da natureza da atividade social humana e do ator humano que possam ser postas a serviço do trabalho empírico. A principal

\footnotetext{
${ }^{5}$ Ver minha discussão crítica da concepção de teoria social de Merton em Bernstein [1976:7-18].
} 
preocupação da teoria social é a mesma das ciências sociais em geral: o esclarecimento de processos concretos da vida social". [Giddens, 1984:xvi-xvii]

A extensão da citação acima se justifica não apenas porque ela transmite a ideia do entendimento de Giddens da teoria social e sociológica, mas também porque ela mostra como ele rompe bruscamente com as concepções de teoria mais "precisas" e "restritivas" dos empiristas lógicos. Podemos ver como Giddens está distante dos empiristas lógicos (e de uma geração anterior de cientistas sociais metodologicamente acanhados) que estavam obcecados com o problema de demarcar precisamente a teoria científica daquilo que era considerado especulação não-científica ou pseudocientífica. Mas esta concepção mais aberta de teoria contém seus próprios problemas. Ela é tão aberta que fica difícil discernir o que pertence a uma orientação teórica e o que não pertence.

(2) Giddens claramente quer se distanciar da concepção específica de "teoria crítica" empregada pela Escola de Frankfurt, e especialmente como utilizada por Jürgen Habermas. Ele rejeita categoricamente "o programa de fundamentar a teoria crítica porque eu quero estabelecer a ideia de duas casas, a casa factual e a casa moral-crítica entre as quais nos movemos - e nenhuma delas é segura"6. Ele nos diz que "eu uso o termo teoria crítica, mas eu não tenho em mente nada que esteja ligado aos escritos de Frankfurt de onde o termo obviamente surgiu"" . Mas nos informar aquilo que ele "rejeita" e por que ele se opõe a isso não esclarece o que ele defende.

"Eu quero seguir a estratégia de, por assim dizer, disparar salvas críticas na realidade e tentar focá-las em torno dos assuntos que mencionei antes: a singularidade do mundo moderno, as implicações disso em relação ao mundo tradicional, o que isto permite pensar a respeito de fórmulas óbvias para a teoria política e então como se pode, digamos, tecer uma teia ao redor deles. Eu não acho que apoiaria nenhum programa que tentasse fundamentar a teoria crítica, mas eu também não apoiaria o oposto, quero dizer, a ideia de uma crítica puramente imanente ou uma forma não-fundamentável de crítica. Eu provavelmente trabalharia mais a partir de uma concepção sociológica que para mim sugeriria que algumas coisas são claramente nocivas e outras coisas são claramente desejáveis, e que não é preciso fundamentá-las para proclamar que este é o caso." ${ }^{\prime 8}$

\footnotetext{
${ }^{6}$ Giddens [1982:74].

${ }^{7}$ Giddens [1982:77].

${ }^{8}$ Giddens [1982:72].
} 
Mas por mais atraente que esta concepção pluralista de crítica - quase como uma raposa - possa parecer, ainda temos a sensação desconfortável de que Giddens não está enfrentando alguns assuntos complicados, e sim evitando-os. Analisarei isto com mais detalhes.

Às vezes, ao falar da função crítica da ciência social, Giddens apela ao que pode ser chamado de concepção "minimalista" da crítica. Qualquer orientação teórica, não importa o quão aberta seja, que tiver algum conteúdo determinado excluirá algumas outras orientações teóricas. Neste sentido minimalista, toda teoria tem uma implicação crítica. Se, por exemplo, aceitarmos que a teoria da estruturação é válida, então precisamos rejeitar o funcionalismo ou o estruturalismo. Mas este sentido minimalista de crítica não apenas é reversível (se o funcionalismo é válido, então rejeitaríamos a teoria da estruturação); ele é uma característica das teorias de qualquer disciplina. Então, esta concepção minimalista, apesar de bastante importante quando avaliamos teorias rivais específicas, não nos leva muito longe se quisermos entender o que há de distinto na ciência social crítica, se é que há algo.

Às vezes Giddens confunde o assunto das consequências práticas da ciência social no mundo social com seu impacto crítico. Isto fica evidente em seu apelo ao exemplo do discurso de Maquiavel sobre o estado e a soberania - um exemplo que ele usa em A constituição da sociedade [Giddens, 1984:350-354] e em outros escritos. Seu argumento básico é que os próprios conceitos de Estado e soberania forjados por Maquiavel se tornaram constitutivos da realidade social que os indivíduos confrontavam. Os seres humanos começaram a pensar e agir numa "nova" realidade social. Este exemplo pretende ilustrar o "enorme impacto prático sobre o mundo social" do pensamento social. Ora, apesar de eu concordar com muito do que Giddens diz sobre Maquiavel e sobre as formas em que seu discurso foi apropriado e incorporado pela realidade social, eu não consigo ver como isto seria suficiente para esclarecer a função crítica da ciência e teoria social. Giddens realmente mostra que a ciência social não é um mero epifenômeno, que ela pode ter e tem influências práticas, e mesmo um impacto enorme em nossas vidas cotidianas. Mas será que precisávamos que Giddens nos dissesse isto? Consideremos as muitas formas através das quais a economia clássica e neoclássica influenciaram profundamente nossos modos de pensar, falar e agir. Análises de "custo-benefício" não apenas penetram em nossa linguagem cotidiana, mas influenciam os modos através dos quais muitas pessoas pensam suas carreiras ou 
mesmo suas vidas sexuais. Ou pensemos nas muitas formas pelas quais o jargão psicológico infectou e afetou a vida burguesa contemporânea, especialmente nas sociedades ricas - um tema que Philip Rieff, Christopher Lasch e Alasdair MacIntyre enfatizam em suas análises sociológicas da vida contemporânea. Estes são exemplos onde a ciência social (economia e psicologia) teve "um impacto prático enorme no mundo social", mas isto dificilmente mostra que "a ciência social está necessariamente conectada à teoria crítica, em algum sentido do termo". Para mostrar isto, para realmente enfrentar a questão da função crítica da ciência social, é preciso esclarecer precisamente qual é (ou qual deveria ser) a relação entre a ciência social e os juízos críticos - sejam os juízos críticos de teóricos ou investigadores sociais ou dos participantes numa interação social. Podemos concordar com Giddens quando ele diz que "desenvolver o caráter critico da ciência social significa promover uma percepção conceitual sofisticada das conotações práticas de seu próprio discurso" [Giddens, 1984:353], mas tal "percepção conceitual sofisticada" requer algo "mais" se ela quiser ser genuinamente crítica. Ela precisa de padrões ou critérios para fazer discriminações críticas sobres estas "conotações práticas".

O próprio Giddens distingue uma função crítica "tecnológica" característica da aplicação das teorias e descobertas das ciências naturais da função crítica das ciências sociais. Ele nos diz que

"as ciências sociais, diferente das naturais, estão inevitavelmente envolvidas numa 'relação sujeito-sujeito' com o que elas tratam. As teorias e descobertas das ciências naturais são separadas do universo de objetos e eventos que elas analisam. Isto garante que a relação entre conhecimento cientifico e o mundo dos objetos seja 'tecnológica', em que o conhecimento acumulado é aplicado a um conjunto de fenômenos constituído independentemente. Mas nas ciências sociais a situação é diferente. Como afirma Charles Taylor: 'apesar da teoria da ciência natural também transformar a prática, a prática que ela transforma não é o assunto da teoria (...) isto é pensado como uma "aplicação" da teoria'. Nas ciências sociais, 'a prática é o objeto da teoria. A teoria, neste domínio, transforma seu próprio objeto'”. [Giddens, 1984:348]

O enunciado acima é uma variação de um tema persistente na obra de Giddens a "hermenêutica dupla" entre a ciência e a teoria social. (Ver seu Glossário [Giddens, 1984:374] para uma caracterização sucinta da "hermenêutica dupla".) Mas mesmo que aceitemos alguma forma da tese da "hermenêutica dupla" de Giddens, isto ainda deixa 
em aberto questões cruciais sobre a função crítica da teoria social e da ciência social. Primeiro, como Giddens sabe e já mostrou, uma atitude ou abordagem "tecnológica" não se limita à aplicação das descobertas e teorias das ciências naturais. Esta é precisamente a atitude que muitos cientistas sociais envolvidos em políticas sociais adotam para usar as descobertas das ciências sociais. O fato de que a "aplicação" de tais descobertas pode transformar os objetos que elas tratam (por exemplo, seres humanos) não questiona de forma alguma a possibilidade ou sucesso de tal aplicação tecnológica de descobertas das ciências sociais. Podemos usar as técnicas de modificação comportamental para eliminar sintomas comportamentais indesejáveis ou para fazer lavagem cerebral de seres humanos. A questão crítica ainda está em aberto: para que fins ou propósitos devemos usar nosso "conhecimento científico"? Em segundo lugar, mesmo se aceitarmos a afirmação de Giddens de que, em muitos casos, os participantes - os sujeitos estudados - podem apropriar, e apropriam, aquilo que o investigador social descobre, isto ainda deixa em aberto questões importantes sobre o uso crítico do conhecimento das ciências sociais.

Giddens analisa extensivamente o estudo de Paul Willis (Aprendendo a trabalhar) sobre crianças de classe operária numa escola localizada numa área pobre de Birmingham. Ele pensa que esta é uma pesquisa exemplar e teoricamente sugestiva quando abordada do ponto de vista da teoria da estruturação. Mas apesar da discussão esclarecedora que o próprio Giddens faz desta pesquisa, ele nos deixa com uma ambiguidade crucial em relação à função crítica da ciência social. Enquanto Willis nos permite entender "os rapazes" nesta situação escolar, e mesmo o quanto eles sabem, de forma prática, sobre como a autoridade funciona e como eles podem reagir a ela, esta informação pode ser usada de formas radicalmente diferentes. Ela pode ser usada pelas "autoridades" para aumentar sua "eficiência" e "eficácia" nas escolas. Ou ela pode ser usada pelos "rapazes" ou por pessoas que simpatizam com eles para desmascarar e questionar a legitimidade dessas autoridades. Ainda podemos perguntar quem vai usar este conhecimento, e para quê. Resumindo, eu não acho que o próprio Giddens tenha nos fornecido uma compreensão suficientemente determinada da função crítica da teoria social para distingui-la daquilo que ele rejeita, ou seja, a aplicação "tecnológica" do conhecimento social. Isto fica claro até em sua análise das "contradições" sociais. Giddens quer defender a aplicabilidade do conceito de contradição na análise social. Há contradições estruturais sociais reais (que não devem ser confundidas com conflitos 
sociais). Os conceitos de contradição e conflito precisam ser diferenciados cuidadosamente. A contradição estrutural é a "disjunção de princípios estruturais da organização do sistema", enquanto o conflito é uma "luta entre atores ou coletividades expressa como práticas sociais definidas" [Giddens, 1984:198]. Contradições podem (ou não) gerar conflitos. Mas é difícil ver qual é a diferença que separa este conceito de contradição daquilo que o funcionalismo rotulou de "disfunções sistêmicas". Mais uma vez a questão crítica fica em aberto. Mesmo que concedamos a "legitimidade" do conceito de Giddens de uma contradição estrutural, nossa abordagem pode ser buscar abafar o conflito, encontrando alguma forma de matizar ou eliminar os efeitos perniciosos de tal contradição (sem modificar de forma significativa um "sistema social"), ou buscar alimentar o tipo de conflito onde os atores se tornam "conscientes de seus interesses [e] também motivados para agir em nome deles...” [Giddens, 1984:199]. (Não é preciso dizer que estas não são as únicas duas alternativas.)

Concluirei colocando o problema na forma mais forte possível, que eu acho que Giddens evitou. Giddens pode muito bem achar que qualquer conversa de fundamentar a teoria crítica seja intelectualmente repulsivo e desnecessário. Mas ele precisa, pelo menos, encarar de frente o assunto que tal projeto pretende enfrentar. Qual é a base para nossos juízos e propostas críticas, se é que ela existe? Como devemos fundamentar esses juízos críticos? (E quem é, ou quem deve ser, este "nós"?) Não é preciso endossar alguma forma "ruim" de fundacionalismo para levar em consideração a legitimidade destas questões. Senão, "disparar salvas críticas na realidade" será como atirar no escuro. Giddens claramente fica desconfortável com o "ou... ou...” colocado por Weber versus Habermas onde "precisamos" ou reconhecer que as normas que usamos para fazer juízos sociais críticos não podem ser justificadas racionalmente ou reconhecer que elas se baseiam em "fundações" racionais. Este "ou... ou..." definiu o espaço conceitual para a reflexão sobre o caráter da ciência social como uma disciplina crítica no século XX. Se há uma forma de escapar deste "ou... ou...", Giddens (ainda) não a demonstrou. Giddens não percebe como muito do que diz é compatível com a atitude "tecnológica" à qual ele se opõe. Pois ele deixa em aberto a questão de quem deve usar o conhecimento social e para quais fins. Eu não acredito que Giddens esteja próximo de responder estas perguntas quando ele enfatiza a consciência prática e habilidade cognitiva dos atores sociais e a hermenêutica dupla da ciência social. 
Os assuntos que levantei sobre o significado, papel e base de justificação da ciência social crítica são centrais para o próprio entendimento de Giddens da teoria da estruturação. A não ser que ele esclareça e encare de frente estes assuntos, e até que ele o faça, há um sério perigo de que a teoria da estruturação se transformará no oposto daquilo que Giddens pretende, e que ela será assombrada pelos dilemas e aporias que perseguem qualquer teoria social que evite enfrentar sua função crítica.

\section{Bibliografia}

BERNSTEIN, R. J. [1976] The Restructuring of Social and Political Theory. Oxford: Basil Blackwell.

GIDDENS, A. [1977] Studies in Social and Political Theory. London: Hutchinson.

GIDDENS, A. [1982] "Historical Materialism Today: An Interview with Anthony Giddens", in Theory, Culture \& Society, 1, pp. 63-77.

GIDDENS, A. [1984] The Constitution of Society. Berkeley: University of California Press.

MERTON, R. K. [1949] Social Theory and Social Structure. Glencoe: The Free Press. 


\section{Anthony Giddens - O que fazem os sociólogos?}

A sociologia é uma disciplina estabelecida - na maioria das universidades ao redor do mundo - há muitos anos ${ }^{1}$. Ainda assim, o assunto preocupa algumas pessoas, preocupação esta ausente em relação a outras atividades acadêmicas. Dizer que a sociologia evoca paixões seria exagerar um pouco, mas provavelmente seria justo afirmar que ela frequentemente produz inquietações que não parecem surgir na maioria dos outros campos de pesquisa acadêmica. Há algo na sociologia que tende a eriçar penas que permanecem tranquilas na maioria das outras ocupações acadêmicas. $O$ chauvinismo disciplinar é um fenômeno bastante familiar nas universidades. Podemos legitimamente suspeitar que ele apenas muito raramente se baseia numa familiaridade profunda com qualquer área de estudo que esteja sendo sujeita à depreciação. Mas realmente parece haver algo a mais envolvido nas reações à sociologia do que a expressão rotineira de ressentimento e ignorância que, infelizmente, às vezes nasce nas universidades.

Qual é a fonte do desconforto que a presença da sociologia na academia, até certo ponto, cria? Uma réplica para tal pergunta poderia ser que não há um campo de estudo bem determinado ao qual ela corresponde - nenhum universo de disciplina que pode ser apontado, definitivamente, como os limites de sua província de investigação. Este ponto de vista é sem dúvida muito pouco convincente. A sociologia se preocupa com o estudo comparativo de instituições sociais, dando ênfase particular às formas de sociedade criadas pelo advento do industrialismo moderno. Pode haver diferenças de opinião quanto ao melhor modo de estudar as sociedades modernas, mas sugerir que tais sociedades não são dignas de pesquisas sistemáticas parece ser razoavelmente absurdo.

De qualquer forma, há mais emoções envolvidas nas respostas antagônicas à sociologia do que seria compatível com uma preocupação intelectual quanto à definição ou falta de definição de seu campo de estudo. Será que o impulso gerador poderia ser medo, então? Talvez, por mais vago que isto seja, exista algum tipo de ameaça implicada ao submetermos nosso próprio comportamento social ao escrutínio acadêmico? Isto está mais perto do alvo. Se tiver algum interesse, o trabalho sociológico

\footnotetext{
1 "O que fazem os sociólogos?" foi uma palestra inaugural proferida na Universidade de Cambridge em 29 de janeiro de 1986.
} 
certamente perturba algumas pessoas em algum momento. Mas qualquer um que saiba alguma coisa sobre sociologia afirmará que ela está muito longe de perturbar todas as pessoas o tempo todo. Há alguns que associam ingenuamente a sociologia ao radicalismo político, com uma horda desgrenhada saltando as barricadas para derrubar tudo o que importa para os cidadãos sensatos. Entretanto, há certamente tantos sociólogos conservadores quanto radicais, e a probabilidade é de que a maioria deles seja de centristas políticos, na mesma proporção que ocorre com qualquer outra disciplina. Validar esta afirmação apropriadamente exigiria, ironicamente, um trabalho de pesquisa social bastante extenso. Mas é improvável que qualquer um que tenha desenvolvido uma familiaridade com este assunto suponha que suas principais tradições de pensamento estejam localizadas em algum canto particular do espectro político.

Não, certamente não é uma sensação de oposição crescente ao status quo que pode explicar a atitude de reserva que a sociologia parece provocar. Talvez o problema seja que a sociologia pareça pouco esclarecedora? Será que tendemos a achar que já sabemos o bastante sobre as fontes de nossa própria conduta, e da conduta dos outros em sociedades como as nossas, para não precisar de nada mais? Colocando isto de forma provocativa: podemos dizer que o sociólogo é alguém que afirma o óbvio, mas achando que descobriu alguma coisa. Vocês podem achar que é improvável que qualquer um que aceite a designação de "sociólogo" fique feliz com isto, porque parece que a designação deixaria imediatamente ele ou ela sem emprego. $\mathrm{Na}$ verdade, eu acho que esta é realmente a essência do problema, e ela dá uma força particular à pergunta: 0 que fazem os sociólogos? Colocar esta questão de forma levemente mais elaborada que tipo de esclarecimento os sociólogos podem oferecer sobre as origens e a natureza de nossa própria conduta social? - revela alguns problemas muito reais. Eles são problemas compartilhados, até certo ponto, por todas as ciências sociais, e na verdade, todas as humanidades. Mas eles são colocados de forma peculiarmente aguda na sociologia.

$\mathrm{O}$ assunto pode ser descrito de forma bastante simples. Uma das coisas distintas sobre os seres humanos, que nos separa dos animais, é que normalmente nós sabemos o que estamos fazendo em nossas atividades, e por que as estamos fazendo. Quer dizer, seres humanos são atores portadores de conceitos, cujos conceitos constituem parcialmente o que eles estão fazendo, não contingentemente, mas como um elemento inerente daquilo que eles estão fazendo. Além disso, os atores humanos têm razões para 
suas ações, razões que constantemente caracterizam o fluxo das atividades cotidianas. Nem as razões nem as identificações de atos precisam ser expressas discursivamente para que elas governem o conteúdo do comportamento. Mas, em geral, eu acho que é válido dizer que os atores, virtualmente o tempo todo, sabem quais são suas ações, sob alguma descrição, e por que eles as estão realizando. Há uma outra consideração. É intrínseco à ação humana que, em qualquer situação dada, o ator, como os filósofos às vezes dizem, poderia ter agido de outra forma. Por mais opressivo que seja o peso das circunstâncias particulares sobre nós, nós sentimos que somos livres no sentido que decidimos sobre nossas ações baseados no que sabemos sobre nós mesmos, sobre o contexto de nossas atividades, e sobre seus resultados prováveis. Esta sensação não é espúria. Pois podemos afirmar que é analítico ao conceito de ação que o ator, em algum sentido, "poderia ter agido de outra forma" - ou poderia ter abstido de qualquer ação que ele tenha seguido.

Estas observações parecem complicar duplamente as dificuldades da sociologia. Pois o crítico persistente pode continuar com o argumento, indo além daquele mencionado previamente. Os sociólogos não apenas estão dispostos a afirmar o óbvio, mas eles tendem a enfeitar o que eles têm a dizer com uma terminologia que parece negar aos atores a liberdade de ação que sabemos que temos. Eles podem sugerir que aquilo que fazemos é impelido por forças sociais, ou coerções sociais, independentemente de nossa própria vontade. Nós acreditamos estar agindo livremente, e conhecendo os fundamentos de nossas ações, mas na verdade somos movidos por compulsões que não percebemos. Este tipo de afirmação não parece verdadeiro, pois ele transgride aquilo que sentimos que somos - corretamente, em minha opinião - enquanto atores humanos. A sociologia pode então parecer uma disciplina duplamente redundante, não apenas nos dizendo o que já sabemos, mas disfarçando o que é familiar com vestimentas que escondem sua natureza verdadeira.

Entretanto, eu acredito que a história não termina aqui. Eu não pretendo sugerir que todos os sociólogos devam fazer suas malas e partir para novas pastagens. Estou disposto a aceitar, e até a acentuar, a afirmação de que grandes segmentos da disciplina da sociologia se preocupam com coisas que achamos que sabemos. Mas, longe de tornar a disciplina ou seus praticantes redundantes, ou de tornar suas ideias inúteis, isto faz da sociologia, num certo sentido, a mais desafiadora e exigente das ciências sociais. Eu não quero dizer que não existem versões da sociologia que eu considere questionáveis, ou 
essencialmente desinteressantes, ou ambas. Quando eu falo "o que fazem os sociólogos", isto tem um sentido um tanto optativo. Eu não aprovo, de jeito nenhum, tudo o que os sociólogos fazem. Eu desejo apenas dar exemplos do que a disciplina pode realizar; mostrar por que, enquanto uma área de estudos, a sociologia é tanto intelectualmente atraente quanto de grande importância prática.

\section{Sociologia e conhecimento leigo.}

Para analisar o que fazem os sociólogos, permitam-me começar observando que aquilo que parece óbvio, ou que "todos sabem", pode não apenas não ser nada óbvio, mas também errado. Não há muitos de nós hoje em dia que pertençam à Sociedade da Terra Plana, apesar de parecer bastante óbvio, quando olhamos para ela, que a Terra é tão plana quanto qualquer panqueca. Podemos dizer que, no caso de nosso suposto conhecimento sobre as instituições sociais, somos particularmente inclinados a errar. De qualquer forma, é muito fácil encontrar exemplos. Sabemos - ou acreditamos -, por exemplo, que houve um aumento significativo no número de "lares quebrados", ou famílias com apenas um adulto, durante este último século. Assim, se voltarmos aos tempos vitorianos, vemos um contraste dramático entre as famílias estáveis e integradas daquela época e o desarranjo do período atual. Na verdade, a proporção de famílias com apenas um adulto era possivelmente maior na época vitoriana do que é hoje - não como resultado de divórcios, mas principalmente como consequência de taxas maiores de mortalidade em grupos etários relativamente jovens. Ou, novamente, sabemos que o Reino Unido é bastante propenso a greves, e alguns até consideram sua tendência a perturbações industriais como a principal origem de suas deficiências quanto à sua performance econômica. Entretanto, quando levamos em conta qualquer medição existente, a incidência de greves na Grã-Bretanha não é especialmente alta em comparação com vários outros países de alto desenvolvimento industrial. Para dar outro exemplo, sabemos - ou imaginamos - que a Suécia tem uma taxa extremamente alta de suicídios. Algo no sombrio caráter nórdico, ou os longos anos tolerando um governo socialista, criaria uma disposição para a melancolia ou para o desespero. Na verdade, a Suécia não tem uma taxa de suicídios particularmente alta, e nunca teve.

Não devemos subestimar a contribuição que a pesquisa social pode fazer para identificar crenças falsas ou tendenciosas muito comuns sobre fenômenos sociais. Pois 
estas crenças podem, muitas vezes, tomar a forma de preconceitos, e assim contribuir para a intolerância e a discriminação, ou podem inibir mudanças sociais que, sem elas, seriam consideradas desejáveis. Claramente, uma das tarefas do sociólogo deve ser descobrir até que ponto crenças comuns sobre certos aspectos da vida social são realmente válidas, mesmo que elas pareçam óbvias para todos os outros. E uma consequência disto é que os resultados da pesquisa social, de vez em quando, podem parecer pouco inspiradores, porque aquilo que para nós é óbvio pode realmente ser verdadeiro. Além do mais, não devemos esquecer que uma grande parte do que hoje consideramos coisas que todos sabem sobre instituições sociais é o resultado de análises sociológicas e de pesquisas sociais. Uma quantidade enorme de pesquisas sociais frequentemente realizadas por agências governamentais ou institutos de pesquisas, e não apenas por sociólogos em contextos universitários - acaba fazendo parte do funcionamento rotineiro de uma sociedade moderna. Nós tendemos a ignorar isto, mas sem estas pesquisas, muito daquilo que todos sabem não estaria, de forma nenhuma, em nossa consciência. Todos nós sabemos que as taxas de divórcio na maioria dos países ocidentais são maiores do que eram há duas ou três décadas; mas tendemos a esquecer a quantidade bastante considerável de investigação social contínua necessária para mapear estas tendências.

Se a sociologia se limitasse a isto, provavelmente não haveria muitos motivos para nos animar. A sociologia não serve apenas para corrigir crenças falsas que podemos ter sobre fenômenos sociais - ainda que alguns de seus defensores realmente tenham achado que este era seu único papel. Deixem-me voltar para o teorema que eu enunciei acima. Ser um ator humano é saber, virtualmente o tempo todo, sob alguma descrição, o que está fazendo e por quê. Existe um sentido no qual não podemos estar errados quanto ao que são nossas ações, senão essas ações não existiriam. Eu não posso, por exemplo, escrever um cheque sem saber não apenas o que eu estou fazendo, mas sem também saber uma série complexa de conceitos e regras, que definem o que é "crédito", o que é "ter uma conta", o que é um "banco", etc. A fórmula que afirma que os atores humanos sempre sabem, num certo sentido, o que estão fazendo e por que, envolve necessariamente um conjunto de elementos do contexto institucional mais amplo dentro do qual uma ação em particular é realizada. Não precisamos de pesquisa social para nos dizer quais são esses elementos, porque não apenas nós já os conhecemos, mas precisamos conhecê-los para que a ação em questão seja possível. 
Este tipo de conhecimento - conhecimento das convenções sociais envolvidas nas sociedades em que vivemos - não pode, então, estar sujeito ao esclarecimento pela sociologia. Ou, pelo menos, isso é o que parece. Precisamos apenas de uma curta reflexão para perceber que isto é falso. Na verdade, eu quero propor que existem quatro tipos de questões que podem ser legitimamente perguntadas sobre a conduta social, e que nenhuma delas contradiz a afirmação de que os indivíduos humanos sempre sabem o que são suas ações e por que participam delas. Estes quatro tipos de pergunta, que estão unidos logicamente, fornecem as chaves para entendermos o que fazem os sociólogos - do que se trata a disciplina da sociologia.

Considerem novamente o exemplo de assinar um cheque. Todos numa sociedade moderna sabem o que é assinar um cheque, mas alguém de uma cultura onde não existam bancos, e talvez nem mesmo um sistema monetário, não saberia. Em outras palavras, aquilo que é uma convenção familiar para um indivíduo ou grupo, não o é necessariamente para outro. Isto é válido não apenas entre sociedades ou tipos de sociedades diferentes, mas também dentro delas. Todos nós vivemos nossas vidas dentro de setores particulares das sociedades de que participamos, e os modos de comportamento daqueles que vivem em outros meios podem ser bastante opacos para nós. Mostrar como é viver em um ambiente cultural em particular para aqueles que habitam em outro (e vice-versa) é uma parte significativa daquilo que o sociólogo faz. Isto pode ser chamado de o momento antropológico da pesquisa social, e vale a pena notar algumas de suas implicações. Percebam, por exemplo, que a identificação da diversidade cultural da vida social é, simultaneamente, frequentemente um meio de revelar a racionalidade comum da ação humana. Fornecer uma descrição das convenções envolvidas num dado meio cultural, ou numa dada comunidade, permite uma compreensão das intenções e razões que os atores têm para o que fazem, e isto pode ficar absolutamente fora de nosso alcance se não tivermos tal descrição.

Há problemas filosóficos complicados envolvidos aqui, e não quero subestimálos. Mas é bastante fácil desenvolver o que quero dizer. Num mundo repleto de conflitos e hostilidades, mas ainda assim cada vez mais interdependente, a compreensão mútua através de ambientes culturais diversos torna-se de importância fundamental. O sine qua non desta comunicação intercultural é a execução efetiva das tarefas etnográficas da pesquisa social. Isto vale tanto para a distância cultural que separa comunidades indianas em Brixton de ricos subúrbios brancos (e de Whitehall) quanto, 
por exemplo, para a distância que separa a Revolução Islâmica da cultura do ocidente. Obviamente, atravessar os espaços da dessemelhança cultural não leva, inevitavelmente, a uma redução de conflitos pré-existentes. Quanto melhor se conhece seus inimigos, mais claro pode ficar que a hostilidade a eles é justificável ou inevitável. Mas isto não deve fazer com que duvidemos do papel elementar da etnografia da cultura para forjar entendimentos mútuos. Sua contraparte natural no nível das disciplinas acadêmicas é a ligação íntima entre sociologia e antropologia.

Sem querer parecer desnecessariamente mercenário, deixem-me voltar ao exemplo de assinar um cheque. Todos sabemos o que é assinar um cheque, mas isto não quer dizer que sabemos tudo o que há para se saber sobre isso. Um cheque seria válido se eu o escrevesse atrás de um bilhete de ônibus, em vez do papel impresso que o banco fornece tão atenciosamente? Boa parte do conhecimento que temos sobre as convenções que definem nossas ações é não apenas contextual, mas sim basicamente prático e de caráter ad hoc. Para ter uma conta de banco, e sacar cheques nela, não precisamos ter um entendimento elaborado do sistema bancário. E nem todo mundo seria capaz de colocar em palavras o que é um "cheque" ou uma "conta", se perguntássemos. Todos sabemos (nas sociedades modernas) o que é o dinheiro, no sentido que não temos problemas para cuidar de transações monetárias em nossas vidas cotidianas. Mas, como qualquer economista poderia confirmar, dar uma definição clara do que é o dinheiro tende a ser bem mais complicado do que parece. Como Santo Agostinho percebeu durante suas famosas observações sobre o tempo, todos sabemos o que é o tempo - até que alguém nos pergunte.

Poderíamos tirar várias inferências disto, mas eu quero me concentrar em apenas uma delas: que nosso discurso - o que conseguimos botar em palavras - sobre nossas ações, e nossas razões para elas, toca apenas certos aspectos daquilo que fazemos em nossas vidas cotidianas. Há um lado não-discursivo altamente complexo em nossas atividades que é de particular interesse para a sociologia, e também para outras ciências sociais. Não seria paradoxal dizer aqui que a sociologia, neste respeito, realmente estuda coisas que já sabemos - mas normalmente não as sabemos no sentido de estarmos totalmente conscientes delas. Para colocar o assunto de outra forma, uma grande parte de nosso conhecimento sobre as convenções sociais, como Wittgenstein formulou de forma célebre, consiste em saber "participar" ["go on"] dos inúmeros contextos de 
atividade social. O estudo de como nós conseguimos fazer isso é um assunto de grande interesse - e tem consequências potencialmente profundas, como tentarei indicar depois.

Podemos oferecer como um exemplo as brilhantes observações de Erving Goffman sobre o idioma corporal ${ }^{2}$. Para ser um ator humano, é preciso não apenas saber o que se está fazendo, mas também demonstrar isso para os outros de forma visível. Todos esperamos que todos nós mantenhamos um tipo de "estado de alerta controlado" em nossas ações. Fazemos isto através do gerenciamento disciplinado da aparência corporal, do controle da postura corporal e das expressões faciais. Goffman mostra como são inacreditavelmente complexos os rituais corporais com os quais "exibimos nossa presença" para os outros, e assim, rotineira e cronicamente, defendemos nossas posições como atores. As melhores percepções sobre como nossa exibição pública de nós mesmos é fortemente controlada podem ser obtidas analisando-se as circunstâncias onde ela falha. Assim, podemos investigar deste ponto de vista o comportamento de crianças pequenas, porque as crianças levam anos para adquirir a linguagem corporal controlada dos adultos. Ou podemos estudar interrupções desatentas do gerenciamento corporal - atos falhos, lapsos no controle da postura, expressão facial ou das roupas. Neste contexto, há conexões intrigantes entre Goffman e Freud, mas não as desenvolverei aqui.

O mundo social nunca mais parece o mesmo depois de lermos Goffman. O gesto mais inofensivo fica carregado de associações potenciais, e nem todas elas são agradáveis. Mas por que isso é assim? O que explica o fato de que, para a maioria de seus leitores, os escritos de Goffman tendem a produzir uma sensação de penetração privilegiada nas coisas mundanas? Eu acho que é porque eles tratam daquilo que é íntimo e familiar, mas a partir de seu lado não-discursivo. Eles acentuam nosso entendimento sobre nós mesmos precisamente porque revelam o que já sabemos, e precisamos saber, para nos virarmos no mundo social, mas que não conhecemos discursivamente. Desta perspectiva, não há paradoxo nenhum ao dizermos que devemos estudar detalhadamente o que já sabemos, e que ainda assim o resultado de tal estudo não é óbvio de jeito nenhum. Poderíamos falar a mesma coisa sobre a investigação da linguagem. Os linguistas passam todas suas carreiras profissionais estudando o que já sabemos, e que precisamos saber se quisermos ter a capacidade de falar nossa

\footnotetext{
${ }^{2}$ Goffman [1963], e outros escritos.
} 
linguagem. Mas isto não prejudica a importância da linguística, nem faz dela menos exigente que outras áreas de pesquisa.

Até agora, eu distingui duas qualificações para a proposta de que todos sabemos, na maior parte do tempo, quais são nossas ações, e por que as realizamos - que todos nós habitamos meios restritos dentro de um mundo culturalmente diverso, e que nós, discursivamente, pouco conseguimos identificar dos esquemas de convenções complexos de nossas atividades. A estas qualificações, precisamos adicionar uma terceira: que nossas atividades constantemente, e eu diria até rotineiramente, têm consequências que não tencionamos, e que podem passar bastante despercebidas quando realizamos o comportamento em questão.

Vamos subir novamente a High Street até o banco. Um sistema monetário moderno depende da confiança do público nas transações que ele regulariza para poder continuar funcionando. Num dado momento, os bancos só possuem moeda suficiente para cobrir uma pequena fração dos depósitos que eles abrigam. Desta forma, apesar de todo credor individual poder retirar tudo o que depositou quando quiser, o mesmo não vale para todos os credores. Se houver uma corrida para um banco, o resultado poderá ser uma diminuição drástica na confiança da habilidade do banco de pagar, levando talvez a seu colapso. Ora, é muito provável que poucos, e talvez nenhum, dos clientes do banco tivessem a intenção de iniciar essa espiral. Pode ser que o resultado não tenha sido desejado por nenhum deles, ainda que tenha sido criado por sua ação. O exemplo da corrida ao banco é um caso especial, mas não tão especial assim. Há, por exemplo, uma categoria geral de consequências não- intencionais que os sociólogos muitas vezes rotulam de "efeitos perversos". Vejam o exemplo seguinte. O governo estadual da Flórida tornou ilegal a caça ou captura de aligátores, para salvá-los da extinção iminente. Mas as áreas pantanosas, que antes davam um pequeno lucro para os fazendeiros ao serem usadas para a criação de aligátores para caça, tornaram-se improdutivas. Como resultado, os fazendeiros começaram a drenar a terra, para preparálas para o cultivo. A consequência foi que o habitat dos aligátores desapareceu, e eles foram exterminados na mesma região onde eles deveriam ter sido protegidos ${ }^{3}$.

Ou então vejam este exemplo retirado de pesquisas realizadas sobre programas de renovação urbana. Em alguns destes programas nos Estados Unidos, introduziram-se

\footnotetext{
${ }^{3}$ Sieber [1981:59].
} 
leis para forçar os donos de construções dilapidadas a restaurá-las, especialmente quando os prédios tinham inquilinos. Como consequência, alguns donos abandonaram seus prédios completamente, enquanto outros os reformaram apenas quando podiam aumentar substancialmente os aluguéis ou transformar os prédios em acomodações não alugadas. O resultado final foi uma diminuição na quantidade disponível de habitações alugáveis para grupos de baixa renda, além de mais deterioração do estoque de habitações nas áreas envolvidas.

É claro que nem todas as consequências não-intencionais são perversas. Schelling fornece o seguinte exemplo. Nos anos 1930, um seguro federal foi introduzido para recompensar as pessoas que perdiam seus depósitos bancários ${ }^{4}$. Ao gerar confiança, o efeito do seguro foi exatamente de aumentar a tendência a prevenir o comportamento que levou ao problema. Da mesma forma, aqueles que agem de forma puramente egoísta podem, sem ter a intenção, contribuir para o bem-estar coletivo. Eles ecoam o Mefistófeles de Goethe, que é "uma parte daquela força que sempre tenciona o mal e sempre faz o bem". Efeitos perversos são uma classe particularmente significativa e interessante das consequências não-intencionais, em parte porque eles têm uma certa ironia, algumas vezes trágica, outras deliciosamente cômica; mas principalmente porque o efeito bumerangue que eles expressam é uma característica comum da criação de políticas sociais. O que eu quero, entretanto, não é apenas sugerir que uma das coisas que os sociólogos podem e devem fazer é estudar os efeitos perversos que as tentativas de intervenção social muitas vezes trazem consigo. O que eu quero é enfatizar como a análise de consequências não-intencionais de ações intencionais é fundamental para toda a atividade sociológica. Porque é isto, mais do que qualquer outra coisa, que significa que, apesar de nós, enquanto atores sociais, sermos necessariamente os criadores da vida social, a vida social, ao mesmo tempo, não é nossa própria criação.

Os exemplos de consequências não-intencionais que eu dei até agora são episódios onde há um resultado singular e distinto. E, é claro, muitas das consequências não-intencionais que nos preocupam na análise social são deste tipo. Ninguém tencionou a sequência geral de eventos que levou à Revolução Russa de 1917, nem mesmo Lênin e os bolcheviques, por mais ansiosos que eles estivessem para dirigir a história sobre certos trilhos. Nenhum evento social cataclísmico é resultado de planos intencionais. Mas as consequências não-intencionais não se limitam a sequências de

\footnotetext{
${ }^{4}$ Schelling [1984:8].
} 
eventos com resultados distintos. Quando eu falo inglês de uma forma sintaticamente correta, não é minha intenção reproduzir as estruturas da língua inglesa. Mas, de qualquer forma, esta é uma consequência do ato de eu falar corretamente, mesmo que minha contribuição para a perpetuação da linguagem seja bastante modesta. Generalizando esta observação, podemos dizer que as consequências não-intencionais estão profundamente envolvidas na reprodução de instituições sociais, por mais que tal reprodução também seja governada por intenções e maquinações; e o estudo da interligação entre o que é e o que não é intencional é o quarto tipo de tarefa de importância elementar para a sociologia.

Isto precisa de alguns comentários, porque nos permite, de certa forma, conectar todos os aspectos do estudo sociológico. Como uma forma de pensar naquilo que está envolvido aqui, vejamos o exemplo de um ciclo de pobreza. Nas áreas destituídas das cidades, muitas vezes somos capazes de traçar uma continuidade de pobreza através de várias gerações. Estas áreas tendem a ter escolas com poucos recursos, com professores que precisam passar mais tempo mantendo algum tipo de ordem na sala de aula do que ensinando, falando com alunos cuja motivação para seguir o roteiro acadêmico não é muito grande. As crianças dessas escolas inevitavelmente tendem a ter oportunidades limitadas no mercado de trabalho quando saem do local de educação. Assim, é provável que elas vivam em áreas tão pobres quanto as de seus pais. Estas áreas terão escolas com poucos recursos... e assim o ciclo continua. Tal ciclo de pobreza não é tencionado por nenhum daqueles afetado por ele, nem por ninguém mais. Ele pode ser explicado através de uma "mistura" de ações intencionais e consequências não-intencionais, mas é preciso notar que estas têm um efeito de retroalimentação, de forma a se tornarem condições de ações posteriores. Isto é uma verdade difusa da vida social como um todo, e forma um ponto de conexão com a contextualidade ou diversidade cultural mencionada anteriormente. Visto que toda ação está situada em contextos espaçotemporais limitados, segue-se que todos nós somos influenciados por ordens institucionais que nenhum de nós, tomado isoladamente - e talvez nenhum de nós tomados coletivamente - estabelece intencionalmente.

Tudo que eu faço, sob alguma descrição, eu faço intencionalmente e sabendo o que estou fazendo. Entretanto, isto não me torna mestre de meu próprio destino, de forma alguma. Ao seguir as rotinas da minha vida cotidiana, eu ajudo a reproduzir instituições sociais de cuja criação eu não participei. Elas são mais do que simplesmente 
o ambiente de minha ação, já que, como eu enfatizei antes, elas participam constitutivamente do que eu faço enquanto ator. Da mesma forma, minhas ações constituem e reconstituem as condições institucionais das ações de outros, assim como as ações desses outros constituem e reconstituem as condições das minhas. Eu gosto de chamar o conceito chave que liga as várias atividades da sociologia que eu listei de "natureza recursiva da vida social". Quando eu realizo as atividades de minha vida diária, eu utilizo cronicamente convenções estabelecidas - de uma forma, ao mesmo tempo, extraordinariamente complexa e em grande parte tácita - para fazer isso. Mas o próprio processo de utilizar as convenções as reconstitui, parte como uma influência sobre o comportamento dos outros, parte como do meu. Desta maneira, minhas atividades constituem e também são incorporadas em propriedades estruturais de instituições que vão muito além de mim no espaço e no tempo.

Num dos enunciados metodológicos mais citados da sociologia, Émile Durkheim observou: "o sistema de sinais que eu emprego para expressar meus pensamentos, o sistema monetário que uso para pagar minhas dívidas, os movimentos de crédito que utilizo em minhas relações comerciais, as práticas que sigo em minha profissão, etc., todos funcionam independentemente do uso que eu fizer deles. Assim, há formas de agir, pensar e sentir que possuem a propriedade notável de existir fora da consciência do indivíduo"5. Não há nada de errado com o sentido geral deste enunciado, mas a conclusão é bastante equivocada. Pois Durkheim foi levado a negar o próprio sentido de ação que todos nós temos. É inteiramente possível reconhecer a força de seu argumento sem retirar a implicação que, afinal, não somos todos os atores racionais com propósitos que pensamos que somos.

Durkheim tendia a dizer que apenas o estudo dos processos de larga escala e de longo prazo eram importantes o suficiente para ter a atenção da sociologia. Entretanto como mais um elemento para juntar as várias correntes da pesquisa sociológica que eu identifiquei - podemos demonstrar facilmente que a análise do que é aparentemente trivial ou efêmero pode contribuir de forma fundamental para entendermos as características mais duráveis das instituições sociais. Vejam este pequeno excerto de uma conversa. Um casal está conversando enquanto assistem televisão. O marido afirma que está cansado. Depois disto, a conversa toma este rumo:

\footnotetext{
${ }^{5}$ Durkheim [1982:51].
} 
Mulher: "Como você está cansado? Fisicamente, mentalmente, ou apenas entediado?"

Marido: "Eu não sei, acho que só fisicamente, no geral."

Mulher: "Você quer dizer que seus músculos doem, ou são os seus ossos?"

Marido: "Qual é o problema com você? Você sabe o que eu quero dizer."

Mulher: "Eu queria que você fosse mais específico."

Marido: "Você sabe o que eu quero dizer! Vai pro inferno!"6

O que está acontecendo aqui? Bom, o que está acontecendo na verdade é uma pesquisa social. A esposa participava de um estudo que pretendia investigar a natureza da linguagem ordinária. As pessoas envolvidas no estudo deviam simplesmente falar com alguém que conhecessem e tentar fazer com que essa pessoa esclarecesse o sentido de observações comuns que fossem ditas. Olhando deste jeito, seria difícil pensar em algo mais trivial para se gastar dinheiro de pesquisa, e, realmente, muitos sociólogos tiraram exatamente esta conclusão. Eu acho que essa posição é bastante errada. A pesquisa é interessante de vários ângulos. A própria severidade das respostas extraídas indica que o desvio de certos cânones aceitos das conversas ligeiras era percebido como algo perturbador. Porque a quebra na comunicação, e o fato da vítima assumir uma posição que os pesquisadores chamaram, de forma charmosa, de "hostilidade justa", ocorreram muito rapidamente. Há alguma coisa nas convenções tácitas da conversa ligeira que tem uma fixidez moral muito poderosa. Esta coisa pode ser definida como uma confiança não enunciada na integridade dos outros, ancorada no caráter mútuo pressuposto daquilo que não é dito nas palavras da conversa. A exigência do fornecimento de precisão de significado foi experimentada como um rompimento de confiança.

A vaguidade aparente da linguagem ordinária expressa bem o fato dela estar atrelada às práticas sociais, e a base de seu significado é nosso conhecimento tácito das convenções que ordenam essas práticas. Esta é essencialmente a descoberta que Wittgenstein fez, através de um caminho muito diferente, quando abandonou suas posições anteriores para adotar a ideia de que a linguagem é o que a linguagem faz. A linguagem ordinária não pode ser espremida e transformada num simulacro da

\footnotetext{
${ }^{6}$ Retirado de Garfinkel [1963:222]. Eu abreviei um pouco a conversa.
} 
linguagem científica. Aquilo que não é dito - e, em certo sentido, que não pode ser dito - nas conversas cotidianas precisa ser aceito na base da confiança. Para a maioria de nós, isto se tornou completamente natural. Mas imaginem como seria o mundo social se ninguém conseguisse se sentir seguro para confiar na mutualidade das convenções nãodeclaradas compartilhadas com os outros. Quero dizer, imaginem um universo social onde os indivíduos experimentassem todas as interações como algo sob ameaça de desabar, como aconteceu na pesquisa citada. Pois como posso ter realmente certeza de que o outro participante numa situação de interação não nutre más intenções a meu respeito? Mesmo o gesto mais inofensivo pode parecer uma ameaça em potencial. Ora, é provável que seja exatamente assim que a vida social pareça para alguns dos indivíduos que chamamos de doentes mentais. Há trabalhos muito promissores sendo feitos que relacionam a doença mental à incapacidade (ou à falta de disposição) de alguns tipos de pessoas para confiar naquilo que, para a maioria de nós, quase nunca é fonte de preocupações sérias. Isto está diretamente ligado à discussão de Goffman sobre a linguagem corporal e sua relação com a continuidade do eu. Pacientes mentais muitas vezes se sentam de forma relaxada e movem-se abruptamente, em vez de ter a fluidez e o controle que nós normalmente esperamos de outros agentes; e podem exibir um vestuário bagunçado aleatoriamente. Eles podem evitar o olhar de quem estiver falando com eles, podem escarnecer da convenção de que não se deve falar sozinho em público, e geralmente não observam outras convenções tácitas da comunicação e da interação.

A questão não é que estas categorias são necessariamente relevantes, num sentido etiológico, para as desordens mentais, mas que elas comprovam como características aparentemente triviais de microambientes são importantes para instituições mais amplas. As convenções complexas que seguimos na vida cotidiana não são apenas um verniz superficial sobre as instituições de grande escala, elas são na realidade a substância de sua continuidade e fixidez. É por isso que não surpreende que os historiadores sociais franceses, encabeçados por Fernand Braudel, concentram-se na "longa duração" mas ao mesmo tempo são fascinados pelas rotinas aparentemente insignificantes da vida cotidiana mundana. Pois a história institucional de longo prazo que absorve o interesse deles está sedimentada nas práticas rotineiras da atividade social cotidiana. Entre as coisas que os sociólogos fazem, e precisam fazer, está o estudo dos padrões de longo prazo de estabilidade e mudança institucional. Apesar de poderem existir diferenças de ênfase em relação ao trabalho dos historiadores, com os sociólogos 
estando menos preocupados em recuperar um sentido de "passado" e mais interessados em demonstrar o impacto do passado no presente, as linhas divisórias são difíceis de traçar - e é assim que devem ser.

Como exemplo, podemos olhar para o aumento repentino de trabalhos recentes sobre o desenvolvimento de instituições carcerárias. Esta é uma área, entre muitas outras, onde houve uma fertilização cruzada maravilhosamente frutífera entre a sociologia e a história. Nas sociedades modernas, certas categorias de indivíduos são mantidas isoladas do contato casual com a maioria da população. Há formas de ocultação estruturadas que removem da vista um conjunto de pessoas que, de algum modo, divergem do funcionamento normal das atividades na vida cotidiana. Estes grupos incluem os doentes e os moribundos. A visão da morte não é uma experiência comum para a grande maioria daqueles que vivem em sociedades modernas hoje em dia. Ambulâncias normalmente têm janelas escuras, para esconder dos passantes o espetáculo potencialmente perturbador dos ferimentos e da morte:

"Closed like confessionals, they thread

\section{Loud noons of cities, giving back}

\section{None of the glances they absorb"}

Mais significativos sociologicamente são prisões e sanatórios, "instituições totais" que confiscam do mundo cotidiano os criminosos e doentes mentais. Elas são substancialmente criações do século XVIII. Antes deste período, como Foucault mostrou - posteriormente seguido por muitos outros historiadores mais escrupulosos, mas menos inovadores -, o encarceramento era relativamente raro. Assim, para reduzir a influência do crime, a punição, longe de ser escondida - incluindo a pena capital - era um espetáculo, uma exibição aberta. A disciplina anônima e impessoal da prisão, onde as principais sanções não são mais a humilhação pública ou marcas no corpo através da imposição de dor física, mas sim a perda do "tempo livremente controlado", é algo muito diferente. E mesmo onde ela ainda existe, a pena capital é na realidade uma "restrição máxima do tempo", onde, longe de demonstrar publicamente o processo da execução de uma pessoa, temos um procedimento mais ou menos privado, onde se tenta minimizar a dor.

\footnotetext{
7 "Fechadas como confessionários, elas trilham / Barulhentos meios-dias das cidades, não devolvendo / Nenhuma das olhadelas que absorvem". Larkin [1971:33].
} 


\section{Questões atuais.}

Até agora, eu estive analisando o que fazem os sociólogos como se a disciplina fosse imutável, e como se houvesse um acordo completo entre seus praticantes quanto a seus objetivos e métodos. Mas nenhuma destas suposições é verdadeira e, na próxima parte de minha discussão, eu quero indicar algumas das mudanças ocorrendo na sociologia hoje em dia e para onde elas provavelmente nos levarão. Assim como ocorreu nas ciências sociais em geral, a sociologia passou por uma mutação considerável nos últimos anos - e se o termo não tivesse sido usado de forma tão exagerada desde os escritos de Kuhn sobre filosofia da ciência, poderíamos, de forma mais ou menos justificada, falar de uma revolução no pensamento sociológico. As mudanças são tanto substantivas quanto metodológicas.

O final do século XVIII e o século XIX estabeleceram a agenda substantiva e também o conteúdo metodológico da sociologia no século XX. A sociologia tem suas origens no advento da modernidade - na dissolução do mundo tradicional e na consolidação do moderno. Exatamente o que significam "tradicional" e "moderno" é uma questão debatida constantemente. Mas o que se segue é evidente: com a chegada do industrialismo, a transferência de milhões de pessoas de comunidades rurais para cidades, o desenvolvimento progressivo da democracia de massa, e outras mudanças institucionais fundamentais, o novo mundo foi arrancado brutalmente do antigo. O que começou como uma série de transformações em grande parte internas à Europa e à América do Norte cada vez mais atravessa o globo. O cambaleante carro de Jagrená da mudança que o ocidente lançou ainda está vagando erraticamente através da superfície da Terra. A sociologia nasceu da tentativa de rastrear seu caminho, mas até boa parte do século XX ela mesma ainda estava marcada demais pelo contexto de suas origens.

Por exemplo, ao contrastar a modernidade com a tradição, as escolas de pensamento dominantes da sociologia costumavam enfatizar com força demais tendências e mecanismos que seriam presumivelmente inerentes às próprias sociedades industrializadas. Como resultado, as sociedades tradicionais - aquelas que ainda existem em outras partes do mundo, e aquelas que já foram engolidas pela história - são vistas com muita frequência como essencialmente desinteressantes. Elas são encaradas como nada mais que um contraste ao desenvolvimento de uma ordem industrial 
triunfante. Daí surgiu uma disjunção infeliz entre a sociologia e a antropologia; a fratura entre o moderno e o tradicional se tornou também uma cisão disciplinar. Mas certamente agora já ficou claro que a antropologia não pode mais se confinar a uma preocupação com o outro, assim como a sociologia não pode se dar ao luxo de não examinar a conexão destrutiva que liga as sociedades modernas aos outros tipos de sociedades.

A modernidade no século XX revelou-se incontestavelmente como um processo histórico mundial no verdadeiro sentido desse termo. Ao mesmo tempo, apesar de precisarmos reconhecer que as instituições criadas pelo advento da modernidade têm origens e alcances diferentes, vemos com cada vez mais clareza que hoje nossas vidas são dominadas por influências das quais ninguém, em nenhum lugar do mundo, é capaz de escapar totalmente. Ainda assim, junto com o resto das ciências sociais, apenas agora a sociologia está começando a chegar a um acordo com um sistema global cada vez mais interdependente. Além do mais, parece que estamos vivendo uma fase de mudança social acelerada. Enquanto o século XXI se aproxima, estamos experimentando um período de transformação social tão espetacular quanto qualquer outra coisa que tenha acontecido nas fases anteriores da era moderna. Parece certo que alguns dos principais conceitos e teorias da sociologia precisarão de uma revisão substancial se quisermos compreender tanto isto quanto a consolidação de algo que pareça uma sociedade mundial. Entre as mudanças que aqui poderiam ser destacadas estão: inovações tecnológicas excepcionalmente rápidas, devido ao impacto da informática e da robótica; uma erosão aparente da base manufatureira estabelecida das economias ocidentais, associada com uma transferência da produção industrial básica para o leste; o envolvimento mais profundo de todas as sociedades industrializadas numa divisão do trabalho global cada vez mais integrada; um descontentamento político generalizado dentro das democracias ocidentais, associado a realinhamentos em padrões de votos e apoio político; e a ameaça de proliferação das armas nucleares, combinada com a aplicação contínua da ciência e da tecnologia para a intensificação de sistemas bélicos.

Esta lista é formidável, e eu certamente não quero afirmar que a sociologia é a única disciplina relevante para cuidar dela. Mas por mais assustadores que sejam os problemas intelectuais e práticos que precisamos enfrentar no final do século $\mathrm{XX}$, certamente não podemos negar que eles são, acima de tudo, de caráter organizacional e institucional. Isto quer dizer que eles são, num sentido fundamental, sociológicos. A 
atividade sociológica é agora ainda mais essencial para as ciências sociais como um todo, e, na verdade, para toda a cultura intelectual atual, do que jamais foi antes. Hoje nós vivemos, sem exagerar muito, num mundo na corda bamba entre possibilidades extraordinárias e desastres globais. Não podemos nem dizer com certeza qual destas alternativas é a mais provável. Este é o resíduo da modernidade para todos nós, e está realmente distante das sequências de acontecimentos esperadas pelos mais otimistas dos fundadores da sociologia dos séculos XVIII e XIX. Pois eles esperavam que a modernidade culminasse, de um jeito ou de outro, numa ordem social humana e racional. Tendo em vista as tendências de desenvolvimento do século atual, precisamos considerar estas previsões no mínimo prematuras e apressadas.

De qualquer forma, precisamos manter a intenção prática que está por trás de seus escritos. Precisamos defender a ambição prática da sociologia de ter uma influência positiva para a condição humana. Esta ideia permite que eu monte uma conclusão, e também que eu volte para os temas da abertura de minha fala. Pois, até certo ponto, o caráter perturbador da sociologia é derivado da posição especial que ela tem a respeito do direcionamento prático da mudança social. A sociologia ocupa uma zona de transição tensa entre o diagnóstico e o prognóstico; e esta é outra área onde uma enxurrada de controvérsias nos últimos anos permitiu que conseguíssemos esclarecer qual pode e deve ser o papel da sociologia.

Estas controvérsias não podem ser compreendidas sem uma análise de problemas metodológicos da sociologia - e é justo dizer que os sociólogos têm reavaliado radicalmente o que eles mesmos fazem. A maioria dos primeiros fundadores da sociologia, no final do século XVIII e no século XIX, tentou derivar a lógica e o método de seu campo a partir de estudos das ciências naturais. Esta tentativa nunca deixou de ter opositores, pois tal ideia é difícil de reconciliar com as características da ação humana que eu discuti. Consequentemente, a disciplina - e, num grau considerável, todas as ciências sociais - tendeu a estar dividida entre a noção de que uma ciência natural da sociedade é possível e a posição oposta de que a sociologia é essencialmente um tipo de humanismo. Para os defensores do primeiro ponto de vista, tudo que não for um conjunto de leis especificadas precisamente sobre a vida social é uma decepção. Por outro lado, aos olhos dos antinaturalistas as tentativas da sociologia de imitar as ciências naturais são espúrias e enganosas. Esta divisão metodológica recebeu por muitos anos forma conceitual através do contraste entre Verstehen e 
Erklären - compreensão versus explicação - retirado das tradições alemãs de historiografia. Ambos os lados aceitavam que as ciências naturais tratavam da explicação. As diferenças de opinião se preocupavam com a questão de se o reino da Erklären também poderia ser estendido para a explicação das instituições sociais humanas.

Hoje sabemos que a separação entre Verstehen e Erklären era uma forma enganosa de caracterizar tanto as ciências sociais quanto as naturais. Para resumir rapidamente assuntos complicados, avanços na filosofia das ciências naturais deixaram claro que a compreensão, ou a interpretação, são tão elementares nessas ciências quanto são para as humanidades. Por outro lado, apesar das generalizações nas ciências sociais serem logicamente discrepantes das generalizações nas ciências naturais, não há razão para duvidar que elas envolvam atribuições causais. Precisamos então descartar o disfarce conceitual do debate entre Verstehen e Erklären. Não há problemas em continuar a usar a frase "ciências" sociais, pelo contrário. As ciências sociais compartilham com a ciência natural o respeito pela clareza lógica na formulação de teorias e pela investigação empírica disciplinada. Mas a ciência social não é um velho navio a vapor caindo aos pedaços sofrendo para acompanhar o belo iate das ciências naturais. O que acontece, em grande parte, é que as duas navegam em oceanos diferentes, ainda que elas compartilhem alguns procedimentos de navegação. Assim, há diferenças profundas entre as ciências sociais e as naturais, mas elas não tratam da presença ou ausência de interpretação. Em vez disso, elas estão ligadas com o que chamei, em outro lugar, certamente de forma bastante desajeitada, de "hermenêutica dupla" . Como me esforcei para enfatizar antes, os sujeitos de estudo nas ciências sociais e nas humanidades são seres que utilizam conceitos, e estes conceitos participam de forma constitutiva do significado de suas ações. A vida social não pode nem sequer ser descrita adequadamente por um observador sociológico, e muito menos elucidada causalmente, se esse observador não dominar a série de conceitos empregados (discursivamente ou não) pelas pessoas envolvidas.

Para falar claramente, toda ciência social parasita conceitos leigos, e isto é uma condição lógica de suas atividades. Os sociólogos inventam suas próprias metalinguagens conceituais, e precisam fazer isso por razões que foram descritas anteriormente - eles tentam compreender aspectos das instituições sociais que não são

\footnotetext{
${ }^{8}$ Giddens [1984].
} 
descritos pelos conceitos dos atores. Entretanto, diferentemente da ciência natural, nas ciências sociais não há como evitar que o aparato conceitual do observador - seja na sociologia, na ciência política ou na economia - seja apropriado pelos atores leigos. Em outras palavras, os conceitos e teorias inventados pelos cientistas sociais entram e saem do mundo social que eles foram criados para analisar. As melhores e mais originais ideias das ciências sociais, se quiserem ter alguma influência na realidade que precisam capturar, tendem a ser apropriadas e utilizadas pelos próprios atores sociais. John Barnes expressou isto com precisão quando escreveu que a sociologia permite que nós "tenhamos uma visão mais informada e profunda sobre a situação social" do que aqueles "que não foram treinados para ter uma visão de fora de suas próprias instituições sociais e que não têm a oportunidade de comparar essas instituições com arranjos alternativos encontrados em outras sociedades". Notando que a sociologia "trata das regularidades e da falta de regularidades nas instituições", ele adicionou: "Há uma relação de mão dupla, ou dialética, entre o aparato conceitual do sociólogo e a visão de mundo das pessoas cujas ações, sentimentos e crenças ele tenta entender"" Entretanto, esta relação de mão dupla merece uma apreciação cuidadosa, pois compreender sua natureza nos leva a uma reavaliação fundamental da influência prática da sociologia sobre as sociedades modernas.

Pensamos frequentemente que as ciências sociais - não apenas a sociologia não tiveram sucesso para ajudar a criar políticas sociais. Talvez esta seja até uma razão final para seus críticos as considerarem insuficientes. Afinal, considerem o impacto que a ciência natural teve, através da implementação da tecnologia, na moldagem de nossas interações com o mundo material. As ciências naturais claramente aumentaram nossa capacidade de controlar os contextos materiais de nossas atividades. Certamente não podemos dizer o mesmo da ciência social, não é? Pois simplesmente não existem as tecnologias sociais que permitem que controlemos a vida social da mesma forma que a tecnologia material nos permite utilizar as forças da natureza.

Entretanto, podemos ver este assunto sob uma luz completamente diferente se seguirmos as implicações da hermenêutica dupla. Aqueles que discutiram este problema, particularmente filósofos das ciências sociais, tenderam a concentrar sua atenção na forma em que os conceitos leigos intrometem-se obstinadamente no discurso técnico da ciência social. Poucos trataram o assunto de forma inversa. Mas os conceitos

\footnotetext{
${ }^{9}$ Barnes [1970:19].
} 
das ciências sociais não são produzidos para tratar de um universo de disciplina constituído independentemente, que continua a existir sem a interferência desses conceitos. As "descobertas" das ciências sociais muitas vezes entram na constituição do mundo que descrevem. Fornecerei exemplos de várias das ciências sociais para mostrar como esta afirmação é importante.

Quando, no início do século XV, Bodin, Maquiavel e outros inventaram algumas ideias novas sobre o poder político e o governo, eles não simplesmente descreveram uma série de mudanças sociais que ocorria independentemente disso. Eles ajudaram a constituir as formas de Estado que emergiram dessas mudanças. Os Estados modernos não poderiam existir se conceitos como "cidadão", "soberania" e mesmo "governo" não tivessem sido dominados pelos indivíduos que os administram e aqueles sujeitos a seu poder. Desde então, a teoria política está ligada reflexivamente ao seu próprio assunto: a elucidação da mecânica do governo dos estados modernos. Algo muito similar ocorre a partir do final do século XVIII com a economia e a sociologia. O discurso da economia não apenas permitiu que pudéssemos entender - dentro de certos limites - o funcionamento das economias modernas, mas também se tornou básico para definir o que são essas economias. Mudanças de uso de termos como "econômico" e "industrial" foram alimentadas, parcialmente, pelos escritos de economistas acadêmicos, ajudando a introduzir nos campos recém-formados de atividade econômica os conceitos que constituem aquilo que esses campos se tornaram. Desde então, a economia está implicada reflexivamente em processos de continuidade e mudança nos sistemas econômicos modernos.

O mesmo pode ser dito sobre a sociologia em relação a todo um espectro de instituições sociais modernas. Um dos melhores exemplos que pode ser dado sobre isto é o cotejo de estatísticas sociais. Pois as pesquisas estatísticas podem parecer, à primeira vista, a coisa mais distante possível de ser incorporada nos assuntos de que tratam. Estatísticas sobre a distribuição da população, padrões de taxas de nascimentos e mortes, ou sobre o casamento e a família, tudo isto pode parecer simplesmente análises quantificadas de conjuntos de fenômenos dados objetivamente. E, num certo sentido, são. Mas como eu enfatizei no começo, a reunião de estatísticas sociais também participa de forma fundamental na constituição das sociedades modernas. As sociedades modernas não poderiam existir se suas características demográficas não fossem mapeadas e analisadas regularmente. No estudo de divisões de classe, burocracia, 
urbanismo, religião e muitas outras áreas, os conceitos sociológicos entram em nossas vidas regularmente e ajudam a redefini-las.

As inferências que podem ser retiradas disto não são nada simples, mas têm importância muito considerável. Por um lado, somos capazes de ver por que mesmo as ideias mais brilhantemente inovadoras das ciências sociais correm o risco de se tornarem banais. Afinal, quando elas se tornam parte constitutiva daquilo que fazemos, elas são parte dos padrões de nossas atividades cotidianas e podem se tornar quase insensivelmente familiares. Toda vez que eu uso um passaporte para viajar para o exterior, eu demonstro minha compreensão prática do conceito de soberania; longe de ser algo novo, ele se tornou uma parte totalmente rotineira da vida moderna. Precisamente por causa de sua adoção pela própria sociedade, o conhecimento gerado pelas ciências sociais não tem uma forma elegantemente cumulativa. Com isto eu não quero dizer que não aprendemos progressivamente mais sobre as instituições sociais do que sabíamos antes, ou que não existam inovações conceituais e teóricas. Mas as realizações das ciências sociais tendem a ficar longe de nossa vista devido a seu próprio sucesso. Por outro lado, exatamente por causa disto podemos, com toda a seriedade, dizer que as ciências sociais influenciaram "seu" mundo - o universo da atividade social humana - com muito mais força que as ciências naturais influenciaram o "delas". As ciências sociais estão reflexivamente envolvidas de forma básica nas próprias transformações da modernidade que dão a elas seu principal universo de pesquisa.

Não há opções aqui. O impacto prático das ciências sociais é profundo e inescapável. As sociedades modernas, junto com as organizações que as compõem e que participam delas, são como máquinas de aprendizado, bebendo informação para regularizar seu autodomínio. Por causa da perversidade das consequências nãointencionais, e da própria contingência da mudança social, podemos pressupor que tal domínio nunca será completo. Mas é sobre as capacidades de aprendizado social, no mundo que é o legado da modernidade, que predicamos nosso futuro. Apenas sociedades reflexivamente capazes de modificar suas instituições diante de mudanças sociais aceleradas serão capazes de enfrentar esse futuro com alguma confiança. A sociologia é o meio principal dessa reflexividade. Assim, o grau de atividade e imaginação da cultura sociológica de uma sociedade será uma medida de sua flexibilidade e de sua abertura. 


\section{Bibliografia}

BARNES, J. A. [1970] Sociology in Cambridge. Cambridge: Cambridge University Press.

DURKHEIM, É. [1982] The Rules of Sociological Method. London: Macmillan.

GARFINKEL, H. [1963] "A Conception of, and Experiments with, 'Trust' as a Condition of Stable Concerted Actions", in O. J. Harvey (ed.): Motivation and Social Interaction. New York: Ronald Press.

GIDDENS, A. [1984] The Constitution of Society. Cambridge: Polity Press.

GOFFMAN, E. [1963] Behavior in Public Places. New York: Free Press.

LARKIN, P. [1971] The Whitsun Weddings. London: Faber and Faber.

SCHELLING, T. C. [1984] Choice and Consequence. Cambridge (Mass.): Harvard University Press.

SIEBER, S. D. [1981] Fatal Remedies. New York: Plenum Press. 


\section{Ira J. Cohen - O estatuto da teoria da estruturação: uma resposta a McLennan}

Tanto a oportunidade para o programa na teoria da estruturação que Giddens iniciou, quanto os problemas que ela precisa resolver, surgem do estado de desordem sem precedentes das teorias básicas da constituição da vida social e da filosofia da ciência. Giddens [1979:259; 1982:12] comentou em várias ocasiões que, na reconstrução da teoria social, precisamos ter em mente a inter-relação inevitável entre estes domínios. Ocasionalmente [Giddens, 1976:cap. 4; 1977:cap. 1; 1982a:60-66] ele avaliou dilemas básicos que a filosofia da ciência enfrenta hoje em dia. Mas a maior parte de seu trabalho foi dedicada ao estabelecimento das dimensões sociológicas da teoria da estruturação. Na minha opinião, há muito mais reconstrução sintética acontecendo aqui do que McLennan concede ${ }^{1}$. Na verdade, apesar de ainda haver muito trabalho a ser feito em todos os aspectos do programa, eu acredito que ele já apresenta soluções superiores para alguns dos problemas mais duradouros no desenvolvimento de uma abordagem realmente adequada à teoria social [ver Cohen, 1989]. Mas McLennan está certo ao observar - como Giddens reconhece diretamente durante sua entrevista em Theory, Culture \& Society [Giddens, 1982] - que há assuntos básicos de natureza metodológica e epistemológica que ainda precisam ser tratados no programa da estruturação.

A discussão de McLennan menciona vários destes assuntos. Na primeira parte de seu artigo, ele lança uma dúvida sobre a possibilidade de "segurança" na fundamentação epistemológica para a teoria da estruturação. Este tópico atravessa seus comentários sobre o estatuto da teoria crítica na obra de Giddens na parte posterior de seu texto. A nova questão introduzida aqui é de natureza mais metodológica: encontramos uma "coerência" teórica na teoria da estruturação?

Este artigo inverterá a ordem destes tópicos. Eu afirmarei 1) que há uma consistência teórica nos argumentos de Giddens, mas não uma coerência no sentido que

\footnotetext{
${ }^{1}$ A intenção dupla das críticas de Giddens antes de Uma crítica contemporânea envolve: 1) estabelecer as inadequações explicativas de vários pontos das teorias interpretativa [Giddens, 1976)], funcionalista [ver esp. Giddens, 1977:cap. 2] e estruturalista [Giddens, 1979:cap. 1] da constituição da vida social; 2) extrair contribuições construtivas de cada escola de pensamento que são reformuladas e incorporadas nos conceitos relevantes da teoria da estruturação. Posteriormente terei mais a dizer sobre a importância filosófica desta estratégia.
} 
McLennan parece defender; e 2) que é possível justificar a posição de Giddens no contexto da filosofia da ciência pós-empirista, ainda que várias questões importantes precisem ser tratadas. Eu encerrarei com algumas notas breves sobre o estatuto da teoria crítica no programa estruturacionista.

\section{O estatuto analítico da teoria da estruturação}

Utilizando seus comentários em vários pontos, parece que com "coerência" teórica McLennan quer dizer uma descrição das estruturas, ações e sequências que constituem o domínio da investigação na teoria social. Esta descrição deve estipular aspectos de relações sociais que assumem uma posição explicativa privilegiada. Ela deve ser apresentada em conceitos unitários relacionados através de proposições lógicas. O que tudo isto parece pedir é uma sistematização da teoria social. Mas o ponto crucial que McLennan não trata é o nível de análise em que esta sistematização deve ocorrer.

Eu pressuporei que McLennan pretende se referir à sistematização teórica no nível da investigação relacionada aos constituintes universais da vida social. Se McLennan está procurando coerência sistemática neste nível, então a teoria da estruturação certamente o desapontará. Isto não quer dizer que o desenvolvimento da teoria da estruturação de Giddens é inconsistente, ou mesmo "eclético". Como eu logo indicarei, acredito que exista uma consistência básica em sua análise da constituição da vida social. Mas, primeiro, é útil estabelecer objeções ao desenvolvimento da coerência sistemática, como McLennan a concebe, neste nível analiticamente abstrato da teoria social.

Teorias sociais diferem no grau em que seus relatos analíticos da natureza transhistórica de processos e grupos sociais colocam restrições em descrições teóricas e explicações de ordem inferior de eventos historicamente situados. É claro que todas as teorias analíticas colocam alguns limites na capacidade de suas contrapartes substantivas de compreender a contingência da história. Além do mais, cada descrição da constituição da vida social implica uma posição definida sobre questões básicas de filosofia ética e política assim como de antropologia filosófica. Mas enquanto o interesse permanecer focado na adequação explicativa de um programa teórico, é 
desejável que evitemos criar uma cama de Procrusto em termos analíticos à qual todas as teorias substantivas devem se submeter. A contingência da história é preservada quando os conceitos analíticos de qualquer teoria social permitem um grau amplo de variação na construção de teorias pertencentes a diferentes domínios históricos.

Objeções à coerência sistemática (no sentido que acredito que McLennan use o termo) surgem porque formular uma teoria analítica desta forma quase inevitavelmente significa colocar limites bastante firmes na capacidade dessa teoria de gerar descrições substantivas historicamente flexíveis. Apesar de Giddens não colocar a questão exatamente desta forma, um dos temas básicos de Uma crítica contemporânea do materialismo histórico é mostrar como estes limites ocorrem. Referências às descobertas de historiadores e arqueólogos contemporâneos permitem que Giddens demonstre deficiências explicativas no programa analítico de Marx. Entretanto, como objeções similares podem ser apresentadas contra outras teorias sociais clássicas e contemporâneas, eu separarei minhas observações da crítica da teoria marxista per se.

Talvez a forma mais forte de sobrecarregar uma teoria analítica seja incorporar nela uma descrição da evolução social. A coerência sistemática é obtida desta forma através da estipulação a priori de elementos básicos: 1) a função, forma e/ou conteúdo de uma unidade trans-histórica de análise; 2) uma direção de mudança para estas unidades; 3) um critério de demarcação para estabelecer os estágios da evolução. Teorias evolucionistas clássicas também estipulam um conjunto singular de transições evolucionistas assim como um mecanismo básico que propele a direcionalidade do processo evolutivo [ver Nisbet, 1969:cap.5]. Entretanto, teóricos evolucionistas contemporâneos multilineares, empregando estratégias de reconstrução racional em vez de explicação genética, dispensaram os dois últimos itens [ver Habermas, 1979:139ff., 169-170]. Apesar de tais teorias ficarem mais flexíveis com esta base, enquanto a descrição evolucionista mantiver um escopo universal, elas ainda restringem a teoria substantiva e a pesquisa histórica. Um grande problema para todas as teorias deste tipo é manter um "encaixe" apropriado entre o mapeamento analítico que a teoria evolucionista fornece e a variabilidade da história em todas as suas diversas manifestações.

Precisamos nos voltar a uma crítica metodológica para demonstrar os problemas inerentes a estas visões continuístas do curso da história. Sociólogos históricos 
contemporâneos engajados na análise comparativa de sequências de eventos bastante extensas e importantes estão impacientes com as restrições que teorias evolucionistas analíticas impõem. As obras de Skocpol [1979:cap. 1] e Tilly [1975:caps. 1 e 9] oferecem evidências dos problemas teóricos e empíricos na tentativa de derivar teorias substantivas satisfatórias de modelos evolucionistas universais como os fornecidos por parsonianos e marxistas. A evidência das descontinuidades da história aduzidas por Giddens em Uma crítica contemporânea tem escopo mais global, mas é igualmente instrutiva. Parece então que na divergência entre posições analíticas evolucionistas e não-evolucionistas o ônus da prova está mais com aquelas do que com estas. Por mais exasperador que isto possa ser para aqueles que buscam a racionalidade da história, uma teoria evolucionista capaz de mapear universalmente teorias e pesquisas históricas amplas ainda não foi produzida.

É claro que uma teoria da evolução social não é o único modo de produzir uma teoria analítica sistematicamente coerente. Como McLennan deixa implícito, a coerência pode ser fornecida pela estipulação da prioridade explicativa de elementos particulares de relações sociais (cujo resultado podemos agora conceber como de natureza indeterminada). Tais elementos podem se referir a tipos específicos de ação ou práxis (por exemplo, trabalho, orientações de valor, ou trocas utilitárias) e/ou padrões formais de relações sociais (por exemplo, as relações de produção, a teoria funcionalista do sistema social de Parsons [ver esp. Parsons, 1951]). A coerência é mantida aqui pelo desenvolvimento de proposições lógicas ou modelos dedutivos que se referem às relações que são necessariamente implicadas pela prioridade explicativa dos itens estipulados.

Mais uma vez, eu acredito que o ônus da prova esteja com aqueles que aderem às teorias sistematizadas nesta base. Apesar de certamente ser possível desenvolver conceitos e proposições analíticas unitárias desta forma, não há nenhum meio para garantir, em termos analíticos, que os processos ou formas de relações sociais estipuladas compreendem adequadamente a diversidade da história. As observações de Giddens [1981:ver esp. cap. 3] sobre a natureza radicalmente distinta das sociedades capitalistas sugere as dificuldades que teorias marxistas encontram a este respeito. Eu não tentarei criticar outras teorias neste ponto, mas não parece provável que algum outro conjunto de conceitos analiticamente anteriores incorporados numa matriz de proposições lógicas se sairia melhor. 
É importante não saltar de uma rejeição das estratégias analíticas precedentes para a opção igualmente problemática do empirismo histórico ou abstraído. Numa era em que o caráter carregado de teoria de todas as observações foi reconhecido, as deficiências do empirismo são óbvias para todos. Mas se a necessidade de teoria é inevitável, sua possibilidade seria negada se abandonássemos um relato dos constituintes universais da vida social. Precisamos de uma série de conceitos analíticos adequados para gerar diversas teorias substantivas através do conjunto inteiro de casos históricos. Apesar da "coerência" entre estes conceitos ser desnecessária, é preciso manter uma consistência interna não-dedutiva entre eles. A marca deste tipo de consistência é a complementaridade de definições conceituais e a ausência de contradições conceituais.

Há dois outros problemas que esta posição analítica deve enfrentar. Por um lado, há a possibilidade de que a série de conceitos analíticos postulada pode não ser adequada para compreender o conjunto completo de características constitutivas da vida social em geral. Por outro lado, há a dificuldade em manter uma consistência interna entre todos os conceitos sem cair numa coerência sistemática que limite arbitrariamente a variação histórica. Eu acredito que o componente analítico da teoria da estruturação que emergiu na obra de Giddens supera todos estes problemas. Eu não discutirei estes argumentos aqui. Tendo em vista as preocupações expressadas por McLennan, o que desejo discutir é a consistência interna dos principais conceitos da descrição estruturacionista da constituição da vida social ${ }^{2}$.

Esta consistência é estabelecida pelo fato de que todos os conceitos que Giddens introduziu estão ligados à prática situada de atores sociais cognitivamente hábeis. Movendo-se em uma direção, ele abre um modelo estratificado do sujeito ativo [Giddens, 1976:117-118; 1979:55-59, 120-130; 1982a:30ff]. Os conceitos deste modelo tratam da constituição analítica das necessidades, desejos e interesses dos atores. $\mathrm{O}$ modelo, como um todo, fornece meios para analisar as camadas estratificadas da consciência e os motivos para atores que engajam em práticas sociais (ou se esquivam delas). Movendo-se em outra direção, Giddens fornece uma série de conceitos para tratar da produção e constituição das características coletivas da vida social.

\footnotetext{
${ }^{2} \mathrm{Na}$ seção seguinte, eu me referirei a isto como o núcleo metafísico do programa estruturacionista.
} 
A base para este relato é estabelecida no conceito de dualidade da estrutura: ou seja, a implicação recursiva das propriedades estruturais de sistemas sociais nos contextos reunidos por práticas sociais que são ou reproduzidas ou alteradas durante o curso destas práticas [Giddens, 1976:121-122; 1979:69]. Sistemas sociais [Giddens, 1979:65-66; 1981:26] são compostos de práticas recorrentes que, através de sua interdependência ${ }^{3}$ constituem padrões de relações sociais. O conteúdo dos sistemas sociais é dado pela constelação de propriedades estruturais que são reunidas e reproduzidas nestas práticas recorrentes através da dualidade da estrutura. Constelações de propriedades estruturais sempre envolvem distribuições substantivamente combinadas, mas analiticamente separáveis, de controle de recursos de autoridade e alocação interpretados em regras que compreendem códigos normativos e esquemas interpretativos [Giddens, 1979:81-88]. Já que os sistemas sociais envolvem práticas recorrentes, eles podem ser analisados tanto em termos de seus ciclos de reprodução, quanto por referência às transformações ou mediações entre os elementos analiticamente separáveis de suas constelações estruturais [ver Giddens, 1979:106; 1982a:cap. 3].

$\mathrm{Eu}$ acredito que o resumo acima seja suficiente para demonstrar que uma consistência interna nos conceitos de Giddens é mantida através de suas interconexões complementares com o conceito essencial de práticas sociais. Esta descrição não é suficiente para abarcar todas as inovações conceituais que Giddens produziu. Mas há dois pontos que são particularmente pertinentes no contexto atual.

McLennan e outros têm problemas com a natureza "virtual", e não concreta, das propriedades estruturais na teoria de Giddens. Na verdade, esta noção é menos opaca do que eles sugerem. Diferente do que ocorre com organismos biológicos [Giddens, 1977:118-119], a cessação das práticas que reproduzem um sistema social não deixa nenhum resíduo estrutural que possa ser interpretado sem recurso a essas práticas (ainda que reinterpretações extracontextuais não sejam excluídas). Isto ocorre porque é apenas na recorrência das práticas sociais que as distribuições de recursos são reunidas e interpretadas em termos semânticos e normativos. Assim, práticas sociais são uma causa

\footnotetext{
${ }^{3}$ Devemos enfatizar que interdependência não implica solidariedade. Tirando a visão aberta de Giddens da integração social a que eu me refiro subsequentemente, é importante notar que todas as práticas e sistemas sociais envolvem relações de autonomia e dependência [Giddens, 1979:88-93; 1981:28-29, cap. 2]. Esta é uma das poucas áreas em que os conceitos analíticos de Giddens violam a variabilidade da história.
} 
imediata de propriedades estruturais. É claro que participantes de práticas sociais não precisam ter consciência da natureza ou das consequências de todas as suas contribuições para a estruturação de sistemas sociais. Assim, aspectos mais coletivos da análise causal não podem ser excluídos. Mas em todos os conceitos onde processos causais duradouros ocorrem, atores sociais precisam se lembrar de como participar de suas práticas. É por isso que seus "traços de memória" fornecem uma condição necessária para a reprodução da vida social.

O segundo ponto volta ao assunto da contingência histórica deixada aberta nos conceitos analíticos de Giddens. Num sentido negativo, podemos dizer que a teoria da estruturação preserva um alto grau de contingência precisamente porque: 1) ela não incorpora nenhuma teoria de evolução social; 2) ela não estabelece nenhum tipo de prática, padrão sistemático ou propriedade estrutural que assumiria prioridade explicativa numa base trans-histórica. Apesar de todas as coletividades envolverem padrões reproduzidos de controle de recursos (ou seja, estruturas de dominação), a articulação e distribuição destes recursos varia em diferentes tipos de sociedade [Giddens, 1981:52]. Além do mais, Giddens não faz nenhuma reivindicação pela prioridade dos recursos de alocação ou de autoridade, ou de códigos semânticos ou normativos de qualquer tipo em particular. A prioridade explicativa de práticas, sistemas e constelações de propriedades estruturais só pode ser determinada em teorias substantivas.

Num sentido mais positivo, Giddens deixa a contingência da história aberta no nível analítico de várias formas:

1) Para a teoria da estruturação, é fundamental que a extensão dos sistemas sociais deve ser especificada em termos do distanciamento espaço-temporal dentro de suas práticas constitutivas, e entre elas. A reprodução de sistemas sociais na longue durée é determinada num nível mais duradouro de análise espaço-temporal. Assim, tanto a extensão quanto a duração dos sistemas sociais enquanto unidades de análise ficam abertas para serem determinadas no nível substantivo.

2) Apesar de Giddens fornecer uma definição mínima de uma totalidade social incluindo princípios estruturais (e as contradições entre eles) para analisar sua integração geral [Giddens, 1981:41-48; ver também 1979:76-81], ele rapidamente enfatiza três pontos que preservam a contingência da história [ver Giddens, 1981:46]. 
Primeiro, analisar as relações entre sociedades é tão importante quanto analisar suas circunstâncias internas. Segundo, todas as sociedades são sistemas e também são compostas de sistemas, pois sistemas de níveis inferiores (por exemplo, a corporação transnacional moderna, a família nuclear) podem atravessar muitas sociedades diferentes e sobreviver a transformações em qualquer uma delas. Terceiro, o grau de integração social não é pressuposto no nível analítico. Isto também é sempre uma questão para a teoria substantiva.

3) Sistemas sociais mantêm seus padrões e conteúdo apenas enquanto os atores repetirem as práticas que prevalecem. Ao enfatizar a capacidade transformadora de toda ação social [Giddens, 1976:110-118; 1979:88-95], a dialética do controle em estruturas de dominação [Giddens, 1979:144-150], a inevitabilidade de consequências nãointencionais em todos os sistemas sociais [Giddens, 1982b:67], e a probabilidade de contradições entre princípios estruturais integrativos, Giddens estabelece uma possibilidade aberta de que a natureza e as condições das práticas sociais mudarão, contribuindo assim para a transmutação do sistema social. Isto dá profundidade analítica à reivindicação de Giddens [1981:27] de que "toda reprodução é histórica e contingente".

Deve estar aparente que o componente analítico da teoria da estruturação tem escopo compreensivo e deixa aberta uma latitude extremamente ampla para a contingência da história. Mas, precisamente porque a teoria da estruturação evita as estratégias que poderiam alcançar uma coerência sistemática, seus componentes analíticos não fornecem nenhuma proposição explicativa pertencente à teoria substantiva ou à própria história. Isto coloca um grande peso sobre a construção de teorias substantivas. É aqui que respostas devem ser oferecidas para as perguntas básicas de McLennan [1984]: a saber, "quais estruturas, que ações, em que tipo de sequências, acabam compondo o objeto de investigação da teoria social"? Devemos esperar que, no nível substantivo, a teoria da estruturação gerará modelos explicativos sistematicamente coerentes: entretanto, o modelo aplicável em um dado domínio específico de investigação não precisa ser apropriado para outro ambiente.

Giddens iniciou esta tarefa em relação ao capitalismo moderno em Uma crítica contemporânea. Além do mais, ele também oferece uma tipologia básica dos sistemas sociais [Giddens, 1981:96, 159] e intersociais [Giddens, 1981:168] historicamente mais 
importantes. De qualquer forma, como Giddens reconhece espontaneamente [Giddens, 1982b:108; 1981:24], há muito trabalho a ser feito antes que as ideias apresentadas nesse volume estejam completas.

Mas, apesar da coerência das teorias substantivas de Giddens ainda não estar totalmente à vista, deve estar claro que aquilo que estamos vendo num nível analítico é muito mais do que "um amálgama de percepções e exageros pronunciados rapidamente". Em vez disso, o que Giddens produziu é uma teoria ousada e inovadora da constituição da vida social que é notável pelo grau em que a natureza e o curso de eventos históricos (e aqueles que ocorrerão no futuro) são protegidos de prédeterminação de uma base a priori.

\section{O estatuto filosófico da teoria da estruturação}

É mais do que uma mera ortodoxia popular, como McLennan afirma, que joga dúvidas sobre a utilidade da segurança epistemológica como um padrão de juízo para avaliar os méritos de um programa teórico. Existe agora um corpo poderoso de argumentos e evidências na filosofia pós-empirista para substanciar a subdeterminação das teorias pelos fatos e a natureza carregada de teorias dos próprios fatos. Isto levou ao abandono da busca de um critério objetivo e empírico como o árbitro neutro entre teorias diversas [ver Hesse, 1980:vii, 144]. De importância semelhante, o giro histórico na filosofia pós-empirista levou à rejeição daquilo que Lakatos [1970:174-175, passim] chama de ideia de "racionalidade instantânea": a saber, a justificação ou falseamento imediato de teorias baseado em padrões de juízo aduzidos filosoficamente. Programas científicos seguem trajetórias históricas diferentes, e eles inevitavelmente devem competir com outros programas em muitas formas diferentes. Como resultado, a racionalidade científica tende a trabalhar mais lentamente do que a maioria das pessoas pensa.

Teria sido útil se McLennan tivesse tomado uma posição a respeito destes pontos elementares da filosofia pós-empirista. Do jeito que está, seu pedido para que Giddens forneça bases para a segurança epistemológica da teoria da estruturação parece implicar que uma demonstração objetivista da "racionalidade instantânea" pode ser obtida para certas teorias de forma não-problemática. Mas seria insincero rejeitar suas 
perguntas mais específicas nesta base. Se o padrão de segurança epistemológica não é mais aceitável, é o dever daqueles que aderem a qualquer posição teórica de determinar as orientações filosóficas de seu trabalho. O cumprimento desta obrigação é prejudicado pelo dissenso sobre muitas questões fundamentais entre filósofos pós-empiristas. É por esta razão que Giddens [1982a:14] tem relutado em elaborar uma justificação filosófica para sua obra. Não obstante, eu acredito que existam vários pontos básicos que podem ser feitos em relação ao estatuto filosófico da teoria da estruturação.

Para começar, é útil notar que a teoria da estruturação mantém pontos de correspondência e diferença com argumentos propostos por Roy Bhaskar. Como Bhaskar, Giddens [1982a:14] apoia uma ontologia realista do mundo social efetivo ao qual teorias substantivas são endereçadas. Além do mais, suas visões correspondem quanto à transitividade de nosso conhecimento do mundo social ontologicamente existente [cf. Bhaskar, 1979:11-17; Giddens 1977:75-80]. Finalmente, seus argumentos analíticos focam de forma similar as práticas sociais e as características das coletividades como potenciais que são realizados de formas diversas na perpetuação e transformação da vida social através de todos os casos historicamente situados [cf. Bhaskar 1979:24; 1975:164; Giddens 1976:160]. Tanto Bhaskar quanto Giddens se referem a estes potenciais analíticos em termos ontológicos. Mas esta ontologia de potenciais precisa ser diferenciada das pressuposições da existência ontológica de uma realidade à qual nossas teorias substantivas são direcionadas. Há duas diferenças entre Bhaskar e Giddens no nível filosófico. Diferente de Bhaskar, Giddens não fundamenta seu programa numa defesa epistemológica da possibilidade do naturalismo. E ele também não tenta a tarefa imensamente difícil de fornecer uma justificativa epistemológica transcendental para sua abordagem da constituição analítica da vida social.

Qual é, então, o estatuto filosófico da descrição analítica da constituição da vida social na teoria da estruturação? Eu não posso falar por Giddens sobre este assunto, mas minha opinião é que é melhor conceber sua descrição como o núcleo metafísico do programa que ele lançou (sobre o papel da metafísica na ciência ver Watkins [1957]; Lakatos [1970:132-133]; Laudan [1977:78-81]; Kuhn [1977:298]; Thomas [1979:11-12, 137-47]). Com "metafísico" eu quero sugerir a natureza potencial dos conceitos analíticos de Giddens, e também que estes conceitos não podem ser justificados ou refutados através de confrontação direta com observações empíricas. O termo "núcleo" 
implica que estes conceitos são apenas uma parte do programa estruturacionista. Apesar dos conceitos nucleares estabelecerem as características distintivas da teoria da estruturação em geral, o cumprimento do programa requer o desenvolvimento de teoria substantiva e pesquisa empírica.

A justificação de conceitos metafísicos encontra imediatamente o problema do relativismo. Aqui, seguindo argumentos propostos recentemente por Richard Bernstein [1983:parte 2], eu gostaria de sugerir que um dos resultados mais importantes da filosofia pós-empirista foi derrubar a dualidade cartesiana entre objetivismo e relativismo. Apesar de não existir nenhum algoritmo neutro para a escolha entre teorias [cf. Kuhn, 1970:199-200], isto não significa que a ciência é um empreendimento irracional. Ao contrário, os cientistas são obrigados a submeter boas razões para a aceitação de seus programas em preferência a escolas de pensamento rivais. Os critérios aos quais essas razões se referem são estabelecidos como o resultado do desenvolvimento histórico da comunidade de investigação na qual argumentos de justificação são feitos. Isto implica uma rejeição da tese da incomensurabilidade de significado entre teorias (ver a excelente discussão deste tópico em Bernstein [1983:7993]). Nesta base, o apelo racional a critérios científicos envolve um grau limitado de persuasão racional [Bernstein, 1983:72].

A "estratégia intermediária" a que Giddens se refere em Theory, Culture \& Society [Giddens, 1982b:72] parece corresponder aos argumentos de Bernstein. Isto fica claro em outros de seus escritos [Giddens, 1976:139-148; 1977:75-80] onde se sugere que: 1) a racionalidade científica só é justificável em termos das premissas e valores (critérios) desenvolvidos durante seu desenvolvimento histórico; 2) estas premissas e valores fornecem o esquema para padrões sancionados de crítica interna; 3) os cientistas podem mediar entre paradigmas (programas teóricos) para determinar tanto o que é mantido quanto o que está faltando nas transições entre eles. A implicação destes tópicos é que os cientistas podem argumentar em nome de suas teorias apelando a padrões inatos à prática da ciência para demonstrar os problemas em outros programas que eles conseguiram superar com sucesso. O elemento de persuasão racional na ciência é, assim, uma questão de crítica interna e íntegra endereçada a uma comunidade de investigação. 
Aceitando esta posição, é consistente para Giddens reconhecer a probabilidade de "leituras múltiplas" na teoria social, enquanto ao mesmo tempo desejar manter a superioridade do núcleo metafísico da teoria da estruturação. Assumir esta posição é reconhecer que não pode haver nenhuma solução objetiva de questões básicas relacionadas à conduta social humana. Os critérios utilizados pelos argumentos de qualquer teórico não precisam receber proeminência igual por todos aqueles a quem eles são endereçados. Assim, uma multiplicidade de posições sobre a constituição da vida social parece inevitável, a despeito dos argumentos mais fortes que Giddens (ou qualquer outro teórico) possa aduzir. Deste ponto de vista, não é apenas prudente, e sim uma questão de princípio, que Giddens reconheça que ele não persuadirá a todos quanto à superioridade de suas posições.

Tendo em vista estes pontos, deve ser possível interpretar os escritos analíticos de Giddens como argumentos íntegros pela aceitabilidade de seus conceitos nucleares concebidos contra o pano de fundo de conceitos relevantes incorporados em outras escolas teóricas. Eu acredito que este padrão de argumentação racional é identificável em todos os seus textos sobre a teoria da estruturação publicados antes de Uma crítica contemporânea (onde suas discussões analíticas são entremeadas com assuntos mais substantivos).

É bastante fácil ver que a estratégia básica de Giddens é proceder através de críticas internas. Ele raramente introduz um conceito analítico sem referência tanto às forças quanto às fraquezas dos conceitos inatos ao funcionalismo, estruturalismo, sociologias interpretativas ou filosofias da ação. Enquanto ele procede, ele frequentemente insere críticas de várias posições. Há também encontros recorrentes com Habermas, Parsons, Marx, Weber, Durkheim e outros. Em quase todos os casos, estas críticas não têm o simples objetivo de desconstrução, e sim de apropriação positiva das vantagens de cada conceito de uma forma reconstruída que transcenda suas omissões e distorções. Assim, cada conceito no núcleo metafísico da teoria da estruturação é proposto como uma melhoria quanto a seus predecessores.

Como ficou implícito na seção anterior, é minha opinião que o critério científico ao qual as críticas internas de Giddens no nível analítico respondem é a adequação explicativa. Este princípio estipula que um conjunto aceitável de conceitos analíticos deve ser capaz de gerar teorias substantivas que tratem a natureza da vida social em 
todo e qualquer domínio histórico de forma abrangente. A adequação explicativa também implica em permitir a latitude mais ampla possível para as contingências da história. Giddens não formulou este critério explicitamente, mas sua presença pode ser estabelecida através de uma leitura cuidadosa de suas críticas. Na maioria dos casos, sua objeção básica a programas analíticos alternativos é que eles reificam certos elementos da constituição da vida social de forma a bloquear a adequação explicativa, como definida acima.

O apelo à adequação explicativa exclui a justificação do núcleo metafísico da teoria da estruturação em termos de outros critérios científicos básicos como coerência, elegância ou fecundidade empírica. Mas estes critérios não precisam ser inaplicáveis ao programa estruturacionista como um todo. Eles são pertinentes enquanto se referem ao nível substantivo da construção de teorias. A discussão da coerência e elegância de teorias substantivas deve aguardar desenvolvimentos posteriores de Giddens e outros autores. Mas a menção da fecundidade empírica destas teorias levanta a questão incômoda da validade fatual na pesquisa científica. Aqui, eu acredito que tenha ocorrido um avanço, mas um problema muito básico ainda precisa ser resolvido.

Enquanto um realista, Giddens está necessariamente comprometido com a visão que um substrato ontológico único sustenta todas as descrições teóricas num domínio específico. Por isso, não há nenhum problema em aceitar formas diversas de evidência empírica. Entretanto, surgem problemas diferentes para aceitar a precisão de vários tipos de evidência empírica. Uma distinção fundamental neste respeito ocorre entre evidências interpretativas consideradas válidas do ponto de vista de atores situados, e evidências que só podem ser consideradas válidas em referência à orientação teórica no domínio de investigação das ciências sociais.

Do ponto de vista da teoria da estruturação, relatos descritivos contextualmente válidos são essenciais para averiguar a natureza das práticas sociais [Giddens, 1976:150-151). A distinção de Giddens [1976:114-116, 145; 1979:248-253] entre conhecimento mútuo e os critérios de senso comum através dos quais aquele é justificado fornece um meio apropriado para estabelecer a validade contextual de relatos descritivos perante plateias de cientistas sociais. Num trabalho publicado recentemente [Cohen, 1984], eu desenvolvi argumentos para indicar como isto ocorre. O ponto central 
envolve a transposição de critérios de validação do contexto de pesquisa para o contexto profissional em que relatos descritivos são recebidos.

Mas Giddens também enfatiza que os atores nunca terão consciência de algumas (não todas) das condições e consequências de suas práticas sociais. Como resultado, certos aspectos das práticas sociais e da natureza e desenvolvimento histórico das propriedades sistêmicas e estruturais de coletividades só podem ser estudados através do desenvolvimento de teorias e métodos de pesquisa das ciências sociais. O problema que ainda não está resolvido na metodologia da teoria da estruturação se refere à validação da precisão destes relatos. O obstáculo é a ausência de um algoritmo neutro para estabelecer o valor de verdade de descobertas empíricas.

Apesar deste problema, na teoria da estruturação, ser limitado pela possibilidade de validar relatos interpretativos, num sentido mais amplo ele expõe um dilema central da filosofia pós-empirista. Na passagem para além do objetivismo e do relativismo, é preciso encontrar um meio para garantir que evidências produzidas profissionalmente sejam mais do que meramente um artefato de uma teoria em particular. Mesmo a reivindicação de manter uma ontologia realista no domínio da investigação não mitiga este problema. Evidências produzidas nesta base ainda são carregadas de teoria num sentido muito básico. Giddens não está sozinho no combate contra este dilema. McLennan cita Habermas como alguém que buscou o objetivo da segurança epistemológica. Mas Habermas [1982:275; ver também Thompson, 1981:207] admite francamente que de seu ponto de vista a "dimensão evidencial" do conceito de verdade precisa urgentemente de maiores esclarecimentos. Bhaskar, por outro lado, aceita a inevitabilidade do relativismo epistemológico. Os "filósofos", ele assevera [Bhaskar, 1978:249; ver também 1979:73-74] desejam uma teoria da verdade que forneça um critério ou selo de conhecimento. Mas tal selo não é possível. Pois o juízo da verdade de uma proposição é necessariamente intrínseco à ciência em questão ${ }^{4}$.

Giddens [1982b:74] reconhece que não é confortável manter a posição do relativismo epistemológico. Parece haver alguns fatos básicos que não cedem a evidências carregadas de teoria produzidas em programas rivais. Giddens utiliza tais evidências em sua crítica da teoria evolucionista, mas é possível encontrar muitas outras

\footnotetext{
${ }^{4}$ É consistente com esta posição que Bhaskar [1978:190] sugira que na ciência "só se pode dizer que o progresso ocorreu a partir de um certo ponto de vista ou posição teórica". Podemos nos perguntar se Bhaskar cairia então na categoria de "idealista" de McLennan.
} 
instâncias. Por exemplo, todos os relatos demográficos concordam que tem havido um declínio da taxa de fertilidade nos Estados Unidos (ainda que muitos membros da sociedade possam não ter consciência disto). Da mesma forma, evidências de todas as perspectivas teóricas existentes indicam que a desigualdade social continua a existir em todas as sociedades capitalistas em termos de classe, etnia e gênero, e que a mobilidade social em todas estas dimensões é muito inferior à ideia de oportunidade igual. Teorias que concordam quanto à existência destes fatos não precisam concordar sobre sua interpretação ou conexão com outros fatos. Mas qualquer teoria que negasse sua validade poderia ser falseada facilmente.

Eu não conheço nenhum argumento pós-empirista que explique por que alguns fatos parecem ser epistemologicamente seguros, enquanto muitos outros estão sujeitos a contestações aparentemente intermináveis. Mas, como John Dunn [1978:174] observa em sua discussão da história e das ciências sociais sob princípios realistas, "a ausência de um método para descobrir o que é verdade sobre um certo assunto não implica que nada seja verdadeiro sobre ele". Eu acredito que Giddens consideraria esta posição correta. Mas ela é também a fonte de seu desconforto.

Critérios epistemológicos não são os únicos princípios que teóricos podem invocar em nome de seus programas. Mary Hesse [1980:cap. 8] aponta que a subdeterminação das teorias, e a natureza carregada de teoria dos relatos empíricos, cria a abertura para a justificação de teorias através de bases orientadas por valores. É típico nas ciências naturais se referir, neste ponto, a critérios pragmáticos (por exemplo, predição e controle bem-sucedidos). Mas não podemos racionalmente esperar seguir este critério nas ciências sociais. Em vez disso, a justificação de programas nas ciências sociais envolverá referências aos valores éticos e objetivos políticos que ela implica [ver também Thomas, 1979:cap. 4].

O núcleo metafísico da teoria da estruturação ainda não foi analisado deste ângulo. Parece que o próprio Giddens [1979:189; 1981:251] deseja adiar esta tarefa para obras posteriores sobre antropologia filosófica. Entretanto, vários temas básicos já podem ser vistos. Primeiro, há implicações éticas na concepção estruturacionista da ação humana: "ser um ator é ser capaz de fazer uma diferença no mundo (...) como uma parte contínua da vida cotidiana" [Giddens, 1982b:68]. Ou, colocado em termos mais políticos: "o poder e a liberdade na sociedade humana não são opostos; ao contrário, o 
poder está enraizado na própria natureza da ação humana, e assim na liberdade de agir de outra forma" [Giddens, 1981:4]. Um segundo ponto trata da possibilidade inerente da diversidade humana [Giddens, 1981:251]. Finalmente, há a busca do significado que Giddens [Giddens, 1981:156] considera estar no centro de uma antropologia filosófica da cultura humana.

As observações acima fornecem apenas pontos nodais para desenvolver as fundações éticas e políticas da teoria da estruturação. Além do mais, Giddens ainda não resgatou sua crença [Giddens, 1981:175] na possibilidade de várias formas de "sociedades socialistas libertárias", incorporando [Giddens, 1981:24] liberdades e modos de autorrealização sem precedentes. De qualquer forma, em suas concepções de dominação, exploração e da dialética do controle [ver Giddens, 1981:cap. 2; 1982a:cap. 4], Giddens começou a desenvolver conceitos analíticos que implicam conexões fortes com suas observações de antropologia filosófica e seus compromissos políticos socialistas. Assim, ainda que as fundações para uma justificação baseada em valores da teoria da estruturação ainda tenham que ser estabelecidas, o material para esta tarefa está começando a emergir.

\section{O estatuto da teoria crítica}

Deve estar claro que, ao rejeitar a teoria, e a validade universal da investigação nas ciências sociais, Giddens não pode estabelecer o estatuto da teoria crítica da mesma forma que Habermas. De fato, apesar da profundidade e originalidade de seu programa, a viabilidade da abordagem de Habermas à teoria crítica ainda não foi estabelecida. A "reivindicação de razão nunca silenciosa, mas poucas vezes redimida" [Habermas, 1979:97; cf. 1982:221], que fornece a base definitiva, dentro de sua abordagem de teoria da comunicação, para a justificação da teoria crítica, parece ser um tópico notavelmente obscuro a afirmar num mundo em que a possibilidade de aniquilação nuclear, e a realidade da exploração, tortura e outras formas de opressão, além da estultificação dos significados culturais, nos enfrentam todo dia. Consiga Habermas nos persuadir a aceitar sua justificação da teoria crítica ou não, a missão substantiva da teoria crítica tem que ser tratar destes problemas urgentes. 
Giddens deseja apontar sua concepção da teoria crítica nesta direção. Se o núcleo metafísico da teoria da estruturação pode ser justificado em termos de adequação explicativa, assim como nas bases éticas e políticas que ainda precisam ser aduzidas, ele deve ser capaz de gerar percepções substantivas de grande importância para aqueles que buscam transcender a condição da liberdade, autorrealização e de uma vida social significativa. O relato estruturacionista da teoria crítica tem uma intenção prática.

É impossível fornecer uma interpretação metodológica completa da abordagem de Giddens à teoria crítica aqui ${ }^{5}$ (eu iniciei esta tarefa em Cohen [1984]). Mas é importante enfatizar a importância fundamental da hermenêutica dupla: ou seja, a interação bilateral entre esquemas de significado sociológicos e cotidianos [cf. Giddens, 1976:162]. Alguns teóricos (por exemplo, Habermas [1984:110]) destacaram a importância deste conceito para o desenvolvimento da teoria e pesquisa social. Mas como Giddens [por exemplo, 1982a:14] indica, a hermenêutica dupla também implica que as "descobertas" da ciência social inevitavelmente infiltram e influenciam as práticas dos atores a que se referem. É neste sentido que: “A teoria social é inevitavelmente teoria crítica" [Giddens, 1982a:15].

Dizer isto é abrir um conjunto de problemas complexos. Como a teoria crítica influencia a transformação social em oposição à reprodução social? Que grupos serão influenciados? Quando e onde esta influência ocorrerá? Está de acordo com a grande ênfase colocada sobre a análise substantiva na teoria da estruturação sugerir que essas questões precisam ser respondidas em termos historicamente específicos. Não obstante, se a teoria crítica quiser ter uma intenção prática, parece que sua justificação definitiva precisa estar em sua utilidade para grupos que buscam produzir mudanças relacionadas aos princípios éticos e políticos que a teoria da estruturação incorpora ${ }^{6}$. Mas é importante não reduzir os argumentos analíticos a favor da teoria da estruturação a sua justificação crítica-pragmática. A hermenêutica dupla implica em uma interação entre contextos científicos e cotidianos; ela não reduz a prática da ciência social à apreensão interpretativa de problemas sociais. Assim, em oposição àqueles que sugerem que as

\footnotetext{
${ }^{5}$ Particularmente, limitações de espaço impedem o desenvolvimento do contexto necessário para apreciar a importância da concepção de Giddens da perspectiva contrafatual na teoria crítica. Basta dizer que o raciocínio contrafatual representa um papel mais limitado, mas também mais poderoso no programa de Giddens, do que McLennan admite.

${ }^{6}$ Isto sugere o tópico dos meios para apreender necessidades e interesses, dos quais os atores podem não ter consciência em suas circunstâncias num dado momento. Sem entrar em detalhes, devemos notar que a fundamentação de antropologia filosófica da teoria da estruturação pode ter um papel vital neste ponto.
} 
complexidades da justificação não-empírica podem ser destiladas, em última análise, à apropriação de relatos por atores leigos [ver Thompson, 1982:208], apelos a critérios inatos à comunidade de cientistas sociais permanecem essenciais do ponto de vista estruturacionista.

\section{Conclusão}

A crítica de McLennan do estatuto epistemológico da teoria da estruturação pressupõe a vantagem de uma concepção "objetivista" da ciência social. Se fosse possível estabelecer um ponto de Arquimedes para garantir tanto a racionalidade de uma teoria sobre todas as outras, quanto a segurança epistemológica dessa teoria em termos empíricos, quem poderia ser capaz de discordar? Mas, a não ser que estejamos preparados para invalidar todo o assalto da filosofia da ciência pós-empirista, esta possibilidade deve ser abandonada. Na segunda metade deste artigo eu apresentei temas subjacentes que podem ser usados para justificar a teoria da estruturação num contexto pós-empirista. Eu acredito que Giddens é bastante sério quanto à necessidade de levar em conta as inter-relações inevitáveis entre a investigação social e a filosofia da ciência. Talvez uma das formas mais úteis de encarar o programa da teoria da estruturação que ele originou seja como uma apropriação da tradição sociológica em princípios pósempiristas.

\section{Bibliografia}

BERNSTEIN, R. [1983] Beyond Objectivism and Relativism. Philadelphia: University of Pennsylvania Press.

BHASKAR, R. [1978] A Realist Theory of Science. Hassocks: Harvester.

BHASKAR, R. [1979] The Possibility of Naturalism. Hassocks: Harvester.

COHEN, I. [1984] "Participant Observation and Professional Sociology: Transposing and Transforming Descriptions of Everyday Life", in McNall, S. (ed.) Current Perspectives in Social Theory. Greenwich, CN: JAI.

DUNN, J. [1978] "Practising History and Social Science on 'Realist' Assumptions", in Hookway, C. \& Pettit, P. (eds.) Action and Interpretation. Cambridge: Cambridge University Press, pp. 145-176.

GIDDENS, A. [1976] New Rules of Sociological Method. London: Hutchinson. 
GIDDENS, A. [1977] Studies in Social and Political Theory. London: Hutchinson.

GIDDENS, A. [1979] Central Problems in Social Theory. London: Macmillan.

GIDDENS, A. [1981] A Contemporary Critique of Historical Materialism. London, Macmillan.

GIDDENS, A. [1982a] Profiles and Critiques in Social Theory. London: Macmillan.

GIDDENS, A. [1982b] "Historical Materialism Today: An Interview", in Theory, Culture \& Society, n.2, pp. 63-79, 107-113.

HABERMAS, J. [1979] Communication and the Evolution of Society. Boston: Beacon.

HABERMAS, J. [1982] “A Reply to My Critics”, in Thompson, J. \& Held, D. (eds.) Habermas: Critical Debates. London: Macmillan, pp. 219-283.

HABERMAS, J. [1984] The Theory of Communicative Action. Vol. 1. Boston: Beacon.

HESSE, M. [1980] Revolutions and Reconstructions in the Philosophy of Science. Bloomington: Indiana University Press.

KUHN, T. [1970] The Structure of Scientific Revolutions. Chicago: University of Chicago Press.

KUHN, T. [1977] The Essential Tension. Chicago: University of Chicago Press.

LAKATOS, I. [1970] "Falsification and the Methodology of Scientific Research Programmes", in Lakatos, I. \& Musgrave, A. (eds.), Criticism and the Growth of Knowledge. Cambridge: Cambridge University Press, pp. 91-196.

LAUDAN, L. [1977] Progress and Its Problems. Berkeley: University of California Press.

McLENNAN, G. [1984] "Critical or Positive Theory? A Comment on the State of Giddens' Social Theory", in Theory, Culture \& Society, v. 2, n. 2.

NISBET, R. [1969] Social Change and History. New York: Oxford University Press.

PARSONS, T. [1951] Social System. New York: The Free Press.

SKOCPOL, T. [1979] States and Social Revolutions. Cambridge: Cambridge University Press.

THOMAS, D. [1979] Naturalism and Social Science. Cambridge: Cambridge University Press.

THOMPSON, J. [1981] Critical Hermeneutics. Cambridge: Cambridge University Press.

THOMPSON, J. [1982] "Universal Pragmatics”, in Thompson, J. \& Held, D. (eds.) Habermas: Critical Debates. London: Macmillan.

TILLY, C. (ed.) [1975] The Formation of National States in Western Europe. Princeton: Princeton University Press.

WATKINS, J. [1958] "Confirmable and Influential Metaphysics”, in Mind, 67, pp. 344-365. 


\section{Gregor McLennan - Teoria da estruturação e filosofia pós-empirista: uma réplica}

Eu saúdo as observações de Ira Cohen sobre minhas críticas anteriores à teoria da estruturação, e valorizo seus esforços para refinar sua apresentação filosófica [McLennan, 1984; Cohen, 1986]. Ajudado por Cohen, eu vejo que posso ter ludibriado os leitores a pensar que existe uma forma clara e não-problemática de superar os dilemas para a teoria social moderna que detectei na obra de Anthony Giddens. Eu realmente enxergo que uma combinação ampla de realismo científico e materialismo histórico tem vantagens sobre a teoria da estruturação. Mas eu não fingiria que ela seria muito menos afetada pelas pressões geradas por imperativos teóricos contrastantes. $\mathrm{O}$ principal objetivo de meu comentário era, na verdade, dizer que até que os tipos de dilemas que eu apontei sejam resolvidos satisfatoriamente, reivindicações feitas por Giddens e muitos outros autores menos talentosos de ter encontrado um "novo veio" na teoria social devem ser tratadas com muito cuidado. A defesa de Cohen da estruturação não me convenceu que eu já possa relaxar. Na verdade, ele concede que os assuntos que identifiquei realmente contêm grandes problemas não resolvidos para Giddens e ele próprio, enquanto questiona tenazmente minha aparente confiança numa solução mais "objetivista".

\section{Pós-empirismo}

Apesar de Cohen aparentemente aceitar a relevância de meu desafio quanto à falta de "segurança epistemológica" na teoria da estruturação, ele me acusa, por sua vez, de tentar ressuscitar um "ponto de Arquimedes" de avaliação neutra entre teorias a partir do qual a superioridade epistemológica poderia ser adjudicada. Ele observa que esta vã esperança vai contra "todo o assalto" da filosofia pós-empirista. Ele implica que, se eu tivesse demonstrado familiaridade com pontos "elementares" deste tipo de trabalho, eu estaria menos inclinado em alvejar a relutância de Giddens em fornecer uma justificação filosófica para sua teoria social. 
Eu não me incomodo em admitir aqui que meu compromisso com uma posição "realista" às vezes pode parecer uma preferência um tanto intuitiva por um objetivismo antiquado contra as formas de subjetivismo da moda. E já que, aliás, eu li um ou outro texto pós-empirista, eu entendo por que Cohen me lembra que isto não serve. Entretanto, ele mesmo não conseguiu reconhecer o bastante que toda a questão do "objetivismo" surge como um tópico importante dentro do tecido do pós-empirismo. $\mathrm{Na}$ verdade, este termo é empregado de forma duvidosa por Cohen, pois ele é uma tradição teórica normativa dramaticamente menos unificada do que ele parece supor. Além do mais, Cohen esquece de dizer que a própria tradição empirista que foi vagamente substituída pelo "pós-empirismo" tinha um caráter anti-objetivista em vários aspectos. Para mim, isto tudo é parte da substância do tópico em questão, e por isso eu não posso concordar totalmente que meus comentários não tenham valor sob a luz da crítica pósempirista.

O principal "assalto" do pós-empirismo na filosofia da ciência foi levar o convencionalismo inerente, mas implícito, ao positivismo lógico à sua conclusão rigorosa. Carnap e outros tinham criado uma visão do método científico em que a coleção sistemática de descrições de dados sensoriais empíricos era teorizada de acordo com regras de correspondência entre uma linguagem teórica e uma de observação. É no mínimo plausível manter, sequencialmente, que o estatuto de tais regras de "correspondência" no positivismo era completamente convencional; que a "natureza" refletida no "espelho" do positivismo é o reflexo do aparato sensorial humano (ou científico); e que esta visão não-objetivista do conhecimento era (ao contrário de alguns esboços populares de sua história) a visão dominante na filosofia ocidental desde a revolução científica do século XVII. Esta linha de pensamento esquemática é, pelo menos, tão plausível quanto outras por aí. (Outro preceito do pós-empirismo reconhecido recentemente é que o apelo à história da ciência não é menos carregado de teoria do que os apelos ao método científico). Consequentemente, podemos argumentar que o efeito principal do pós-empirismo é fornecer um sentido mais desenvolvido de que todas as referências "empíricas" são feitas dentro de convenções teóricas específicas. Kuhn e Feyerabend, particularmente, insistiram que elas também são feitas dentro de convenções ocupacionais e sociais.

Entretanto, depois disto começam os problemas. Ninguém parece feliz com o rumo de Feyerabend em direção à incomensurabilidade de paradigmas, mas essa é a 
consequência estrita da linha de pensamento geral. Eventualmente, foi então proposto que a própria noção de paradigma como um "esquema conceitual”, firme e empacotado logicamente, não é útil; que se o engajamento científico é convencional ele não precisa ser julgado irracional por isso; que enquanto alguns elementos de um paradigma ou tradição de pesquisa são metafísicos e definitivos, outras partes podem estar sujeitas a intercâmbio entre paradigmas numa base racional. E assim por diante. Todas estas manobras são estratégias mais ou menos plausíveis - Cohen parece tratá-las como demonstrações lógicas estabelecidas - para resgatar a razão e, de fato, um grau de objetividade do giro desconstrutivo da filosofia ocidental.

Existe, é claro, uma tradição pós-empirista ainda mais radical e estimulante convergindo agora sobre a filosofia pós-analítica. "Todo o assalto" da filosofia pósmoderna ou desconstrutiva é levar a carga de teoria a seu lugar de descanso final: a dissolução de qualquer noção de "ciência" cumulativa e "racionalidade", a afirmação e celebração das facetas não-cognitivas da vontade de conhecimento, e o estabelecimento do caráter retórico de todas as reivindicações metanarrativas. Muitos filósofos pósempiristas perecem sob esta espada de Dâmocles, com exceção dos realistas inflexíveis.

Originalmente, eu achei que não era preciso estabelecer este contexto do debate quando notei a parcialidade de Giddens, no simpósio de Theory, Culture \& Society, por uma ou outra formulação desconstrutivista. Entretanto, é preciso apenas uma menção das linhas anteriores para ver que o apelo de Cohen a uma ortodoxia pós-empirista não resolve os tópicos em questão. Bernstein e outros estão certos ao dizer que deveríamos estar indo "além do objetivismo e relativismo". Repetindo: eu não defendo uma posição absolutista que busca estar acima dos compromissos teóricos, e que pode provar que os relativistas estão errados tout court. Mas, ainda assim, há soluções relativamente objetivistas para o dualismo relativismo/absolutismo, assim como há soluções relativamente relativistas! Além do mais, algumas tendências do pós-empirismo consideram um esquema conceitual como completamente essencial, outras não. Algumas reafirmaram a dimensão empírica como um componente relativamente independente da escolha entre teorias, outras optaram pelo jogo discursivo fluido da contrarretórica. Pouco disto aparece na afirmação um tanto perturbadora de Cohen [1986:123] de um cenário "pós-empirista" estabelecido que, não obstante, está num “estado de desordem sem precedentes". Mas é precisamente nesse cenário, no qual, apesar de todas as nuances importantes, uma polaridade metafísica bastante básica é 
continuamente ressuscitada, que algumas variantes da filosofia realista científica parecem especialmente atrativas.

O realismo aceita a carga teórica de todos os dados empíricos, mas sua descrição da textura estratificada de domínios reais e dos poderes causais que os povoam serve para afirmar precisamente um caráter "objetivista" para o propósito e realização da prática científica. Resumindo, a cena pós-empirista não pode mais ser definida (de forma um tanto enganadora) como sendo contra uma ortodoxia passada (o empirismo). Em vez disso, desconstrutivistas, relativistas, anarquistas, pragmatistas, empiristas construtivos, realistas internos e realistas externos variados lutam pela ascensão. É verdade que o ponto de Arquimedes fictício pode ser excluído, mas ainda há escolhas importantes a se fazer. Elas são colocadas de forma aguda nos motivos poderosos tanto dos cenários desconstrutivistas quanto dos realistas para a teoria social. Mas - e é isto que eu queria dizer em meu comentário original - esta é a combinação mais difícil de apresentar de forma consistente. Eu não acho que Cohen discordaria de grande parte do que eu disse até agora, mas isto deve esclarecer que minha posição está perfeitamente dentro da tropa pós-empirista.

\section{Adequação explicativa e compromisso metafísico}

A sugestão do meu artigo não era que a "segurança epistemológica" é uma condição necessária para toda teoria social importante, mas que, quando gestos de fundamentação são feitos, eles devem ser julgados pelo tipo de consistência apropriado nesse nível. Eu disse que a teoria da estruturação é prejudicialmente ambígua aqui, e que, no simpósio, Tony Giddens demonstrou uma atração igual por metáforas epistêmicas contrárias. Tudo isto é confirmado no artigo de Cohen. Na verdade, ele despeja em Giddens mais bagagem metateórica do que este talvez gostaria de aceitar. Cohen não apenas nota o "comprometimento [de Giddens] com uma ontologia realista do mundo social efetivo" [Cohen, 1986:128], mas também que ele parece precisar de um "núcleo metafísico" para sua teoria [Cohen, 1986:129].

Ora, meu argumento era que um comprometimento tão pesado não pode ser reconciliado com uma visão da teoria social como mera crítica interna, desconstrução, ou salvas discursivas [Giddens 1982:27]. Pelo contrário, muitos pós-empiristas 
rejeitariam qualquer utilidade possível num núcleo metafísico, ou, aliás, numa ontologia social. Eu aceitaria, com Cohen, que tal núcleo poderia impulsionar para uma extensão à moralidade política e à antropologia filosófica. Entretanto, num certo sentido, isto fortalece o impulso para uma base filosófica "universalista", já que a fonte clássica da tentativa de misturar teoria cognitiva e normativa é Marx, e vários comentadores desconstrutivistas mostram detalhadamente por que este tipo de projeto de fundamentação é incompatível com a consciência moderna irônica. Cohen tenta aliviar a tensão na obra de Giddens entre uma coceira por fundamentações filosóficas e esse temperamento irônico da época através da introdução da ideia de adequação explicativa como um critério para preferência teórica. Mas esta noção piora o problema. Na verdade, eu mais uma vez me pergunto se esta exposição não vai consideravelmente mais longe do que agradaria Tony Giddens. Cohen define a adequação como algo que exclui critérios como coerência, elegância ou fecundidade empírica [Cohen, 1986:130]. É interessante notar que esta noção de adequação vai completamente contra o entendimento do termo no debate na filosofia da ciência sobre o empirismo construtivo [cf. Churchland e Hooker, 1985]. Pelo contrário, Cohen enxerga a adequação como o processo de "trat[ar] compreensivamente da natureza da vida social em todo e qualquer domínio histórico". Isto é combinado com a suposição implicada pelo realismo que "um substrato ontológico único sustenta todas as descrições teóricas num domínio específico". E tudo isto estaria envolvido na justificação de um "núcleo metafísico".

Um objetivista antiquado, como Cohen supõe que eu seja, não conseguiria encontrar um conjunto de normas mais arquimediano. Mas para mim ele é arquimediano demais: por que a abrangência deveria excluir questões de coerência e fecundidade empírica, especialmente quando concordamos que a "adequação à realidade" provavelmente não pode ser resolvida fora de debates teóricos particulares e desiderata empíricos definidos por teorias? Como um objetivista mais ambíguo do que eu, eu tenho certeza de que Giddens faria tal interjeição ainda mais rapidamente.

Supostamente, então, neste aspecto da questão do relativismo Cohen dá terreno demais para o realismo em seu sentido metafísico completo. E, pelo contrário, na questão da racionalidade ele nem chega perto de ser realista o bastante. Ele percebe, por exemplo, que a incomensurabilidade, se verdadeira, impediria que falássemos uns com os outros. Sua solução, e a de Bernstein, que ele cita com aprovação, é dizer que temos que tentar "mediar entre paradigmas" para desenvolver "aquilo que é mantido e o que 
está faltando em cada um deles" [Cohen, 1986:129]. Quer dizer, na prática interpretativa padrões inatos de persuasão e crítica íntegra podem ser produzidos. A ciência é realmente racional.

Mas, em alguns aspectos, esta é uma solução pré-feyerabendiana. Ela pressupõe a justeza dos cientistas ou acadêmicos, e a natureza íntegra de seus modos de intercâmbio. Isto pode ser aconselhável, ou não. Mas, de qualquer forma, não é suficiente para deter o deslizamento para a incomensurabilidade. Uma solução mais óbvia para isto é (a) enfraquecer a noção do "paradigma" onipresente da ciência, e (b) reintroduzir algum grau sério de adequação empírica ou objetiva no processo da crítica interna. Em outras palavras, só porque todos os dados são subdeterminados teoricamente, isso não implica que nenhuma consideração empírica rigorosa possa ser afirmada como necessária entre teorias, e que deve ser especificada numa descrição de um processo de crítica "racionalmente" válido. Cohen traz preocupações similares para sua ideia de abrangência e adequação, por isso elas deveriam ter um papel na ideia de intercâmbio racional entre teóricos íntegros. Como está, sua descrição da racionalidade é convencionalista demais, e sua descrição da abrangência é realista demais.

$\mathrm{Eu}$ espero que os comentários acima tenham realizado duas coisas úteis. Primeiro, eles devem ter mostrado como a questão do fundacionalismo e sua presença inconsistente no pensamento estruturacionista reaparecem na defesa de Cohen de Giddens, e também neste último (ainda que em termos um tanto diferentes). Segundo, minha própria relutância em endossar um ponto de vista completamente objetivista deve estar evidente. Por exemplo, eu vejo problemas similares com a mistura distinta de relativismo epistemológico e uma ontologia bem povoada de Bhaskar. E também estou convencido que Habermas propõe uma tese universal duvidosamente especulativa sobre a racionalidade, enquanto consegue compartilhar dos sintomas de abstinência atuais relacionados a enunciados de segurança epistemológica. Os dilemas a que me referi são, então, comuns e urgentes. Minha própria contribuição é, consequentemente, de crítica interna e íntegra, nos termos do intercâmbio racional de Cohen, e não filosófica e abstrata. 


\section{Teorização de nivel médio}

Eu sugeri, em meu primeiro artigo, que uma forma pela qual programas de nível médio como o materialismo histórico ou a teoria da estruturação podem ganhar coerência é através de apelos a premissas filosóficas de ordem superior. Mas eu não queria sugerir que critérios filosóficos eram a única fonte de coerência, ou mesmo necessariamente a mais importante. Uma concepção determinada de primazia causal na vida social é uma outra fonte significativa de originalidade e poder. Cohen [1986:124125] mostra, de forma útil, que este critério pode ser desenvolvido separada ou conjuntamente como (a) uma sistematização teórica dos "constituintes universais da vida social"; (b) "uma descrição da evolução social"; e (c) um método analítico enfatizando a prioridade de "elementos particulares de relações sociais". Em cada caso, continua Cohen, o ônus da prova está com o construtor da grande teoria em questão, e não com o crítico cético. Assim, ele nos lembra do repúdio de Giddens de todo funcionalismo e evolucionismo, dos resultados desfavoráveis das grandes teorias nas mãos de sociólogos comparativos inteligentes, e dos perigos do reducionismo "de Procrusto" face à contingência histórica.

Tudo isto é muito bom, e posso ver a razão para a insatisfação de Cohen com meu pedido um tanto abstrato para manter estas possibilidades abertas, face à bateria de qualificações para o marxismo e funcionalismo. Eu estou convencido que este assunto poderia ser levado mais longe no nível substantivo, mas este não é o lugar para tal discussão. Entretanto, é preciso ainda insistir quanto à inabilidade de Giddens e Cohen de adotar abertamente uma simples alternativa à criação de sistemas. Este fato continua a sustentar meu pensamento original de que está em jogo aqui um dilema profundo, e não uma solução para a teoria social.

Antes de notar como Giddens e Cohen "resgatam" algumas das coerências supostamente suspeitas, vejamos novamente a alternativa radical, ou seja, consistente, às "grandes teorias" de alcance médio. Cohen avisa dos perigos do "empirismo histórico ou abstraído" quando o evolucionismo e o universalismo são abandonados. Mas se a preservação da contingência, ação e historicidade é tão vital como os estruturacionistas tendem a dizer, não parece haver razão para considerar problemática a afirmação do pluralismo causal e teórico direto. Mais uma vez, é interessante que isto também seja uma das principais consequências de boa parte da crítica pós-moderna do pensamento 
metanarrativo. A linha de pensamento pluralista radical é consistente aqui com uma deserção das fundações filosóficas e da atribuição causal em favor da "paralogia" teórica e de uma heterogeneidade social infinita.

Assim, a negação completa de Giddens de qualquer versão de evolução social e explicação funcional se encaixa bem com correntes pós-modernas. Mas a própria aspiração de fornecer uma "teoria social" de qualquer tipo, especialmente uma que admite implicações políticas "progressivas", bate de frente contra a lógica desconstrutivista, e isto precisa ser reconhecido. Assim, encontramos em Giddens, mediado por Cohen, algo notavelmente parecido, mas não totalmente parecido, com uma teoria dos constituintes universais da ação social. Isto envolve, como eu suspeitei desde o início, colocar a "dualidade da estrutura" no topo da lista de conceitos básicos na obra de Giddens, apesar de alguns enfeites adicionados pelo próprio autor. Eu aceito a justificação de Cohen da natureza "virtual" das propriedades estruturais na teoria da estruturação, mas adicionaria que seu verniz sugere, além disso, que a noção de dualidade da estrutura é precisamente uma especificação formal de nível superior do tecido necessário de toda vida social.

Num nível inferior, Giddens parecia descartar todas as teorias da evolução social em favor da contingência. Mas Cohen diz [1986:127-128] que "a reprodução de sistemas sociais na longue durée é determinada num nível mais duradouro de análise espaço-temporal", e os aspectos inconscientes coletivos da análise causal de sociedades ainda são considerados importantes. Além disso, uma prática reconstrutiva para proposições evolucionistas multilineares não é excluída como obviamente ilegítima. Também devemos notar que não há nenhuma necessidade de ver a evolução social exclusivamente como um processo "expressivo" teleologicamente necessário trabalhando em formações sociais concretas, e através delas. Pelo contrário, ela pode ser vista como o desenvolvimento determinado destas formações em respeito a um conjunto de propriedades e condições especificadas. Nas concessões representadas pela frase citada, Cohen parece permitir esta aspiração mais fraca, mas ainda importante, para a teoria social. Importante, porque a simples "contingência" não é uma base promissora para qualquer reconstrução racional, e, como foi indicado, nem Giddens nem Cohen adotaram abertamente a alternativa pluralista radical. 
Num nível ainda mais substantivo, Cohen [1986:127] aceita que a estruturação busca "gerar modelos explicativos sistematicamente coerentes" de sociedades particulares. O trabalho de Giddens sobre a relação de alocação-autoridade através de sociedades capitalistas e pré-capitalistas representa o começo deste projeto. Seus quatro eixos institucionais da modernidade, desenvolvidos recentemente [Giddens, 1985:338] para sociedades contemporâneas é outro passo nessa direção. Eu reconheço voluntariamente o valor destas teorizações, mas elas realmente confirmam, para mim, que continuam na linha da teoria social "clássica" ou positiva em vez da crítica per se. Giddens tenta, em $O$ Estado-nação e a violência, mostrar como seus quatro eixos operam de forma autônoma, e que tal autonomia precisa ser reconhecida abertamente. Entretanto, há uma certa indicação de uma lógica geral de coexistência e combinação entre seus elementos, e não há nenhuma sugestão de que qualquer número de outros "fatores" possa ser adicionado de forma válida. Mais uma vez, o pluralismo e a heterogeneidade extravagantes são contidos, e por uma boa razão: o multifatorialismo e a contingência produzem descrições mais ou menos valiosas de partes da sociedade, não uma "teoria da sociedade" em qualquer um dos níveis discutidos [cf. McLennan, 1991].

Finalmente, Cohen diz que a lógica que liga os vários níveis mencionados é uma lógica de consistência interna, e não a lógica mais forte da implicação. Pela mesma razão que Giddens gostaria de se distanciar do fundacionalismo, os perigos do racionalismo direto impedem sua aspiração a tal nível preciso de conexão. Entretanto, fica claro que o movimento entre os níveis que discutimos é mais do que acidental. Todos os estágios, e as ligações, são afirmados como mais do que formais, mas todos recebem avisos de perigo enorme para a atenção do teórico. Este é realmente um programa agradavelmente flexível, e eu aceito o esforço de Cohen para defender seu valor face ao dogmatismo e estruturalismo que tendem a penetrar alternativas racionalistas fortes. Mas a questão de se a flexibilidade vem, como eu sugeri, às custas da coerência (mesmo que este termo seja diluído) não é enfrentada diretamente por Cohen.

Concluindo, eu reafirmo minhas reivindicações de que, filosófica e substantivamente, a teoria da estruturação ocupa uma posição produtiva mas desconfortável entre a lógica de uma opção desconstrutiva dentro da teoria social e um sistema de conceitos mais fundamentado epistemologicamente. Tendo em vista a resposta de Cohen, eu adicionaria agora que eu não enfatizei o suficiente as virtudes 
desta estratégia intermediária quando as armadilhas das versões mais fortes das alternativas são destacadas. Mesmo assim, eu espero ter demonstrado que nem referências ao "pós-empirismo", nem a impossibilidade de uma coerência lógica completa entre os vários níveis substantivos, estabelecem que a teoria da estruturação consegue resolver os dilemas em que ela habita.

\section{Bibliografia}

CHURCHLAND, P. M. \& HOOKER, C. A. (eds.) [1985] Images of Science. Chicago: University of Chicago Press.

COHEN, I. [1986] "The Status of Structuration Theory: A Reply to McLennan", in Theory, Culture \& Society, v. 3, n. 1, pp. 123-134.

GIDDENS, A. [1982] "Historical Materialism Today: An Interview", in Theory, Culture \& Society, v. 2, n. 2, pp. 63-77.

GIDDENS, A. [1985] The Nation-State and Violence. Cambridge: Polity.

McLENNAN, G. [1984] "Critical or Positive Theory? A Comment on the Status of Giddens' Social Theory", in Theory, Culture \& Society, v. 2, n. 2, pp. 123-129.

McLENNAN, G. [1991] Marxism, Pluralism and Beyond. Cambridge: Polity. 


\section{Zygmunt Bauman - Hermenêutica e teoria social moderna}

Na teoria social contemporânea, Anthony Giddens ocupa um lugar exclusivo. É difícil rivalizar com o simples volume de sua contribuição; e o conjunto e centralidade dos tópicos que ele tratou com graus variáveis de profundidade é ainda mais incomum. A intenção ambiciosa da teorização de Giddens é particularmente rara; desde seu começo há mais ou menos uma década, seu objetivo é nada menos do que uma reavaliação crítica do saber teórico, levando à articulação de um novo cânone teórico para a sociologia do futuro. A natureza não-partidária do partidarismo de Giddens é única; e o propósito declarado de seu esforço é integrar, e não dividir, e assim oferecer à teoria sociológica, notoriamente fissípara, a unidade da qual ela nunca desfrutou. A teoria de Giddens tem sido, até o momento, um rio largo e hospitaleiro que admite e absorve águas puras trazidas de todas as fontes montanhosas, além de se alimentar de amplas correntes subterrâneas, e assim promete continuar a ser. Por todas estas razões, sua obra teórica é uma ruptura radical com os propósitos e práticas quase universais da teorização sociológica em anos recentes. Para um número considerável de sociólogos atuais, este trabalho não tem precedentes em sua memória coletiva: não surpreende que ele atraia uma atenção generalizada e crie grandes expectativas. Ele também convida a um escrutínio cuidadoso.

O escrutínio realmente cuidadoso que a obra de Giddens merece está além da minha habilidade. $\mathrm{O}$ poder de síntese de Giddens tem poucos rivais, mas seus produtos estão espalhados através de um grande número de escritos que exigem um esforço de síntese; muitas formulações representam um estágio no desenvolvimento de uma teoria ainda incompleta, e foram (ou provavelmente serão) superadas em algum estágio posterior. Uma avaliação completa da nova teoria não é possível sem sua apresentação final e positiva que - tendo em vista a forma em espiral através da qual as ideias de Giddens se desenvolvem - provavelmente não ocorrerá tão cedo. Por isso, os comentários que se seguem não pretendem ter mais finalidade do que seu assunto. Tendo em vista que a maior parte da obra de Giddens publicada até agora foi claramente classificada como "relatórios de progresso", minhas próprias afirmações poderão ser apenas, no máximo, "relatórios sobre relatórios de progresso". Ainda assim, elas 
provavelmente não estarão à altura da tarefa de uma análise ampla e erudita que o projeto único de Giddens necessitaria; e isto é resultado de minhas próprias deficiências.

Em suas próprias palavras, o propósito de Giddens é a elaboração de uma teoria social instruída hermeneuticamente. Isto envolve, no nível substantivo, o desenvolvimento da ideia de "estruturação", com a intenção de substituir tanto o conceito de "estrutura" herdado da tradição das ciências naturais na sociologia quanto a ideia de "agente livre" que permanece na ciência social como uma lembrança constante de sua origem utilitarista. No nível da metodologia, uma teoria social instruída hermeneuticamente requereria, acima de tudo, uma "hermenêutica dupla", levando em conta a identidade essencial do meio linguístico que tece tanto a realidade social quanto sua descrição sociológica.

A teoria social instruída hermeneuticamente desejada - como Giddens afirmou repetidas vezes - constituirá uma ruptura decisiva com o "consenso ortodoxo" (compreendendo a aceitação do modelo supostamente "das ciências naturais", o funcionalismo e a teoria da sociedade industrial), e simultaneamente encerrará o desarranjo teórico causado por sua morte.

Já que (para parafrasear o adágio de Borges) cada teoria cria seus próprios predecessores, o advento da teoria social instruída hermeneuticamente como, esperamos, o novo consenso da ciência social, exigiria uma reescrita completa da história sociológica, estruturada como estava pela autoconsciência do "consenso ortodoxo". Particularmente, seria preciso revisar a crença na centralidade do "problema da ordem", assim como explodir o mito da origem conservadora da sociologia.

Este resumo nem sequer chega perto de fazer justiça à riqueza e complexidade das várias preocupações de Giddens. Mas ele localiza, até onde posso ver, as principais articulações do projeto. No fim das contas, estes são os temas recorrentes aos quais ele retorna com cada giro sucessivo da espiral. $\mathrm{O}$ que se segue é minha discussão destes temas. Espero, então, que esta discussão tenha uma relação com os tópicos estrategicamente mais importantes do projeto de Giddens, por mais incomensurável que ela seja com tal projeto. 


\section{"Teoria social instruida hermeneuticamente” em perspectiva histórica}

Não há muita dúvida de que o projeto de Giddens está no coração do discurso sociológico contemporâneo. Sua urgência vem das aflições mais pungentes da sociologia atual, e ele busca preencher suas necessidades mais fortemente sentidas. A dissipação de um mundo seguro em que a sociologia estava ancorada a salvo levou a uma busca em pânico por um porto substituto. Desencantada com sistemas claramente insolventes, a sociologia embarcou numa missão de reconhecimento de territórios até aqui mal mapeados, na esperança de descobrir novos fiadores de sua segurança. A maioria dos sociólogos viajou a lugares que pareciam promissores a este respeito precisamente porque os atores, seus motivos, seus significados, pagaram para ver o blefe do controle sistêmico sobre eles, que fracassou miseravelmente. A amnésia coletiva, combinada com o complexo de Colombo (ambos bem documentados, em relação a um episódio semelhante, por Pitirim Sorokin) fizeram o pêndulo das mudanças das preocupações sociológicas se mover completamente e o ajudaram a atingir rapidamente o ponto em que a energia cinética é reduzida a zero e o único movimento possível é uma volta para trás. É contra este pano de fundo específico historicamente que o projeto de Giddens adquire sua importância particular. Ele promete peneirar descobertas valiosas da expedição recente e marcar as trilhas que não deram em nada; mas ele também promete recuperar elementos preciosos da tradição antiga abandonados e condenados rapidamente demais na debandada universal na direção de ídolos passageiros recém-descobertos. Reconhecendo que não há mais combustível na direção que a sociologia tomou nos últimos anos, o projeto de Giddens como todas as tentativas de síntese - promete parar o pêndulo, que está prestes a começar a se mover para trás, antes que ele atinja o outro extremo do qual os sociólogos tentaram escapar há apenas duas décadas.

Mas também não há dúvida de que o projeto de Giddens está situado no próprio coração da sociologia enquanto uma "formação discursiva" - este conjunto supratemporal, duradouro e autorreprodutor de "lugares de autoridade", "superfícies de delineação", e os problemas gerados na cooperação dos dois que fundamenta o mistério da continuidade atingida através de rupturas epistemológicas, e de significados recíprocos entre proposições logicamente contraditórias. De fato, foi o esforço incessante para resolver o quebra-cabeça da ação proposital de atores hábeis produzindo "consequências não-intencionais", ou a incapacidade evidente de "atores livres" de 
exercer sua liberdade no curso de ações orientadas para fins, ou a tendência teimosa da imensidão de ações individuais a se sedimentar numa realidade independente destas ações e por sua vez fazer a ação depender de si mesma que, para todos os propósitos, constituiu a história da sociologia. O enunciado abrupto de Marx sobre pessoas que fazem a história mas que não escolhem as condições desta atividade desenhou a "superfície" na qual todos os problemas importantes da sociologia foram "delineados"; ou apenas os problemas que foram delineados nesta superfície constituíram uma parte da formação discursiva da sociologia. O projeto de Giddens, por sua própria centralidade, é outra, mas certamente não a primeira, tentativa de impedir que esta superfície gere soluções mutuamente incongruentes ou incompatíveis. Se precisamos de mais uma tentativa, não é porque ninguém tentou antes, mas porque a história da sociologia até agora tem sido um cemitério de tentativas fracassadas de superar teoricamente a contradição prática da condição humana: a contradição entre pessoas fazendo a história (sociedade, sistema, estrutura, etc.) e a história (sociedade, sistema, estrutura, etc.) fazendo pessoas. As teorias que tentam superar a contradição são numerosas demais para listar. Basta lembrar Marx (considerem seu famoso paradoxo "liberdade, igualdade, Bentham" no Capital), Durkheim, Weber, Simmel, Mead e Thomas. E, de fato, Parsons. Ou Elias.

É útil lembrarmos que o projeto que Talcott Parsons levou meio século para desenvolver (ainda que não para completar de forma a satisfazer a todos) foi desencadeado por sua preocupação com praticamente o mesmo dilema que torna a obra de Giddens urgente. Parsons embarcou na Estrutura da ação social, o manifesto de mil páginas de sua própria versão de uma "teoria social instruída hermeneuticamente", porque ele estava horrorizado com a incapacidade do utilitarismo (o positivismo aplicado ao estudo dos seres humanos - a visão que Parsons tinha então do "consenso ortodoxo") de resolver a quadratura do círculo da condição humana. Parsons a articulou como o dilema entre a voluntariedade e a não-aleatoriedade evidente da ação humana. $O$ pensamento positivista - reclamava Parsons - “está preso no 'dilema utilitarista'. Isto é, ou a ação ativa do ator na escolha de fins é um fator independente da ação, e o elemento do fim precisa ser aleatório; ou a implicação objetável da aleatoriedade dos fins é negada, mas então sua independência desaparece e eles são assimilados às condições da situação, quer dizer, a elementos analisáveis em termos de categorias não subjetivas, 
principalmente a hereditariedade e o ambiente (...)" ${ }^{\text {"1 }}$ Parsons percebeu que enquanto o modelo das ciências naturais for forçado, pelo "consenso ortodoxo" do positivismo, sobre o estudo da realidade social, a única forma de explicar a regularidade empírica (não-aleatoriedade) do comportamento dos atores é a suposição de algum tipo de "determinismo" - seja ele biológico, ambiental-social ou estrutural (no último caso, o postulado da racionalidade essencial da ação pode ser usado como cavilha).

Foi contra este círculo vicioso do manejo positivista do dilema "voluntariedade/não-aleatoriedade" que Parsons se rebelou. "Contrário a todos os tipos de teoria positivista, o preceito básico da voluntarista é que o esquema metodológico do conhecimento cientificamente válido não exaure nem positiva nem negativamente os elementos subjetivos importantes da ação"2. Para Parsons, os atores precisam ser concebidos como hábeis - como seu exemplo espirituoso do cozimento de batatas nos planaltos do Peru pretendia demonstrar. Os atores são hábeis num sentido muito parecido àquele discutido posteriormente por Schutz em referência às ideias de periodeusis de Carnéades: "vasculhando" o contexto de sua ação, os atores sabem como discernir as "condições situacionais" que precisam ser respeitadas e os recursos que podem ser empregados com uma chance razoável de sucesso. Este é, tanto na visão de Parsons quanto na de Schutz, todo o conhecimento que o ator precisa para agir de forma que se encaixe na descrição em termos de meios e fins, ou seja, para agir com sentido. Apesar de palavras diferentes terem sido usadas, Parsons reconheceria imediatamente seu próprio projeto estratégico nas suposições de Giddens da "capacidade" ou "consciência prática" do ator.

Parsons também redescobriria suas próprias esperanças originais na determinação de Giddens de que "nem o sujeito (ator humano) nem o objeto (a 'sociedade', ou as instituições sociais) devem ser consideradas como tendo primazia. Ambos são constituídos em práticas recorrentes, e através delas". Foi, afinal, Parsons no início de sua jornada de meio século que prometeu, "ao transcender o dilema positivista/idealista, mostrar uma forma de transcender também o velho dilema individualismo/organismo social ou, como ele é frequentemente chamado,

\footnotetext{
${ }^{1}$ Parsons [1949:64].

${ }^{2}$ Parsons [1949:81].
} 
nominalismo/realismo social que aflige a teoria social há tanto tempo com tão pouco propósito"3.

Apesar de tudo que Parsons fez, ele nunca designou nenhuma importância sócioteórica para a questão da "primazia". Em seu esquema teórico, tanto a "sociedade" quanto o "indivíduo" tinham o estatuto de projeções analíticas da única unidade de conhecimento acessível empiricamente - a ação social. Ambos eram, para usar termos husserlianos, "condições transcendentais" da ação, noema constituídos no processo de noesis originários da ideia de ação social; a questão da primazia era assim invalidada $a$ priori pelo próprio estatuto epistemológico de ambos os conceitos. Nas palavras do próprio Parsons, "pode-se considerar que o esquema de referência da ação tenha o que muitos, seguindo Husserl, chamaram de estatuto 'fenomenológico'. Ele não envolve nenhum dado concreto que possa ser 'pensado até o fim', que esteja sujeito à mudança. Ele não é um fenômeno no sentido empírico. Ele é o esquema lógico indispensável em que descrevemos e pensamos sobre os problemas da ação", "A personalidade e o sistema social estão inter-relacionados muito intimamente, mas eles não são idênticos um ao outro nem explicáveis um através do outro"5. Qualquer um que tenha escrito que o sistema social deve ser visto como a "resultante equilibrada e cumulativa (...) estabilizada e reforçada de muitas seleções de muitos indivíduos" não repudiaria a afirmação de Giddens que "sistemas sociais são constituídos como práticas regularizadas, reproduzidas através do tempo e do espaço", ou sua definição de estrutura como "regras e recursos organizados recursivamente". Qualquer um que tenha escrito que "meios são (...) os aspectos de propriedades de coisas que os atores conseguem alterar como desejado através de seu conhecimento e controle deles"7 não teria problemas com a proposição de Giddens de que "recursos são os meios através dos quais o poder é empregado no curso rotineiro da ação social; mas ao mesmo tempo eles são elementos estruturais de sistemas sociais, reconstituídos na interação social".

A semelhança de preocupações e propósitos é realmente notável; entretanto, isto não implica que os dois projetos resultantes sejam idênticos. O de Parsons era, antes de tudo, uma investigação fenomenológica sobre a essência da ação social e o processo

\footnotetext{
${ }^{3}$ Parsons [1949:74].

${ }^{4}$ Parsons [1949:733].

${ }^{5}$ Parsons [1951:7].

${ }^{6}$ Parsons [1951:25].

${ }^{7}$ Parsons [1949:732].
} 
lógico através do qual esta essência, apodicticamente, gera alguns outros noema, como "personalidade" ou "sociedade". A ruína de Parsons talvez tenha sido que, com frequência, provavelmente para aplacar o leitor americano e para tornar sua própria oferta mais palatável, ele se separou de suas verdadeiras crenças e interesses em suas declarações: podemos facilmente colher dos escritos de Parsons um número impressionante de alusões ao estatuto "empírico" de relações descritas, claramente contrastando com a reivindicação proposta muito mais seriamente de sua modalidade fenomenológica (necessária, apodíctica, sine qua non, com a incongruência entre os dois modos ocasionalmente remendada por um prognóstico presunçoso da convergência iminente das sociedades, como elas são, com os modelos construídos fenomenologicamente). Sua fraqueza o deixou vulnerável. Ela convidou os vulgarizadores, e os críticos dos produtos dos vulgarizadores, a interpretar, digamos, "pré-requisitos sistêmicos" como "exigências imperativas do sistema", em vez de "condições de pensabilidade do sistema", como intencionado. Isto, por sua vez, significou a destruição da autoridade de Parsons quando o direito do sistema de fazer exigências, e a sabedoria de atender tais exigências, passaram a ser questionados.

Apesar da apresentação de Giddens de conceitos básicos e suas relações estar repleta de percepções fenomenológicas, o projeto enquanto tal claramente não é outra "busca de essências". Este é um projeto reconhecidamente orientado empiricamente, que localiza as ligações entre atores e sociedades nas práticas dos atores, e não nas características indispensáveis da ação social que poderiam ser escavadas através de um processo semelhante à redução fenomenológica. A discussão de Giddens destas práticas assume a forma de descrições empíricas. Pelo menos até o estágio atual de uma "teoria social instruída hermeneuticamente", a atenção de Giddens parece estar focada na tarefa de elaborar um vocabulário sociológico apropriado a tal descrição da prática humana e capaz de acomodar tanto o aspecto do "fazer" quanto o do "sofrer" da condição humana.

Neste último tópico, o projeto de Giddens tem uma afinidade notável com outra tentativa recente de realizar uma tarefa similar - a "sociologia figuracional" de Norbert Elias.

Até onde posso julgar, a categoria central da sociologia de Elias - "figuração" recebe um significado semelhante, em vários respeitos, à categoria central do projeto de 
Giddens - a de "estruturação". Ambas as categorias pretendem compreender a ligação processual entre o ator e a sociedade; as ligações que (nas palavras de Elias) tornam "o indivíduo" e "a sociedade" "dois níveis diferentes mas inseparáveis do mundo

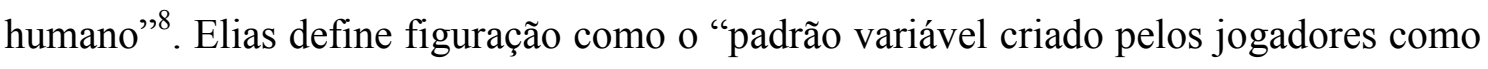
um todo - não apenas através de seus intelectos mas através de seus eus completos, a totalidade de seus procedimentos em suas relações uns com os outros"9. Como não há nenhuma concentração absoluta do poder nas mãos de qualquer um dos jogadores (comparem com a "dialética do controle" de Giddens) - "o curso do jogo não está em poder de nenhum jogador particular" ${ }^{\prime 1}$. Daí a aparência de independência de que o jogo desfruta em relação às jogadas dos jogadores. Jogadas anteriores dos jogadores sedimentam-se, por assim dizer, nas condições de suas jogadas posteriores, que são assim "limitadas" ou "coagidas". "Apenas o entrelaçamento progressivo de jogadas durante o processo do jogo, e seus resultados - a figuração do jogo antes da décimasegunda jogada - pode servir para explicar a décima-segunda jogada"11.

Para explicar a aparente autonomia do jogo em relação aos jogadores, Elias, como Giddens, emprega o conceito de "consequências não-intencionais". Entretanto, ele parece dar mais do que uma importância epifenomenal para a realidade escondida por trás do conceito. Elias castiga as "supostas teorias da ação" por não conseguirem ir além de levar em conta "que interações intencionais têm consequências não-intencionais". O que, para Elias, a teoria da ação, tomando o ator motivado como seu dado primário, é incapaz de compreender é "uma circunstância central à teoria e prática sociológica, a saber, que interdependências humanas não-intencionais estão na raiz de toda interação intencional"; "o curso não planejado do jogo repetidamente influencia as jogadas de cada jogador individual"; "a interdependência das pessoas enquanto jogadores exerce coerção sobre cada um dos indivíduos ligados desta forma; a coerção surge da natureza particular de sua relação e interdependência enquanto jogadores"12.

Para Elias, assim, a autonomia do jogo não é uma mera ilusão. A experiência da autonomia é real, e sua realidade é derivada da rede de interdependências já estabelecida e fixada no momento em que qualquer jogo em particular começa. Esta é uma mudança

\footnotetext{
${ }^{8}$ Elias [1978:129].

${ }^{9}$ Elias [1978:130].

${ }^{10}$ Elias [1978:96].

${ }^{11}$ Kilminster [1979:97)].

${ }^{12}$ Elias [1978:94-96].
} 
de ênfase sutil, mas vital. Ela traz de volta para a visão da teoria social o fato de que nenhuma ação social pode ser concebida como ocorrendo num vazio ou começando do zero (muito parecido com o repúdio de Heidegger à teorização sobre o Ser que já não seja "Ser com outros"). Para que uma figuração exista, é preciso já haver um conjunto dado de dependências entre os atores; de fato, este conjunto é exatamente o que transforma uma coleção de atores numa "figuração", uma entidade social. Mais uma vez descobrimos uma semelhança impressionante com o projeto de Giddens: Giddens dedica muita atenção a "condições não-reconhecidas" da ação, que no curso da interação são modificadas pelas "consequências não-intencionais" do comportamento que, sob outros aspectos, pode ser conhecível. Estruturalmente (do ponto de vista do lugar ocupado no modelo processual da estruturação), "condições não-reconhecidas" são equivalentes às "interdependências" de Elias. Entretanto, substantivamente há uma diferença significativa entre as duas.

Ao optar pelo conceito de condições "não-reconhecidas", Giddens se comprometeu ao critério de conhecimento (mais exatamente: percepção) como uma ferramenta importante na tipologia das fontes de conduta. O que, na visão de Giddens, difere sua própria "teoria instruída hermeneuticamente" do wittgensteinismo radical de Winch é a inclusão na descrição da ação de fontes "inconscientes" do comportamento, além das "conscientes". Giddens insiste que há algumas condições da ação que os atores não percebem. Assim, o que distingue estas condições e baseia seu estatuto especial é a falta de conhecimento dos atores. Elias, por outro lado, enfatiza o fato de que algumas das condições de ação estão irrecuperavelmente além do controle dos atores. Esta falta de controle não é meramente uma função da ignorância, pois a aquisição do conhecimento não alteraria o estatuto "supraindividual" de tais condições.

"Interdependências" capturam, então, um aspecto um tanto diferente da ação humana do que "condições não-reconhecidas". Elas levam em conta o fato de que os atores já entram no campo de interação ligados aos outros participantes não apenas através do uso de recursos compartilhados socialmente (por exemplo, o uso de palavras, que "envolve os oradores na história a longo prazo da linguagem"), mas através da circunstância de que qualquer ação que um ator ou grupo de atores possa realizar necessariamente influenciará a iniciação, o curso e o resultado das ações de todos os outros atores ou grupos pertencentes à mesma "figuração". O que é feito por um ator ou grupo de atores faz diferença para o que outros atores ou um grupo de atores pode fazer 
e realizar; e o volume e direção desta diferença não está de forma alguma relacionado ao grau de percepção de nenhum dos atores sobre a natureza genuína de sua interdependência. $\mathrm{O}$ conhecimento tem realmente importância considerável para aquilo que os atores fazem; mas não para aquilo que eles podem fazer ou qual será o resultado de sua ação. Assim, o aparecimento de duas tribos caçadoras num território onde a caça é escassa demais para preencher as necessidades de alimentação de ambas, ou o aparecimento de cem candidatos para uma vaga de professor universitário, torna, inadvertidamente, as figurações das quais as tribos ou os candidatos participam um jogo "de soma zero", fazendo com que o fracasso de alguns se torne a condição do sucesso de outros, que a cooperação entre participantes se torne pragmaticamente inviável, e que o antagonismo mútuo seja a forma racional de adaptação. Nenhum dos participantes, por mais habilidade cognitiva que tenha, pode mudar esta "lógica figuracional"; isto, na visão de Elias, é a substância da "autonomia" da figuração em relação às capacidades psicológicas dos atores - uma circunstância que fornece o tema de estudo da sociologia.

Há uma outra característica da "interdependência", diferente de "fontes nãoreconhecidas" da ação, que vale a pena mencionar. O conceito de interdependência (ou, melhor ainda, "rede de dependências") junta a ideia das pré-condições da ação desde o começo com o reconhecimento da diferenciação dos atores e suas capacidades devido a seu envolvimento na figuração. Se a "habilidade cognitiva" é uma qualidade que pode, a princípio, ser distribuída igualmente entre os parceiros da interação, a ideia de "rede de dependência" traz para o primeiro plano a assimetria possível da localização dentro da figuração. Se a interdependência coage os atores, ela coage atores diferentes de formas diferentes. Não é apenas a informação sobre circunstâncias universais de "atores humanos" enquanto tais que pode ser lida com a investigação da própria figuração antes de aplicar a hermenêutica aos feitos de seus atores, mas também muita informação bastante específica sobre limitações peculiares da ação e de seus resultados prováveis no caso de prisioneiros e guardas, pais e filhos, generais e soldados, "estabelecidos" e "forasteiros", etc. Supostamente, é isto que Elias entendia por seu preceito de que "ações e ideias não podem ser explicadas e entendidas se forem tratadas isoladamente; elas precisam ser entendidas e explicadas dentro do esquema" da figuração ${ }^{13}$.

Os projetos de Elias e de Giddens são duas reações ao descontentamento com a tentativa de Parsons de resolver o dilema central da sociologia (e particularmente contra

\footnotetext{
${ }^{13}$ Elias [1978:96].
} 
a "era da hipóstase" em que a dominação parsoniana da cena sociológica se degenerou). Os dois projetos têm muito em comum; eles também partilham muito da teoria que pretendem superar (o exemplo mais óbvio, suas esperanças originais). Entretanto, eles também diferem entre si em alguns aspectos importantes. Eu acho que a diferença essencial entre os dois projetos pode (não sem um certo risco) ser resumida da seguinte forma: Giddens quer resolver o dilema sociológico central com uma teoria que incorpora tanto o ator voluntário e hábil quanto o sistema (mesmo se definido etiologicamente, como "reproduzido"). Elias quer realizar a mesma tarefa com uma teoria que torna ambos redundantes. A estratégia de Giddens o coloca perigosamente próximo a Parsons; será preciso um grande esforço para impedir que a "teoria instruída hermeneuticamente" caia em algum momento no ponto que frustrou as esperanças de Parsons. A estratégia de Elias, apesar de ter sido proposta há quase um século por Simmel, ainda não foi submetida a um teste conclusivo.

\section{Sobre "estruturação"}

Junto com "hermenêutica dupla", "estruturação" é o conceito chave na "teoria social instruída hermeneuticamente" de Giddens.

Ao introduzir a ideia de estruturação, Giddens legitima sua empreitada através da necessidade dupla de evitar as armadilhas de uma teoria social "objetivista" ("na qual a ação humana aparece apenas como o resultado determinado de causas sociais") e afugentar a ameaça de "escorregar para o subjetivismo" - o destino que as reações iniciais afobadas demais ao colapso do domínio de Parsons não conseguiram evitar. Mas o miolo do problema - a própria razão pela qual devemos nos dar ao trabalho de criar conceitos como "estruturação" - é, para Giddens, a necessidade de "recuperar o sujeito" como um "ser que raciocina e age".

O objetivo que o novo conceito deve servir é duplo: por um lado, destronar o conceito de "estrutura" como um determinante da ação externo e preexistente; por outro, negar o caráter aleatório ou inteiramente autopropelido do comportamento dos atores. Eu notei antes que este propósito duplo, tirando o vocabulário atualizado, é uma reafirmação da preocupação dupla que desencadeou a obra de Parsons na Estrutura da ação social. 
E afinal, Giddens não dispensou o conceito de "estrutura" completamente. Entretanto, ele foi mantido num papel subsidiário de "metaestruturação". O conceito de estrutura foi transferido do reino dos objetos para o reino das regras. Como as ações humanas têm um caráter "estruturante", e não apenas o caráter de um movimento browniano, podemos - começando com o reconhecimento de sua regularidade identificar "estruturas" como "conjuntos ou matrizes de propriedades de regras/recursos que governam transformações". E assim, mais uma vez, a estrutura "governa" a ação, mas desta vez no sentido algébrico, e não mecânico. Seja qual for o sentido, a estrutura redefinida permanece, como antes, fora do reino da ação. A "estruturação" se refere à mediação dos atores entre "condições não-reconhecidas" e "consequências nãointencionais" da ação, que por sua vez se tornam, como era de se esperar, condições para a atividade futura dos atores. Mas ela não se refere, pelo que entendo, ao questionamento, negociação ou transformação das próprias regras de mediação, quer dizer, as "estruturas" em suas novas formulações. Não obstante a mudança de definição, as estruturas ainda estão isentas do poder "estruturante" dos atores humanos. A substituição da "estrutura" universal de Lévi-Strauss pelo plural "estruturas" aumenta o mistério, em vez de resolvê-lo, pois agora nos sentimos ignorantes não apenas quanto à etiologia da estrutura, mas também sobre o mecanismo responsável por sua diferenciação, influência entre estruturas, difusão, etc. Por outro lado, podemos argumentar que ao redefinir "estrutura" como o fez, Giddens usa o termo "estrutura" de forma muito parecida com a qual Parsons usou "cultura", para denotar o conjunto de regras/recursos que governa normativamente a ação social. Poderíamos supor que se Giddens, num estágio futuro de seu projeto, confrontasse a tarefa de enumerar e classificar as regras cujo conjunto formam estruturas, ele muito provavelmente acabaria com uma descrição similar, em princípio, à famosa tipologia parsoniana de normas culturais (cognitivas, catéticas, valorativas, etc.).

Mais uma vez, a necessidade de explicar a não-aleatoriedade da ação levou à postulação de uma força externa (seja ela substantiva ou normativa) que circunscreve a ação sem ser circunscrita por ela. Dizer, com Giddens, que "sistemas sociais não são estruturas; eles têm estruturas, ou, de forma mais precisa, exibem propriedades estruturais", transfere a preocupação inicial para um lugar diferente, mas não a dissipa de forma alguma. E Giddens precisa de algum tipo de força externa; depois de, como Parsons, selecionar a ação motivada como o miolo da teoria social desejada, ele precisa 
postular uma força externa para não escorregar para um "voluntarismo aleatório" do tipo utilitarista.

Em sua essência mais elementar, independente de escolas, a ideia de estrutura transmite o reconhecimento do fato de que em um certo conjunto de eventos as probabilidades não estão distribuídas aleatoriamente: em outras palavras, que alguns eventos, dado um tempo suficientemente longo e um grande volume de casos, têm maior probabilidade de ocorrer do que suas alternativas. Muito antes de receber uma articulação teórica sofisticada (muitas vezes banhada com hipóteses etiológicas), o termo "estrutura" é usado rotineiramente para encapsular observações elementares como "uma garota negra de um bairro pobre de Londres tem muito menos chance de se tornar uma gerente financeira do que um aluno branco de Eton matriculando-se em Oxford", "é provável que, entre mil pessoas de cinquenta anos, ocorram menos casamentos no ano que vem do que entre mil pessoas de vinte anos"; "é mais provável que trabalhadores de uma fábrica de automóveis entrem em greve depois do anúncio de um congelamento de salários do que ao ouvirem falar de um aumento radical do índice de desemprego". Neste nível, "estrutura" simplesmente denota a seguinte característica evidente do senso comum da realidade social: nem tudo pode acontecer (normalmente), e alguns eventos são mais prováveis que outros.

A dificuldade começa quando teóricos sociais, ostensivamente ocupados com a tarefa de "definir", "esclarecer", ou tornar o conceito preciso de alguma forma, tentam na verdade substituir a pergunta "o quê" pela pergunta "como"; quando, em outras palavras, eles tentam explicar como a estrutura surge e como "ela" "opera". É então, e apenas então, que o perigo aparece. O nome do perigo é hipóstase.

Na fala cotidiana, a hipóstase é comum. Nós normalmente a consideramos útil, muitas vezes indispensável, raramente confusa. Nós dizemos "o rio corre", "a chuva cai”, "o vento está soprando". A hipóstase em tais figuras de linguagem é inofensiva, porque nós não perguntamos "o que é o rio em si mesmo, independentemente de sua manifestação ao correr?", “o que o vento faz quando ele não sopra?”, ou “como é a chuva quando ela não cai?” Portanto, nós não supomos seriamente que o rio seja um objeto que corre da mesma forma que um rifle dispara, ou que o vento é uma "força externa" cuja atividade consiste em soprar. Nós não supomos todas estas coisas, e ainda assim consideramos estas formas de expressão quasehipostasiadas convenientes. 
Supostamente, sentimos a necessidade de "condensar" o verbo, que se refere a uma atividade, em um substantivo, porque queremos relatar a estabilidade, regularidade, resiliência da atividade em questão: “o correr” está constantemente na mesma trajetória; o ar ou as gotas d'água se movem estavelmente em uma direção, e não nas várias outras. Enquanto é isto que fazemos, o erro lógico da hipóstase não se materializa e não confunde a clareza de nosso pensamento. Não é nada difícil, na fala cotidiana, limitar os usos de um substantivo para impedir que levemos a sério a sugestão que o substantivo representa algo mais do que um movimento estável.

Quanto menos nossa fala está sujeita às coerções da vida cotidiana ("coerções" significa aqui a eliminação virtual de ocasiões para autorreflexão semântica), quanto mais distante seu referente estiver da experiência direta, quanto mais o conteúdo da fala for banhado por interpretações mediadoras e secundárias, mais fácil será para os hábitos quasehipostasiantes da fala produzirem, através de práticas recursivas da teoria, os erros lógicos da hipóstase. Os conceitos de "sistema", "sociedade", "cultura" - e, de fato, "estrutura" - nos dão exemplos radicais de tal situação.

Sem a intervenção da reflexão teórica, uma oração como "a estrutura coage" transmite meramente uma observação simples de que a probabilidade das pessoas fazerem algo difere dependendo de quem forem as pessoas em questão. Dificilmente ocorre para o orador não-teórico de que em algum lugar pode ser encontrada uma "coisa" esperando para ser chamada de "estrutura" que realmente confina os movimentos das pessoas (lembrem-se dos esforços árduos de Durkheim para convencer seus leitores, contra todos os seus hábitos de leitura, de que normas morais podiam e deviam ser tratadas como coisas; e pensem na experiência de nosso ritual anual de vender esta ideia para nossos alunos de primeiro ano).

A forma substantiva em que a ideia de "estrutura" é expressa não implica necessariamente num compromisso com o determinismo; nem na negação do caráter processual ou reprodutivo da diferenciação social. Tanto o compromisso quanto a negação são "preços adicionados" à ideia de estrutura no estágio da explicação e modelação teórica. Por si mesmo, "estrutura" conota meramente a regularidade através da qual a alocação de posições e ações sociais tende a se reproduzir no tempo. Este significado elementar de "estrutura" foi purificado de distorções teóricas e trazido 
novamente ao primeiro plano quando Giddens propôs encapsulá-lo no conceito de estruturação.

Mas Giddens fez mais que isto. Ao remover do conceito de estrutura seu conteúdo elementar, para o qual um termo novo foi criado, ele deixou o conceito antigo denotando apenas a casca teórica: exatamente a coisa que causou nosso descontentamento com a ideia de estrutura usada e abusada na prática teórica. Eu temo que - ao contrário das intenções de Giddens - um conceito de estrutura tão "purificado" assim estará ainda mais exposto, em vez de menos, aos perigos de se tornar o "apoio metafísico" da nova teoria social "orientada hermeneuticamente". Ele pode se oferecer, ainda mais do que antes, como o "determinante" necessário para todos aqueles que gostariam de perguntar e responder a pergunta de por que as pessoas agem como agem, e o fazem tão teimosamente. Além do mais, depois de separado do mecanismo e do processo de estruturação, a "estrutura" parece mais do que nunca ser um nome para uma "força externa", um pré-requisito indispensável para todas as ações e que não pode ser afetado por nenhuma ação.

Portanto, eu não acredito que a dualidade nociva da ação e seus determinantes externos foi realmente superada pela conceitualização que Giddens propõe. Ela talvez até tenha sido reafirmada e rearticulada; num certo sentido, até reforçada - através da transformação de uma confusão interna dentro do conceito de estrutura numa oposição aberta de dois conceitos separados.

Em sua tentativa de reconceitualizar a investigação sociológica, Norbert Elias foi movido, assim como Anthony Giddens, pelo abuso teórico do conceito de estrutura que, na opinião de Elias, havia sido pervertido além de qualquer reparo. A cunhagem de "figuração" foi, de certo modo, uma tentativa de escapar dos usos irremediavelmente distorcidos de um termo desacreditado para recuperar seu conteúdo puro e ainda válido. Entretanto, o que Elias supôs era que para fazer isto não era o bastante substituir os termos antigos, emaranhados demais em interpretações impróprias para serem salvos, por termos novos e recém-definidos. Para restaurar a intuição elementar encapsulada na ideia de estrutura como a regularidade da interação social, também é necessário dispensar a "ação social" (quase por definição, mas certamente por implicação, significando "ação individual") como a peça central da teoria social. Quando a ação social é mantida como a "unidade básica" do modelo sociológico, como a "coisa a ser 
explicada", o resto se segue inexoravelmente. Afinal, ninguém conseguiu desafiar com sucesso a precisão da alegação de Parsons de que a oposição entre personalidade, cultura e sociedade, assim como a oposição entre "o ator" e "o sistema", estão irremovivelmente contidas na essência da "ação social". De fato, a análise fenomenológica pode mostrar que eles são apodicticamente necessários. Parece que Elias concluiu que continuar a construir uma teoria a partir e em torno do conceito de ação social e torcer que seria possível escapar dos "erros" de nossos predecessores é fútil. Daí não apenas a recuperação da ideia original de estrutura (com sua Aufhebung das oposições entre continuidade e mudança, ação e sistema, voluntarismo e determinação), não apenas a encapsulação desta ideia do caráter “estruturado" da interação social em um termo novo, livre de usos impróprios, mas também a substituição da ação social por esta ideia como o eixo da teorização sociológica.

O resultado é uma "sociologia figuracional" em vez de uma versão corrigida da “teoria da ação social”. Aparentemente, Elias não acreditava que esta pudesse ser retificada, pois a própria ação social é um começo falso para a teoria social. Podemos dizer que a "figuração" de Elias difere da "ação social" tanto quanto o "Dasein" de Heidegger diferia da "subjetividade transcendental" de Husserl, evitando assim a tarefa irrealizável de gerar um "mundo intersubjetivo". A realidade social a partir da qual Elias começa sua teorização é, ursprünglich ${ }^{14}$, de interdependências, e por isso provê a substância da diferencialidade regular das ações e suas consequências. A mensagem contida nesta escolha é que não podemos conceber a realidade social como algo receptivo à teorização fora de algo já "estruturado". A ideia de um ator social pronto para agir mas que precisa de normas e recursos para fazê-lo é tão ridícula quanto a ideia do sistema precisar de "pré-requisitos funcionais" para continuar a existir. Diferente de "ação" ou "sistema", "figuração" é uma entidade fenomenologicamente sustentada e explicada por si mesma, e por isso não tem necessidades nem pré-requisitos. Portanto, ela é imune à hipóstase.

Ao promover a ideia de estruturação, Giddens pretendia realizar, para a compreensão da ação social, o mesmo ato de emancipação que Espinosa realizou em relação a nosso tratamento da natureza, quando ele proclamou que Natura era tanto naturans quanto naturata. Entretanto, o que foi deixado na sombra é a circunstância de que os dois aspectos da "estruturação" - "estruturar" e "ser estruturado" - são, da

\footnotetext{
14 "Originalmente" (N.T.)
} 
perspectiva dos atores, distribuídos desigualmente. Alguns estão numa posição de "estruturar" mais do que de "ser estruturados"; outros, ao contrário, têm mais chance de "ser estruturados" do que de "estruturar". Este aspecto crucialmente importante da realidade social foi bem incorporado no conceito de "figuração", e recebeu um papel fundamental. Ele não pode ser bem assimilado na ideia de ação social quando esta é tratada num nível de generalidade semelhante ao notório "homem enquanto tal", "homem enquanto espécie", etc. Portanto, ao contrário da intenção original, uma teoria social que começa da ideia da ação confrontando a tarefa da estruturação, em vez do reconhecimento de um-mundo-já-estruturado, inevitavelmente gerará a necessidade de algum "apoio metafísico" para explicar a distribuição desigual de probabilidades empiricamente evidente.

\section{Sobre "hermenêtica dupla"}

Seguindo Winch, Giddens introduz a ideia de "hermenêutica dupla" no contexto da relação entre o vernáculo de membros leigos da sociedade e a linguagem técnica criada artificialmente e empregada pelos cientistas. O contexto, e as preocupações que ele tende a gerar, são peculiares para as ciências sociais, pois os objetos dos cientistas naturais não têm um equivalente na linguagem ordinária, e por isso a linguagem artificial da ciência é a única linguagem que os cientistas interpretam e entendem.

Portanto, a hermenêutica dupla foi legitimada em termos dos assuntos implicados na comunicação interlinguística, ou a tradutibilidade mútua, das duas linguagens. Como ambas são linguagens, a tarefa de tradução parece ser trivial. Como em todos os casos semelhantes, precisamos de dicionários, regras de correspondência, algum conhecimento de expressões idiomáticas, etc. Entretanto, isto por si só não sustenta a ideia da hermenêutica dupla. Suspeitamos que a necessidade da hermenêutica dupla está apenas aparentemente enraizada na mera necessidade de tradução. Há algo a mais envolvido. Parece que as preocupações da hermenêutica dupla são derivadas não tanto das preocupações ordinárias da tradução, e sim da tentativa de justificar uma intenção excepcional de obter regras de tradução que, por sua natureza, são aplicáveis através de apenas uma forma. Ou, para falar de modo mais geral, elas são derivadas do conflito sobre a autoridade para declarar a justeza da tradução. 
As formulações de Giddens não deixam esta verdade aparente. A controvérsia que esperamos que a hermenêutica dupla resolva foi apresentada como uma controvérsia sobre quem deve entender o quê, em vez de sobre quem tem a autoridade de declarar a precisão da tradução. Giddens não concorda com o preceito de Schutz de que os conceitos das ciências sociais, para serem adequados, precisam "ser entendidos pelos próprios atores em termos de seus próprios conceitos”. Em sua réplica, Giddens adota a posição de que a condição da adequação de conceitos das ciências sociais não é que os atores cuja conduta está sendo descrita devam ser "capazes de compreendê-los". Isto, entretanto, não abrange totalmente a ideia de Schutz. Ou, melhor, a réplica de Giddens implica uma interpretação um tanto limitada do preceito de Schutz. O problema, da forma em que Giddens parece articulá-lo, é um problema de conhecimento ou ignorância de uma linguagem; se uma competição por direitos está envolvida, ela é apenas um conflito sobre o direito do cientista social de empregar uma linguagem técnica que não foi dominada pelos objetos do estudo social-científico. Além do mais, não fica claro no argumento de Giddens que propósito útil teria o domínio eventual desta linguagem pelos objetos de estudo - já que a adequação da hermenêutica socialcientífica depende, de acordo com Giddens, apenas de "que o cientista social observador entenda com precisão os conceitos através dos quais a conduta dos atores é orientada". Mas esta resposta atenua outro postulado, mais perturbador, potencialmente contido no princípio de Schutz, e relacionado a um assunto que Giddens não enfrenta: quem é que julga a "precisão" do entendimento?

Duas questões diferentes residem lado a lado no postulado de Schutz. Uma é a questão do direito do cientista social de desenvolver e empregar sua própria linguagem, e assim expressar suas observações e interpretações num vocabulário diferente daquele usado pelos objetos destas observações para explicar e interpretar suas ações. Outra é a questão da autoridade do cientista social para imputar (em qualquer linguagem) aos atores motivos e orientações que eles não reconheceriam como seus. A primeira é a questão da forma linguística. A segunda é a questão dos conteúdos que uma ou outra linguagem exprime em formas mutuamente traduzíveis. Giddens toma uma posição na primeira questão. Mas ele ignora a segunda. Além do mais, ele apresenta suas opiniões de uma forma que se abre à seguinte interpretação: ele implica que o reconhecimento do direito do cientista social questionado na primeira questão (algo facilmente concedido) 
concede automaticamente a autoridade questionada na segunda (algo que requer um argumento muito mais complexo, quando enfrentado à queima-roupa).

A segunda questão, por sua vez, é uma mistura de dois problemas distintos, em grande parte autônomos, e que requerem um argumento separado. O primeiro problema é o da necessidade, desejabilidade ou simples relevância do consenso entre cientistas sociais e seus objetos. A negociação das descobertas é uma parte integral de sua verificação? O processo de descoberta da verdade está completamente contido no estudo do cientista social? O cientista social tem a palavra final (e a única palavra relevante) na decisão da adequação de sua descrição? O segundo problema é a velha questão do significado da hermenêutica quando voltada à vida social: o que deve ser entendido? Em termos do quê deve o cientista social interpretar a conduta de seus objetos? Consequentemente, o que deve ser negociado com os objetos no curso da verificação de suas descobertas, se é que algo deve ser negociado?

Como sabemos muito bem, o segundo problema tem uma história tão longa quanto a da própria sociologia. Por muitas décadas ele foi discutido em termos da oposição entre "explicação" e "compreensão". Weber e seus discípulos se puseram a transcender esta oposição assimilando a tarefa da explicação à da compreensão e provando que a compreensão é a forma científica de explicar fenômenos sociais. Foi Weber que cunhou a frase "compreensão explicativa", que deveria casar de uma vez por todas a tarefa da explicação na ciência social com a do estudo e reprodução dos motivos dos atores. Entretanto, se tomado literalmente, isto chegava perigosamente próximo da delegação aos próprios atores da autoridade suprema e final sobre a descrição de suas ações, e do enfraquecimento da autoridade do cientista social. O perigo foi afastado desde o começo através do estratagema de "motivos inconscientes" (de forma muito semelhante a "5 horas no Sol", como zombaria Wittgenstein). A posição ameaçada do cientista social fora reforçada pela afirmação que "na grande maioria dos casos a ação real ocorre num estado de semiconsciência desarticulada ou inconsciência real de seu sentido subjetivo" 15 . Portanto, o motivo (da ação do ator) podia ser definido como "um complexo de sentido subjetivo que parece para o próprio ator ou para o observador uma base adequada para a conduta em questão" ${ }^{\text {16 }}$. Ostensivamente, tal definição coloca o ator e seu observador em posições iguais: sua explicação é tão boa quanto a minha.

\footnotetext{
${ }^{15}$ Weber [1964].

${ }^{16}$ Weber [1964:98-99, ênfase minha].
} 
Mas, para que isto não coloque a análise social no apuro da inconclusividade perpétua, esta igualdade é imediatamente qualificada: "a tarefa de um sociólogo é" "descrever e analisar" os motivos mesmo que eles realmente não tenham sido "concretamente parte da 'intenção' consciente do ator" ${ }^{\prime 1}$. Com um golpe de mestre, livramo-nos de duas preocupações: a ameaça à autoridade do cientista social de julgar na questão da “compreensão verdadeira", e a ameaça a seu estatuto científico contida na ideia da compreensão como uma experiência congenial dos pensamentos e sentimentos de outra pessoa. Entretanto, o preço desta realização notável foi a abertura da questão persistente da imputação, e, portanto, mais uma vez em outro nível, do velho problema do papel do ator na negociação da verdade sobre suas ações. A única forma de sair do novo dilema era aceitar uma teoria quase-psicanalítica do comportamento humano. Weber o fez, até certo ponto, intuitivamente. Habermas meramente a explicou detalhadamente e assim expôs a prática da sociologia pós-weberiana à crítica. Apesar da crítica, a prática parece inevitável enquanto a imputação for vista como o método da sociologia compreensiva; vejam as "fontes inconscientes da conduta" de Giddens. Desistir da teoria psicanalítica seria investir os objetos da investigação sociológica, e não os sujeitos, do controle final sobre a verdade - precisamente o efeito que tornou Thomas ("definição da situação"), Znaniecki ("coeficiente humanístico") ou Winch inaceitáveis como fundamentações da ciência social.

Toda a questão da legitimidade e da validade da imputação se torna um problema quando a compreensão que a sociologia consegue obter é interpretada como a reconstrução (ou construção) dos motivos e orientações dos atores. Normalmente, a prática da imputação se torna imune a questionamentos através do expediente de redefinir os motivos e orientações em questão como construtos das operações analíticas do cientista social, relacionados apenas hipoteticamente às verdadeiras molas da ação descrita. Tais motivos e orientações são fundamentados apenas na teoria e metodologia do analista, e portanto seu reconhecimento pelos atores é irrelevante para o sucesso da atividade. O problema é que tais "motivos" são realmente como "5 horas no Sol". Uma concha verbal, esvaziada de seu significado original, foi mantida provavelmente para tranquilizar o analista de que sua sociologia ainda é "orientada subjetivamente". Aquilo que agora é uma ilusão se apoia apenas em associações verbais ostensivas - já que a

\footnotetext{
${ }^{17}$ Weber [1964:97].
} 
intenção original de esquadrinhar a experiência dos atores sociais foi abandonada, para todos os efeitos práticos.

Este dilema pode ser traçado, em última instância, ao "pecado original" de selecionar a ação social como a unidade básica da análise sociológica. Para compreender a ação, realmente é preciso se referir a motivos, reais ou construídos, e todos os problemas listados acima se seguem imediatamente. Talvez a ação social seja o local errado para construirmos a sociologia como uma atividade válida? Nós já conhecemos os defeitos estruturais impertinentes de tal edifício, e há uma experiência grande o suficiente para sugerir que estes defeitos têm algo a ver com a qualidade do local, e que provavelmente nenhuma habilidade de um construtor futuro será capaz de impedir que eles reapareçam.

Eu gostaria de sugerir, mais uma vez, que a "figuração" pode muito bem se mostrar um local alternativo e confiável. O domínio apropriado que o cientista social deve compreender é a rede de dependências nas quais os atores estão emaranhados e que estabelecem os parâmetros do que quer que os atores possam fazer e do que quer que seja provável que eles façam. A rede complexa de dependências entrecruzadas não é, e não pode ser, vista do ponto de vista da experiência do ator individual. Não é provável que o ator a explore sem auxílio. Mas o ator precisa de tal exploração; suas descobertas não apenas ofereceriam a ele uma "versão melhorada" daquilo que ele supostamente já sabe, ou seria capaz de saber, mas também genuinamente ampliariam sua compreensão (quem sabe? Talvez até o domínio) de seu apuro. Ao estudar a figuração da qual o ator faz parte, o cientista social pode falar ao ator sobre não apenas aquilo que era conhecível mas estava desconhecido, mas sobre o que estava, sob as circunstâncias, além de seu controle, quer fosse conhecido ou não.

O primeiro de nossos dois problemas (a negociação das descobertas é uma parte integral de sua verificação?) aparece neste caso sob uma nova luz. Advertências do tipo "a adequação da descrição não depende do reconhecimento dos atores" repentinamente se tornam redundantes, pois não há motivo para supor algo diferente. A autoridade do cientista social não está em questão nem precisa ser defendida por postulados arbitrários ou analogias exageradas. E quanto à descrição, é a tarefa do cientista social, e apenas do cientista social, testar e verificar a estrutura e o mecanismo da figuração. 
Sem negociação da verdade, então? Não, desde que o trabalho pare na descrição. Entretanto, inevitavelmente, quando o cientista social consegue demonstrar a autossuficiência da figuração, o fato de que ela não precisa de nenhuma base além de sua própria presença, surge a possibilidade de que a figuração em questão pode ser diferente daquilo que é. O que se abre então é o reino do possível, o território explorado pela sociologia crítica. Suas proposições têm modalidade epistemológica diferente. Elas estão relacionadas à verdade não através do processo de verificação, mas através da prática da autenticação. É em tal prática que o diálogo entre o cientista social e seus objetos se torna uma parte integral do esforço para estabelecer a verdade. Mas as proposições sujeitas a tal negociação e que podem provar sua verdade apenas através dela não se preocupam com a forma da figuração como ela foi ou é, mas com o grau de sua solidez, e portanto com a possibilidade do rebaralhamento das probabilidades atuais da ação social ${ }^{18}$.

\section{"Teoria social instruída hermeneuticamente" na perspectiva sociológica}

O estado de um diálogo com seu objeto - a sociedade - é, para a sociologia, uma questão metodológica fundamental. Mas ele também é seu modo de existência enquanto uma formação discursiva.

$\mathrm{Eu}$ acho que uma característica muito distintiva da sociologia como um "desenho de superfície" contínuo e uma atividade "delineadora de problemas" é que ela é uma formação discursiva sans frontières. A promoção de Giddens da "hermenêutica dupla" é, afinal, um chamado para maior autoconsciência do que um postulado para reformar o engajamento da sociologia com seu objeto. Não faria muito sentido aconselhar, digamos, um bioquímico a embarcar num exercício de hermenêutica dupla. Endereçado para um sociólogo, o preceito significa, essencialmente, apenas "conheça-se a si mesmo".

A formação discursiva chamada de sociologia não tem nenhuma fronteira claramente definida ou bem desenhada pela razão simples que o campo de fenômenos que constitui o objeto da interpretação sociológica não está sob o controle dos sociólogos. Os eventos que o sociólogo considera sua tarefa interpretar estão, como um

\footnotetext{
${ }^{18}$ Cf. Kilminster [1979:268-269].
} 
todo, disponíveis para observação geral e portanto abertos a muitos intérpretes; e estes intérpretes também não estão mutuamente limitados por uma estrutura de autoridade conjunta, ou sujeitos a um código normativo conjunto que legitima os "lugares" de onde se pode falar com autoridade. Não há, então, nenhuma base a priori para a superioridade da interpretação sociológica sobre a "leiga". Uma das consequências desta situação incomum da sociologia é a atenção igualmente incomum que os sociólogos dão para a "cientificidade" de seus métodos; afinal, na sociologia os métodos precisam carregar o peso carregado facilmente em outras disciplinas pelo monopólio do controle. Entretanto, este não é um tópico que podemos ou devemos desenvolver no contexto atual. Outra consequência da abertura da sociologia enquanto, por assim dizer, uma formação discursiva incompleta (subestruturada?) é muito mais relevante para a questão presente: a falta de controle endêmica dos sociólogos sobre o assunto de sua própria disciplina.

Não são os sociólogos que estabelecem a agenda para sua discussão. Tendo em vista que o objeto de sua interpretação já está saturado com significados "leigos" (de fato, ele é, em última análise, um arranjo de significados leigos), a liberdade de interpretação dos sociólogos é limitada severamente desde o começo. Os sociólogos devem fornecer uma interpretação significativa daquilo que já é significativo; e sua interpretação precisa ser reconhecível enquanto tal - quer dizer, permanecer mutuamente "traduzível" com as interpretações leigas. E mais, os sociólogos não recebem, pelo menos a longo prazo, o direito de decidir unilateralmente sobre as regras de tradutibilidade. Se alguns usurpam tal direito, eles o fazem por sua própria conta e risco. Cedo ou tarde eles são relegados a uma posição de marginalidade, proclamados um "consenso ortodoxo" e finalmente substituídos por um novo conjunto de interpretações melhor sintonizado com a autoconsciência variável do mundo leigo.

Desde seu início, os produtos da hermenêutica sociológica continham marcas inconfundíveis das interpretações leigas introduzidas na realidade social que eles deveriam interpretar. Os produtos diferiam uns dos outros (como várias marcas diferentes de pasta de dente, com o objetivo de lidar com o problema definido como “apodrecimento dos dentes"), mas, para cada estágio na história da sociologia, não havia muita dúvida sobre o que tinha que ser interpretado. Os temas da investigação sociológica eram, e ainda são, e provavelmente sempre serão, determinados pela forma em que aqueles que têm poder para fazer isto definem o significado da realidade social. 
Os temas que ocuparam as mentes dos "pais fundadores" da sociologia foram ditados pela autoconsciência do século XIX. Nomeemos alguns deles.

Primeiro, a direção em que o mundo se desenvolverá fora estabelecida e, a princípio, não é mais uma questão de acidente ou conjetura. Esta direção, de modo geral, vai no sentido de uma sociedade em que os processos de trabalho estão sujeitos ao critério de uma eficiência cada vez maior, e, portanto, baseados numa divisão detalhada de tarefas e uma proficiência melhorada em sua realização.

Segundo, de forma paralela e relacionada à anterior, haverá uma sincronização crescente entre as necessidades que surgem da administração eficiente da sociedade como um todo e as molas da ação individual. Com o progresso geral em direção à racionalidade, os atores cada vez mais preferirão um comportamento eficiente e efetivo em vez de uma conduta induzida por um conhecimento inadequado ou informações errôneas.

Terceiro, ambos estes desenvolvimentos prepararão o palco para uma congruência crescente entre a modalidade da realidade social (tanto no nível social quanto individual) e a da ciência. Quando a ação social se torna cada vez mais uma aplicação da razão à administração de assuntos sociais, ela precisa de perícia científica; e a ciência, exclusivamente equipada como ela é para testar e medir a relação entre meios e fins, causas e efeitos, tornará a sociedade cada vez mais "transparente" e desmistificada.

Estas três crenças se combinaram numa visão de um mundo sólido e confiável que - para lembrar a opinião confiante de Marx - não colocará em sua agenda problemas que ainda não for capaz de resolver. Incluída nesta visão estava uma sociedade que cada vez mais se tornará um objeto de administração inteligente. Mesmo que o termo ainda não fosse de uso geral, a ideia de "engenharia social" era uma fonte inconteste de legitimidade do trabalho social-científico. Projetada sobre a visão de mundo compartilhada, a ideia parecia garantir a congruência da ciência social racional com o processo histórico levando a uma sociedade cada vez mais racional povoada de atores cada vez mais racionais. A própria ciência social parecia uma unidade de reconhecimento de coisas por vir. 
Nenhuma destas crenças é particularmente popular hoje. Seu descrédito foi causado apenas parcialmente por mudanças na moda intelectual. Há outras razões mais sérias. Algumas delas foram capturadas em suas manifestações, mesmo que não em suas raízes, por autores tão diversos quanto Sennett, Carroll ou Lasch: a ascensão da "era mim", o recuo da arena pública, a obsessão com a intimidade, a absorção na cultivação do eu junto com uma ansiedade crescente quanto à sua identidade; as profundezas arcanas do eu, e não o palco público, parecem ser agora o local verdadeiro da realidade humana. Outras razões foram enunciadas por Habermas e Offe: o desaparecimento do princípio da realização (o principal dispositivo que ligava a racionalidade individual e social), ou, de forma mais geral, a crise da legitimação. Ainda outros estão ligados à mudança do equilíbrio de poder mundial, a erosão da superioridade do ocidente, e a diversificação cada vez mais evidente de tendências de desenvolvimento. Finalmente, há um desencantamento crescente com a benignidade pastoral do Estado, com a velha utopia da sociedade protetora se transformando numa distopia do estado ubiquamente opressor, enquanto o indivíduo se sente cada vez mais vigiado, testado, avaliado, gravado, disciplinado e comandado por forças que ele não controla e só compreende vagamente. Além disso, a mensagem das novas mídias visuais, que tudo penetra, ajudou a dissolver o imaginário do público e do supraindividual na experiência familiar do pessoal e subjetivo.

Se o mundo dos pais fundadores - tanto em sua estrutura de potências reais e suas articulações intelectuais - se baseava na superioridade-cum-confiança do ocidente, nosso mundo está rapidamente se aproximando de uma nova congruência "infra/superestrutura" quando a superioridade desmoronante de uma civilização particular passa a ser refletida no derretimento de sua autoconfiança. Para lembrarmos das divagações do Marx adolescente, mais uma vez - como mariposas - buscamos a luz da lâmpada doméstica quando está escuro lá fora. Enquanto a esperança e o desejo da mistura perfeita de racionalidade social e felicidade individual se desvanecem, buscamos no eu o baluarte contra a desarmonia que se aproxima. Torcemos mais uma vez para que muitas lâmpadas domésticas de alguma forma clareiem a escuridão assustadora do outro lado da janela.

É neste novo mundo que as ciências sociais precisam redefinir seu papel. A percepção crescente de que o papel tacitamente (e confortavelmente) assumido no passado não era mais viável, e a pressa resultante em encontrar uma nova raison d'être 
das ciências sociais, provavelmente será vista por historiadores futuros como a principal causa da orgia recente de autoflagelação sociológica e a proliferação de fórmulas escatológicas. No passado, o direito da sociologia de falar com autoridade foi tecido num mundo sólido com uma história conclusiva e um futuro sem ambiguidades. Tal direito era a prerrogativa dos sociólogos enquanto legisladores ou comentadores peritos sobre a atividade dos legisladores. Mas isto não serve mais em nosso mundo, que não pode se gabar nem de um passado conclusivo nem de um futuro claro; acima de tudo, este mundo não parece mais sólido, quando a hierarquia fantástica da superioridade foi deslocada pela multidão de autoridades em conflito num ambiente cada vez mais policêntrico. Em tal mundo, as tarefas da comunicação parecem muito mais atuais e imperativas do que as da administração; e o papel de intérpretes muito mais realista e urgentemente necessário do que o de legisladores.

Daí a popularidade crescente das muitas variedades de "sociologia interpretativa" inspiradas hermeneuticamente (bem representadas por instâncias tão diferentes, em outros aspectos, como a etnometodologia ou a "descrição densa" de Geertz), e o interesse súbito por Verstehen. O respeito anteriormente depositado no "sistema" agora é cada vez mais realocado para o ator. São os atores que, esperamos, fornecem as poucas rochas sólidas no mar de totalidades flutuantes; é nestas rochas que muitos sociólogos hoje em dia querem construir sua segunda igreja.

A crise recente da sociologia foi, antes de qualquer outra coisa, uma crise da autoridade da sociologia (isto não era realmente visível do ponto de vista de um país onde tal autoridade jamais fora verdadeiramente estabelecida). A legitimação do direito da sociologia de falar com autoridade para um mundo em transformação, e dentro desse mundo, ocupou a maior parte do tempo e dos esforços dos teóricos. Não surpreende que a maioria dos teóricos não tenha se preocupado com uma grande revisão da substância da teoria social, confinando-se a um balanço sucessivo do pêndulo dentro do esquema tradicional do discurso sociológico. Uma mudança verdadeiramente radical ocorreu apenas na fonte de autoridade citada: aqui a hermenêutica substituiu as leis naturais.

A preocupação com o direito de falar com autoridade é um artefato da vida acadêmica. Ela surge da necessidade de justificar o lugar da sociologia entre disciplinas acadêmicas melhor estabelecidas. Daí a quantidade notável de tempo que novas áreas acadêmicas de estudo de proveniência um tanto incerta (ou seja, áreas que ainda não se 
“desprenderam" claramente da colmeia antiga) dedicam à questão da "cientificidade" de seus métodos (ou seja, as razões pelas quais suas atividades devem ser reconhecidas pelas disciplinas com um estatuto incontestado como pertencentes ao mesmo tipo delas). Daí também por que a questão da confiabilidade e validade do trabalho sociológico teve um lugar privilegiado no pensamento e nos textos dos professores Durkheim ou Weber. Afinal, a questão ocupou muito menos espaço nos escritos de Marx ou Simmel - isto foi posteriormente visto por seus leitores melhor situados academicamente como um caso lamentável de negligência metodológica.

Giddens é muito menos culpado do que a maioria deste "viés sindicalista" da teorização social atual. Ele, diferente de muitos outros teóricos, está engajado numa análise profunda da sociedade moderna e na reavaliação de sua história sob a luz de tendências reveladas até o momento. Este outro aspecto da obra de Giddens eu valorizo bastante, e considero um dos desenvolvimentos mais fundamentais da sociologia contemporânea; mas ele não é o tópico deste capítulo. Aqui, estou preocupado com Giddens enquanto teórico, o papel em que seu impacto na sociologia britânica e internacional foi, pelo menos até agora, sentido mais fortemente. E enquanto um teórico, Giddens não se desvia, ou não se desvia visivelmente o bastante, da tendência atual. A mensagem que os escritos teóricos de Giddens transmite é que na sociologia a teoria é, acima de tudo, a teoria da "cientificidade da sociologia"; e que a estrada real para sair da crise atual passa pela concepção e adoção de métodos corretos que podem estabelecer as credenciais relevantes da atividade sociológica para o papel que ela busca atualmente; o que precisamos, em outras palavras, é de um conjunto de "novas regras do método sociológico".

Entretanto, mais uma vez, regras de método são uma questão interna da sociologia, parte de sua retórica de poder e de um discurso de incentivo virado sobre si mesmo; acima de tudo, esta retórica é uma manifestação de uma crise de confiança causada pela incerteza em relação à substância do projeto sociológico. "Regras de método" nos dizem pouco sobre o assunto da sociologia; além do mais, elas não contêm de forma alguma uma garantia de que a sociologia teria algo válido e relevante a dizer sobre este assunto. Uma teoria que estabelecerá de vez, ou não, a relevância da sociologia no mundo contemporâneo precisa ser uma teoria da sociedade contemporânea, e não uma teoria contemporânea da sociologia. 
O tópico da teorização em geral, e em particular a forma de distribuição de prioridades no projeto teórico, reflete o diagnóstico das raízes da fraqueza atual da prática sociológica. Eu desejo propor que estas raízes não estão nas ambições "naturalcientíficas" obsoletas, no funcionalismo estrutural datado, na hipóstase da estrutura ou no desprezo da hermenêutica. Eu desejo propor que estas raízes estão, em vez disso, no fracasso da sociologia em lidar com o que é realmente novo na sociedade de hoje em dia, e sua tendência persistente em barrar a compreensão de fenômenos contemporâneos ao tentar contê-los numa camisa de força de conceitos tradicionais e que se encaixam cada vez pior.

Se nossa sociologia ainda é "oitocentista", isto não ocorre por causa da crença em um modelo datado de ciência ou da ignorância de ideias filosóficas mais recentes. Isto ocorre, sim, porque o sistema conceitual da sociologia que ainda opera, e quase nunca foi questionado seriamente, foi projetado para lidar com as experiências e expectativas do século passado. A "sociedade" compreendida quase sempre como equivalente ao Estado-nação; a direção da mudança guiada pela "classe histórica"; o conflito entre trabalho/capital coincidente com o problema da divisão do excedente social; a divisão de classes como sinônimo de desigualdade social; o trabalho como o local central da integração e controle social; a política como a manifestação institucionalizada de interesses de sujeitos sociais pré-formados; o poder como uma propriedade que pode ser compartilhada de várias formas; o poder como uma extensão da luta econômica através de meios políticos: estes são apenas alguns exemplos das sabedorias do passado das quais a sociologia atual permanece uma guardiã dedicada. Qualquer um que queira contribuir para a compreensão da sociedade do final do século XX precisaria em primeiro lugar examinar se seria sábio preservar tal sabedoria.

Falando de forma explícita, o ambiente acadêmico da sociologia moderna induz a um esforço para atualizar os métodos de investigação de assuntos cada vez mais datados. Nós realmente fazemos progressos na sofisticação filosófica de nossos métodos de interpretação. Entretanto, com todo este refinamento, ainda temos pouco a dizer sobre a experiência crucial de nosso tempo. Aqui, a maioria dos enunciados sociológicos quase não pode ser distinguida da "opinião pública bem informada". Como o resto de nós, o corpo principal da sociologia reproduz a memória histórica coletiva, para cuja forma os ancestrais da sociologia contemporânea contribuíram de forma fundamental, mas que a sociologia contemporânea não parece mais capaz de revisar. 
Como os generais, a sociologia tende a lutar as batalhas vitoriosas do passado repetidamente.

É por isto que penso que para reivindicar o direito de falar com autoridade a sociologia precisaria atualizar sua teoria da sociedade, e não sua ideia de ação social. Concentremo-nos nesta tarefa central.

\section{Bibliografia}

ELIAS, N. [1978] What Is Sociology? London: Hutchinson.

KILMINSTER, R. [1979] Praxis and Method. London: Routledge

PARSONS, T. [1949] The Structure of Social Action. New York: Free Press.

PARSONS, T. [1951] Social System. New York: Free Press.

WEBER, M. [1964] Theory of Social and Economic Organization. New York: Free Press. 


\section{John B. Thompson - A teoria da estruturação}

O problema da relação entre o indivíduo e a sociedade, ou entre a ação e a estrutura social, está no coração da teoria social e da filosofia da ciência social. Nos escritos da maioria dos principais teóricos, de Marx, Weber e Durkheim a vários autores contemporâneos, este problema é trazido à tona e alegadamente resolvido de uma forma ou de outra. Tais soluções geralmente se resumem à ênfase de um termo às custas do outro: ou a estrutura social é tomada como o principal objeto de análise e o agente é efetivamente eclipsado, como no marxismo de Althusser, ou os indivíduos são considerados os únicos constituintes do mundo social e suas ações e reações, suas razões, motivos e crenças, são os únicos ingredientes da explicação social. Em ambos os casos, o problema não é exatamente resolvido, e sim dissolvido, quer dizer, liquidado sob uma plataforma filosófica e metodológica que já está localizada em um dos campos. Poucas questões na teoria social permanecem tão refratárias a uma análise cogente do que a questão de como, e precisamente em que formas, a ação de agentes individuais está relacionada às características estruturais das sociedades das quais eles fazem parte.

Nos últimos anos, vários autores enfrentaram diretamente o problema da relação entre a ação e a estrutura social e tentaram lidar com ele de forma construtiva e sistemática $^{1}$. A mudança de uma perspectiva estática para uma dinâmica é essencial para estas tentativas, de uma teoria da estrutura para uma teoria da estruturação. O que deve ser compreendido não é como a estrutura determina a ação ou como uma combinação de ações forma a estrutura, mas sim como a ação é estruturada em contextos cotidianos e como as características estruturadas da ação são, através da própria execução de uma ação, desta forma reproduzidas. A teoria da estruturação é assim inseparável de uma descrição da reprodução social, ou seja, de uma descrição das formas pelas quais sociedades, ou formas específicas de organização social, são reproduzidas pelas atividades de indivíduos levando suas vidas cotidianas. A teoria da estruturação também está ligada, de forma fundamental, a outros aspectos da análise social. Pois uma caracterização adequada da relação entre ação e estrutura social forneceria um esquema dentro do qual outras preocupações, como a análise do poder e da ideologia, poderiam ser remodeladas.

\footnotetext{
${ }^{1}$ Além dos escritos de Anthony Giddens (citados na nota 3), ver Bourdieu [1977; 1980] e Bhaskar [1979].
} 
Meu objetivo neste capítulo é examinar algumas das reivindicações e prospectos da teoria da estruturação ${ }^{2}$. Eu o farei focando a contribuição de seu principal expoente, Anthony Giddens. Numa série de publicações que se estende por quase uma década ${ }^{3}$, Giddens elaborou uma formulação altamente original da teoria da estruturação, uma formulação de detalhes muito mais sofisticados e de aplicação muito mais sugestiva do que qualquer uma das outras versões encontradas atualmente na literatura. A primeira seção deste capítulo apresentará uma breve visão geral dos elementos básicos da teoria de Giddens. Entretanto, para oferecer uma avaliação rigorosa desta teoria, é preciso retraçar um desenvolvimento particular na obra de Giddens. Pois apesar da concepção de estrutura apresentada originalmente nas Novas regras do método sociológico ser preservada a princípio em seus escritos mais recentes, esta concepção é suplementada na prática por uma descrição muito mais ramificada das características estruturais das sociedades. Portanto, eu começarei minha avaliação crítica focando a formulação original e argumentando que ela é deficiente em certos aspectos-chave. Então apresentarei a descrição mais ramificada e tentarei mostrar que ela tem sucesso apenas parcial na superação das deficiências da formulação original. Na seção final eu focarei na análise de Giddens sobre a ação, sugerindo que esta análise não consegue fazer justiça ao papel da coerção estrutural. Entre estes comentários críticos, eu apontarei algumas das formas através das quais a teoria da estruturação deveria, creio eu, ser desenvolvida e refinada. Pois minha opinião é que, apesar dos detalhes da exposição de Giddens poderem ser insuficientes, seus objetivos gerais são perfeitamente sólidos: o dualismo entre ação e estrutura precisa abrir caminho para o estudo sistemático de processos de estruturação e reprodução social.

\section{Esboço da teoria}

Começarei esboçando os temas centrais do relato de Giddens. Este relato é formulado com a ideia de se basear nas forças e evitar as fraquezas de certas orientações teóricas das ciências sociais. O funcionalismo enfatizou corretamente as características institucionais do mundo social, e focou sua atenção nas formas pelas quais as

\footnotetext{
${ }^{2}$ Este capítulo desenvolve observações feitas inicialmente em Thompson [1981:143-149, 173-178; 1984a:543-551]. Eu agradeço Michelle Stanworth por seus comentários úteis sobre um rascunho anterior do artigo.

${ }^{3}$ As publicações de Anthony Giddens mais relevantes para este ensaio são as seguintes: Giddens [1976; $1977 ; 1979 ; 1981 ; 1984]$
} 
consequências não-intencionais da ação servem para manter relações sociais existentes. Abordagens estruturalistas e "pós-estruturalistas" desenvolveram concepções novas de estrutura, de processos estruturantes e do sujeito, concepções que foram aplicadas com eficácia especial à análise de textos e objetos culturais. Mas o que falta ao funcionalismo e ao estruturalismo, apesar de muita discussão do "esquema de referência da ação" e da "teoria do sujeito", é uma descrição adequada da ação e da agência. Estas têm sido preocupações principais da "filosofia analítica" durante as duas últimas décadas, e também das "sociologias interpretativas" influenciadas por Husserl, Wittgenstein e outros. De várias formas, estes filósofos e sociólogos retrataram indivíduos como agentes competentes que sabem muito sobre o mundo social, que agem com propósito e reflexão e que podem, se questionados, fornecer razões para o que fizeram. Mas onde o funcionalismo e o estruturalismo são fortes, a filosofia analítica e a sociologia interpretativa são fracas, pois eles negligenciam de modo geral problemas de análise institucional e estrutural.

Giddens busca se mover para além destas várias orientações, repensando as noções de ação e estrutura e as relações entre elas. Em vez de enxergar a ação e a estrutura como os elementos contrapostos de um dualismo, devemos vê-los como os termos complementares de uma dualidade, a "dualidade da estrutura". "Com a dualidade da estrutura", escreve Giddens, "quero dizer que estruturas sociais são constituídas pela ação humana, e ao mesmo tempo são o próprio meio desta constituição"4 . Todo ato de produção é ao mesmo tempo um ato de reprodução: as estruturas que tornam uma ação possível são, na realização desta ação, reproduzidas. Mesmo uma ação que perturba a ordem social, quebrando convenções ou desafiando hierarquias estabelecidas, é mediada por características estruturais que são reconstituídas pela ação, ainda que de forma modificada. Esta conexão íntima entre produção e reprodução é o que Giddens chama de "caráter recursivo" da vida social. Sua teoria da estruturação é uma tentativa sistemática de desemaranhar as linhas tecidas neste fato aparentemente não problemático.

A ação, de acordo com Giddens, deve ser concebida como um fluxo contínuo de intervenções no mundo que são iniciadas por agentes autônomos. A ação precisa ser diferenciada de "atos", que são segmentos discretos da ação que são cortados do fluxo contínuo por processos explícitos de categorização e descrição. Nem toda ação é

\footnotetext{
${ }^{4}$ Giddens [1976:121].
} 
"propositada", no sentido de ser guiada por propósitos claros que o ator tem em mente; mas a maioria das ações é "proposital" no sentido de ser monitorada por atores que inspecionam continuamente o que estão fazendo, como os outros reagem ao que estão fazendo, e as circunstâncias em que estão fazendo o que fazem. Um aspecto importante desta monitoração reflexiva da ação é a habilidade dos atores de explicar, tanto para si mesmos quanto para outras pessoas, por que agem como agem, dando razões para a sua ação. Giddens repetidamente enfatiza que indivíduos são atores com habilidade cognitiva que são capazes de explicar sua ação: eles não são nem "patetas culturais" nem meros "suportes" de relações sociais, e sim atores hábeis que sabem muito sobre o mundo em que agem. Se a "racionalização da ação" se refere às razões que os agentes oferecem para explicar sua ação, a "motivação da ação" se refere aos motivos ou desejos que a impulsionam. A motivação inconsciente é uma característica crucial da conduta humana, e Giddens traz a bordo, principalmente através de uma avaliação crítica da pretensa "psicologia do eu" de Erikson e Sullivan, um aglomerado de conceitos psicanalíticos. Entretanto, em vez da tríade psicanalítica de eu, super-eu e id, Giddens adere a distinções entre o inconsciente, a consciência prática e a consciência discursiva. Enquanto as duas últimas estão separadas do inconsciente pela barreira da repressão, a fronteira entre a consciência prática e a discursiva é vaga e flutuante. Muito do que os atores sabem sobre o mundo faz parte de sua "consciência prática", no sentido de que isto é conhecido sem ser articulado enquanto tal; mas o fato de que tal conhecimento poderia ser tornado explícito e incorporado na "consciência discursiva" é uma consideração vital que tem consequências importantes para o estatuto da pesquisa nas ciências sociais.

Estes vários aspectos da ação e da agência fazem parte daquilo que Giddens chama de "modelo de estratificação da ação". O modelo pode ser representado como mostrado na figura $1^{5}$.

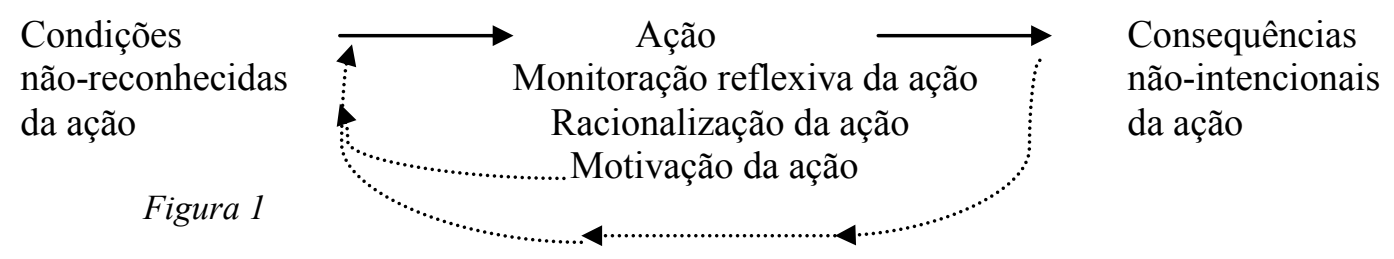

Este modelo ressalta as limitações de qualquer tentativa de analisar a ação focando o ator individual. Pois as descrições que os atores são capazes de dar sobre suas

\footnotetext{
${ }^{5}$ Adaptado de [Giddens 1979:56].
} 
ações são "limitadas", tanto por consequências não-intencionais da ação quanto pelas condições não-reconhecidas da ação (incluindo fontes inconscientes de motivação). A importância das consequências não-intencionais é enfatizada por Merton, que introduz o conceito de "função latente" para mostrar que as práticas podem servir para manter instituições e organizações, sendo este resultado intencionado pelos atores em questão ou não. Giddens rejeita firmemente qualquer sugestão de que tal demonstração explicaria a existência da prática: "não há nada", afirma ele, "que possa valer como uma "explicação funcionalista" "6 . Mas ele quer preservar a ideia de que a ação pode ter consequências não-intencionais que se tornam as condições não-reconhecidas de ações posteriores. Este processo de retroalimentação, na teoria de Giddens, pode ocorrer através de duas formas principais. Consequências não-intencionais podem se tornar condições não-reconhecidas ao serem incorporadas em "círculos causais homeostáticos", como o suposto "ciclo da pobreza" de privação material $\rightarrow$ educação ruim $\rightarrow$ emprego de baixa remuneração $\rightarrow$ privação material. Consequências nãointencionais também podem se tornar condições não-reconhecidas quando a consequência não-intencional da ação é a reprodução da estrutura que torna ações posteriores possíveis. Para esclarecer este último processo, precisamos tratar da discussão de Giddens do conceito de estrutura.

Na literatura sociológica, a "estrutura" muitas vezes é concebida numa forma quase-mecânica, quase visual, como as vigas de um prédio, o esqueleto de um corpo ou o "padrão" de relações sociais. Giddens não repudia completamente esta conotação; como veremos, ele preserva elementos dela em sua noção de "sistema social". Entretanto, ele designa um sentido diferente ao conceito de estrutura. Aqui eu me concentrarei no sentido designado em Novas regras do método sociológico, guardando para mais tarde uma consideração de certas modificações apresentadas em obras subsequentes. Nas Novas regras do método sociológico, Giddens aborda o conceito de estrutura através de uma comparação entre linguagem e fala - "não porque a sociedade é como uma linguagem", ele adiciona apressadamente, “mas, ao contrário, porque a linguagem enquanto uma atividade prática é tão central para a vida social que em alguns aspectos básicos ela pode ser tratada como algo que exemplifica processos sociais em geral"”. Assim, enquanto a fala é espacial e temporalmente situada, pressupondo um

\footnotetext{
${ }^{6}$ Giddens [1981:17].

${ }^{7}$ Giddens [1976:127].
} 
sujeito e também algum outro a quem ela se endereça, a linguagem é "virtual e fora do tempo" e "não tem sujeito", no sentido de que ela nem é o produto de um sujeito particular, nem orientada para qualquer pessoa em particular. Giddens emprega esta comparação para elaborar uma distinção similar entre interação e estrutura na análise social. Enquanto a interação é constituída nas atividades dos agentes, e através delas, a estrutura tem uma "existência virtual": ela consiste de "regras e recursos" que são implementados na interação, que a partir daí estruturam a interação e que são, através deste processo, reproduzidos. Como Giddens explica, “com o termo 'estrutura' eu não me refiro, como é convencional no funcionalismo, à análise descritiva das relações de interação que 'compõem' organizações ou coletividades, mas a sistemas de regras geradoras e recursos" $"$.

Giddens analisa as regras e recursos que abrangem a estrutura em termos de três dimensões ou "modalidades". Estas modalidades são as linhas de mediação entre interação e estrutura, como a figura 2 indica ${ }^{9}$.

\begin{tabular}{|c|c|c|c|}
\hline Interação & Comunicação & Poder & Sanção \\
\hline (Modalidade) & Esquema interpretativo & Recurso $^{10}$ & Norma \\
\hline Estrutura & Significação & Dominação & Legitimação \\
\hline
\end{tabular}

Figura 2

$\mathrm{Na}$ comunicação do significado na interação, os atores utilizam esquemas interpretativos que, no nível da estrutura, podem ser analisados como "regras semânticas”. Quando atores aplicam sanções na interação, eles utilizam normas que, no nível da estrutura, podem ser analisadas (parcialmente) ${ }^{11}$ como "regras morais". O uso do poder na interação envolve a aplicação de recursos [facilities] que permitem que os agentes assegurem resultados específicos; no nível estrutural, estes recursos [facilities] podem ser analisados como "recursos" que compõem estruturas de dominação. Giddens enfatiza que a distinção entre estas três modalidades é mais analítica que substantiva. "Em qualquer situação concreta de interação, os membros da sociedade utilizam estas

\footnotetext{
${ }^{8}$ Giddens [ibid.]

${ }^{9}$ Giddens [1976:122]; modificada de acordo com o diagrama em Giddens [1979:82].

${ }^{10}$ Facilities no original, um conceito diferente de resource, também traduzido como "recurso". Salvo indicação em contrário, a palavra "recurso" se refere a resource. (N.T.)

${ }^{11}$ Nas Novas regras Giddens escreve: "a constituição moral da interação envolve a aplicação de normas que se baseiam numa ordem legítima (...) Estruturas de (...) legitimação [podem ser analisadas] como sistemas de regras morais" [Giddens, 1976:122-124]. Em escritos posteriores a noção de regra moral é subsumida sob a categoria mais geral de "sanção normativa" (ver Giddens [1979:270-271n63]).
} 
[regras e recursos] como modalidades de produção e reprodução, mas como um conjunto integrado em vez de três componentes separados"12. Assim, a comunicação do significado não pode ser separada completamente do uso do poder ou da aplicação de sanções. Estas modalidades diferentes são tecidas juntas nas práticas sociais, de forma que mesmo a ação ou interação mais mundana exprime aspectos sobrepostos do todo estrutural.

As regras e recursos que compõem a estrutura podem ser considerados "propriedades dos sistemas sociais". Sistemas sociais são padrões de interação regularizados envolvendo indivíduos e grupos; eles não são estruturas por si mesmos, e sim "têm" estruturas, no sentido de que eles são estruturados por regras e recursos. Estruturas não "existem" no tempo e no espaço a não ser enquanto momentos na constituição dos sistemas sociais. Quando as práticas regularizadas estruturadas por regras e recursos "formam camadas profundas" no tempo e no espaço, Giddens fala de “instituições”. Instituições são aglomerados das práticas que constituem os sistemas sociais; elas podem ser classificadas de acordo com a modalidade mais central em sua estruturação. Em Problemas centrais da teoria social, Giddens oferece a seguinte classificação $^{13}$ :
S-D-L
Ordens simbólicas/modos de discurso
D (aut.)-S-L
Instituições políticas
D (aloc.)-S-L
Instituições econômicas
L-D-S
Lei/modos de sanção

As letras à esquerda se referem aos aspectos da estrutura distinguidos acima ( $\mathrm{S}=$ significação, $\mathrm{D}=$ =dominação, $\mathrm{L}=$ legitimação); a primeira letra de cada sequência indica qual aspecto é primário na estruturação das instituições. Quando estudamos instituições legais, por exemplo, focamos principalmente no aspecto da legitimação, ainda que a significação e a dominação também estejam envolvidas. A diferenciação entre instituições políticas e econômicas se baseia numa distinção importante entre dois tipos de recursos. "Autoridade" se refere a capacidades que geram comando sobre pessoas, enquanto a "alocação" se refere a capacidades que geram controle sobre

\footnotetext{
${ }^{12}$ Giddens [1976:124].

${ }^{13}$ Giddens [1979:107].
} 
objetos. Esta distinção dá a Giddens uma vantagem crítica sobre certas formas de teoria social, especialmente aquelas formas de marxismo que tendem a associar a dominação com a posse ou controle de propriedade e que dão atenção insuficiente a problemas de autoridade.

Em seus escritos recentes, Giddens tem se preocupado cada vez mais em examinar as formas pelas quais os conceitos de tempo e espaço entram na teoria da estruturação. Sistemas sociais não são apenas estruturados por regras e recursos, sendo também situados dentro do tempo e do espaço; portanto, "a teoria social precisa reconhecer, o que não ocorreu até agora, as interseções espaço-temporais como algo envolvido de forma essencial em toda existência social" ${ }^{\prime 14}$. Giddens afirma que o tempo e o espaço não devem ser pensados como fronteiras da análise social ou esquemas dentro dos quais a vida social ocorre. É muito mais frutífero pensar o tempo e o espaço nos termos heideggerianos de "presença" e "ausência" - ou, mais exatamente, em termos de "presenciação" ou "estar presente". Toda interação mistura a presença e a ausência de formas complicadas. Na interação face a face, o outro está presente tanto no espaço quanto no tempo. A interação ocorre num ambiente ou "local" definido, e dura um período definido; os atores normalmente empregam as características espaciais e temporais da interação como um meio de organizar seu intercâmbio. Entretanto, com a extensão dos sistemas sociais no tempo e no espaço, o outro pode não estar mais imediatamente presente. Tal distanciação espaço-temporal (ou "distanciamento", como Giddens a chama) foi muito facilitada pelo desenvolvimento da escrita, que torna possível a comunicação com o passado, assim como com indivíduos fisicamente ausentes. Nos anos mais recentes, avanços tecnológicos nos transportes e nos meios de comunicação transformaram rapidamente a constituição espaço-temporal dos sistemas sociais, como os "geógrafos temporais" como Hägerstrand mostraram. Com grande imaginação, Giddens analisa as formas pelas quais estas transformações estão ligadas com a geração de poder. O desenvolvimento da escrita, por exemplo, aumentou muito a capacidade das sociedades de armazenar informação sobre suas populações, e assim de monitorar e controlar suas atividades. Se o poder dos Estados-nação e a ameaça do controle político totalitário são características difusas do mundo moderno, suas origens não podem ser entendidas sem examinar as transformações nas relações espaçotemporais que tornaram possíveis poder e controle tão terríveis.

\footnotetext{
${ }^{14}$ Giddens [1979:54].
} 


\section{Estrutura como "regras e recursos"}

Quero começar minha avaliação crítica do relato de Giddens voltando à sua concepção de estrutura. Poucos conceitos nas ciências sociais são tão básicos e essenciais, mas ainda assim tão ambíguos e contestados, quanto o de estrutura. Giddens merece crédito por tentar dar a este conceito um sentido claro e integrá-lo num esquema conceitual sistemático. Ao fazê-lo, ele também dá ao conceito de estrutura um sentido novo, que diverge consideravelmente dos modos em que este conceito normalmente é usado na literatura das ciências sociais. Embora eu não deseje discutir a importância de inovações conceituais, minha opinião é que a proposta de Giddens de conceber a estrutura em termos de regras e recursos tem valor questionável, porque é uma proposta que gera mais confusões do que resolve, e que tende a obscurecer alguns assuntos importantes. Tentarei fundamentar esta opinião focando, em primeiro lugar, o caráter frouxo e abstrato da concepção de Giddens. Este caráter é derivado tanto das ambiguidades do termo "regra" quanto da própria generalidade da proposta de Giddens, generalidade que fica aparente em sua tentativa de formular uma noção geral de estrutura e em sua tendência de negar as características especificas da estrutura social.

"Estrutura" é um termo vago e ambíguo; o problema com "regra", como Austin poderia dizer, é que ele não nos deixa numa posição muito melhor ${ }^{15}$. Usamos a expressão "regra" de várias formas diferentes. Falamos de regras morais, regras de tráfego, regras burocráticas, regras gramaticais, regras de etiqueta, regras de futebol. Falamos que alguém que faz algo regularmente num momento certo faz isso "como de regra". Trabalhadores que resistem a seus empregadores cumprindo exatamente o que seus contratos dizem estão "seguindo a regra". Giddens tem plena consciência da diversidade de sentidos encapsulada na expressão "regra". Seu modo de reduzir estes sentidos e tentar dar a "regra" uma aplicação mais rigorosa é utilizar criticamente a análise de Wittgenstein sobre o comportamento seguidor de regras. Saber as regras de um jogo é saber como jogá-lo; saber uma regra matemática para o cálculo de uma série de números é saber como continuar a série, quer dizer, “como ir em frente”. Saber uma

\footnotetext{
${ }^{15}$ Aludindo a filósofos que nos intimaram a parar de falar sobre significado e, em vez disso, estudar como expressões são usadas na vida cotidiana, Austin reclama que "“uso' é uma palavra irremediavelmente ambígua ou ampla, assim como a palavra 'significado', que hoje em dia costuma-se ridicularizar. Mas 'uso', sua substituta, não tem lá grandes vantagens”. [Austin, 1976:100]
} 
regra não quer dizer necessariamente conseguir formulá-la. Enquanto atores sociais competentes, sabemos regras incontáveis que teríamos dificuldade de expressar de forma explícita: elas fazem parte, nos termos de Giddens, de nossa consciência prática. Entretanto, Giddens corretamente nos avisa sobre a tendência de Wittgenstein e seus seguidores de privilegiar o exemplo das regras de um jogo, como o xadrez. Pois estas regras, Giddens observa, raramente são contestadas cronicamente. As regras que compõem a estrutura estão envolvidas em conflitos, sujeitas a interpretações rivais e continuamente transformadas através de sua própria aplicação. As regras, em outras palavras, não podem ser concebidas isoladas dos recursos que facilitam o exercício do poder.

Estas observações de cautela certamente são apropriadas, mas elas ainda não nos dão uma ideia clara de exatamente o que, na teoria de Giddens, são as regras que compõem a estrutura social. Nas Novas regras do método sociológico Giddens sugere, como indiquei anteriormente, que estruturas de significação podem ser analisadas como "regras semânticas" e estruturas de legitimação podem ser analisadas como "regras morais". Em outros textos ele modifica esta descrição, colocando menos ênfase em dois tipos de regras e focando, em vez disso, na ideia de que todas as regras têm dois "aspectos": elas estão ligadas tanto à constituição do significado quanto à sanção da conduta. Mas o que, poderíamos perguntar com razão, seria um exemplo de tal regra? Seriam "Isso é uma "borboleta", dito para uma criança em sua primeira excursão ao campo, ou "Segure sua escova de dentes horizontalmente", dito por um dentista a um paciente com má higiene bucal, exemplos do tipo de regra que alguém interessado na estrutura social deveria estudar? Na verdade, até a publicação recente da Constituição da sociedade, Giddens não disse praticamente nada sobre estes assuntos. Na Constituição da sociedade ele analisa vários candidatos para o tipo de regra mais relevante para a estrutura social - ou, como ele prefere dizer, qual é mais relevante para a análise da "vida social". Ele deixa de lado o sentido de "regra" válido para jogos como o xadrez ("a regra que define o xeque-mate é..."); o sentido de "regra" mais ou menos equivalente a hábito ou rotina (“eu me levanto, via de regra, às 6 da manhã”); o sentido de regra exemplificado por regulações como "todos os trabalhadores devem entrar no serviço às 8 da manhã". Giddens sugere que o sentido de "regra" mais relevante para a análise da vida social é aquele expresso por fórmulas como $a_{n}=n^{2}+n-1$. Ele afirma que "é na natureza das fórmulas que melhor podemos descobrir qual é o sentido 
analiticamente mais efetivo de "regra' na teoria social"' 16 . Analiticamente efetivo ou não, esta sugestão não ajuda muito a esclarecer o caráter preciso das regras que, na teoria de Giddens, deveriam compor a estrutura social. Estaria ele sugerindo, de forma muito implausível, que regras semânticas e morais devem ser vistas como fórmulas quase-

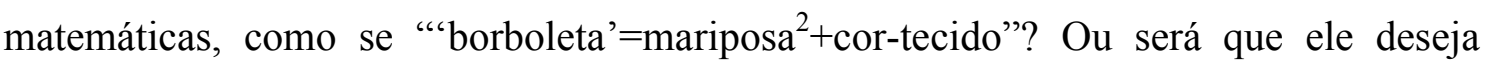
afirmar que tais fórmulas transmitem o sentido de regras que não sejam semânticas e morais, em cujos termos estruturas de significação e legitimação aparentemente podem ser analisadas, e se for isso, quais regras são essas? Se Giddens espera que seus leitores aceitem sua proposta de conceber a estrutura em termos de regras e recursos, então é dele o ônus de fornecer exemplos claros e consistentes do que contaria como uma "regra" relevante.

Até o momento, eu me preocupei em destacar a frouxidão do conceito de estrutura de Giddens; quero agora oferecer alguns argumentos contra a visão de que é útil e satisfatório identificar a estrutura social com regras (e recursos). Ao oferecer estes argumentos, eu focarei o estudo das regras, supondo, na falta de uma explicação mais precisa de "regra" do próprio Giddens, um entendimento intuitivo desta noção. Buscarei estabelecer o seguinte ponto: apesar de regras de vários tipos serem características importantes da vida social, o estudo de regras (e recursos) não é idêntico à análise da estrutura social - é algo diferente, e em outro nível. Há quatro argumentos que me parecem fundamentar este ponto ${ }^{17}$. O primeiro trata da vaguidade do termo "regra" e a incapacidade de Giddens, até agora, em tornar este termo mais preciso. Esta incapacidade não é mero lapso, pois Giddens não consegue esclarecer o sentido de "regra" e os tipos de regras que são relevantes para a estrutura social sem pressupor um critério de importância, e este critério não pode ser derivado levando em consideração apenas regras. Assim, por um lado, Giddens quer tratar as regras como procedimentos generalizáveis implementados em todo tipo de práticas sociais - resumos taquigráficos, por assim dizer, daquilo que os atores sabem sobre seu mundo e sobre como agir nele, sobre ensinar e datilografar, falar e comprar, votar, cozinhar e fazer piadas. Por outro lado, Giddens tem plena consciência de que algumas regras, ou alguns tipos ou aspectos de regras, são muito mais importantes que outros para a análise, por exemplo, da estrutura social das sociedades capitalistas. Mas o que justifica este critério de

\footnotetext{
${ }^{16}$ Giddens [1984:20].

${ }^{17}$ Ver Thompson [1981:144].
} 
importância implícito, se não uma análise da estrutura social que é diferente do estudo destas regras que são destacadas em seu nome?

O segundo e terceiro argumentos dão força para a primeira crítica ao chamar a atenção para o que pode ser chamado de diferenciação estrutural. Vejamos primeiro o caso de um aglomerado de "regras semânticas", como aquelas que governam a aplicação de um adjetivo como "maldito" ["bloody"] ou um substantivo como "a esquerda" na Grã-Bretanha contemporânea. Entretanto, estudar estas regras não é por si só analisar parte da estrutura social da Grã-Bretanha. O estudo de regras semânticas pode realmente ser relevante para a análise da estrutura social; e um modo de mostrar essa relevância é demonstrar que as regras são diferenciadas de acordo com classe, sexo, região, e assim por diante. Mas estudar sua diferenciação pressupõe algum esquema, alguns pontos de referência estruturais que não são propriamente regras, dos quais estas regras semânticas são diferenciadas. Vejamos em seguida o caso de instituições, como escolas ou universidades, em que certos indivíduos, ou certos grupos e classes de indivíduos, têm oportunidades restritas de entrada e participação. Parece evidente que tais restrições não podem ser concebidas adequadamente em termos de "regras morais" ou "sanções", já que tais restrições podem operar independentemente dos direitos e deveres dos agentes em questão. Também não parece adequado conceber tais restrições como consequências não-intencionais, como os círculos causais homeostáticos envolvidos no ciclo da pobreza. Pois a questão não é tanto se as restrições são consequências intencionais ou não que podem se tornar as condições de ações posteriores. Em vez disso, o que está em jogo é o fato de que as restrições de oportunidades operam de modo diferencial, afetando desigualmente vários grupos de indivíduos cuja categorização depende de certas suposições sobre a estrutura social; e esta operação ou efeito diferencial que não pode ser compreendido apenas com a análise de regras.

Se a concepção de Giddens tende a embaçar a questão da diferenciação, ela também não fornece nenhum modo de compreender as características que múltiplas "regras" podem ter em comum. Quer dizer, ela não fornece nenhum modo de formular a ideia de identidade estrutural: este é o quarto argumento contra sua posição. A importância desta ideia pode ser demonstrada considerando duas empresas em setores diferentes da economia britânica, como as fábricas da Ford Motor Company na Inglaterra e os vários estabelecimentos da editora Macmillan. Ambas estas empresas são 
instituições complexas com vastos recursos de maquinaria, matéria-prima e capital. Elas são instituições organizadas e operadas com o auxílio de regras específicas e detalhadas que estipulam como o trabalho deve ser feito, como decisões devem ser tomadas, como funcionários devem ser contratados e demitidos, e assim por diante. Mas além das regras e recursos particulares que caracterizam cada uma destas instituições, há certos aspectos que a Ford e a Macmillan têm em comum, a saber, aqueles que as definem como empresas capitalistas. Estas características não são "regras" adicionais "utilizadas" por atores dentro destas instituições, da mesma forma que um supervisor poderia "utilizar" uma regra no contrato para demitir um trabalhador que não apareceu para o serviço. As características comuns são de uma ordem completamente diferente; elas são melhor concebidas, creio eu, como uma série de elementos e suas interrelações, que juntas limitam os tipos de regras que são possíveis e que assim delimitam o escopo de variação institucional ${ }^{18}$. Sejam quais forem os méritos desta concepção alternativa, estes quatro argumentos contra a posição de Giddens, espero, demonstrarão que a proposta de conceber a estrutura em termos de regras (e recursos) é deficiente, pois ela pressupõe mas não consegue tratar de algumas das preocupações mais importantes da análise estrutural.

\section{Niveis de análise estrutural}

Desejo agora voltar aos textos de Giddens e seguir uma linha de pensamento que se tornou cada vez mais proeminente em sua obra recente. Eu acho que Giddens agora aceitaria que a descrição da estrutura apresentada em Novas regras do método sociológico não é satisfatória em alguns aspectos. Talvez seja parcialmente em resposta a considerações como aquelas mencionadas acima que ele tenha tentado distinguir mais claramente entre níveis de abstração diferentes na análise das características estruturais dos sistemas sociais. Em Uma crítica contemporânea do materialismo histórico esses níveis são retratados como na figura $3^{19}$ :

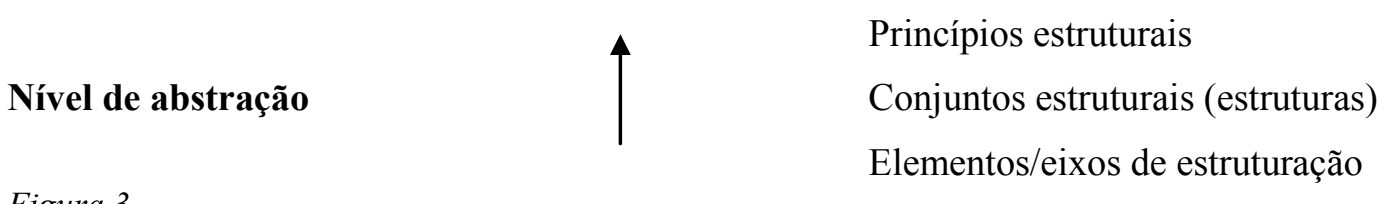

Figura 3

\footnotetext{
${ }^{18}$ Esta proposta é desenvolvida em Thompson [1981:145ff.]; e na parte III de Thompson [1984b].

${ }^{19}$ Giddens [1981:54].
} 
O estudo de "princípios estruturais" é o nível mais abstrato de análise. Estudar tais princípios é examinar os principais alinhamentos, os modos de articulação e diferenciação, das instituições que constituem uma sociedade. Nas palavras de Giddens, “princípios estruturais são princípios de organização implicados nas práticas sedimentadas mais 'profunda' (no tempo) e 'difusamente' (no espaço) em uma sociedade"20. A identificação de princípios estruturais fornece a base para a classificação tríplice de tipos de sociedade de Giddens. Nas "sociedades tribais", incluindo bandos de caçadores e coletores e comunidades agrícolas assentadas, o princípio estrutural dominante "opera através de um eixo", como diz Giddens, entre parentesco e tradição; o distanciamento espaço-temporal é baixo, redes de parentesco são o lócus da interação e as ligações com o passado são mantidas apenas através da efetivação da tradição. O princípio estrutural dominante das "sociedades divididas em classes" (cidades-estados, impérios antigos e sociedades feudais) opera através de um eixo relacionando áreas urbanas ao interior rural. A cidade - centrada em templos e cercada por muralhas - emerge como um tipo especial de "recipiente de armazenamento" para a geração de poder político e militar. Diferentes das sociedades divididas em classes, as sociedades de classe do capitalismo moderno são organizadas através de um eixo que relaciona instituições do Estado e instituições econômicas. A expansão rápida de uma economia baseada na relação capital/trabalho assalariado cria as condições para o acúmulo de poder político nas mãos do Estado-nação. Ao mesmo tempo, o predomínio da relação cidade-campo é destruído pela mercantilização incessante do tempo e do espaço, que produz o "ambiente criado" onde a maior parte das pessoas vive sua vida cotidiana.

Num nível menos abstrato de análise, as características estruturais de sistemas sociais podem ser estudadas como "conjuntos estruturais". Com "conjuntos estruturais" Giddens quer dizer "conjuntos de regras e recursos, especificados em termos de ‘aglomerações' de relações de transformação/mediação" ${ }^{21}$. É neste nível de análise, afirma Giddens, que podemos entender a descrição de Marx das principais relações estruturais envolvidas no sistema de produção capitalista. Considerem as relações envolvidas no seguinte "conjunto estrutural":

propriedade privada : dinheiro : capital : contrato de trabalho : lucro

\footnotetext{
${ }^{20}$ Giddens [1981:54-55].

${ }^{21}$ Giddens [1981:55].
} 
O desenvolvimento do capitalismo é caracterizado pela universalização da forma mercadoria. A condição desta universalização é a formação de uma economia monetária na qual o dinheiro, como o meio de valor de troca puro, permite que a propriedade privada seja convertida em capital e permite que a força de trabalho seja constituída enquanto uma mercadoria, para ser comprada e vendida no mercado como qualquer outra. O capital e o trabalho assalariado podem assim entrar num tipo definido de relação, governada pelo contrato de trabalho, em que a força de trabalho é trocada por salários e na qual o lucro é produzido através da extração da mais-valia. Ao estudar as várias relações de conversibilidade entre propriedade privada, dinheiro, capital, e assim por diante - um estudo que poderia se estender, como sugere Giddens, para a autoridade industrial, vantagens educacionais e posições ocupacionais - podemos identificar algumas das principais características estruturais das instituições criadas pelo capitalismo.

O nível mais concreto de análise se preocupa com "elementos" ou "eixos" de estruturação. Este nível é o mais concreto porque ele trata mais diretamente das relações de copresença estabelecidas entre atores na interação social. Giddens oferece o exemplo da divisão do trabalho na atividade capitalista. A divisão do trabalho é uma fonte daquilo que Giddens chama, em A estrutura de classes das sociedades avançadas, de "estruturação imediata" ${ }^{22}$ : ela liga as características mais amplas do capitalismo com a organização mais imediata da atividade industrial. No desenvolvimento inicial da indústria manufatureira, prevaleciam duas formas da divisão do trabalho. Por um lado, os capitalistas reuniam operários com habilidades artesanais diferentes e coordenavam suas atividades para a produção de um produto particular; por outro lado, trabalhadores com as mesmas habilidades eram reunidos e cada trabalhador precisava produzir o mesmo produto. Em ambos os casos o processo produtivo era separado em tarefas detalhadas, resultando, nas palavras de Marx, num "mecanismo produtor cujas peças são seres humanos" ${ }^{23}$. A divisão do trabalho é vital para a organização da atividade capitalista não apenas porque melhora a produtividade e lucratividade da atividade, mas também porque cria condições para a vigilância direta da força de trabalho e para a consolidação da disciplina operária. Desenvolvimentos tecnológicos estão intimamente ligados com a divisão do trabalho, alterando profundamente tanto a natureza das tarefas

\footnotetext{
${ }^{22}$ Ver [Giddens, 1973:107-108].

${ }^{23}$ Marx [1970:320]. Para a discussão de Giddens da teoria de Marx, ver [Giddens, 1984:189-190].
} 
quanto as fronteiras entre elas. Estas fronteiras, por sua vez, têm um efeito significativo sobre a formação e fragmentação da consciência de classe em sociedades capitalistas contemporâneas.

Esta tentativa de distinguir vários níveis de análise estrutural representa, creio, uma melhoria substancial quanto à descrição bastante embaçada da estruturação apresentada nas Novas regras do método sociológico. De qualquer forma, me parece que estas distinções criam sérias dificuldades para certos aspectos da abordagem de Giddens. Ao discutir estas dificuldades eu, de modo geral, deixarei de lado a questão do conteúdo, quer dizer, a adequação empírica e histórica das análises de Giddens. Em vez disso, eu me concentrarei em questões de forma ou consistência conceitual. A primeira dificuldade trata das implicações destas distinções para a concepção de estrutura enquanto regras e recursos. Mesmo em seus escritos mais recentes, Giddens continua a aderir a esta concepção. Assim, na Constituição da sociedade, ele escreve: "Eu trato a estrutura, pelo menos em seu significado mais elementar, referindo-se a (...) regras (e recursos" 24 . Mas aderir a esta concepção de estrutura, e ao mesmo tempo reconhecer a necessidade do estudo de "princípios estruturais", "conjuntos estruturais" e "eixos de estruturação", é simplesmente uma receita de confusão conceitual. Um princípio estrutural, como aquele que "opera através de um eixo" relacionando áreas urbanas ao interior rural, não é uma "regra" em nenhum sentido ordinário: ele não é nem uma regra semântica, nem uma regra moral, nem uma "fórmula" que expressa o que os atores sabem quando saber agir na vida social. Insistir que um princípio estrutural precisa ser alguma regra desse tipo, ou que precisa ser capaz de ser analisado em termos de regras, é forçar sobre o material um modo de conceitualização que não é apropriado a ele, e que surge nem tanto de uma reflexão sobre as características estruturais da vida social, e mais de uma ontologia implícita da estrutura. Da mesma forma, parece ser enganador e não muito útil interpretar a descrição de Marx das relações estruturais envolvidas no sistema capitalista de produção em termos de "conjuntos de regras e recursos". A constituição da força de trabalho como uma mercadoria, a determinação de seu valor como o tempo de trabalho socialmente necessário para sua produção, sua troca no mercado sob condições que garantem que ela seja trocada pelo seu valor e ainda assim simultaneamente produza mais-valia e lucro: estas características do sistema capitalista não podem ser tratadas como várias "regras" que os trabalhadores seguem quando

\footnotetext{
${ }^{24}$ Giddens [1984:17].
} 
chegam aos portões da fábrica, como se cada trabalhador que aceita um emprego tivesse um conhecimento implícito (ainda que parcial) do Capital de $\operatorname{Marx}^{25}$. Eu penso que a descrição oferecida por Marx seria melhor vista como uma tentativa de identificar e explicar os tipos variáveis de condições que possibilitam os processos de produção e troca capitalista. Estas condições vão das circunstâncias que facilitam a formação de uma força de trabalho "livre" para os elementos, relações princípios envolvidos na constituição do valor e geração de lucro. Eu não vejo mérito algum em tentar forçar estas condições variadas no molde conceitual da estrutura qua regras e recursos. Além do mais, eu acho difícil reconciliar qualquer tentativa deste tipo com a afirmação de Marx de estar descobrindo a essência das relações capitalistas que está escondida sob sua forma fenomenal, uma forma em cujos termos a natureza e o valor das mercadorias são mal entendidos pelos próprios indivíduos envolvidos em sua produção ${ }^{26}$. A descrição de Giddens tende a igualar a estrutura social com o conhecimento prático e, assim, a suprimir a distinção entre uma análise das condições estruturais de um certo tipo de sociedade, por um lado, e um mero resumo daquilo que os atores já sabem quando sabem "como agir" nesta sociedade, por outro ${ }^{27}$. Eu acredito que seja importante preservar esta distinção, tanto para os propósitos da análise social quanto para as tarefas da ciência social enquanto crítica. Além do mais, eu acredito que esta distinção possa ser preservada sem sucumbirmos à "derrogação do ator leigo" contra a qual Giddens nos avisa tão corretamente.

A segunda dificuldade que desejo mencionar trata das consequências das distinções de Giddens para o problema da reprodução social. Parte da atração da concepção da estrutura em termos de regras e recursos é que ela oferece um quadro

\footnotetext{
${ }^{25}$ Eu não desejo negar que as pessoas sabem bastante sobre as condições em que trabalham. Num estudo notável, discutido de forma esclarecedora por Giddens [1984:289-304], Willis afirma que certos aspectos do comportamento de jovens da classe operária podem ser interpretados como "penetrações culturais" das condições estruturais da produção capitalista; sua evasão da autoridade no local de trabalho, por exemplo, pode ser interpretada como uma penetração do fato de que a força de trabalho é um recurso variável na sociedade capitalista (ver Willis [1977]). Mas Willis também afirma que estas penetrações são parciais, relacionadas com apenas alguns aspectos do sistema capitalista e que mesmo assim elas são "reprimidas, desorganizadas e impedidas de atingir seu potencial pleno ou uma articulação política por divisões profundas, básicas e desorientadoras" (Willis [1977:145]). A interpretação de penetrações como parciais pressupõe uma análise da estrutura da produção capitalista que é independente do conhecimento limitado possuído pelos jovens.

${ }^{26}$ Ver especialmente a discussão de Marx sobre o "fetichismo da mercadoria" em Marx [1970:76-87]; ver também sua análise da "forma mistificada" na qual o lucro é entendido pelos capitalistas e economistas em Marx [1970, vol. 3:25-40].

${ }^{27}$ Bourdieu critica, na minha opinião corretamente, a tendência a projetar sobre o objeto (ou sujeito) da investigação os próprios modelos que construímos para entendê-lo (ou explicá-lo). Esta tendência é exacerbada pela noção de regra, que facilita a "escorregada do modelo da realidade para a realidade do modelo" [Bourdieu, 1980:67].
} 
simples e de fácil compreensão de como os indivíduos, ao tratarem de suas atividades cotidianas, reproduzem a estrutura social. Pois ao tratarem de suas atividades, os indivíduos "utilizam" regras e recursos que são assim reproduzidos, assim como ao falar inglês "utilizamos" e reproduzimos as regras da gramática inglesa. Este quadro está no coração da teoria de Giddens; ele é o ponto de referência constante em suas várias discussões sobre a dualidade da estrutura e o caráter recursivo da vida social. Mas o quadro é enganosamente simples. Ele pressupõe que todas as características estruturais dos sistemas sociais podem ser concebidas em termos de regras e recursos, onde através de "regras" entendemos algo semelhante às regras da gramática inglesa. Eu afirmei que esta pressuposição não pode ser mantida. Eu também afirmei que as próprias distinções de Giddens entre níveis diferentes de análise estrutural não podem ser reconciliadas facilmente com esta pressuposição. Estes argumentos questionam, por sua vez, a adequação da teoria da reprodução de Giddens. E eu diria que realmente não faz sentido supor que "princípios estruturais" são reproduzidos através de sua "utilização" por indivíduos na interação social ${ }^{28}$. Assim, aquilo que pode ter parecido ser a principal atração da abordagem de Giddens é na verdade uma de suas principais deficiências: o problema da reprodução é, na melhor das hipóteses, resolvido apenas parcialmente. Para lidar mais adequadamente com o assunto, eu acredito que precisemos fazer uma distinção mais aguda entre a reprodução das instituições e a reprodução da estrutura social que a de Giddens. Instituições são caracterizadas por regras, regulamentações e convenções de vários tipos, por tipos e quantidades de recursos diferentes e por relações hierárquicas de poder entre os ocupantes de posições institucionais. Quando agentes agem de acordo com estas regras e regulamentações, ou exercitam o poder que recebem institucionalmente, podemos dizer que eles reproduzem as instituições. Se, ao fazê-lo, as instituições continuarem a satisfazer certas condições estruturais, tanto no sentido de condições que delimitam o escopo de variação institucional quanto condições que fundamentam a operação de diferenciação estrutural, então podemos dizer que os agentes reproduzem a estrutura social. Assim, podemos dizer que indivíduos que, em suas atividades produtivas cotidianas, reproduzem as instituições da Ford Motor Company também reproduzem as condições através das quais estas instituições são capitalistas. Mas não é difícil imaginar circunstâncias em que indivíduos podem

\footnotetext{
${ }^{28}$ Giddens parece reconhecer este ponto em sua discussão um tanto críptica de "circuitos de reprodução" em Giddens [1984:190-192]; pois os "princípios estruturais" estão aqui situados fora da "dualidade da estrutura" que liga as "propriedades estruturais" à "monitoração reflexiva da ação".
} 
efetivamente transformar essas instituições sem transformar suas condições estruturais. Todo ato de produção e reprodução também pode ser um ato potencial de transformação, como Giddens corretamente insiste; mas a amplitude em que uma ação transforma uma instituição não coincide com a amplitude da transformação resultante da estrutura social.

Como um terceiro e último ponto, eu desejo antecipar uma objeção possível às críticas feitas acima. Pode-se dizer que eu certamente deixei passar as várias referências de Giddens ao papel da "separação metodológica". De acordo com Giddens, podemos escolher entre duas abordagens ao estudo das características institucionais dos sistemas sociais. Por um lado, podemos conduzir uma análise institucional em que características estruturais são tratadas como propriedades cronicamente reproduzidas dos sistemas sociais; por outro lado, podemos realizar uma análise da conduta estratégica, focando nas formas em que os atores utilizam características estruturais durante a interação social. Giddens aponta que esta distinção metodológica é meramente uma diferença de ênfase: "não há uma linha clara que pode ser traçada entre elas, e - o que é crucial cada uma delas deve ser a princípio completada por uma concentração sobre a dualidade da estrutura"29. Entretanto, esta é uma distinção que precisa ser tratada com grande cuidado. Pois ela pode muito facilmente servir como um cobertor metodológico para encobrir dificuldades conceituais que acredito que sejam profundas no projeto de Giddens. Assim, não será suficiente objetar às minhas críticas dizendo que a análise de princípios estruturais, conjuntos estruturais e assim por diante não deve mostrar como tais características são invocadas e assim reproduzidas por agentes na interação social, já que ela coloca a análise interacional em parênteses metodológicos. Isto não será suficiente porque o problema não é metodológico, e sim conceitual: um princípio estrutural que governe o alinhamento das instituições não se torna uma regra utilizada na interação através da mera remoção de parênteses metodológicos. Eu não acho que Giddens gostaria de afirmar o contrário; mas até agora ele se recusou a admitir, como acho que deve, que o reconhecimento de níveis diferentes de análise estrutural coloca um peso intolerável sobre sua concepção original de estrutura.

\footnotetext{
${ }^{29}$ Giddens [1984:288].
} 


\section{Ação, estrutura e coerção}

Até agora eu me concentrei no lado estrutural da tentativa de Giddens de superar o dualismo entre ação e estrutura. Desejo agora voltar minha atenção brevemente para sua análise da ação e sua relação com a estrutura e a coerção. Giddens sugere que a ação pode ser concebida em termos de um modelo de estratificação que leva em conta a monitoração reflexiva da ação que os agentes rotineiramente desempenham, assim como a racionalização e motivação da ação (incluindo fontes inconscientes da motivação). É essencial para o modelo de estratificação a ideia de que, apesar de grande parte da vida cotidiana ocorrer como um fluxo contínuo de ação intencional, muitos atos têm consequências não-intencionais que podem se tornar as condições não-reconhecidas de atos posteriores. É primariamente através desta forma, de acordo com Giddens, que a ação está ligada à estrutura. Pois, ao realizar um dado curso de ação, o agente utiliza as regras e recursos que compreendem a estrutura, reproduzindo assim, de forma nãointencional, as condições estruturais de atos posteriores. " $A$ estrutura então não deve ser concebida como uma barreira à ação, mas como envolvida de forma essencial em sua produção" $0^{, 0}$ : a estrutura é permissiva além de coerciva, e está implicada até nos processos mais radicais de mudança social.

Há muitos aspectos do modelo de estratificação de Giddens que eu considero atraentes. Ele oferece um esquema para a análise da ação que abre espaço para as ideias de muitos autores - de Heidegger e Schutz a Garfinkel, Goffman e Freud - sem negligenciar a dimensão das instituições e da estrutura social. De qualquer forma, eu acredito que há certos problemas com esta abordagem. Alguns dos problemas podem ser colocados perguntando se, ao afirmar o caráter permissivo da estrutura, Giddens faz justiça ao papel da coerção estrutural ${ }^{31}$. Começarei a examinar esta questão voltando para as Novas regras do método sociológico, onde as regras constitutivas da estrutura são caracterizadas como regras semânticas e morais. Em que sentido estas regras operam como coerções sobre cursos possíveis de ação? Regras semânticas são coercivas no sentido que obrigam um orador, que deseja ser entendido por outra pessoa, a adotar certas formas linguísticas e gramaticais; um orador que pronunciasse uma expressão como "políticos roxos soletram ao dormir" simplesmente não seria entendido por um

\footnotetext{
${ }^{30}$ Giddens [1979:70].

${ }^{31}$ Para outras discussões do tratamento de Giddens da coerção estrutural, ver Carlstein [1981]; Archer [1982]; e Dickie-Clark [1984].
} 
falante competente do português. Regras morais são coercivas no sentido em que estão associadas com sanções que podem ser "internas", baseadas no compromisso moral do agente, ou no medo ou culpa, ou "externas", baseadas na oferta de recompensas ou ameaça de força. Estes são tipos importantes de coerção, e sua significância na vida social não deve ser subestimada. Entretanto, parece evidente que eles não são os únicos tipos de coerção relevantes para a análise social. Quando alguém que abandona a escola enfrenta a escolha de se juntar a um centro de treinamento de jovens ou entrar no seguro-desemprego, as coerções que operam aqui não são simplesmente de compreensibilidade ou de sanções. Pois é o conjunto de alternativas que é restrito, e estas restrições não surgem de regras semânticas ou morais, e sim das condições estruturais para a persistência (e declínio) de instituições produtivas.

Giddens reconhece a importância da coerção estrutural, e sem dúvida aceitaria que suas afirmações iniciais sobre este tema precisam ser elaboradas. Na Constituição da sociedade ele retorna ao tema e busca mostrar que sua descrição pode acomodar completamente o papel da coerção. Para começar, não é difícil mostrar que a teoria da estruturação é compatível com o reconhecimento de limites impostos pelo ambiente físico. Da mesma forma, não é problema algum reconhecer que instituições, concebidas como práticas regularizadas "dispostas em camadas profundas" no tempo e no espaço, preexistem e perduram além das vidas dos indivíduos que as reproduzem, e podem assim ser resistentes a manipulações ou mudanças de qualquer agente em particular. Mas e a coerção estrutural, ou seja, a coerção que não é derivada nem das condições físicas nem de instituições específicas, mas da estrutura social? "Como com as qualidades coercivas das sanções", Giddens propõe, "é melhor descrevê-la como colocando limites sobre o conjunto factível de opções abertas a um ator numa dada circunstância ou tipo de circunstância"32. Consideremos os limites impostos pelas "relações contratuais da indústria moderna". Para indivíduos que foram deixados sem propriedade e meios de subsistência, só há uma alternativa: a saber, vender sua força de trabalho àqueles que possuem os meios de produção. Dizer que há apenas uma alternativa é dizer que há apenas uma "opção factível” - ou seja, uma opção que atores que tenham certos padrões de motivação (neste caso, o desejo de sobreviver) considerarão racional escolher. Apesar do trabalhador poder ter uma escolha entre várias possibilidades de emprego, no final das contas estas opções se reduzem a uma,

\footnotetext{
${ }^{32}$ Giddens [1984:176-177].
} 
pois essencialmente o trabalhador não tem escolha a não ser aceitar um emprego, seja lá qual for.

Esta elaboração das posições de Giddens concorda com algumas das modificações discutidas na seção anterior e, mais uma vez, é bem-vinda. Não obstante, me parece que esta elaboração gera dois grandes problemas para a teoria de Giddens. Em primeiro lugar, o que Giddens descreve agora como "coerção estrutural" não pode ser reconciliado facilmente com sua proposta de conceber a estrutura como regras e recursos. As coerções que reduzem as opções de indivíduos sem propriedades a apenas uma - e, hoje em dia, cada vez mais à "opção" do desemprego - são parcialmente impostas pelas condições da produção e troca capitalistas; e eu já afirmei que é enganador e não muito útil tentar forçar estas condições no molde conceitual da estrutura qua regras e recursos. O segundo problema trata da relação entre coerção estrutural e ação. Um tema central da teoria de Giddens é que o conceito de ação implica que uma pessoa "poderia ter agido de outra forma": "um agente que não tem opção alguma", ele insiste, "não é mais um agente" 33 . Entretanto, em sua discussão da coerção estrutural, Giddens reconhece a possibilidade de que tal coerção pode reduzir as opções de um indivíduo a apenas uma. Não é difícil enxergar que um indivíduo que só tem uma opção não tem opções, pois não há nenhum outro curso de ação que o indivíduo poderia escolher, e, assim, parece não fazer sentido dizer que ele ou ela "poderia ter agido de outra forma". A estrutura e a ação não parecem mais ser termos complementares de uma dualidade, e sim os polos antagonistas de um dualismo, de modo que a coerção estrutural pode limitar tanto as opções de um indivíduo, que a ação efetivamente se dissolve.

A resposta de Giddens a este problema evidente é enfatizar a distinção entre “opção" e "opção factível”. Um indivíduo que só tem uma opção não é um agente, pois não há nenhum sentido em que esse indivíduo "poderia ter agido de outra forma". Mas um indivíduo que só tem uma opção factível é um agente, pois a opção é limitada a apenas uma no sentido que, dados os desejos e vontades do indivíduo, só há uma opção que ele consideraria racional escolher. Entretanto, esta resposta não resolve o problema; ela meramente desvia o problema reafirmando um conceito de ação que é, para todos os propósitos práticos, irrelevante. Simplesmente não há nenhuma circunstância imaginável em que um indivíduo não poderia ter agido de outra forma se, com "o

\footnotetext{
${ }^{33}$ Giddens [1981:63].
} 
indivíduo", entendemos algum eu puro e rarefeito, abstraído de toda vontade e desejo e sempre capaz de escolher ${ }^{34}$. Giddens admite isto; mesmo um prisioneiro que esteja amordaçado e amarrado e colocado na solitária ainda é um agente, "como greves de fome, ou a 'recusa definitiva' - o suicídio - indicam"35. Giddens consegue preservar a complementaridade entre ação e estrutura apenas ao definir a ação de forma que qualquer indivíduo em qualquer situação não poderia não ser um agente.

Creio que um confronto mais direto com estes assuntos requereria uma concepção mais satisfatória de estrutura e coerção estrutural, assim como uma análise mais sistemática das vontades e desejos relevantes para a ação e escolhas individuais. Todas as opções são "opções factíveis" no sentido em que elas dependem das vontades e desejos dos atores cujas opções elas são: um curso de ação possível não seria uma opção para um agente se ele não tivesse relevância alguma para qualquer coisa que o agente quisesse. Mas as opções variam muito em seu alcance, natureza, e no caráter das vontades e desejos dos quais dependem. Uma das principais tarefas da análise social é explorar este espaço de possibilidades, tanto em termos da distribuição diferencial das opções de acordo com classe, idade, sexo, e assim por diante, quanto também em termos dos tipos de vontades e desejos, interesses e necessidades, que são eles mesmos possuídos de forma variada ${ }^{36}$. A distribuição variada de opções e necessidades implica que certos indivíduos ou grupos de indivíduos têm um escopo maior de ação e escolha que outros indivíduos ou grupos de indivíduos: poderíamos dizer que a liberdade é desfrutada por pessoas diferentes em graus variados. Explorar o espaço entre a distribuição diferencial de opções, por um lado, e as vontades e necessidades de tipos diferentes e de categorias diferentes de indivíduos, por outro, é examinar os graus de liberdade e coerção que são implicados pela estrutura social. Tal análise mostraria que, ainda que a estrutura e a ação não sejam antinomias, não obstante elas não são tão complementares, nem se sustentam tão mutuamente como Giddens gostaria que acreditássemos.

Concluirei este ensaio resumindo minhas principais críticas à obra de Giddens. Eu comecei esboçando os temas centrais de sua teoria e mostrando como, nas Novas

\footnotetext{
${ }^{34}$ Como Lukes observa, "a forma pela qual respondemos a pergunta 'poderia o ator ter agido de outra forma?' depende crucialmente de como o ator é concebido” (Lukes [1977:25]).

${ }^{35}$ Giddens [1981:63].

${ }^{36} \mathrm{O}$ sugestivo conceito de habitus de Bourdieu representa uma tentativa de explorar o papel de vontades e necessidades duráveis e distribuídas de forma variada. Ver especialmente Bourdieu [1977:cap. 2].
} 
regras do método sociológico, o conceito de estrutura é tratado através de uma comparação entre linguagem e fala. Apesar de Giddens qualificar cuidadosamente esta abordagem, não obstante eu acredito que ela seja a fonte de muitas das dificuldades em seu relato. Pois é através de uma reflexão sobre a linguagem e sua relação com a fala que ele formula inicialmente uma concepção geral de estrutura como regras e recursos. Eu afirmei que a proposta de conceber a estrutura desta forma é insatisfatória por várias razões: (1) a noção de regra é terrivelmente vaga e Giddens não consegue fornecer uma explicação clara e consistente; e (2) o estudo de regras (e recursos) não remete diretamente a algumas das principais preocupações na análise da estrutura social, como a análise da diferenciação estrutural e o estudo da identidade estrutural. Não precisamos de uma concepção geral de estrutura da qual a estrutura social, ou as "estruturas mais relevantes para a análise da vida social”, seriam uma instância específica; precisamos de uma explicação cuidadosa daquilo que está envolvido na estrutura social e nas várias formas de análise estrutural na investigação social. Em seus escritos recentes, Giddens responde com mais detalhes a esta última exigência e distingue mais claramente entre níveis diferentes de análise estrutural. Apesar destas distinções ajudarem, eu acredito que elas colocam um peso intolerável sobre a concepção de estrutura qua regras e recursos, uma concepção à qual Giddens continua a aderir, um tanto tenazmente. Além do mais, estas distinções meramente enfatizam as deficiências da abordagem de Giddens ao problema da reprodução, uma abordagem baseada no quadro simplificado demais de um ator "utilizando" uma regra. Finalmente, voltando minha atenção brevemente à análise da ação, eu tentei mostrar que a ênfase de Giddens sobre o caráter permissivo da estrutura o levou a subestimar o papel da coerção estrutural. Eu acho que um tratamento mais adequado desta última precisaria reconhecer que a ação e a estrutura social não são termos contraditórios nem complementares, e sim dois polos que estão numa relação de tensão um com o outro. Pois apesar da estrutura social ser reproduzida e transformada pela ação, também é verdade que o conjunto de opções disponível para indivíduos e grupos de indivíduos é distribuído de forma variável e circunscrito estruturalmente.

Ao desenvolver minhas críticas, eu enfoquei principalmente a concepção de estrutura qua regras e recursos e a relação entre ação e coerção estrutural. Por motivos de concisão, eu não examinei as muitas contribuições interessantes e importantes que Giddens fez para a análise do poder, a teoria da ideologia e a concepção do tempo e do 
espaço, para não falar de sua obra mais substantiva sobre a estrutura de classes e o Estado. Eu deixei de lado estas contribuições parcialmente porque eu aceito a visão de Giddens que a relação entre ação e estrutura é num certo sentido primária, pois é em termos desta relação que a análise do poder, a teoria da ideologia e a concepção do tempo e do espaço devem ser lançadas. É minha opinião que Giddens fez mais do que qualquer outro pensador contemporâneo para avançar nosso entendimento das formas complexas em que a ação e a estrutura se interseccionam nas atividades rotineiras da vida cotidiana. Se minhas críticas da teoria de Giddens forem válidas, então elas meramente contribuirão para uma tarefa que ele, acima de todos, estabeleceu para a teoria social.

\section{Bibliografia}

ARCHER, M. S. [1982] "Morphogenesis versus Structuration: on Combining Structure and Action", in British Journal of Sociology, 33, pp. 455-483.

AUSTIN, J. L. [1976] How to Do Things with Words. Oxford: Oxford University Press.

BHASKAR, R. [1979] The Possibility of Naturalism. Brighton: Harvester.

BOURDIEU, P. [1977] Outline of a Theory of Practice. Cambridge: Cambridge University Press.

BOURDIEU, P. [1980] Le sens pratique. Paris: Minuit.

CARLSTEIN, T. [1981] "The Sociology of Structuration in Time and Space: A TimeGeographical Assessment of Giddens' Theory”, in Svensk Geografisk Arsbok, 57.

DICKIE-CLARK, H. F. [1984] "Anthony Giddens' Theory of Structuration" in Canadian Journal of Political and Social Theory, 8, pp. 92-110.

GIDDENS, A. [1973] The Class Structure of the Advanced Societies. London: Hutchinson.

GIDDENS, A. [1976] New Rules of Sociological Method. London: Hutchinson.

GIDDENS, A. [1977] Studies in Social and Political Theory. London: Hutchinson.

GIDDENS, A. [1979] Central Problems in Social Theory. London: Macmillan.

GIDDENS, A. [1981] A Contemporary Critique of Historical Materialism. London, Macmillan.

GIDDENS, A. [1984] The Constitution of Society. Cambridge: Polity.

LUKES, S. [1977] Essays on Social Theory. London: Macmillan.

MARX, K. [1970] Capital. London: Lawrence \& Wishart.

THOMPSON, J. B. [1981] Critical Hermeneutics: A Study in the Thought of Paul Ricoeur and Jürgen Habermas. Cambridge: Cambridge University Press. 
THOMPSON, J. B. [1984a] "Rethinking History: For and Against Marx", in Philosophy of the Social Sciences, 14, pp. 543-551.

THOMPSON, J. B. [1984b] "Theories of Ideology and Methods of Discourse Analysis: Towards a Framework for the Analysis of Ideology", in Studies in the Theory of Ideology. Cambridge: Polity Press.

WILLIS, P. E. [1977] Learning to Labour : How Working Class Kids Get Working Class Jobs. Westmead: Saxon House. 


\section{Gianfranco Poggi - Anthony Giddens e "os clássicos"}

\section{A dívida de Giddens com os clássicos}

$\mathrm{Eu}$ posso dar uma ideia do peso daquilo que pretendo argumentar neste capítulo dizendo que Giddens deve muito aos clássicos - e vice-versa. Primeiro, Giddens deve muito aos clássicos num sentido que podemos chamar de biobibliográfico. Não é possível que eu seja a única pessoa que foi forçada a tomar nota de seu nome por causa de seu ensaio de 1970 sobre "Marx, Weber e o desenvolvimento do capitalismo" [Giddens, 1970]. Fui levado por esse texto a um ensaio mais antigo, também no modo de exegese, sobre “"Poder' nos escritos recentes de Talcott Parsons” [Giddens, 1968]; e estes dois ensaios, juntos com “O ‘indivíduo' nos escritos de Émile Durkheim” [Giddens, 1971b], induziram-me a esperar com ansiedade, cheio de expectativa nescio quid maius nascitur ${ }^{1}$, o livro Capitalismo e teoria social moderna [Giddens, 1971a]. Esta obra, de sucesso bastante espetacular e duradouro ao redor do mundo também em termos de vendas - para os padrões de livros acadêmicos -, fez de Giddens uma figura destacada na sociologia, e predispôs plateias cada vez maiores na profissão (especialistas, pesquisadores e estudantes avançados) a prestar atenção respeitosa à sua obra posterior.

Esta disposição, primeiramente gratificada por outras obras no modo exegético (como o curto e vigoroso Política e sociologia no pensamento de Max Weber [Giddens, 1972b] e uma excelente antologia de Durkheim [Giddens, 1972a]), ajudou subsequentemente a recepção inicial dos escritos nos quais Giddens se encarregou de voar sozinho e começou a elaborar a teoria da estruturação; apesar de ser concebível, julgando, mais uma vez, a partir de sensações que ocasionalmente me passam pela cabeça, que alguns dos primeiros admiradores do Giddens exegético às vezes consideraram o teórico da estruturação ligeiramente menos magistral e atraente.

Assim, il lungo studio e il grande amore ${ }^{2}$ que Giddens investiu nos clássicos da sociologia renderam excelentes frutos no crescimento inicial de sua reputação. Mas há

\footnotetext{
${ }^{1}$ Expressão de Sexto Propércio, poeta latino do século I a.C., sobre a composição da Eneida: "nescio quid maius nascitur Iliade", "algo maior que a Ilíada está nascendo". (N.T.)

2 "O longo estudo e o grande amor", retirado de Dante Alighieri, A divina comédia - Inferno, 1:83. (N.T.)
} 
outro sentido mais intrínseco no qual a trajetória ainda ininterrupta da teoria da estruturação decolou de uma pista conscientemente construída com os resultados das visitas iniciais de Giddens aos clássicos. Falar do "modo exegético" não dá a ideia completa dos usos aos quais essas visitas foram destinadas. Pois Giddens não se contentou em avaliar, juntar, expor, comparar e contrastar os conteúdos dos escritos dos clássicos. Ele os usou como fontes inigualáveis de ideias (por mais hesitantes, contrastantes e contraditórias que elas pudessem ser) sobre a natureza da sociedade em que esses escritos foram produzidos. Ele também os usou como points de repère ${ }^{3}$, como material de partida na construção de uma teoria social de nossa própria sociedade, não apenas como realizações passadas a serem reverenciadas e contempladas.

Falar da "visita de Giddens aos clássicos", como eu fiz, é potencialmente enganoso; o que acontecia, mais frequentemente, era seu próprio confronto com eles. Os dois primeiros capítulos da primeira obra maior em que ele voou sozinho, $A$ estrutura de classe das sociedades avançadas [Giddens, 1973] são particularmente indicativos desta disposição que Giddens manteve e aperfeiçoou em seus escritos "pós-exegéticos"; "A teoria de classes de Marx" e "A crítica weberiana" daquela não são simplesmente evocadas respeitosamente para fins de genealogia intelectual, e muito menos tratadas como estabelecendo as fronteiras definitivas da discussão teórica sobre o assunto. Em vez disso, elas são vistas, por um lado, como enunciados teóricos poderosos sobre uma configuração histórica de relações de classe particular, e, por outro lado, como desafios à conceitualização e avaliação imaginativas de mudanças sucessivas e significativas dessa configuração.

Assim, Giddens tem várias dívidas com os clássicos. Ele tratou os escritos deles como "ombros de gigantes" em três sentidos: ele os usou como uma "barra de exercícios" com a qual desenvolveu seus próprios músculos; ele se fez visível ao endereçar sua própria plateia da altura de seu próprio entendimento sofisticado destes escritos; finalmente, a partir dessa altura ele tentou olhar além dos próprios horizontes em que esses textos se inscreveram para objetos da experiência socio-histórica - as "sociedades avançadas" da segunda metade do século XX - que esses escritos simplesmente não podiam imaginar, já que não existiam quando eles foram redigidos. Este último uso exigente e ousado que Giddens fez dos clássicos foi assinalado pelos títulos de dois de seus livros: Novas regras do método sociológico [Giddens, 1976] e

\footnotetext{
3 "Pontos de referência". (N.T.)
} 
Uma crítica contemporânea do materialismo histórico [Giddens, 1981]. A "Introdução" de seus Estudos de teoria social e política [Giddens, 1977] enuncia o programa resultante como se segue:

"É hora de transcender os termos de referência nos quais o debate entre a teoria da sociedade industrial e a teoria marxista tem ocorrido, que são derivados da experiência das sociedades europeias no século XIX e no início do XX" [Giddens, 1977:18].

Mas Giddens só pôde se endividar com os clássicos no grau que eu sugeri porque os absorveu de forma distintamente vigorosa e imaginativa - graças à qual ele (um pouco mais figurativamente) tornou-se credor dos clássicos.

\section{A dívida dos clássicos com Giddens}

As visitas/confrontações de Giddens com os clássicos ocorreram numa base textual notavelmente ampla e sólida. Auxiliado por sua própria familiaridade com o alemão e o francês, infelizmente tão rara entre acadêmicos britânicos e americanos, Giddens teve acesso, particularmente em Capitalismo e teoria social moderna [Giddens, 1971a] a textos de Marx, Durkheim e Weber (e de seus comentadores) utilizados anteriormente apenas por especialistas. Uma das forças de seu Émile Durkheim: Textos selecionados [Giddens, 1972a], assim como a de um volume mais recente de seleções dos escritos políticos de Durkheim, era que ele utilizou - quando apropriado - vários textos relativamente obscuros. Desta forma, leituras (ou erros de leitura) anteriores deste ou daquele autor (ou deste ou daquele assunto em seus textos) feitas por outros expositores e comentadores filologicamente menos equipados foram peremptoriamente moderadas, melhoradas - ou refutadas - por Giddens.

A esta capacidade de detectar, interpretar e dominar uma quantidade enorme de materiais relevantes - uma capacidade que a partir de meados dos anos 1970 Giddens utilizou de forma excelente também para monitorar e comentar a cena da teoria social contemporânea da Europa continental - Giddens adiciona uma facilidade igualmente invejável de expor de forma compacta, bem organizada e lúcida. A melhor evidência disto está em Capitalismo e teoria social moderna. Mais de quinze anos depois de minha primeira leitura, eu continuo impressionado pelo feito deste livro de comprimir em 250 páginas descrições (que ainda me parecem) razoavelmente compreensivas e 
detalhadas do pensamento de Marx, $e$ Durkheim, $e$ Weber, e mais uma sequência de exercícios de "comparação e contraste" envolvendo estes autores ao redor de uma seleção imaginativa de tópicos significativos.

Eu tenho a sensação de que o estatuto canônico inatacável de serem os Grandes da Sociologia que Karl, Émile e Max parecem possuir estes dias, em todos os lugares, é em grande parte o resultado do sucesso desse livro, e sinaliza da mesma forma a dívida dos clássicos com Giddens. Esses três clássicos, aliás: pois eu muitas vezes lamento que o mesmo estatuto pareça não valer para Alexis, Georg e Vilfredo (e talvez para George Herbert e Sigmund? $)^{4}$ e me pergunto se esse livro talvez não tenha sido, de forma certamente não intencional, uma espécie de obstáculo a uma visão mais ampla da herança intelectual da sociologia.

De qualquer forma, o trio canônico (apesar de, em menor escala, isto também se aplicar a outros autores tratados menos frequentemente por Giddens, como Comte) se beneficiou também do esforço de Giddens em posicioná-los historicamente, construí-los como pensadores que lidavam, antes de qualquer outra coisa, com aquilo que consideravam os problemas sociais e políticos dominantes de suas próprias sociedades, e que propunham uma solução distinta e inevitavelmente interessada a esses problemas.

Sem gastar, até onde sei, muita energia no debate dos últimos quinze a vinte anos sobre as formas apropriadas de ler os grandes teóricos sociais e políticos do passado, Giddens discretamente assumiu uma posição intermediária entre os dois extremos do debate. Ele não leu os escritos de seus autores como sendo capazes de serem entendidos e interpelados puramente como Grandes Obras Atemporais, nem se ocupou de uma reconstrução detalhada das circunstâncias biográficas e históricas específicas de seus escritos e da literatura intelectual e jornalística relacionada. Ele identificou problemas amplos comuns a todas as sociedades ocidentais do final do século XIX e início do XX - industrialização e conflito de classes, secularização e o papel crescente do Estado - assim como alguns mais específicos a contextos nacionais individuais, e enxergou seus autores lidando com eles; mas não a ponto de esquecer uma sensibilidade às reivindicações de validade intrínseca e às vezes de significância universal que esses autores ocasionalmente faziam para suas próprias preocupações, abordagens e posições substantivas distintas. Quando, por exemplo, na "Introdução"

\footnotetext{
${ }^{4}$ Alexis de Tocqueville, Georg Simmel, Vilfredo Pareto, George Herbert Mead e Sigmund Freud. (N.T.)
} 
que já citei, Giddens identifica "o impulso dominante das preocupações (de Weber)" como "uma tentativa de produzir uma versão retrabalhada do liberalismo político num contexto político hostil a princípios liberais tradicionais" [Giddens, 1977:21], ele reconhece, dessa forma, tanto o enraizamento do pensamento de Weber em circunstâncias nacionais distintivas e sua orientação constante e atormentada a um complexo de ideias e de práticas institucionais mais amplo - com o qual, incidentalmente, Giddens afirma que os outros dois grandes autores também tiveram que se relacionar de alguma forma. Entretanto, tais ideias e práticas são por sua vez implicitamente consideradas como representando opções distintivas e carregadas de interesse, e não conjuntos de ideais platônicos e atemporais.

Até aqui, eu construí "a dívida dos clássicos com Giddens" como resultado daquelas que poderiam ser consideradas as propriedades formais de sua contribuição à história do pensamento social: uma base textual particularmente extensa e sólida; uma capacidade diferenciada de realizar relatos compreensivos e compactos de autores ou escritos individuais; uma atenção constante ao contexto histórico desses autores e escritos, que, entretanto, não historiciza demais nosso próprio interesse neles. (Talvez fosse possível adicionar uma atenção igualmente constante às escoras metodológicas de nível superior de vários autores e escritos, particularmente evidente no retorno frequente de Giddens ao assunto do positivismo.) Mas e a substância dessa contribuição? Que diferença Giddens fez ao nosso entendimento desses teóricos sociais do passado que ele discutiu, e particularmente do trio canônico?

Eu me sinto incapaz de dar a esta pergunta difícil a resposta minuciosamente refletida e bem informada que ela merece, porque, entre outras razões, fazer isto exigiria "comparar e contrastar" as contribuições de Giddens com os principais comentários não só da época em que foram escritos mas também subsequentemente. Eu me contentarei em relatar as principais impressões que tive de minha recente releitura dos textos mais relevantes de Giddens, à maioria dos quais eu já me referi.

\section{Giddens sobre Marx e Weber}

A impressão dominante é a da validade contínua (e não apenas “em sua época") das contribuições de Giddens. Relido vinte anos depois de sua publicação, por exemplo, 
o ensaio sobre Marx, Weber e as origens do capitalismo mais uma vez me pareceu convincentemente afiado e "no alvo", apesar do fato de que conheço várias discussões posteriores desse mesmo tópico. Na verdade, apresentações mais recentes de outros autores sobre as "relações Marx/Weber" mais amplas que, ao lê-las, me pareceram particularmente válidas, acabaram sendo em grande parte antecipadas por esse ensaio de 1970 e amplificadas em Capitalismo e teoria social moderna. Nesse trabalho, em especial, Giddens utiliza particularmente bem sua distinção entre o que Weber pensava sobre Marx (ou às vezes sobre ideias que ele não sabia que Marx tinha) e o que ele pensava sobre o marxismo. Entretanto, eu tenho algumas reservas em relação às opiniões de Giddens sobre "Marx versus Weber sobre a desigualdade social", estando entre aqueles que - talvez de forma simplista - sentem que Weber diferia de Marx muito, muito mais por adicionar "Stand" e "partido" à "classe" do que em sua construção do último conceito.

Eu não estou atualmente muito au fait com a literatura marxológica, e não sei até que ponto aquilo que originalmente considerei e ainda considero como a reconstrução inteligente e sólida de Giddens do pensamento do próprio Marx é ecoado, moderado ou refutado nos trabalhos contemporâneos. Minha aposta é que, agora que a loucura althusseriana passou, a probabilidade dessa reconstrução de informar e inspirar o leitor é ainda maior, pelo menos quando se trata de localizar e avaliar a importância sociológica do pensamento de Marx e sua relação aos outros clássicos. Por sua vez, os dois volumes de Giddens da "crítica contemporânea ao materialismo histórico" devem ser considerados como algumas das entradas mais significativas no corpo de literatura grande e crescente que pretende fazer tal crítica; mas seu conteúdo estritamente marxológico é relativamente pequeno.

Por outro lado, ao reler Giddens para este exercício, eu também acabei lendo, por outras razões, várias adições recentes ao corpo sempre crescente de estudos weberianos. Mais uma vez posso apenas relatar uma impressão dupla desta "leitura cruzada" (por assim dizer). Por um lado, grande parte da obra atual parece confirmar a relevância da perspectiva apresentada por Giddens em seu livrinho sobre a política e sociologia de Weber [Giddens, 1972b], apesar dele na época ter assumido o que poderíamos chamar de uma visão geral macroscópica dessa perspectiva, que desde então foi adotada em muitos trabalhos no nível microscópico. Por outro lado, nas décadas de 1970 e 1980, tanto o debate alemão sobre a unidade temática (se é que ela 
existe) da obra de Weber quanto a discussão (relacionada) de suas pressuposições e implicações morais e filosóficas parecem ter sugerido perguntas e proposto respostas que mereceriam uma consideração mais próxima em qualquer revisita de larga escala do pensamento de Weber do que receberam de Giddens até agora.

\section{Giddens sobre Durkheim: o desafio a estudos convencionais}

“Giddens sobre Durkheim” é um assunto mais complexo. Uma vez mais, não acompanho a literatura secundária relevante hoje em dia, e basearei os comentários seguintes principalmente em minha releitura dos textos de Giddens relevantes. Estes textos são numerosos e significativos, pois apesar de eu já ter visto Giddens ser chamado de neomarxista ou de neoweberiano em seu pensamento substantivo, mas nunca de neodurkheimiano, eu não tenho dúvida de que em seu trabalho como historiador do pensamento social ele desempenhou um papel mais distinto e significativo como um comentador de Durkheim, e não de Marx ou Weber; e de que ele teve um impacto mais profundo e (espero) mais duradouro nos estudos de Durkheim do que nos de Marx ou Weber.

Desde o começo, a contribuição de Giddens aos estudos de Durkheim foi caracterizada - e, podemos supor, motivada - por sua orientação polêmica para o que ele enxergava como uma visão convencional em grande parte insustentável do conteúdo e intenção da vida de Durkheim: visão essa proposta mais completamente na teoria da ação social de Parsons, e articulada mais eloquentemente em vários escritos de Robert Nisbet. Além do mais, essa visão tornara-se central a um entendimento mais amplo da própria natureza da sociologia, dos impulsos históricos por trás de suas origens, da importância ideológica contínua da disciplina. Esse entendimento, largamente compartilhado tanto por defensores quanto opositores da sociologia, foi atacado por Giddens, que o considera em grande parte mitológico; e a principal investida do ataque se constituiu numa reconsideração extensa, imaginativa e esmerada do corpus inteiro dos escritos de Durkheim.

Giddens desafiou a noção amplamente aceita de que o pensamento de Durkheim era intrinsecamente conservador, por causa de sua preocupação prevalente com o "problema da ordem" e seu compromisso obstinado em obter uma solução normativa e 
consensual a esse problema. Em vez disso, ele enfatizou o esforço persistente de Durkheim de projetar intelectualmente, e ajudar a estabelecer pragmaticamente, conjuntos de instituições que ordenariam o processo social sob condições especificamente modernas de divisão do trabalho avançada, diferenciação cultural, secularização, pluralismo de interesses, abertura a mudanças. Ele focou sua atenção na orientação direta e explícita a este problema na Divisão do trabalho social, uma obra cuja importância havia sido menosprezada por intérpretes anteriores.

Estes últimos haviam afirmado que obras posteriores mostraram o domínio cada vez maior na mente de Durkheim de uma convicção de que, sob quaisquer condições sociais, a deriva agourenta para a desordem hobbesiana só pode ser contra-atacada se os participantes absorverem e concordarem com entendimentos compartilhados daquilo que é verdadeiro e apropriado; tais entendimentos precisavam ser moldados, e periodicamente revisitados, através da autoidolatria da sociedade em rituais, e sistematicamente mantidos e afirmados por todas as instituições.

Em vez disso, Giddens afirmou, com boa base textual, que a dicotomia entre solidariedade mecânica e orgânica fundamentou partes dessas obras posteriores, particularmente aquelas que apresentaram as repetidas aventuras de Durkheim na engenharia social de gabinete. Estes textos mostraram, em particular, por um lado a preocupação específica de Durkheim com as necessidades e potencialidades do contexto social contemporâneo, e por outro lado sua orientação política-ideológica predominantemente liberal, e não conservadora. Eles também mostraram que Durkheim estava alerta aos problemas da esfera pública moderna que não podiam ser acomodados no (mau) entendimento anterior das preocupações e orientações predominantes de Durkheim.

Se eu me perguntar quid sentiam ${ }^{5}$ sobre o esforço motivado e poderoso de reinterpretação do pensamento de Durkheim, e de suas interpretações anteriores, realizado por Giddens em vários livros e ensaios, minha recente releitura desses escritos sugere uma resposta que eu gostaria de considerar nuancée, mas que outros podem rotular de insípida. Eu certamente sinto que, como já sugeri, nosso entendimento de Durkheim foi irreversivelmente afetado e consideravelmente melhorado por esse esforço. Porém, deixem-me enfatizar que falo apenas de uma "sensação", devido a,

\footnotetext{
5 "O que sinto". (N.T.)
} 
como já confessei, minha pouca familiaridade com estudos de Durkheim pós-Giddens. Além do mais, minha própria revisita à contribuição de Giddens sugeriu várias pequenas ressalvas, e uma grande.

\section{Giddens sobre Durkheim: algumas pequenas ressalvas}

Permitam-me dar alguns exemplos das pequenas ressalvas, todas elas apontando para omissões nas descrições de Giddens sobre o pensamento de Durkheim que me parecem difíceis de justificar. Dado que Giddens provavelmente contribuiu várias centenas de páginas aos estudos de Durkheim, é incômodo que ele não tenha confrontado adequadamente, pelo que posso julgar, os seguintes três temas.

Primeiro, Giddens segue sem questionamentos a prática questionável de Durkheim de usar o termo "moral" como se ele possuísse um significado unívoco. Nos próprios escritos de Durkheim ele significa três coisas em momentos diferentes: moral=humano (contra natural, animal), mental, consciente; moral=envolvendo obrigação sancionada institucionalmente; moral=envolvendo a aceitação e resignação conscientes de um sujeito à superioridade intrínseca de reivindicações superiores às suas. Cada significado é um subconjunto do anterior; mas Durkheim não os diferencia suficientemente - e nem Giddens (apesar dele ter, por exemplo, "desembalado" os significados de termos durkheimianos relacionados como "exterioridade" e "sanção").

Segundo, entre os textos de Durkheim que buscam caracterizar a condição moderna, alguns sugerem uma tentativa potencialmente promissora de mapear as formas pelas quais, com o progresso da modernidade, os vários domínios da atividade social mudam em suas relações uns com os outros, estendendo ou diminuindo a quantidade de paisagem social que eles ocupam e ganhando ou perdendo centralidade em relação aos outros. Por exemplo, na minha leitura de Durkheim, muitos problemas sociais modernos característicos estão associados ao fato de que o domínio do trabalho e da economia - um domínio que para Durkheim é distintamente anômico, principalmente por causa de sua profanidade intrínseca, e sua receptividade à mudança - acabam ocupando uma posição muito maior $e$ muito mais central na paisagem social moderna do que em sociedades anteriores. Isto significa que no próprio coração da sociedade moderna há um enorme pântano institucional, que Durkheim espera que 
possa ser drenado e tornado navegável através de operações de engenharia social apropriadas. Este imaginário inspirador (para mim) da modernidade, seus problemas e soluções possíveis não são ecoados adequadamente nas apresentações de Giddens do pensamento de Durkheim.

Finalmente, eu sinto que, estritamente em termos de história intelectual, Giddens não se perguntou que relações existem (se for o caso) entre o pensamento de Durkheim e as versões francesas (e italianas) da teoria da sociedade de massas na virada do século XX.

\section{Giddens sobre Durkheim: uma grande ressalva}

Mas estas objeções tratam de aspectos relativamente periféricos da reconstrução de Giddens do pensamento de Durkheim. Seu tema central - a afirmação vigorosa de que Durkheim estava preocupado de forma muito mais persistente e significativa com as características e problemas distintivas da sociedade moderna do que com as características e problemas genéricos de todas as sociedades - levanta a seguinte questão. Essa afirmação pode ser correta, mas quanto se ganha, fora de um sentido puramente exegético, ao se enfocar aquelas preocupações de Durkheim em vez destas? Será que aprendemos muito de importância considerável e distinta ao encarar Durkheim principalmente como um teórico da sociedade moderna? Estamos prestando um serviço a ele se o tratarmos dessa forma?

Minha sensação é de que Giddens teve sucesso ao forçar nossa atenção a aspectos significativos da oeuvre de Durkheim que haviam sido indevidamente negligenciados, menosprezados ou entendidos incorretamente por comentadores anteriores, e particularmente aqueles que propuseram a visão convencional da obra de Durkheim - aspectos que expressavam a preocupação de Durkheim de identificar as características institucionais distintivas da sociedade moderna. (Estou pensando, por exemplo, na visão de Durkheim da importância moral do individualismo, enfatizada de forma tão atraente por Giddens.) Entretanto, de modo geral Giddens superestimou a validade e relevância substanciais e permanentes de seu Durkheim enquanto teórico da sociedade moderna. 
A apresentação de Giddens do pensamento de Durkheim, apesar de alguns "pontos perdidos" como os mencionados acima, é compreensiva e penetrante o bastante para sugerir, ainda que de forma não sistemática e voluntária, várias fraquezas muito consideráveis e danosas do pensamento de Durkheim, em vista das quais não podemos dizer que Durkheim contribuiu para a teoria da sociedade moderna de forma sequer remotamente comparável em importância intrínseca às de Marx e Weber.

Eu não tenho como tentar um argumento apropriadamente detalhado e rigoroso a este respeito aqui. Oferecerei apenas alguns pontos dispersos de importância variável. Para começar, o que Durkheim está fazendo num livro chamado CAPITALISMO e teoria social moderna? Ele não parece ter empregado nem discutido o conceito de “capitalismo" de forma sistemática. É verdade que, como Giddens nos lembra, há uma importante conceitualização alternativa do aspecto distintivo da condição social moderna - a "sociedade industrial"; mas Durkheim também não a considerou e desenvolveu seriamente. (É difícil de retirar de sua oeuvre qualquer impressão da mudança da paisagem produtiva da sociedade europeia, talvez porque tais mudanças fossem um pouco menos profundas na França de sua época do que na Inglaterra ou na Alemanha.)

Além do mais, a maioria dos ovos teóricos de Durkheim, quando se trata de explicar a mudança social, foram colocados na cesta do desenvolvimento da divisão do trabalho. Mas mesmo seu entendimento desta é altamente defeituoso; para começar, ele não oferece nenhum reconhecimento e tratamento sistemáticos da distinção entre divisão do trabalho social e técnica. Outras "falhas de conceitualização" danosas, mais ou menos associadas com a anterior, têm a ver, por exemplo, com a natureza e papel dos mercados, ou a distinção entre sistemas de estratificação baseados em classes ou status.

Giddens parece rebater bem a afirmação de Nisbet que, mesmo na própria Divisão do trabalho, a distinção entre solidariedade mecânica e orgânica desmorona inadvertidamente devido à convicção crescente de Durkheim da importância anterior e necessidade continuada da primeira. Mas é difícil entender por que, se essa distinção realmente permaneceu tão central ao pensamento de Durkheim como Giddens insiste, ela aparece tão pouco depois da Divisão do trabalho. Além disso, a obra de Durkheim mostra outros casos de dicotomias propositalmente agudas e importantes que desabam enquanto seu pensamento avança. Isto acontece, no Suicídio, com a distinção entre os 
aspectos associativos e reguladores da vida coletiva, introduzida para apoiar a distinção entre egoísmo e anomia. E também não existe a suposta summa divisio entre sagrado e profano, nas Formas elementares e outros textos. Durkheim caracteriza a religião como o conjunto das manières d'agir et de penser ligadas ao domínio sagrado; mas o que acontece é que a própria divisão entre o sagrado e o profano é sagrada; assim, a religião leva tudo.

$\mathrm{Na}$ própria Divisão do trabalho - uma obra cuja importância Giddens corretamente enfatizou - muitas das dificuldades que afligem a concepção de sociedade moderna de Durkheim (nessa obra e em textos posteriores) resultam de um fato de evidência tão óbvia que, de alguma forma, a maioria dos comentadores, incluindo Giddens, ignorou completamente sua importância. O fenômeno-chave escolhido para receber atenção e sobre o qual todo o peso teórico é colocado - o desenvolvimento de formas de divisão de trabalho que não sejam aquelas primordiais em termos exclusivamente de idade e sexo - não tem nada a ver com a modernidade enquanto tal; ele é anterior ao advento da modernidade, qualquer que seja nossa concepção dela, por inúmeras gerações, pois seu local original é, suponho, a revolução neolítica. É verdade que esse desenvolvimento continuou indefinidamente depois disso: mas, pelo mesmo motivo, a utilidade analítica do construto relacionado se tornou cada vez menor. Para parafrasear Hegel sobre Schelling, a divisão do trabalho de Durkheim, se aplicada à modernidade, se torna como uma noite em que todas as vacas são indiferentemente diferentes; ela simplesmente não consegue abranger o caráter distintivo e a ênfase peculiar da passagem para a modernidade. Uma indicação significativa disto é o fato que Luhmann, talvez o autor contemporâneo que (seguindo Parsons) mais tenha utilizado a ênfase de Durkheim (e Spencer) na diferenciação como a tendência principal da evolução social, substituiu a própria dicotomia de Durkheim com uma sucessão de três modos de diferenciação primários: segmental, hierárquico, funcional.

Em suma, Giddens desafiou a visão convencional sobre Durkheim ao mostrar que aspectos de seu pensamento considerados recessivos nessa visão merecem, em vez disso, ser tratados como dominantes. Esta operação foi ao mesmo tempo certa e errada: certa ao desenvolver aquela que provavelmente é uma apresentação mais correta da intenção e conteúdo da obra de Durkheim; errada ao diminuir, por causa disso, nossa sensação das realizações de Durkheim, que melhora muito se reenfatizarmos em sua obra os temas e abordagens propositalmente depreciados pelo próprio Giddens. Neste 
sentido, Durkheim não foi homenageado apropriadamente por Giddens, apesar da amplitude e profundidade de sua leitura.

\section{Conclusão}

Voltando ao "imaginário da dívida": qualquer que seja o saldo entre o que Giddens deve aos clássicos e o que os clássicos devem a Giddens, este se tornou credor de todos aqueles entre nós que, constante, periódica ou ocasionalmente, se voltam aos clássicos em busca de inspiração.

\section{Bibliografia}

GIDDENS, A. [1968] "Power' in the Recent Writings of Talcott Parsons", in Sociology, v. 2, pp. 257-272.

GIDDENS, A. [1970] "Marx, Weber and the Development of Capitalism", in Sociology, v. 4, pp. 289-310.

GIDDENS, A. [1971a] Capitalism and Modern Social Theory. Cambridge: Cambridge University Press.

GIDDENS, A. [1971b] “The 'Individual' in the Writings of Émile Durkheim”, in Archives Européenes de Sociologie, v. 12, n. 2, pp. 210-228.

GIDDENS, A. [1972a] Émile Durkheim: Selected Writings. Cambridge: Cambridge University Press.

GIDDENS, A. [1972b] Politics and Sociology in the Thought of Max Weber. London: Macmillan.

GIDDENS, A. [1973] The Class Structure of the Advanced Societies. London: Hutchinson.

GIDDENS, A. [1976] New Rules of Sociological Method. London: Hutchinson.

GIDDENS, A. [1977] Studies in Social and Political Theory. London: Hutchinson.

GIDDENS, A. [1981] A Contemporary Critique of Historical Materialism. London, Macmillan. 


\section{William Outhwaite - Ação e estrutura}

"A tentativa de formular um relato coerente da agência humana e da estrutura exige (...) um esforço conceitual muito considerável." [Giddens, 1984:xxi]

A oposição entre "ação" ou "agência" e "sistema" ou "estrutura" é uma das mais penetrantes na tradição inteira da teoria social. Alan Dawe coloca o assunto de forma muito clara:

"Então, numa sociologia do sistema social, os atores sociais são retratados como estando basicamente na posição de receptores do sistema social. Em termos de sua existência e natureza enquanto seres sociais, seu comportamento e relações sociais, e seu próprio sentido de identidade pessoal enquanto seres humanos, eles são determinados pelo sistema. O processo os socializa nos valores centrais da sociedade e nas normas apropriadas para os papéis que eles devem desempenhar na divisão do trabalho (...) A ação social é então completamente o produto e derivado do sistema social.

Em oposição completa a isto, uma sociologia da ação social concebe o sistema social como derivado da ação e interação sociais, um mundo social produzido por seus membros, que são assim retratados como seres ativos, com propósitos, e criativos individual e socialmente" [Dawe, 1978:366-367] $]^{1}$.

Um dos principais temas da teoria da estruturação de Giddens é a tentativa de transcender este dualismo através da "dualidade da estrutura", na qual "as propriedades estruturais dos sistemas sociais são tanto o meio quanto o resultado das práticas que elas organizam recursivamente" [Giddens, 1984:25]. Seu relato é melhor entendido em oposição a um conjunto de identificações que tenderam a organizar discussões anteriores desta oposição.

Primeiro, e mais importante, a estrutura não deve ser identificada apenas com coerção: "as propriedades estruturais dos sistemas sociais devem, em vez disso, ser vistas como coercivas e permissivas a respeito da ação humana” [Giddens, 1982:30]. “Coerções estruturais não operam independentemente dos motivos e razões que os

\footnotetext{
${ }^{1}$ Para uma discussão importante, ainda que hoje um tanto fora de moda, destes assuntos na França ver Gurvitch [1963].
} 
atores têm para aquilo que fazem" [Giddens, 1984:181]. Segundo, a distinção entre ação e estrutura não deve ser identificada com a distinção micro/macro: por que deveríamos pressupor que "a estrutura só é relevante para questões macrossociológicas? (...) a atividade em microcontextos tem propriedades estruturais definidas fortemente" [Giddens, 1984:141]. Terceiro, a ação não deve ser definida em termos de intenção. "A ação não se refere às intenções que as pessoas têm ao fazer coisas, mas à sua capacidade de fazer essas coisas, antes de tudo. Não devemos confundir 'a monitoração constante da ação que indivíduos realizam' com 'as propriedades definidoras dessa ação enquanto tal"" [Giddens, 1984:9]. Quarto, estrutura(s) e sistemas não são a mesma coisa: "estruturas" existem enquanto regras e recursos, e enquanto propriedades de "sistemas" ordenados de relações sociais [Giddens, 1984:377].

Recuemos um pouco destas distinções conceituais. As duas últimas, que podem à primeira vista parecer meramente terminológicas, marcam uma característica fundamental do relato da estruturação de Giddens, a saber, sua radicalização do conceito de ação. Giddens leva muito a sério o princípio, anteriormente anunciado apenas no interacionismo e na etnometodologia ${ }^{2}$, que a "sociedade" deve ser vista como uma realização de agentes que têm um bom conhecimento daquilo que estão fazendo (ou seja, eles não são, na frase clássica de Garfinkel, "patetas culturais"). Daí, 1) sua ênfase na monitoração reflexiva da ação; 2) seu conceito de estrutura como regras seguidas por seres humanos ativos, e recursos usados por eles; 3) seu relato da coerção estrutural como na passagem citada acima, que continua: "As propriedades estruturais dos sistemas sociais não agem, nem 'agem sobre' qualquer pessoa como forças da natureza para 'compeli-la' a se comportar de qualquer forma em particular” [Giddens, 1984:181].

\section{Acionalismo}

Eu sugeri anteriormente que Giddens "radicaliza" o conceito de ação. Depois argumentarei que ele faz o mesmo com "estrutura" e "sistema". Em outras palavras, sua estratégia é oposta àquela adotada por Parsons, que começa com um conceito "voluntarista" de ação mas o atenua imediatamente, colocando-o como uma propriedade do sistema. Será útil, em primeiro lugar, examinar mais detalhadamente a teoria da ação e agência de Giddens, antes de nos voltarmos a seus conceitos de estrutura e sistema.

\footnotetext{
${ }^{2}$ Sobre a relação de Giddens com a etnometodologia, ver particularmente Giddens [1977].
} 
As discussões mais substanciais de Giddens sobre ação e agência são encontradas em Giddens [1976; 1979:cap. 2; 1984]. Mais uma vez, podemos começar nos livrando de duas razões para focar a ação que não são as razões de Giddens. Uma é a reivindicação epistêmica de que a ação é tudo que podemos observar diretamente. Giddens corretamente rejeita, ou pelo menos coloca em segundo plano, as preocupações epistemológicas que dominam o pensamento ocidental desde Descartes ${ }^{3}$.

“(...) a concentração em questões epistemológicas desvia a atenção de preocupações mais 'ontológicas' da teoria social, e é nelas que a teoria da estruturação se concentra primariamente. Em vez de se preocupar com disputas epistemológicas (...) eu sugiro que aqueles que trabalham na teoria social deveriam se preocupar antes de tudo em retrabalhar concepções do ser humano e do fazer humano, da reprodução social e da transformação social" [Giddens, 1984:xx].

Este giro ontológico, que encontra um paralelo no "realismo transcendental" de Roy Bhaskar, não significa que Giddens defende a importância da ação porque apenas indivíduos e suas ações são reais [Giddens, 1984:163, 213-21]: “Os pretensos estudos 'microssociológicos' não lidam com uma realidade que é de alguma forma mais substancial do que aquela tratada pela análise "macrossociológica" [Giddens, 1984:xxvi].

Ao mesmo tempo, ele mantém a posição acionalista fraca de que o indivíduo e a atividade coletiva têm algum tipo de lugar privilegiado na teoria social. Como diz Giddens em sua discussão sobre a polêmica entre E. P. Thompson e Perry Anderson:

"Toda investigação de pesquisa nas ciências sociais ou na história envolve relacionar a ação à estrutura, traçar, explicitamente ou não, a conjunção ou disjunções das consequências intencionais e não-intencionais da atividade e como elas afetam os indivíduos. Nenhum malabarismo com conceitos abstratos pode substituir o estudo direto de tais problemas nos contextos efetivos de interação" [Giddens, 1984:219].

Eu voltarei a esta concepção posteriormente, ao defender a teoria da estruturação de Giddens contra teorias de morfogênese. Por enquanto, devemos notar duas outras características da teoria da ação de Giddens: primeiro, o que chamarei de "modelo de fluxo"; segundo, a conexão que ele estabelece entre ação e poder. O modelo de fluxo é

\footnotetext{
${ }^{3}$ No contexto da teoria social elas são relevantes, primeiro na forma do empirismo lógico, e segundo em várias teorias pós-empiristas recentes, sejam elas neo-instrumentalistas na tradição analítica, ou estruturalistas e pós-estruturalistas num modo de filosofia mais continental.
} 
uma tentativa de ir além da preocupação, na fillosofia analítica da ação, com "o fornecimento de descrições de atos" [Giddens, 1984:9] definido em termos de intenções reificadas.

"A ação humana ocorre como uma durée, um fluxo contínuo de conduta, como a cognição. A ação proposital não é composta de um agregado de intenções, razões e motivos separados. Assim, é útil falar da reflexividade como algo baseado na monitoração contínua da ação que os seres humanos exibem e esperam que os outros exibam (...) A 'ação' não é uma combinação de 'atos': 'atos' são constituídos apenas por um momento discursivo de atenção à durée da experiência vivida. E a 'ação' também não pode ser discutida separada do corpo, suas mediações com o mundo ao seu redor e a coerência de um eu ativo. O que chamo de modelo de estratificação do eu ativo envolve tratar a monitoração reflexiva, a racionalização e a motivação da ação como conjuntos implantados de processos" [Giddens, 1984:3].

A teoria do poder de Giddens está ligada logicamente a este modelo de ação. Ele insiste que agir é ser capaz de agir de outra forma:

"Ser capaz de 'agir de outra forma' significa ser capaz de interferir no mundo, ou de se abster de tal interferência, com o efeito de influenciar um processo ou estado de coisas específico. Isto pressupõe que ser um agente é ser capaz de direcionar (...) um conjunto de poderes causais, incluindo aquele de influenciar os poderes direcionados por outras pessoas. A ação depende da capacidade do indivíduo de 'fazer diferença' em um estado de coisas ou curso de eventos preexistente. Um agente deixa de sê-lo se ele ou ela perder a capacidade de 'fazer diferença', ou seja, de exercer algum tipo de poder" [Giddens, 1984:14].

O poder não é apenas uma grande preocupação na macrossociologia de Giddens, e particularmente na sua crítica do marxismo; a noção realista de poderes causais é (corretamente) utilizada bem no começo de sua descrição da ação. O poder, como a ação, não deve ser definido em termos de intenções, já que neste sentido amplo de capacidade transformadora ele é "logicamente anterior à subjetividade" [Giddens, 1984:15]. "Nesta concepção, o uso do poder não caracteriza tipos específicos de conduta, e sim toda a ação, e o poder não é propriamente um recurso. Recursos são meios através do qual o poder é exercido, como um elemento rotineiro da instanciação da conduta na reprodução social" [Giddens, 1984:15-16]. Finalmente, esta descrição da 
ação e do poder coloca limites, mais uma vez, à noção de coerção. Como foi notado anteriormente, Giddens rejeita teorias da coerção expostas em termos naturalistas:

“(...) circunstâncias de coerção social em que indivíduos 'não têm escolha' não devem ser igualadas com a dissolução da ação enquanto tal. 'Não ter escolha' não significa que a ação foi substituída pela reação (como quando uma pessoa pisca quando ocorre um movimento rápido perto dos olhos). Isto pode parecer tão óbvio a ponto de não precisar ser dito. Mas algumas escolas muito importantes de teoria social, associadas principalmente com o objetivismo e a 'sociologia estrutural', não reconheceram esta distinção. Elas pressupõem que coerções operam como forças na natureza, como se 'não ter escolha' fosse equivalente a ser impulsionado irresistível e incompreensivelmente por pressões mecânicas" [Giddens, 1984:15].

Ele segue:

"Não devemos conceber as estruturas de dominação estabelecidas nas instituições sociais como se moessem 'corpos dóceis' que se comportam como os autômatos sugeridos pela ciência social objetivista. $\mathrm{O}$ poder nos sistemas sociais que desfrutam de alguma continuidade no tempo e no espaço pressupõe relações regularizadas de autonomia e dependência entre atores ou coletividades em contextos de interação social. Mas todas as formas de dependência oferecem alguns recursos através dos quais aqueles que são subordinados podem influenciar as atividades de seus superiores. Isto é o que chamo de dialética do controle em sistemas sociais" [Giddens, 1984:16].

Eu citei extensamente as páginas acima porque elas abrem, de várias formas, as questões de estrutura que nos preocuparão na próxima seção. Entretanto, antes de discuti-las de modo formal, mencionarei algumas implicações práticas que Giddens retirou de seu modelo.

Em vários lugares, e em relação a vários exemplos bem conhecidos de trabalho sociológico, Giddens desenvolve o tema de que os atores não são nem tão mistificados, nem tão impotentes como eles muitas vezes são apresentados. Contra as concepções da burocracia como uma jaula de aço de Max Weber, Giddens afirma que relações de autoridade formal podem criar formas para lográ-las [Giddens, 1979:147]. Ele sugere que a descrição do taylorismo de Braverman subestima a capacidade dos operários de perceber e resistir a práticas administrativas. De forma mais geral, o contrato de trabalho capitalista pode ser voltado a favor dos operários quando eles interrompem seu trabalho coletivamente [Giddens, 1979:149-150]. Uma sensibilidade para a habilidade 
cognitiva dos seres humanos pode desvendar várias técnicas de resistência em fábricas, escolas e outras instituições autoritárias que são invisíveis para uma sociologia que trata atores humanos como marionetes de estruturas sociais.

Este conceito da "dialética do controle" também é central para a descrição de Giddens da democracia de massa nos estados modernos. Correndo o risco de simplificar demais um argumento complexo e com camadas múltiplas, podemos dizer que enquanto os estados camponeses do antigo regime deixavam suas populações em grande parte a seus afazeres tradicionais, invadindo-as de forma mais ou menos regular para propósitos fiscais ou militares [Giddens, 1985:76ff.], o Estado moderno precisa praticar uma vigilância muito mais intensiva, gerando "controle sobre as vidas cotidianas do populacho" [Giddens, 1985:323]. Uma forma disto é a ditadura totalitária; outra é a poliarquia democrática liberal, baseada na diferenciação institucional e em vários tipos de direitos de cidadania. Aquela é notoriamente instável; esta forma de governo por consentimento rotinizado fortalece as possibilidades, por exemplo, de contestação por novos movimentos sociais, "orientados para reformar os desequilíbrios do poder envolvido na vigilância" [Giddens, 1985:314].

\section{Estrutura}

Os principais temas da teoria da estrutura de Giddens já foram apresentados de forma sumária. Relações estruturais não devem ser igualadas à coerção, pois elas também são permissivas. De forma mais precisa, elas são permissivas para a ação humana - uma conexão demonstrada por sua definição da estrutura em termos de regras e recursos. A coerção também não deve ser naturalizada, e sim vista como uma coerção sobre práticas, e feita de práticas. "Não são as muralhas que criam uma prisão", e sim as práticas de aprisionamento humanas e modificáveis.

Giddens rejeita a concepção empirista da estrutura como alguma forma de "padronização" de relações sociais observáveis. Ele tem mais simpatia com modelos de estrutura linguística e teorias estruturalistas e "pós-estruturalistas" formuladas em termos de relações mais abstratas de "presença e ausência: códigos subjacentes têm que ser inferidos a partir de manifestações na superfície" [Giddens, 1984:16]. Ao mesmo tempo, ele não gosta do verniz metateórico que tende a acompanhar isto, como a 
"mistura curiosa de nominalismo e racionalismo que Lévi-Strauss parece defender. Eu afirmo que a estrutura tem uma 'existência virtual', enquanto instanciações de momentos; mas isto não é a mesma coisa que identificar a estrutura meramente com modelos inventados por observadores sociológicos ou antropológicos (...) Eu considero os conceitos que formulo abaixo compatíveis com uma epistemologia realista" [Giddens, 1979:63].

Em sua exposição mais recente, e mais sistemática, da teoria da estruturação, Giddens assume uma linha bem mais conciliadora quanto aos conceitos empiristas e estruturalistas de estrutura:

“(...) ambos estão relacionados a aspectos importantes da estruturação das relações sociais, aspectos que, na teoria da estruturação, são compreendidos pelo reconhecimento de uma diferenciação entre 'estrutura' e 'sistema'. Ao analisar relações sociais, temos que reconhecer tanto uma dimensão sintagmática, a padronização de relações sociais no espaço-tempo envolvendo a reprodução de práticas situadas, e uma dimensão paradigmática, envolvendo uma ordem virtual de 'modos de estruturação' implicados recursivamente em tal reprodução. A estrutura, assim, se refere (...) às propriedades estruturantes que permitem a 'ligação' do espaço-tempo em sistemas sociais, as propriedades que possibilitam que práticas sociais discernivelmente similares existam através de distâncias variáveis de tempo e espaço e que dão a elas formas sistêmicas" [Giddens, 1984:17].

Como vimos anteriormente, Giddens define estrutura como regras e recursos, e estruturas como "conjuntos isoláveis de regras e recursos". Isto pode parecer uma definição um tanto estreita, como vários críticos sugeriram [Layder, 1981; Thompson, 1981:144]. Numa resposta implícita a estas críticas, Giddens enfatiza, primeiro, que as regras devem ser entendidas num sentido mais amplo do que o da noção de seguir regras de Winch [1958]: “Consideremos as regras da vida social, então, como técnicas ou procedimentos generalizáveis, aplicados na realização/reprodução de práticas sociais" [Giddens, 1984:21]. Segundo, ele dá uma proeminência maior àquilo que chama "princípios estruturais": "as propriedades estruturais incrustadas mais profundamente". Entretanto, ao mesmo tempo, ele continua a insistir que a "estrutura existe, enquanto presença espaço-temporal, apenas em sua instanciação em (...) práticas [sociais reproduzidas] e como traços de memória orientando a conduta de agentes humanos com habilidade cognitiva" [Giddens, 1984:17]. "A estrutura não tem 
existência independente do conhecimento que os atores têm sobre aquilo que fazem em sua atividade cotidiana" [Giddens, 1984:26].

Definir a estrutura desta forma é, como Giddens nota, empurrar para o conceito de sistema social muito daquilo que "estrutura" quer dizer em outras teorias sociais. Por que esta multiplicação de entidades e distinções sutis, como aquela entre estrutura e propriedades estruturais? Eu sugiro que seja pelo mesmo motivo que Max Weber, seguindo Simmel, preferia o termo "sociação" (Vergesellschaftung) a "sociedade", a saber, para combater a reificação conceitual e manter uma referência forte à ação.

“(...) Sistemas sociais (...) compreendem as atividades situadas de atores humanos, reproduzidas através do tempo e do espaço. Analisar a estruturação de sistemas sociais significa estudar os modos pelos quais tais sistemas, baseados nas atividades cognitivamente hábeis de atores situados que utilizam regras e recursos em diversos contextos de ação, são produzidos e reproduzidos na interação" [Giddens, 1984:25].

O que isto significa na prática, inter alia, emerge na crítica de Giddens de concepções "substantivistas" de, por exemplo, “a economia” ou "a política". Estas muitas vezes são tratadas como sistemas autossuficientes, latentes em sociedades "primitivas" e presentes substantivamente nas modernas, ou definidos em termos abstratos como algo baseado em lutas por recursos. Uma abordagem mais frutífera é distinguir, como faz Giddens, entre recursos de alocação e de autoridade em processos de estruturação [Giddens, 1984:33-34; cf. Outhwaite, 1987]. De forma semelhante, a teoria social deve evitar a reificação das sociedades, definidas pelas fronteiras dos Estados-nação [Giddens, 1981; 1985].

Ficará claro que tenho muita simpatia com o projeto geral de Giddens e sua teoria da ação e estrutura. No restante deste capítulo, discutirei duas linhas possíveis de críticas. Como muitos autores que trabalham neste tópico, Giddens tenta traçar um curso intermediário entre o "desvio para a esquerda" do acionalismo voluntarista e o "desvio para a direita" do estruturalismo reificado. Eu o defenderei primeiro contra a acusação de esquerdismo, já que a maioria das críticas vem nesta direção, e em segundo lugar defenderei sua concepção geral contra a abordagem rival "morfogenética" proposta por Margaret Archer [1982]. 


\section{Muito pouca estrutura}

Eu me referi acima a críticas feitas por John Thompson [1981] e Derek Layder [1981]. Thompson se incomoda com o modelo regra-recurso de estrutura:

"Esta concepção resulta, na minha opinião, em uma diluição indesejável do conceito de estrutura social, já que 'propriedades estruturais' são aparentemente definidas por toda e qualquer 'regra' que os atores empregam; e nesta concepção não parece haver nenhuma base intrínseca para considerar algumas 'regras' mais fundamentais que outras. Além do mais, esta concepção não deixa espaço nenhum para uma análise estrutural das condições e limites nos quais aglomerados particulares de regras e recursos são possíveis. Eu sugiro, então, que o conceito de Giddens de estrutura social pode ser visto mais apropriadamente como uma noção de instituição social, que se aplica às redes de relações sociais em que os agentes estão inseridos. Uma concepção alternativa de estrutura social tem que levar em conta a estabilidade profunda de características estruturais entre os contextos institucionais sempre em transformação em que elas aparecem". [Thompson, 1981:144]

Numa nota de rodapé a esta passagem, Thompson aponta a proeminência cada vez maior na obra de Giddens de conceitos mais estruturais, indicando um afastamento do modelo regra-recurso. (Sua própria alternativa é esboçada em Thompson [1981:174175]).

Layder também se incomoda com a distinção entre sistema/estrutura, que seria “desnecessária e enganosa (...) não há vantagem alguma em tratar 'relações sociais' como algo separável das regras, recursos e estruturas de poder e dominação mais amplas que as baseiam e legitimam" [Layder, 1981:3-4]. Layder também não gosta do foco de Giddens sobre a ação, preferindo contrastar a estrutura à interação: "estruturas são as condições socialmente estruturadas, e às vezes pré-constituídas, da interação, onde o termo 'condições' deve ser entendido como gerador em vez de simplesmente descritivo, mediando elementos do ambiente da interação" [Layder, 1981:4, cf. 62-70; também Clegg, 1979].

Numa comparação breve mas esclarecedora entre Giddens e Bourdieu, Layder sugere que ambos estão comprometidos com aquilo que ele chama de "modelo de simultaneidade": "Podem estruturas objetivas estar fora da interação, serem determinadoras dela, enquanto ao mesmo tempo são o resultado gerado internamente de 
tais interações? É isto que o modelo de simultaneidade nos pede para aceitar" [Layder, 1981:73].

Esta é uma área difícil, e não devemos estar muito certos de que podemos distinguir facilmente entre diferenças de ênfase, formulações descuidadas, etc., por um lado, e oposições teóricas substantivas por outro. Falando de formulações descuidadas, talvez seja significativo que Layder tenda a falar da "produção" ou "geração" da estrutura ao afiar uma das pontas do dilema em que ele deseja empalar Giddens e Bourdieu, enquanto estes autores, ao contrário de, digamos, Touraine, falam mais frequentemente em termos de reprodução, sustentação, etc. Layder não parece fazer justiça aos elementos estruturais do modelo de Giddens, apesar de ser provável que o próprio Giddens tenha alterado sua ênfase nessa direção.

Sobre a questão de princípio colocada por Layder, não está nada claro que haja qualquer coisa contraditória quanto à noção de estruturas que governam a ação mas que são ao mesmo tempo sustentadas e reproduzidas apenas na ação. Onde mais, podemos perguntar, elas estariam localizadas, se não em algo como o conceito amplo de Giddens de traços de memória?

Vejamos, com todo o devido cuidado quanto ao uso de exemplos linguísticos, o caso de uma linguagem natural, por exemplo, o córnico. Ela tem uma estrutura objetiva, sem dúvida similar à de outras linguagens celtas, que é constitutiva do ato de falar ou escrever sentenças em córnico. Suponhamos que o último falante de córnico morra; a linguagem pode sobreviver de forma vestigial em textos, gramáticas, fitas, mesmo que nenhum linguista utilize esses recursos. Ela ainda poderia ser revivida; a princípio ela poderia ser imposta como uma linguagem regional, nacional ou mundial. Entretanto, suponhamos que, numa concatenação de atos de incompetência bibliotecária, todos estes registros fossem irrecuperavelmente perdidos, junto com tudo que poderia permitir sua reconstrução através de extrapolação de linguagens relacionadas. Agora ela realmente está tão morta quanto um dodô; mas ainda é o caso que a estrutura era da forma que era, apesar de ninguém mais saber como ela era. O que é importante aqui é que, se quisermos adotar uma visão ontológica realista das estruturas, como Giddens 
acredita que devamos, precisamos tomar muito cuidado com o estatuto que reivindicamos para elas ${ }^{4}$.

Talvez seja útil aqui fazer uma referência ao "modelo transformacional da atividade social" de Roy Bhaskar, que é de modo geral convergente com a concepção de Giddens. Se tomarmos "a ação intencional humana como um critério para a esfera social, distinta da esfera puramente natural" [Bhaskar, 1986:122], devemos imediatamente reconhecer que formas sociais são uma pré-condição da maioria dos atos humanos intencionais. "Neste modelo, então, a sociedade é ao mesmo tempo a condição sempre presente e o resultado continuamente reproduzido da atividade humana (...)" [Bhaskar, 1986:123]. Estruturas sociais dependem de atividades: elas "existem apenas em virtude das atividades que governam, permitem e coagem" ${ }^{\text {" }}$. Elas dependem de conceitos, pois "a atividade só é intencional enquanto for baseada (cocausada) pelas crenças de um ator". Elas dependem do espaço-tempo, pois "a atividade social ocorre num lugar e leva tempo, o lugar e o tempo do agente", e elas dependem de relações sociais: "Caracteristicamente, a atividade social ocorre quando agentes ocupam posições e se engajam em práticas efetivamente dadas a eles, que eles reproduzem ou transformam" [Bhaskar, 1986:130-131; cf. 1979:cap. 2]. Estas peculiaridades ontológicas diferenciam estruturas sociais de estruturas naturais, mas não as tornam menos reais. Apesar delas só poderem ser observadas, como campos magnéticos, em seus efeitos, e além do mais não existirem exceto em seus efeitos efetivos ou potenciais sobre a atividade humana, sua realidade é uma condição da atividade social. Sua dependência de conceitos e de atividades, longe de ser uma fraqueza idealista, é um recurso epistêmico, um meio que podemos usar para conhecê-las: “(...) o reconhecimento que a identificação de práticas sociais (atividades e atos) depende da mediação de significados requer uma noção estendida do empírico" [Bhaskar, 1986:133]. Em outras palavras, é preciso que existam estruturas sociais, é preciso que possamos conhecê-las em um certo grau para funcionarmos como agentes. A ciência social, como a ação social, é uma transformação de material existente: neste caso, nossas intuições sobre a sociedade. As formas particulares destas estruturas são o objeto das ciências sociais, e não de investigações filosóficas transcendentais. Entretanto, a

\footnotetext{
${ }^{4}$ Bourdieu, por sua vez, facilita sua vida quando sugere que todos os enunciados nas ciências sociais devem ser precedidos por um "Tudo acontece como se..." implícito [Bourdieu, 1977:203n49].

${ }^{5}$ Isto também precisa incluir atividades potenciais: uma estrutura militar-política complexa, por exemplo, envolvendo várias atividades contínuas, possibilita para certos líderes políticos o ato (até agora felizmente não realizado) de iniciar um ataque nuclear devastador.
} 
análise de estruturas sociais deve manter em mente sua dependência de atividades e conceitos (nos termos de Giddens, a habilidade cognitiva - corrigível - de atores sociais). É um mérito considerável da abordagem de Giddens, e da de Bhaskar, que sua teorização, por mais que tenha um certo esplendor barroco, mantenha um pé no chão da ação.

\section{Morfogênese}

Uma crítica mais específica de Giddens é fornecida por Margaret Archer [1982], que defende uma abordagem alternativa em termos da teoria dos sistemas. Enquanto a concepção de Giddens da dualidade da estrutura busca transcender os dualismos entre estática e dinâmica, estrutura e ação, a abordagem "morfogenética" de Archer envolve um dualismo analítico:

“A ação obviamente nunca cessa, e é essencial tanto para a continuação quanto para a elaboração posterior do sistema, mas a interação subsequente será diferente de ações anteriores porque é condicionada pelas consequências estruturais dessa ação anterior. Assim, a perspectiva morfogenética é não apenas dualista mas sequencial, lidando com ciclos infinitos de condicionamento estrutural/interação social/elaboração estrutural, revelando desta forma a inter-relação dialética entre estrutura e ação" [Archer, 1982:458].

Desta perspectiva, a radicalização de Giddens tanto da ação quanto da estrutura aparece como uma contradição:

“(...) a própria dualidade da estrutura oscila entre as duas imagens divergentes que ela transpõe - entre (a) a hiperatividade da ação, cujo corolário é a volatilidade inata da sociedade, e (b) a coerência rígida de propriedades estruturais, associadas, ao contrário, com a recursividade essencial da vida social" [Archer, 1982:459)].

\section{Como resultado, Giddens}

"não consegue especificar quando haverá 'mais voluntarismo' ou 'mais determinismo' (...) Apesar da estruturação tentar transcender a divisão voluntarismo/determinismo através de um único salto conceitual (a 'dualidade da estrutura'), a morfogênese enfrenta os respectivos lastros dos dois aspectos analisando a 
severidade de coerções e graus de liberdade em contextos estruturais diferentes e para grupos sociais diferentes" [Archer, 1982:459, 465].

Isto, como Gandhi disse da "civilização ocidental", parece uma boa ideia, e é certamente algo que Giddens busca fazer em sua teorização. Eu não tenho certeza de que é possível examinar frutiferamente as oposições entre estas duas perspectivas adversárias com mais profundidade sem analisar em mais detalhes o modo como elas funcionam na prática. Entretanto, como Archer implica, talvez com razão, que Giddens está passando alguns cheques teóricos em branco bastante grandes, vale notar alguns problemas com a abordagem morfogenética. Minhas principais dúvidas tratam dos assuntos relacionados ao estatuto ontológico das estruturas postuladas nesta abordagem e a concepção implícita da natureza da teoria nas ciências sociais.

Sem questionar a possibilidade de identificar características estruturais de sistemas sociais, como o nível e distribuição da alfabetização em Cuba nos anos 1960 [Archer, 1982:468-471], podemos querer questionar as separações implicadas nas distinções analíticas entre estrutura, ação e elaboração estrutural. A teoria dos sistemas escorregou bem facilmente de um conceito realista empírico de estrutura para algo que parece muito mais um conceito modelador frouxo escorado por uma filosofia da ciência convencionalista, em que teorias científicas nunca podem ser mais do que dispositivos hipotéticos para fazer justiça a fenômenos inelutavelmente ambíguos. Como Buckley afirmou, "a estrutura é um construto abstrato, não algo distinto do processo interativo contínuo, mas sim uma representação temporária e acomodatícia dele em qualquer dado momento" [Buckley, 1967:18]. O problema com tal abordagem aparentemente flexível e relaxada à teorização é que ela tende a se esquivar de questões de ontologia social. A proliferação em Giddens de princípios estruturais, bordas espaço-temporais, e assim por diante é uma expressão de uma abordagem mais cuidadosamente realista; a complexidade destas formulações pretende evitar a reificação de estruturas hipotéticas. O cuidado bem fundamentado de Giddens nesta área se reflete em sua concepção do estatuto da teoria da estruturação, que ele enxerga basicamente como um conjunto de “dispositivos sensibilizadores" [Giddens, 1984:326]. Esta concepção um tanto tradicional de teoria, cujo principal expoente talvez tenha sido Max Weber, deve ser contrastada com uma visão mais cientificista que predominou na ciência social de língua inglesa nas décadas anteriores e posteriores à Segunda Guerra Mundial, e que enxergava a teoria em termos de testabilidade, generalizações universais, e assim por 
diante [cf. Outhwaite, 1987]. A nova "teoria dos sistemas com uma face humana" não rompeu o suficiente com concepções deste tipo, que continuam a dominar algumas áreas teoricamente não sofisticadas mas atualmente prediletas da ciência social aplicada, como estudos de administração e teorias da organização, e ainda são predominantes na psicologia social.

A distinção que estou tentando fazer não é fácil de compreender, e pode ser útil relacioná-la com a distinção de Roy Bhaskar entre ontologia filosófica e científica. Uma ontologia filosófica é um conjunto muito geral de princípios como aqueles que o próprio Bhaskar desenvolve: para que a ciência seja possível, o mundo tem que ter uma estrutura objetivamente existente e relativamente duradoura. Entretanto, de que entidades essa estrutura consiste é uma questão que as ciências individuais devem investigar, de forma aberta e sempre corrigível. Em outras palavras, assim como o conceito geral de matéria que subjaz o materialismo filosófico, há um conjunto aberto de entidades diferenciadas: moléculas, átomos, quarks, e assim por diante.

Bhaskar combina um forte realismo ontológico com um cuidado extremo quanto a qualquer reivindicação existencial particular feita por uma ciência em particular. Afirmar, como um realista científico, a realidade dos átomos não significa se amarrar a uma linha em particular sobre a existência ou não de partículas subatômicas específicas. Da mesma forma, na teoria social, insistir sobre a existência da sociedade não é adotar nenhuma visão particular sobre a forma em que ela é constituída (conflito de classes, lutas de poder, interpretações, etc.).

Ser um realista neste sentido é levar compromissos ontológicos a sério, e assim postular entidades com um cuidado extremo. Giddens certamente não tem medo de inovações terminológicas, como uma olhadela para o glossário em $A$ constituição da sociedade [Giddens, 1984.:373-377] confirmará. Entretanto, ao mesmo tempo, deve estar claro, pelo uso que ele faz desses termos, que sua intenção é manter uma referência permanente à ação como um foco central da teoria social.

A estratégia alternativa, na qual eu suspeito que a morfogênese ainda se encaixa, como formas anteriores da teoria dos sistemas, é ser um tanto casual quanto à proliferação de conceitos de sistema e então retroceder dando a eles um verniz convencionalista. Como eu sugeri em outro texto [Outhwaite, 1987:105; cf. Burger, 1977], Parsons foi desencaminhado por seu desejo de mapear as ciências sociais 
existentes (psicologia, economia, sociologia, etc.) em seus modelos de sistema, em vez de enxergar a vida social como um todo que requer uma ontologia social sistemática. É difícil demonstrar precisamente a diferença entre as duas abordagens, mas não obstante ela é real e importante.

\section{Conclusão}

Apesar de Giddens ser uma figura de importância excepcional na teoria social contemporânea, sua carreira é de muitas formas um microcosmo das principais linhas de desenvolvimento da sociedade britânica, e em menor grau norte-americana, desde cerca de 1968. Ele começou com uma releitura intensa de Marx, Weber e Durkheim, e seu livro de exposição [1971] facilitou muito a recepção deles no mundo de língua inglesa. Ele então passou de uma crítica positiva da sociologia interpretativa, estruturalismo e outras perspectivas teóricas à concepção desenvolvida de estruturação [1984]. Finalmente, ele aplicou este esquema a uma análise do Estado-nação e outras estruturas de poder que reformula algumas das preocupações clássicas da sociologia num idioma moderno e original. Seu desenvolvimento é paradigmático de pelo menos uma tendência muito importante na sociologia britânica recente: uma grande marcha através da "grande teoria" para uma nova abordagem de assuntos substantivos. A tentativa de Giddens de juntar as "duas sociologias" é uma característica central deste desenvolvimento.

\section{Agradecimento}

Gostaria de agradecer a Anthony Giddens e Laura Marcus por seus comentários úteis sobre este capítulo.

\section{Bibliografia}

ARCHER, M. [1982] "Morphogenesis versus Structuration: On Combining Structure and action", in British Journal of Sociology, v. 33, n. 4, pp. 455-483.

BHASKAR, R. [1979] The Possibility of Naturalism. Brighton: Harvester.

BHASKAR, R. [1986] Scientific Realism and Human Emancipation. London: Verso. 
BOURDIEU, P. [1977] Outline of a Theory of Practice. Cambridge: Cambridge University Press.

BUCKLEY, W. [1967] Sociology and Modern Systems Theory. Englewood Cliffs: PrenticeHall.

BURGER, T. [1977] "Talcott Parsons, the Problem of Order in Sociology, and the Program of an Analytical Sociology", in American Journal of Sociology, vol. 83, n. 2, pp. 320-334.

CLEGG, S. [1979] The Theory of Power and Organisation. London: Routledge.

DAWE, A. [1978] "Theories of Social Action", in Bottomore, T. \& Nisbet, R. (eds.), A History of Sociological Analysis, New York: Basic Books, pp. 362-417.

GIDDENS, A. [1971] Capitalism and Modern Social Theory. Cambridge: Cambridge University Press.

GIDDENS, A. [1976] New Rules of Sociological Method. London: Hutchinson.

GIDDENS, A. [1977] Studies in Social and Political Theory. London: Hutchinson.

GIDDENS, A. [1979] Central Problems in Social Theory. London: Macmillan.

GIDDENS, A. [1981] A Contemporary Critique of Historical Materialism. London, Macmillan.

GIDDENS, A. [1982] Profiles and Critiques in Social Theory. London: Macmillan.

GIDDENS, A. [1984] The Constitution of Society. Cambridge: Polity.

GIDDENS, A. [1985] The Nation-State and Violence. Cambridge: Polity.

GURVITCH, G. [1963] Déterminismes sociaux et liberté humaine. Paris: PUF.

LAYDER, D. [1981] Structure, Interaction and Social Theory. London: Routledge.

OUTHWAITE, W. [1987] "Laws and Explanations in Sociology", in Anderson, R. J. et al (eds.), Classic Disputes in Sociology. London: Allen \& Unwin, pp. 157-183.

THOMPSON, J. [1981] Critical Hermeneutics. Cambridge: Cambridge University Press.

WINCH, P. [1958] The Idea of a Social Science. London: Routledge. 


\section{Hans Joas - A crítica de Giddens ao funcionalismo}

Quando, em 1976, Anthony Giddens publicou uma crítica do funcionalismo, ele o fez a partir de uma sensação de escrever après la lutte [Giddens, 1977]: depois de uma batalha em que os críticos admitidamente ganharam terreno, mas que terminara não numa derrota clara para os funcionalistas, e sim numa exaustão geral de ambos os lados. Esta impressão foi enganosa, porque na década seguinte o funcionalismo, e a crítica ao funcionalismo, passaram por um renascimento periódico, ganhando novos impulsos e motivações. Durante o processo, os críticos do funcionalismo romperam sua fixação em Talcott Parsons e se voltaram ao ataque ao funcionalismo clandestino, que eles descobriam em "escolas" e autores que nunca se descreviam como "funcionalistas". O objeto de crítica preferido eram as pressuposições funcionalistas escondidas de autores marxistas, e dos próprios Marx e Engels. Nos escritos de Jon Elster em particular [Elster, 1979; 1982], os argumentos duradouros dos críticos foram reunidos com grande brilhantismo e claridade intelectual num ataque devastador.

Entretanto, em paralelo a esta crítica, foram feitas tentativas, ainda que em duas direções bastante diferentes, de levar adiante e desenvolver o legado de Talcott Parsons. $\mathrm{Na}$ Alemanha, Niklas Luhmann, numa profusão de escritos programáticos e substantivos, desenvolvia uma teoria social funcionalista completa que - agora quase totalmente livre de seu conflito interno com a teoria da ação e a prática da pesquisa empírica - prometia uma solução aos problemas não resolvidos de Parsons, e atualmente gera um grande interesse como um paralelo "cientificista" ao pósestruturalismo. Também na obra de Habermas, particularmente na Teoria da ação comunicativa [Habermas, 1984; 1988], a influência do funcionalismo de Luhmann é claramente detectável. Ao mesmo tempo, um círculo de sociólogos americanos ao redor de Jeffrey Alexander tentava, sob o título bastante infeliz de "neofuncionalismo", circundar os problemas inegáveis nos escritos posteriores de Parsons voltando à sua teoria inicial da ação ou contestando descontinuidades em sua obra como um todo. Alguns dos escritos de Richard Münch na Alemanha também estão aliados intimamente aos dos "neofuncionalistas". 


\section{A crítica de Giddens ao funcionalismo}

Giddens exprimiu opiniões claras sobre os desenvolvimentos recentes na crítica ao funcionalismo. Ele adotou o impulso principal da crítica de Elster em seus próprios textos [Giddens, 1982], e também apresentou sua própria análise das características funcionalistas do marxismo [Giddens, 1981]. Entretanto, não conseguimos encontrar em sua obra um debate mais profundo com as tentativas mais recentes de elaborar um novo tipo de sociologia funcionalista ou neofuncionalista. A questão interessante é, obviamente, não o que Giddens realmente pensa a respeito de Luhmann, Alexander ou Münch, mas se suas objeções anteriores ainda se aplicam a estas novas versões do funcionalismo. O objetivo deste capítulo não é resumir detalhadamente a crítica ao funcionalismo de Giddens, mas explorar até que ponto ela mantém sua validade tendo em vista estes desenvolvimentos recentes inovadores do próprio funcionalismo. Não há, é claro, nenhuma garantia quanto à possibilidade de que o próprio Giddens chegaria a conclusões bastante diferentes daquelas feitas aqui.

A crítica ao funcionalismo de Giddens pode ser resumida em dois argumentos principais. Primeiro, ela se dirige contra a possibilidade de explicações funcionais. Para Giddens, proposições funcionalistas são admissíveis apenas enquanto enunciados contrafatuais sobre as condições necessárias para consequências possíveis. Segundo, ele contesta que o uso "essencialista" de modelos funcionalistas tenha significado. Isto, é claro, não quer dizer que ele simplesmente negue a existência de processos regulatórios ou autorregulatórios. Entretanto, ele nega a possibilidade das ciências sociais estabelecerem claramente as necessidades do sistema que - como pontos de referência ou valores orientadores - são as únicas que tornam um modelo funcionalista aplicável e com significado. Assim, ele acusa as teorias funcionalistas de predeterminar, num nível metateórico, a questão da existência de processos autorregulatórios em vez de tratá-la como uma questão empírica, e assim manter aberta a questão do "grau de sistematicidade" [Giddens, 1984:283].

Começando por uma crítica à distinção célebre, mas obscura, de Merton entre funções manifestas e latentes [ver Demerath \& Peterson, 1967], Giddens consegue demonstrar a indispensabilidade, ao analisar fenômenos sociais, de alguma referência às intenções e expectativas cognitivas de pessoas ativas reais. Sua estratégia geral é mostrar que em todos os casos o conceito de função é ou enganoso ou redundante. $\mathrm{Na}$ 
maioria das vezes, ele consegue recorrer ao argumento de autores anteriores tratando da explicação funcional e do problema do "ponto de referência" das análises funcionalistas. A originalidade das observações de Giddens não está tanto em seus argumentos críticos substantivos, mas sim no fato de que eles não são conduzidos nem do ponto de vista do individualismo metodológico, nem do positivismo lógico. A reivindicação de Giddens é conseguir produzir uma teoria social superior às teorias da ação racional, mas que não é nem funcionalista nem "individualista”. Assim, não é coincidência que o ensaio de 1976 de Giddens sobre o funcionalismo contenha o esboço mais antigo de sua teoria da estruturação. $\mathrm{Na}$ verdade, fica cada vez mais claro que a teoria de Giddens deve ser vista como surgindo diretamente de um debate com a síntese teórica de Parsons. Giddens não está interessado nem em suplementar a obra de Parsons, nem em submetêla a uma crítica detalhada, e nem em negá-la completamente. Sua crítica de uma versão mais geral do "funcionalismo" permite que ele incorpore partes "não-funcionalistas" da obra de Parsons em sua teoria. Analisando contribuições recentes ao funcionalismo com base nos escritos de Giddens, é assim possível examinar se existe alguma teoria alternativa atual superior à fundamentação na teoria da ação de uma teoria social nãofuncionalista de Giddens. Esta questão será examinada no resto deste capítulo através da análise breve de sua relação com o funcionalismo de Luhmann, Habermas e Alexander.

\section{A teoria funcionalista de Niklas Luhmann}

Ninguém agarrou o touro funcionalista pelos chifres de forma mais corajosa e inteligente que Niklas Luhmann. Em seus ensaios do início dos anos 1960 [Luhmann, 1970], ele já estava engajado em argumentos que podem ser encontrados na crítica subsequente de Giddens. Apesar das muitas mudanças em sua teoria até sua obra principal, Sistemas sociais [Luhmann, 1984], os argumentos básicos de Luhmann sobre a possibilidade de um método funcional ainda são os mesmos. Já que o próprio Luhmann estabelece uma distinção clara - programaticamente, ainda que nem sempre na realidade - entre o método funcional e a estrutura interna da teoria dos sistemas, este capítulo se concentrará em sua posição vis-à-vis o método funcional.

Luhmann concede abertamente que os resultados da análise funcional não constituem explicações causais. Ele também concede que o problema da estabilidade e 
da existência de sistemas sociais ainda não foi resolvido, e por isso não pode ser o ponto de referência definitivo para a análise funcional. Esta última percepção surgiu particularmente de seus primeiros estudos sobre sociologia organizacional e administrativa. Em seu ensaio de 1962, "Função e causalidade", Luhmann declarou que todas as tentativas de reconciliar o método funcional nas ciências sociais com concepções de causalidade metodologicamente rigorosas fracassaram. Nem a referência a necessidades imutáveis ou claramente identificáveis, nem a adoção de alguma ideia de equilíbrio da termodinâmica ou da biologia, nem a ideia de Gouldner de "reciprocidade funcional", conseguiram explicar causas através de efeitos. De forma igualmente explícita, Luhmann fornece um resumo claro das dificuldades encontradas nas tentativas de definir funções como a "produção da estabilidade e existência, ou de precondições individuais da estabilidade e existência, de um sistema de ação" [Luhmann, 1970:18]. Sistemas sociais não são "tipos fixos" [ibid.], ou seja, eles não estão ligados de forma definitiva a uma identidade específica, e o significado da morte, um problema tangível e inequívoco na biologia, não está claro a respeito de sistemas sociais. A ideia de precondições individuais de estabilidade e existência (separadas da estabilidade e existência em geral) também não nos dá uma saída para esta dificuldade, pois elas também requerem uma conexão a alguma ideia de um sistema social geral ou de necessidades gerais do sistema. Assim, em ambos estes pontos fundamentais, Luhmann parecia estar de acordo com a crítica de Giddens ao funcionalismo.

Entretanto, ele chega a conclusões bem diferentes de Giddens. Sua estratégia é inverter o ônus da prova. Se o método funcional não consegue cumprir as exigências de uma concepção de causalidade metodologicamente rigorosa, então isto pode ser o resultado de um entendimento falso da natureza da causalidade. Se o problema da estabilidade do sistema é demonstravelmente inapropriado como um ponto de referência definitivo para a análise funcional, então isto pode significar que é preciso identificar um ponto de referência diferente. Se surgem dificuldades na verificação empírica de enunciados funcionalistas, isto pode significar que precisamos de outros métodos de verificação. Finalmente, se é necessário alterar nosso entendimento da causalidade, do problema da estabilidade do sistema, dos procedimentos de verificação, e assim por diante, então isto pode demonstrar que o método de análise funcional é bastante diferente da tradição ontológica ocidental desde a antiguidade clássica, e que é exatamente o poder desta tradição de pensamento que precisa ser derrubado. 
É claro que estas são reivindicações extremamente amplas, até extremas. Só podemos testar a possibilidade de sua realização contra a própria teoria de Luhmann, e não no contexto imediato de argumentos sobre o funcionalismo enquanto método. Neste contexto, a questão mais importante que surge é: se a análise funcional é incapaz de fornecer explicações causais, o que ela pode fornecer? A resposta de Luhmann é que ela:

"usa relações com o objetivo de entender aquilo que existe como contingente, e aquilo que é diferente como comparável. Ela relaciona aquilo que é dado, sejam situações ou eventos, a perspectivas de problemas e busca deixar claro e compreensível que o problema pode ser resolvido de uma forma ou de outra. A relação entre problemas e soluções de problemas não pode ser entendida simplesmente em seus próprios termos; ela serve como um guia na missão por outras possibilidades, na busca de equivalentes funcionais" [Luhmann, 1984:83-84].

Então, de acordo com Luhmann, o ponto de partida da análise funcional não é conexões entre causa e efeito, como na análise causal, mas conexões entre problemas e soluções de problemas. O resultado potencial de tal análise, portanto, consiste não em ligações causais entre causas e efeitos, mas na abertura de um conjunto de equivalentes funcionais potenciais. Isto significa que para efeitos existentes é possível identificar e comparar várias combinações causais, e para dadas causas, efeitos particulares. A descoberta e eliminação de equivalentes funcionais é assim a verdadeira realização deste método, que é essencialmente comparativo.

Talvez seja mais exato falar de um "efeito de alienação", para usar o termo de Bertolt Brecht, já que não é uma questão de comparar estados de coisas existentes uns com os outros, mas de transpor o familiar para os reinos de possibilidades não realizadas, e talvez na prática não realizáveis. Inicialmente, pode parecer que Luhmann estaria sendo relativamente modesto ao meramente fazer uma reivindicação heurística para a análise funcional. A renúncia a reivindicações causais pareceria confirmar isto. Se isto fosse verdade, então não esperaríamos que Giddens fizesse qualquer objeção, pois isto concordaria completamente com sua própria ideia de relações causa-efeito concebíveis. Entretanto, este caráter alienante da abordagem de Luhmann é mais do que puramente "heurístico". 
De fato, sua reivindicação é problemática em pelo menos dois aspectos. Primeiro, seu conceito de "alienação" precisa ser diferenciado do de Brecht, pois Luhmann não está preocupado com alternativas práticas, realizáveis, e moral e politicamente justificadas à realidade atual "cruel", mas sim com a impressão de uma irrealidade difusa e uma mera potencialidade de todos os estados de coisas existentes. Neste respeito, ele talvez esteja mais próximo da ironia romântica ou do teatro do absurdo do que de Brecht. Segundo, Luhmann só aparentemente escapa dos problemas de causalidade. Ele é forçado a interpretar "outras possibilidades" ou "equivalentes funcionais" contra um esquema causal metodologicamente rigoroso. Ao fazê-lo, ele precisa recorrer a intuições sobre conexões causais plausíveis. Estas intuições não podem deixar de ser examinadas no debate acadêmico.

Luhmann concede abertamente que o recurso à causalidade é inevitável. Entretanto, ele afirma que é possível obter ganhos cognitivos através da análise funcional, "mesmo quando causalidades inicialmente precisam ser imputadas hipoteticamente por ainda não terem sido pesquisadas adequadamente. A tarefa, então, é não simplesmente esquecer o caráter hipotético puro das pressuposições causais, mas incorporá-lo na comparação" [Luhmann, 1984:84-85)]. A princípio, este é o mesmo argumento proposto por G. A. Cohen em sua defesa de um método funcional de argumentação no marxismo ortodoxo, sob o título de "leis de consequência" [Cohen, 1978]. Entretanto, Cohen admitiu inequivocamente que tais enunciados podem ser apenas orientações heurísticas. Então, neste aspecto, os argumentos de Giddens também se aplicam a Luhmann [Giddens, 1982:530]. Luhmann é capaz de defender o significado heurístico de proposições funcionais, mas não mais do que isto; o efeito de "alienação" de sua teoria, apesar de certamente ter qualidades literárias e, por causa disso, avançar o conhecimento, não tem validade científica-acadêmica.

Como Luhmann tenta escapar das dificuldades lendárias do "problema da estabilidade do sistema"? A resposta é: deslocando-o ou "temporalizando-o", não apenas uma vez, mas várias vezes. Em seus primeiros escritos, a solução é procurada na ideia de uma hierarquia de níveis de problemas. Não devemos sempre focar a atenção no nível primário na estabilidade de um sistema enquanto tal; também podemos identificar e analisar problemas funcionais com alguma promessa de sucesso, por exemplo, nos níveis secundário e terciário. Assim, os problemas que surgem de soluções de problemas se tornam o ponto de partida para novos problemas funcionais 
num nível superior. Luhmann acredita até que, com esta abordagem, ele encontrou um compromisso razoável entre o funcionalismo sistemático de Parsons e as "teorias de alcance médio" orientadas para problemas de Merton [Luhmann, 1970:22].

Entretanto, o compromisso alcançado não é nada claro. Luhmann não dá detalhes sobre o que faz alguém identificar estados de coisas particulares como problemas no nível secundário ou terciário, nem como o problema no nível primário pode ser concebido como algo que não seja um problema de estabilidade do sistema. A falta de clareza conceitual, lamentada pelos críticos do funcionalismo, continua assim tão grande quanto antes. Parece que a única saída para Luhmann seria reconhecer o estatuto analítico normativo da análise funcional, aceitar que seu ponto de referência básico é algo estabelecido caso a caso para propósitos analíticos, e não fazer nenhuma reivindicação de validade empírica além dessa. Mas tal modéstia não parece ser compatível com as ambições globais de Luhmann.

Inicialmente, portanto, ele escolhe o método de fuga "temporalizante". Em seu ensaio de 1967, "A sociologia como a teoria dos sistemas sociais", ele supera o problema da estabilidade social declarando sua intenção de sujeitar processos de mudança e origem das estruturas à análise funcional. Este interesse em processos de estruturação e também em estruturas dá a impressão que ele estaria bastante próximo à teoria posterior de Giddens. Mas uma inspeção mais cuidadosa mostra que isto não é verdade. Luhmann simplesmente transmuta a questão do ponto de referência definitivo de análises funcionais para uma questão da função dos processos de formação de estruturas. A natureza problemática deste procedimento foi reconhecida claramente por Jürgen Habermas em sua longa crítica a Luhmann de 1971: “A função da formação de estruturas não pode ser examinada sem referência a um sistema mais completo cujas estruturas precisam então ser mantidas constantes para propósitos analíticos. A falta de simetria entre estabilidade do sistema (estrutura) e realizações que mantêm o sistema (processo) não pode ser resolvida num nível analítico" [Habermas \& Luhmann, 1971:153].

Entretanto, quando esta crítica foi feita, Luhmann já tinha avançado mais um passo na tentativa de encontrar um ponto de referência definitivo para a análise funcional. Ele viu isso como a redução da "complexidade do mundo", que ele identificou como um problema de todos os sistemas. A objeção de Habermas a isto foi 
que não fazia sentido falar da "complexidade do mundo" enquanto tal, porque tal conceito precisa inevitavelmente ter uma referência a algum sistema para o qual o problema da complexidade do mundo surge. Luhmann reconheceu isto em sua resposta a Habermas, mas argumentou que o problema da complexidade do mundo era fundamental e independente de qualquer sistema em particular. Ela poderia assim receber, justificadamente, o estatuto de um ponto de referência definitivo [Habermas \& Luhmann, 1971:299]. Esta resposta de Luhmann é incompreensível, já que Habermas não o acusara de estabelecer uma relação específica com um sistema específico, e sim de vacuidade semântica no uso do termo "complexidade do mundo" enquanto tal. Apesar de seus protestos, portanto, o conceito de Luhmann de um ponto de referência definitivo é semanticamente sem significado.

Posteriormente a isto, Luhmann desenvolveu sua teoria dos sistemas na direção de um sistema autorreferencial "autopoiético". Neste processo, o "problema da estabilidade" sofreu mais uma reformulação. Por exemplo, ele escreveu em 1984:

"Não é mais uma questão de um sistema unificado com propriedades particulares sobre cuja estabilidade ou falta de estabilidade tomamos uma decisão geral; e sim uma questão de continuar ou descontinuar a reprodução de elementos (do sistema) através de um arranjo relacional desses mesmos elementos. A manutenção (do sistema) significa aqui a manutenção da completude e o caráter incessante da reprodução dos elementos, que já desaparecem logo quando emergem" [Luhmann, 1984:86].

Entretanto, isto ainda deixa completamente obscuro se o problema foi realmente transformado por causa da redefinição da estabilidade do sistema em termos da manutenção de um processo de reprodução. Com efeito, a questão de se um processo de reprodução foi interrompido ou descontinuado provoca os mesmos problemas de identificação hermenêutica que Luhmann reconhecera em relação à "morte" ou à perda de identidade de sistemas sociais.

O passo justificativo mais recente de Luhmann, que vai além da substancialização de uma escolha particular de método para o nível da epistemologia, não pode ser discutido em detalhes aqui por falta de espaço. Entretanto, ao criticar Luhmann, sempre enfrentamos o problema de que qualquer objeção à sua obra é reformulada em sua própria linguagem teórica e, neste processo, perde seu aguçamento crítico. Por exemplo, diante do problema da verificação da análise funcional, Luhmann 
foge apressadamente, e volta imediatamente sugerindo que a aplicabilidade de suas pressuposições a um conjunto tão amplo de fenômenos sociais é uma prova clara de sua plausibilidade. Evidentemente, a aplicabilidade é determinada ou pelo próprio Luhmann, ou pelo acólito deslumbrado por seu brilhantismo retórico. Se argumentamos desta forma, não é mais possível distinguir entre conhecimento testado intersubjetivamente e um emaranhado de monólogos naquilo que se tornou um sistema bem amarrado mas autoilusório.

\section{Habermas e o funcionalismo.}

A crítica mais poderosa e extensa da obra de Luhmann foi feita no início dos anos 1970 por Jürgen Habermas. Ele também dedicou uma longa seção de seu $O$ discurso filosófico da modernidade [Habermas, 1985] à obra principal de Luhmann de 1984. Este fato, e o subtítulo do segundo volume da Teoria da ação comunicativa de Habermas [1988], "Uma crítica da razão funcionalista”, podem fazer com que pareça surpreendente ver Habermas arrolado com os funcionalistas e submetido junto com eles à crítica de Giddens ao funcionalismo. Entretanto, um resultado irônico do debate Habermas-Luhmann é que Habermas realizou várias revisões necessárias de sua própria teoria incorporando elementos de Luhmann.

De modo abstrato, não pode haver objeções a isto; a instrução mútua é o resultado desejado de todas as controvérsias acadêmicas. Entretanto, é importante fazer perguntas mais específicas quanto ao significado destes "empréstimos". Habermas consegue superar as fraquezas que identificou em sua própria teoria com a ajuda da obra de Luhmann, ou será que a teoria de Luhmann simplesmente o leva a problemas mais novos e sérios? Antes de tentar incorporar aspectos da teoria de Luhmann, será que Habermas levou suficientemente em conta os problemas da análise funcional e os caminhos alternativos possíveis abertos a ele?

Muitos autores fizeram esta pergunta a respeito da Teoria da ação comunicativa de Habermas. Por exemplo, Thomas McCarthy [1985] analisou os perigos que surgem para Habermas da "sedução da teoria dos sistemas"; eu mesmo descrevi a teoria de Habermas como "o casamento infeliz da hermenêutica com o funcionalismo" [Joas, 1988a]; Axel Honneth já identificou nos escritos de Habermas do final dos anos 1960 
um conflito entre duas tendências, das quais apenas uma, apontando na direção da teoria de Luhmann, foi seguida [Honneth, 1985]. O próprio Giddens expressou sua avaliação ambivalente de Habermas neste ponto numa espécie de "esquizofrenia metod(ológ)ica", louvando a tentativa de Habermas de ligar a teoria dos sistemas com a ideia do "mundo da vida" numa teoria da modernidade, mas ao mesmo tempo o censurando por não criticar o suficiente o funcionalismo [Giddens, 1985:119]. Para Giddens, os resultados contingentes das lutas históricas de indivíduos e grupos não são representados adequadamente na teoria de Habermas. Já que, enquanto isso, Habermas reagiu a essas objeções [Habermas, 1986], a questão de sua relação atual com o funcionalismo, incluindo sua própria crítica anterior, pode agora ser discutida numa nova base.

Para Habermas, a prova teórica inicial de Luhmann dos limites de todas as teorias sociológicas da ação foi convincente e instrutiva [Habermas \& Luhmann, 1971:270]. A razão mais importante de sua prontidão a ser persuadido da necessidade de fornecer uma adição da teoria dos sistemas à sua abordagem da teoria da ação é descrita como se segue:

"Já que o sujeito coletivo (uma ideia emprestada da filosofia transcendental) de um mundo da vida constituído de forma significativa se mostrou, pelo menos na sociologia, ser uma ficção enganosa, parece que o conceito de sistema é mais apropriado. Sistemas sociais são unidades que podem resolver problemas apresentados objetivamente através de processos de aprendizagem intersubjetivos" [Habermas \& Luhmann, 1971:271]

Este, então, é o motivo que está por trás da busca de Habermas de um conjunto de conceitos que não conceba sociedades em geral como um tipo de sujeito autoesclarecedor expandido.

Muitas direções ao mesmo tempo impeliram Habermas a esta busca. Primeiro, a ideia de história precisava ser resgatada da ficção de um sujeito histórico em autodesenvolvimento contínuo, a espécie humana; segundo, a categoria da autorreflexividade precisava ser reconciliada com a transparência nunca completa das situações de vida humanas; terceiro, o ideal normativo da democracia precisava ser diferenciado da ideia de converter todos os processos sociais a um modo participativo; e finalmente, o caminho para o progresso precisava ser mantido livre das legitimações de “super" sujeitos autônomos, como na concepção de Lukács do Partido Comunista. A 
introdução da ideia de sistema parecia ajudar todos esses objetivos, desde que ela fosse integrada com a própria teoria da comunicação de Habermas e fundamentada numa teoria evolucionista. Os escritos da década seguinte continham tentativas parcialmente divergentes de realizar este programa teórico. A variação representada pela Teoria da ação comunicativa consiste em manter a teoria dos sistemas sob controle, afirmando a primazia da análise do mundo da vida. Entretanto, ao fazer isso, a distinção entre sistema e mundo da vida foi usada em tantos níveis lógicos simultaneamente que o resultado inevitável foi confusões múltiplas. A distinção pretendia exprimir várias coisas: a diferença metodológica entre a perspectiva do participante e a do observador; a diferença entre integração social através de orientações à ação e a integração do sistema através das consequências da ação; e, finalmente, a estrutura básica da história no sentido de uma divisão crescente entre o sistema e o mundo da vida.

McCarthy demonstrou, de forma impressionante, a impossibilidade de reconciliar esta profusão de objetivos. Em particular, ele estabelece que, ao usar o conceito de sistema, Habermas está tentando derrotar num nível metateórico certas exigências políticas da democratização da economia e do estado. Isto não ocorre porque Habermas rejeitou suas convicções políticas democráticas radicais anteriores, mas porque ele confunde a justificação geral da necessidade de métodos e técnicas de "direção" social na arena política e econômica com o estabelecimento de fronteiras entre mundos da vida e o "complexo burocrático-monetário". A ideia central na minha caracterização do "casamento infeliz da hermenêutica com o funcionalismo" era que Habermas era obrigado a tomar este passo por causa de seu fracasso em reconhecer o estatuto da teoria da ação e da construção particular de sua própria teoria. O fracasso já pode ser identificado no ponto em que Habermas se une a Luhmann ao pressupor os limites de todas as teorias da ação.

Em sua resposta a seus vários críticos, Habermas ofereceu vários esclarecimentos e autocorreções implícitas e explícitas. Por exemplo, a relação exclusiva da teoria dos sistemas com o campo da reprodução material é agora expressamente contestada. Entretanto, no final das contas, Habermas continua a defender a tentativa de fornecer uma síntese entre sua teoria da ação hermenêutica e o funcionalismo de Luhmann. Ele propõe dois argumentos principais em defesa do uso de análises e modelos funcionais. Primeiro, ele defende veementemente o uso "essencialista" do conceito de sistemas contra o uso puramente analítico. Sabemos que 
Luhmann, diferentemente de Parsons, escolhera como o ponto de partida de sua teoria a clara proposição: "sistemas existem" [Luhmann, 1984:30]. Segundo, ele diferencia um uso descritivo e um uso crítico do conceito de sistemas. Com uso "crítico", ele quer dizer uma versão aceitável (por padrões atuais) da ideia de Marx de uma reificação ou independência de relações sociais em que algumas áreas do mundo da vida são demonstravelmente irreconciliáveis com interações lideradas pela mídia.

A crítica de Giddens ao funcionalismo não pode se opor ao uso descritivo de um modelo funcionalista enquanto houver um esclarecimento anterior do "grau de sistematicidade", que Giddens considera uma pré-condição para a aplicação empírica destes modelos. De acordo com esta perspectiva, existem coisas chamadas sistemas, mas nem todos os fenômenos sociais preenchem as condições para a aplicação da teoria dos sistemas. Em muitos casos, estas condições estão presentes de forma tão limitada que a teoria dos sistemas pode apenas provocar um efeito de distorção sobre o objeto de análise. Uma diferença de Habermas é que não há nenhuma afirmação geral de que todos os fenômenos devem ser subsumidos sob um "mundo da vida" e uma análise funcional. Para Giddens, várias condições e pré-condições devem ser preenchidas para a aplicação válida da análise funcional. A análise funcional só faz sentido quando o fenômeno tem um caráter de sistema real em termos funcionalistas.

Ao mesmo tempo, Habermas pretende que a aplicação "crítica" de uma concepção essencialista do funcionalismo expresse o pathos da crítica da reificação de Marx e uma ruptura radical com ideias (originárias da filosofia da práxis) de uma sociedade que se tornou totalmente transparente para si mesma. Inicialmente, então, não parece haver nenhuma diferença aqui entre os objetivos de Habermas e de Giddens. $\mathrm{O}$ programa de Giddens de uma transformação sociológica da filosofia da práxis tem consciência dos perigos totalitários de uma utopia social que não incorpore em seu aparato conceitual os problemas da centralização excessiva e da falta de pluralismo. Através de sua recepção do estruturalismo, Giddens também aprendeu a lição do "descentramento do sujeito". Entretanto, o que surge deste programa não é uma restrição da "perspectiva de mudança" para uma defesa do mundo da vida vis-à-vis os imperativos funcionais da economia e do estado, mas sim a questão de alternativas democráticas-socialistas, particularmente nos domínios da economia e do estado. Ao revisar estas alternativas, não é necessário falar da abolição ou da "morte lenta" do 
dinheiro, do mercado e do Estado. Entretanto, o discurso sobre a relação correta entre participação e “direção" pela mídia é recomendado, e não excluído.

\section{Jeffrey Alexander, Richard Münch e a tradição parsoniana}

Jeffrey Alexander e Richard Münch seguem um caminho bastante diferente de Luhmann ao continuar a tradição parsoniana. Ambos os autores merecem grande crédito por obter um quadro mais preciso da teoria de Parsons depois de muitos anos de representações grosseiras e de sua rotulação disseminada como conservadora, incapaz de explicar conflitos e mudanças, conformista em sua teoria da personalidade, formalista, e empiricamente intestável. Ao enfatizar a continuidade e homogeneidade na obra de Parsons, Münch chega ao ponto de negar a existência de tensões internas entre tendências diferentes dentro dela, incluindo o método funcional de explicação. Münch afirma que este "nunca teve um lugar sistemático na teoria da ação de Parsons no sentido metodológico do modelo explicativo de Hempel para sistemas concretos" [Münch, 1980:503].

Tudo isto depende do que queremos dizer com um lugar "sistemático". Se isto significa que Parsons sempre soube, na construção de sua teoria, do caráter exclusivamente analítico de seu conceito de sistemas, então Münch encontra dificuldades com as próprias formulações de Parsons, mesmo em seções que ele mesmo cita. Por exemplo, Münch se refere corretamente ao fato de que Parsons operava com múltiplos pontos de referência do sistema, jogando fora assim um funcionalismo de sistemas simples e permitindo a consideração simultânea de sistemas culturais, sociais e pessoais. Entretanto, isto não significa que ele superou ou rejeitou o funcionalismo de sistemas, e sim que ele o tornou um pouco mais sofisticado. A interpretação de Münch deixa Parsons menos contraditório do que era, e ainda não esclarece para que serve uma interpretação funcionalista de sistemas e subsistemas que só existem num nível analítico.

Neste aspecto, Alexander procede de forma mais diferenciada e radical. Alexander compartilha com Münch a percepção da importância contínua da teoria da ação de Parsons e a defesa da perspectiva normativa de Parsons de uma evolução da ação, no sentido da significância crescente da responsabilidade pessoal individual. Uma 
das realizações mais importantes de sua recepção dos clássicos, sob outros aspectos muitas vezes problemática [Joas, 1988b], é certamente desembaraçar o famoso esquema AGIL de relações de troca entre subsistemas funcionais de sua leitura funcionalista. Para Alexander, este modelo não é sustentável como um modelo funcionalista da sociedade; ele simplesmente formula uma taxonomia de abstrações analíticas num nível metateórico. Alexander mostra como Parsons tentou, depois de 1945, especificar suas pressuposições metateóricas ao adotar um modelo de sistema funcionalista. Ele toma o cuidado de enfatizar que esta foi uma decisão específica de Parsons, que pode assim ser separada do próprio nível metateórico. Parsons acreditava que, ao adotar um modelo de sistemas funcionalista, seria possível evitar os perigos do reducionismo biológico ou uma identificação de totalidades sociais com "totalidades culturais". Além disso, o uso de Parsons do modelo de sistemas, incluindo sua incorporação da cibernética, sempre foi cuidadoso e cauteloso. Entretanto, Alexander mostra com grande perspicácia os vários graus e aspectos em que Parsons reificou as pressuposições do modelo, entrando assim em conflito com outras partes de sua própria teoria. O julgamento de Alexander soa devastador:

"Foi com o intercâmbio (...) que a confusão metodológica de Parsons alcançou seu ponto mais alto (...) Cada um dos termos principais do modelo de intercâmbio - as 'dimensões' do intercâmbio, as 'fronteiras' entre dimensões sistêmicas, as 'entradas' e 'saídas' entre estruturas dimensionais diferentes - é apresentado agora como se fosse derivado de alguma lógica inerente dos sistemas, em vez de serem derivados do esforço de Parsons para modelar sua síntese analítica da ordem normativa-instrumental" [Alexander, 1983:271].

Entretanto, para o próprio Alexander este julgamento não tem um teor devastador, porque ele não acredita nem na continuidade da obra de Parsons, nem em seus méritos na construção de modelos funcionalistas. Ele consegue desemaranhar o que é para ele uma identificação duplamente falsa, de relações supraindividuais com ordens sociais livres de conflito, e entre estas com estados de equilíbrio sistêmicos, e ainda permanecer um parsoniano.

Mas então por que Alexander se agarra ao título de (neo)funcionalismo no nome do círculo de jovens sociólogos americanos? De fato, Alexander dá as razões para isto com toda a clareza necessária quando afirma que o conceito de "funcionalismo" não é nem preciso nem viável como um termo para um esquema conceitual particular, nem 
como um método, modelo ou ideologia. Não obstante, ele representa simbolicamente uma tradição altamente pluralista que merece ser continuada [Alexander, 1985]. Entretanto, todas as tentativas de definir as características comuns desta tradição são extremamente vagas e, como o próprio Alexander admite, de modo algum válidas apenas para esta tradição. Sua afirmação de que aquilo que diferencia esta tradição das outras é que todas as características comuns estão presentes simultaneamente ainda não foi fundamentada. Se perguntarmos se a crítica ao funcionalismo de Giddens também se aplica ao "neofuncionalismo", então precisamos concluir que ela não atinge mais seu alvo porque o alvo foi removido da linha de tiro. O neofuncionalismo, nos termos de Giddens, simplesmente não é funcionalista. Assim, uma decisão sobre a validade do neofuncionalismo e sua relação com a teoria da estruturação de Giddens precisa ser feita numa arena temática diferente. Ela pode até provar que as características comuns um tanto vagas de uma suposta tradição funcionalista, tomadas em conjunto, também se aplicam à teoria de Giddens. Numa leitura positiva, isto significa que um diálogo construtivo poderia acontecer entre versões sofisticadas do parsonianismo, como as de Eisenstadt e Alexander, e a própria teoria de Giddens. Numa leitura negativa, isto significa que a caracterização de Alexander do "neofuncionalismo" como a continuação de uma tradição perde toda sua precisão analítica fora do contexto da sociologia americana.

\section{Conclusão}

Resumindo, os argumentos dos críticos do funcionalismo são aceitos tacitamente no neoparsonianismo de Münch e Alexander. As tentativas de Luhmann de defender a análise funcional e sua cosmologia da teoria dos sistemas não são convincentes. $O$ uso de Habermas da obra de Luhmann cria mais problemas que soluções. Entretanto, tanto o neoparsonianismo quanto as teorias de Habermas e Giddens mostram que a crítica do funcionalismo não nos força a alguma forma de individualismo metodológico ou de sua teoria da ação restritiva. A tarefa comum, então, é desenvolver uma teoria social que é fundamentada na teoria da ação; não confunde a análise funcional com a explicação causal; e contém os benefícios de um uso controlado de modelos de sistemas.

Neste respeito, as principais escolas contemporâneas de teoria social apontam para direções diferentes. Uma comparação substantiva de seus programas não é possível 
aqui. Entretanto, talvez seja permissível fazer um breve apelo por uma aplicação "realista" de um modelo de sistemas sobre a base de uma teoria de ação individual e coletiva. Com "realista", eu quero dizer que a análise dos sistemas deve ser restringida aos efeitos recíprocos reais das interações entre atores sociais. Esta foi a abordagem esboçada vinte anos atrás por Amitai Etzioni, mas que infelizmente não foi melhor desenvolvida. Ele escreveu:

“(...) 'Constituir um sistema' é tratada como uma proposição sujeita a teste empírico; duas unidades quaisquer não formam necessariamente um sistema. Quando os atores são menos relacionados, quando não há um efeito de retroalimentação ou quando ele é apenas esporádico e inconsequente, nós nos referiremos à relação como uma 'situação'. Unidades sociais (...) frequentemente se 'comportam' como se estivessem ligadas como um sistema (...) Mas, diferente do sistema analítico, que é composto de variáveis, este sistema é composto de coletividades, organizações, movimentos, e agências governamentais" [Etzioni, 1968:125].

De Parsons até Luhmann e Habermas, sistemas analíticos foram interpretados de forma essencialista. Etzioni, Touraine e Giddens, pelo contrário, estabeleceram as précondições para uma aplicação da teoria dos sistemas exclusivamente para as interações empiricamente controláveis entre atores individuais e coletivos. De forma consistente com esta abordagem, Giddens define sistemas como "relações reproduzidas entre atores ou coletividades organizadas como práticas sociais regulares" [Giddens, 1984:25]. Evitar o termo "função" - como Giddens propõe - ou não se torna então uma questão meramente terminológica. Apenas uma aplicação "realista" da teoria dos sistemas como esta permite que enfrentemos um dos requerimentos mais importantes da teoria social contemporânea: a consideração dos efeitos de processos de interação sobre o ambiente de unidades sociais. Evitar um uso metafórico do conceito de sistemas é uma précondição para sua aplicação empírica produtiva. Da mesma forma, evitar um uso metafórico do conceito de ambiente é uma pré-condição para uma incorporação significativa de resultados e efeitos ecológicos na análise de processos sociais. Não é um embuste conceitual que transformará a sociedade humana num verdadeiro "sistema ecológico", e sim apenas uma reforma completa. 


\section{Bibliografia}

ALEXANDER, J. [1983] The Modern Reconstruction of Classical Thought: Talcott Parsons. Berkeley: University of California Press.

ALEXANDER, J. (ed.) [1985] Neofunctionalism. London: Sage.

COHEN, G. A. [1978] Karl Marx's Theory of History: A Defence. Oxford: Clarendon.

DEMERATH, N. \& PETERSON, R. (eds.) [1967] System, Change and Conflict. New York: Free Press.

ELSTER, J. [1979] Ulysses and the Sirens. Cambridge: Cambridge University Press.

ELSTER, J. [1982] "Marxism, Functionalism and Game Theory", in Theory and Society, v. 11, pp. 453-482.

ETZIONI, A. [1968] The Active Society. New York: Free Press.

GIDDENS, A. [1977] "Functionalism: après la lutte", in Studies in Social and Political Theory. London: Hutchinson, pp. 96-129.

GIDDENS, A. [1981] A Contemporary Critique of Historical Materialism. London: Macmillan.

GIDDENS, A. [1982] "Functionalism: Commentary on the Debate", in Theory and Society, v. 11, pp. 527-539.

GIDDENS, A. [1984] The Constitution of Society. Cambridge: Polity.

GIDDENS, A. [1985] "Reason without Revolution? Habermas' Theorie des kommunikativen Handelns", in Bernstein, R. (ed.), Habermas and Modernity. Cambridge: Polity, pp. 95121.

HABERMAS, J. [1984] Theory of Communicative Action, v. 1. Boston: Beacon.

HABERMAS, J. [1985] Der philosophische Diskurs der Moderne. Frankfurt: Suhrkamp.

HABERMAS, J. [1986] "Entgegnung", in Honneth, A. \& Joas, H. (eds.). Kommunikatives Handeln. Frankfurt, Suhrkamp, pp. 327-405.

HABERMAS, J. [1988] Theory of Communicative Action, v. 2. Boston: Beacon.

HABERMAS, J. \& LUHMANN, N. [1971] Theorie der Gesellschaft oder Sozialtechnologie. Frankfurt: Suhrkamp.

HONNETH, A. [1985] Kritik der Macht. Frankfurt: Suhrkamp.

JOAS, H. [1988a] "The Unhappy Marriage of Hermeneutics and Functionalism", in Praxis International, v. 8, pp. 34-51.

JOAS, H. [1988b] “The Antinomies of Neofunctionalism”, in Inquiry, v. 31, pp. 471-494.

LUHMANN, N. [1970] Soziologische Aufklärung, v. 1. Opladen: Westdeutscher Verlag.

LUHMANN, N. [1984] Soziale Systeme. Frankfurt: Suhrkamp.

McCARTHY, T. [1985] "Complexity and Democracy, or the Seducements of Systems Theory", in New German Critique, n. 35, pp. 27-53.

MÜNCH, R. [1980] "Teleonomie und voluntaristische Handlungstheorie: Replik auf Helmut Fehr", in Soziale Welt, v. 31, pp. 499-511. 


\title{
11. Edward Soja - Espacializações: uma crítica da versão giddensiana
}

\begin{abstract}
“É (...) como se cada nova agressão do exterior cósmico aparecesse ao mesmo tempo como uma disparidade a ser absorvida e como a oportunidade talvez única de recomeçar, em novas bases, a grande preparação de totalidades que tenta assimilar contradições antigas e indestrutíveis, ou seja, superá-las numa unidade que é finalmente rigorosa - uma unidade que se manifestaria como uma determinação cósmica (...) Pode-se visualizar o movimento circular num espaço tridimensional como uma espiral cujos muitos centros são incessantemente desviados e incessantemente se erguem pela execução de um número indefinido de revoluções em torno de seu ponto de partida. Tal é a evolução personalizadora, pelo menos até o momento (...) da esclerose ou involução regressiva. Nesta última circunstância o movimento se repete indefinidamente, passando pelos mesmos lugares novamente, ou então numa queda abrupta de uma revolução mais alta para uma inferior" [Sartre, L'idiot de la famille, I, 1971:656-657].
\end{abstract}

\section{Redobrando a hélice: o espaço-tempo e Anthony Giddens}

Por mais de uma década, Anthony Giddens vem se espiralando na direção de uma reconceitualização crítica da teoria social, numa sequência de livros extraordinariamente conectados que o colocou como um dos principais intérpretes contemporâneos de língua inglesa da teoria social. A partir de suas primeiras resenhas críticas das origens da sociologia até suas sínteses teóricas mais recentes, o projeto de Giddens evoluiu na forma de uma hélice. Seus argumentos se movem convincentemente para a frente através das antinomias acumuladas que tradicionalmente dividem a ciência social e a filosofia, mas sempre se curvam de volta para ganhar novas perspectivas quanto às raízes históricas da análise e teoria sociológicas. Esta trajetória e estilo distintivos foram estabelecidos em suas obras iniciais, quando ele tentou relançar a teoria social através de uma apropriação e modernização sincrética e crítica dos programas teóricos clássicos de Durkheim, Weber e Marx. Com cada novo avanço em seu pensamento, Giddens quase zelosamente volta para evocar e reconsiderar esta herança da Europa continental de um ponto de vista diferente, um tanto mais distante, mas nunca a ponto de perder de vista as tradições duradouras. 
Por exemplo, em Novas regras do método sociológico [Giddens, 1976], Giddens condensou sua crítica em torno de uma teoria analítica do significado e da ação construída sobre uma reavaliação construtiva da sociologia interpretativa e da hermenêutica. O caminho da hélice atravessou reinos amplos dos humanismos e filosofias da ação do século XX para se centrar na força criativa da ação e práxis humanas. Ela então se curvou de volta para esfolar um funcionalismo persistente (um tema recorrente na obra de Giddens), repeneirar o legado durkheimiano, e exorcizar mais uma vez o fantasma de Talcott Parsons, cuja irritante teoria da ação moldou tão poderosamente a sociologia acadêmica do pós-guerra e permanece no segundo plano da maioria dos textos de Giddens.

Em Problemas centrais da teoria social [Giddens, 1979], ocorreu uma mudança importante. Giddens engajou sua teoria da ação revigorada com uma crítica simpática das principais correntes do pensamento estruturalista. Através desta conjunção excitante entre a ação humana e a estrutura determinadora, Giddens juntou dois discursos teóricos que se desenvolveram através do século $X X$ numa oposição explosiva e não reconciliada. Em Problemas centrais o engajamento dialético entre ação e estrutura, subjetividade e objetividade, foi colocado peremptoriamente no centro da teoria social, reconceitualizada por Giddens numa florescente teoria da estruturação que situava a práxis e a reprodução social no "tempo e espaço como um fluxo contínuo de conduta" [Giddens, 1979:2]. Esta confluência inclusiva de ideias marcou, para Giddens, a culminação de uma espiral de reinterpretação crítica e o começo de outra, mais comprometida e construtiva que a primeira.

Cada livro de Giddens contém as sementes do próximo, um padrão cujo melhor exemplo é a ligação entre Problemas centrais e sua próxima grande obra, Uma crítica contemporânea do materialismo histórico [Giddens, 1981]. A Crítica é muito mais que - e muito menos que - uma reinterpretação eficaz do materialismo histórico de Marx, um pequeno passo à frente para mais uma vez olhar para trás para o século XIX. Apesar de Marx, Durkheim e Weber continuarem a preencher mais espaço do que quaisquer outros autores, a Crítica se tornou a asserção mais explícita e empenhada de Giddens de sua própria concepção da teoria social, uma afirmação construtiva da capacidade de geração de teorias do nexo ação-estrutura. Ela é oferecida, cautelosamente, como uma propedêutica, "um estímulo para reflexões posteriores em vez de (...) se aproximar de uma análise exaustiva do principal assunto que ela levanta" [Giddens, 1981:24]. 
Propedêutica ou não, a Crítica é o livro mais original, e por isso mais vulnerável, de Giddens, ao mesmo tempo um motivo para celebração e um convite a uma reavaliação crítica de todo o projeto teórico deste autor.

A Crítica deve ser avaliada num nível substantivo e teórico, e simultaneamente como uma crítica desconstrutiva e uma tentativa de afirmação reconstrutiva. Giddens nos dá uma prévia de sua abordagem do materialismo histórico em Problemas centrais [Giddens, 1979:53], onde ele afirma que “os escritos de Marx ainda representam o fundo de ideias mais significativas que podem ser utilizadas na busca do esclarecimento de problemas de ação e estrutura”. Entretanto, seus poderes de esclarecimento devem ser abrilhantados através do descarte seletivo de um estorvo de conceitos analíticos “errôneos, ambíguos ou inconsistentes" e os muitos erros de marxismos subsequentes. Remover este estorvo é o objetivo declarado da Crítica.

Muitos dos alvos selecionados por Giddens são temas familiares de discussão na literatura marxista contemporânea: a inadequação do esquema evolucionista e da antropologia antiquada de Marx; os perigos do economismo e do determinismo estruturalista; o uso exagerado de categorias e explicação funcionalistas; a ausência de teorias apropriadas do Estado, da política, da urbanização, do poder. Há um ataque ao modo de produção como conceito analítico, uma negação do aumento incessantemente progressivo das forças de produção, uma recusa em aceitar "toda a história" como a história da luta de classes. A falange de repúdios críticos sem dúvida enfurecerá e irritará alguns leitores marxistas. Outros argumentarão, com mérito, que exatamente os mesmos assuntos foram tratados mais eficazmente por teóricos críticos menos adversos a aceitar o rótulo de "marxista" do que Giddens.

Ainda assim, apesar de seus resmungos, Giddens continua peculiarmente simpático e acolhedor, comprometido com a centralidade do materialismo histórico na construção da teoria social crítica. De fato, a crítica do materialismo histórico que ele oferece é primariamente um acessório para a aplicação e elaboração da teoria da estruturação de Giddens e, particularmente, a distinção embutida entre sociedade “dividida em classes" e "de classe" proposta em Problemas centrais. Os capítulos substantivos da Crítica giram em torno desta distinção, numa tentativa de lidar com a especificidade do capitalismo industrial em comparação com fases anteriores da história mundial. As diferenças entre sociedades divididas em classes (principalmente Estados 
agrários em que existem classes, mas para os quais "a análise de classes não serve como uma base para identificar o princípio estrutural de organização básico" [Giddens, 1981:7] e as sociedades de classe (quer dizer, o capitalismo, onde o conflito, luta e análise de classes são essenciais e centrais) se desenrolam numa série de ensaios críticos que estão cheios de "aprendizados preliminares", percepções propedêuticas sintetizadas frouxamente, que suspeito que não suportariam facilmente uma análise crítica rigorosa, especialmente se feitas talvez pelo próprio Giddens.

O capítulo 3, "A sociedade como viajante do tempo: capitalismo e história mundial", é uma análise das contradições entre o esquema evolucionista de Marx e as percepções mais resguardadas contidas na seção "Formen" dos Grundrisse. Ele é seguido por "Distanciamento espaço-temporal e a geração de poder" (uma asserção da importância de relações espaço-temporais contra relações com a natureza, numa interpretação materialista da história significativamente reorientada); "Propriedade e sociedade de classes" (sobre a geração da sociedade de classes no entrelaçamento do capital e do trabalho assalariado numa "dialética do controle" moldada pela posse privada da propriedade); "Tempo, trabalho e a cidade" (sobre a mercantilização do tempo e do espaço na vida cotidiana sob o capitalismo, uma síntese eclética de Lefebvre, Castells, Harvey, Mumford, Wirth, Christaller, Sjoberg, et al.); "Capitalismo: integração, vigilância e poder de classe" (uma outra exploração da especificidade do capitalismo em termos de meios de controle, do papel do Estado, e do surgimento de sistemas mundiais de integração intersocial); “O Estado-nação, o nacionalismo e o desenvolvimento capitalista" (uma excursão interessante de Montesquieu à nova divisão internacional do trabalho); e "O Estado: conflito de classes e ordem política" (um passeio criativo, mas limitado, pelos debates atuais na teoria do Estado). A Crítica termina, como de costume, com as sementes de suas sequências projetadas ( $O$ Estadonação e a violência e Entre o capitalismo e o socialismo ${ }^{1}$ ), emaranhadas numa discussão de "Contradição e exploração".

Entretanto, antes de permitimos que Giddens salte à frente para outro estágio do caminho de sua hélice, precisamos de considerações cuidadosas sobre os argumentos conceitualizadores que emolduram estes capítulos substantivos, e que são apresentados na Crítica [Giddens, 1981:3] como "elementos de uma interpretação alternativa da

\footnotetext{
${ }^{1}$ Este último volume apareceu, depois do colapso do comunismo, como Para além da esquerda e da direita, em 1994. (N.T.)
} 
história". Particularmente, a teoria da estruturação precisa ser submetida à mesma "crítica positiva" que Giddens aplicou com tanto sucesso a outras teorias. Ao fazê-lo, podemos argumentar que a trajetória em espiral que marcou o longo projeto de Giddens e o propeliu para as realizações perspicazes da Crítica pode ter se tornado sua própria armadilha conceitual, restringindo, em vez de gerando, desenvolvimentos teóricos posteriores. Um livro propedêutico talvez mereça uma avaliação propedêutica, um convite a maiores reflexões, em vez de uma análise exaustiva.

A teoria da estruturação de Giddens é construída sobre (e elabora) a máxima enérgica de Marx que "os homens fazem a história, mas não sob circunstâncias de sua própria escolha", ainda hoje o resumo mais evocativo da relação entre ação e estrutura na teoria social. À construção da história, Giddens adiciona, desajeitadamente no começo, e sem a consciência total de suas implicações, aquilo que pode ser descrito como a "construção da geografia", a produção social do espaço embutida na mesma dialética da práxis. A Crítica pede a injeção da temporalidade e da espacialidade no centro da teoria social, e conecta e separa a teoria da estruturação em relações espaçotemporais. "Toda interação social”, escreve Giddens, "consiste de práticas sociais, situadas no espaço-tempo, e organizadas de forma cognitivamente hábil por atores humanos" [Giddens, 1981:19]. Entretanto, a habilidade cognitiva e a ação são sempre "limitadas" pelas propriedades estruturais de sistemas sociais, que são ao mesmo tempo o meio e o resultado de atos sociais (formando o que Giddens chama de "dualidade da estrutura"). Sistemas sociais são assim concebidos como práticas situadas, relações padronizadas (estruturadas) reproduzidas socialmente através do tempo e do espaço, como história e geografia ${ }^{2}$.

A teoria da estruturação é amplificada por uma combinação de três discursos que servem para ligar a articulação de relações espaço-temporais diretamente com a geração de poder e a reprodução de estruturas de dominação. A filosofia de Heidegger do Tempo e do Ser, os esquemas estruturalistas de Althusser, e os escritos de geógrafos modernos sobre conceitos como "geografia temporal" ["time-geography"] e a subjetividade da distância, são recompostos por Giddens para descrever "como a forma ocorre", como práticas situadas unem "momentos" temporal, estrutural e espacialmente na constituição da vida social. Aquilo que surge mais claramente na nuvem de

\footnotetext{
${ }^{2}$ É interessante notar que Giddens consistentemente enfatiza a combinação "espaço-tempo", mas nunca usa explicitamente "geografia histórica".
} 
neologismos e vocabulário renovado (para os quais Giddens compreensivelmente implora indulgência) é uma ênfase institucional na operação do poder, dentro da qual Giddens propõe outra bifurcação definitiva. O poder e a dominação são unidos na estruturação do controle de alocação (sobre o mundo material) e do controle da autoridade (sobre o mundo social). A alocação e a autoridade passam assim a definir, respectivamente, os domínios do econômico e do político, e conectam a teoria geral da estruturação com os temas e literatura referidos no subtítulo da Crítica: poder, propriedade e o Estado.

Entretanto, a teoria da estruturação esboçada na Crítica permanece impalpável, e de intenção muito mais atraente do que sua execução. Parte do problema está na imensidão da tarefa e nas linguagens díspares unidas de forma não convencional em torno da ligação ação-estrutura. Além disso, a estratégia recorrente de Giddens para formular argumentos teóricos tem sido estender esquemas classificatórios interligados, uma prática que se torna intratavelmente densa na Crítica, mais frequentemente confundindo do que esclarecendo o argumento. Todavia, o ponto mais fundamental é que a teoria da estruturação é construída em torno de uma premissa geradora que requer um ajuste de perspectiva teórica mais formidável do que Giddens consegue obter ${ }^{3}$. Apesar de sua intenção repetida ser projetar tanto a temporalidade quanto a espacialidade para o coração da teoria social crítica, supostamente no equilíbrio explícito do espaço-tempo, Giddens - muito semelhante a Heidegger - consegue, de forma não intencional, perpetuar a antiga submissão do espacial sob a primazia ontológica e epistemológica do tempo e da história. Para Giddens, a história e a sociologia se tornam "metodologicamente indistinguíveis", mas a análise da estruturação espacial continua periférica, um acessório perspicaz.

A descoberta de Giddens dos "textos de geógrafos modernos" e da espacialidade da estruturação é, não obstante, o ingrediente novo mais importante tanto em Problemas centrais quanto na Crítica. Ele distingue estas obras mais favoravelmente do que qualquer outra coisa das contribuições anteriores deste autor, onde a espacialidade da vida social era virtualmente invisível. Infelizmente, o debate contemporâneo crescente sobre a teoria social e a estrutura espacial, sobre a dialética entre a sociedade e a espacialidade, quase não é visto por Giddens, que apresenta sua descoberta quase como

\footnotetext{
${ }^{3}$ Pode ser mais preciso descrever esta premissa geradora como uma afirmação ontológica derivada primariamente de Heidegger, cujas obras foram particularmente influentes nas teorizações de Giddens.
} 
se ele fosse um pioneiro solitário. Isto o leva a utilizar pedaços desconjuntados dos textos de contribuintes chave deste debate, como Lefebvre, Foucault, Harvey, Castells e Poulantzas, sem reconhecer que eles forneceram a substância teórica para uma conceitualização alternativa da constituição espaço-temporal dos sistemas sociais tão central para a Crítica. Em Estado, poder, socialismo, por exemplo, Poulantzas [1978] refocou sua análise da materialidade institucional do Estado em torno da formação e transformação de "matrizes espaciais e temporais", manifestas nos temas do território e da tradição. Estas matrizes foram definidas como as "pressuposições" (ao contrário de meras pré-condições ou resultados) do capitalismo, implicadas nas relações de produção e na divisão do trabalho. A temporalidade e a espacialidade são apresentadas juntas como a concretização de relações sociais e da prática social, o "substrato verdadeiro" de representações míticas, religiosas, filosóficas e experienciais do espaço-tempo. A Crítica teria sido muito mais rica se Giddens tivesse incorporado o caráter explícito e o equilíbrio da interpretação de Poulantzas, tanto no nível da teoria quanto nos capítulos substantivos sobre o espaço e o nacionalismo, onde sua ausência é mais perturbadora. A exposição de Giddens do distanciamento espaço-temporal, da presença e da ausência, da mercantilização do tempo e do espaço, da alocação e da autoridade, também teria fícado mais clara e compreensível. Em vez disso, não há nenhuma menção desta dimensão crucial da última grande obra de Poulantzas.

A ironia da Crítica é que Giddens perde aquilo que sua hélice realizou tão produtivamente durante a última década: uma oportunidade de reavaliar e reconstituir as contribuições clássicas de Marx, Weber, Durkheim, e as realizações do século XX da hermenêutica e do estruturalismo. Há outra hélice da teoria crítica, ainda por ser escrita, que traçaria a história (e geografia?) da primazia teórica do tempo sobre o espaço até suas raízes geradoras. Nesta espiral, Durkheim, Weber e Marx são mais uma vez fontes. Foi nos mananciais anti-hegelianos do materialismo histórico que o tempo e a história revolucionários deslocaram a espacialidade (na forma espiritual do Estado e consciência territorial hegelianos) e a relegaram ao estatuto de fetichismo idealista e diversivo. $\mathrm{O}$ desenvolvimento de uma teoria materialista efetiva do Estado, do nacionalismo e do regionalismo, da coletividade e consciência territoriais, foi restringido desde então. Da mesma forma, os programas teóricos de Durkheim e Weber, construindo uma ciência social relativamente sem espaço baseada em interpretações divergentes da ligação entre ação individual e consciência coletiva, também deslocaram o espacial para a periferia, 
tornando-o uma externalidade quase mecânica. A espacialidade se tornou um espelho/recipiente passivo para o jogo vigoroso da ação humana e do processo social libertados da determinação "ambiental".

A hermenêutica e o estruturalismo reproduziram grande parte deste desequilíbrio tradicional. A fenomenologia existencial, apesar da qualidade inerentemente espacial de conceitos como Dasein, Etre-là, Ser-lá, continuou a se concentrar na temporalidade do Ser e do Vir-a-ser. Para Heidegger em particular, o espaço do ser foi um problema crônico, em mais de uma forma. A celebração estruturalista do sincrônico, em comparação, estava cheia de metáforas espaciais promissoras, mas relativamente poucas análises espaciais explícitas. Não obstante, tanto a hermenêutica quanto o estruturalismo abriram novas janelas pelas quais as relações espaço-temporais podem ser reengajadas numa simetria mais apropriada.

Por mais combativos e procrustianos que o estruturalismo e a hermenêutica tenham sido, sua conjunção recente e ainda hesitante em torno da relação ação-estrutura (da qual a obra de Giddens é apenas um grande exemplo) exigiu um nexo apropriadamente dialético, sem nenhuma prioridade forçada da ação sobre a estrutura, e vice-versa. Significativamente, esta conexão dialética entre ação e estrutura foi acompanhada por uma atenção crescente a outra dualidade tradicional, o espacial e o temporal, que requer uma conceitualização similar: epistemologicamente coiguais, dialeticamente relacionados em sua expressão material, unificados na práxis, e posicionados no coração da teorização social crítica.

Giddens se aproxima desta reconceitualização crítica, certamente mais do que qualquer outro sociólogo contemporâneo de língua inglesa. Entretanto, seu "espaço" teórico ainda é restrito demais. Por exemplo, não há nenhuma menção na Crítica a Derek Gregory, seu colega em Cambridge, cuja obra sobre teoria social e estrutura espacial no contexto da relação ação-determinação iluminou tão claramente a literatura geográfica contemporânea ${ }^{4}$. Também há uma apropriação muito estreita e intermitente da teoria social francesa. Particularmente, as obras extensas de Lefebvre sobre a espacialidade da vida social e da reprodução social, sobre a dialética da ação e da estrutura embutida na produção social do espaço, não podem ser reduzidas a seus

\footnotetext{
${ }^{4}$ Ver Gregory [1978], em particular. Depois da publicação da Crítica, houve muito mais contato entre Giddens e Gregory. Ver Gregory [1984], Gregory \& Urry [1985], e o artigo de Gregory sobre "Teoria da estruturação" no Dicionário de geografia humana [Johnston et al.; 1986].
} 
comentários sobre le quotidien e uma reificação errante do "urbano", como Giddens o fez (seguindo, como também muitos outros, a voz de Castells em A questão urbana).

Apesar destas fraquezas poderem ser definidas como "estruturais", elas não são, obviamente, determinadas conclusivamente, especialmente tendo em vista o ator humano reflexivo e hábil envolvido. Logo depois da publicação da Crítica, e antes de terminar suas sequências prometidas, Giddens mudou para outro nível de desenvolvimento teórico, passando pelos mesmos lugares novamente, mas com mais clareza e um intuito de maior formalização. Na Constituição da sociedade [Giddens, 1984], Giddens simultaneamente respondeu a seus críticos, explicitou as fontes ecléticas de sua recente "evolução personalizadora", e consolidou cuidadosamente uma teoria da estruturação preparadora de totalidades. As sementes propedêuticas da Crítica agora floresceram num jardim maduro e organizado, com cada espécie de flor cuidadosamente rotulada quanto à sua herança ontogenética e filogenética. A Constituição oferece assim outra oportunidade para tratarmos da trajetória proposta pela Crítica, e para reconstruir, em bases mais firmes, a versão giddensiana da reafirmação do espaço.

\section{A constituição da sociedade e a reconstituição da teoria social.}

Numa entrevista com Derek Gregory em Society and Space, Giddens descreveu seu projeto pessoal distintivo:

"Eu não acho que esteja de forma alguma trabalhando de forma inovadora em assuntos epistemológicos, e eu tento 'colocá-los entre parênteses' de forma substancial. O que estou tentando fazer é trabalhar no que essencialmente descrevo como uma ontologia da sociedade humana, quer dizer, concentrando-me em assuntos de como teorizar a ação humana, quais são as implicações dessa teorização para analisar instituições sociais, e então qual é a relação entre esses dois conceitos elaborados em conjunção um com o outro (...) Eu não acho que seja nem necessário nem possível supor que você pode formular uma epistemologia completa e então de alguma forma partir em segurança para estudar o mundo. Então minha ideia é disparar salvas na realidade social, por assim dizer; salvas conceituais, que não fornecem uma epistemologia geral consolidada" [Gregory, 1984:124].

O que emana destas salvas conceituais na Constituição é uma teoria do ser reformulada, da natureza da existência social. Colocada na perspectiva apropriada, a 
Constituição se destaca como o enunciado ontológico mais rigoroso, equilibrado e sistemático atualmente disponível sobre a estruturação espaço-temporal da vida social. Sua posição e linhagem dentro do discurso da teoria social crítica são óbvias, mas sua realização é mais ampla, através dos caminhos filosóficos desbravados pelos esforços de Husserl, Heidegger e Sartre para dar um "lugar" ao ser. É aqui que suas realizações principais precisam ser localizadas.

A ausência intencional de uma epistemologia formal dificulta bastante qualquer tradução simples e direta da ontologia de Giddens para uma pesquisa empírica demonstrativa, e sua inventividade conceitual necessária continua a causar malentendidos, especialmente entre aqueles que buscam tais percepções empíricas diretas e simples na obra de Giddens. Não obstante, a Constituição da sociedade fornece linhas gerais esclarecedoras, ainda que complexamente sinuosas, para a análise empírica e, particularmente, para uma reinterpretação crítica da geografia histórica do capitalismo. Ela não apresenta fórmulas e esquemas fáceis, nem propõe posturas rigidamente categoriais quanto aos caminhos teóricos a serem seguidos. Mas esta é sua força, e não sua fraqueza.

A teoria da estruturação na Constituição é uma síntese elástica da concatenação quase infinita de dualismos associados que se seguiram à oposição quase sempre congelada entre subjetividade e objetividade. Ação e estrutura, o individual e o social, são combinados flexivelmente por Giddens, e esta flexibilidade e fusão ontológicas é a mensagem principal.

Os principais conceitos sintetizadores que afirmam este equilíbrio ontológico podem ser alçados do Glossário convenientemente anexado [Giddens, 1984:373-377]. Nossa linguagem conceitual herdada é tão distorcida quando se trata de relações espaçotemporais, que precisa ser reestruturada radicalmente para expressar a articulação entre espaço, tempo e ser social, uma tarefa que Giddens intencionalmente se propõe na Constituição. O glossário conceitual resultante é um exemplo de equilíbrio engenhoso que consistentemente insere o espaço unido ao tempo, mas nunca o espaço sozinho, na constituição da sociedade.

Contextualidade: o caráter situado da interação no espaço-tempo, envolvendo o ambiente da interação, atores copresentes e a comunicação entre eles; 
Local: uma região física envolvida como parte do ambiente de interação, tendo fronteiras definidas que ajudam a concentrar a interação de uma forma ou de outra;

Regionalização: a diferenciação temporal, espacial, ou espaço-temporal de regiões, ou dentro de locais, ou entre eles; a regionalização é uma noção importante para contrabalançar a suposição de que sociedades são sempre sistemas homogêneos e unificados;

Integração social: a reciprocidade de práticas entre atores em circunstâncias de copresença, entendida como continuidades e disjunções de encontros;

Integração sistêmica: a reciprocidade entre atores ou coletividades através do espaço-tempo estendido, fora de condições de copresença;

Distanciamento espaço-temporal: o esticamento de sistemas sociais através do espaço-tempo estendido, baseado em mecanismos de integração social e sistêmica.

Apesar dos avanços conceituais, a dama de companhia temporal se torna ocasionalmente protetora demais, pois Giddens está determinado a reconhecer o espaço sem sucumbir aos vieses disciplinares da Geografia Moderna e seu separatismo peculiar. Entretanto, há muito menos cautela em relação à história e suas inclinações disciplinares. Como resultado, o tempo e a história frequentemente aparecem sozinhos na Constituição da sociedade, com autoridade e alocação, muito mais "estabelecidos" do que o "outsider" geográfico menos familiar". A ordem forçada é sempre "espaçotempo", ligados na mesma sequência de dominado para dominador, como em "periferiacentro"

Giddens, assim, falha mais uma vez em iniciar a crítica necessária do historicismo que deve acompanhar a reestruturação contemporânea da teoria social crítica $^{7}$. Todavia, o vocabulário conceitual reformulado de Giddens pode ser apropriado eficazmente para reconstruir a substância e o significado da estruturação espaço-

\footnotetext{
${ }^{5}$ O glossário de Giddens inclui uma entrada para historicidade: "a identificação da história como mudança progressiva, junto com a utilização cognitiva de tal identificação para aumentar essa mudança. A historicidade envolve uma visão particular do que é a 'história', o que significa usar o conhecimento da história para mudá-la". Não há uma entrada equivalente para a espacialidade.

6 "Time-space" e "core-periphery" no original. A sentença teve que ser invertida de forma um tanto deselegante para transmitir a ideia desejada pelo autor. A expressão "Time-space" é costumeiramente traduzida para o português por "espaço-tempo", construção muito mais disseminada do que "tempoespaço". (N.T.)

${ }^{7}$ Mas é preciso adicionar que também falharam todos os teóricos sociais espacializadores que discuti, de Foucault e Lefebvre (que foi quem chegou mais perto) a Harvey, Mandel e Jameson.
} 
temporal. Com algumas extensões adaptativas, o esquema de conceitos estabelece uma ontologia social provocante condutiva ao desenvolvimento do materialismo históricogeográfico, muito mais apropriada para esta tarefa do que qualquer outra que emergiu do encontro entre a Geografia Moderna e o marxismo ocidental.

Giddens, para ser mais específico, chega mais perto do que qualquer outro teórico social influente de descobrir aquilo que, na minha opinião, é a generalização contextual mais fundamental sobre a espacialidade da vida social: que o mundo da vida inteligível do ser é sempre, e em todo lugar, composto de um sistema em múltiplas camadas de regiões nodais criadas socialmente, uma configuração de locais diferenciados e organizados hierarquicamente. As formas e funções específicas desta estrutura espacial existencial variam significativamente dependendo da época e do lugar, mas quando o ser é situado-no-mundo, o mundo em que ele está se torna social dentro de uma matriz espacial de locais estabelecidos. A estrutura topológica é mutável e permutável, mas ela sempre está lá para envolver e abranger, situar e constituir toda a ação humana, concretizar a realização da história e da geografia.

Geógrafos e sociólogos examinaram pedaços desta espacialização existencial e produziram uma literatura impressionante descrevendo as particularidades e geometrias hipotéticas de suas aparições empíricas reais ou esperadas ${ }^{8}$. Entretanto, as fontes geradoras da matriz espacial são evasivas e ilusivas. $O$ fracasso da geografia e da sociologia em recompor uma ontologia apropriada na qual, para usar uma expressão da moda, "o espaço importa" (em vez de simplesmente estar lá) manteve o significado existencial do contexto espacial escondido. Examinemos agora como a aproximação de Giddens pode ser estendida de modo eficaz para destacar mais claramente a generalidade e especificidade espacial do ser social.

Primeiro, há o conceito evocativo de local, uma região limitada que concentra a ação e junta na vida social o único e particular com o geral e nomotético. Como Giddens nota, é uma noção um tanto semelhante a "lugar", utilizada nos escritos de geógrafos culturais (onde, posso adicionar, ela muitas vezes e proposta como uma

\footnotetext{
${ }^{8}$ A teoria do lugar central, por exemplo, descreve uma geometria idealizada da matriz espacial sob condições em que se supõe que relações de mercado e comportamento minimizador de distâncias, em relação ao fornecimento de serviços sociais, dominam a produção social do espaço. Seus modelos ocasionalmente revelam uma semelhança fortuita com as paisagens geográficas reais das sociedades capitalistas, em grande parte porque eles também são estruturados em torno de uma matriz espacial pressuposta de locais estabelecidos. Eles representam uma das raras tentativas na história da teoria social de tratar de aspectos seletos desta espacialização existencial.
} 
alternativa superior a "espaço" e "região"). Mas ela provoca uma comparação ainda mais direta com o uso de "lugar" nas ontologias de Heidegger e Sartre. Para Giddens, os locais se referem ao "uso do espaço para fornecer os ambientes da interação, que por sua vez são essenciais para especificar sua contextualidade" [Giddens, 1984:118]. Estes ambientes podem ser um cômodo numa casa, uma esquina, um chão de fábrica, uma prisão, um sanatório, um hospital, um bairro/cidade/região definível, as áreas territorialmente demarcadas ocupadas por Estados-nação, até a Terra ocupada como um todo. Locais são estabelecidos em muitas escalas diferentes, e esta hierarquia dos locais em múltiplas camadas é reconhecível como um construto social e uma parte vital do serno-mundo 9 .

A concentração da interação nos locais está ligada a outra especificidade contextual do ser social que Giddens hesita em reconhecer. Ela pode ser melhor descrita como a nodosidade da vida social, o agrupamento ou aglomeração socioespacial de atividades em torno de centros ou nós geográficos identificáveis. A nodosidade e o centramento, por sua vez, pressupõem uma condição social de caráter periférico: para cada centro há uma retroterra mais ou menos limitável definida por uma diminuição geográfica da nodosidade, causada principalmente por controles sobre o acesso às vantagens da aglomeração. A nodosidade e o caráter periférico existem, até certo ponto, em todos os lugares, mesmo que apenas como um produto dos esforços individuais e coletivos para enfrentar a fricção ontologicamente dada da distância imposta imediatamente sobre o ser-no-mundo. A existência, a própria presença do ser, significa ter que lidar com a fricção da distância, seja no nível do "ambiente primário" ou nas rotinas monótonas da vida cotidiana. Uma padronização espaço-temporal ordenada por distâncias penetra assim no ambiente existencial da interação humana, e não pode ser ignorada na construção de teorias.

Mas a fricção da distância também não pode ser arrancada de sua contextualidade social e modelada como uma "variável independente" quase newtoniana determinando a nodosidade dos locais, como ocorre tão frequentemente nos modos quantitativos ou "científicos" da Geografia Moderna. Como Giddens sugere na

\footnotetext{
${ }^{9}$ A escala e a hierarquia também devem ser vistas como construtos sociais, não simplesmente como dados existenciais. Para algumas discussões recentes das escalas espaciais distintas associadas ao desenvolvimento capitalista (no nível global, do Estado-nação e do urbano), ver Taylor [1981] e Smith [1984]. Entretanto, estas obras são pouco mais que sondagens iniciais de um assunto muito complexo e pouco estudado.
} 
sua discussão breve demais sobre distinções centro-periferia e "desenvolvimento desigual", a operação do poder de alocação e autoridade regula a formação de centros e periferias através de todo o conjunto de ambientes-locais. Ao tentar evitar as táticas obscurantistas do separatismo espacial, com sua despolitização inerente da espacialidade, Giddens embute a nodosidade e suas extensões espaciais na temporalidade das relações de poder, num eixo do "estabelecimento" antecedente do controle sobre pessoas e recursos, que subsequentemente define o estado de estar "do lado de fora". Este eixo temporal de diferenciação intersecciona aquele entre regiões centrais e periféricas para formar as linhas básicas das noções de Giddens de distanciamento espaço-temporal e regionalização, de como a interação humana é "esticada" através do tempo e do espaço numa série de ambientes desenvolvidos e diferenciados desigualmente ${ }^{10}$. De forma mais simples, a espacialidade e temporalidade dos locais são entrelaçadas contextualmente e conectadas inseparavelmente com relações de poder do princípio até o desfecho. Regiões centrais e periféricas são assim homólogas com a criação de uma oposição social primordial entre aqueles dentro e fora do poder, para remeter a meu argumento sobre a natureza e necessidade do desenvolvimento geograficamente desigual e das relações entre espacialidade e classe.

A nodosidade, a regionalização e o poder também estão envolvidos em outra característica contextualizadora do ser social, a criação de recintos fechados que demarcam o que Giddens chama de "disponibilidade de presença” (presença/ausência) da interação humana. Aqui, dois termos adicionais e intimamente relacionados, "territorialidade" e "regionalismo", precisam ser incluídos ao glossário giddensiano e tecidos na teoria da estruturação. Ambos servem, de muitas formas diferentes, para segregar e compartimentar a interação humana ao controlar a presença/ausência e inclusão/exclusão. Como a distinção centro-periferia, com a qual estão intimamente ligados, a territorialidade e o regionalismo expressam o poder de alocação e autoridade que opera em locais. Para usar termos de Foucault, eles são produtos da instrumentalidade do espaço/poder/conhecimento, e fornecem a base para tornar a operação do poder tanto espacial quanto temporal.

\footnotetext{
${ }^{10}$ Giddens apresenta um diagrama simples [Giddens, 1984:131] para descrever estas relações. O eixo vertical tem "estabelecidos" no topo, "outsiders" na base. Ele é cruzado por um eixo horizontal partindo de "regiões centrais" para "regiões periféricas".
} 
A territorialidade é o termo mais geral, e contém pistas de noções particularizadas como soberania, propriedade, disciplina, vigilância e jurisdição ${ }^{11}$. Ela se refere à produção e reprodução de recintos espaciais que não apenas concentram a interação (uma característica de todos os locais) mas também intensificam e impõem seu caráter delimitado. A territorialidade, quase por definição, está presente em todo local pelo menos como o limite externo (onde a ausência de interação começa). Mas esta delimitação pode ser mais ou menos rígida ou permeável, e pode mudar de forma com o tempo. Ela também pode existir dentro do ambiente do local. Esta territorialidade intralocal pode coincidir ou não com regiões centrais e periféricas, mas está sempre associada à regionalização, com divisões espaço-temporais de atividades e relações. A diferenciação regional dentro e entre locais é, por sua vez, o ambiente para um regionalismo contingente, uma consciência e afirmação ativas de regiões particulares, vis-à-vis outras regiões, enquanto recintos territoriais e sociais. Como uma expressão da territorialidade dos locais, o regionalismo está baseado na geografia do poder.

O ser material, na forma do corpo, é a instanciação inicial e pré-figurativa desta hierarquia de locais nodais diferenciados. $\mathrm{O}$ eu é o centramento primário e cheio de tensões do ser, e à sua volta se forma uma regionalização criada que até muito recentemente escapou de análises formais, pois ela permaneceu teimosamente fora do que Giddens descreve como nossa consciência discursiva (em oposição à consciência prática). Giddens se volta principalmente à sociologia dos encontros de Goffman e à geografia temporal de Hägerstrand para buscar percepções sobre esta regionalização centrada no eu, mas salvas conceituais igualmente perceptivas podem ser encontradas na obra de Edward Hall, Robert Sommer e outros que ajudaram a espacializar o eu através de uma crítica cultural, e do início de uma psicologia ambiental da cognição espacial [Soja, 1971]. O que se tornou cada vez mais claro nesses escritos é uma microgeografia notável da interação humana presa em torno das bolhas portáteis de zonação do espaço pessoal e de comportamento "proxêmico", uma linguagem ordinária da intersubjetividade espacial não verbal e não escrita.

\footnotetext{
${ }^{11} \mathrm{Eu}$ comecei a explorar o conceito de territorialidade humana e sua relação com a organização política do espaço no final dos anos 1960 [ver Soja, 1971]. Grande parte desse trabalho teve de ser puramente defensivo, porque a visão que prevalecia da territorialidade na época estava cheia de imperativos bioetiológicos que obscureciam qualquer interpretação sociopolítica. Para uma tentativa recente de recuperar e relançar os debates sobre a territorialidade humana, ver Sack [1986]. Entretanto, nem minha obra anterior nem a de Sack fornecem uma ontologia social satisfatória da territorialidade.
} 
Mas isto é apenas o começo, a primeira de muitas camadas de locais e regionalizações criados ondulando a partir da espacialidade subjetiva do eu portátil para se imprimir na paisagem humanizada. A nodosidade entrelaça atividades coletivas ao redor de outros ambientes centrados e relativamente fixos, que também são regionalizados e mais ou menos limitados territorialmente. No mundo moderno, o lugar de trabalho e o lugar de residência são os locais nodais predominantes da copresença social, e sua separação e territorialidade locacional induzem sua própria padronização ordenada em distâncias, mas produzida socialmente, da interação e experiência humanas. Em contextos menos modernos, estes dois locais são tipicamente cocentrados, e se reforçam mutuamente para definir recintos limitados mais estritamente de integração social relativamente impermeável à interação em escalas geográficas maiores, exceto através da aglomeração de locais nodais e microgeografias individuais em assentamentos humanos, ou naquilo que pode ser proveitosamente chamado de localidades.

Localidades - outro termo que Giddens não usa - podem ser definidas como tipos particulares de locais duráveis, estabilizados social e espacialmente através do assentamento aglomerado de lugares de atividades primárias e o estabelecimento de comunidades territoriais propínquas. Como todo local, elas são estruturações espaçotemporais surgindo da combinação da ação humana e do impacto condicionante de condições espaço-temporais pré-existentes. Elas fornecem outro ambiente criado, construído de forma mais elaborada, para a interação humana aumentado em escopo, densidade, diferenciação social e ligação coletiva ao lugar. Elas também são locais geradores para aquilo que Giddens define como "distanciamento", o esticamento de sistemas sociais através do espaço-tempo, da copresença da interação social local às coletividades e reciprocidades mais abrangentes e elásticas da integração do sistema. As localidades são assim os tijolos da urbanização: a formação de locais coesivos e nodalmente aglomerados diferenciados regionalmente internamente (dentro do aglomerado), comparativamente (um local urbanizado contra outro), e hierarquicamente (posicionados num sistema de múltiplos níveis de locais urbanos). Cidades podem ser descritas como localidades que englobam contextos, recintos e concentrações nodais de interação humana que são ligadas à integração social e do sistema, e, portanto, a redes múltiplas de poder social. No contexto do mundo contemporâneo, a localidade pode variar do menor assentamento ou bairro até a maior conurbação. 
A urbanização, entretanto, representa uma ruptura da generalidade ontológica, e força uma transição para uma geografia histórica especificada mais concretamente, uma mudança que Giddens não deixa suficientemente explícita. Todas as sociedades humanas que existiram foram contextualizadas e regionalizadas em torno do estabelecimento, em camadas múltiplas, de locais nodais supraindividuais - uma base para a alimentação coletiva e reprodução biológica, lugares e territórios de coleta de alimentos e matérias-primas, centros cerimoniais e lugares de lazer, espaços compartilhados e terrenos proibidos, bairros definíveis e recintos territoriais. Mas apenas em algumas sociedades estes locais foram aglomerados em assentamentos especificamente urbanos, e apenas nos últimos dois séculos a urbanização se expandiu a ponto de se tornar o ambiente de vida dominante para uma grande parte da população mundial, mesmo em áreas definidas convencionalmente como "não-urbanas" ou rurais. Esta é a definição estendida do urbano usada por Lefebvre para descrever a geografia específica do capitalismo.

Assim, entender a urbanização e o urbanismo na contextualidade de locais centrados hierarquicamente projeta, e não rejeita, a ontologia giddensiana. Giddens não consegue desenvolver uma teoria da urbanização rica e rigorosa, preferindo em vez disso focar suas projeções no Estado-nação (como se o Estado suplantasse, em vez de incorporar, a urbanização como o loco primário do poder). Mas ele de fato insiste em localizar o urbano no coração da teoria social crítica e no meio da estruturação do espaço-tempo. A especificidade do urbano, aquela antiga questão que tanto dividiu geógrafos e sociólogos marxistas, recebe assim um novo olhar e importância.

A urbanização pode ser vista como uma das várias grandes acelerações do distanciamento espaço-temporal que estenderam a escala das interações humanas sem necessariamente destruir sua anatomia espacial fundamental. Você e eu ainda vivemos numa hierarquia de regionalizações nodais emanando de nossos corpos, mas a interação social e a integração societária agora se expandiram numa escala mundial, um alcance global em que o processo de urbanização foi um dos principais veículos. A especificidade do urbano é assim definida não como uma realidade separável, com suas próprias regras de formação e transformação sociais e espaciais; ou meramente como um reflexo e imposição da ordem social. O urbano é uma parte e particularização integral da generalização contextual mais fundamental sobre a espacialidade da vida social - que nós criamos e ocupamos uma matriz espacial de múltiplas camadas de 
locais nodais. Em sua particularidade, sua especificidade social, o urbano é permeado com relações de poder, relações de domínio e subordinação, que canalizam diferenciações regionais e regionalismo, territorialidade e desenvolvimento desigual, rotinas e revoluções, em muitas escalas diferentes.

As generalidades descritivas da Escola de Chicago e da maior parte da geografia e sociologia urbanas modernas - afirmando que cidades são diferenciadas (supostamente do rural e do não-urbano) por seu tamanho, densidade, heterogeneidade, anomia, solidariedades funcionais, concentricidades e axialidades geográficas - não estão erradas. Mas elas escondem a especificidade mais fundamental do urbano que surge da conjunção entre nodosidade, espaço e poder. As cidades são aglomerações nodais especializadas construídas ao redor da "disponibilidade de presença" instrumental do poder social. Elas são centros de controle, cidadelas projetadas para proteger e dominar através daquilo que Foucault chamou de "as pequenas táticas do habitat", através de uma geografia sutil de fechamento, confinamento, vigilância, compartimentalização, disciplina social e diferenciação espacial.

A habilidade de controlar emana em grande parte da própria nodosidade/centralidade, e se estende para fora através de pelo menos dois planos, um diretamente do centro para a retroterra (um controle vicinal que tipifica a integração social) e o segundo de um centro nodal para outros (um controle hierárquico característico da integração do sistema). Juntas, estas emanações de poder e controle urbanas e territoriais definem a própria natureza do Estado. Elas também definem um terreno contestável de política espacial e conflito cívico sobre le droit à la ville, os "direitos à cidade", nos termos de Lefebvre, o poder dos cidadãos de controlar a produção social do espaço ${ }^{12}$.

Como Giddens escreve, a cidade é "muito mais do que um mero milieu físico. Ela é um 'recipiente de armazenamento' de recursos administrativos" [Giddens, 1984:183] ao redor do qual Estados são construídos. Ele nota as mudanças dramáticas na contextualidade da cidade que surgem com a ascensão da industrialização capitalista

\footnotetext{
${ }^{12}$ Ver Michael Mann, As fontes do poder social [vol. 1, 1986] para o começo do que promete ser uma das poucas análises explicitamente geográficas do Estado e da estratificação social. Mann inicia com a seguinte afirmação destacada: "Sociedades são constituídas de múltiplas redes de poder socioespacial sobrepostas e cruzadas" [1986:1]. Ele continua, comentando que "a maioria dos teóricos prefere noções abstratas de estrutura social, e por isso ignoram aspectos geográficos e socioespaciais das sociedades. Se mantivermos em mente que 'sociedades' são redes, com contornos espaciais definidos, podemos remediar isto" [1986:9].
} 
e sua mercantilização do tempo e do espaço no final de um capítulo sobre "Tempo, espaço e regionalização". Ele então se volta, apropriadamente, para Foucault, em busca de percepções críticas sobre a "temporalização e espaçamento" do poder disciplinar, transformando estas percepções numa análise subsequente dos princípios estruturais de sociedades tribais, divididas em classes e de classe (capitalista). Aqui surge uma distinção importante entre a organização de locais dominante das sociedades divididas em classes, enraizada na simbiose entre a cidade e o campo, o "eixo que relaciona áreas urbanas com suas hinterlândias rurais"; e a organização de locais dominante do capitalismo, a "expansão esparramada de um 'ambiente criado' ou manufaturado". Como isto chega perto de focar nossa atenção sobre a espacialização problemática e instrumental que marcou a geografia histórica do capitalismo, que Lefebvre desmascarou e amarrou de forma tão apertada à urbanização, que outros começaram a identificar como a chave para entender a sociedade capitalista contemporânea.

Mas Giddens mais uma vez segue a espiral até a borda da versão lefebvreana, apenas para se recusar a dar o próximo passo (lateral?). Na segunda metade da Constituição, a hélice giddensiana começa uma involução quase regressiva, repetindose sem avançar muito para a frente. A significância vívida e central da espacialidade parece ser arrancada pedaço a pedaço até ficarmos, num longo capítulo sobre a aplicação da teoria da estruturação à pesquisa empírica e à crítica social (que se segue a outro exorcismo de Talcott Parsons!), quase sem espaço nenhum. Há uma breve menção do desenvolvimento desigual tendo "uma aplicação mais ampla do que normalmente se reconhece" [Giddens, 1984:319] seguida de várias sentenças quase wallersteinianas sobre a regionalização produzindo e difundindo contradições sociais. Mas os conselhos explícitos dados ao "analista social" parecem omitir a afirmação vigorosa de que, afinal, “o espaço importa”. Não surpreende que a resposta sociológica a Giddens, tanto a favor quanto contrária, quase totalmente deixa de reconhecer a importância de seu giro espacial pronunciado, pois o próprio Giddens parece ocultá-lo nos momentos mais críticos.

Giddens, no final da Constituição, se esforça bastante para recuperar sua geografia, depois de enfurná-la nas 150 páginas anteriores. Colocada como a reflexão tardia definitiva, ele escreve: 
"A frase pode parecer bizarra, mas os seres humanos 'fazem sua própria geografia' tanto quanto 'fazem sua própria história'. Isto quer dizer, as configurações espaciais da vida social são uma questão de importância básica para a teoria social tanto quanto as dimensões da temporalidade" [Giddens, 1984:363].

Estas são as últimas sentenças do texto:

“O espaço não é uma dimensão vazia na qual agrupamentos sociais se estruturam, e tem que ser considerado em termos de seu envolvimento na constituição de sistemas de interação. O mesmo argumento feito para a história se aplica à geografia (humana): não há diferenças lógicas ou metodológicas entre a geografia humana e a sociologia!" [Giddens, 1984:368].

É difícil prever se estes enunciados finais, com ponto de exclamação, sobre "Ciência social, história e geografia" serão as palavras finais de Giddens sobre o assunto, ou se tornarão as sementes para outra obra em espiral.

Revendo a Constituição da sociedade, temos muito a louvar. Na minha opinião, a infusão do poder numa ontologia da sociedade explicitamente espacializada, e, assim, em interpretações sobre a realização da geografia ao lado da realização da história, é o principal êxito de Giddens. Argumentos semelhantes existem na obra de Foucault, Lefebvre, Poulantzas, Sartre, e talvez outros que eu tenha esquecido. Mas, na Constituição, Giddens junta quase tudo numa síntese monumental que fornece, pela primeira vez, uma ontologia social sistemática capaz de sustentar a reafirmação do espaço na teoria social crítica.

A crítica mais fácil de fazer a Giddens é a mais complicada e possivelmente a mais fútil, pois ele vestiu uma armadura muito forte contra ela em sua evolução pessoal. Ao deixar a epistemologia para outros e se concentrar na ontologia social, Giddens se liberta para mergulhar na análise empírica quando quiser e sem se comprometer com nenhum esquema de interpretação que não seja o seu, sua própria "determinação cósmica" (para trazer mais uma vez a epígrafe de Sartre). Isto, é claro, não é incomum entre os melhores teóricos sociais e filósofos. Mas deixa Giddens vulnerável a não perceber as particularidades do momento contemporâneo, suas novas possibilidades e rupturas com o passado. Como o sociólogo e realista teórico John Urry escreve:

"[Giddens] tende a negligenciar os problemas de explicar as causas e consequências das transformações recentes na estruturação espacial do capitalismo tardio. 
Além do mais (...) esta omissão é particularmente séria, já que o espaço, e não o tempo, é a dimensão distintamente significativa do capitalismo contemporâneo, tanto em termos de seus processos mais salientes quanto em termos de uma consciência social mais geral. Como o historiador da longue durée, Braudel, afirma, 'todas as ciências sociais precisam abrir espaço para uma concepção da humanidade cada vez mais geográfica" [Urry, 1985:21].

Isto é essencialmente um chamado para uma aplicação da teoria social crítica mais empírica e mais centrada espacialmente às perplexidades do momento atual. E ele nos leva a outra rodada de reestruturação, uma desconstrução e reconstituição mais profunda e radical da teoria social crítica do que Giddens aparentemente contemplou.

Entender a modernidade contemporânea, ou a pós-modernidade, se quiserem, não pode ser feito simplesmente anunciando a equivalência lógica e metodológica da história, geografia e sociologia em seus disfarces modernistas, e exaltando a fecundidade de suas reconexões nascentes. Todo o tecido da divisão do trabalho acadêmico e intelectual moderna que definiu, limitou e reificou estas disciplinas desde o final do século XIX precisa ser radicalmente reformulado. O sociologismo residual de Giddens assume assim uma nova importância, pois a sociologia que foi consolidada e expandida tão ricamente por Giddens representa hoje um dos muitos monumentos disciplinares reificados que precisa ser desconstruído antes que possamos ter sucesso em fazer qualquer coisa nova.

\section{Bibliografia}

CASTELLS, M. [1977] The Urban Question. London: Edward Arnold.

FELL, J. [1979] Heidegger and Sartre: An Essay on Being and Place. New York: Columbia University Press.

GIDDENS, A. [1976] New Rules of Sociological Method. London: Hutchinson.

GIDDENS, A. [1979] Central Problems in Social Theory. London: Macmillan.

GIDDENS, A. [1981] A Contemporary Critique of Historical Materialism. London, Macmillan.

GIDDENS, A. [1984] The Constitution of Society. Cambridge: Polity.

GREGORY, D. [1978] Ideology, Science and Human Geography. London: Hutchinson.

GREGORY, D. [1984] "Space, Time and Politics in Social Theory: An Interview with Anthony Giddens", in Environment and Planning: Society and Space, v. 2, pp. 123-132. 
GREGORY, D. \& URRY, J. (eds.) [1985] Social Relations and Spatial Structures. London: Macmillan.

JOHNSTON, R. J., GREGORY, D. \& SMITH, D. M. [1986] The Dictionary of Human Geography. Oxford: Blackwell.

MANN, M. [1986] The Sources of Social Power, v. 1. Cambridge: Cambridge University Press.

POULANTZAS, N. [1978] State, Power, Socialism. London: Verso.

SACK, R. [1986] Human Territoriality: Its Theory and History. Cambridge: Cambridge University Press.

SARTRE, J-P. [1971] L'idiot de la famille. Paris: Gallimard.

SMITH, N. [1984] Uneven Development. Oxford: Blackwell.

SOJA, E. [1971] The Political Organization of Space. Washington: Association of American Geographers, Resource Papers.

TAYLOR, P. [1981] "Geographical Scales in the World Systems Approach", in Review, v. 5, pp. 3-11.

URRY, J. [1985] "Social Relations, Space and Time, in Gregory, D. \& Urry, J. (eds.) Social Relations and Spatial Structures. London: Macmillan, pp. 20-48. 


\title{
12. Richard Kilminster - A teoria da estruturação como uma visão de mundo
}

\begin{abstract}
"Sínteses (...) não flutuam num espaço abstrato, sem sofrer influência da gravidade social; é a configuração estrutural da situação social que faz com que seja possível que elas surjam e se desenvolvam." [Mannheim, 1928:225]
\end{abstract}

\section{Introdução}

Ao contrário dos receios de alguns comentadores, por exemplo, Hirst [1982], a teoria da estruturação de Giddens, elaborada em $A$ constituição da sociedade [Giddens, 1984], é um exemplo não de ecletismo, mas de síntese teórica. Como um expoente da síntese, ele divide o palco sociológico com outros sintetizadores, incluindo Parsons [1937], Lenski [1966] e Collins [1985]. Como Stephen K. Sanderson [1987] apontou de forma útil, o ecletismo envolve uma justaposição mecânica de elementos de tradições de pesquisa, enquanto a síntese teórica combina elementos para que a recombinação produza uma fusão nova, qualitativamente distinta de todos os componentes combinados. A nova combinação adquire, então, suposições, conceitos e princípios próprios, formando uma nova base para esforços de pesquisa. Os ecléticos, por outro lado, sempre defendem o uso de abordagens multiteóricas como princípio (por exemplo, Merton [1981] $)^{1}$. Giddens diz de forma explícita, e, em minha opinião, razoável, que ele não consegue enxergar a força da objeção de que sua obra seria inaceitavelmente eclética [Giddens, 1984:xxii]. Seu envolvimento com as várias escolas de sociologia e filosofia ocorre inteiramente com o propósito de extrair o fio orientador, conceito ou percepção central relevantes para recombiná-los com outros elementos. Ele escreve:

"A teoria da estruturação foi estabelecida como uma tentativa de transcender, sem descartar completamente, três tradições de pensamento proeminentes na teoria e filosofia

\footnotetext{
${ }^{1}$ Sanderson [1987] menciona muitos outros ecléticos assumidos proeminentes na sociologia, incluindo Ralf Dahrendorf, Arthur Stinchcombe, Jack Goody e Jonathan Turner. No marxismo, a palavra "eclético" é usada como um insulto. Ver, por exemplo, a avaliação de Habermas em Therborn [1971]. O termo ecletismo usado para se referir a empréstimos arbitrários se tornou um termo pejorativo no final do século XVIII e início do XIX na filosofia e na pintura. Os românticos contrastavam os empréstimos estilísticos de ecléticos e plagiadores com o poder exaltado de imaginação associado ao gênio. Ver Wittkower [1965].
} 
social: a hermenêutica ou 'sociologias interpretativas', o funcionalismo e o estruturalismo. Na minha opinião, todas estas tradições incorporam contribuições distintas e valiosas para a análise social - e todas tenderam a sofrer de várias limitações definidas." [Giddens, 1981:26]

Neste respeito, ele compartilha pelo menos o método do projeto de Parsons na Estrutura da ação social [1937] mesmo que ele se distancie do determinismo, funcionalismo e naturalismo sistêmicos de Parsons [Giddens, 1976:cap. 3; 1984:xxxvii]. Há uma discussão extensa de Parsons na obra de Giddens porque de muitas formas Parsons forneceu o ponto de partida teórico para suas reflexões, como ocorreu com vários outros sociólogos nas décadas de 1950 e 60, como David Lockwood [1956], Alan Dawe [1970], Percy Cohen [1968] e Harold Garfinkel [1967]. Obviamente, Giddens está operando num contexto novo, com um conjunto diferente de teóricos e filósofos daquele usado por Parsons para construir sua teoria geral da ação nas décadas de 1930 e 40. Mas, como Parsons, Giddens procede usando a matéria-prima de várias teorias para erguer um andaime de conceitos sintetizados com o propósito de embasar pesquisas posteriores; e ambos os esquemas resultantes são formas de teoria da ação. Nenhum deles constrói sua teoria a partir de fecundação cruzada com evidências; em vez disso, exemplos empíricos são acrescentados ilustrativa ou sugestivamente.

Parsons escreveu que a Estrutura da ação social era um "estudo de teoria social, não de teorias" [Parsons, 1937:v] e o fator que unificava a discussão era a consideração que cada autor discutido teria feito, de forma diferente, uma contribuição importante para "este corpo de teoria único e coerente", ou seja, a teoria da ação social de Parsons. Giddens não enxerga o mesmo tipo de convergência imanente em todos os escritores recentes que discute, mas eles são de qualquer forma descritos como "trabalhando num conjunto de problemas comum" [Giddens, 1982b:175] e que "eles se unem nas seguintes conclusões" [Giddens, 1976:52]; ou que há "afinidades entre" [ibid.] várias ideias de diferentes tradições. Em outras palavras, Giddens também toma emprestado contribuições valiosas de diversas escolas para forjar o que é efetivamente outro "corpo de teoria único e coerente", ou seja, a teoria da estruturação. Ele explicitamente descreve esta teoria como um exemplo de "teoria social em geral" [Giddens, 1984:xvii]. (NB. Giddens nega que suas Novas regras fosse um livro de síntese por causa de sua seletividade [Giddens, 1976:20], mas eu não acho que isto valha para $A$ constituição $d a$ sociedade, que integra na teoria conceitos derivados de muitas outras fontes, incluindo a 
geografia humana e a fenomenologia existencial, e que ele descreve como uma "soma" [Giddens, 1984:prefácio] de seu trabalho anterior neste assunto.)

Entretanto, apesar de seu nível de abstração e método de construção, a teoria da estruturação não é tão divorciada da relevância para a pesquisa empírica como poderia ter sido a impressão nas versões anteriores. Giddens enxerga sua teoria como uma ligação teórica entre vários níveis do processo social total no espaço-tempo que pode guiar a pesquisa empírica tanto de modo geral quanto em cada nível: "A teoria da estruturação não terá muito valor se ela não ajudar a iluminar problemas de pesquisa empírica" [Giddens, 1984:xxix]. Os conceitos "devem ser considerados dispositivos sensibilizadores para propósitos de pesquisa (...) úteis para pensarmos problemas de pesquisa e a interpretação de resultados de pesquisa" [Giddens, 1984:326-327]. Os conceitos de ação em Giddens são mais sofisticados que os de Parsons, assim como as técnicas de pesquisa recomendadas para cada nível. Isto ocorre por causa da insistência de Giddens no caráter reflexivo da ação social constitutiva de atores hábeis cognitivamente e as consequências metodológicas da "hermenêutica dupla". Mas a ambição geral de que o esquema teórico deva fundamentar a pesquisa empírica é algo que ele compartilha com Parsons, que escreveu, sobre sua própria teoria da ação generalizada: "Ela (...) constitui um guia crucialmente importante para a direção da pesquisa frutífera" [Parsons, 1938:89]. Eu compreendo que também existem várias descontinuidades na obra de Parsons, e objetivos que Giddens não compartilha com ele: por exemplo, Giddens não busca universais ou outras constantes sociais; e ele critica a "hierarquia cibernética" de Parsons. Mas a comparação serve para colocar a teoria da estruturação em perspectiva como uma espécie de teoria da ação com as suposições e limitações características que isto implica.

Um tema deste capítulo será a existência de preceitos na teoria da estruturação cuja presença não é explicável inteiramente porque Giddens estava racional ou intelectualmente convencido de sua solidez, assim como outras suposições tácitas das quais ele dificilmente tem consciência. A teoria da estruturação é, por um lado, uma metateoria da ação, e, por outro, uma amarração de uma seleção de conceitos, preceitos, suposições, ênfases e elementos normativos cuja unidade constitui uma visão de mundo. Como veremos repetidamente, algumas destas características são derivadas dos traços, dentro da teoria da estruturação assim como da sociologia em geral, das grandes ideologias do século XIX - liberalismo, socialismo e conservadorismo - e seus 
desenvolvimentos posteriores. Outras são derivadas da localização institucional do projeto e outras ainda das convicções morais e políticas do autor.

Comecemos examinando a importância de algumas das orientações de Giddens para a pesquisa empírica na Constituição da sociedade [1984] sob a luz destas considerações. Giddens quer direcionar a pesquisa para preocupações hermenêuticas, ou a mediação de esquemas de significado; as perícias de atores hábeis cognitivamente; e a constituição espaço-temporal da vida social. Estas propostas pretendem suplementar o foco sociológico mais costumeiro nas instituições. Ele diz que são as preocupações do pesquisador que determinam a ênfase em qualquer um destes níveis e a suspensão metodológica resultante dos outros. Por exemplo, ao analisar a conduta estratégica dos atores, o foco está nos modos através dos quais os atores, em seus planos e intenções, utilizam o conhecimento das propriedades estruturais das instituições. Para este propósito, estas instituições são consideradas "dadas" metodologicamente. Mas ele adiciona:

"Não há, é claro, obrigação nenhuma para qualquer um que faça pesquisa empírica detalhada num ambiente localizado particular de trazer a bordo um rol de noções abstratas que meramente atravancariam aquilo que poderia ser descrito de forma econômica e na linguagem ordinária" [Giddens, 1984:326].

A estranheza deste comentário deve estar aparente. Na teoria da estruturação Giddens gasta bastante energia para estabelecer teoricamente as ligações entre "integração social" e "integração sistêmica", quer dizer, entre os encontros face a face de atores copresentes e a formação social mais ampla da qual eles fazem parte. Como vimos, além da pesquisa hermenêutica defendida, ele também recomenda a pesquisa da constituição espaço-temporal; mas então, na citação anterior, ele parece jogar fora este impulso de sua obra ao desvalorizar sua expressão teórica como um mero atravancamento. Uma consequência não intencional da recomendação de "suspensão" metodológica, e desta forma de representá-la, é fornecer uma legitimação para que pesquisadores permaneçam em seu "ambiente localizado" ou pequeno canto da teia social total. Ela desencoraja os pesquisadores de qualquer ambição que possam ter de fazer as ligações com as interconexões mais amplas e vastas implicadas pela teoria.

Entretanto, se os sociólogos quiserem adotar este objetivo substantivamente, e não apenas no nível da metateoria, então eles precisam desenvolver formas de 
apresentar suas descobertas que mostrem estas ligações simultâneas. (Contudo, eles teriam que ir além de Giddens se quisessem representar a sociedade como uma figuração na terminologia de Norbert Elias. Isto incorporaria os pontos de vista interpenetrantes de grupos por toda a rede social, algo não imaginável na teoria da estruturação: falarei mais sobre isto depois.) Certamente, atingir este objetivo não é uma tarefa fácil, mas ele não está fora do alcance da imaginação sociológica: é uma ambição que une obras de objetivos, períodos e assuntos tão diversos quanto a Fenomenologia do espírito de Hegel [1807], o Capital de Marx [1867, 1885, 1894] e O processo civilizador de Elias [1939]. Este conselho metodológico de Giddens, junto com a ênfase em esquemas de significado, legitima os esforços de pesquisa empírica fragmentados, ainda que escrupulosos, sobre os ambientes institucionalizados da sociologia contemporânea.

As recomendações metodológicas parecem incorporar uma timidez liberal sobre a possibilidade de representar e teorizar "todos sociais", temendo que este procedimento apagasse os indivíduos. Esta incerteza é reminiscente da desconfiança gerada pela publicação da Miséria do historicismo de Karl Popper na década de 1960, e, realmente, as recomendações de Giddens parecem compatíveis com as censuras de Popper contra o holismo [Popper, 1961:79]. É fácil perceber quantas páginas Giddens dedica na Constituição $d a$ sociedade para refutar os argumentos dos individualistas metodológicos, cuja obra ele leva muito a sério: "eles estão muito bem justificados ao suspeitarem das aspirações da 'sociologia estrutural"' [Giddens, 1984:220]. Ele não se contenta em deixar o debate repousar onde foi deixado por Steven Lukes na década de 1970, preocupando-se com permutas entre Perry Anderson e Edward Thompson antes de concluir que o debate inteiro pressupõe uma falsa antinomia entre indivíduo/sociedade. Isto é verdade, mas o que importa aqui é a preocupação.

O envolvimento histórico da tradição sociológica europeia com o desenvolvimento do liberalismo, tanto como doutrina política quanto estilo de pensamento, é bem conhecido [Mannheim, 1928:216ff.; 1929:276ff.; Seidman, 1983] assim como as outras conexões da sociologia com o socialismo e o conservadorismo. Ao esboçar a linha liberal na seção que se segue, não quero implicar que a sociologia em geral, nem a teoria da estruturação de Giddens em particular, são redutíveis a seu ingrediente liberal. Traços de todas as três grandes ideologias do século XIX podem ser 
encontrados no tecido da sociologia [Goudsblom, 1977:cap. 5] e também na obra de Giddens. Eu também não faço nenhum juízo pejorativo com esta observação.

A tradição do liberalismo europeu em vários contextos nacionais colocou a liberdade e autorrealização do indivíduo no centro da doutrina. O liberalismo, no início, se preocupava completamente em proteger o indivíduo contra o poder arbitrário, mas nos primeiros anos deste século o "novo liberalismo" desenvolveu, entre outros princípios, uma concepção mais ampla do indivíduo [Freeden, 1978]. Nas palavras de Bramsted e Melhuish, o indivíduo agora era encarado como "potencialmente único e espontâneo", uma linha de pensamento cujas origens estão no Renascimento, e eles adicionam:

“O individualismo enquanto 'hábito mental', enquanto o direito do indivíduo de seguir seus próprios gostos e preferências dentro dos limites impostos pela lei em vez de tê-los ditados pelas convenções da sociedade, tornou-se uma corrente adicional da atitude liberal" [Bramsted e Melhuish, 1978:xviii, itálicos meus].

O novo liberalismo era, em parte, uma doutrina política, mas também era uma ontologia do indivíduo, visto como o centro único, delimitado e dinâmico da atividade do eu, colocado contra o poder arbitrário no reino político e contra a "sociedade" em geral. O liberalismo deriva grande parte de sua força de sua fundamentação na experiência do eu e no tipo de formação da consciência dos indivíduos nas redes de interdependências cada vez mais complexas das sociedades avançadas e urbanizadas.

Não seria muito exagerado notar a facilidade com que a teoria da estruturação de Giddens se harmoniza com este estilo de pensamento. Um dos preceitos centrais da teoria é que, contra o funcionalismo e o estruturalismo, o ator não deve ser visto como um "pateta cultural", quer dizer, não como um mero reflexo conformado e que busca a aprovação de um sistema central de valores que o ator conseguiu internalizar e traduzir em motivações. E o ator também não é simplesmente construído por discursos, como afirmam os estruturalistas anti-humanistas. Giddens enfrenta estas distorções com um apelo à dignidade de atores humanos capazes, que têm "habilidade cognitiva", uma capacidade de monitoração do eu reflexiva, conhecimento discursivo e tácito, e "consciência prática". Atores individuais cuja ação é considerada hábil cognitivamente e intencional estão embutidos na teoria, limitados por um lado por instituições objetivas, e por outro pelo seu inconsciente. Giddens [1984:90-92] lista de forma elaborada as 
condições que permitem que atores conscientes consigam obter a penetração cognitiva diferencial de processos sociais mais amplos. Como todo liberalismo, esta dimensão da teoria busca maximizar as condições para a racionalidade de modo a minimizar, e assim controlar, o irracional.

Além do mais, para Giddens, a ação de atores humanos envolve a possibilidade de "fazer outra coisa", de ser capaz de fazer uma diferença no mundo - um princípio que para Giddens tem o estatuto de um "teorema filosófico" [Giddens, 1982a:30]. Entretanto, ele percebe que diferenciais de poder limitam as capacidades relativas dos atores de mobilizar recursos para fazer uma diferença. A implicação é clara: a premissa de valor não mencionada desta perspectiva sobre a ação humana é que a dignidade, autoexpressão e liberdade humanas deveriam ser maximizadas dentro de, e contra, parâmetros institucionais, e contra chances de poder desiguais. Faz sentido para Giddens terminar uma análise da resistência dos operários no chão da fábrica com as palavras evocativas: “exatamente porque eles não são máquinas, os atores humanos, sempre que podem, tramam modos de não serem tratados como tal" [Giddens, 1982a:45].

Obviamente, estes compromissos funcionam num nível tácito na teoria da estruturação, e, depois de localizá-los, é preciso explicar como e por que eles chegaram lá na hora que chegaram. Não posso abordar esta questão aqui. Será suficiente dizer que a corrente liberal é a dominante, fornecendo uma concepção exagerada - e até prometéica - do ator individual extraordinariamente hábil na reprodução social.

\section{O escopo da sociologia}

Giddens foi influente para estabelecer nas instituições educacionais, recentemente, uma construção particular da tradição sociológica consistindo primariamente do triunvirato de Marx, Weber e Durkheim [Giddens, 1971]. Ele despacha Simmel porque seu uso de evidências é descuidado e sua terminologia é frouxa [Giddens, 1965]; Comte é dispensado como uma figura excêntrica do século XIX cujas obras extravagantes revelam uma fé ingênua na ciência [Giddens, 1982b:68- 
$75]^{2}$; e podemos multiplicar o número de figuras iniciais importantes que mal são mencionadas, e muito menos discutidas com a mesma profundidade: Spencer, Tönnies, Tocqueville, Hobhouse, Pareto, Sorokin, Elias. Por trás da teoria da estruturação está não apenas uma fundamentação completa nesta "tradição seletiva" tripartite [Williams, 1973:9] e sua consolidação parsoniana (parcial), mas também um compromisso firme com a importância da atividade sociológica como tal. Giddens compreendeu que a sociologia em geral sempre teve a capacidade de contribuir a um entendimento da exequibilidade dos planos e objetivos oferecidos por várias ideologias e grupos políticos, apesar do fato de que a maioria de seus próprios praticantes mais destacados abraçou uma ou outra ideologia. Nesta veia, ele comenta o trabalho dos três grandes nomeados da seguinte forma:

"Os escritos de Durkheim e Weber têm sua origem numa tentativa de defender ou, melhor, de reinterpretar - as reivindicações do liberalismo político dentro das pressões conjuntas do conservadorismo hipernacionalista romântico por um lado, e o socialismo revolucionário do outro. Os escritos de Marx, por outro lado, constituem uma análise e crítica do capitalismo inicial" [Giddens, 1971:244].

É notável que Giddens não tente em lugar nenhum reunir argumentos para basear uma sociologia especificamente "crítica" ao modo de Habermas [1968] ou Bauman [1976], porque ao absorver a tradição clássica ele já pressupôs que a sociologia é inerentemente crítica. Ele escreve: "Enquanto teoria crítica, a sociologia não toma o mundo social como um dado, mas coloca as perguntas: que tipos de mudança social são exequíveis e desejáveis, e como devemos nos esforçar para obtê-los?" [Giddens, 1982c:166] $]^{3}$.

Em formulações posteriores das implicações práticas da pesquisa sociológica, ele adicionou a nova dimensão - implicada pela teoria da estruturação e o princípio da "hermenêutica dupla" - que os conceitos construídos dentro da própria sociologia, através de um processo de "escorregamento" [Giddens, 1976:162] para o mundo da vida

\footnotetext{
${ }^{2}$ Giddens reconhece a estatura do Curso de filosofia positiva de Comte, mas sugere que sua Religião da humanidade posterior constituiu um certo declínio do "racionalismo frio" da obra anterior por causa de sua "defesa apaixonada". Mas, ele afirma, como um todo, a obra de Comte tem pouca relevância para a sociologia hoje. Entretanto, é possível perceber o quanto Giddens desfila de forma irreverente os detalhes picantes da vida controversa de Comte (sua relação com uma prostituta, suas fúrias violentas, seus acessos de loucura, os espancamentos de sua mulher) em sua discussão da obra deste. Supostamente, isto é feito para desacreditar as ideias de Comte por associação [Giddens, 1982b]. Para uma avaliação contrastante, ver Elias [1970:cap. 1].

${ }^{3}$ Ver também Giddens [1982d:72], onde ele expande sua visão sobre a natureza "crítica" da sociologia.
} 
cotidiana, podem vir a ser apropriados pelos leigos cuja conduta esses conceitos foram originalmente cunhados para analisar [Giddens, 1984:348-354]. Giddens não dá muitos exemplos de conceitos que se tornaram uma característica integral da vida social dessa forma, mas talvez "alienação" seja um deles. De um conceito técnico conhecido e usado por apenas um punhado de sociólogos e filósofos há algumas décadas, ele agora se tornou uma palavra que pessoas vivendo em cidades grandes usam com frequência para descrever todo um conjunto de sensações de estranhamento, frustração e solidão que elas experimentam.

Giddens cumpriu seu aprendizado sociológico no ambiente muito sério da escola de sociologia de Leicester, construída, em grande parte, a partir de tradições de teoria e pesquisa da Europa continental por Ilya Neustadt e Norbert Elias (antes de sua aclamação mundial) nas décadas de 1950 e 60 [Neustadt, 1965; Marshall, 1982; Brown 1987]. Apesar de não unificado intelectualmente, este departamento foi por muito tempo o maior fora de Londres. Todos os relatos concordam que ele gerou em seus participantes um entusiasmo considerável pela disciplina e cultivou um grau particularmente alto de autoconfiança. O compromisso sociológico de Giddens traz as marcas de suas origens lá, onde ele lecionou por seis anos. É muito perceptível como sua absorção de uma orientação sociológica completa acabou imunizando-o contra o risco de ser levado por qualquer uma das muitas perspectivas, escolas, manifestos e modas que subsequentemente inundaram a sociologia ${ }^{4}$. Como ele diz repetidas vezes em suas várias discussões dessas escolas, ele está preparado para aprender ou tomar emprestado delas sem se tornar um discípulo ou partidário de qualquer uma em particular.

Uma percepção desta dimensão ilumina a atitude de Giddens quanto aos ataques feitos durante as décadas de 1960 e 70 contra a própria possibilidade de uma ciência da sociedade, que muitas vezes se baseavam em tradições mais antigas de antissociologia. Das escolas em proliferação recentes, os expoentes mais radicais de três delas em particular - neomarxismo, etnometodologia e wittgensteinismo - afirmaram que a sociologia era suspeita. Rapidamente, suas bases eram que a sociologia era respectivamente: (a) uma reação burguesa ao socialismo e marxismo que justificava a

\footnotetext{
${ }^{4}$ É claro que não estou sugerindo que o tipo de compromisso sociológico que poderia permitir que alguém colocasse em perspectivas os muitos paradigmas rivais que surgiram no cenário sociológico nas décadas de 1960 e 70 só poderia ter vindo do Departamento de Leicester.
} 
desigualdade em sociedades capitalistas; (b) em seu modo profissionalizado e positivista ela contrabandeava ilegitimamente os significados dos atores leigos em suas explicações; e (c) seu assunto pertencia à filosofia.

Como Giddens reage a estes ataques? Seus escritos do inicio da década de 1970 estão saturados com os problemas levantados pela então atual controvérsia marxismoversus-sociologia, e ele claramente está au fait com o esboço geral do debate [Giddens, 1971:introdução; 1973:passim]. Mas ele simplesmente o despacha: "Eu não quero discutir aqui os méritos relativos destas visões rivais" [Giddens, 1973:17]. Entretanto, seguindo sua estratégia costumeira, ele diz que retirará do debate apenas as implicações "para a identificação das tarefas com as quais a teoria social contemporânea deve se preocupar" [ibid.]. Não se encontra em seus escritos deste período uma discussão sistemática dos ataques feitos à sociologia nos textos de, digamos, Lukács ou Adorno, que haviam sido redescobertos e retrabalhados nessa época [Kilminster, 1979]. Giddens se eleva acima da controvérsia apontando tanto o exagero dos marxistas em relação à sociologia em seu modo "fim-da-ideologia" rasteiro, e seu fracasso simultâneo em dar conta da falta de revoluções proletárias no ocidente e da legitimação da dominação em nome de Marx na Europa Oriental. Daí temos: "vivemos numa sociedade que é 'pósmarxista' e 'pós-burguesa', mas não numa sociedade 'pós-capitalista', muito menos "pós-industrial"' [Giddens, 1973:19]. A questão é que a justificação oculta de Giddens para transcender estas antinomias enganosas é um compromisso anterior com o ponto de vista da sociologia como um esquema abrangente e mediador, ainda que seja apenas implícito.

Em relação à etnometodologia, Giddens corretamente aponta que as implicações dos conceitos de Garfinkel de reflexividade e indexicalidade, tomadas em conjunto, levam em duas direções. Uma era na direção de uma espécie de naturalismo, resultando na análise de conversas, e a outra era um regresso infinito do círculo hermenêutico. Esta foi a direção mais radical do projeto de "Teorização" associado com Alan Blum e Peter McHugh [Giddens, 1976:52]. Este projeto filosófico abandonou todas as tentativas de gerar conhecimento confiável da sociedade, celebrando em vez disso o processo contínuo de investigação coletiva para seu próprio bem sobre a base ontológica coletiva que possibilita a própria investigação [Blum, 1974; McHugh et al., 1974]. Das sociologias interpretativas, incluindo a etnometodologia, Giddens toma emprestado quatro ideias básicas para incorporar na teoria da estruturação. Elas são: (a) a sociologia 
utiliza os mesmos recursos que as pessoas leigas; (b) as pessoas têm conhecimento pragmático; (c) os conceitos sociológicos estão ligados a conceitos leigos; e (d) Verstehen deve ser tratada como "genérica em toda explicação social" [Giddens, 1976:52]. Este preceito é transcrito no princípio explicativo da "hermenêutica dupla".

Mas ao extrair estes princípios Giddens não trata da discussão profunda de Garfinkel da distinção, na filosofia alemã, entre Verstehen (o estado de entendimento) e Begreifen (o processo de chegar a um entendimento) [Garfinkel, 1967:24ff.], e este último conceito não tem nenhuma participação na teoria de Giddens, nem nenhum equivalente, por razões que logo ficarão claras. A tendência da Teorização, que assimilou este último conceito, é abandonada sem discussão, merecendo apenas o comentário de que Blum, McHugh e seus seguidores ingleses [ver Sandywell et al., 1975; Dobson, 1979] são "todos viajantes intrépidos, agora girando impotentemente no vórtice do redemoinho hermenêutico" [Giddens, 1976:166].

Entretanto, é óbvio que este comentário retórico não lida realmente com os argumentos dos Teorizadores e, na verdade, até onde eu sei ainda não houve uma resposta sociológica séria ao programa desse grupo. Seu abandono sumário por Giddens é irônico porque eles levaram muito a sério o conceito de Heidegger de "presenciação", que também inspirou o desenvolvimento de sua própria concepção de tempo [Giddens, 1979:3ff., 54ff.; 1984:45]. Como Attewell [1974] percebeu, a teoria de Garfinkel das descrições dos membros funde "fazer" interação com "contar" sobre ela. Esta fusão efetivamente reduz Verstehen a Begreifen. Assim, na versão forte da etnometodologia (por exemplo, a Teorização), o entendimento se torna totalmente processo, cuja concepção enfraquece o projeto sociológico de tentar substituir as expressões indéxicas ubíquas por expressões objetivas, ou seja, científicas. Esta substituição, diz Garfinkel, "permanece programática em qualquer caso particular e em qualquer ocasião real em que a distinção ou capacidade de substituição precisa ser demonstrada" [Garfinkel, 1967:6]. Isto porque as descrições dos sociólogos (incluindo suas supostas expressões objetivas) inevitavelmente continuam a ser características organizadas dos ambientes de pesquisa que, ao organizar, eles descrevem. Como Attewell diz corretamente, o enunciado de Garfinkel, nesta forma radical, é talvez o mais extremo encontrado na sociologia: "É um enunciado tão extremo quanto a declaração de forma sem conteúdo, ou sujeito sem objeto" [Attewell, 1974:202]. 
Giddens não enfrenta o desafio da tendência Teorização, que tomou este caminho radical de Garfinkel. Esta omissão encontra um contraste marcante com sua discussão longa nas Novas regras do método sociológico das ideias wittgensteinianas radicais de Peter Winch [Giddens, 1976:44-51]. Eu acho que a Teorização é despachada com um argumento ad hominem porque não ocorre a Giddens que uma crítica filosófica tão fundamental à sociologia sequer precise ser discutida seriamente. A escola não o preocupa o suficiente para que ele se dê ao trabalho de refutá-la. Esta abstenção indica a força de sua perspectiva sociológica e o estágio de desenvolvimento da sociologia britânica em que ela foi adquirida.

Winch, por outro lado, tem mais credibilidade profissional, mesmo que ele tenha declaradamente montado uma tentativa fracassada de absorção da sociologia pela filosofia. Em suas observações sobre jogos de linguagem, Winch está pelo menos dizendo algo relevante para o entendimento empírico de formas de vida. É este núcleo antropológico da obra de Winch que interessa a Giddens [1982c:22ff.]. Ele nota, com aprovação e alívio agradecido, que Winch "foge apressadamente de um relativismo desabrochado" [Giddens, 1976:50] mesmo que seja na direção de universais biológicos duvidosos como alicerces do entendimento intercultural [Giddens, 1976:49].

Assim, há um compromisso sociológico sólido de um tipo específico incorporado na obra de Giddens. Mas o que mais podemos discernir sobre sua natureza? Apesar da defesa de Giddens em seu livro didático recente [Giddens, 1989:prefácio e cap. 1] de que a sociologia deve ser uma disciplina com uma dimensão histórica fundamentalmente importante, uma leitura atenta de seus outros escritos revela inconsistências e equívocos sobre os assuntos de desenvolvimento e sociogênese. Ele parece ter reagido exageradamente tanto em relação às fraquezas do pensamento especificamente evolucionista na sociologia e aos temores dos filósofos de que apelar à sociogênese de conceitos ipso facto enfraquece a validade e racionalidade. Esta ambiguidade se mostra de duas formas.

Primeiro, não há nenhum dispositivo histórico e genético na construção da teoria de Giddens que possa levar em conta como as diferentes escolas e perspectivas entre as quais ele vaga abstratamente atingiram a especificidade e destaque institucional que possuem na forma em que ele as encontra. Sem um princípio dinâmico, ele só pode avaliar logicamente o valor cognitivo das perspectivas e escolas, que ele trata como 
comparáveis e equipolentes. Este procedimento tem um efeito nivelador nas teorias e autores. Assim, ele não consegue, por exemplo, distinguir avanços teóricos verdadeiros de becos sem saída revividos porque ao evitar o desenvolvimento ele se privou de qualquer teoria de progresso ou avanço científico que poderia permitir que ele realizasse isto. Em outras palavras, ele não permite que considerações genéticas tenham papel nenhum na formação de conceitos. (Eu retornarei a este assunto posteriormente). Por enquanto, podemos apontar o fato de que, há bastante tempo, Giddens rejeitou a utilidade da sociologia do conhecimento para estabelecer conceitos válidos, e não escreveu nada sobre o assunto. Ele disse adeus a esta tradição usando um argumento padrão:

"Mas não é preciso nenhuma perspicácia especial para ver o petitio principii envolvido na noção de que tal exercício pode por si mesmo produzir um novo esquema teórico para a sociologia; a transmutação da sociologia na sociologia do conhecimento é um empreendimento logicamente impossível" [Giddens, 1973:15].

Segundo, a concepção de Giddens do domínio de investigação da sociologia se baseia num compromisso a priori com uma visão fragmentada, ou descontinuísta, da história. Ele escreve:

"O mundo moderno nasceu da descontinuidade com o que veio antes, e não da continuidade. É a natureza desta descontinuidade - a especificidade do mundo anunciado pelo advento do capitalismo industrial, originalmente localizado e fundado no ocidente que a sociologia deve explicar da melhor forma possível [Giddens, 1984:329].

Em outro texto, ele escreve que está comprometido com esta visão, "não importa quais as continuidades que possam existir com o que aconteceu antes" [Giddens, 1982b:107], o que sugere que ele não nega que continuidades existam lado a lado com descontinuidades, mas que neste equilíbrio ele simplesmente quer privilegiar a descontinuidade.

Mas com que forma de "fragmentarismo" (“caesurism") [Martins, 1974:280] está Giddens nos comprometendo aqui? E será que este compromisso vai além da mera preferência ou simples convicção enquanto reação, ou mesmo revulsão, contra o evolucionismo arcaico? Giddens indica que é intelectualmente convencido pelo descontinuísmo. Ele afirma que com uma visão descontinuísta da história ele quer dizer sua crença - derivada de Ernest Gellner [1964] - de que a transformação do ocidente 
nos últimos trezentos anos não tem precedentes na história e é um rompimento de escala maior com o que veio antes do que qualquer rompimento anterior [Giddens, 1982d:107; 1984:237-238]. Esta configuração claramente delimitada das sociedades industrializadas modernas dá o terreno para a sociologia, que emergiu precisamente como a disciplina par excellence para explicar este mundo limitado mas historicamente descontínuo e distintivo. Ele escreve: "A história humana não é, para usar o termo de Gellner, uma 'história do crescimento do mundo"' [Giddens, 1984:237; ver também 1982d:76ff].

Um comentário perceptivo de Hermínio Martins é um ponto de partida para enunciarmos os problemas envolvidos aqui:

“A versão de Gellner do fragmentarismo é particularmente atraente para sociólogos, especialmente porque num certo sentido sua concepção do mundo moderno implica num lugar bastante central para a sociologia contra a história, e até certo ponto também contra concepções não-sociológicas da epistemologia e da ética. (...) Como uma caracterização geral do mundo moderno, da estrutura fundamental de 'nosso tempo', ela ainda é altamente plausível. (...) Como um lembrete poderoso das obrigações morais fortes e, em alguns casos, supremas de sociólogos e acadêmicos no mundo contemporâneo, ela permanece válida.” [Martins, 1974:282]

Realmente, eu acho que o compromisso de Giddens com o descontinuísmo à la Gellner está atravessado por considerações morais, além de empíricas ou científicas. Ele se encaixa muito bem com sua defesa frequentemente repetida da vocação "crítica" do sociólogo de iluminar a estrutura deste mundo singularmente moderno. E se assenta confortavelmente com suas convicções socialistas relacionadas [Giddens, 1982d] ${ }^{5}$, que em parte guiaram sua anexação de grande parte da ontologia econômica socialistamarxista a esta teoria, junto com os componentes da ação. Então, previsivelmente, Giddens usa uma linguagem altamente emotiva e avaliativa para descrever o caráter deste mundo moderno descontínuo: "É muito mais esclarecedor enxergá-lo como estabelecendo uma ruptura com o mundo tradicional, que ele parece corroer e destruir irrecuperavelmente" [Giddens, 1984:239, itálico adicionado]. E, mais notavelmente, sobre o capitalismo:

"Uma antropologia filosófica relevante para o socialismo precisa prestar bastante atenção àquilo que podemos reter da diversidade humana que está sendo devorada pela

\footnotetext{
${ }^{5}$ Giddens escreve: "Aqui eu devo declarar parti pris, e dizer que minhas simpatias políticas estão com a esquerda" [Giddens, 1982b:227]. Ver também Giddens [1982d, passim].
} 
expansão voraz do 'espaço criado' do capitalismo - pois no mundo que o capitalismo criou, o tempo não é mais entendido como o meio do Ser, e o desenrolar da vida do dia-adia através da tradição compreendida é substituído pelas rotinas vazias da vida cotidiana. Por outro lado, a humanidade inteira agora vive sob a sombra da possível destruição. Esta conjunção única entre o banal e o apocalíptico, este é o mundo que o capitalismo modelou." [Giddens, 1981:252]

Não surpreende que, com uma convicção moral de tal intensidade emocional guiando seu compromisso com o fragmentarismo gellneriano, Giddens não se interesse pelo desenvolvimento de um quadro mais sóbrio do equilíbrio entre continuidade/descontinuidade em vários níveis; ou em recuperar o bebê desenvolvimentista jogado fora com a água da bacia evolucionista para colocar na agenda o desenvolvimento estruturado de longo prazo. Como podemos ver na citação anterior, o capitalismo, nas mãos de Giddens (como ocorreu com Marx), às vezes assume o caráter de uma força irresistível se espalhando como um contágio através do globo $^{6}$. Mas ele exagerou a penetração e os efeitos das relações econômicas capitalistas globais, que ele enxerga apenas como tráfego de mão única. E o resultado é que ele subestima movimentos contrários, por exemplo, movimentos políticos e religiosos fundamentalistas em várias partes do mundo, incluindo, nas sociedades avançadas, movimentos que buscam reafirmar identidades nacionais ou étnicas como um tipo de protecionismo cultural contra a globalização crescente que está juntando as nações [Robertson e Lechner, 1985].

Além do mais, a visão de mundo de Giddens desencoraja perguntarmos qual é a ordem sequencial de processos de diferenciação/integração a prazo mais longo que moldou as condições atuais e prenuncia a próxima fase emergente (ver Elias [1987]); por sua vez encorajando, aparentemente, apenas olhar para processos sociais e políticos no presente nacional e global para buscar um diagnóstico da situação atual e suas possibilidades $^{7}$. O problema da ordem sequencial é suprimido por causa da suposição de que o estudo de mudanças no desenvolvimento de longo alcance só pode ser evolucionista, quer dizer, uma investigação que segundo ele contém a falha fatal de

\footnotetext{
${ }^{6}$ A visão do capitalismo como invadindo incessantemente cada vez mais áreas da vida social, criando monopólios e se espalhando através do globo para formar um mercado mundial é exposta mais vigorosamente por Marx no Manifesto Comunista de 1848, cujo conteúdo neste tópico devia muito ao economista político francês Constantin Pecquer. Ver Owen [1951].

${ }^{7}$ Esta tendência na obra de Giddens fica aparente particularmente na justificativa apresentada para a coleção Perfis e críticas [Giddens, 1982b:prefácio e cap. 15] e em Giddens [1985:caps. 1 e 11].
} 
enxergar a modernidade como uma acentuação inevitável de tendências anteriores, seu ápice. Mas isto é um exagero.

Colocando a correção rápida e abstratamente para nossos propósitos atuais: prestar atenção à ordem sequencial de correntes de desenvolvimento contínuas mas desiguais, que fornece conjuntos sucessivamente novos de pré-condições para o surgimento da próxima fase de mudança social, pode iluminar o problema de como tais combinações resultam na produção de descontinuidades e especificidades sociais. Tanto a continuidade quanto a descontinuidade estão implicadas no desenvolvimento social e não é preciso implicar nenhuma inevitabilidade ou teleologia. Um diagnóstico social da situação atual mais completo e melhor sintonizado exigirá estender a análise para ligações não-econômicas (ver p. 342) e também voltar para a ordem e sequenciamento de continuidades de longo prazo que o descontinuísmo de Giddens, por princípio, negligencia.

Finalmente, um outro exemplo da forma pela qual o entusiasmo valorativo de Giddens interfere com uma análise sociológica sóbria das realidades sociais humanas ocorre quando ele é levado, por uma entrevista, para o assunto da relação entre os seres humanos e a natureza. Num enunciado romântico inspirado por Lévi-Strauss, ele declara:

"Uma (...) das principais características das civilizações mundiais modernas é a perda de uma relação genérica entre os seres humanos e a natureza, e eu acho que esta é realmente uma perda tremenda para o estilo de vida que vivemos porque vivemos apenas num meio essencialmente artificial em que não há mais nenhum contato com a natureza do tipo tradicional. Eu acho que passear em feriados, fazer turismo, ou ir para o interior nos fins de semana é diferente da forma em que as pessoas sempre viveram lidando com a natureza". [Giddens, 1982d:68].

É como se Giddens nunca tivesse ouvido falar da tradição inteira vinda de Marx, Simmel, Lukács e Elias até a Escola de Frankfurt e muitos outros que, de formas diferentes, estabeleceram a variabilidade histórica da "natureza humana" e questionaram a ideia de que já houve um período em que os seres humanos estabeleceram uma relação autêntica com a natureza. O caráter da relação entre os seres humanos e a natureza não-humana, assim como a inter-relação entre a sociabilidade humana e o nível biológico que ela continua, dependem do estágio de desenvolvimento social. Na citação 
anterior, Giddens irrefletidamente interpõe a sociedade moderna como um meio "artificial" entre o homem e a natureza, onde o homem é inconcebível fora de relações sociais ou separado da natureza biológica. A sociedade tornou-se possível por causa de uma pré-condição evolucionária anterior. A "natureza” é uma categoria criada pelos homens, tanto quanto a "sociedade". Mas nós nunca afirmaríamos que as ciências naturais são ciências de algo artificial. Giddens reproduziu um juízo de valor de que, comparada com a natureza real, genuína, prístina, a sociedade moderna é uma invenção meramente artificial, sintética e, por implicação, um tanto degradada. Estamos vivendo de uma forma que nos impede de ter uma comunhão autêntica com a natureza. Giddens reforça o velho dualismo entre natureza e cultura ao sobrepô-lo à distinção tradicional/moderno, reproduzindo-o em sua forma mais mistificadora.

\section{Filosofia e "teoria social"}

Ao examinar as credenciais sociológicas de Giddens, percebemos, surpresos, sua visão muito convencional da relação entre sociologia e filosofia, mas também detectamos uma certa ambivalência quanto a este assunto. Como eu demonstrarei, ele aceita sem questionamentos as estipulações dos filósofos sobre os conjuntos de questões que devem ser alocadas para os respectivos estabelecimentos acadêmicos. Vale a pena prestar atenção a este tópico porque ele é importante para o estatuto da teoria da estruturação enquanto "teoria social" e afeta nossa avaliação da estratégia teórica "sistemática" que ela exemplifica, em vez de histórica ou genética.

A atitude de Giddens diante deste assunto pode ser retirada destas duas citações: "tanto a análise social empírica quanto a teorização social envolvem esforços inerentemente filosóficos" [Giddens, 1982b:175] e: "as ciências sociais estão perdidas se não forem relacionadas diretamente a problemas filosóficos por aqueles que as praticam" [Giddens, 1984:xvii]. Entretanto, como eu demonstrei mais completamente em outro texto [Kilminster, 1989], a evidência sugere que, com a ascensão das ciências sociais e da sociologia em particular no desenvolvimento social europeu, ficou cada vez mais difícil para os filósofos justificarem uma área autônoma de competência para sua disciplina. (Realmente, podemos dizer que este problema alcançou proporções de crise na filosofia contemporânea [Baynes et al., 1987; Rorty, 1982].) 
A sociologia gradualmente tomou e transpôs para um novo nível questões sobre a natureza do conhecimento e da moralidade que anteriormente eram feitas por filósofos ou teólogos, ou que estavam presas nas grandes ideologias do século XIX. Estes problemas foram incorporados à estrutura conceitual da sociologia e estão preservados profundamente nela, levados adiante num estado reformulado. Enquanto isso, o estabelecimento filosófico recuou cada vez mais para o desenvolvimento de suas habilidades lógicas e conceituais, transformando a filosofia principalmente numa disciplina técnica, particularmente na tradição anglo-saxônica, e erguendo barreiras de argumentos e profundidade cultivada em torno de si para realizar o fechamento profissional de seus assuntos.

Se este quadro geral do destino histórico da filosofia tiver um mínimo de precisão, então precisamos tomar mais cuidado do que Giddens ao aceitar a autonomia e o valor cognitivo da filosofia e o conjunto de especialismos dentro dela que encontramos prontos nos livros atuais produzidos nesse campo. Em um nível, Giddens parece compreender a profunda relevância social valorativa da tradição sociológica que ele enxerga como um compromisso "crítico", pagando tributo ao chavão atual. Mas Giddens também se acovarda ao não levar esta percepção em relação à filosofia até o fim.

Giddens traz para o jogo o termo confuso "teoria social", que ele admite "não ser um termo com qualquer precisão" [Giddens, 1984:xvii], derivado da tradição parsoniana-mertoniana, para construir pontes na direção da filosofia. O "campo" da teoria social supostamente abrange assuntos sobre a natureza e conceitualização da ação humana em relação a instituições e às conotações práticas da análise social, que seriam aplicáveis a todas as ciências sociais. A "teoria sociológica", por outro lado, supostamente seria relevante apenas para as sociedades industrializadas avançadas e seria uma espécie da teoria social. É uma teoria social que supostamente trata de assuntos que "se derramam na filosofia" (ibid.). A incerteza do campo chamado de teoria social pode ser vista prontamente se compararmos a sociologia com a ciência da psicologia. Alguém nesta disciplina faria referência à "teoria psíquica"?

O problema que estou colocando em foco aqui é que os conceitos filosóficos, diferentemente dos sociológicos, não foram desenvolvidos através de fecundação cruzada com evidências empíricas, e que a importância desta diferença é embaçada pela 
aceitação da legitimidade da atividade de teoria social. Estranhamente, em uma ocasião Giddens reconhece exatamente esta diferença. Falando sobre divergências entre a concepção da história em Marx e as observações de críticos posteriores, ele diz que não acha que as divergências possam ser validadas ou invalidadas por um teste empírico convencional: "Mas elas também não são refratárias à referência empírica no sentido em que teorias filosóficas o são" [Giddens, 1971:x]. Mas na Constituição da sociedade ele enxerga as concepções da ação e agência humanas como produzidas pela teoria social como teoremas que "podem ser colocados a serviço do trabalho empírico" [Giddens, 1984:xvii]. A ideia supostamente é que ao fazer teoria social trabalhamos conceitos de ação e agência encontrados na filosofia de forma a deixá-los receptivos à pesquisa empírica. Eu digo supostamente, porque isto não está claro de forma alguma.

Além do mais, o assunto fica ainda mais vago devido à sua terminologia casual e indiscriminada. Ao descrever a textura da atividade filosófica que supostamente estaria ligada à teoria social, Giddens se move livremente entre "conceitos", "teorias", "questões" e "debates" filosóficos. Entretanto, se estes termos forem estudados separadamente, a incerteza em torno do estatuto da teoria da estruturação aumenta. "Conceitos" filosóficos não têm, como Giddens claramente também sabe, nenhuma referência ou intenção empírica direta, e são, por isso, inúteis em si mesmos para propósitos de pesquisa. De fato, devido à sua própria natureza, conceitos filosóficos são considerados partes de um tipo de discurso transcendental, quer dizer, não-empírico [Kilminster, 1989]. Do ponto de vista da visão sociológica da teoria como algo envolvido numa inter-relação com a evidência, certamente a frase "teorias filosóficas" é uma contradição em termos. Além do mais, por causa da autonomia historicamente duvidosa da filosofia, não está claro de forma alguma que existam "questões" filosóficas, muito menos questões que sejam relevantes para as ciências sociais. "Debates" filosóficos certamente existem, mas seu valor cognitivo não pode ser garantido. Eles são muitas vezes arbitrários e têm relevância apenas acidental para a sociologia.

Tendo em vista o que foi dito, podemos então perguntar: no que consiste a sobreposição percebida entre o tratamento dos filósofos e dos sociólogos de assuntos no estudo da ação social? Ambos os grupos supostamente estão trabalhando "num conjunto comum de problemas" [Giddens, 1982b:175] mas certamente isto só é verdade num sentido abstrato, enquanto todos os autores envolvidos estão falando sobre a ação 
humana de modo geral e as formas pelas quais os sociólogos tentaram explicá-la. Sob a rubrica de teoria social, Giddens consegue se mover livremente entre autores tão diversos como Weber, Garfinkel, Durkheim, Gadamer, Erikson, Austin, Schutz e Wittgenstein; um exercício que grosseiramente achata a especificidade histórica e nacional distintiva de suas obras, e também elimina a distinção entre sociologia e filosofia. Além do mais, já que os filósofos, pela natureza do que fazem, só podem desenvolver seus conceitos e discussões sem uma inter-relação direta com evidências empíricas, nunca podemos ter certeza se suas asserções ou conclusões não são hipóstases de sua própria autoexperiência ou a de grupos particulares de nossa sociedade ou de alguma outra sociedade ou período. A convergência aparente observada também pode ser parcialmente causada pelo derramamento de descobertas e conceitos sociológicos $n a$ filosofia, que são então retrabalhados num vocabulário diferente e caracteristicamente filosófico. Eles são então devolvidos para a sociologia como descobertas obtidas de forma aparentemente independente.

O estatuto da teoria social, e seu papel no pensamento de Giddens, precisam ser vistos em contraste com sua descrição do campo apropriado da sociologia. Como já vimos, para Giddens, a sociologia é a ciência social que lida apenas com as sociedades avançadas, e seus conceitos são desenvolvidos em relação ao caráter distinto do mundo moderno industrializado descontínuo. Assim, a sociologia "não é uma disciplina genérica que lida com as sociedades humanas como um todo" [Giddens, 1984:xvii]. Mas se a sociologia não é esta disciplina genérica, então qual é? Supostamente, a imprecisa teoria social, que deveria abranger todas as ciências sociais. A teoria social, então, como um conjunto de "segunda ordem" de reflexões conceituais sobre a natureza da ação, ocupa um lugar estruturalmente semelhante em relação à sociologia como aquele que a sabedoria convencional afirma que a filosofia ocupa em relação a todas as ciências. De fato, pelo que posso ver a teoria social é um outro nome para a filosofia.

A teoria da estruturação, enquanto teoria social, nasce de um estilo de pensamento que pressupõe que a filosofia é a disciplina mestre unificando as ciências e, enquanto tal, reforça este papel. Giddens não pode considerar a possibilidade de que a ciência mestre possa ser a sociologia, porque isto para ele cheiraria a comteanismo, cientificismo e positivismo e doutrinas similares que, juntas à ideia de progresso, aparentemente celebraram a superioridade do ocidente. É por isto que (como vimos na seção anterior) ele rejeita tão categoricamente todas as teorias da evolução [Giddens, 
1984:cap. 5], porque elas são consideradas como parte do mesmo pacote indesejável de ideias do século XIX; mas ao fazer isto ele também descarta uma sensibilidade ao desenvolvimento, que não é a mesma coisa.

A resposta de Giddens à obra de Habermas, como o principal expoente da teoria "crítica" na tradição marxista, é interessante tendo em vista o que discuti nesta seção e nas anteriores. Habermas produziu um conjunto vasto e pesado nestes últimos vinte e cinco anos e tem sido altamente influente por causa da forma desafiadora em que ele reconstruiu o legado marxiano para uma geração envolvida com a política radical dos anos 1960 e 70. Como se sabe, ele continua a obra dos autores anteriores da Escola de Frankfurt, e a Dialética do Iluminismo de Horkheimer e Adorno [1947] tem forte presença em seu desenvolvimento intelectual. Por causa desta tradição filosófica transcendental alemã particular de que Habermas vem e a problemática marxista especificamente ocidental em que sua obra está cravada, só podemos entender completamente sua obra se levarmos em conta certos princípios kantianos e relacionarmos seu projeto à estrutura de pensamento hegeliana exemplificada pelo ensaio de Horkheimer "Teoria tradicional e teoria crítica" de 1937 e, em última análise, à História e consciência de classe de Lukács [Kilminster, 1979]. Assim, quando Habermas emprega em sua obra conceitos e ideias derivadas da filosofia da linguagem, linguística, psicologia do desenvolvimento e teoria dos sistemas, eles são enxertados num ponto de vista filosófico-sociológico já consolidado em que temas kantianos e hegelianos estão entrelaçados de formas interessantes e, na minha opinião, contraditórias.

Boa parte do centro de gravidade desta tradição da teoria crítica se perde nas discussões de Giddens (sob outros aspectos claras e concisas) sobre os escritos de Habermas. Ele parece aprender pouco com Habermas e nenhum de seus conceitos é integrado diretamente à teoria da estruturação. Giddens expõe Habermas de forma desinteressada, dispondo as ideias clinicamente e avaliando-as sob a luz de seu próprio interesse sobre a natureza da ação humana hábil. E ele explica a importância de apenas uma corrente da tradição filosófica em que Habermas se encontra (aquela que localizou as ciências sociais como Geisteswissenschaften), que é a mais relevante ao assunto em questão. Ele se aproxima de Habermas como um observador curioso, mas cético, que quer levar sua obra a sério por causa de sua eminência, mas que acaba não conseguindo enxergar o porquê da coisa toda. 
As críticas que Giddens faz a Habermas são na verdade bastante comuns, feitas frequentemente por críticos. Ele diz que as duas distinções, trabalho/interação e ciência nomológica/hermenêutica em Habermas se interpenetram de tal forma na vida real que ele questiona a utilidade de separá-las analiticamente em primeiro lugar. Ele também questiona a analogia de Habermas entre a relação de psicanalistas comunicando-se com pacientes e cientistas sociais comunicando conhecimento sobre estruturas de desigualdade na sociedade para leigos. E ele se pergunta se Habermas não teria exagerado a penetração da consciência tecnocrática no capitalismo tardio [Giddens, 1977:135-164; 1982a: cap. 7].

Giddens obviamente não tem simpatia com todo o projeto e estilo de Habermas, referindo-se à sua "obscuridade quase-hegeliana" [Giddens, 1974:20]. Ele às vezes faz objeções substantivas astutas, mas muitas vezes entende incorretamente ou desconsidera a importância da dimensão transcendental da obra de Habermas, ou seja, os aspectos metateóricos, aos quais ele dá muito menos atenção. Claramente, se você pensa que a sociologia já é "crítica", por que se dar ao trabalho de avaliar argumentos filosóficos projetados para demonstrar isso? Entretanto, não é o bastante simplesmente dizer, como Giddens faz, que a situação do discurso ideal, porque é um ideal, não pode ser usada para analisar situações linguísticas concretas; ou que seu uso para avaliar o discurso distorcido pressupõe conhecimento nomológico dessa situação de discurso. É claro que pode, nos termos de Habermas, porque os interesses constitutivos do conhecimento têm um estatuto transcendental e analítico.

Estes comentários não abrangem as implicações mais complicadas de Habermas (e de Karl-Otto Apel) sobre a situação do discurso ideal como um princípio regulador, na terminologia kantiana. A situação do discurso ideal se realiza parcialmente no discurso distorcida do presente, mas até agora ainda não se realizou. $\mathrm{Na}$ teoria da comunicação, seu estatuto utópico é considerado como tendo base mais firme. Este modelo serve como um ideal, uma base para crítica e avaliação, como algo a que devemos aspirar e também empregar como um baluarte contra elites socialistas burocráticas que podem afirmar que a utopia se realizou na sociedade que eles governam. Quer dizer, ele fornece um critério para não nos deixarmos enganar por utopias espúrias ou afirmações falsas de "universalidade". Apenas por este motivo, neste esquema de referência, a situação do discurso ideal, enquanto uma utopia, não pode e não deve ser considerada como algo realizável concretamente. Em outras 
palavras, ela se relaciona com situações empíricas tanto concreta quanto "potencialmente".

Consequentemente, a teoria de Habermas implica que condições que sustentem alguma comunicação distorcida precisam, falando dialeticamente, sempre existir para que a situação do discurso ideal tenha sua existência transcendental e, assim, seu poder crítico. Há ecos aqui do "reino da necessidade" de Marx. Também por esta razão, a situação do discurso ideal não é realizável concretamente. Paradoxalmente, uma vez construída ou criada, quer dizer, realizada na prática neste mundo, a situação do discurso ideal perderia então sua função crítica. Segue-se, então, que enquanto isso o teórico crítico só pode trabalhar na direção de realizar uma situação idealizada que é inerentemente irrealizável. Eu discuti as implicações sérias deste paradoxo em outra ocasião [Kilminster, 1982]. O que quero dizer aqui, entretanto, é que o tipo particular de compromisso sociológico primário que Giddens tem o insensibiliza para as tensões da teoria crítica, que requerem entendimento sociológico. Eu, também, gostaria de rejeitar este programa, mas sinto que ele precisa ser avaliado completamente em toda a sua dignidade. Esse paradoxo constitui, para os praticantes da teoria crítica, um dilema espiritual agonizante. Eles são levados por sua consciência a tentar alcançar um ideal inalcançável, contra o qual seus esforços são eternamente condenados à inadequação. Em nenhum lugar o superego protestante impulsionado pela culpa aparece mais fortemente do que na dimensão kantiana da teoria crítica.

\section{Interação ou interdependência?}

Enquanto um tipo de teoria da ação, a teoria da estruturação de Giddens é uma tentativa de juntar conceitualmente, através de um processo de raciocínio, os dois níveis de ação e sistema. Partindo de uma crítica da teoria de Parsons da socialização através da internalização, ele passa a mostrar como o processo real de interação de atores com habilidade cognitiva produz e reproduz a estrutura e distribuição geral - ou grau de "sistematicidade" - das relações sociais. Esta estratégia supera tanto a tendência de Parsons de reificar sistemas sociais quanto a objeção poderosa feita por vários autores, notavelmente Percy Cohen em seu influente Teoria social moderna, que "Parsons quase não se preocupa com a ação em si, e sim com as condições que levam a ela" [Cohen, 1968:237]. 
Giddens tece então uma variante de teoria da ação do princípio da ubiquidade do poder nas relações sociais, uma realidade humana estabelecida na sociologia de Norbert Elias e também derivável de Foucault e dos esforços de Max Weber de mostrar como a análise de Marx do poder econômico era apenas um exemplo de um fenômeno genérico $^{8}$. Sem explicitar, Giddens está conjurando uma carga enorme de tradição sociológica quando escreve: "Não há nenhum conceito mais elementar do que o de poder" [Giddens, 1984:283]. Esta jogada permite que ele insista que as trocas interpretativas hábeis dos atores não devem ser vistas como algo que ocorre entre iguais (como Garfinkel deu a entender), e sim que provavelmente serão enviesadas ou desequilibradas pela distribuição do poder na sociedade em geral. E, para completar as coisas (e para garantir a exigência contemporânea de reflexividade), Giddens enxerta o preceito de que tanto as consequências não-intencionais da ação quanto o conhecimento dos atores dos mecanismos de reprodução do sistema podem entrar retroativamente na reprodução do sistema. A essência da teoria da estruturação pode assim ser compreendida com as seguintes duas citações:

"Todas as propriedades estruturais dos sistemas sociais (...) são o meio e o resultado das atividades realizadas contingentemente por atores situados. A monitoração reflexiva da ação em situações de copresença é a principal característica de ancoragem da integração social, mas tanto as condições quanto os resultados da interação situada vão bem além destas situações enquanto tais. Os mecanismos de 'esticamento' são variáveis, mas nas sociedades modernas eles tendem a envolver a própria monitoração reflexiva. Isto quer dizer, entender as condições da reprodução do sistema se torna parte das próprias condições de reprodução do sistema." [Giddens, 1984:191]

“O poder não é, enquanto tal, um obstáculo para a liberdade e a emancipação, e sim seu próprio meio (...) A existência do poder pressupõe estruturas de dominação através das quais o poder que 'flui suavemente' em processos de reprodução social (e, por assim dizer, 'não é visto') opera. O desenvolvimento da força, ou a ameaça dela, não é, desta forma, o caso típico do uso do poder." [Giddens, 1984:257]

De modo semelhante às minhas observações na seção anterior, vários críticos sugeriram que a ênfase de Giddens na habilidade cognitiva e monitoração reflexiva das

\footnotetext{
${ }^{8} \mathrm{O}$ enunciado clássico de Max Weber é: “O poder 'economicamente condicionado' não é, obviamente, igual ao 'poder' enquanto tal. Pelo contrário, a emergência do poder econômico pode ser a consequência da existência do poder em outras bases. $\mathrm{O}$ homem não luta pelo poder apenas para enriquecer economicamente" [Weber, 1922:926].
} 
pessoas perturba o equilíbrio da teoria da estruturação na direção do subjetivismo. Vale a pena seguir esta pista. Johnson, Dandeker e Ashworth, por exemplo, afirmam que apesar de sua intenção de transcender o dualismo subjetivismo/objetivismo ao reformulá-lo como a "dualidade da estrutura", a atitude ambígua de Giddens quanto ao realismo significa que ele continua sendo um subjetivista [Johnson et al., 1984:205213]. E Margaret Archer enfatiza isto ao apontar, a partir de uma perspectiva da teoria dos sistemas, o poder arrogante que Giddens designa para a ação humana, incluindo o de gerar propriedades aparentemente socioestruturais, sendo todas elas instanciadas pela ação. Mas ela afirma que nem todas estas características são alteráveis igualmente pelos atores. Elas incluem algumas que mudam rapidamente, como regras de impostos, outras que demoram mais, como distribuições demográficas e algumas, como recursos naturais ou linguagens, que são efetivamente imutáveis. O compromisso total de Giddens com a eficácia da ação monitorada reflexivamente achata estas distinções cruciais, deixando-o incapaz de lidar com graus de coerção. Ela escreve que ele assim "fornece uma descrição insuficiente dos mecanismos de replicação estável" [Archer, 1982:479].

$\mathrm{Na}$ Constituição da sociedade Giddens tenta retaliar implicitamente esta objeção e outras críticas semelhantes, particularmente na seção "Três sentidos de coerção" [Giddens, 1984:174ff.]. Ele reconhece coerções corporais e materiais, que ele distingue de sanções negativas coercivas e da coerção estrutural derivada do contexto dado de atores situados e com poder diferenciado. Todas elas limitam o conjunto de opções aberto a atores hábeis, e ele afirma que algumas destas coerções, que incluem propriedades estruturais, não podem ser alteradas, mas estas não são nomeadas [Giddens, 1984:176]. Essencialmente, ele distingue este assunto de forma weberiana, afirmando que há tipos diferentes de coerção que funcionam em contextos diferentes de ação; de qualquer forma, coerções em um nível podem permitir a ação individual em outro.

Giddens afirma que são as propriedades estruturais das instituições (ordens simbólicas, dimensões política, econômica e legal) que são objetivas para o ator individual. (Ele chama as propriedades fincadas mais profundamente de princípios estruturais.) Entretanto, a estrutura, enquanto regras e recursos, tem uma existência paradigmática, e supostamente só é instanciada na ação e em traços de memória, fornecendo a ordem "virtual" da distribuição das práticas sociais no sistema social. Neste sentido, a "estrutura" na teoria de Giddens é interna aos atores [Giddens, 
1984:25]. Mas será que estas definições respondem à crítica de Archer sobre a objetividade problemática das coerções na teoria de Giddens?

Ao falar destas propriedades estruturais das instituições em detalhe, Giddens diz que este só é um procedimento válido "se for reconhecido como algo que coloca uma époché - mantém em suspensão - na conduta monitorada reflexivamente" [Giddens, 1984:30]. O que isto significa? Supostamente que com os parênteses metodológicos removidos, as propriedades estruturais também são - como a estrutura - instanciadas uniformemente na realidade na conduta monitorada reflexivamente. Ou será que ele quer dizer que a conduta monitorada reflexivamente pode ocorrer com instituições existindo como um pano de fundo objetivo? E se este for o caso, qual é seu estatuto ontológico? A primeira sugestão encontra apoio numa formulação anterior de Giddens [1979:80] que parecia implicar que por causa da "dualidade da estrutura", também estas propriedades estruturais são instanciadas na ação humana, tanto coagindo-a quanto permitindo-a. Esta última interpretação parece se encaixar com o comentário de Giddens sobre ordens simbólicas na semiótica como uma coerção no reino da significação: "Sinais 'existem' apenas enquanto o meio e o resultado de processos comunicativos na interação" [Giddens, 1984:31]. Mas estas formulações contrastam com a definição de "propriedades estruturais" dada no glossário da Constituição da sociedade, que menciona apenas características "institucionalizadas" e "estruturadas", sem nenhuma referência à conduta monitorada reflexivamente ou à instanciação.

$\mathrm{Eu}$ acho que a fonte destas inconsistências está parcialmente no caráter específico do conceito estruturalista que ele usou. (Eu retornarei a este conceito na próxima seção.) Além disso, o problema surge da natureza da teoria da estruturação enquanto teoria da ação. O ponto de partida para Giddens é o problema teórico herdado de como as ações de atores hábeis produzem e reproduzem continuamente a sistematicidade de padrões mais amplos de relações sociais. Assim, Giddens precisa fornecer um modo de falar sobre os padrões de interconexões entre correntes vastas de grupos e indivíduos interdependentes que retêm o ator com habilidade cognitiva, fundamental, e que também não reificam a estrutura como uma fonte externa de coerção, reproduzindo assim o dualismo indivíduo/sociedade falacioso. Ele está tentando lidar com a interdependência na linguagem da interação. 
Examinemos este problema mais de perto, sob a luz do comentário de Elias de que "o conceito de 'indivíduo' refere-se a pessoas interdependentes no singular, e o conceito de 'sociedade' a pessoas interdependentes no plural” [Elias, 1970:125]. O que devo demonstrar aqui é que a teoria da estruturação não contém em nenhum nível uma concepção completamente relacional da coerção por causa da falha de Giddens em incorporar a realidade e o conceito da interdependência humana nesta teoria. Ele não oferece uma discussão conceitual do termo "interdependência" em lugar nenhum. O termo aparece ocasionalmente em seus escritos, como quando ele está expondo a concepção dos funcionalistas da interdependência entre as partes e o todo, ou quando ele é utilizado frouxamente em discussões com o significado de interação ou interrelação. Em outros lugares, ele está claramente consciente do significado socioeconômico do conceito na teoria da divisão do trabalho em Marx e Durkheim [Giddens, 1971; 1982a:36] mas estes são os únicos sentidos em que Giddens parece conhecer o conceito. A interdependência não tem nenhum papel sistemático na teoria da estruturação.

Depois de começar a seguir a estrada da teoria da ação, esta abordagem então define os problemas para Giddens e circunscreve sua solução. Quando o ponto de partida é indivíduos em interação e tipos de indivíduos, em vez da pluralidade de pessoas em redes de interdependências, duas características passam a dominar a análise.

Primeiro, uma tendência a enxergar consequências não-intencionais e condições não-reconhecidas da ação apenas como condições ou consequências de ações individuais, e não como algo endêmico às ações de muitos indivíduos interdependentes numa sociedade em desenvolvimento. As ramificações destas ações reverberam através de correntes de pessoas interligadas entre nações, e ao redor do mundo e de volta outra vez. Da mesma forma, as ambíguas "propriedades estruturais" das instituições, que eu mencionei anteriormente, também tendem a ser consideradas objetivas apenas em relação ao indivíduo. Apesar de sua tentativa de transcender a dicotomia indivíduo/sociedade através da dualidade entre ação e estrutura, o fantasma do velho dualismo assombra a teoria porque seu ponto de partida é a teoria da ação, que carrega o dualismo em seu núcleo.

Segundo, os indivíduos em interação em condições de copresença (a integração social aplica-se aqui) só podem ser visualizados como conectados a outros indivíduos 
que não estão presentes através de metáforas como o "esticamento" de práticas sociais (“distanciamento espaço-temporal”); ou através de referência a suas propriedades "laterais" ou à "canalização de caminhos espaço-temporais de indivíduos" na integração sistêmica [Giddens, 1984:142]. Ao falar sobre a integração social ele às vezes se refere a "outros ausentes" ou "aqueles que estão fisicamente ausentes" [Giddens, 1984:37]. O mais próximo que Giddens chega de conceber a interdependência ocorre quando ele faz uma distinção em uma passagem (que não é mantida através da Constituição $d a$ sociedade) entre "interação social" e "relações sociais":

"A interação social se refere a encontros em que indivíduos engajam-se em situações de copresença, e assim à integração social como um nível dos 'blocos de construção' onde as instituições de sistemas sociais são articuladas. Relações sociais certamente estão envolvidas na estruturação da interação, mas também são os principais 'blocos de construção' em torno dos quais as instituições são articuladas na integração sistêmica. A interação depende do 'posicionamento' de indivíduos nos contextos espaçotemporais da atividade. Relações sociais tratam do 'posicionamento' de indivíduos dentro de um 'espaço social' de laços e categorias simbólicas." [Giddens, 1984:89]

Eu citei esta passagem complicada inteira para demonstrar em relevo as ambiguidades e elisões da teoria. Esta citação articula o ponto mais profundo possível dentro da teoria da ação mas ainda assim não consegue resolver o dualismo ação/sistema. Interações individuais em condições de copresença parecem ter precedência e formar o ponto de partida. Elas supostamente envolvem procedimentos aplicados reflexivamente por atores com habilidade cognitiva que alcançam a integração. Mas percebam a vaguidade dos termos "blocos de construção", "relações" sociais", "laços e categorias simbólicas" para descrever a forma em que a integração é obtida no nível do sistema. "Relações sociais" não especificadas estariam envolvidas em ambos os níveis, e o "posicionamento" diferencial dos indivíduos é considerado importante. Apesar das relações de palavras, indivíduos são vistos aqui apenas na primeira pessoa, como posições. Não há nenhuma compreensão conceitual da perspectiva pela qual eles são enxergados por outros na teia social total, nem do caráter de suas relações combinadas. A teoria da estruturação é uma visão unidimensional da sociedade que não permite que o sociólogo demonstre este jogo combinado de relações e perspectivas em toda a sua riqueza e equilíbrios de poder complexos. 
A questão aqui é esta: qual é a natureza da interconectividade social, dos "laços" não-especificados que ligam as pessoas tanto em redes menores quanto em redes mais amplas que reverberam além de seu meio imediato? Para estender a pergunta: o que torna socialmente possível que pessoas rompam contatos e se desloquem espacialmente para iniciar outros, para então quebrar estes, e assim por diante, da forma descrita tão vividamente por Giddens (e Simmel antes dele)? Em todos os casos, eu sugeriria que é sua interdependência inescapável com outras pessoas. Atores realmente têm intenções, planos, objetivos e habilidade cognitiva, e possuem uma "penetração" cognitiva discursiva de validades diferentes quanto a interconexões sociais mais amplas. Mas eles não podem escapar de sua interdependência complexa com outros, presentes ou ausentes, não importa o quão penetrante seu conhecimento seja. Na frase memorável de John Lennon: "a vida é aquilo que acontece com você enquanto você está ocupado fazendo outros planos". As ações racionais e conscientes das pessoas podem ter consequências não planejadas, que elas não previram e nem podem controlar, causadas pelas repercussões das ações de outros que elas não conhecem mas com quem são interdependentes. E este processo funciona no sentido contrário, não como uma "interação" ou reciprocidade simples, mas como um nexo funcional (ver p. 340). O teorema de Giddens dos indivíduos "fazendo diferença" tem que ser repensado e purificado de seu caráter racionalista e voluntarista.

A complexa natureza entrelaçada da ligação social que conecta a integração social e sistêmica, na terminologia de Giddens, permanece numa vaguidade confusa na teoria da estruturação pela natureza de seu molde cognitivo. Como vimos, Giddens só consegue visualizar a interdependência em seu modo econômico parcial em suas discussões de Durkheim e do contrato de trabalho assalariado capitalista em Marx. Mas mesmo esta dimensão é marginal para a teoria da estruturação como um todo. Ele assim não consegue compreender a interdependência como uma estrutura muito mais multinivelada, complexa e relacional, envolvendo ligações humanas de vários tipos, incluindo políticos, econômicos e afetivos. Como Elias fala das múltiplas funções que as pessoas realizam para outras:

“As pessoas precisam umas das outras, elas se dirigem e se ligam umas com as outras como resultado da divisão do trabalho, de especialização profissional, de integração em tribos ou Estados, ou um senso comum de identidade, e de seu antagonismo comum para outros ou seu ódio e inimizade entre si." [Elias, 1970:175n.1] 
Ao analisar tais nexos funcionais multidimensionais, podemos mostrar como a natureza dos laços entre indivíduos e grupos muda com o tempo enquanto partes de mudanças sociais mais amplas. Por exemplo, o laço entre pai e filho passa por vários estágios durante a vida das duas pessoas, enquanto o equilíbrio de poder muda de um para o outro como parte do jogo variável de forças através da rede familiar e da sociedade como um todo.

Com seu conceito da "dialética do controle" [Giddens, 1984:283], Giddens conceitualizou o fato importante de que grupos subordinados podem, através do uso de recursos abertos para eles, exercer algum controle sobre grupos superiores, mesmo que o equilíbrio seja altamente assimétrico. Este conceito bem-vindo, apesar de não ser essencialmente original, contribui bastante para o debate sobre a natureza do poder social e, corretamente, tem uma posição de destaque na teoria da estruturação. Mas ele não tem a mesma força explicativa que tem compreender tal relação de desequilíbrio de poder como uma relação de interdependência funcional no sentido anterior, através da qual cada grupo ou unidade depende do outro para sua própria existência social. E às vezes grupos ou unidades sociais mais amplas serão levados a conflitos implacáveis entre si através da estrutura de sua relação, apesar de seu entendimento mútuo desta relação. Giddens só consegue compreender este tipo de interdependência-porantagonismo na forma mais fraca e voluntarista de: "controle (...) como a capacidade que alguns atores, grupos ou tipos de atores têm de influenciar as circunstâncias da ação de outros" [ibid.]. Mas esta formulação ignora que estes grupos ou atores já estão presos em formas de ligação com aqueles que estão tentando influenciar, e estes com aqueles, vice-versa, formando um nexo funcional numa rede mais ampla de interdependências. Como diz Elias: "sob todas as interações intencionadas dos seres humanos está sua interdependência não-intencional" [Elias, 1969:143].

A teoria da estruturação incorpora uma imagem racionalista de pessoas cuja vida emocional - e prontidão para se conectar com outras nesta dimensão da ligação - é excluída pela prescrição metodológica de que o ator que monitora reflexivamente é limitado pelas instituições, por um lado, e pelo inconsciente pelo outro, que supostamente - seguindo a psicologia do eu - estaria pouco implicado na conduta prática [Giddens, 1984:50]. A dívida de Giddens com esta escola de psicanálise e, dentro dela, com Erik Erikson, ajuda a focar o modelo do ator racional no centro da teoria. A obra de Erikson, e desta escola em geral, é famosa por ampliar o alcance da 
psicanálise para incluir os interesses conscientes do eu e das relações do indivíduo com símbolos coletivos e instituições sociais que não sejam a constelação familiar edipiana associada com o freudismo clássico.

Giddens aceita grande parte do corretivo sociológico de Erikson aos aspectos mais míticos e individualistas de Freud. Ao fazer isto, ele incorpora uma noção do ator muito semelhante à versão de Erikson do "ideal do eu" de Freud, visto por Erikson como mais flexível, mais consciente e mais ligado a valores sociais prevalentes e suscetível a mudanças do que o supereu internalizado mais completamente de Freud [Erikson, 1968:210]. Há assim uma consistência interessante na obra de Giddens. Este modelo do ator racional se encaixa bem com a fascinação de Giddens com as capacidades extraordinárias do ator hábil derivada de Garfinkel e anda de mãos dadas com o impulso neoliberal tácito da teoria de que as capacidades das pessoas de "fazer diferença" devem ser maximizadas. Citando Hoffman, sobre o conceito de Erikson de "ideal do eu": "Esta definição, mais que a de Freud, lembra a noção liberal clássica de uma consciência 'diretora interna' e supõe que os indivíduos são capazes de participar da direção de suas próprias vidas” [Hoffman, 1982:140].

Resumindo, a teoria da estruturação articula, com uma ênfase normativa implícita, a autoexperiência dominante e o código de comportamento público de indivíduos altamente autocontrolados nas sociedades industrializadas avançadas. Mas ela é incapaz de mostrar como este tipo de indivíduo surgiu: para Giddens, as pessoas, aparentemente, têm sido as mesmas desde o amanhecer da história. Eu não estou negando a importância da psicologia do eu, que fornece, por exemplo, um entendimento profundo da formação da identidade individual como uma série de estágios. Nem que a incorporação de conceitos derivados dela em programas de pesquisa não esclareceria pelo menos um certo conjunto de problemas na sociologia. O que quero dizer é que se seguirmos apenas uma teoria que incorpore o modelo do ator descrito acima, pagaremos um preço alto. Ela efetivamente fecha a porta para um entendimento do papel crucial desempenhado na sociedade de instintos e impulsos controlados e regulados socialmente. Por causa de sua própria estrutura e pressuposições conceituais, a teoria da estruturação não pode tratar da "constituição da sociedade" emocional. Fica excluído o estudo de padrões sociais de controle emocional e autocontrole individual. Fica fora da teoria a regulação social variável do prazer, desejo e agressão através da vergonha, 
constrangimento e repugnância. Estas emoções foram sistematicamente excluídas desde o começo como não-sociológicas ${ }^{9}$.

\section{Sistemática ou sociogênese?}

A teoria da estruturação é concebida como uma metateoria da ação relevante para todas as ciências sociais, um esforço conceitual de construção sintética de teoria para consolidar desenvolvimentos atuais na teoria e reconstruir o consenso ortodoxo. Mas, como estive dizendo, ela é mais do que isto. Ela também é a reunião, num pacote sociológico mais ou menos coerente, de uma seleção particular de conceitos, preceitos, suposições, ênfases e elementos normativos, cuja unidade pode ser considerada como constituindo uma visão de mundo. O princípio seletivo subjacente a suas partes componentes é sua força prescritiva como uma plataforma moral-política para a crítica social da modernidade do ponto de vista da liberdade do indivíduo, visto como potencialmente autodirigente e expressivo. Esta ênfase valorativa, assim como critérios racionais e intelectuais, determinam o que é incluído ou excluído do corpo da teoria. A corrente liberal é a mais dominante, em vários sentidos, como vimos. A corrente socialista é representada pela apropriação da ontologia econômica marxista do trabalho e a ênfase na liberdade individual também é compatível com formas de socialismo democrático. O conservadorismo fornece a longue durée de instituições sedimentadas e reproduzidas e o conceito de contradição existencial, ambos ocupando uma posição menos chamativa na teoria.

Eu não acho que representar a visão de mundo implícita na teoria da estruturação como o farei agora imponha um grau de coerência grande demais. A sociologia é vista como a ciência social "crítica" que lida com as sociedades de classes do mundo capitalista "moderno" descontínuo. Sua preocupação central é examinar que condições de ação maximizarão a capacidade de atores com habilidade cognitiva de fazer uma

\footnotetext{
${ }^{9}$ Eu obviamente não estou sugerindo que Giddens nega que as pessoas tenham emoções, apenas que o estudo de sua regulamentação social é excluído da teoria da estruturação por sua própria natureza. Numa palavra, a teoria é racionalista. Esta é uma questão da qual Giddens tem plena consciência, mas ele não a investiga. Ao discutir os escritos de Herbert Marcuse, ele corretamente aponta as apropriações diferentes de Freud por Marcuse e Habermas: “(...) a concepção da situação ideal do discurso [em Habermas], por mais interessante que seja por si só, permanece num nível peculiarmente cognitivo. E as emoções, a sexualidade, o amor, o ódio e a morte? Enquanto a formulação de Marcuse da teoria crítica se baseia numa preocupação permanente com estes fenômenos, a descrição de Habermas não fornece muitos modos para lidar com eles conceitualmente." [Giddens, 1982b:158] Et tu, Giddens!
} 
diferença nesta sociedade quando eles são dotados de acesso diferencial a recursos socialmente. A sociologia precisa estar aberta à filosofia porque aqui encontramos discussões convenientes de racionalidade e ação intencional que são apropriadas para entender o tipo de pessoas automonitoradoras características do mundo racionalizado da modernidade. Nós nos concentramos na habilidade cognitiva, consciência prática e consciência discursiva porque nos Estados-nação modernos pacificados internamente a formação de personalidade dos atores é tal que o inconsciente não está muito implicado em sua ação cotidiana. Por isso ele pode ser excluído. A escolha de Marx, Weber e Durkheim como a "tradição seletiva" é apropriada porque eles foram preeminentemente os sociólogos da modernidade descontínua e de seus problemas. Eles criticaram, respectivamente, o capitalismo inicial, a racionalização capitalista crescente, e os aspectos anômicos posteriores da vida econômica. Esta versão da natureza e do papel da sociologia no mundo moderno é institucionalmente proeminente de várias formas. Isto porque ela é evidentemente plausível, de forma automática, para as pessoas altamente autocontroladas e automonitoradoras que participam da comunidade sociológica e que encontram espelhadas no programa suas obrigações morais sentidas mais profundamente enquanto críticos sociais.

No interesse do contraste e para abrir um diálogo com esta forma de fazer sociologia, eu contrapus vários princípios opostos. Esta tática foi empregada para recuperar da bacia teórica alguns bebês conceituais jogados fora apressadamente. Estas recuperações, com sorte, também acabarão transformando as implicações normativas ao reconstituírem um equilíbrio mais realista. Em vez de uma sociologia da modernidade estreita, eu contrapus uma concepção de sociologia mais ampla como a ciência social unificadora aplicável a todas as sociedades históricas. Em vez do descontinuísmo, eu opus o continuísmo. Em vez do ator com habilidade cognitiva, eu coloquei padrões variáveis de compulsão figuracional. Contra a interação eu propus a interdependência. Em vez de abraçar a filosofia, eu sugeri que nos esquivemos dela. Em vez de atores como "posições" em primeira pessoa eu defendi relações multiperspectiva. Contra o ator racionalista eu contrapus um modelo mais completo de pessoas no plural, que incorpora a regulação variável do afeto e autocontroles individuais. E contra o diagnóstico sociopolítico "hodicêntrico" (centrado no hoje) [Goudsblom, 1988:7ff., 78, 168], eu propus o estudo da ordem sequencial de desenvolvimento de longo prazo para ajudar a discernir a forma geral do futuro que parte da condição global e nacional atual. 
Eu expressei estas oposições rígida e vigorosamente para obter um efeito, e posso fazer apenas poucas das qualificações necessárias para evitar ser mal entendido. Não pretendo criar outro conjunto de dualismos. E nem estou contrapondo uma visão de mundo rival, porque eu evito considerações normativas desde o começo. Meu objetivo é simplesmente abrir um conjunto diferente de perguntas. A tarefa, essencialmente, é obter um quadro sociológico da sociedade mais completo do que aquele possível através da teoria da estruturação, por mais esclarecedora que ela seja para alguns propósitos. Por exemplo, seria tolo e enganoso simplesmente contrapor outro a priori do continuísmo contra o descontinuísmo. Apenas um conservador enxergaria somente continuidades. Em vez disso, a chave é a avaliação do equilíbrio destas e outras dimensões juntas com uma ênfase no desenvolvimento social de longo prazo. Da mesma forma, é claro que os atores realmente têm habilidade cognitiva e são até certo ponto racionais em todas as sociedades, e talvez o sejam cada vez mais em nossa própria sociedade. Mas este foco exclusivo é uma ênfase arbitrária colorida pela racionalidade dominante de nossa sociedade que coloca entre parênteses a ligação emocional enormemente importante na vida social. Ela também tende a pressupor que as pessoas têm sido iguais através da história, não levando em consideração o estudo das formas pelas quais as próprias pessoas mudam durante transformações sociais, mesmo durante a curta fase "moderna".

A apropriação de Giddens da versão da hermenêutica de Hans-Georg Gadamer [1960] ilustra muito bem a natureza do conjunto particular de ênfases e pressuposições do programa estruturacionista. Para Gadamer, a compreensão não é um método especial de Verstehen, mas uma condição ontológica da humanidade. Na interpretação de textos escritos em períodos diferentes, é impossível eliminar os preconceitos que trazemos a eles, porque não podemos escapar da tradição a partir da qual entramos no assunto do texto. Tanto o intérprete quanto a tradição sendo investigada através do texto contêm seu próprio "horizonte", nos termos de Gadamer, por isso a tarefa da investigação hermenêutica é uma tarefa circular de integrar nosso próprio horizonte com aquele da tradição em questão numa "fusão de horizontes". Este é um processo incessante através do qual testamos nossos pré-entendimentos, mudando assim nossa compreensão do passado e de nós mesmos num processo contínuo. Assim, o presente sempre é formado através de um contato e intercâmbio constantes com o passado, que Gadamer chama de nossa história efetiva (Wirkungsgeschichte). Gadamer não está oferecendo uma 
metodologia para as ciências humanas, em vez disso, seu trabalho é uma tentativa filosófica de "entender o que as ciências humanas realmente são, além de sua autoconsciência metodológica, e o que as liga com a totalidade de nossa experiência no mundo" [Gadamer, 1960.:xiii].

Como Outhwaite mostrou, a radicalização heideggeriana de Gadamer da tradição hermenêutica tem uma influência crescente nas ciências sociais: "Fica cada vez mais claro que os cientistas sociais não podem mais ignorar as fundamentações hermenêuticas de sua prática, nem despachá-las para o domínio de uma sociologia verstehende opcional" [Outhwaite, 1985:37]. Como Habermas, Giddens leva a hermenêutica a sério. De forma consistente com suas simpatias individualistas, ele critica Gadamer por exagerar em sua reação contra versões empáticas anteriores da hermenêutica textual eliminando totalmente as intenções do ator. (Esta é uma crítica similar à que Giddens dirige ao estruturalismo.) Mas o que é mais importante é que Giddens incorpora a visão ontológica de Gadamer do entendimento enquanto fusão de horizontes diretamente em suas prescrições para a explicação na sociologia em sua concepção da "hermenêutica dupla". Este processo duplo é aquele através do qual os sociólogos mediam os significados da linguagem ordinária dos atores, obtidos a partir da imersão dos sociólogos nas formas de vida, com a metalinguagem técnica da sociologia [Giddens, 1976:161-162].

Então Giddens traz à bordo a hermenêutica existencial, mas, contrário a todas as intenções de Gadamer, ele reformula sua essência como um método, quer dizer, como uma prescrição explicativa para a sociologia. Esta jogada é consistente com sua estratégia costumeira de tirar das filosofias e escolas sociológicas apenas o que ele precisa para reconstruir a tradição sociológica, que tem prioridade. Ao mesmo tempo, ele se preocupa em apropriar este tipo de hermenêutica sem levar a sociologia a um relativismo epistemológico, um perigo conhecido nesse campo. Tal resultado, obviamente, enfraqueceria seu compromisso com a eficácia do conhecimento sociológico confiável no mundo moderno. Assim, nos debates hermenêuticos ele apoia a insistência de Emilio Betti em manter a integridade e autonomia do objeto, quer dizer, o texto como uma "criação situada de seu autor" [Giddens, 1976:63]. E ele se agarra à distinção feita por filósofos entre o sentido e a referência para reconciliar o respeito pela autenticidade de esquemas de significado mediados com a questão da validade do conhecimento. Ele enxerga o entendimento hermenêutico como uma "condição da" 
[Giddens, 1976:145] validade, em vez de algo que a exclui. Entretanto, como é de praxe em Giddens, por razões de princípio [Giddens, 1984:xx], ele não continua a investigar esta questão epistemológica aborrecida; para ele estes tipos de debates atrapalham a pesquisa sociológica. Assim, é previsível que ele apoie Betti, ainda que fazer isto vá contra a corrente dos comentários mais céticos recentes. Por exemplo, Bleicher considera a preocupação de Betti em preservar uma objetividade limitada para a hermenêutica um "resíduo da abordagem cientística à esfera não-natural" [Bleicher, 1980:125].

Além do mais, Habermas objetou que a hermenêutica de Gadamer não consegue lidar com a emancipação de estruturas de dominação e autoridade incorporadas na linguagem e nas tradições. Bleicher, mais uma vez, localiza a verdadeira vocação da hermenêutica em sua função de emancipação. Há um "momento crítico-antecipador no entendimento" que não pode ser intuído por Gadamer: "Essencialmente, a possibilidade da hermenêutica crítica depende do esquema que Habermas está tentando construir a partir de uma teoria materialista da sociedade e da evolução social em conjunção com uma teoria da linguagem ordinária" [Bleicher, 1980:258]. Por outro lado, Giddens vê a asserção de Habermas de que a linguagem é um meio de dominação como algo que concede demais para a hermenêutica porque isso transmuta o poder em comunicação deformada ideologicamente. Ao mesmo tempo, Habermas concede muito pouco porque para Giddens a mediação de esquemas de significado precisa formar uma base para a crítica da ideologia enquanto uma atividade humana [Giddens, 1977:153].

Numa palavra, Giddens abandona a questão epistemológica complicada da validade que surge da hermenêutica porque ele tem um compromisso anterior de evitar discussões epistemológicas elaboradas. Assim, ele é capaz de apropriar a hermenêutica de forma metodológica e ainda conseguir dormir à noite. E ele não é perturbado pelo problema Habermas-Bleicher de reconciliar a hermenêutica persuasiva de Gadamer com a "crítica" porque, como vimos anteriormente, ele já considera a sociologia uma atividade inerentemente "crítica", emprestando as ressonâncias estabelecidas do termo para seus próprios propósitos.

Finalmente, voltemo-nos mais explicitamente para o que estou chamando de método "sistemático" de Giddens para contrastá-lo com uma abordagem sociogenética, para desenhar um quadro dos ganhos e perdas comparativos de cada uma para a tarefa 
de síntese sociológica. O termo "sistemático", no sentido que estou usando aqui, tem origem kantiana e é um lado da distinção entre investigações sistemáticas e históricas, delineando uma divisão de trabalho entre a filosofia e disciplinas das ciências sociais. "Sistemático" se refere a um conjunto de reflexões de tipo conceitual ou transcendental surgindo dos dados socio-históricos fatuais coletados pelas ciências sociais.

O uso sociológico relacionado - e este é o sentido incorporado implicitamente no método de Giddens - foi codificado por R. K. Merton em seu ensaio "Sobre a história e a sistemática da teoria sociológica" [Merton, 1968]. Com "sistemática" ele se referia à substância das teorias, quer dizer, o produto conceitual generalizável derivável independentemente de sua história ou origens. Sua análise foi acompanhada de um pedido para não misturar ou embaçar a distinção, o que os sociólogos tendem a fazer muito mais do que físicos ou químicos. (Como ficará claro mais tarde, eu aceito este conselho geral, mas, por causa das várias desvantagens da sistemática analítica da abordagem de Giddens, eu defendo uma "sistemática histórica".)

Giddens só se envolve com o pensamento desenvolvimentista levemente em suas discussões sobre instituições e várias áreas empíricas em seu livro O Estado-nação e a violência [Giddens:1985]. Ele, de modo geral, não se interessa pelo estudo de processos de longo prazo no nível de sua metateoria na Constituição da sociedade [Giddens:1984]. Estes dois livros incorporam a equação: desenvolvimento é igual à evolução. E sua dispensa sumária da sociologia do conhecimento bloqueia o acesso à utilidade desta tradição não apenas para estabelecer os interesses ocultos dos enunciados de adversários, mas também para ajudar a própria formação de conceitos adequada de forma desenvolvimentista e histórica. A sociologia do conhecimento envolve mais do que simples desmascaramentos. Além do mais, seu uso da hermenêutica recomenda a mediação de esquemas de significado ou formas de vida com as metalinguagens da ciência social. Mas este método parece ser aplicável apenas a mediações entre o ocidente e outras culturas, entre formas de vida na sociedade do aqui-e-agora ou entre as formas de vida atuais e passadas a curto prazo dentro do mundo "moderno". O programa hermenêutico de Giddens exclui o projeto de assegurar uma compreensão histórico mais profunda e de maior alcance da humanidade recuperando os desenvolvimentos distantes esquecidos que moldaram nosso mundo e nós mesmos. 
Metodologicamente, mover-se nesta direção significa abraçar (sem teleologia e com outras modificações) o princípio encapsulado no dito de Marx de que "a anatomia do homem contém a chave para a anatomia do macaco", quer dizer, que a estrutura de um estágio posterior de desenvolvimento potencialmente nos permite compreender melhor estágios anteriores, cujos traços podem ser encontrados incorporados ao estágio posterior. Este impulso também aparece de várias formas em Hegel, autores na tradição alemã do historicismo, vários marxistas ocidentais, incluindo Gramsci, Collingwood e Sartre em sua Questão de método [Kilminster, 1979, parte III e cap. 15; Collingwood, 1946]. Por não ter uma consciência histórica neste sentido, Giddens não conhece bem estas tradições ${ }^{10}$. De forma significativa, ele retira de Marx apenas o apelo aos aspectos "descontínuos" do capitalismo, desconsiderando completamente sua orientação histórico-genética igualmente central, o chamado método dialético. Assim, não surpreende que Giddens tenda a supor que conceitos em geral são simplesmente abstratos em relação ao concreto, ou empírico. Ele não tem nenhuma concepção de conceitos como sintéticos, quer dizer, tendo incorporados neles traços de estágios anteriores de desenvolvimento social e cientifico.

A estratégia sistemática de Giddens trata as diferentes escolas de filosofia e sociologia discutidas como equivalentes, e, assim, como abstratamente comparáveis. Todas supostamente fornecem produtos substantivos independente de sua natureza e origem. O projeto foi possibilitado pela institucionalização da sociologia em tempos recentes, na qual, nas palavras de Edward Shils, as instituições "alimentam a produção de obras" e "criam um ambiente intelectual ressonante com repercussões" [Shils, 1970:272]. Neste mundo intelectual ressonante, Giddens (certamente de forma hábil e inteligente) descobre convergências entre as escolas que encontra à disposição e lado a lado em currículos, revistas e publicações, mas pressupõe sua especificidade, e como elas obtiveram sua importância. O perigo da abstração exagerada é aumentado pela falta de reconhecimento do estatuto e valor cognitivo potencialmente diferentes da contribuição de cada escola. Como Shils avisa: “A institucionalização não é uma garantia de veracidade: ela apenas torna mais provável a consolidação, elaboração e difusão de um conjunto de ideias" [Shils, 1970:277]. É claro que é possível produzir sínteses num certo nível de abstração, como Parsons e Giddens mostraram, e elas podem ter um certo valor heurístico. Mas ambas pressupõem coisas demais. Entretanto,

\footnotetext{
${ }^{10}$ Neste gênero, há uma breve discussão de Michael Oakeshott em Giddens [1984:355-356].
} 
seguindo Elias e a tradição da sociologia do conhecimento, eu gostaria de defender a injeção, no processo de formação de teorias, de uma forma histórica e sociogenética de controlar a validade ou valor cognitivo de componentes sintetizados para suplementar os critérios lógicos empregados por Giddens. Talvez este método possa ser chamado de "sistemática histórica". Expostos na barraca teórica da sociologia contemporânea estão vários produtos teóricos, cujas origens foram quase totalmente esquecidas, alguns filosóficos, outros sociológicos, ou vários híbridos dos dois. A teoria da estruturação sintetiza um conjunto dos resultados teóricos de um desenvolvimento social e institucional complexo que criou os paradigmas e os colocou lado a lado. O que importa aqui é que, por não ter uma teoria do desenvolvimento da sociedade e da ciência (que, a princípio, devem andar de mãos dadas), Giddens não tem como separá-las do ponto de vista de se qualquer teoria ou conceito entre elas é um avanço sobre um estágio anterior de elaboração mais ou menos adequada. Apenas com tal referência poderíamos julgar corretamente quais das teorias e conceitos contemporâneos que encontramos disponíveis e disseminados:

1. são reelaborações de avanços teóricos já obtidos no passado;

2. são novos arranjos de coisas que já eram becos sem saída mesmo num estágio anterior;

3. são baseados em abstrações filosóficas; ou

4. são inovações genuínas na teoria sociológica.

Teorias e conceitos em todas estas quatro categorias podem ser consolidadas institucionalmente, misturadas e disponíveis para análise, por isso elas precisam ser diferenciadas. Giddens, por outro lado, trabalhando sistematicamente, funde muitos conceitos e percepções num certo nível de abstração, mas não explicita seus critérios de seleção. Entretanto, o problema é: qual é o valor cognitivo da síntese se ela contém conceitos ou suposições de valor cognitivo ou relevância sociológica duvidosos? Uma abordagem sociogenética, por outro lado, poderia a princípio fornecer critérios para rejeitar ou ignorar teorias do tipo (2) ou (3), consideradas imprestáveis. Assim, uma síntese sociogenética assumiria uma forma diferente e com sorte seria de um tipo mais robusto para auxiliar investigações sociológicas empíricas porque conteria apenas 
componentes que foram estabelecidos sociologicamente. Ela abrangeria assim um tipo diferente de abstração.

Eu compreendo que esta abordagem, que posso esboçar apenas programática e esquematicamente aqui, ao defender uma teoria de desenvolvimento científico como parte de uma teoria do desenvolvimento social, vai contra o teor de grande parte da filosofia da ciência contemporânea que fala de "progresso" apenas através da mudança de programas de pesquisa, se é que usa o termo. E eu compreendo a magnitude da tarefa. Meu objetivo é justapor uma abordagem sociogenética para abrir os assuntos. Deste ponto de vista, posso ver três outras desvantagens da síntese sistemática, particularmente nas mãos de Giddens, e cada uma delas põe em relevo a posição contrária. Mais uma vez, estas ideias são expostas provisoriamente com a ideia de começar um diálogo.

1. Para repetir um ponto importante: já que os conceitos são descobertos prontos para serem usados dentro dos ambientes altamente institucionalizados da sociologia, então a pressuposição costuma ser que, já que eles estão lá de forma articulada como parte de uma escola, eles devem ser críveis e válidos. Entretanto, como Shils disse, isto não pode ser pressuposto, e nem a sua utilidade para propósitos sociológicos. Por exemplo, há muitos conceitos usados na teoria da estruturação que têm origem filosófica - como "práxis", “contradição", "presença", "historicidade" - que precisam ser analisados a este respeito. Eu examinarei rapidamente em mais detalhes um deles, a apropriação de Giddens do conceito de "estrutura" do estruturalismo, para explicar o que quero dizer.

O conceito de "estrutura" é usado na teoria da estruturação em vários sentidos e combinações de palavras, mas um deles - o de estrutura virtual paradigmática e atemporal - é particularmente problemático. Nas obras de Lévi-Strauss, tipicamente dentro da tradição estruturalista [Lévi-Strauss, 1962; 1964:abertura], o conceito de estrutura neste sentido tem uma função epistemológica particular. Para ele, e outros, a estrutura não é um agregado, nem um composto, nem uma essência ou Zeitgeist por trás das aparições do agregado, e sim as leis cognitivas de relação entre as unidades em questão. A estrutura está presente nas unidades observáveis nas relações entre elas na rede, e também é geradora delas, incluindo ausências assim como presenças [Piaget, 1971:caps. I, VI]. Lévi-Strauss chegou a esta concepção complexa dentro de um 
discurso filosófico. O conceito é alimentado por uma tentativa de resolver uma questão epistemológica (na verdade, metafísica) da filosofia da percepção sem cair no empirismo, idealismo, essencialismo ou subjetivismo. Seus alvos implícitos são o positivismo e a fenomenologia.

Ora, Giddens incorpora este conceito, neste sentido, em sua síntese pressupondo que a ideia lógico-filosófica da existência de estruturas paradigmáticas não-essenciais é uma forma de conceitualizar dados automaticamente aplicável ao estudo de padrões da vida social. Mas por que seria este o caso, quando o conceito de estrutura dos estruturalistas foi moldado para a solução de um problema colocado pelo dualismo pensamento/realidade da epistemologia tradicional? Giddens então torna este conceito de estrutura relevante para padrões de vida social como regras e recursos instanciados em práticas sociais e encontrados em traços da memória. Mas certamente seu uso por Giddens em sua teoria é um ardil, a importação acrítica para a teoria sociológica de uma forma filosófica de enxergar a percepção humana e o problema do conhecimento. Ela parece ter sido trazida simplesmente porque estava lá, disponível como parte de um paradigma academicamente respeitável na sociologia institucionalizada, implorando para ser integrada na teoria da estruturação. Mas sua adequação e propriedade para o objeto da sociologia me parecem questionáveis. Estou dizendo que apenas uma formação de teoria alerta ao estatuto e às origens dos conceitos pode nos impedir de entrar em tais becos sem saída.

2. A técnica de argumentação básica de Giddens é dizer que dualismos, digamos, indivíduo/sociedade ou subjetivismo/objetivismo, podem ser "resolvidos" através do raciocínio. Este procedimento consiste em dizer que sabemos, racionalmente, que os dois lados não são mutuamente exclusivos e foram erroneamente considerados como alternativas. Assim, eles podem ser substituídos pelas dualidades de ação/estrutura e coerção/permissão. Sua resolução através do raciocínio desta forma é uma tentativa de resolver os dualismos de forma filosófica, realizada frequentemente por Giddens com, certamente, muita engenhosidade e habilidade. Depois de fazer este trabalho filosófico, o caminho aparentemente se abre para investigações empíricas livres destes dualismos, que foram neutralizados. Entretanto, outra forma seria realizar uma investigação sociogenética para mostrar, primeiro, como os dualismos surgiram e adquiriram sua força cognitiva; segundo, testar até que ponto eles realmente articulam dois lados de relações sociais reais em casos reais. Um certo trabalho teórico e conceitual será 
necessário junto com esta pesquisa empírica, mas isto não é a mesma coisa que tentar resolver ou neutralizar os dualismos através de raciocínio anterior à pesquisa empírica. Em outras palavras, este método estabelece a validade e alcance da aplicabilidade dos dualismos empírica e geneticamente. É um procedimento científico, e não fílosófico.

3. O método "sistemático" incorporado na teoria da estruturação não consegue compreender que os paradigmas, tendências e escolas que ela utiliza também foram, seguindo Karl Mannheim [1928], interpretações do mundo. Eles também foram, e até certo ponto ainda são, as bandeiras sob as quais grupos marcharam numa competição para impor sua definição da realidade contra a definição dominante - aquela que Giddens chama de consenso ortodoxo.

Giddens tem alguma concepção da vida em grupo extrateórica por trás de paradigmas quando ele nota que: "Qualquer esquema teórico generalizado nas ciências naturais ou sociais é em certo sentido uma forma de vida por si só, cujos conceitos precisam ser dominados como um modo de atividade prática gerando tipos específicos de descrições" [Giddens, 1976:162]. Mas esta é uma visão anódina e pálida da vida em grupo. Para Giddens, a mediação hermenêutica de formas de vida divergentes e a imersão de sociólogos em culturas estranhas são essencialmente negociações suaves e harmoniosas. Também não há nenhuma concepção de que as metalinguagens da ciência social - como o estruturalismo, a etnometodologia, o althusserianismo ou a Teorização - passaram por batalhas, envolvendo paixão, compromisso, embates e conflito. Isto porque elas também foram interpretações da sociedade, carregadas por grupos em conflito cuja existência e identidade sociais estavam amarradas a elas. De que outro modo seria possível explicar a paixão dos desafios à autoridade epistemológica em anos recentes, o zelo dos manifestos por novas perspectivas na sociologia, o conflito e a luta do período Sturm und Drang da guerra das escolas? Toda a emoção destes conflitos se perde no método analítico-sistemático de Giddens, em cujas mãos cada paradigma se torna, nas famosas palavras de Hegel, "um cadáver que deixou seu impulso vital para trás” [Hegel, 1807:69, tradução levemente alterada]. 


\section{Conclusão}

Uma teoria da mudança cognitiva baseada na competição entre grupos para a interpretação pública da realidade pode, com algumas modificações e extensão, dar um ponto de partida para uma abordagem sociogenética que poderia produzir uma síntese mais realista e apropriada. Ela também nos permite explicar as condições de possibilidade da própria síntese - algo que é impossível visualizar na teoria da estruturação.

Como uma aproximação preliminar, baseada na primeira formulação do problema por Mannheim [1928], podemos ver no desenvolvimento recente da sociologia ocidental um estágio monopolista, quando o estabelecimento acadêmico assegurou sua vantagem através de seu monopólio da interpretação enquanto a ortodoxia estrutural-funcionalista, que era ortodoxa porque era dominante. A partir de sua posição de desvantagem relativa, grupos de oposição desafiaram esta orientação dominante porque ela não parecia consistente com sua experiência de vida e aspirações enquanto uma geração, dentro de polarizações políticas mais amplas, e parte delas. Seguiu-se então um período de conflito intenso quando os grupos desafiaram a autoridade epistemológica da ortodoxia. Durante este estágio competitivo, as escolas competiram ferozmente para serem ouvidas e a ortodoxia as enfrentou, às vezes concedendo terreno, o que é um dos primeiros sinais de uma síntese iminente. Nesta fase, foram exprimidas dúvidas sobre verdades universais, e hierarquias de valores e relativismo eram a ordem do dia.

Durante o estágio de concentração posterior, os grupos foram forçados pela natureza de seus conflitos entrelaçados, enquanto o gradiente de poder entre os grupos em competição diminuiu e alianças e fusões ocorreram, a tomar conceitos de outros e desistir de alguns conceitos próprios. Os debates então começaram a se polarizar em torno de algumas das principais antinomias, que, nos anos 1980, parecem ser:

construtivismo/realismo

ação/estrutura

significado/causa

subjetivismo/objetivismo 
No caso britânico, uma polarização básica tomou forma em torno dos lados esquerdo e direito destas antinomias. O lado esquerdo representa os resíduos das ênfases dos radicais, ativistas e forasteiros do estabelecimento acadêmico que, através destes conceitos, expressaram sua convicção de que não havia, em qualquer campo, limites para a mudança porque toda a cultura era construída por atores dotadores de significado, e por isso poderia ser mudada por eles. No outro lado, esta tendência representa o polo mais cuidadoso e realista, enfatizando os limites das mudanças dentro do reino da coerção. Mas traços das alianças de grupos se desfizeram quando os diferenciais de poder de grupos diminuíram e conceitos se tornaram a propriedade comum de todos, e são cada vez mais vistos como reconciliáveis. Conceitos que anteriormente eram motivos de conflitos - por exemplo, indexicalidade, reflexividade, significado, atores leigos e hermenêutica (das escolas inspiradas pela fenomenologia), ou modo de produção, luta de classes, crítica, práxis, força de trabalho e alienação (do marxismo) se tornaram moedas correntes, mais ou menos aceitos e não problemáticos.

As condições para a síntese bem sucedida estão agora maduras; uma síntese é algo que todos os lados querem pela natureza de sua existência social. Aquilo que normalmente chamamos de sensibilidade "pós-moderna" na sociologia do período atual é, eu gostaria de especular, simplesmente um produto da transição entre o estágio da concentração e a formação de uma nova síntese, pronta para se tornar uma ortodoxia qualitativamente nova em outro nível. E então o ciclo recomeça quando novos grupos surgirem para desafiá-la, e este processo constitui a forma pela qual o progresso ocorre nas ciências sociais. Minha abordagem adiciona uma dimensão de conflito de grupos à percepção de Weber que: “Os maiores avanços na esfera das ciências sociais estão substantivamente ligados com a mudança em problemas culturais práticos e tomam a forma de uma crítica da construção de conceitos" [Weber, 1904:106].

Pode-se objetar que esta abordagem sociológica sobre a construção e avaliação da formação de teorias desvaloriza o papel da mente que raciocina no processo da criação de síntese, deixando-a aparentemente relegada a um reflexo de interesses e poder. Mas o que quero dizer, seguindo Weber e Mannheim, é que é através de processos reais do tipo esboçado acima, que são entendidos apenas parcialmente, que o progresso nas ciências sociais ocorre. Além do mais, apenas um método sociogenético pode fazer justiça a este processo e dar a base para uma formação de conceitos adequada na sociologia. A questão da validade não é, acho, uma dificuldade tão séria 
quanto os filósofos a consideram e, de qualquer forma, pode ser recolocada sociologicamente em outro nível. É claro que não posso justificar esta afirmação num ensaio programático deste tipo. O que quero dizer é que a abordagem sociológica da formação de conceitos e síntese defendida aqui pode ser realizada de forma imparcial, organizada, científica e "racional", e não é de forma alguma um método que inevitavelmente cai nos braços da "irracionalidade". Há algo duvidoso sobre esta antinomia. O modo alternativo analítico-sistemático de abordar a síntese, se perseguido exclusivamente, corre o risco de dotar a mente pensante de um poder de racionalidade autônomo quase místico. Para terminar com as palavras de Mannheim:

"Qualquer um que queira arrastar o irracional onde quer que a lucidez e a acuidade da razão ainda precisem governar por direito meramente demonstra que tem medo de encarar o mistério em seu lugar legítimo". [Mannheim, 1928:229]

\section{Agradecimentos}

Sou muito grato a Zygmunt Bauman, Ian Burkitt e Terry Wassall por muitas discussões estimulantes sobre os temas deste artigo, e a Eric Dunning e Ian Varcoe por seus comentários incisivos sobre um rascunho anterior. Eu aprendi muito com todos eles.

\section{Bibliografia}

ARCHER, M. [1982] "Morphogenesis versus Structuration: On Combining Structure and Action", in British Journal of Sociology 33, pp. 455-483.

ATTEWELL, P. [1974] "Ethnomethodology since Garfinkel", in Theory and Society, 1; pp. $179-210$.

BAUMAN, Z. [1976] Towards a Critical Sociology. London: Routledge.

BAYNES, K.; BOHMAN, J. e McCARTHY, T. (eds.) [1987] After Philosophy: End or Transformation? Cambridge, MA: The MIT Press.

BLEICHER, J. [1980] Contemporary Hermeneutics. London: Routledge.

BLUM, A. [1974] Theorizing. London: Heinemann.

BRAMSTED, E. e MELHUISH, K. (eds.) [1978] Western Liberalism: A History in Documents from Locke to Croce. London: Longman. 
BROWN, R. [1987] "Norbert Elias in Leicester: Some Recollections", in Theory, Culture and Society, 4, pp. 533-539.

COHEN, P. [1968] Modern Social Theory. London: Heinemann.

COLLINGWOOD, R. [1946] The Idea of History. Oxford: Oxford University Press.

COLLINS, R. [1985] Three Sociological Traditions. New York: Oxford University Press.

DAWE, R. [1970] “The Two Sociologies”, in British Journal of Sociology, 21, pp. 107-118.

DOBSON, K. [1979] "Persons and People: Conceptualizing Individuality and Collectivity through Evelyn Waugh's The Ordeal of Gilbert Pinfold", in Leeds Occasional Papers in Sociology, 9.

ELIAS, N. [1939] The Civilizing Process, vol. 1. Oxford: Blackwell.

ELIAS, N. [1969] "Sociology and Philosophy", in Foulkes, S. e Prince, G. S. (eds.), Psychiatry in a Changing Society. London: Tavistock.

ELIAS, N. [1970] What Is Sociology? London: Hutchinson.

ELIAS, N. [1987] "The Retreat of Sociologists into the Present", in Theory, Culture and Society, 4, pp. 223-247.

ERIKSON, E. [1968] Identity: Youth and Crisis. London: Faber.

FREEDEN, M. [1978] The New Liberalism: An Ideology of Social Reform. Oxford: Clarendon.

GADAMER, H. [1960] Truth and Method. London: Sheed \& Ward.

GARFINKEL, H. [1967] Studies in Ethnomethodology. Englewood Cliffs: Prentice-Hall.

GELLNER, E. [1964] Thought and Change. London: Weidenfeld \& Nicolson.

GIDDENS, A. [1965] "Georg Simmel”, in Raison, T. (ed.) Founding Fathers of Sociology. Harmondsworth: Penguin.

GIDDENS, A. [1971] Capitalism and Modern Social Theory. Cambridge: Cambridge University Press.

GIDDENS, A. [1973] The Class Structure of the Advanced Societies. London: Hutchinson.

GIDDENS, A. [1974] Positivism and Sociology. London: Heinemann.

GIDDENS, A. [1976] New Rules of Sociological Method. London: Hutchinson.

GIDDENS, A. [1977] Studies in Social and Political Theory. London: Hutchinson.

GIDDENS, A. [1979] Central Problems in Social Theory. London: Macmillan.

GIDDENS, A. [1981] A Contemporary Critique of Historical Materialism. London, Macmillan.

GIDDENS, A. [1982a] Classes, Power and Conflict (editado com David Held). London: Macmillan.

GIDDENS, A. [1982b] Profiles and Critiques in Social Theory. London: Macmillan.

GIDDENS, A. [1982c] Sociology: A Brief but Critical Introduction. London: Macmillan.

GIDDENS, A. [1982d] "Historical Materialism Today: An Interview with Anthony Giddens", in Theory, Culture and Society, 1, pp. 63-77. 
GIDDENS, A. [1984] The Constitution of Society. Cambridge: Polity.

GIDDENS, A. [1985] The Nation-State and Violence. Cambridge: Polity.

GIDDENS, A. [1989] Sociology. Cambridge: Polity.

GOUDSBLOM, J. [1977] Sociology in the Balance. Oxford: Blackwell.

HABERMAS, J. [1968] Knowledge and Human Interests. London: Heinemann.

HEGEL, G. [1807] The Phenomenology of Mind. London: Sonnenschein.

HIRST, P. [1982] "The Social Theory of Anthony Giddens: A New Syncretism", in Theory, Culture and Society, 1, pp. 78-82.

HOFFMAN, L. [1982] "From Instinct to Identity: Implications of Changing Psychoanalytical Concepts of Social Life from Freud to Erikson", in Journal of the History of the Behavioural Sciences, 18, pp. 130-46.

HORKHEIMER, M. [1937] "Traditional and Critical Theory", in Critical Theory: Selected Essays. New York: Herder.

HORKHEIMER, M. e ADORNO, T. [1947] The Dialectic of Enlightenment. New York: Herder.

JOHNSON, T., DANDEKER, C. e ASHWORTH, C. [1984] The Structure of Social Theory. London: Macmillan.

KILMINSTER, R. [1979] Praxis and Method. London: Routledge.

KILMINSTER, R. [1982] "Zur Utopiediskussion aus soziologischer Sicht”, in Vosskamp, W. (ed.), Utopieforschung. Stuttgart: Metzler Verlag.

KILMINSTER, R. [1989] "Sociology and the Professional Culture of Philosophers", in Haferkamp, H. (ed.), Social Structure and Culture. Berlin: de Gruyter.

LENSKI, G. [1966] Power and Privilege. New York: McGraw-Hill.

LÉVI-STRAUSS, C. [1962] The Savage Mind. London: Weidenfeld \& Nicolson.

LÉVI-STRAUSS, C. [1964] The Raw and the Cooked. New York: Harper \& Row.

LOCKWOOD, D. [1956] "Some Remarks on the Social System", in British Journal of Sociology, 7, pp. 134-143.

LUKÁCS, G. [1923] History and Class Consciousness. London: Merlin.

McHUGH, P., RAFFEL, S., FOSS, D. e BLUM, A. [1974] On the Beginning of Social Enquiry. London: Routledge.

MANNHEIM, K. [1928] Essays on the Sociology of Knowledge. London: Routledge.

MANNHEIM, K. [1929] Ideology and Utopia. London: Routledge.

MARSHALL, T. H. [1982] "Foreword", in Giddens, A. e Mackenzie, G. (eds.) Social Class and the Division of Labour: Essays in Honour of Ilya Neustadt. Cambridge: Cambridge University Press.

MARTINS, H. [1974] "Time and Theory in Sociology", in Rex, J. (ed.) Approaches to Sociology. London: Routledge.

MARX, K. [1867; 1885; 1894] Capital. Moscow: Foreign Languages Publishing House. 
MERTON, R. [1968] Social Theory and Social Structure. New York: Collier-Macmillan.

MERTON, R. [1981] "Foreword: Remarks on Theoretical Pluralism", in Merton, R. e Blau, P. (eds.) Continuities in Structural Inquiry. Beverly Hills: Sage.

NEUSTADT, I. [1965] “Teaching Sociology", palestra inaugural. Leicester: University of Leicester.

OUTHWAITE, W. [1985] "Hans-Georg Gadamer", in Skinner, Q. (ed.) The Return of Grand Theory in the Human Sciences. Cambridge: Cambridge University Press.

OWEN, D. [1951] Social Romanticism in France, 1830-48. Oxford: Oxford University Press.

PARSONS, T. [1937] The Structure of Social Action. Glencoe: Free Press.

PARSONS, T. [1938] "The Role of Theory in Social Research", in Hamilton, P. (ed.) Readings from Talcott Parsons. London: Tavistock.

PIAGET, J. [1971] Structuralism. London: Routledge.

POPPER, K. [1961] The Poverty of Historicism. London: Routledge.

ROBERTSON, R. e LECHNER, F. [1985] "Modernization, Globalization and the Problem of Culture and World-Systems Theory", in Theory, Culture and Society, 2, pp. 103-117.

RORTY, R. [1982] Consequences of Pragmatism. Brighton: Harvester.

SANDERSON, S. [1987] "Eclecticism and Its Alternatives", in Wilson, J. (ed.) Current Perspectives in Social Theory, vol. 8. Greenwich, CT: Jai Press.

SANDYWELL, B. et al. [1975] Problems of Reflexivity and Dialectics in Sociological Inquiry. London: Routledge.

SARTRE, J-P. [1960] The Problem of Method. London: Methuen.

SEIDMAN, S. [1983] Liberalism and the Origins of European Social Theory. Oxford: Blackwell.

SHILS, E. [1970] "Tradition, Ecology and Institution in the History of Sociology", in Daedalus, 99, pp. 760-825.

THERBORN, G. [1971] "Habermas: A New Eclectic”, in New Left Review, 67, pp. 69-85.

WEBER, M. [1904] “'Objectivity' in Social Science and Social Policy”, in Methodology of the Social Sciences. Glencoe: Free Press.

WEBER, M. [1922] Economy and Society. New York: Bedminster.

WILLIAMS, R. [1973] "Base and Superstructure in Marxist Cultural Theory", in New Left Review, 82, pp. 3-13.

WITTKOWER, R. [1965] "Imitation, Eclecticism and Genius", in Wasserman, E. (ed.) Aspects of the Eighteenth Century. Baltimore: Johns Hopkins Press. 


\section{Anthony Giddens - Teoria da estruturação: passado, presente e futuro}

\section{O desenvolvimento da teoria da estruturação}

Eu considero a teoria da estruturação apenas uma parte de meus escritos como um todo. Especificamente, ela é o rótulo que associo à minha preocupação de desenvolver um esquema ontológico para o estudo das atividades sociais humanas. Com "ontologia", quero dizer uma investigação conceitual da natureza da ação humana, das instituições sociais e das inter-relações entre ação e instituições. Eu cheguei a estas considerações a partir de uma preocupação anterior com o desenvolvimento da teoria social clássica. Nessas obras anteriores, eu queria fornecer uma nova abordagem para classificar e interpretar o pensamento social clássico. Quando Capitalismo e teoria social moderna [Giddens, 1971] foi publicado, há quase vinte anos, alguns comentadores perguntaram por que eu não submeti as ideias dos autores discutidos nele a uma crítica mais sistemática. A razão era que eu não estava interessado em oferecer uma analise crítica das figuras envolvidas em termos de seus próprios pontos de vista; e nem buscava demonstrar que sua obra tendia na direção de uma grande síntese da teoria social como Parsons havia argumentado em seu famoso estudo A estrutura da ação social [Parsons, 1937]. Eu queria desenvolver uma crítica muito mais "extensa" da teoria social clássica através de projetos que ou recomeçavam a partir do ponto em que os fundadores clássicos da sociologia haviam parado, ou que desenvolviam linhas de raciocínio completamente diferentes.

Hoje, eu ainda mantenho as palavras com as quais encerrei Capitalismo e teoria social moderna: que precisamos buscar romper, no final do século $\mathrm{XX}$, com as formulações feitas pelos pensadores sociais clássicos. O que acabei chamando de "teoria da estruturação" é uma das formas pela qual, nos meus próprios escritos, tentei seguir este preceito. Minhas primeiras tentativas de amplificar temas assinalados em Capitalismo e teoria social moderna estavam localizadas mais na área da discussão substantiva do que em análise metodológica, e se concentravam especialmente em problemas de estrutura de classes. O livro que escrevi sobre o assunto, A estrutura de classe das sociedades avançadas [Giddens, 1973] é talvez aquele com o qual eu me 
sinta menos feliz quando olho novamente para minhas primeiras obras depois destes anos. Hoje eu ainda defenderia alguns dos principais argumentos do livro particularmente, a afirmação de que a divisão em classes é uma característica fundamental de uma ordem social capitalista - mas alteraria muitas outras partes de forma substancial. Em A estrutura de classes eu introduzi pela primeira vez o termo "estruturação", mas sem, naquela época, refletir sobre sua importância provável como um conceito geral na teoria social. O termo aparece com bastante frequência nas obras de autores franceses, mas, até onde eu sei, fora raramente usado em inglês anteriormente - o que talvez não surpreenda, porque, apesar de soar razoavelmente elegante quando usado em francês, ele não tem um tom muito atraente em inglês! Eu introduzi a noção em $A$ estrutura de classes para enfatizar a natureza complicada e variável das relações de classe em diferentes sociedades. Classes, eu pensei, eram concebidas demasiadamente como entidades ou grupos; parecia-me que uma forma mais apropriada de entender "classe" era analisando as formas pelas quais relações de classe tornavamse bases de formação de grupos. Classes, desta forma, não são nem grupos nem comunidades, mas várias características de sistemas de classes podem fornecer a base "estruturante" de afiliações de grupo.

O estudo de sistemas de classe traz à tona de forma aguda a questão da relação entre ação e estrutura. Pelo menos desde os tempos de Marx, estabeleceu-se bem que relações de classe são elementos "objetivos" - quer dizer, institucionalizados - de sistemas sociais. Por outro lado, o estudo de classes também sugere o assunto embaraçoso da natureza da consciência de classe e sua conexão a estas circunstâncias sociais "objetivas". Em A estrutura de classes, ao invés de operar simplesmente com uma noção de "consciência de classe", eu introduzi a noção de "percepção de classe" [class awareness]. Com isso, eu quis indicar que há mais no lado "subjetivo" das relações de classe do que simplesmente a questão de se as pessoas são diretamente conscientes da classe a que pertencem, ou de se elas realmente empregam terminologia de classes em suas conversas cotidianas. A percepção de classe se refere a formas de cognição que expressam divisões de classe sem para isso usar a linguagem de classe. Parecia plausível supor, por exemplo, que o "individualismo" encontrado frequentemente entre aqueles cujas posições econômicas permitiam mobilidade na carreira e avanço econômico pessoal podia ser visto como uma forma de percepção de classe. A distinção entre consciência e percepção de classe pode ser útil, ou não. Mas foi 
um fator que me levou a pensar mais sobre como poderíamos conceituar melhor os aspectos "subjetivos" das relações sociais sem identificar esta subjetividade simplesmente com conhecimento "sobre" essas relações. Em outras palavras, o conhecimento é de alguma forma incorporado em relações sociais de forma constitutiva, sem se opor à sua "objetividade" num sentido simples.

A partir daí eu comecei a levar a noção de "estruturação" a sério e tentei usá-la para preparar uma interpretação abstrata da natureza da reprodução social. Novas regras do método sociológico [Giddens, 1976] retratou de forma esquemática as bases de uma abordagem que elaborei de forma mais significativa em publicações posteriores. É claro que a teoria da estruturação é mais do que apenas uma exploração da própria ideia de “estruturação". Eu percebi que uma "ontologia da vida social" precisa fornecer um entendimento detalhado da natureza da ação, junto com aquilo que o pós-estruturalismo descreve como uma "teoria do sujeito"; e que, da mesma forma, a própria noção de "estrutura" é complicada e difícil. O debate preexistente sobre a relação entre "o indivíduo" e "a sociedade", que se sobrepunha à controvérsia entre individualistas metodológicos e seus adversários, parecia-me enganoso em seus termos de referência. De acordo com a abordagem estruturacionista, a teoria social não "começa" nem com o indivíduo nem com a sociedade, pois ambas são noções que devem ser reconstruídas através de outros conceitos. Na teoria da estruturação, a principal preocupação das ciências sociais são práticas sociais recorrentes e suas transformações.

Apesar de no título de $A$ estrutura de classes e em vários pontos de seu texto o termo "estrutura" ser usado de forma bem convencional e casual, ao formular a teoria da estruturação eu procurei dar à noção um sentido mais abstrato e técnico. A noção de que a estrutura, em seu aspecto mais elementar, deve ser vista como regras e recursos envolvidos na instanciação de sistemas sociais foi criticada extensamente. Entretanto, não vejo motivos para alterar este ponto de vista. Sistemas sociais têm propriedades estruturais, incluindo aquela "fixidez" institucional que sociólogos durkheimianos tanto amam, mas não são, enquanto tais, estruturas. "Estrutura" pressupõe continuidade de reprodução social através do tempo e do espaço, mas ela é tanto meio quanto resultado de tal reprodução. O teorema da dualidade da estrutura ocupa uma posição central na teoria da estruturação exatamente porque ele encapsula os elementos recursivos da vida social fundamentais para a organização e mudança social. No sentido em que eu utilizo o termo - para me referir à forma em que atividades sociais regularmente reconstituem 
as próprias circunstâncias que as geraram -, "recursividade" tem uma conexão tênue com o sentido matemático do termo, e fui mais influenciado por teorias de autopoiese (quer dizer, sistemas autorreprodutores) da biologia do que pelo conceito matemático.

A teoria da estruturação não pretende ser uma teoria "de" coisa nenhuma, no sentido de propor generalizações sobre a realidade social. Apesar desta ênfase ter enfurecido alguns críticos, ela é certamente necessária para qualquer tentativa de fornecer uma ontologia da atividade social no sentido apontado anteriormente. Ao se atracar com os problemas de ação e estrutura, a teoria da estruturação oferece um esquema conceitual que permite o entendimento de como os atores são os criadores dos sistemas sociais ao mesmo tempo que são criados por eles. Críticos que afirmam ou que a teoria da estruturação deixa muito pouco espaço para a ação livre ou que, por outro lado, subestima a influência da coerção estrutural (ambas estas críticas foram feitas) não entenderam o principal. A teoria da estruturação não é uma serie de generalizações sobre até que ponto a "ação livre" é possível diante da "coerção estrutural". Em vez disso, ela é uma tentativa de fornecer os meios conceituais para analisar as misturas muitas vezes delicadas e sutis entre a ação organizada reflexivamente e a coerção institucional.

Eu considero A constituição da sociedade [Giddens, 1984] como a exposição mais completa da teoria da estruturação que tentei fornecer, mas eu não penso que o livro meramente substitui meus escritos anteriores sobre o assunto. Eu vejo livros anteriores, especialmente Novas regras e Problemas centrais da teoria social [Giddens, 1979] como complementares a ele. Novas regras se concentrou, como o subtítulo do livro indica, numa dissecação crítica de sociologias interpretativas, tentando forjar uma posição que reconhece a centralidade da interpretação do significado - em vários níveis - para a análise social, mas ao mesmo tempo mostrando por que a sociologia não pode ser totalmente "interpretativa". Em Problemas centrais eu estava mais preocupado com a crítica do pensamento estruturalista e pós-estruturalista, e também em tratar de temas trazidos ao primeiro plano pelo marxismo. Apesar de eu ter sido influenciado de várias formas por todas essas tradições, eu estava particularmente interessado em justapô-las com elementos retirados da filosofia wittgensteiniana - ou de minha versão dela. $\mathrm{O}$ pensamento pós-estruturalista agora está começando a exercer uma forte influência na sociologia de língua inglesa, particularmente ao ser filtrado por debates sobre modernidade e pós-modernidade. Mas eu acredito que a obra de Wittgenstein tenha 
importância mais duradoura. Sua especificação das "diferenças" mediadas na práxis dos jogos de linguagem me parece superior àquela filtrada através de significantes ou "discurso", como entendido no pós-estruturalismo.

A teoria da estruturação deve ser algo que possa ser utilizado em trabalhos concretos das ciências sociais - mas com isto não quero dizer simplesmente "aplicada" em programas de pesquisa empírica. Ao desenvolver os pressupostos da teoria da estruturação, eu consistentemente não me esqueci de questões mais empíricas de organização e desenvolvimento social, especialmente aquelas ligadas às trajetórias de mudança de instituições modernas. Os vários volumes de Uma crítica contemporânea do materialismo histórico [Giddens, 1981; 1985], existentes e $\operatorname{projetados}^{1}$, formam a principal base de minha tentativa de lidar com estes problemas. Apesar destes estudos utilizarem alguns dos principais conceitos da teoria da estruturação (de forma frutífera, espero), a maior parte das ideias que eles propõem não depende do valor desses conceitos.

A teoria da estruturação representa um esforço para reconstruir algumas das premissas mais básicas da análise social; em minha outra obra, mais substantiva, o elemento da "desconstrução" é mais marcante. Apesar de minha ênfase principal ser a natureza da modernidade, eu me interesso, de forma geral, por questões de história e mudança social. Acho que as ciências sociais são irremediavelmente históricas. Entretanto, "história" é uma noção complexa, e não apenas por causa da distinção comum entre história enquanto eventos e enquanto recontar ou analisar esses eventos. Considerar o que é a história, em ambos esses sentidos, nos coloca face a face com a necessidade de teorizar a temporalidade, uma noção ao mesmo tempo banal e inefável. Tentei mostrar como conceitos de tempo - e espaço - poderiam ser trazidos para o núcleo da teoria social e que implicações isso poderia acarretar para o entendimento da história. Esta tentativa significa, em parte, escrever uma história da temporalidade como "lidamos" com o tempo, ou, de forma mais precisa, o espaço-tempo, em diferentes tipos de sistema social, entrando desta forma em sua constituição. Ela também significa romper drasticamente com a ideia de que a história pode ser reduzida à mudança social - como se coisas que permanecem iguais não tivessem "história". A

\footnotetext{
${ }^{1}$ Este artigo é de 1991. Como se sabe, o terceiro volume de Uma crítica contemporânea nunca foi publicado, mas uma versão altamente modificada apareceu como Para além da esquerda e da direita em 1994. (N.T.)
} 
escrita da história e dos eventos-como-história se juntam numa forma especial de engajamento temporal no qual os seres humanos entram com seu passado e futuro prospectivo: isto é a "historicidade". A historicidade entra na "história" com o próprio surgimento das formas de escrita que tornaram o registro da história possível.

Estas reflexões sobre temporalidade e história formam uma parte de minha tentativa de desconstruir alguns dos tipos dominantes de teorização sobre a mudança social. Em Uma crítica contemporânea, eu enfoquei particularmente o materialismo histórico e teorias evolucionistas nas ciências sociais. Eu argumentei que estas abordagens são não apenas empiricamente duvidosas, mas têm limitações lógicas. Elas não podem ser reconstruídas, devendo ser substituídas por uma abordagem de caráter diferente. Esta afirmação recebeu algumas pancadas de críticos, particularmente, é claro, daqueles que defendem o materialismo histórico e o evolucionismo. Entretanto, na verdade, minha desconstrução das teorias de mudança social se estende muito além destas duas tradições de pensamento.

Em minha opinião, as generalizações sobre mudança social, e sobre a "história" de forma mais ampla, são possíveis e válidas. Mas o alcance e esfera de aplicação destas generalizações são muitas vezes mais restritos do que normalmente admitimos. $\mathrm{O}$ fator da habilidade cognitiva humana, quando atrelado à historicidade, altera as condições causais sob as quais ações de outro modo comparáveis são realizadas. Mas isso não é tudo. Sempre que analisamos grandes faixas da história, é provável que nos encontremos com um agregado de "influências causais" em vez de generalizações conclusivas sobre por que as coisas "tinham que acontecer" como aconteceram. Isto não tem nada a ver com contingência histórica; e sim exprime a natureza necessariamente incompleta de explicações generalizantes nas ciências sociais. Não há padrões de causalidade universal nas ciências sociais - quer dizer, condições sob as quais a circunstância Y seguirá, e deverá seguir, a circunstância $\mathrm{X}$ - porque todas as conexões causais na vida social humana são mediadas de alguma forma pela habilidade cognitiva e razões dos atores. Ao analisar períodos históricos longos, e ao procurar dinâmicas gerais de mudança social, raramente (ou nunca) podemos ter conhecimento detalhado dos processos de raciocínio dos atores. Apesar de às vezes podermos inferir sobre eles, ou generalizar a partir destas inferências, nossas tentativas de explicar padrões gerais de mudança social provavelmente sempre permanecerão bastante fragmentárias [cf. Giddens, 1990b]. 


\section{Trabalho atual e futuro}

A modernidade é a preocupação central da sociologia. A sociologia foi estabelecida como uma tentativa de entender as enormes mudanças que, desde o século XVIII, perturbaram modos de vida tradicionais e introduziram formas bastante novas de organização social. Enquanto escrevia $A$ constituição da sociedade, eu percebi que as conexões entre sociologia e modernidade eram consideravelmente mais complicadas do que eu imaginara anteriormente. Conceitos, teorias e descobertas sociológicas não são apenas modos de analisar um domínio dado de forma independente - eles fazem parte diretamente daquilo que as instituições modernas são. Este envolvimento constitutivo com a modernidade caracteriza todas as ciências sociais, e, em parte, todas as humanidades; mas a sociologia tem uma posição peculiarmente central a este respeito por causa de seu foco analítico na vida social moderna.

O trabalho sociológico é um componente central daquilo que passei a ver como a reflexividade intrínseca da modernidade. Os seres humanos, em todas as sociedades, monitoram reflexivamente suas ações e, através delas, processos de reprodução. Entretanto, sob condições de modernidade, marcadas por uma historicidade intrusiva, a ordenação e reordenação reflexiva das condições de reprodução do sistema é mais ou menos onipresente. Em outras palavras, a modernidade é marcada pela tendência rotineira de incorporar novas informações sobre condições de ação como um meio de alterar ou reorganizar essas condições. A reflexividade da modernidade está diretamente ligada ao pensamento do Iluminismo, que, inicialmente, parecia fornecer fundamentações para o conhecimento, inclusive o conhecimento sociológico, em vez de - como acabou acontecendo - corroer a própria base do fundacionalismo. A "circularidade" do envolvimento da sociologia com a modernidade faz parte de uma circularidade mais ampla do conhecimento, baseada mais na radicalização da dúvida do que em assegurar certezas. Todas as reivindicações de conhecimento estão a princípio abertas a revisão, levando em consideração informações posteriores. Na perspectiva da modernidade, nada é sagrado, se este termo se refere a crenças ou princípios que são considerados "inquestionáveis".

Como em minha obra anterior, eu não estou particularmente interessado nos aspectos epistemológicos desta situação. Eu não acredito que eles impliquem em 
relativismo ou na ideia, às vezes associada com o pós-estruturalismo, de que todo o conhecimento, ou mesmo a "verdade", é apenas contextual. Ao contrário, em minha visão, aqueles que têm tal ponto de vista interpretaram erroneamente o que é essencialmente um conjunto de mudanças institucionais profundas (o desenvolvimento e radicalização da modernidade) como o enfraquecimento de reivindicações de conhecimento válidas como tal. Sua posição é tanto uma expressão destas transformações institucionais quanto um meio de compreendê-las adequadamente. Em meus escritos atuais, estou preocupado em relacionar o tema da reflexividade inerente da modernidade a uma análise institucional concreta da vida social moderna.

Eu ofereci um esboço de tal relato no segundo volume de Uma crítica contemporânea (O Estado-nação e a violência [Giddens, 1985]), e atualmente estou estendendo - e, espero, aprofundando - esta análise. Numa obra posterior [Giddens, 1990a], tento tratar do dinamismo extremo da modernidade - a forma pela qual ela arrancou nossas vidas das ordens tradicionais de qualquer tipo - e traçar suas implicações em vários níveis. Desenvolvendo os argumentos do capítulo final de $O$ Estado-nação e a violência, eu proponho que a modernidade é multidimensional no nível das instituições. Algumas das perspectivas sociológicas melhor estabelecidas buscam uma única ordem institucional principal ao tentar analisar a natureza das sociedades modernas. Em particular, debates sobre este assunto centram-se sobre a pergunta: as sociedades modernas são “capitalistas" ou "industriais"? Muitos autores, especialmente aqueles influenciados pelo marxismo, consideraram o capitalismo como a força motriz preeminente da história moderna. Para eles, assim como para Marx, a produção industrial deve ser entendida principalmente em termos do surgimento anterior do capitalismo, do qual ela é um adjunto. Outros autores, em contraste, insistem que o industrialismo é a força dinâmica primária alavancando o mundo moderno para longe das culturas tradicionais. Em sua visão, o capitalismo é um subtipo do industrialismo, característico de um período inicial do surgimento das ordens industriais modernas. O debate entre os dois lados traz algumas questões reais, mas, em grande parte, se baseia em premissas falsas, já que cada um tende a defender um reducionismo - ou do industrialismo ao capitalismo, ou o contrário.

De acordo com meu ponto de vista, o capitalismo e o industrialismo são duas dimensões da modernidade parcialmente independentes - dimensões, certamente, que se sobrepõem, mas que são diferenciáveis analiticamente e têm consequências divergentes. 
Com "capitalismo" eu quero dizer um sistema de produção de mercadorias, envolvendo mercados competitivos tanto para os bens quanto para a força de trabalho. Industrialismo, por outro lado, refere-se ao uso de fontes inanimadas de energia na produção, ligado ao papel central da maquinaria no processo de produção. Cada uma destas dimensões da modernidade é, por sua vez, separável do controle da informação, ou "vigilância", enquanto um meio de poder administrativo nas sociedades modernas. $\mathrm{O}$ poder administrativo que estados e outras organizações conseguem gerar não é apenas um resultado direto do capitalismo ou do industrialismo, mas depende da supervisão coordenada das populações. A vigilância, por sua vez, pode ser separada de uma quarta dimensão da modernidade, que é o controle dos meios de violência no contexto da industrialização da guerra. Um dos objetivos de $O$ Estado-nação e a violência era ajudar a enfrentar a negligência da violência militar nas tradições centrais da teoria social. Como as capacidades de vigilância, o poder militar coordenado esteve desde o começo associado com o desenvolvimento de Estados; mas no período moderno, onde os aparatos governamentais em grande parte monopolizam com sucesso o controle dos meios de violência, e onde a produção industrial é utilizada diretamente na organização militar, o poder militar assume certas qualidades muito distintivas.

A associação da modernidade com um poder militar de potencial destrutivo enorme é uma das principais razões pelas quais, como qualquer um pode ver hoje em dia, a modernidade é um fenômeno de dois gumes. O desenvolvimento das instituições modernas abriu uma vasta gama de oportunidades para a humanidade; ao mesmo tempo, a modernidade tem muitos aspectos sombrios e ameaçadores. Eu não acho que o lado escuro da modernidade tenha sido compreendido adequadamente em formas preexistentes de teoria social. Consequentemente, eu foco uma parte substancial de minha discussão nos temas de segurança e perigo no mundo moderno, usando conceitos de confiança e risco para tentar analisá-los. A noção de confiança está diretamente ligada ao conceito de distanciamento espaço-temporal que eu introduzi em obras anteriores. Uma das características chave das instituições modernas, em cada uma das quatro dimensões identificadas, é que elas "desencaixam” relações sociais de contextos de ação locais. O desencaixe significa "levantar" relações sociais de envolvimentos locais e sua recombinação através de grandes extensões de espaço-tempo. Os mecanismos de desencaixe dependem de confiança, que é definida como ter "fé" (de 
algum tipo) no funcionamento de sistemas, ou processos, que só são conhecidos de forma limitada.

O dinheiro é um exemplo de um mecanismo de desencaixe, assim como formas de conhecimento profissional e sistemas peritos de todos os tipos. A confiança em mecanismos de desencaixe é depositada não principalmente em indivíduos, mas em capacidades abstratas. Alguém que usa uma ficha monetária, por exemplo, supõe que outras pessoas - que podem estar muito distantes no tempo e no espaço - honrarão seu valor. Mas "confiamos" no dinheiro como tal em vez de apenas, ou principalmente, nas pessoas envolvidas em transações monetárias específicas.

Podemos analisar sentimentos de segurança e perigo sob condições de modernidade olhando até que ponto mecanismos de desencaixe alteram parâmetros de risco, tanto em relação a atores individuais quanto a sistemas sociais mais amplos. Podemos localizar muitas das contingências que afetam a vida cotidiana, mas que também operam numa escala global, no equilíbrio entre confiança e risco. A modernidade é inerentemente globalizante como resultado da capacidade de mecanismos de desencaixe de organizar conexões sociais através de setores indefinidos de espaço-tempo. Entretanto, as influências globalizantes da modernidade não devem ser entendidas simplesmente como a unificação crescente de uma "sociedade mundial" emergente. A intensificação de relações sociais mundiais cria laços dialéticos entre o global e o local, de modo que o que acontece em qualquer meio particular é uma expressão de formas sociais distanciadas - mas também pode frequentemente representar uma contradistinção a elas. Assim, a prosperidade de uma área na divisão internacional de trabalho pode ser a própria origem do empobrecimento de outra.

A globalização do risco é claramente um aspecto fundamental de processos de globalização em geral. O risco de guerra nuclear, ou riscos de catástrofes ambientais, afetam todos os seres humanos do mundo. Entretanto, ao mesmo tempo, estes riscos de "alta consequência" produzem muitas formas de experiência e reação locais. Todos na Terra têm de viver com o risco de guerra nuclear, mas indivíduos em contextos particulares podem decidir aceitar este risco passivamente, esperando que líderes políticos e outros peritos evitem entrar em guerras; outros podem tentar influenciar processos políticos diretamente, ou talvez participar de movimentos pacifistas. 
Assim, uma das características mais significativas da modernidade é a conexão entre vida cotidiana e eventos e conexões globais vastos. Uma teoria da vida cotidiana sob condições de modernidade pode ser desenvolvida através das noções de confiança e risco. A confiança depositada em mecanismos de desencaixe está associada a uma "desabilitação" da atividade diária: muitos aspectos de nossas vidas cotidianas são filtrados pela intrusão do conhecimento perito. Todos nós temos algum tipo de "fé" nos sistemas que nos envolvem e que entram nas partes mais íntimas de nossas vidas - os sistemas que fornecem água, geram a produção de comida, nos transportam de um lugar para outro, interpretam a saúde e a doença, e inúmeras outras coisas. Entretanto, é enganoso ver esta situação nos termos de Habermas, como "a colonização do mundo da vida por sistemas peritos". Assim como no caso dos processos "desabilitadores" no local de trabalho, há uma tensão constante entre a apropriação de conhecimento pelos peritos e outros funcionários e sua reapropriação por atores leigos nos contextos da vida cotidiana. Isto é intrínseco à própria reflexividade da modernidade. Assim, uma pessoa que contrai uma doença qualquer pode consultar um médico sobre ela, mas também pode investigar a doença sistematicamente através das descrições populares disponíveis, e pode talvez, baseado nisso, optar por sair do sistema oficial de medicina, buscando terapias alternativas, ou talvez até rejeitando totalmente praticantes especialistas. É claro que há limites para até que ponto qualquer indivíduo pode se desencaixar de todo o conjunto de sistemas peritos que permeiam a vida moderna.

Os aspectos "extensionais" e "intensionais" da modernidade se entrelaçam para afetar a natureza da identidade pessoal e do eu nas sociedades contemporâneas. Assim como é um erro falar na colonização do mundo da vida, é errado supor que o impessoal inunda o pessoal cada vez mais. O que acontece não é uma simples diminuição da vida pessoal devido à influência cada vez mais penetrante de sistemas organizados impessoalmente; em vez disso, o que ocorre é uma transformação genuína da natureza do próprio conceito de "pessoal". Relações de confiança entre indivíduos num nível pessoal não podem mais se sustentar pelos pontos de referência relativamente fixos do parentesco ou da comunidade local, como no caso da maioria dos sistemas prémodernos. A confiança se transforma em algo que tem que ser "trabalhado", e exige a abertura do indivíduo para o outro - um processo de autorrevelação mútua que também é parte do fenômeno de "se encontrar". Como outros aspectos da vida, o eu em circunstâncias de modernidade se torna um projeto reflexivo. 
A "busca pela identidade do eu" não é, como muitas vezes se sugere, simplesmente um processo defensivo através do qual a pessoa busca enfrentar as invasões de um mundo social de escala cada vez maior sobre o qual ele ou ela tem pouca ou nenhuma influência. Esta relação, mais uma vez, é dialética, na qual a realização do eu assume formas ricas e novas. Podemos viver "no" mundo da modernidade de forma muito mais integral do que jamais foi possível antes do advento dos sistemas modernos de representação, transporte e comunicação. Em muitas situações, as condições da modernidade promovem o ativismo, e não o privatismo, por causa da reflexividade inerente da modernidade, e por causa das muitas oportunidades de ação individual e organização coletiva que são oferecidas.

A "pós-modernidade", de acordo com este ponto de vista, é uma condição ainda a ser realizada: ela é um conjunto de desenvolvimentos possíveis além da modernidade, em vez de algo que exista no aqui-e-agora. Um mundo pós-moderno poderia ser um universo social mais benigno, onde certos tipos de riscos de alta consequência são minimizados ou eliminados, e o lado mais "positivo" da modernidade é desenvolvido de forma mais completa. Uma teoria crítica que trate das possibilidades iminentes da modernidade precisa reconhecer que a história não oferece garantias, e precisa equilibrar o realismo com um elemento utópico. O que precisamos é da criação de modelos daquilo que chamarei de realismo utópico - o que não é tão contraditório quanto parece. A ligação entre realismo e utopia é fundamental num mundo ameaçado por riscos de alta consequência. O pensamento utópico, sozinho, pode ser altamente perigoso - se for aplicado, digamos, à política de intimidação nuclear. Qualquer um que se preocupe com o futuro das armas precisa estar alerta às questões táticas e estratégicas envolvidas em processos potenciais de desmilitarização, e não pode apenas ser impelido por pura convicção moral. Por outro lado, se o realismo não for moderado por um componente utópico, as transições radicais que são imperativas para garantir um futuro estável e seguro não se materializarão.

$\mathrm{Eu}$ acho que o realismo utópico pressupõe dois tipos de engajamento político: um que chamo de "política de emancipação", e outro de "política da vida, ou "política da realização do eu". A política da emancipação se refere aos engajamentos políticos que tratam da liberação - com o alívio da opressão. Na política de emancipação sempre há "outros" - os ricos contra os pobres, brancos contra negros, homens contra mulheres, e por aí vai. Na esfera da política da vida não há “outros". A política da vida trata do 
desenvolvimento de uma vida satisfatória e plena para todos, no contexto de um mundo em que o local e o global estão continuamente envolvidos um com o outro. Questões como a relação apropriada dos seres humanos com a natureza, o legado de atos presentes para gerações futuras, o controle sobre o corpo e suas capacidades reprodutivas, e a estética do ambiente construído - tudo isso faz parte da política da vida.

No terceiro volume de Uma crítica contemporânea, ainda incompleto, eu examino alguns destes assuntos em mais detalhes e os ligo a debates atuais sobre o futuro do capitalismo e do socialismo. O capitalismo é parte da modernidade, e um de seus grandes propulsores dinâmicos; mas ele existe em conjunção com os outros complexos institucionais mencionados anteriormente. Mesmo se o socialismo fosse em algum sentido o "futuro" do capitalismo, sua influência se estenderia apenas a certos aspectos de uma ordem pós-moderna. Assim, apesar de no terceiro volume eu discutir dilemas atuais do socialismo, o estudo como um todo está mais preocupado em analisar os contornos gerais de um sistema pós-moderno. A diferenciação entre política de emancipação e da vida é elaborada de forma detalhada, e a obra dedica bastante atenção ao problema do eu e da realização do eu. Eu examino os temas da segurança ontológica e da ansiedade existencial, que introduzi bem no começo de meus escritos mas que até agora não consegui tratar de forma satisfatória. Se as pessoas ainda não estiverem entediadas demais com este empreendimento duradouro, eu gostaria de produzir um quarto volume de Uma crítica contemporânea, concentrado sobre a natureza da teoria crítica, particularmente a crítica da ideologia. Eu gostaria também de propor em algum momento escrever um livro sobre religião. O princípio de que "nada é sagrado" inclusive esse mesmo princípio - continuamente cria fricções. Uma fonte de tais fricções, ainda que certamente não a única, é a persistência ou redescoberta de atitudes de religiosidade. Eu gostaria de produzir uma interpretação teórica da religião que tomasse esta situação como ponto de partida ${ }^{2}$.

\footnotetext{
${ }^{2}$ Nem o quarto volume de Uma crítica contemporânea, nem esta obra sobre religião, apareceram até hoje. (N.T.)
} 


\section{Os usos da teoria da estruturação}

No capítulo final de $A$ constituição da sociedade, eu expus algumas das conexões que consigo enxergar entre a teoria da estruturação e a pesquisa social. Meu objetivo era explorar a relevância empírica de alguns dos conceitos discutidos no livro em relação a projetos de pesquisa de vários tipos. Alguns comentadores consideraram esta abordagem inadequada. O que eu deveria ter feito, de acordo com eles, era mostrar como a teoria da estruturação gera seus próprios projetos de pesquisa distintos. Entretanto, apesar da teoria da estruturação tocar a conduta da pesquisa social em muitos pontos, ela não é um programa de pesquisa. Como eu já afirmei várias vezes anteriormente, seus conceitos devem ser encarados como dispositivos sensibilizadores, para serem usados de forma seletiva ao pensarmos sobre perguntas de pesquisa ou na interpretação de achados. Eles não fornecem um programa de pesquisa distinto como, por exemplo, a etnometodologia de Garfinkel, nem identificam uma "fatia" definida da vida social para ser estudada, como a "ordem de interação" de Erving Goffman.

A teoria da estruturação, e conceitos ou ideias introduzidos em outras partes de meus escritos, foram usados em uma grande variedade de contextos de pesquisa. De modo geral, eu gosto menos daquelas obras em que autores tentaram importar a teoria da estruturação in toto para sua área de estudos. Eu espero que o esquema geral da teoria da estruturação seja relevante para qualquer um que escreva sobre questões muito amplas de organização e transformação social, como eu mesmo tendo a fazer. Em muitas outras áreas mais confinadas de pesquisa social, não é especialmente útil arrastar um grande aparato de conceitos abstratos. Eu gosto mais dos usos em que conceitos, ou do esquema lógico da teoria da estruturação ou de outros aspectos de meus escritos, são usados de forma esparsa e crítica. Há agora muitos desses exemplos na literatura, mas permitam-me mencionar alguns que gostaria de endossar em particular.

Um é o estudo de Patrick Burman sobre desemprego [Burman, 1988]. A pesquisa foi desenvolvida numa área do Canadá nos anos 1982-3, num período em que as taxas de desemprego estavam muito altas. A maioria dos trabalhos anteriores sobre desemprego, de acordo com Burman, assumem o que ele chamou de uma "vista aérea" do fenômeno. Isto quer dizer, eles pesquisam o assunto em termos de estudos de larga escala de agregados de pessoas. Os desempregados, por assim dizer, são vistos à distância, e reduzidos, nas palavras de Burman, "a um complexo de funções e atributos 
num sistema socioeconômico" [Burman, 1988:4]. O indivíduo desempregado não aparece, nessas pesquisas, como um ator com habilidade cognitiva que passa pelas várias experiências envolvidas em se tornar desempregado. Isto é um tipo de "descentramento do sujeito", diz Burman, apesar de obviamente não no sentido comum em que este termo é entendido na teoria pós-estruturalista. Este "descentramento" não está confinado ao nível analítico: muitos dos indivíduos entrevistados no estudo de Burman afirmaram que perder o emprego corroeu seu próprio sentido de ação. Como um deles mencionou, "eu sinto que não tenho mais uma vida... eu sou um participante num roteiro que alguma outra pessoa assumiu" [Burman, 1988:5]. Mas poucos dos indivíduos envolvidos no estudo recaíram num estado de anuência anestesiada; quase todos fizeram tentativas de "recentrar" suas vidas, reordenando ativamente suas relações sociais e condições materiais de vida.

Burman utiliza a noção de dualidade da estrutura para preparar e interpretar os resultados de sua pesquisa. As unidades-chave de análise são práticas sociais recorrentes, e Burman tenta analisar como a mobilização ativa de tipos particulares de prática é influenciada por sistemas maiores ao mesmo tempo em que remodela ordens institucionais maiores. Particularmente, Burman mostra como atividades no que ele chama de "esfera microssocial" (indivíduos, famílias e grupos, amigos) se cruzam com aquelas realizadas na "esfera de comunidade intermediária" (organizações de desemprego, sindicatos locais, empresas locais e redes sociais) e na "esfera macrossocial" das organizações maiores, incluindo burocracias estatais.

Burman devota atenção considerável à organização temporal da vida cotidiana, mostrando que o desemprego altera tanto a experiência do tempo quanto os modos pelos quais a conjunção temporal de práticas sociais é organizada. Para uma pessoa que trabalha ou estuda em tempo integral, os períodos do dia são organizados de forma bastante fixa, assim como a organização temporal das semanas, meses e anos. A perspectiva e situação temporal da pessoa desempregada é bastante diferente, envolvendo grandes acres de "tempo incipiente", separado das práticas regulares que ocupam os empregados. Enquanto algumas pessoas responderam de forma bastante intensa ao serem confrontadas com grandes faixas de "tempo mal estruturado", fazendo cursos, trabalho voluntário, ocupando-se com hobbies diversos e trabalho doméstico, outros muitas vezes "não faziam nada". "Não fazer nada", obviamente, também é uma forma de gerenciamento do tempo, e na verdade sempre envolve fazer alguma coisa: 
como dormir, assistir TV ou sentar num parque em períodos regulares. É difícil dizer qual teria sido a diferença no trabalho de Burman se ele não tivesse sido influenciado pela teoria da estruturação. Entretanto, ele leva muito a sério as conexões sutis entre modos de reprodução e transformação e as atividades situadas de indivíduos e grupos.

Como um segundo exemplo, apresentarei Gênero e poder, de R. W. Connell [1987]. O livro é uma contribuição muito importante para o entendimento das relações de gênero, e utiliza várias tradições teóricas além da teoria da estruturação. Connell critica minha abordagem e a utiliza apenas em alguns pontos de seu argumento. Mas estes me parecem fundamentais para as reivindicações gerais do trabalho e resultam num ponto de vista que considero persuasivo. Connell afirma que uma interpretação adequada do gênero depende de uma descrição sofisticada da relação entre ação e estrutura. Precisamos compreender, nas palavras de Connell, a "presença ativa da estrutura e da prática, e a constituição ativa da estrutura pela prática" [Connell, 1987:94]. Ela critica minhas formulações particulares, mas desenvolve esta perspectiva de forma notável. Tipos diferentes do que Connell chama de "regimes de gênero" são identificados em vários contextos estruturados de ação. Considerem, por exemplo, a divisão sexual do trabalho. Em qualquer ambiente de trabalho, a divisão de trabalho entre os sexos estabelece coerções estruturais quanto a qualquer realização possível de um indivíduo. Assim, mercados de trabalho segregados estabelecem restrições sobre promoções no emprego através da influência de habilidades diferenciadas e outros fatores. A discriminação institucionalizada tende a ser perpetuada como resultado de escolhas "racionais" na alocação de trabalho feitas por empregadores em tais circunstâncias. A interseção do trabalho remunerado com a esfera doméstica, com a expectativa de que as mulheres assumam a maior parte do trabalho de casa e da educação de crianças, também influencia as desigualdades de gênero. Estes fatores não operam apenas "externamente", mas são incorporados nas várias práticas desempenhadas no trabalho remunerado e no lar. A divisão sexual do trabalho não deve ser vista como uma estrutura por si só, mas parte de um "sistema sexuado de produção, consumo e distribuição”. Connell sugere que o gênero não é uma propriedade de pessoas individuais, mas um fenômeno intrínseco à organização de tipos definidos de práticas sociais. Assim, ele não é uma dicotomia dominante, mas uma série de oposições em cujos termos formas de crenças e relações sociais são organizadas. 
Estas ênfases permitem que Connell desenvolva uma discussão sutil de ideologias sexuais, entre outros assuntos. Não é o bastante, ela afirma, analisar a ideologia apenas em termos de "discursos" tratados como sistemas fechados; modos sintáticos e simbólicos de exprimir diferenciais de poder estão profundamente implicados em atividades práticas cotidianas, muitas vezes do tipo mais mundano. Todos esses elementos entram na discussão de Connell sobre como a "masculinidade hegemônica" é reproduzida. "Masculinidade" e "feminilidade" não são simplesmente conceitos dados, em vez disso, são reconstituídos e reformados repetidamente no contexto de diferenciais de poder. A relação "econômica" entre empregador e secretária, por exemplo - dado o desequilíbrio sexual no preenchimento dessas posições reproduz diferenciações de gênero através do próprio poder desigual que ela incorpora. A masculinidade hegemônica, na análise de Connell, é muito diferente de descrições estabelecidas anteriormente de "papéis" masculinos e femininos. As ideias ou ideais que reproduzem imagens da masculinidade não se conformam necessariamente às personalidades ou ações reais da maioria dos homens. Imagens midiáticas da masculinidade, por exemplo, muitas vezes envolvem figuras de fantasia distantes da vida cotidiana, como personagens de filmes, mas que ainda assim mantêm uma aura que influencia contextos de ação ordinários. Apesar de não haver uma feminilidade que corresponda à masculinidade hegemônica, identidades femininas frequentemente têm uma forma muito pública - Connell chama isto de "feminilidade enfatizada", como se vê em inúmeros programas de mídia, artigos e anúncios publicitários:

"Práticas que impedem que outros modelos de feminilidade ganhem articulação cultural são centrais para a manutenção da feminilidade enfatizada (...) o que se esconde é a experiência de solteironas, lésbicas, sindicalistas, prostitutas, loucas, tias rebeldes e virgens, trabalhadoras manuais, parteiras e bruxas. E o que está envolvido na política sexual radical, em uma de suas dimensões, é precisamente a afirmação e recuperação de formas marginalizadas de feminilidade na experiência de grupos como esses" [Connell, 1987:188]

Como uma terceira ilustração, apresentarei um estudo bastante diferente dos anteriores: a discussão recente de Christopher Dandeker sobre vigilância, poder burocrático e guerra [Dandeker, 1989]. O livro de Dandeker utiliza noções de meus escritos mais substantivos, em vez daquelas que concernem a teoria da estruturação enquanto tal. Seu livro desenvolve essas noções de forma a fornecer uma descrição nova 
da natureza do poder administrativo nas sociedades modernas. A noção de vigilância, é claro, vem primariamente de Foucault, mas Dandeker adota minha versão da noção e a liga à designação institucional da modernidade em quatro eixos que eu mencionei anteriormente. Seu livro discute os modos em que várias grandes tradições da teoria social lidaram com a questão da vigilância, e tenta especificar as condições sob as quais as capacidades de vigilância de formas diferentes de organização são ou desenvolvidas ou inibidas. Baseado nisto, Dandeker consegue jogar uma nova luz sobre debates longevos das características da burocracia nas sociedades modernas.

Eu não tenho espaço aqui para representar os argumentos de Dandeker de forma detalhada. Ele tem muito de interessante a dizer sobre o desenvolvimento do Estadonação moderno, sua conexão com a atividade capitalista, e a relação de ambos com o poder militar. As forças armadas, ele afirma, constituíram o ramo mais importante e desenvolvido do Estado moderno nascente em termos de complexidade organizacional, nível de gastos estatais e número de indivíduos envolvidos. A burocratização das forças armadas fornece um estudo de caso vital da expansão do poder burocrático ao mesmo tempo que oferece lições para a interpretação mais amplas de mecanismos burocráticos em outros lugares. Desenvolvendo um tema discutido em $O$ Estado-nação e a violência, Dandeker mostra como a burocratização das forças armadas foi acompanhada por um declínio em seu papel enquanto meio de sustentar a ordem política interna. Mecanismos de vigilância que produziram a ascensão do policiamento e as origens do "desvio" definido legalmente formam a contraparte das "máquinas militares" que se confrontam no sistema de Estados-nação.

Uma contribuição importante do livro de Dandeker é que ele documenta detalhadamente o argumento de que o Estado moderno envolve não apenas um isolamento do poder político e econômico, mas uma separação de ambos da organização militar. Em relação à esfera econômica, as capacidades de vigilância crescentes dos empreendimentos comerciais modernos formam um elemento fundamental da independência relativa das atividades econômicas quanto à supervisão estatal direta nos sistemas capitalistas. Dandeker mostra que as capacidades de vigilância da organização comercial moderna não são apenas um meio de consolidar o controle de empregadores ou gerentes sobre os empregados, mas um meio de coordenar operações de mercado e monitorar relações com outras organizações. 
Em geral, diz Dandeker, quando consideramos o papel da vigilância em sistemas burocráticos precisamos diferenciar vários dos principais processos envolvidos. Há, como Weber afirmou, uma mudança de relações pessoais de patrão-empregado para o controle impessoal baseado em regulamentações formais-legais, que são usadas para exercer e legitimar o governo. Entretanto, tal mudança precisa ser distinguida conceitualmente de mudanças na natureza do poder e disciplina de supervisão. Isto não é marcado por uma transição linear do pessoal para o impessoal, mas por novas estratégias de afiliação pessoal como meios de exercer a autoridade, como no pensamento de "relações humanas" da administração "de estilo japonês". Estes dois processos, por sua vez, são separáveis do desenvolvimento de sistemas de coleta, armazenamento e processamento de informação usada para propósitos de vigilância. Os "arquivos" organizacionais não são apenas registros recuperáveis, mas fazem parte de forma constitutiva do modo de operação da organização. Finalmente, precisamos reconhecer a importância parcialmente independente da perícia que indivíduos possuem em diferentes níveis nas organizações. Dandeker afirma que a perícia (e eu concordo com isto) é ela mesma uma forma de vigilância, na qual o acesso a conhecimento especializado forma um elemento central de sistemas de poder em sociedades modernas - ainda que, como em todos os outros aspectos da vigilância, muitos tipos de contestação de diferenciais de poder sejam encontrados.

Eu não gostaria de endossar todos os argumentos feitos pelos autores nos três estudos mencionados, mas todos são contribuições válidas para a literatura preexistente. Eles não exaurem de forma alguma aquelas tentativas que eu considero interessantes e válidas de utilizar minhas ideias. Estudos de interesse e apelo comparáveis influenciados pela minha perspectiva podem ser encontrados, por exemplo, em estudos de mídia, análise urbana, comunicações, sistemas educacionais e relações internacionais, entre outros. Todos estes são campos sobre os quais eu tenho um interesse pessoal direto e para os quais eu já tentei contribuir, ou gostaria de fazê-lo no futuro.

\section{Sociologia: estado atual e perspectivas futuras}

Considerada como uma disciplina acadêmica, a sociologia sem dúvida passou por um período difícil nos últimos quinze anos, tanto na Grã-Bretanha quanto 
internacionalmente. Em termos de número de estudantes, a sociologia hoje tem um apelo limitado comparado com o entusiasmo que ela já gerou, apesar de termos sinais de que o pêndulo está voltando. Será que este período também representou um declínio intelectual neste assunto? Muitos provavelmente enxergam as coisas dessa forma. Nos anos 1960, os pensadores sociológicos pareciam estar na vanguarda dos debates públicos e (para alterar levemente a metáfora) na ponta de novos desenvolvimentos intelectuais. Num exame superficial, isto parece menos verdadeiro no período mais recente. Onde estão as figuras comparáveis a Parsons, Merton, Mills ou Bell em seu ápice? A posição de superioridade intelectual hoje parece estar ocupada por pensadores da filosofia, teoria cultural ou história, como Habermas, Foucault ou Derrida.

A suposta diminuição intelectual da sociologia, entretanto, é mais aparente que real. Em parte, ela expressa um momento que se distancia de um período em que a sociologia norte-americana era completamente dominante internacionalmente, em direção a um período em que influências europeias se reafirmaram - como é indicado pelo fato de que todos os pensadores mencionados no segundo grupo são europeus. Outros fatores também são importantes. Ideias e métodos de pesquisa desbravados pela sociologia se tornaram extremamente influentes em disciplinas vizinhas das ciências sociais: por exemplo, a história, ciência política e geografia humana mudaram de forma bastante pronunciada nos últimos anos como resultado da incorporação de perspectivas sociológicas. Estas ideias e métodos são assim menos proeminentes enquanto distintivamente "sociológicos" mas pela mesma moeda influenciaram profundamente as ciências sociais concebidas de forma mais ampla. E, o que talvez seja o mais importante, durante este período nosso entendimento da natureza da sociologia foi alterado consideravelmente. $\mathrm{O}$ funcionalismo e $\mathrm{o}$ naturalismo praticamente desapareceram como resultado de desenvolvimentos teóricos e metodológicos. Em algum ponto deste processo, podia parecer que a sociologia estava prestes a se quebrar, pelo menos enquanto disciplina com um grau razoável de integração teórica geral. Vários pontos de vista teóricos em conflito apareceram, cujos proponentes pareciam ser incapazes de escutar uns aos outros e tratar de assuntos e problemas comuns. Entretanto, esta acabou sendo algo como uma fase de transição. Sem dúvida, sempre haverá uma diversidade teórica considerável na sociologia, como no resto das ciências sociais; mas novas sínteses emergiram, diferentes dos panoramas dominantes de vinte anos atrás. Eu espero que meus esforços para desenvolver a teoria da estruturação tenham feito uma 
contribuição para estes empreendimentos sintetizadores, quaisquer que sejam as falhas de meus conceitos e formulações.

Uma reação às circunstâncias difíceis da sociologia nos últimos anos tem sido a concentração em áreas limitadas de trabalho empírico, especialmente aquelas relevantes a questões de políticas sociais. Muitos sociólogos frequentemente optaram por investigações tecnicamente sofisticadas e incisivas que dão ao assunto um ar de cientificidade. Eu não acho que esta perspectiva seja de bom agouro para o futuro da sociologia se a disciplina quiser manter um lugar central na vida intelectual contemporânea. A pesquisa "dura" é importante, mas as reivindicações intelectuais da sociologia não estão baseadas distintivamente sobre ela. Toda pesquisa social, no meu ponto de vista, não importa o quão matemática ou quantitativa, pressupõe a etnografia. Aqueles que podem ser vistos como estilos de pesquisa "mole" são na verdade integrais para todos os tipos de atividade de pesquisa. Além do mais, muito da importância da sociologia se baseia na reflexão teórica. Com isto não estou falando apenas da afirmação convencional de que a pesquisa "precisa" da teoria. A reflexão teórica na sociologia tem um estatuto distintivo por causa da natureza constitutiva do conhecimento social, e acontece nas fronteiras entre o que "é" e o que "pode ser" na vida social. Sociólogos profissionais não têm nenhum monopólio sobre tal reflexão, mas eles devem estar numa posição capaz de influenciá-la de formas fundamentais.

Como resultado desta relação reflexiva, a sociologia tem ligações íntimas com movimentos sociais: não apenas com movimentos "progressivos", mas também outros. Os movimentos sociais têm seu próprio engajamento reflexivo com as organizações que eles enfrentam e as instituições que eles buscam alterar. Por definição, os movimentos sociais não consideram que o mundo social seja imutável, e se colocam contra a ordem existente das coisas. O estudo dos movimentos sociais, enquanto tal, é um assunto da sociologia. Mas os movimentos sociais têm uma relação dupla com a análise sociológica porque eles muitas vezes também identificam características previamente não diagnosticadas de uma ordem social - ou possibilidades iminentes dentro dela. Vários dos movimentos sociais "progressistas" mais influentes hoje em dia enfocam exatamente assuntos que os sociólogos analisam de forma relativamente fraca. Um exemplo evidente, em relação ao que eu mencionei anteriormente, é o movimento pacifista. Movimentos pacifistas nos forçaram a ver que a questão de controlar os meios da violência não pode ser resolvida simplesmente em termos de discussões tradicionais 
de capitalismo e socialismo. O movimento feminista levou os sociólogos - e também vários outros em muitas outras disciplinas - a começar a repensar algumas de suas concepções mais básicas. Movimentos verdes trouxeram para o primeiro plano assuntos que até então haviam sido entendidos precariamente pela sociologia. Algo similar também ocorre em muitos outros movimentos "reacionários". A revitalização religiosa, e movimentos fundamentalistas, por exemplo, em sua reação contra a modernidade têm algo a ensinar sobre os limites da modernidade e a natureza da religiosidade. Movimentos "pró-vida" forçam a entrada de questões sobre o controle social do corpo na agenda sociológica e política.

Os desafios que a sociologia enfrenta no final do século XX refletem os assuntos que os novos movimentos sociais trouxeram para o primeiro plano, e outros mais. A lista é formidável. No nível extensional, processos cada vez mais rápidos de globalização exigem análise direta e ameaçam varrer a preocupação tradicional dos sociólogos com o estudo das "sociedades". Talvez o mundo seja, em algum sentido, uma única sociedade, mas, se isto for o caso, quais são suas principais características institucionais e quais são as principais dinâmicas que o transformam? Uma perspectiva global deve se tornar cada vez mais central para o trabalho sociológico, com todas as complexidades e dificuldades que isto implica. No nível intensional, estão ocorrendo transmutações nas relações de gênero, vida pessoal e nas condições da atividade social cotidiana. Como devemos tentar interpretar estas mudanças num mundo em que a distância e a proximidade se combinam de forma cada vez mais emaranhada? No nível dos sistemas políticos, influências em mutação na soberania nacional de países ocidentais estão alterando as condições de envolvimento democrático, enquanto que no leste europeu e em outras regiões, está ocorrendo uma reorganização política e econômica de grandes proporções. Podemos ver, nestes eventos, sinais de um mundo além do capitalismo e do socialismo? Ainda não podemos ter certeza.

No meio de tudo isto, desigualdades pronunciadas de riqueza e poder persistem entre indivíduos, coletividades e comunidades nacionais. As tensões que elas produzem provavelmente não serão contidas facilmente. É muito difícil avaliar até que ponto o conjunto de riscos de alta consequência que todos nós enfrentamos hoje poderá ser resolvido. A sociologia tem um papel chave a desempenhar na exploração dos contornos deste meio global, o mundo da alta modernidade. Somos nós que devemos 
garantir que a imaginação sociológica não seja insuficiente em um período tão complexo e perturbador do desenvolvimento social humano.

\section{Bibliografia}

BURMAN, P. [1988] Killing Time, Losing Ground. Toronto: Wall \& Thompson.

CONNELL, R. W. [1987] Gender and Power. Cambridge: Polity.

DANDECKER, C. [1989] Surveillance, Power and Modernity. Cambridge: Polity.

GIDDENS, A. [1971] Capitalism and Modern Social Theory. Cambridge: Cambridge University Press.

GIDDENS, A. [1973] The Class Structure of the Advanced Societies. London: Hutchinson.

GIDDENS, A. [1976] New Rules of Sociological Method. London: Hutchinson.

GIDDENS, A. [1979] Central Problems in Social Theory. Berkeley: University of California Press.

GIDDENS, A. [1981] A Contemporary Critique of Historical Materialism. London, Macmillan.

GIDDENS, A. [1984] The Constitution of Society. Berkeley: University of California Press.

GIDDENS, A. [1985] The Nation-State and Violence. Berkeley: University of California Press.

GIDDENS, A. [1990a] The Consequences of Modernity. Stanford: Stanford University Press.

GIDDENS, A. [1990b] "Structuration Theory and Sociological Analysis", in Clark, Jon, Modgil, Celia \& Modgil, Sohan (eds.) Anthony Giddens: Consensus and Controversy. London: Falmer Press, pp. 297-315.

PARSONS, T. [1937] The Structure of Social Action. Glencoe: The Free Press. 


\section{Christopher G. A. Bryant - Sociologia sem filosofia? O caso da teoria da estruturação de Giddens}

A relação entre sociologia e filosofia tem sido contestada há muito tempo por sociólogos e filósofos. Eu quero argumentar que a sociologia pode operar sem filósofos, mas não sem a filosofia. A sociologia inevitavelmente suscita questões de ontologia, epistemologia e teoria normativa. Ou os sociólogos precisam se basear, implícita ou explicitamente, em posições articuladas por filósofos, ou eles precisam enfrentar as questões sozinhos e chegar a algo melhor. Eu ilustrarei meu argumento considerando o desenvolvimento da teoria da estruturação de Anthony Giddens. David Jary e eu deixamos claro, em outro texto, que acreditamos que as realizações de Giddens são bastante consideráveis [Bryant \& Jary, 1991b]. Entretanto, tendo em vista suas opiniões gerais sobre a filosofia, é irônico que duas deficiências importantes na teoria da estruturação, em sua formulação atual, surjam da falta de preocupação de Giddens em articular e justificar suas próprias posições filosóficas; uma se refere à epistemologia, a outra à antropologia filosófica e filosofia política. Depois de considerar a questão geral da relação entre sociologia e filosofia, eu examinarei cada uma delas. Eu também sugerirei que Giddens não pode se dar ao luxo de ignorá-las, porque sua omissão prejudica a recepção mais ampla da teoria da estruturação.

\section{Sociologia e filosofia}

Num ensaio brilhantemente resoluto, Kilminster [1989] argumentou que os filósofos, por causa de seu estabelecimento mais antigo na academia e sua posição quase sempre superior, foram em grande parte bem-sucedidos na imposição de sua definição da relação entre sociologia e filosofia para a academia em geral, e para os sociólogos em particular. A figura 1 lista as "estipulações dos filósofos dos campos disciplinares" de Kilminster. Ele afirma que aquilo que as diferentes escolas de filosofia fazem é admitir o interesse da sociologia no empírico enquanto mantêm para si mesmas a competência sobre o transcendental, o universal, o conceitual e o moral. Na verdade, ele continua, os filósofos precisam tentar impor uma tal distinção; senão, tendo em vista sua própria não-competência em assuntos empíricos, eles não teriam o que fazer. Kilminster se opõe fortemente a esta 
jogada porque ela se baseia numa reivindicação insustentável da autonomia da filosofia, e ele critica os sociólogos que acredita terem aceitado essa reivindicação - incluindo Giddens (ele não discute filósofos, como Rorty, que a rejeitam: ver Rorty [1982]).
Sociologia
Filosofia

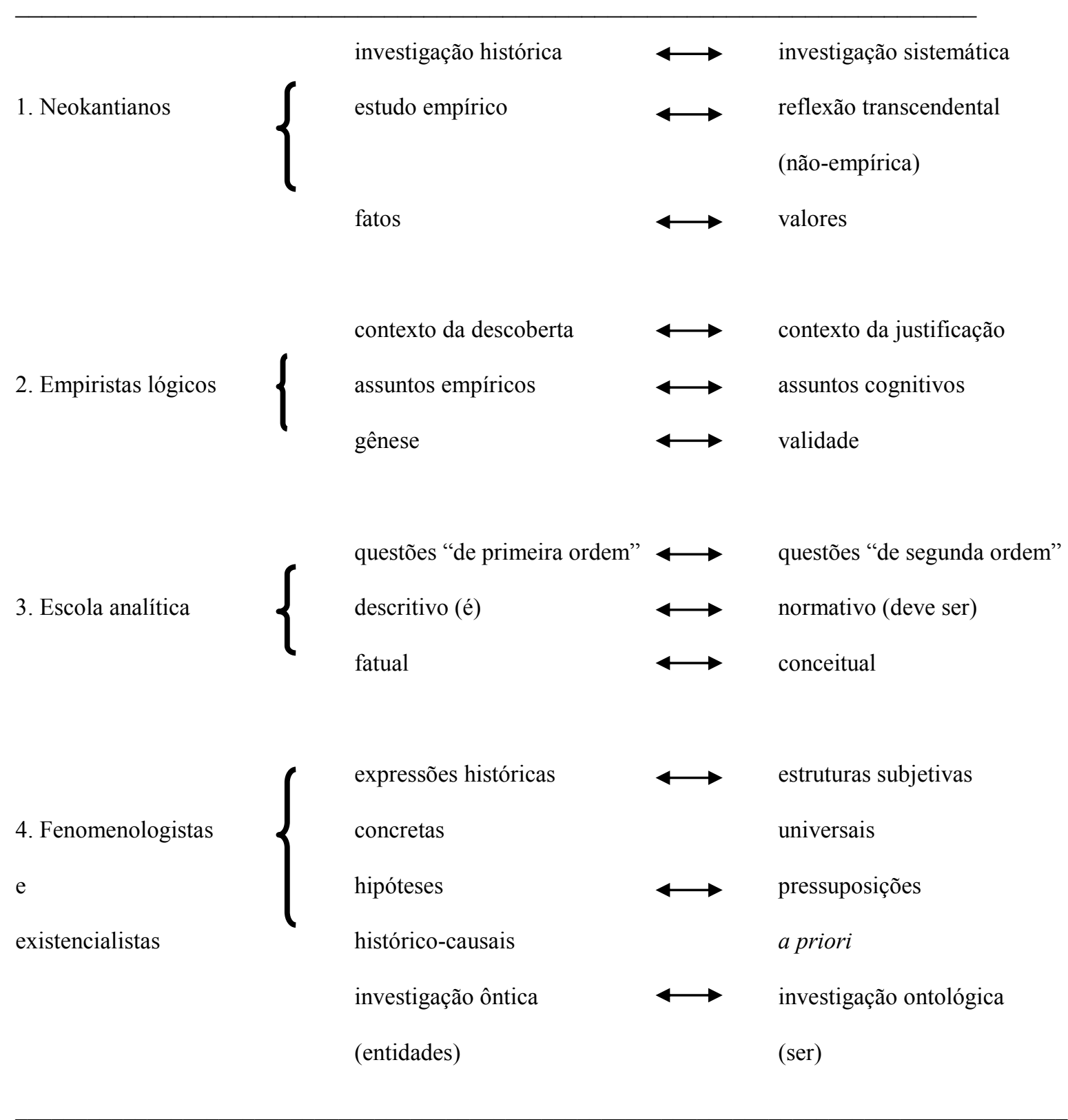

Figura 1. As estipulações dos filósofos dos campos disciplinares

Fonte: Kilminster [1989:299]

Giddens assume uma posição similar. Ele cuidou de seu próprio trabalho, incluindo o desenvolvimento da teoria da estruturação, utilizando e discutindo qualquer autor em qualquer disciplina que ele considere útil. A teoria da estruturação, de acordo com Giddens, é uma versão da teoria social, e enquanto tal ela "abrange assuntos" que são da preocupação 
comum de todas as ciências sociais e que "transbordam para a filosofia" [Giddens, 1984:xvi-xvii]. Como consequência, "as ciências sociais estão perdidas se não forem relacionadas diretamente a problemas filosóficos por aqueles que as praticam" [Giddens, 1984:xvii]. Mas isto não significa que as ciências sociais são "inerentemente especulativas, e não empíricas" [ibid.]. Pelo contrário,

"A teoria social tem a tarefa de fornecer concepções da natureza da atividade social humana e do ator humano que podem ser colocadas a serviço do trabalho empírico. A principal preocupação da teoria social é a mesma das ciências sociais em geral: a iluminação de processos concretos de vida social" [ibid.].

Eu não tenho nada contra a posição básica de Giddens quanto às ciências sociais e a filosofia. Minha reclamação é a ironia de que a própria teoria da estruturação se arrisca a perder seu rumo como consequência de sua separação de duas atividades filosóficas. Giddens planeja desenvolver uma ontologia do social 1) sem participar de debates epistemológicos (pelo menos desde 1977) e 2) sem articular e justificar uma teoria normativa (seja uma antropologia filosófica, ou uma filosofia política).

A primeira omissão é surpreendente. A ontologia é normalmente associada com a epistemologia - o que existe para conhecermos com como podemos conhecê-lo - mas Giddens decidiu há muito tempo não entrar em debates epistemológicos. $\mathrm{O}$ exemplo mais recente disto é encontrado no volume de Clark, Modgil e Modgil, Anthony Giddens: consenso e controvérsia [1990]. Lá, Hekman [1990] acusa Giddens de não oferecer uma epistemologia viável. Em seu ensaio final, tudo que ele diz como resposta é "Eu não estou particularmente interessado na epistemologia, e sim na ontologia da vida social" [Giddens, 1990b:300]. Se esta primeira omissão importa ou não depende de se os filósofos, ou outros cientistas sociais, acabarão fazendo o trabalho epistemológico que a ontologia de Giddens requer.

A segunda omissão é menos surpreendente já que muitos, talvez a maioria dos cientistas sociais, passam longe da antropologia filosófica e da filosofia política. Entretanto, ela está ligada à primeira, e também é mais séria, tendo em vista que a comunidade de investigadores pós-empiristas, com quem Giddens se identifica, pode considerar uma virtude os fatores políticos e éticos que baseiam a ciência social, mas ela ainda não tem nenhum meio estabelecido para avaliar valores diferentes e rivais; e mesmo se tivesse, ela não poderia inventar a posição de Giddens para ele. Em outras palavras, a princípio (mas 
talvez não na prática) Giddens pode deixar que outros resolvam sua primeira omissão, mas ele não tem base para esperar que outros solucionem sua segunda.

\section{Giddens, epistemologia e ciência social}

Halsey escreveu recentemente que "a maioria dos teóricos consegue pelo menos concordar que a pesquisa empírica na sociologia pode proceder sem esperar um acordo epistemológico" [Halsey, 1989:354]. A alternativa, afinal, ainda é a suspensão da pesquisa social por tempo indeterminado. Esta também é a posição de Giddens: "Eu acho que é errado inclinar a teoria geral de forma inequívoca demais na direção de questões de epistemologia abstratas e altamente generalizadas, como se qualquer desenvolvimento importante na ciência social tivesse que esperá-las" [Giddens, 1984:xviii]. Entretanto, as aparências enganam. Sem nenhum aviso, Giddens muda de uma posição sólida (a pesquisa empírica não pode esperar a solução definitiva de questões na epistemologia) para uma frágil (a elaboração de uma ontologia do social é separável do debate epistemológico). Esta posição é frágil porque ela evita questões que qualquer um preocupado com o estatuto da teoria da estruturação acabará fazendo. Como sabemos que a humanidade e o mundo social são como a teoria da estruturação diz que eles são? O que faz da teoria da estruturação mais do que apenas um entre vários esquemas que podemos escolher ao nosso bel-prazer? E por que a hermenêutica dupla vale apenas para relações entre discursos leigos e dos cientistas sociais, e não a relações entre discursos leigos e de outros especialistas? Por que os membros leigos devem tratar aquilo que os sociólogos dizem, mesmo quando de acordo com os princípios da teoria da estruturação, como mais válido do que aquilo que jornalistas, políticos, profetas, poetas ou outros cidadãos dizem?

Uma resposta seria que as reivindicações de conhecimento da ciência social têm um estatuto diferente de outras reivindicações de conhecimento, e que os membros leigos podem ser persuadidos a respeitar essa posição. Em sua recusa persistente a desautorizar a ciência social, Giddens confirma que acredita nisto, mas ele tem muita relutância para especificar o que baseia estas reivindicações. O máximo que ele diz é "a sociologia é uma disciplina científica no sentido em que ela envolve métodos sistemáticos de investigação, análise de dados e avaliação de teorias com base em evidências e argumentos lógicos" [1989b:21-22]. Ele, assim, se fecha a uma das apostas mais comuns dos ontologistas, que é afirmar que o mundo deve ser como se diz que é se quisermos ter o conhecimento dele que temos; esta aposta depende de uma justificativa anterior de alguma reivindicação de 
conhecimento (baseada em experimentação, predição, aplicação tecnológica, vindicação na prática, e assim por diante). Outra resposta trataria dos méritos dos argumentos a favor da antropologia filosófica quase toda implícita que baseia a teoria da estruturação, e fornece a ela seu potencial crítico (no momento ainda subdesenvolvido); entretanto, aqui também Giddens tende a evitar argumentos sistemáticos.

Numa entrevista publicada em Theory, Culture \& Society em 1982, perguntou-se a Giddens como ele basearia o tipo de ciência social crítica que ele buscava [Bleicher \& Featherstone, 1982:72]. Ele respondeu que não sabia, mas adicionou que é preciso dirigir entre duas estratégias irrealizáveis: a primeira é buscar uma epistemologia segura ou uma teoria normativa segura a partir da qual sair para estudar o mundo; a outra é rejeitar a epistemologia e a teoria normativa coerente em favor de alguma teoria sociológica muito forte de como o mundo é (como a tese forte da sociologia da ciência de Barnes [1974] ou, ele poderia adicionar, a sociologização da filosofia de Kilminster). Em vez disso, ele recomenda um caminho intermediário: "Eu quero seguir a estratégia de (...) disparar salvas críticas na realidade" [Bleicher \& Featherstone, 1982:72] e "estabelecer a ideia de duas casas, nenhuma delas segura, a casa fatual e a casa crítica moral, entre as quais nos movemos" [Bleicher \& Featherstone, 1982:74]. De modo mais desafiador, ele disse que queria trabalhar "dentro de um compromisso sociológico que me pareceria sugerir que algumas coisas são claramente nocivas e outras claramente desejáveis, e que não é necessário fundamentá-las para poder proclamar que este é o caso" [Bleicher \& Featherstone, 1982::72].

Mesmo se descontarmos possíveis infelicidades de respostas de entrevistas, parece haver problemas com a posição que Giddens pressagia aqui. Estes problemas foram examinados por McLennan, que afirma que a posição intermediária da qual Giddens busca lançar suas salvas duplas é, na melhor das hipóteses, injustificada, e na pior insustentável [McLennan, 1984:124]. Particularmente, McLennan reclama que a orientação crítica de Giddens não se estende para uma especificação de "quais estruturas, que ações, em que tipo de sequências, acabam compondo o objeto de investigação da teoria social" [McLennan 1984:125, itálico do autor]. Giddens não oferece, de modo geral, nem teorias positivas nem normativas, e sim costura conceitos que satisfazem as aspirações da teoria social (como evitar simultaneamente o objetivismo e o subjetivismo). Esta parece também ser a posição atual de Cohen: 
"A ontologia estruturacionista se volta exclusivamente para os potenciais constitutivos da vida social: as capacidades humanas genéricas e as condições fundamentais através das quais o curso e os resultados dos processos e eventos sociais são gerados e moldados nas formas múltiplas em que isto pode ocorrer" [Cohen, 1989:17].

A única exceção possível, de acordo com McLennan, é a postulação de ordens virtuais - as estruturas (de regras e recursos) que existem apenas em suas instanciações na estruturação de sistemas sociais e nos traços de memória que constituem a habilidade cognitiva dos atores sociais. O problema com essas ordens, ele continua, é que elas permanecem tanto substantivamente nebulosas "porque Giddens não especifica os elementos sociais concretos que devem ser considerados predominantemente estruturais" quanto "[t]eoricamente nebulosas porque o significado de existência 'virtual' não é nada óbvio, e por isso não podemos dizer se a relação entre estrutura e sistema é gerativa e causal, ou (por contraste), expressiva e lógica" [McLennan, 1984:127]. Outros, incluindo Layder [1981], Urry [1982] e Thompson [1984] também perguntaram como é possível investigar uma estrutura de regras e recursos "quando essa estrutura nunca produz um conjunto de efeitos não mediados" que confirmaria sua existência [Urry, 1982:102].

Poderíamos argumentar que Giddens às vezes é mais claro do que McLennan e outros afirmam. A ideia geral de "ordens virtuais" que só podem ser inferidas de seus efeitos reais é compreensível, mesmo que seja difícil de utilizar operacionalmente. Além do mais, como Jary [1991] sugere, Giddens realmente busca definir "princípios estruturais" para (tipos de) sociedades particulares. O que Giddens não faz é especificá-los com clareza suficiente para testá-los. Assim, o conceito de estrutura de Giddens per se é menos suspeito do que alguns dos exemplos de seu uso que ele coloca para nós. Como Layder, Urry, Thompson e outros sugerem, a subespecificação de Giddens dos modos de produção, classes sociais, o Estado, e assim por diante, dificulta saber como passar de tais estruturas de regras e recursos para padrões de interação efetivos mais ou menos sistemáticos. Poderíamos adicionar que é igualmente difícil saber como se mover de efetividades para estruturas.

Cohen aponta que tanto Giddens quanto Bhaskar "focam de forma similar as práticas sociais e as características das coletividades como potenciais que são realizados de formas diversas na perpetuação e transformação da vida social através de todos os casos historicamente situados" e que ambos "se referem a estes potenciais analíticos em termos ontológicos" [Cohen, 1986:128; ver Cohen, 1989:12-18; Bhaskar, 1975, 1978]. Outhwaite 
[1990] também enfatiza as similaridades entre Giddens e Bhaskar [1986], mas Giddens não endossa em lugar nenhum o "realismo científico" de Bhaskar e outros. Se Johnson, Dandeker \& Ashworth [1984] atualizassem sua comparação entre Giddens e Bhaskar, eles provavelmente ainda seriam movidos a acentuar as diferenças. O próprio Cohen está se aproximando desta opinião [Cohen, 1989:19]. Giddens se contenta em dizer, como disse para Jary e eu, que ele é um realista ingênuo; há um mundo lá fora, e a facilidade com que podemos dar um encontrão nele é, para Giddens, assim como para Durkheim, confirmação de sua facticidade.

É verdade que em Problemas centrais [1979], Giddens se dissocia da visão que as “estruturas" são meramente modelos inventados por sociólogos ou antropólogos, e ele adiciona que considera os conceitos que formula lá "compatíveis com uma epistemologia realista" [Giddens, 1979:63]. Mas parece que com isso ele quer dizer apenas que esses conceitos nos sensibilizam para como o mundo é constituído, e o que nossas investigações empíricas devem permitir. Ele certamente se recusa a postular estruturas profundas que existem independentemente de traços de memória e instanciações na ação. $\mathrm{O}$ vocabulário de Bhaskar da profundidade ontológica e estratificação da realidade não é para ele, com a implicação de que o cientista social tem um acesso sob a superfície que privilegia suas reivindicações de conhecimento e os programas políticos consistentes com essas reivindicações [ver Bryant, 1989:70-76].

Qual é, então, a relação entre estruturas virtuais e sistemas efetivos? A resposta mais provável parece requerer metade de cada um dos dois pares de McLennan - ou seja, gerativa mas não causal, expressiva mas não lógica. Estruturas são gerativas porque elas produzem, mas não são causais porque não determinam; sistemas são uma expressão de estruturas, mas eles não são logicamente implicados por elas. Apenas desta forma podemos manter a habilidade cognitiva e a capacidade integrais para a ação.

Diferente de Parsons, Giddens nunca desejou que pesquisadores empíricos incorporassem seu vocabulário conceitual inteiro em seu trabalho. O que importa não é a terminologia, e sim a orientação estruturacionista à constituição da sociedade que essa terminologia exprime. É possível, na opinião de Giddens, ser um estruturacionista sem o saber (ver os pesquisadores citados com aprovação em A constituição da sociedade [Giddens, 1984:cap. 6]). A elaboração formal da teoria pode inspirar algumas pessoas a ir em frente e formular teorias explicativas de acordo com seus princípios, mas ela também serve seu propósito quando fornece padrões contra os quais as vantagens e desvantagens 
das teorias geradas independentemente delas podem ser avaliadas, pelo menos em alguns aspectos. Como Cohen diz, em si mesmos "[os] componentes analíticos [da teoria da estruturação] não fornecem nenhuma proposição explicativa pertencente à teoria substantiva ou à própria história", o que torna as reivindicações de Giddens quanto à sua “adequação explicativa" um tanto obscuras [Cohen, 1986:127].

Giddens recentemente confirmou, ainda que indiretamente, este ponto. Desafiado por Gregson [1989] a esclarecer a relevância da teoria da estruturação para a pesquisa empírica, ele esboçou "um programa estruturacionista de pesquisa para a ciência social moderna" [Giddens, 1989:300]. Este programa (1) "se concentraria nas ordenações de instituições através do tempo e do espaço", (2) analisaria sistemas sociais em termos de modos variáveis de articulação institucional”, (3) "teria sensibilidade contínua às intrusões reflexivas do conhecimento sobre as condições da reprodução social" e (4) "estaria orientado ao impacto de sua própria pesquisa sobre as práticas sociais e formas de organização social que ele analisa" [ibid.]. Isto claramente não é um programa de pesquisa no sentido de Lakatos; e sim uma especificação daquilo que McLennan dispensa injustamente como os meros desiderata da teoria social. É apenas na construção de teorias substantivas que podemos encontrar respostas para as perguntas de McLennan: que estruturas, que ações e que sequências? Exemplos de tal teorização podem ser encontrados na crítica de Giddens do materialismo histórico e em As consequências da modernidade [Giddens, 1990a]. Teorias substantivas boas correspondem aos princípios da teoria da estruturação, mas a teoria da estruturação não é uma substituta de teorias substantivas boas.

Cohen [1986] está correto quando diz que Giddens consistentemente localiza sua obra naquilo que hoje é chamado de tradição pós-empirista. Em sua introdução a Positivismo e sociologia [1974], Giddens ficou curiosamente quieto quanto à sua própria posição, mas dois anos depois ele a deixou perfeitamente clara nas Novas regras: uma das tarefas primárias da ciência social é definida lá como "a explicação e mediação hermenêuticas de formas de vida divergentes nas metalinguagens descritivas da ciência social" [Giddens, 1976:162]. No ensaio "O positivismo e seus críticos" [1977] ele endossou o modelo de redes da ciência natural de Hesse, com sua recusa em dicotomizar termos teóricos e observacionais e as linguagens científicas e naturais, e com sua adoção de elementos tanto da teoria da verdade por correspondência quanto da por coerência [Hesse, 1974]. Os escritos "pós-positivistas" de Hesse e outros autores sobre a ciência natural, por sua vez, tiveram implicações não só para as tradições da ciência social derivadas de Comte 
e Durkheim, mas também para a tradição das Geisteswissenschaften. Particularmente, eles ajudaram a erodir o contraste entre Erklären (explicação) e Verstehen (compreensão).

Nos anos 1980, Giddens não demonstrou muito interesse na epistemologia, mas em 1987, Giddens e Turner forneceram este excelente resumo do pós-empirismo:

“[A] ideia de que pode haver observações teoricamente neutras é repudiada, enquanto sistemas de leis ligadas dedutivamente não são mais canonizados como o maior ideal da explicação científica. E, o que é mais importante, a ciência é pressuposta como uma atividade interpretativa, de tal forma que problemas de significado, comunicação e tradução são imediatamente relevantes para as teorias científicas" [Giddens e Turner, 1987:2].

\section{Cohen argumenta corretamente que:}

“um dos resultados mais importantes da filosofia pós-empirista foi derrubar a dualidade cartesiana entre objetivismo e relativismo. Apesar de não existir nenhum algoritmo neutro para escolha entre teorias [cf. Kuhn, 1970:199-200], isto não significa que a ciência é um empreendimento irracional. Ao contrário, os cientistas são obrigados a submeter boas razões para a aceitação de seus programas em preferência a escolas de pensamento rivais. Os critérios aos quais essas razões se referem são estabelecidos como o resultado do desenvolvimento histórico da comunidade de investigação na qual argumentos de justificação são feitos. Isto implica uma rejeição da tese da incomensurabilidade de significado entre teorias [ver (...) Bernstein, 1983:79-93]. Nesta base, o apelo racional a critérios científicos envolve um grau limitado de persuasão racional [Bernstein, 1983:72]” [Cohen, 1986:129].

Neste contexto, a indiferença de Giddens quanto à epistemologia e sua recusa em abandonar a ideia da ciência social são fáceis de entender. Elas fazem parte de uma divisão de trabalho em que ele continua a desenvolver a teoria da estruturação enquanto outros agonizam, instrutiva e inconclusivamente, sobre os princípios e práticas de justificação. Há grandes vantagens nesta posição: só porque Giddens fez a maior parte das coisas, não significa que ele deva fazer todas. Entretanto, o fato que a determinação de passar longe de argumentos epistemológicos pode levar a uma discussão truncada artificialmente é fácil de demonstrar com as seções sobre a diferença entre conhecimento mútuo e senso comum, e entre critérios de credibilidade e de validade na Constituição da sociedade [Giddens, 1984].

O conhecimento mútuo "se refere à autenticidade da crença, ou a entrada hermenêutica na descrição da vida social" [Giddens, 1984:336]. O senso comum se refere às "crenças proposicionais implicadas na conduta das atividades cotidianas" [Giddens, 1984:337]. Ao contrário do empirismo e do objetivismo, "as crenças de senso comum, 
incorporadas no uso da linguagem e na ação cotidianas, não podem ser tratadas como meros impedimentos a uma caracterização válida ou verídica da vida social" porque elas são parcialmente constitutivas dela [Giddens, 1984:336]. Isto não as torna incorrigíveis. Supor que é isto que acontece é sucumbir "a uma paralisia da vontade crítica" que vitimou muitos sociólogos interpretativos [ibid.]; “o senso comum é o conhecimento mútuo tratado não como conhecimento, mas como crença falível” [Giddens, 1984:337].

Neste ponto, Giddens utiliza uma distinção entre "critérios de credibilidade" e "critérios de validade":

"Critérios de credibilidade se referem a critérios de caráter hermenêutico usados para indicar como a compreensão das razões dos atores ilumina exatamente aquilo que eles fazem baseado nessas razões. Critérios de validade tratam de critérios de evidência fatual e compreensão teórica empregados pelas ciências sociais na avaliação de razões como boas razões" [Giddens, 1984:339].

Critérios de validade são parte integral da ciência social; eles têm um papel na sua constituição. (Também podemos dizer que eles fornecem uma das ideias reguladoras para a ciência social.)

"O principal papel das ciências sociais a respeito da crítica do senso comum é a avaliação das razões como boas razões em termos do conhecimento ou simplesmente indisponível para os atores leigos, ou construído por eles de forma diferente daquela formulada nas metalinguagens da teoria social" [ibid.].

Esta posição pressupõe, como Giddens reconhece, um ponto de vista epistemológico específico - "que é possível demonstrar que algumas afirmações de crenças são falsas, e outras são verdadeiras" [Giddens, 1984:340]. Mas como? "Eu pretendo arriscar o desdém dos leitores filosoficamente sofisticados afirmando, sem maior discussão, que considero que estas coisas são o caso" [ibid.]. Fim da história, nesse ponto e desde então.

Será que Giddens, em particular, pode se dar ao luxo de ser tão peremptório, tendo em vista sua própria ontologia e tudo aquilo que ela implica em termos de relações entre discursos leigos e de cientistas sociais? O pós-empirismo sugere que a sociologia tem que combinar técnica $e$ argumento, análise $e$ interpretação, ciência $e$ política. Se os sociólogos têm dificuldade para acomodar esta ideia, imagine como é mais difícil para os atores leigos, cujas ideias de ciência, sejam elas rudes ou sofisticadas, são mais consistentes com a antiga 
tradição analítica do que com qualquer uma das construções mais complexas hoje preferidas pelos pós-empiristas. A teoria da estruturação pressupõe uma versão da ciência que ainda não obteve o apoio de muitos cientistas sociais, e que não foi adotada por quase nenhum ator leigo. Entretanto, o próprio Giddens não demonstra nenhum interesse em explicá-la e promovê-la.

As consequências da modernidade oferecem um entendimento adicional sobre a indiferença de Giddens à epistemologia. Vale a pena citar uma passagem inteira:

"[A] tese de que quanto mais conhecimento tivermos sobre a vida social (mesmo que tal conhecimento seja o mais escorado empiricamente possível), maior será nosso controle sobre nosso destino é falsa. Ela é (supostamente) verdadeira em relação ao mundo físico, mas não quanto ao universo de eventos sociais. Expandir nosso entendimento do mundo social poderia produzir uma compreensão cada vez mais esclarecedora das instituições humanas e, assim, aumentar o controle 'tecnológico' sobre elas, se fosse verdade que a vida social é inteiramente separável do conhecimento humano sobre ela, ou que o conhecimento pode ser filtrado continuamente para gerar razões para a ação social, produzindo incrementos passo a passo na 'racionalidade' do comportamento em relação a necessidades específicas.

Ambas as condições realmente valem para muitas circunstâncias e contextos da atividade social. Mas ambas não chegam nem perto do impacto totalizador que a herança do pensamento iluminista considera um objetivo" [Giddens, 1990a:44-45].

Giddens diz que quatro conjuntos de fatores são responsáveis por esta situação. Primeiro, a apropriação de conhecimento muitas vezes é mais disponível para aqueles em posições de poder. Segundo, "mudanças de perspectiva derivadas de entradas de conhecimento têm uma relação móvel com mudanças em orientações de valores" [Giddens, 1990a:44]. Terceiro, o impacto das consequências não-intencionais. Quarto, a reflexividade da modernidade: "o conhecimento reivindicado por observadores peritos (parcial e variadamente) se reúne com seus sujeitos, assim (em princípio, mas também na prática) alterando-o" [Giddens, 1990a:45]. A reflexividade da vida social moderna não permite nenhuma redução simples no escopo das consequências não-intencionais: "a questão não é que não existe nenhum mundo social estável para conhecer, mas que o conhecimento desse mundo contribui para seu caráter instável ou mutável" [ibid.].

“A modernidade é constituída no conhecimento aplicado reflexivamente e através dele", de acordo com Giddens, mas, ao contrário dos philosophes e (poderíamos adicionar) de Comte e os positivistas franceses, "a equação do conhecimento com a certeza se mostrou 
uma concepção errônea" [Giddens, 1990a:39; Bryant 1985:cap. 2]. Giddens claramente considera a epistemologia dedicada à busca da verdade apodíctica um anacronismo, mas poderíamos esperar que ele se interessasse pela epistemologia dedicada à busca do conhecimento sem fundamentações, ao alcance do consenso num contexto de incertezas. Mas ao responder a pergunta “Por que a generalização da 'doce razão' não produziu um mundo sujeito à nossa predição e controle?” ele mais uma vez invoca quatro fatores "erros de projeto" social, "erros de operadores", consequências não-intencionais e a reflexividade ou circularidade do conhecimento social - "nenhum dos quais (...) tem nada a ver com a ideia de que não temos mais nenhum método viável para sustentar reivindicações de conhecimento no sentido de Lyotard e outros" [Giddens,1990a:151; Lyotard, 1979]. Em vez de dizer que a doce razão não fornece o resultado que seus defensores esperavam porque nem o conhecimento nem o mundo são desse jeito, Giddens quase que perversamente trata apenas do mundo, da ontologia. É como se o estatuto epistemológico de reivindicações de conhecimento fosse irrelevante para sua reapropriação pelos atores leigos - apesar das referências favoráveis mas quase não explicadas à ciência social.

\section{Giddens e a teoria normativa}

Cohen atribui um "núcleo metafísico" à teoria da estruturação. Jary e eu [Bryant \& Jary, 1991b] preferimos falar da antropologia filosófica de Giddens; Kilminster [1991] escreve sobre sua visão de mundo. Weber poderia ter simplesmente se referido a seus valores. Qualquer que seja a linguagem, surge a questão de como justificar as escolhas feitas. Como Cohen diz:

“Critérios epistemológicos não são os únicos princípios que teóricos podem invocar em nome de seus programas. Mary Hesse [1980:cap. 8] aponta que a subdeterminação das teorias, e a natureza carregada de teoria dos relatos empíricos cria a abertura para a justificação de teorias através de bases orientadas para valores.” [Cohen, 1986:131]

Neste ponto, os cientistas naturais frequentemente introduzem os critérios pragmáticos de predição e controle bem-sucedidos. Os cientistas sociais não podem esperar fazer o mesmo e, Hesse sugere, devem em vez disso se referir a valores éticos e objetivos políticos. O que está errado com Giddens, de acordo com esta posição, não é sua adoção evidente de valores particulares, mas sim sua falta de preocupação em justificá-los. 
Elementos de relevância universal são centrais para a teoria da estruturação - a habilidade cognitiva e capacidade dos atores, a dialética do controle, a hermenêutica dupla, a reflexividade do conhecimento, e assim por diante - e eles são hostis à possibilidade de leis universais na ciência social. Juntos, eles formam uma antropologia filosófica que apresenta os homens e mulheres como iguais em todas as épocas e lugares. Em contraste, Giddens adota uma visão descontinuísta da história. No começo, ele estava preocupado com as descontinuidades, e não as continuidades, entre sociedades tribais, divididas em classes e de classe - suas três categorias principais. Hoje ele está preocupado com a descontinuidade entre o mundo pré-moderno e a modernidade. Já que as sociedades não são as mesmas em todo o mundo, podemos esperar que o equilíbrio entre a permissão e a coerção que suas estruturas fornecem também varie. Mas Giddens, em vez de mirar nas variações da capacidade humana para ações transformadoras, continua preferindo afirmar uma caracterização nobre do ser-espécie do homo sapiens, quase prometéica. Eu sugiro que ela é central para sua versão de uma sociologia crítica [ver Bryant, 1991].

Kilminster [1991] chegou a conclusões bastante similares. Ele afirma que o "princípio seletivo" subjacente às partes componentes da teoria da estruturação é "sua força prescritiva como uma plataforma moral-política para a crítica social da modernidade do ponto de vista da liberdade do indivíduo, visto como potencialmente autodirigente e expressivo" [Kilminster, 1991:102]. Ele também sustenta que a sociologia, para Giddens, é a ciência social crítica que lida com as sociedades de classe do mundo moderno "examina[ndo] que condições de ação maximizarão a capacidade de atores com habilidade cognitiva para fazer uma diferença nesta sociedade quando eles são dotados de acesso a recursos diferencialmente socialmente" [Kilminster, 1991:103].

Esta insistência sobre a capacidade transformadora humana é somada a um “socialismo libertário" [Giddens, 1981:175], que parece tão natural para Giddens que quase não precisa de justificação:

"Se o projeto de Marx deve ser visto como a extensão, através da conjunção da análise social e atividade política, das formas de sociedade humana em que a massa dos seres humanos pode atingir liberdades e modos de autorrealização maiores do que eles poderiam ter alcançado antes, quem pode discordar disto?" [Giddens, 1981:24]

Então, em seu engajamento com a sociedade, os sociólogos não devem ter medo de combinar sua sociologia, quando for apropriado, com a filosofia - incluindo a teoria normativa. Realmente, Giddens endossa o dispositivo do contrafatual normativo ("uma 
teoria contrafatual da exploração reconheceria que, não obstante revoluções e reformas que possam ocorrer, sempre há espaço para avanços") e recomenda que prestemos atenção, apesar de seus problemas, à teoria da justiça de Rawls e à concepção de Habermas da "situação de discurso ideal como a base para uma crítica das assimetrias de poder" [Giddens, 1981:247; Habermas, 1979; Rawls, 1971]. Ainda assim, Bernstein [1986] fez a reclamação legítima que Giddens não usou nenhum desses dispositivos para justificar seus próprios juízos críticos - ou o que eu chamaria de sua antropologia filosófica ahistórica [ver também Bertilsson, 1984]. A teoria da estruturação é crítica num sentido mínimo enquanto sugere que os agentes humanos sempre podem agir de outra forma; mas ela não será crítica num sentido mais completo até que uma teoria normativa contrafatual seja fornecida para justificar ou a antropologia filosofia que atualmente a sustenta, ou alguma sucessora mais histórica.

Respondendo a Bernstein, Giddens argumenta que o engajamento na atividade das ciências sociais envolve quatro níveis de crítica. O primeiro, a crítica intelectual, trata do escrutínio disciplinar crítico na comunidade dos cientistas sociais. $\mathrm{O}$ segundo, a crítica prática, tem a ver com a hermenêutica dupla e a forma pela qual a ciência social é constitutiva das próprias práticas que ela transforma em seu objeto. O terceiro, a crítica ideológica, se refere ao "papel das reivindicações de conhecimento enquanto aspectos dos sistemas de poder" [Giddens, 1989a:290]. A identificação deste papel é crítica porque "o diagnóstico de ideologia provavelmente comprometerá as reivindicações de crença de pelo menos alguns agentes envolvidos num conjunto particular de relações de poder" [ibid.]. O quarto, a crítica moral e como ela é justificada, é o nível que Bernstein acredita que Giddens não consegue tratar apropriadamente. Giddens discorda e invoca sua extensão de 1977 do modelo da ciência em rede de Hesse para a determinação de juízos de valor: “de acordo com esta concepção, juízos de valor não são mais 'arbitrários' do que teorias científicas, e estão sempre a princípio sujeitos à avaliação empírica, ainda que subdeterminada pelos fatos" [Giddens, 1977:95]. Ele agora chama esta posição de "racionalismo moral contingente" e a elabora da seguinte forma:

"De acordo com esta perspectiva, enquanto cientistas sociais praticantes, podemos legitimamente fazer críticas morais de estados de coisas, apesar de precisarmos buscar justificar essas críticas quando solicitados a fazê-lo. Não podemos basear a crítica moral no próprio modo de justificação (ou argumentação), e no sentido de achar 'fundamentações puras', não podemos baseá-la de jeito nenhum. Mas isto não significa que a crítica moral é derivada meramente de caprichos ou sentimentos, ou que estamos à mercê de uma conjuntura 
histórica particular. O diálogo é possível com todo e qualquer ponto de vista moral, e sempre envolve uma fusão de disputas morais e fatuais. Na maior parte do tempo, a maioria de nós não se encontra em circunstâncias de perplexidade moral quando confrontados com estados de coisas particulares, do modo em que relatos filosóficos da dificuldade, ou da impossibilidade, de fundamentar avaliações morais poderiam nos levar a supor" [Giddens, 1989a:291].

Assim, ao contrário de Weber, o debate moral não termina em submissão aos demônios que controlam os próprios fios de nossas vidas. Entretanto, também não é possível "fundamentar um programa de teoria crítica, da forma que Habermas busca fazer, de modo que possamos fornecer bases racionais completas para a crítica moral" [ibid.]. Assim Giddens considera "implausível a afirmação de Habermas que uma situação de discurso ideal está implicada contrafatualmente em qualquer tentativa de comunicação linguística" [ibid.]. Ele também rejeita a crítica imanente sugerida por Adorno (supostamente por sua teleologia).

Resumindo, Giddens mantém que as reivindicações de verdade e de justeza envolvem redes variáveis de enunciados teóricos e empíricos. Ele abomina todas as reivindicações de que uma rede estaria completa ou que não poderia ser conectada a outras redes: "assim como a posição relativista naufraga na hermenêutica, também a respeito de avaliações morais não há nenhuma posição valorativa situada em redes discursivas completamente desconectadas de todas as outras" [Giddens, 1989a:292]. Ele também acredita que a exaustão de tradições herdadas do pensamento social e político é cada vez mais aparente e que precisamos "[nos] engajar em novas formas de pensamento contrafatual para fornecer um estímulo à transformação social" de nossa era de alta modernidade [Giddens, 1989a:293].

A maioria dos críticos consegue de Giddens apenas uma reafirmação de sua posição. Confirmamos que Bernstein colocou o dedo na ferida porque ele recebeu uma resposta de Giddens que vai além de tudo que este já escrevera anteriormente. Poderia parecer que ele finalmente reconheceu a necessidade de desenvolver uma teoria normativa contrafatual própria. Ele agora requer a criação de modelos de "realismo utópico" que incorporam dois tipos de engajamento político, a saber, a política de emancipação (ou a política da desigualdade) e a política da vida (ou a política da autorrealização). Em seu livro mais recente, As consequências da modernidade, Giddens adota uma "teoria crítica sem garantias" que combina uma análise de possibilidades institucionais imanentes com modelos da boa sociedade, modelos de autorrealização e uma ética (weberiana) da 
responsabilidade [Giddens, 1990a:154-158]. Em um de seus ensaios mais recentes, ele oferece esta elaboração:

"Uma teoria crítica que se engaje com as possibilidades imanentes da modernidade precisa reconhecer que a história não dá nenhuma garantia, e precisa equilibrar o realismo com um elemento utópico (...) A ligação entre o realismo e o utopianismo é fundamental num mundo ameaçado por riscos de alta consequência. O pensamento utópico, adotado sozinho, pode ser muito perigoso - se aplicado, por exemplo, às políticas de coibição [nuclear]. Qualquer um preocupado com o futuro das armas precisa estar alerta às questões táticas e estratégicas envolvidas em processos possíveis de desmilitarização, e não pode ser impulsionado apenas por uma convicção moral pura. Por outro lado, se o realismo não for temperado por um componente utópico, as transições radicais imperativas para garantir um futuro estável e seguro não se materializarão" [Giddens, 1991:211].

É claro que a introdução do utópico complica ainda mais as relações entre o virtual, o real e o efetivo; será fascinante ver como Giddens lida com este assunto.

A análise da modernidade de Giddens enfoca a segurança e o perigo, confiança e risco, segurança ontológica e ansiedade existencial. Ela forma um comentário sobre a condição humana, confirmando que uma ontologia do social é inseparável de uma ontologia da pessoa - uma antropologia filosófica. No contexto da hermenêutica dupla, ontologizar o social é também desempenhar um papel, por menor que seja, na constituição e reconstituição da sociedade. Assim, a ontologização do social é também inseparável da realização de uma filosofia política. No passado, Giddens hesitou em justificar uma filosofia política. Isto pode estar prestes a mudar. Ele agora certamente criou sua própria deixa para uma contribuição séria para a teorização contrafatual normativa, e criou expectativas que o terceiro volume de sua crítica do materialismo histórico preencherá o conteúdo de seus modelos da boa sociedade e do eu realizado.

\section{Conclusão}

Giddens se aproveita de ideias correntes na comunidade de investigadores pósempiristas às quais ele pouco contribuiu para desenvolver ou promover, pelo menos desde os meados da década de 1970, mesmo que sua ontologia do social necessite delas como um complemento. É uma questão aberta a discussão de se na prática é sábio deixar a epistemologia para os outros. Se o próprio Giddens não sente nenhuma obrigação em forjar 
as conexões entre a teoria da estruturação e o pós-empirismo, por que qualquer outro deveria senti-la? De qualquer forma, e para repetir, a comunidade de investigadores pósempiristas pode considerar uma virtude os fatores políticos e éticos que baseiam a ciência social, mas ela ainda não tem nenhum meio estabelecido para avaliar valores diferentes e rivais; e mesmo se tivesse, ela não poderia inventar a posição de Giddens para ele. Giddens precisa articular e justificar uma teoria normativa para si próprio. Sem teorização contrafatual normativa, modelos bem resolvidos de realismo utópico, ou algum outro meio de justificar reivindicações sobre o ser social, a teoria da estruturação continuará com uma certa qualidade de "ame-a ou deixe-a".

\section{Agradecimentos}

Este artigo inclui uma extensão de um argumento sobre Giddens e a epistemologia que eu formulei inicialmente em colaboração com David Jary. Eu continuo muito grato a ele por sua contribuição. Eu também agradeço a todos aqueles que comentaram um rascunho anterior apresentado no $12^{\circ}$ Congresso Mundial de Sociologia, realizado em Madri, em julho de 1990, e aos dois peritos anônimos da revista Sociological Theory que forneceram comentários escritos.

\section{Bibliografia}

BARNES, B. [1974] Scientific Knowledge and Sociological Theory. London: Routledge.

BERNSTEIN, R. [1983] Beyond Objectivism and Relativism. Oxford: Blackwell.

BERNSTEIN, R. [1986] "Structuration as Critical Theory", in Praxis International, v. 6, pp. 235249.

BERTILSSON, M. [1984] "The Theory of Structuration: Prospects and Problems", in Acta Sociologica, v. 27, pp. 339-353.

BHASKAR, R. [1975] A Realist Theory of Science. Brighton: Harvester.

BHASKAR, R. [1979] The Possibility of Naturalism. Brighton: Harvester.

BHASKAR, R. [1986] Scientific Realism and Human Emancipation. London: Verso.

BLEICHER, J. \& FEATHERSTONE, M. [1982] "Historical Materialism Today: An Interview with Anthony Giddens", in Theory, Culture \& Society, v. 1, pp. 62-113.

BRYANT, C. [1985] Positivism in Social Theory and Research. London: Macmillan. 
BRYANT, C. [1989] "Sociology without Foundations", in Polish Sociological Bulletin, 87-88, pp. 61-79.

BRYANT, C. [1991] "The Dialogical Model of Applied Sociology”, in Bryant, C. \& Jary, D. (eds.), Giddens' Theory of Structuration: A Critical Appreciation. London: Routledge, pp. 176200.

BRYANT, C. \& JARY, D. [1991] "Introduction: Coming to Terms with Anthony Giddens", in Bryant, C. \& Jary, D. (eds.), Giddens' Theory of Structuration: A Critical Appreciation. London: Routledge, pp. 1-31.

CLARK, J., MODGIL, C. \& MODGIL, S. (eds.) [1990] Anthony Giddens: Consensus and Controversy. London: Falmer.

COHEN, I. [1986] “The Status of Structuration Theory: A Reply to McLennan”, in Theory, Culture \& Society, v. 3, pp. 123-133.

COHEN, I. [1989] Structuration Theory. London: Macmillan.

GIDDENS, A. (ed.) [1974] Positivism and Sociology. London: Heinemann.

GIDDENS, A. [1976] New Rules of Sociological Method. London: Hutchinson.

GIDDENS, A. [1977] Studies in Social and Political Theory. London: Hutchinson.

GIDDENS, A. [1979] Central Problems in Social Theory. London: Macmillan.

GIDDENS, A. [1981] A Contemporary Critique of Historical Materialism. London, Macmillan.

GIDDENS, A. [1984] The Constitution of Society. Cambridge: Polity.

GIDDENS, A. [1987] "The Social Sciences and Philosophy: Trends in Recent Social Theory", in Social Theory and Modern Sociology. Cambridge: Polity, pp. 52-72.

GIDDENS, A. [1989a] "A Reply to My Critics", in Held, D. \& Thompson, J. (eds.), Social Theory of Modern Societies: Anthony Giddens and His Critics. Cambridge: Cambridge University Press.

GIDDENS, A. [1989b] Sociology. Cambridge: Polity.

GIDDENS, A. [1990a] The Consequences of Modernity. Cambridge: Polity.

GIDDENS, A. [1990b] "Structuration Theory and Sociological Analysis", in Clark, J., Modgil, C. \& Modgil, S. (eds.) Anthony Giddens: Consensus and Controversy. London: Falmer, pp. 201-221.

GIDDENS, A. \& TURNER, J. (eds.) [1987] Social Theory Today. Cambridge: Polity.

GREGSON, N. [1989] "On the (Ir)relevance of Structuration Theory to Empirical Research", in Held, D. \& Thompson, J. (eds.), Social Theory of Modern Societies: Anthony Giddens and His Critics. Cambridge: Cambridge University Press, pp. 235-248.

HABERMAS, J. [1979] Communication and the Evolution of Society. London: Heinemann.

HALSEY, A. H. [1989] “A Turning of the Tide”, in British Journal of Sociology, v. 40, pp. 353373. 
HEKMAN, S. [1990] "Hermeneutics and Giddens' Theory of Structuration: A Critique of Giddens' Epistemology", in Clark, J., Modgil, C. \& Modgil, S. (eds.) Anthony Giddens: Consensus and Controversy. London: Falmer.

HESSE, M. [1974] The Structure of Scientific Inference. London: Macmillan.

HESSE, M. [1980] Revolutions and Reconstructions in the Philosophy of Science. Brighton: Harvester.

JARY, D. [1991] "Society as Time-Traveller: Giddens on Historical Change, Historical Materialism and the Nation-State in World Society", in Bryant, C. \& Jary, D. (eds.), Giddens' Theory of Structuration: A Critical Appreciation. London: Routledge, pp. 116-159.

JOHNSON, T.; DANDECKER, C. \& ASHWORTH, C. [1984] The Structure of Social Theory. London: Macmillan.

KILMINSTER, R. [1989] "Sociology and the Professional Culture of Philosophers", in Haferkamp, H. (ed.), Social Structure and Culture. Berlin: de Gruyter, pp. 289-312.

KILMINSTER, R. [1991] "Structuration Theory as a World-View", in Bryant, C. \& Jary, D. (eds.), Giddens' Theory of Structuration: A Critical Appreciation. London: Routledge, pp. 74-115.

KUHN, T. [1970] The Structure of Scientific Revolutions. Chicago: University of Chicago Press.

LAYDER, D. [1981] Structure, Interaction and Social Theory. London: Routledge.

LYOTARD, J-F. [1984] The Postmodern Condition. Manchester: Manchester University Press.

McLENNAN, G. [1984] "Critical or Positive Theory? A Comment on the Status of Anthony Giddens' Social Theory”, in Theory, Culture \& Society, v. 2, pp. 123-129.

OUTHWAITE, W. [1990] "Agency and Structure", in Clark, J., Modgil, C. \& Modgil, S. (eds.) Anthony Giddens: Consensus and Controversy. London: Falmer, pp. 63-72.

RAWLS, J. [1971] A Theory of Justice. Cambridge: Harvard University Press.

RORTY, R. [1982] Consequences of Pragmatism. Minneapolis: University of Minnesota Press.

THOMPSON, J. [1984] Studies in the Theory of Ideology. Cambridge: Polity.

URRY, J. [1982] "Duality of Structure: Some Critical Issues", in Theory, Culture \& Society, v. 1, pp. 100-106. 


\section{Colin Hay, Martin O’Brien \& Sue Penna - Giddens, modernidade e identidade do eu: o "esvaziamento" da teoria}

\section{social}

\section{Introdução}

Desde a publicação de $O$ Estado-nação e a violência ${ }^{1}$, Anthony Giddens rapidamente se estabeleceu como um dos principais teóricos da modernidade. Grande parte da originalidade da obra de Giddens vem da ênfase colocada na interação entre o indivíduo e as forças institucionais na formação das características estruturais de nosso mundo. Isto fornece um corretivo importante, ainda que, como argumentaremos, problemático ao objetivismo de grande parte da literatura sobre a modernidade. De fato, o caráter distintivo de As consequências da modernidade, Modernidade e identidade do eu e $A$ transformação da intimidade ${ }^{2}$ está na tentativa de Giddens de injetar o momento da ação no esquema institucional e histórico que ele esboçara anteriormente em $O$ Estado-nação e a violência. Modernidade e identidade do eu demonstra sua inovação conceitual ininterrupta. O livro é uma digressão desafiadora sobre temas chave emergindo na teoria social, forçando a reflexão sobre as dimensões pessoais e políticas da vida moderna através de um engajamento com um conjunto amplo de debates contemporâneos. Junto com A transformação da intimidade, mais populista, a própria obra recente de Giddens pode ser vista como uma intervenção direta nas formas em que o eu, a sociedade e o conhecimento se interseccionam nos dias atuais.

Neste artigo, nós refletimos criticamente sobre o projeto de Giddens, enfocando particularmente as formas em que a perspectiva da estruturação desenvolvida por Giddens em obras anteriores é aplicada à análise da identidade do eu desenvolvida nos dois livros recentes sobre a identidade do eu na modernidade. A discussão está dividida em quatro partes. Na primeira, fornecemos um breve esboço da análise apresentada em Modernidade e identidade do eu e A transformação da intimidade. O esboço servirá para apresentarmos um conjunto de conceitos e ideias que examinaremos de forma mais

\footnotetext{
${ }^{1}$ Giddens [1985]. Gostaríamos de agradecer o Lancaster Regionalism Group pelos comentários a várias versões deste artigo, com um agradecimento especial para Lisa Adkins, Trevor Purvis, e os editores e o parecerista anônimo do Arena Journal.

${ }^{2}$ Giddens [1990; 1991; 1992a].
} 
abrangente nas seções seguintes. Na segunda seção, elaboramos o esquema geral de Giddens, enfocando o conceito de "reflexividade" nos níveis institucional e pessoal de seu programa teórico. Na terceira seção, trataremos das observações de Giddens sobre a experiência na alta modernidade, em termos dos tipos diferentes de "processos mediadores" que servem como recursos para a construção da identidade. Na quarta seção, passamos para o nível micro da análise de Giddens, investigando o voluntarismo que escora seu conceito de "relação pura". Em todas estas seções argumentamos que o esquema teórico de Modernidade e identidade do eu e $A$ transformação da intimidade não consegue conectar micropráticas com macroestruturas. Em nossa conclusão, afirmamos a necessidade de conceitos sociológicos que estejam fundamentados mais claramente nos contextos vividos de grupos sociais diferentes - em particular, uma definição mais sofisticada do poder e um reconhecimento das desigualdades fundamentais que estruturam e reproduzem identidades modernas diferenciais. Sem esta adição, argumentamos que a obra recente de Giddens não tem as ferramentas sociológicas necessárias para ligar as dimensões local e global da experiência moderna.

\section{Modernidade e identidade do eu: reflexividade e política da vida.}

“(...) a política da vida trata de questões políticas que surgem de processos de efetivação do eu em contextos pós-tradicionais, onde influências globalizantes penetram profundamente no projeto reflexivo do eu, e inversamente onde processos de realização do eu influenciam estratégias globais”3.

Esta citação indica dois pontos de partida na obra recente de Giddens: um teórico, o outro analítico. Teoricamente, Giddens busca resgatar um sujeito ativo para a teoria social a partir do objeto descentrado dos discursos pós-estruturalistas ${ }^{4}$. Esta tentativa é feita, em primeiro lugar, colocando o sujeito como um parceiro ativo na construção de sua identidade do eu e, em segundo lugar, propondo um esquema unitário da experiência mediada através da qual esta identidade é constituída. Analiticamente, Giddens detalha uma mudança no modo de referencialidade do eu. Esta mudança está no coração da distinção rígida que ele traça entre ordens sociais tradicionais e modernas. No contexto tradicional, identidades são formadas dentro de comunidades fixas. Os

\footnotetext{
${ }^{3}$ Giddens [1991:214].

${ }^{4}$ Giddens [1990:150; 1991:169-170].
} 
recursos para a construção da identidade estão amarrados ao lugar, no sentido que os costumes, hábitos, conhecimentos e mesmo o ambiente físico impõem restrições tanto sobre o conjunto quanto sobre a natureza dos materiais disponíveis para o autoentendimento e a construção da identidade. Tais referentes tradicionais formam "sistemas externamente referenciais", o que quer dizer que a constituição da identidade do eu na sociedade tradicional é constituída através de papéis sociais designados e meios culturais fixos - idade, ocupação, costumes e sexo, por exemplo, delimitam as possibilidades de ação e autoentendimento ${ }^{5}$.

A sociedade moderna, ao contrário, é caracterizada pela ausência de referentes tradicionais que fundamentem as experiências da vida cotidiana nos parâmetros institucionais do mundo social mais amplo. Esta condição possibilita encontros existenciais com "fronteiras de experiência abertas", , aparentemente não fundamentadas em sistemas normativos. Fronteiras de experiência abertas surgem através de uma diminuição das ligações associadas com laços de parentesco, lugar e propriedade, que por sua vez levam a um rompimento de passagens ritualizadas da vida, como a infância e o casamento ${ }^{7}$.

Giddens afirma que neste contexto pós-tradicional, o progresso da vida do indivíduo assume um conjunto completamente novo de possibilidades. Em vez de "fixar" o curso da vida de um indivíduo, o parentesco, a localidade, e assim por diante, se tornam recursos menores da construção da identidade e do estilo de vida. Na modernidade tardia, a conexão forte entre lugar e identidade é rompida ${ }^{8}$. Sob o impacto de relações de produção capitalistas, a formação de um Estado centralizado e o surgimento de meios de comunicação modernos, as relações sociais e os recursos simbólicos que as sustentam se tornam "desencaixados" de contextos locais 9 . A migração em grande escala para cidades, a extensão do direito ao voto e a ascensão de uma autoridade política unificada, a confusão de crenças, estilos e comportamentos surgindo de interações desterritorializadas, e a extensão de relações de trabalho

\footnotetext{
${ }^{5}$ Giddens [1990:36-38].

${ }^{6}$ Giddens [1991:148].

${ }^{7}$ Giddens [1991:147].

${ }^{8}$ Resumido por Giddens [1991:17]: “A organização social moderna pressupõe a coordenação precisa das ações de muitos seres humanos fisicamente ausentes uns dos outros; o 'quando' destas ações está ligado diretamente ao 'onde', mas não, como em épocas pré-modernas, através da mediação do lugar". Apesar de Giddens desejar manter um papel analítico para "lugar" na análise, seu tratamento deste conceito efetivamente oblitera sua importância enquanto determinante.

${ }^{9}$ Giddens [1990:21-29; 1991:17-21].
} 
assalariado para a maior parte da população disponibilizam um conjunto comum de experiências junto com modos comuns de ação e interação. As novas aglomerações institucionais que governam a vida moderna, incluindo a mídia e as instituições financeiras - e suas interconexões - criam uma moldura para esta experiência e ação. Esta moldura é ela própria constituída através da disseminação de fichas simbólicas universais ${ }^{10}$, do surgimento de sistemas $\operatorname{peritos}^{11}$ e da disponibilidade de mercadorias culturais de massa através da mídia impressa e eletrônica.

A separação entre o lugar e o espaço é acompanhada pelo "distanciamento" do tempo e do espaço de contextos locais de ação. Enquanto em sociedades pré-modernas o tempo da atividade estava intricadamente ligado com sua localização espacial, a modernização resulta numa padronização do tempo através de contextos espaciais. Isto se reflete no surgimento de uma forma unificada e distintivamente "moderna" de temporalidade, que cria uma história única enquanto também acelera o passo das mudanças sociais.

Estas mudanças criam condições que requerem a organização reflexiva individual do tempo da vida: um processo que depende do equilíbrio entre "risco" e "confiança" nas redes sociais e institucionais da modernidade ${ }^{12}$. O risco e a confiança se tornam importantes precisamente porque o progresso do indivíduo através da vida não é mais determinado externamente. Pelo contrário, o indivíduo precisa cada vez mais fazer escolhas sobre seu próprio desenvolvimento da identidade, adotando estratégias reflexivas para a vida. A reflexividade aqui se refere à suscetibilidade de relações individuais e institucionais a sofrerem mudanças profundas face a novos conhecimentos e informações ${ }^{13}$. É a reflexividade da organização tanto do tempo de vida, quanto de seus parâmetros institucionais na modernidade, que expõe sua referencialidade interna.

O resultado da mudança no modo de referencialidade - de externo para interno na transição da sociedade tradicional para a modernidade é a evolução do "projeto

\footnotetext{
${ }^{10}$ Das quais o dinheiro, enquanto meio de troca padronizado, e por isso intercambiável através de múltiplos contextos sociais, é o exemplo mais claro. Símbolos nacionais e internacionais como bandeiras, logotipos e estereótipos também podem ser incluídos aqui.

${ }^{11}$ Que Giddens enxerga como regimes de poder-conhecimento dependentes da legitimidade reconhecida de conhecimentos profissionais e técnicos.

${ }^{12}$ Giddens [1990:cap. 4; 1991:114-143]. Em particular, as relações de confiança em sistemas peritos, desde a arquitetura até a zoologia, e experiências de risco na distribuição e uso de tecnologias estranhas e em situações pertinentes aos contornos em contínua mutação da sociedade moderna.

${ }^{13}$ Giddens [1990:38; 1991:20; 1992a:28-9]. Voltaremos a este conceito, mais detalhadamente, abaixo.
} 
reflexivo do eu"14. Dentro das fronteiras deste projeto, a identidade do indivíduo é construída como uma narrativa biográfica - uma projeção (mais ou menos) coerente das escolhas feitas e dos riscos encontrados no tempo da vida. É importante reconhecer que o eu é uma projeção neste sentido: uma projeção no presente da moldura de escolhas e mecanismos de confiança que um indivíduo traz de seu passado, e os riscos potenciais localizados no futuro. A ontologia do eu de Giddens - sua realização - é propositalmente ambivalente: a identidade do eu é o gume da faca da escolha, equilibrando a confiança e a dúvida nos contornos arriscados da alta modernidade ${ }^{15}$.

A distinção adicional entre modernidade e "alta modernidade" na obra recente de Giddens prepara uma distinção entre política da emancipação e política da vida, levantando questões sociológicas e implicações políticas complexas às quais retornaremos abaixo. Aqui, precisamos apontar que Giddens está contrastando uma política de autonomia e liberação (emancipação) com uma política de escolha e estilo (vida) $^{16}$. Não é um contraste simples entre modernidade inicial e tardia. Em vez disso, ele pretende destacar a trajetória histórica de uma série de molduras políticas no contexto de uma modernidade dinâmica e radical. A ação política de emancipação leva a uma transformação das ordens institucionais da vida social moderna, gerando novos alvos morais e políticos para a ação, que, por sua vez, se refletem em mudanças institucionais posteriores. Cada vez mais, as relações entre ação e mudança institucional na alta modernidade resultam na formação de movimentos "da política da vida"17, contestando a organização da sexualidade, do meio ambiente, do direito à vida, etc.

Estes movimentos da política da vida surgem das tensões entre sistemas internamente referenciais e o ethos do crescimento pessoal implicado no projeto reflexivo do $\mathrm{eu}^{18}$. A narrativa da identidade do eu impele os indivíduos a tratar do futuro, e os sistemas peritos que contribuem para a construção desta narrativa simultaneamente reprimem e permitem a remoralização da vida. No decorrer do planejamento reflexivo da vida, os indivíduos "redescobrem" os problemas

\footnotetext{
${ }^{14}$ Giddens [1992a:30, passim; 1991:7-8, passim].

${ }^{15}$ Giddens [1991:109-137; 1992a:32].

${ }^{16}$ Giddens [1991:211, 214].

17 "A política da vida se refere a engajamentos radicais que buscam aumentar as possibilidades de uma vida completa e satisfatória para todos, e para a qual não existem 'outros"” [Giddens, 1990:156]. Voltaremos a esta concepção problemática de um mundo "sem outros" abaixo.

${ }^{18}$ Giddens [1991:209].
} 
existenciais $^{19}$ até agora reprimidos, e forçam questões morais à agenda política ${ }^{20}$. O indivíduo, em condições de alta modernidade, não é o sujeito fragmentado, dócil ou descentrado do discurso pós-estruturalista, e sim um agente ativo na construção do projeto reflexivo do eu e das atividades da política da vida que são o seu potencial. Com a passagem de Giddens da análise institucional das Consequências da modernidade para a análise subjetiva da Transformação da intimidade, os contornos da política moderna são vistos como algo cada vez mais impulsionado por escolhas e ações na esfera privada - relacionamentos, sexualidade e amor. A transformação da intimidade na esfera pessoal é causada pela apropriação reflexiva individual de sistemas peritos: de manuais de terapia e romances melosos a novas tecnologias de controle de natalidade ${ }^{21}$. Esta conexão pessoal-política, para Giddens, é a fonte de novas possibilidades democráticas baseadas numa ética do desenvolvimento do eu, da realização pessoal e da negociação íntegra. Resumindo, a transformação dos relacionamentos pessoais fornece um modelo para a política democrática global ${ }^{22}$.

Como podemos ver na descrição acima dos contornos teóricos da análise de Giddens, as relações políticas entre instituições e projetos, entre identidades e contextos, e entre ação e estrutura não são incidentais. O próprio dinamismo da modernidade, o imperialismo de seus sistemas peritos, a organização racional de seu tempo histórico e o desencaixe da vida social de contextos locais da ação estão todos envolvidos profundamente na transformação estrutural e política que Giddens sugere que anuncia o surgimento da alta modernidade ${ }^{23}$.

\footnotetext{
${ }^{19}$ Com o que Giddens quer dizer problemas relacionados a "como a própria existência deve ser compreendida e "vivida", que se dissolvem em opções de estilo de vida (ver Giddens [1991:224-225]). Giddens fornece uma lista substantiva de tais questões existenciais/morais, incluindo: "que responsabilidades os seres humanos têm em relação à natureza?", "que limites devem ser impostos à inovação científica/tecnológica?" e "que direitos o indivíduo tem sobre seu corpo?" Ver Giddens [1991:227].

${ }^{20}$ Cf. Giddens [1991:cap. 6].

${ }^{21}$ Giddens [1992a:caps. 3 e 4].

${ }^{22}$ Baseada numa "tentativa de descobrir as preocupações e interesses subjacentes uns dos outros, identificando um conjunto de opções possíveis" para que seja possível "sermos firmes sobre a substância da negociação enquanto apoiamos e respeitamos o outro lado" [Giddens, 1992a:196].

${ }^{23}$ Giddens [1991:208].
} 


\section{O esvaziamento da teoria social}

Como esboçada acima, a obra recente de Giddens é uma tentativa de formular um esquema capaz de conceber as interconexões complexas entre o local e o global sob as condições da modernidade tardia. Como um pré-requisito teórico a isto, Giddens identifica dois polos de análise, que de modo geral correspondem à dicotomia açãoestrutura: o da extensionalidade - de influências, propriedades estruturais e dinâmicas globalizantes; e o da intensionalidade - de disposições, escolhas e experiências pessoais. A ambição de Giddens, inspirada pela teoria da estruturação e sua tentativa de síntese da macro e microssociologia, é suplementar o foco extensional de suas análises anteriores - principalmente $O$ Estado-nação e a violência - tratando explicitamente das dimensões de ação da modernidade.

Entretanto, apesar deste foco na ação, a obra mais recente de Giddens reafirma o tema central de O Estado-nação e a violência - que "a modernidade deve ser compreendida num nível institucional" ${ }^{\text {24 }}$. Esta ênfase, enfocando aglomerações institucionais, fornece uma consolidação das elaborações anteriores de Giddens dos "contornos da (alta) modernidade": o industrialismo (o ambiente criado); o capitalismo (a classe/propriedade privada); o militarismo (a consolidação de um controle centralizado sobre os meios de violência); e a vigilância (o controle social). Tal análise institucional e estrutural, surgindo dessa forma de uma crítica extensa do materialismo histórico, claramente pretende evitar aquilo que Giddens enxerga como o reducionismo "vulgar" do marxismo clássico.

Apesar do nível da análise institucional fornecer o esquema em que a microssociologia da identidade do eu de Giddens está situada, Modernidade $e$ identidade do eu e $A$ transformação da intimidade são caracterizados por surpreendentemente poucas referências a aglomerações institucionais e contextos coagidos (ou mesmo permitidos) de interação humana. Entretanto, devemos notar que a ênfase da macrossociologia de Giddens em Modernidade e identidade do eu e $A$ transformação da intimidade não está primariamente nos parâmetros institucionais da modernidade, e sim, seguindo a trilha aberta pelas Consequências da modernidade, no dinamismo e no potencial de democratização das sociedades modernas ${ }^{25}$. De qualquer

\footnotetext{
${ }^{24}$ Cf. Giddens [1991:1].

${ }^{25}$ Giddens [1991:16-20; 1992a:188-192].
} 
forma, a aparente incapacidade de Giddens de demonstrar uma ligação clara entre a rica textura da vida cotidiana e as aglomerações institucionais abstratas da modernidade (que, segundo ele, estabelecem os parâmetros em que tais detalhes emergem) é certamente uma grande lacuna. Além do mais, ela sugere que devemos adotar um certo ceticismo quanto à afirmação de Giddens de ter finalmente transcendido o dualismo entre estrutura e ação, macro e microssociologia.

Para entendermos como Giddens constrói os contornos políticos da modernidade tardia, é necessário analisarmos seu uso da teoria da estruturação para explicar a mudança social. A teoria da estruturação representa uma tentativa teórica ambiciosa de transcender a dicotomia estrutura-ação ${ }^{26}$. Giddens prefere o conceito de "dualidade", onde a estrutura e ação são vistas como lados da mesma moeda, ao de "dualismo", em que estrutura e ação são relacionadas externamente. Giddens considera este dualismo como algo característico de dois campos hostis da teoria social: o estruturalista e o intensionalista. Teorias estruturalistas concebem a ação como um mero artefato de imperativos estruturais essencialmente determinantes. Teorias intensionalistas focam na exibição livre da ação de indivíduos autônomos efetivamente desconectados de estruturas sociais e políticas. Com a noção de "estruturação", Giddens apresenta a ideia da dependência mútua e da relação intrínseca entre estrutura e ação. Esta relação é a base do conceito de Giddens da "dualidade da estrutura", com o qual ele quer dizer que:

"estruturas sociais são constituídas pela ação humana e ainda assim, ao mesmo tempo, são o próprio meio desta constituição"27.

As proposições de Giddens sobre a transformação do conhecimento e da ação na sociedade contemporânea são estimulantes, e potencialmente aplicáveis em termos empíricos - o próprio Giddens esboça brevemente algumas consequências de seu argumento geral na seção final de $A$ constituição da sociedade ${ }^{28}$. Mas os procedimentos para inferir significância dos dados discutidos aqui e em outros textos ${ }^{29}$ são confusos e

\footnotetext{
${ }^{26}$ Isto é, uma separação rígida entre estrutura e ação que faz com que elas sejam vistas como aspectos independentes do mundo social, em vez de aspectos intrinsecamente relacionados e mutuamente constitutivos.

${ }^{27}$ Giddens [1976:121]. Ver Hay [1995].

${ }^{28}$ Ao desenvolver sua exposição da teoria da estruturação, Giddens é notavelmente reticente em engajar o leitor em qualquer diálogo com seu esquema epistemológico, afirmando que suas ideias pressupõem "um esquema epistemológico definido sem apoiá-lo em detalhes". Ver Giddens [1984:338ff.].

${ }_{29}$ Notavelmente nas Novas regras do método sociológico [Giddens, 1976]. De fato, Giddens é bastante descuidado em seu uso de evidências para apoiar proposições teóricas, ocasionalmente comentando
} 
inconsistentes. Apesar da teoria da estruturação ter se mostrado muito influente em vários campos ${ }^{30}$, ainda restam problemas-chave na aplicação deste esquema à análise da vida social. Em nossa opinião, o problema central com a tentativa de integração teórica deste tipo concerne questões epistemológicas, em particular uma fusão da ação e da estrutura, e uma fusão relacionada de proposições teóricas e empíricas. Lidaremos agora com ambas estas fusões.

O problema da fusão tem sua origem na decisão de Giddens de tratar tanto os atores quanto os contextos da ação como possuindo poderes causais (ou "transformativos"); em outras palavras, a dualidade da estrutura contém uma dualidade da ação. Por um lado, ele diz que as instituições sociais, por exemplo, do direito, da medicina, da ciência ou da educação são utilizadas e simultaneamente reproduzidas por atores individuais com interesses e objetivos diversos. Por outro lado, estes mesmos aglomerados institucionais são concebidos como agentes reflexivos, capazes de apropriar, monitorar, gerar (e, supostamente, destruir) a ação e o conhecimento. Num nível altamente abstrato, esta abordagem tem algumas características atraentes - ela fornece uma ontologia do conhecimento/ação intrinsecamente contextual, potencialmente permitindo uma macrossociologia hermenêutica da mudança social. Entretanto, num nível mais concreto - na interpretação de instâncias específicas da ação social - não há técnicas metodológicas disponíveis para imputar a ação a qualquer elemento particular numa situação real.

O problema procedimental da especificação e categorização nunca foi abordado por Giddens em seus escritos de orientação mais metodológica, e, consequentemente, ele foi trazido para a exploração da mudança social e a análise política da realização do eu focadas pela obra recente de Giddens. Nos exemplos que Giddens usa, é impossível distinguir entre os efeitos gerados pelo contexto institucional e os efeitos engendrados por atores específicos dentro desses contextos, já que a forma da ação e a forma do contexto são reproduzidas mutuamente em sua coalizão ativa.

explicitamente que a representatividade dos dados é irrelevante para sua análise da mudança pessoal e social. Ver Giddens [1992a:134].

${ }^{30}$ Ver, inter alia, Stones [1991]; Cerny [1989]; Dessler [1989]; Gregory [1990]; Wharton [1991]. 
Por exemplo, Giddens afirma que o fenômeno do rompimento de casamentos e a escolha das mulheres de viver independentemente ${ }^{31}$ é uma consequência da transformação da esfera da intimidade, uma transformação liderada pelas mulheres. Nesta leitura, a luta pessoal das mulheres leva a transformações sociais que fazem da vida independente uma opção realista, e efetivamente politiza papéis e relações antes aceitas sem discussão. Nós não negamos que Giddens tenha identificado algo de interesse sociológico neste processo; contrapomos, entretanto, que tal interpretação vai contra as evidências disponíveis. O material sobre a posição socioeconômica e a mobilidade das mulheres ainda é esparso, e a maior parte dele replica pressuposições sobre comportamento econômico e produtivo e seu impacto na vida social feitas por gerações anteriores de pesquisadores ${ }^{32}$. As poucas evidências históricas disponíveis, na verdade, indicam que há uma tendência para mulheres escolherem arranjos de vida independente quando os recursos econômicos e sociais para uma vida independente sustentável se tornam disponíveis, sem levar em consideração as mudanças "revolucionárias" que Giddens discute ${ }^{33}$. Aqui, podemos facilmente - com o apoio da pesquisa histórica - apontar a relação entre contexto socioeconômico e escolha pessoal sem fundir os dois como parte de um único processo. É claro que Giddens reconhece que as chances de vida condicionam as escolhas de vida, mas ele imediatamente cai no voluntarismo quando descreve "sistemas modernos de intimidade sexual e amizade"34. Giddens não vê nenhum problema com esta fusão; a ação é uma característica universal e a priori da vida social, e não precisa de especificação em relação a um efeito dado; tudo que é preciso apontar na estruturação de encontros sociais é que os atores não têm escolha que não seja se reproduzir ${ }^{35}$.

Uma outra dificuldade relacionada persiste na especificação das consequências da exposição de Giddens sobre a reflexividade. Este problema toca de forma importante na relação entre a construção de enunciados teóricos, por um lado, e enunciados

\footnotetext{
${ }^{31}$ Ver Giddens [1991:89-90]. A independência e a autonomia na discussão do casamento significam mulheres vivendo sem homens - de forma alguma apenas uma aberração moderna. Não temos espaço aqui para examinar os conceitos de independência e autonomia da forma que eles merecem, mas sugerimos que o argumento político oferecido por Giddens seria fortalecido significativamente através de uma atenção maior ao conceito de autonomia e à questão do contexto socioeconômico.

${ }^{32}$ Ver Hayes \& Miller [1993].

${ }^{33}$ Agradecemos Mike Savage por nos apontar a direção correta aqui. Ver Sharpe [1991]; Berg [1993]; Savage [1988]. Voltaremos a isto na seção 4.

${ }^{34}$ Giddens [1991:87]. Este comentário aparece depois de uma (breve) discussão sobre as escolhas limitadas de uma mãe solteira negra.

${ }^{35}$ Mas é importante notar que a natureza empírica de qualquer ator reproduzido nunca é especificada por Giddens.
} 
empíricos (ou, pelo menos, “evidenciais”) pelo outro, dentro da síntese analítica que Giddens tenta realizar. A forma mais clara de desenvolver esta questão é comparar o uso de Giddens de tipos diferentes de produtos discursivos na disposição do esquema teórico da estruturação em Modernidade e identidade do eu e $A$ transformação da intimidade. Quando fazemos isto, descobrimos que recursos discursivos diferentes recebem estatutos diferentes no desenvolvimento da descrição da reflexividade do eu e da reflexividade institucional. Alguns tipos de configurações de conhecimento (ou "discursos"), como a análise pós-estruturalista do discurso, são usados para apoiar reivindicações analíticas sobre a natureza da mudança histórica. Entre estes, é notável o uso de Giddens de Foucault na Transformação da intimidade. Aqui, as descrições de Foucault sobre a importância analítica de práticas sexuais, do cuidado de si ou da disciplina social são tomadas como explicações potencialmente rivais dos fenômenos que Giddens busca investigar, e são sujeitas à crítica baseada em leituras alternativas da mesma evidência histórica. Assim, enquanto ele aceita que "Foucault está certamente correto ao afirmar que o discurso se torna constitutivo da realidade social que ele retrata"36, Giddens questiona a análise "de mão única" de Foucault dos regimes de conhecimento-poder, afirmando que o desenvolvimento sexual deve ser visto, pelo contrário, como um fenômeno da reflexividade institucional ${ }^{37}$. Não queremos debater esta leitura de Foucault, ainda que tenhamos vários problemas com ela. Em vez disso, queremos apontar a diferença entre esta leitura teórica e os comentários de Giddens sobre a terapia - que é tratada empiricamente, como indicativa tanto da mudança histórica quanto da forma especificamente "moderna" de autonomia (sexual) tornada acessível pelo fenômeno mencionado anteriormente da reflexividade institucional. E Giddens aceita esta literatura sem questionamentos, mas de forma muito diferente de seu tratamento de Foucault ${ }^{38}$. A mídia terapêutica, de autoajuda e romântica é lida de forma mecanicista, como manifestos pela liberação do eu, ou, em outras palavras, no nível de fatos empíricos ${ }^{39}$. A leitura de Giddens desta mídia faz um paralelo com a

\footnotetext{
${ }^{36}$ Giddens [1992a:28].

${ }^{37}$ Giddens [1992a:28].

${ }^{38}$ A transformação da intimidade adota uma posição explicitamente terapêutica da transformação social. Giddens propõe utilizar a literatura terapêutica e de autoajuda criticamente [Giddens, 1992a:64] mas não oferece crítica nenhuma. O mais perto que ele chega de criticar a terapia ocorre na página 201, quando ele sugere que a terapia "faz vista grossa" à modernidade - dada a intenção de Giddens de desenvolver uma teoria social moderna, o comentário perde qualquer força crítica.

39 Giddens enuncia claramente uma intenção de ler a literatura de terapia e autoajuda "seguindo o 'método documentário' de Garfinkel, como um documento sobre mudanças pessoais e sociais em processo, mas também sintomático delas" [Giddens, 1992a:86n4].
} 
forma de raciocínio que ele afirma ser característica da consciência prática empregada pelos indivíduos na organização de suas identidades. Literaturas, símbolos e representações populares diversas, assim como conhecimentos e tecnologias peritos, são usados rotineiramente, de acordo com Giddens, por todos num processo que efetivamente liberta as relações de âncoras e expectativas externas, preparando assim o caminho para a transformação da intimidade denotada na relação pura ${ }^{40}$. Não é preciso nenhuma análise crítica destas literaturas: a terapia e todos os seus antecedentes psicanalíticos são absorvidos como recursos teóricos; como se a terapia nunca tivesse sido um objeto de interesse das ciências sociais anteriormente; como se o modelo terapêutico não tivesse sido submetido a uma crítica minuciosa - tanto "internamente", por seus próprios adeptos, quanto "externamente", por seus comentadores e aqueles que foram sujeitos à "solução de problemas" terapêutica. É preciso reconhecer que os discursos terapêuticos não têm nenhum estatuto neutro especial na pesquisa e teorização das ciências sociais: eles são produzidos por - e por sua vez reproduzem - conflitos políticos mais amplos em torno de problemas sociais e identidades sociais. Disputas dentro e sobre a terapia trazem as marcas de conflitos sociopolíticos sobre recursos, estratégias legítimas e ilegítimas para lidar com o mal-estar pessoal, assim como contradições culturais sobre modos de expressão do eu ${ }^{41}$. A terapia não pode ser invadida seletiva e não-problematicamente para gerar um modelo de mudança social; ela não é uma caixa de "coisas boas" sem “coisas ruins". Mas Giddens não disponibiliza nenhuma destas divisões e disputas sutis (e barulhentas) para a reflexão. Afirmações sobre sexualidade cujo caráter freudiano é expurgado, pesquisas não representativas e exemplos de experiência pessoal metodologicamente inseguros são reproduzidos para o leitor como se fossem verdades autoevidentes, em vez de documentos problemáticos que requerem exploração conceitual rigorosa e investigação empírica contínua ${ }^{42}$.

\footnotetext{
${ }^{40}$ Ver as discussões sobre dieta e casamento em Giddens [1992a:32, 57]; e a discussão de relações e autonomia em Giddens [1991:95-96]. Voltaremos à questão da relação pura em maiores detalhes abaixo.

${ }^{41}$ Ver a discussão de abordagens terapêuticas a questões políticas na crítica clássica de Pearson da teoria do desvio [Pearson:1975]. Ver também Rojek, Peacock \& Collins [1988:esp. cap. 1]; assim como a crítica generalizada do Estado terapêutico em Zola [1975].

${ }_{42}$ Ver a discussão de Giddens da relação entre o falo, o pênis e a "autointegridade" das mulheres [1992a:154], e sua apresentação da pesquisa de Lillian Rubin [1992:9-12]. Quanto a esta última, Giddens pergunta ao leitor o quanto podemos aprender com uma pesquisa tão pequena, enfocando um grupo social específico numa pequena seção do globo, e responde: "Acho que podemos aprender essencialmente o que precisamos saber para os propósitos deste estudo". Ele então continua, tratando a obra como um indício da mudança sexual enquanto tal, desconsiderando quaisquer fontes alternativas ou pesquisas que pudessem problematizar esta leitura [1992a:12].
} 
Por que estas leituras - de Foucault, por um lado ${ }^{43}$, e de documentos "terapêuticos" e neofreudianos, por outro - divergem tanto? Afinal, tanto a terapia e a mídia romântica moderna estão tão encaixadas na filosofia e na análise quanto os escritos de Foucault na literatura e na estética ${ }^{44}$. O próprio Giddens reconhece que os discursos das ciências sociais rotineiramente entram na vida cotidiana e adquirem, assim, o estatuto de "documentos" de forma muito parecida com o discurso terapêutico e de autoajuda. Qual, exatamente, é a diferença entre um domínio empírico e um teórico na explicação da transformação? Por que as literaturas terapêuticas devem ser vistas como sintomas e recursos da mudança, enquanto os discursos neomarxistas ou pósestruturalistas são construídos como abordagens mais ou (normalmente) menos adequadas para compreender tal mudança?

Esta é uma questão crucial porque ela determina como a própria obra de Giddens deve ser lida. Por exemplo, é claramente possível ler Modernidade e identidade do eu e A transformação da intimidade como meros "documentos" de mudanças sociais impactando atualmente a vida política e social. Em particular, estes livros podem ser lidos como sintomas da maré rampante de neoliberalismos individualistas que está infestando instituições políticas e econômicas globais na era da modernidade tardia. Para substanciar esta leitura, poderíamos recuperar os escritos de Wilhelm von Humboldt sobre o amor comum e a intimidade, ou os escritos de John Stuart Mill sobre a experiência e desenvolvimento do $\mathrm{eu}^{45}$, e apontar para as congruências entre o tratamento de Giddens do surgimento do eu moderno ou da "consciência prática" e as proposições de Friedrich von Hayek tratando do surgimento de uma "ordem espontânea" a partir da complexidade das ações individuais ou sobre a natureza do "conhecimento tácito"46. Assim, elementos de Modernidade e identidade do eu e $A$ transformação da intimidade poderiam então ser construídos como exemplos da intrusão de ideologias políticas problemáticas na análise sociológica. Nosso argumento não é que estes livros necessariamente deveriam ser lidos desta forma - quer dizer, como documentos empíricos de outras transformações sociopolíticas que o autor não

\footnotetext{
${ }^{43}$ E também de Marcuse e Reich, entre outros. Ver Giddens [1992a:cap. 9].

${ }^{44}$ De fato, Modernidade e identidade do eu e $A$ transformação da intimidade são notáveis pela ausência de qualquer discussão da tradição romântica ou de considerações sérias das fontes complexas da terapia moderna.

${ }^{45}$ Cf. Humboldt [1903: vol. I, pp. 106-108]; Stuart Mill [1962:115].

${ }^{46}$ Sobre a ordem espontânea e o conhecimento tácito de regras de conduta, ver Hayek [1979:25-48, passim]. Há muito mais na obra de Hayek sobre a distinção entre sociedades tradicionais e modernas que representa um paralelo com a interpretação de Giddens da transição de sistemas de referência "externos" para "internos".
} 
percebeu. O problema é que parece não haver fundamentos na obra de Giddens para fazer distinções entre domínios teóricos e empíricos - dando a impressão de que tais questões epistemológicas não são importantes - e como consequência, uma leitura neoliberal destas obras se torna plausível. Nós afirmamos que a distinção aparente entre domínios empíricos e teóricos em Modernidade e identidade do eu e A transformação da intimidade reveste uma fusão real de proposições empíricas e teóricas no conceito de Giddens de reflexividade.

Giddens define a reflexividade em dois sentidos distintos: no primeiro, a reflexividade se refere à ação, aquilo que em outros textos Giddens chama de "monitoração reflexiva da ação" "47; no segundo sentido, a reflexividade se refere a conhecimento e significado $^{48}$. Esta distinção persiste na análise de Giddens da vida social moderna, apesar de sua tentativa de suplantar a primeira pela segunda em Modernidade e identidade do $e u^{49}$. O conceito é utilizado para dar conta tanto da construção de estilos e relações pessoais autônomas no nível da consciência prática cotidiana, quanto da apropriação de significados e conhecimentos no nível da consciência discursiva institucionalizada ${ }^{50}$. A reflexividade institucional é a força motriz por trás do "rompimento cada vez mais radical das instituições da modernidade com a tradição, e a intrusão crescente de seus sistemas de controle através de fronteiras préexistentes da ação social" ${ }^{\prime 51}$. Por sua vez, este rompimento leva a um sequestro institucional da experiência, que compreende uma forma de "repressão" ou "esquecimento" de modos de ação tradicionais ou alternativos.

Se a reflexividade institucional pode tomar a forma de um "esquecimento", então ela deve significar uma operação da consciência discursiva ${ }^{52}$. Isto coloca um problema chave para a teoria sociológica da reflexividade que Giddens desenvolve. Já que as instituições são mantidas por indivíduos que possuem uma consciência prática, e, assim, monitoram suas próprias ações rotineiramente, parece haver apenas dois modos para as instituições poderem apropriar ou sequestrar áreas da experiência cotidiana. Um

\footnotetext{
${ }^{47}$ Ver Giddens [1990:36-38].

48 "no sentido que termos apresentados para descrever a vida social rotineiramente entram nela e a transformam (...)" [Giddens, 1992a:28-29].

${ }^{49}$ Giddens [1991:20].

${ }^{50}$ A distinção entre consciência prática e discursiva é uma distinção entre conhecimento tácito (conhecimento utilizado na vida cotidiana de forma irrefletida) e conhecimento disponível para a reflexão cognitiva.

${ }^{51}$ Giddens [1992a:175].

${ }^{52}$ A consciência prática, por definição, não tem conteúdo discursivo, e por isso não é capaz de "esquecer" ou "reprimir" nada.
} 
seria em termos de motivações e determinações externas influenciando os conhecimentos e comportamentos dos atores ${ }^{53}$; o outro surgiria de alguma característica intrínseca da relação entre a consciência prática cotidiana e a consciência discursiva institucionalizada $^{54}$. A teoria de Giddens não é adequada a nenhuma destas proposições, já que a primeira sugere a hipótese empírica de que referentes externos são mais importantes na determinação da ação do que o mero fato da reflexividade institucional permitiria, enquanto a segunda sugere a hipótese teórica de que a consciência prática é cúmplice de sua própria apropriação discursiva.

Esta questão é crucial porque a teoria de Giddens da reflexividade institucional sustenta sua teoria da repressão institucional, que por sua vez forma um mecanismo causal na remoralização da vida social, e, assim, das possibilidades de política da vida de transformação social. A repressão institucional é o aspecto "estrutural" do sequestro/apropriação da experiência - a separação da experiência de questões morais e existenciais - que resulta da socialização da natureza causada por sistemas peritos, por exemplo, a subjugação do ambiente através da engenharia genética ou das tecnologias de controle de natalidade ${ }^{55}$. O problema com esta linha de argumentação é que Giddens não fornece nem uma análise empírica das estruturas institucionais necessárias para incorporar a informação reflexivamente, nem as ligações teóricas entre vigilância, potencialidades, industrialismo e o "ambiente criado" e o capitalismo (que podem ser vistas como determinantes coletivos da reflexividade institucional). Assim, aspectos da socialização da natureza e uma consequente remoralização da vida social podem ser vistos na ascensão do ambientalismo em muitos países industrializados ${ }^{56}$ - um fenômeno que teve um impacto enorme em muitos projetos nacionais e pan-nacionais. Entretanto, tal "remoralização" não teve o mesmo impacto nas experiências de todas as pessoas: a criação de devastações tóxicas em nações industrialmente desenvolvidas, a

\footnotetext{
53 Tais como ideologias, interesses de classe ou mesmo a "compulsão monótona da necessidade econômica".

${ }^{54}$ Em outras palavras, alguma dimensão da composição mental dos seres humanos e a efetivação desta composição em estruturas e sistemas existentes, um argumento muito próximo da determinação por aquilo que, em outros contextos, é chamado de "natureza humana". É interessante que o elogio de Dennis Wrong a este tema da natureza humana seja reproduzido na contracapa de Modernidade e identidade do $e u$.

${ }^{55}$ Ver as discussões sobre o controle de natalidade e a sexualidade plástica em Giddens [1992a:26-28; 179-181]. Também a discussão mais geral da socialização da natureza em Giddens [1991:144-145; 164$169]$.

${ }^{56}$ Com "ambientalismo" nos referimos ao surgimento de questões ambientais em arenas políticas (como legislaturas), econômicas (como mercados) e culturais (como meios de comunicação), assim como a novos movimentos sociais definidos através de protestos e ações ambientais.
} 
transferência de industrias tóxicas, assim como o envio de lixo tóxico, para nações subdesenvolvidas ou endividadas, a fuga do capital para regiões econômicas desreguladas, e o ataque a regulações de saúde e segurança em nações ocidentais e não ocidentais sugerem que processos de "sequestro" e "repressão" não unem o mundo numa única identidade global, mas sim o dividem precisamente em termos de experiências reais ${ }^{57}$.

Ao se mover do abstrato para o concreto, Giddens transita entre uma análise da reflexividade institucional da modernidade e uma análise de "arenas de sequestro (experiencial)" para especificar os contornos do projeto do eu reflexivo. Piorando ainda mais o problema da especificação, seu argumento não especifica como os mecanismos da reflexividade diferem em cada nível, e que implicações estas diferenças têm para a formação e persistência de movimentos políticos e oportunidades socioeconômicas. É um tanto simplista propor que a modernidade une indivíduos, instituições, blocos socioeconômicos e redes geopolíticas numa única apropriação transformadora de ambientes subjetivos, institucionais e naturais. Pois dentro dos confins de tal argumento, o "eu" cujo projeto é a justificação do argumento de Giddens desaparece, e nos resta um exame estrutural do projeto reflexivo de uma modernidade sem eu. Isto sugere a crítica mais geral de que a dinâmica da modernidade não está ligada o bastante a suas aglomerações institucionais. Por sua vez, esta falta de ligação entre as duas dimensões enfraquece a teoria da reflexividade, que é expressamente a chave da transformação da vida social moderna. O esquema teórico que Giddens busca desenvolver é efetivamente esvaziado.

A análise de Giddens da modernidade oferece prospectos e problemas para a teoria social contemporânea. A decisão de lidar com a modernidade em termos de “aglomerações institucionais", a ênfase na incorporação reflexiva do autoconhecimento em operações institucionais, e a avaliação das implicações de processos globais-locais no desencaixe das relações sociais dirigem a atenção da sociologia para as relações complexas entre conhecimento, ação e organização nas sociedades industriais modernas. Entretanto, nós notamos que a tese de Giddens sofre de uma ausência de conceitos conectores no retrato das relações entre o sujeito (ou eu) da mudança e seus

\footnotetext{
${ }^{57}$ Cf. Davis [1986; 1993]; Kopinak [1993].
} 
correlatos institucionais. Esta ausência é ainda mais pronunciada no tratamento de Giddens da natureza mediada da experiência nas condições de modernidade $\operatorname{tardia}^{58}$.

\section{A mediação da experiência}

“Ao contrário [de 'sistemas mundiais' pré-modernos] a modernidade tardia produz uma situação em que a humanidade em alguns aspectos se torna um 'nós', enfrentando problemas e oportunidades onde não existem 'outros" $" 59$.

O humanismo absoluto de Giddens compreende uma tentativa de universalizar as molduras experienciais da modernidade e estabelecer um sujeito da ação e compreensão social contra o "outro" descentrado do pós-estruturalismo. Ao construir este argumento, Giddens invoca a noção de uma reorganização psíquica profunda que resulta em parte da dependência crescente de sistemas abstratos, e em parte do crescimento de sistemas de mediação experiencial. Queremos focar aqui no segundo destes fenômenos. Seus problemas podem ser divididos em duas partes: os problemas analíticos associados com o argumento da forma em que ele é apresentado atualmente, e os problemas substantivos e teóricos resultantes daquilo que Giddens não considerou sob o conceito de mediação experiencial.

$\mathrm{O}$ argumento de Giddens sobre a mediação da experiência foca quase totalmente as relações entre meios dominantes de comunicação de massa - o texto impresso e o sinal eletrônico - e a recepção e incorporação psicológica de suas mensagens pelos indivíduos. De acordo com Giddens, a mídia moderna permite que a massa da sociedade experimente fenômenos de grande diversidade em locais espaço-temporais amplamente separados - o que tem os efeitos psicológicos de diminuir o papel do "lugar" na constituição da identidade ${ }^{60}$ e de "atenuar" e "enriquecer" ao mesmo tempo "sensibilidades existenciais"

Reivindicações como estas precisam ser baseadas em análises reais de processos mediados de constituição da identidade - processos de aquisição de gênero, expressão sexual, demarcação racial, estipulação de interesses de maiorias e minorias, e criação de

\footnotetext{
${ }^{58}$ Giddens [1991:23-27, passim].

${ }^{59}$ Giddens [1991:27].

${ }^{60}$ Giddens [1991:146-147].

${ }^{61}$ Giddens [1991:168-169].
} 
invalidezes, entre outros - que Giddens não fornece. Mesmo sem elas, Modernidade e identidade do eu fornece apenas uma compreensão muito limitada da análise da mídia uma área de investigação sociológica em que conceitos como os de "ideologia", "discurso" ou "texto" têm um papel crucial. Tais conceitos persistem em estudos de mídia precisamente porque a pesquisa mostrou que as plateias não representam uma única "massa" (passiva) cujas interpretações psicológicas podem ser "lidas" a partir das formas de tecnologias particulares. Trabalhos acadêmicos a partir dos anos $1970^{62}$ persuadiram os sociólogos a tomar cuidado com teorias que afirmam inferir efeitos nas plateias a partir de leituras de causa única. No entanto, esta estratégia é a chave do engajamento de Giddens com processos de mediação da experiência. Ela é claramente visível em sua afirmação de que a modernidade fornece um "mundo único" e um "esquema unitário da experiência" ${ }^{63}$, e é derivada de uma escassez de ferramentas teóricas para conceber as relações complexas entre autonomia e coerção, e atividade e passividade em interações mídia-plateia. Questões sobre a apropriação social da mídia e lutas quanto a conteúdo, significado e disseminação são características endêmicas da reprodução cultural moderna, e precisam ser reconhecidas.

É igualmente importante considerar aquilo que Giddens omitiu de sua análise da mediação experiencial. Ao buscar rejeitar as análises pós-estruturalistas da alteridade e de subjetividades descentradas, Giddens corre o risco de negligenciar algumas percepções cruciais que ajudariam a fundamentar mais concretamente o exame teórico das transformações da modernidade - em particular, as conexões entre processos micro e macrossociais. O pós-estruturalismo oferece a percepção importante de que aquilo que é omitido é tão significativo na construção do sentido e da compreensão quanto aquilo que é incluído. Isto é especialmente importante em relação à mídia moderna, já que textos supostamente inclusivos operam através do banimento da diferença e da alteridade para as margens do significado. Filósofos pós-estruturalistas (como Derrida e Foucault), e teóricos e pesquisadores sociais que aplicam perspectivas pósestruturalistas $^{64}$, apontam para a absoluta impossibilidade de um mundo em que não existam "outros". Cada vez mais publicações apontam para o papel da "alteridade" no favorecimento da constituição do conhecimento moderno. A alteridade é um componente central na fabricação de identidades socioculturais. Para alguns, o "outro"

\footnotetext{
${ }^{62}$ Cf. CCCS [1980]; Gurevitch, Bennett, Curran \& Woolacott [1982]; Thompson [1991]; Lull [1990].

${ }^{63}$ Giddens [1991:5].

${ }^{64}$ Spivak [1987]; Said [1985].
} 
compreende a pedra de toque do desenvolvimento sociopolítico do Estado moderno ${ }^{65}$. Não é necessário adotar todos os argumentos do pós-estruturalismo para apreciar a importância deste ponto para a análise sociológica e política.

Hall $^{66}$, por exemplo, traça o surgimento da identidade histórica do ocidente em termos do encontro entre "o ocidente e o resto" ["the West and the Rest"], afirmando que este encontro serviu para gerar um discurso da identidade ocidental como moderna, esclarecida, progressiva, civilizada e libertadora:

“Sem o resto (ou seus próprios 'outros' internos), o ocidente não teria sido capaz de se reconhecer como o ápice da história humana. A figura do 'Outro', banido para a borda do mundo conceitual e construído como o oposto absoluto, a negação de tudo que o ocidente representava, reapareceu no centro do discurso da civilização, refinamento, modernidade e desenvolvimento no ocidente. 'O Outro' era o lado 'negro' - esquecido, reprimido e negado; a imagem oposta do esclarecimento e da modernidade" ${ }^{\circ 7}$.

Nas próprias raízes históricas da identidade ocidental moderna, de acordo com Hall, persiste a "alteridade": a base genealógica da identidade do eu postulada por Giddens está imbuída por marginalizações, opressões, divisões e oposições. E estas categorias constituintes da identidade não são apenas de interesse histórico. Hall investiga as relações entre identidade cultural e a diáspora, referindo-se à dispersão de africanos através do globo: uma dispersão tão crucial para a formação de uma identidade política-cultural negra quanto é para uma identidade política-cultural branca ("ocidental"), mesmo quando estes processos constituintes da identidade seguem direções diferentes, e empregam materiais diferentes para sua realização ${ }^{68}$. Identidades raciais são constituídas em parte através de uma história de relações imperialistas, cujo legado permeia instituições sociopolíticas e práticas culturais contemporâneas ${ }^{69}$. Experiências racializadas são mediadas não apenas através da mídia de massa, mas também em encontros entre grupos étnicos, o sistema legal e o Estado; por exemplo, no impacto de leis de imigração e regras de residência, ou do policiamento diferenciado de comunidades negras e brancas. A discriminação disseminada enfrentada por negros afeta todos os aspectos da experiência - tanto "negra" quanto "branca" - ou diretamente

\footnotetext{
${ }^{65}$ Bauman [1990].

${ }^{66}$ Hall [1992].

${ }^{67}$ Hall [1992:314].

${ }^{68}$ Hall [1990].

${ }^{69}$ Ver Thompson [1993]; Solomos [1991]; Young [1990]; Gilroy [1987]; Braham, Rattansi \& Skellington [1992].
} 
através de formas de institucionalização mais ou menos repressivas, ou mais indiretamente, através de discursos de identidade circulados por meios de comunicação. O retrato de Giddens do caráter mediado da experiência não fornece ferramentas para entender estes fenômenos. Mesmo se sua análise focasse apenas a mídia, os problemas não diminuiriam, já que a maioria dos estudos de mídia sobre esta questão demonstra que tanto a forma quanto o conteúdo são racializados ${ }^{70}$.

Observações similares precisam ser feitas em relação à interseção de raça, sexo, classe e cultura. Enloe, desenvolvendo uma política internacional feminista, chama nossa atenção para as interações de micropráticas e macroestruturas, usando a conexão pessoal-política para estabelecer as identidades diferenciais que são geradas nos encontros entre banqueiros, diplomatas, turistas e outros ocidentais, e culturas do "terceiro mundo". Sua pesquisa mostra como micropráticas de consumo ou uso de mídia e mesmo do turismo estão completamente implicadas nas macrodivisões entre grupos sociais racializados e sexualizados num contexto internacional. Enloe aponta para a crescente indústria internacional do sexo, e seu impacto cultural desigual sobre mulheres e crianças em países do terceiro mundo, muitas das quais se juntam a um mercado de trabalho cada vez maior ao redor de uma indústria do sexo que serve para construir identidades culturais inclusivas e exclusivas ${ }^{71}$.

Aceitar que identidades modernas são tanto inclusivas quanto exclusivas, que elas consistem de assimilações e rejeições, e que o eu persiste nas fronteiras dos outros e através delas não leva necessariamente à análise sem sujeitos que Giddens busca rejeitar. Teorias antirracistas, pós-imperialistas e feministas problematizam a noção de um "nós" unitário de formas que enfatizam a importância da consciência, hábitos e interesses de atores sociais particulares.

A partir destas várias análises, podemos concluir que a formação de uma identidade "moderna" (seja inicial ou tardia) é irremediavelmente mediada por encontros "entre o ocidente e o resto" como dois lados da experiência moderna: ambos estão envolvidos na criação um do outro. A experiência é mediada não apenas por

\footnotetext{
${ }^{70}$ Ver Troyna [1981; 1987].

${ }^{71}$ Enloe [1989]. Entre muitos outros exemplos relevantes, Enloe examina a relação exótica/erótica nas apreensões de culturas do leste asiático, seu impacto socioeconômico nas vidas de mulheres do leste asiático em sua permeação através de um grande conjunto da mídia cultural ocidental. Os vários atores desta economia sexual só podem ser descritos como constituindo um único "nós", ou compartilhando os meios e recursos necessários para projetos modernos do eu, no uso mais não-sociológico desses termos.
} 
aquilo que está presente no mundo rotineiro do indivíduo, mas também por aquilo que é apresentado e ocultado pelas interações entre o eu e fatores institucionais. A formação de identidade é um processo em que a manufatura da diferença e da alteridade está completamente implicada. O retrato de campos unificados da experiência na obra recente de Giddens atenua a marginalização, supressão e exílio de grupos específicos da construção de identidades.

\section{O problema do voluntarismo: gênero e a relação pura}

“A intimidade implica numa democratização em grande escala do domínio interpessoal, de forma completamente compatível com a democracia na esfera pública (...) As mudanças que agora afetam a sexualidade são realmente revolucionárias, de forma muito profunda" ${ }^{\text {72 }}$.

Até agora, examinamos o "projeto do eu" de Giddens em relação à teoria da estruturação e ao conceito central de reflexividade, e em relação ao entendimento de Giddens da mediação da experiência na sociedade moderna. Em ambos estes casos, observamos que o esquema proposto não tem a elaboração teórica necessária para estabelecer relações claras entre significados e ações subjetivos por um lado, e os contextos estruturais dentro dos quais eles são realizados pelo outro lado. Quando nos movemos para o nível pessoal (ou micro) do esquema, omissões conceituais similares se tornam aparentes. Em particular, afirmamos que o emprego de Giddens do conceito da "relação pura" tem uma desavença com um voluntarismo mais profundo contido na posição teórica proposta em Modernidade e identidade do eu e A transformação da intimidade. Além disso, propomos que este voluntarismo enfraquece a descrição de Giddens da conexão entre a relação pura e a democratização, que está ela própria baseada numa análise insustentável do poder.

Antes de investigarmos o voluntarismo e a relação pura, é importante apontar que o conceito de "relação pura" é expresso como um tipo ideal" ${ }^{73}$. Isto é importante porque é a forma que Giddens constrói seu tipo ideal que sublinha seu impulso voluntarista. Se o propósito do tipo ideal é desenvolver um modelo que, apesar de não corresponder à experiência fenomenal, serve como uma ferramenta contra a qual dados

\footnotetext{
${ }^{72}$ Giddens [1992a:3].

${ }^{73}$ Ver Giddens [1991:89].
} 
podem ser avaliados ou argumentações podem ser esclarecidas, nossa posição é que este tipo ideal em particular não é útil, porque Giddens representa erroneamente a dinâmica institucional, experiencial e pessoal em que as relações de gênero estão envolvidas. Consequentemente, a relação pura não consegue desempenhar o papel teórico designado para ela. Em Modernidade e identidade do eu e A transformação da intimidade, a relação pura é o local da "transformação da intimidade" - a interseção entre o local e o global - onde o ethos do crescimento do eu que acompanha a transformação da intimidade age como a espora da remoralização da ação política na modernidade tardia, estabelecendo as condições para a democratização da vida pessoal e pública ${ }^{74}$. Para explorar esta interseção, focaremos nossa discussão em três das características distintivas que Giddens designa para a relação pura.

De acordo com Giddens, a relação pura contém um conjunto de "elementos centrais" que são característicos de relações íntimas entre amantes hetero e homossexuais, ou entre amigos muito próximos ${ }^{75}$. Citando o Relatório Hite, Giddens descreve o desconforto de uma mulher com sua relação (heterossexual), e comenta que "poderíamos concluir que relações de gênero deveriam ser a preocupação principal aqui" 76 . Giddens continua: "sem negar a importância destas características, eu quero focar outras coisas" ${ }^{, 77}$. O gênero, nesta construção, não é um dos elementos centrais da relação pura. Esta conclusão nos confunde, já que ela requer que os leitores pressuponham que relações heterossexuais - ou homossexuais - não são intrinsecamente sexualizadas. Tal confusão no coração do conceito de uma "relação pura" é transmitida para cada um de seus elementos centrais. Como mostraremos abaixo, o conceito de Giddens não tem nenhuma vantagem necessária, e contém algumas desvantagens claras. Se o gênero fosse considerado intrínseco a relações entre homens e mulheres, o tipo ideal teria um aspecto muito diferente. É esta dimensão que desejamos perseguir em nossa discussão.

O primeiro elemento central da relação pura é que "em contraste com as ligações pessoais próximas em contextos tradicionais, a relação pura não está ancorada em condições externas da vida social e econômica - ela, por assim dizer, flutua

\footnotetext{
${ }^{74}$ Giddens [1992a:188].

${ }^{75}$ Giddens [1991:89-98].

${ }^{76}$ Giddens [1991:89].

${ }^{77}$ Ibid.
} 
livremente" ${ }^{78}$. Esta falta de referencialidade situacional leva diretamente ao segundo elemento central: a relação é mantida para a satisfação emocional mútua derivada dela, e é neste sentido que a relação é "pura",79. Problemas entre os parceiros ameaçam a própria relação, e ela é "muito difícil de 'empurrar com a barriga', como é possível fazer numa relação social dominada por critérios externos" ${ }^{\prime 80}$. Giddens ilustra este ponto notando que, apesar das mulheres estarem se desvencilhando do casamento em grandes números, elas continuam a procurar relações satisfatórias. Aqui ele cita uma mulher:

"De alguma forma que eu ainda não consigo encontrar as palavras, o amor romântico contém a chave para minha identidade - para me descobrir, meu ser interior" ${ }^{\prime \prime 1}$.

Giddens reconhece que há dificuldades para sustentar a relação pura, mas:

"as dificuldades de encontrar e continuar uma relação satisfatória em parte têm a ver com problemas de assimetrias de amor e gênero; mas elas também têm a ver de forma muito substancial com os esforços intrínsecos à relação pura. As sensações de 'nunca estar satisfeito' com a relação, descritas pela entrevistada citada anteriormente, refletem as dificuldades inerentes à criação ou manutenção de uma relação onde há equilíbrio e reciprocidade, satisfação para ambos os parceiros, entre o que cada um traz para o laço e o que cada um recebe dele" ${ }^{\prime 2}$.

Esta discussão ilustra precisamente as dificuldades de tratar o gênero fora dos “elementos centrais" da relação pura. Não duvidamos que podemos observar mudanças nas relações. Mas o casamento e outras relações heterossexuais envolvem homens e mulheres, identidades totalmente sociais e que ainda estão numa relação hierárquica entre si. É por isso que a igualdade ainda é uma questão de lutas contínuas: as relações de gênero são imediata e intimamente estruturadas por relações de poder. O poder afeta e permeia todos os aspectos das relações heterossexuais, como uma quantidade respeitável de trabalhos vem demonstrando há algum tempo ${ }^{83}$.

Tomemos a afirmação de que, cada vez mais, as relações não estão ancoradas por fatores econômicos e sociais externos, flutuando livremente. A noção de uma

\footnotetext{
78 Ibid.

${ }^{79}$ Giddens [1991:90].

${ }^{80}$ Ibid.

${ }^{81}$ Giddens [1991:91].

${ }^{82}$ Ibid.

${ }^{83}$ Cf. Butler [1990]; Smart \& Smart [1978]; Delphy [1984]; Sassoon [1987]; Cocks [1989]; Risman \& Schwarz [1989]; Perelberg \& Miller [1990]; Schneider [1991]; Delphy \& Leonard [1992].
} 
relação que flutua livremente implica uma quantidade de escolha considerável na negociação de seus termos. A escolha sobre a conduta de relações contemporâneas varia, muitas vezes de acordo com aqueles mesmos referentes externos que Giddens afirma terem se tornado tão mais fracos em seu poder sobre a ação individual. Por exemplo, pesquisas mostram que as estruturas de relações em grupos étnicos minoritários no Reino Unido e em outros lugares diferem de forma significativa das estruturas operando nas populações etnicamente majoritárias. Estas diferenças surgem em parte de referentes operando na cultura minoritária, e em parte de referentes impostos sobre essa cultura pela maioria política e economicamente dominante ${ }^{84}$. Aqui, como em outros lugares, a análise de Giddens não deixa espaço para os impactos diferenciais de processos modernizadores em grupos sociais reais, parecendo em vez disso propor que a modernidade inunda a experiência como uma grande onda, afetando a todos essencialmente da mesma forma.

Similarmente, se considerarmos a escolha de mudar uma relação, precisamos reconhecer que oportunidades e recursos para causar a mudança não são distribuídos igualmente entre parceiros heterossexuais: o sexo importa. Por exemplo, várias análises feministas apontam para o fato de que mulheres não são capazes de abandonar relações tão facilmente quanto homens. Primeiro, as consequências econômicas da separação ou divórcio não são experimentadas da mesma forma por homens e mulheres. Apesar de homens sustentando duas famílias poderem ter problemas financeiros, mulheres sofrem uma dificuldade financeira desproporcional devido a suas posições no mercado de trabalho e a falta de creches que elas são capazes de $\operatorname{pagar}^{85}$. A pobreza feminina é bem documentada ${ }^{86}$, e significa que condições econômicas colocam a maioria das mulheres numa relação subordinada aos homens.

Além do mais, homens usam a violência como um meio de controlar mulheres. A violência contra mulheres é muito mais frequente do que imaginávamos uma década atrás, e em vez de indicar uma forma de relação patológica ou atípica, autoras feministas afirmaram que a violência de homens contra mulheres é uma norma social derivada de

\footnotetext{
${ }^{84}$ Cf. Anthias \& Yuval-Davis [1993:esp. cap. 4]; Mama [1992]; Ballard [1982]; Oakley [1982]. Não podemos entender como Giddens pode reconhecer a mesma questão (e citar Ballard) em seu livro-texto básico de sociologia, e ainda assim não levar em conta o problema que ele traz para a teoria geral que ele desenvolve. Ver Giddens [1992b:395].

${ }^{85}$ Apesar de estudos numerosos tratando exatamente deste problema, Giddens só toca em questões de recursos na página 195 de $A$ transformação da intimidade, apenas nove páginas antes do final do livro. Cf. Walby [1986]; Smart [1984]; Glendinning \& Millar [1992].

${ }^{86}$ Ver Glendinning \& Millar [1992].
} 
pressuposições culturais arraigadas sobre a inferioridade das mulheres em relação aos homens e sua falta de poder nas esferas econômica, política e familiar. A violência contra mulheres frequentemente começa quando o primeiro arroubo de paixão e romance passou, e as mulheres desafiam a definição da situação de seus parceiros, desafiando assim a autoridade masculina ${ }^{87}$. Algumas autoras feministas desenvolveram a conexão entre violência masculina e poder masculino para demonstrar que a violência faz parte de uma estratégia com a qual os homens lutam para manter e reforçar seu domínio sobre as mulheres. Desta perspectiva, a relação entre os sexos é vista como uma relação de luta pelo poder, com a sexualidade feminina sendo uma área chave sobre a qual os homens buscam exercer controle.

É, assim, legítimo afirmar que a vitimação de mulheres por homens ocorre simplesmente porque elas são mulheres. Seu sexo coloca as mulheres, enquanto categoria, numa relação desigual com os homens, enquanto categoria, com as relações pessoais, o casamento, a família, os mercados de trabalho, os processos legais, e assim por diante, enraizados numa estrutura de dominação e subordinação. Isto pode ser visto como um componente sistêmico das conexões pessoais-institucionais da modernidade tardia. Em outras palavras, os processos modernizadores identificados por Giddens - o distanciamento espaço-temporal, o desencaixe e a ascensão de sistemas abstratos - são em aspectos importantes sexualizados a priori. Se é verdade que estes processos são sexualizados, então não podemos concluir que as transformações sociais da intimidade levam à emancipação - já que estas transformações serão estruturadas pelas desigualdades que as identidades de gênero modernas significam ${ }^{88}$.

As mulheres experimentam, de várias formas tanto no nível público quanto no privado, formas abertas ou sutis de controle sobre o seu comportamento, o que coloca a desigualdade sexualizada do poder no centro das relações pessoais. É por isso que as mulheres "nunca estão satisfeitas" nas relações, e a evocação do amor romântico

\footnotetext{
${ }^{87}$ Cf. Dobash \& Dobash [1992]. Não é que Giddens não reconheça a violência e o abuso em relações (ver, por exemplo, Giddens [1992a:189]); nossa crítica aqui é que estes fenômenos são considerados extrínsecos à forma de relação (pura) surgindo em condições modernas. Giddens foca exclusivamente a mudança de relações, mas há grandes evidências de que a violência e o abuso podem ser vistos como elementos de continuidade na vida moderna. Tais continuidades são igualmente importantes na análise sociológica tanto de relações pessoais quanto de ordens globais.

${ }^{88}$ Depois de reivindicar em Modernidade e identidade do eu e $A$ transformação da intimidade que transformações íntimas anunciam o potencial para a política de emancipação, no final de $A$ transformação da intimidade Giddens afirma que o resultado pode não ser tão otimista quanto sua análise sugere. Ver o contraste entre a discussão da emancipação sexual (Giddens [1992a:182]) e relacionamentos sexuais (Giddens [1992a:196]).
} 
certamente não as ajudará. A busca do amor romântico (Modernidade e identidade do $e u$ ), ou mesmo do amor confluente (A transformação da intimidade) ${ }^{89}$, e a forma da "relação pura" que eles implicam, são um beco sem saída enquanto um meio para a "realização do eu", e é surpreendente que Giddens rejeite a tese do "amor como ideologia" tão facilmente. As mulheres são encorajadas, através dos vários meios de comunicação que Giddens descreve, a construir identidades pessoais dentro de um discurso do amor - um discurso que contém um conjunto de pressuposições sobre mulheres que relega suas experiências a uma posição psicossocial inerentemente contraditória. Como Firestone afirmou há algum tempo, não pode haver nenhuma relação de amor satisfatória na prática até que as mulheres não sejam mais subordinadas aos homens, tanto econômica quanto culturalmente. Dentro de relações de poder desiguais, o "amor" serve apenas para mistificar a falta de poder das mulheres, tornando-as assim incapazes de identificar a fonte de seu descontentamento.

Um problema semelhante surge com o terceiro "elemento central" da relação pura de Giddens: sua "organização reflexiva” através dos vários meios de comunicação que proliferam com conselhos sobre o gerenciamento de relações. Giddens não leva em conta a estrutura sexualizada de grande parte deste material. Vejamos, por exemplo, a publicação mensal britânica Cosmopolitan, que tem uma base de leitores ampla, alvejando mulheres de carreira independentes. Dando conselhos a mulheres sobre como tornar "sensacional" o sexo heterossexual bom, a "lista de perícias" inclui o seguinte conselho:

"Esta mulher sabe como transformar qualquer ambiente, mesmo o balcão da cozinha, no pano de fundo para sexo sensacional, e mantém as superfícies livres, limpas e prontas para qualquer ação espontânea" 90 .

Isto é tão representativo da literatura contemporânea sobre relações sexuais quanto o material que o próprio Giddens cita. É uma literatura que coloca sobre as mulheres a responsabilidade do serviço doméstico e emocional nas relações. Através de tais textos e sistemas peritos, as identidades das mulheres são construídas de acordo

\footnotetext{
${ }^{89}$ Giddens contrasta o amor romântico com o confluente ao redor do eixo da igualdade: "o amor romântico é totalmente enviesado em termos de poder", enquanto "o amor confluente pressupõe igualdade no toma-lá-dá-cá emocional" (Giddens [1992a:62]). Já que este é o único tipo de análise do poder contido em Modernidade e identidade do eu e $A$ transformação da intimidade, é difícil ver como uma sociologia das relações modernas poderia ser desenvolvida a partir dessas obras sem negar ou abandonar desigualdades estruturais.

${ }^{90}$ Cosmopolitan, março de 1992, p. 214.
} 
com uma visão particular do "feminino", que por sua vez é entranhada profundamente nas práticas sociais. A reprodução destas práticas é demonstrada por estudos de adolescentes e jovens em que papéis masculinos e femininos tradicionais são realizados $^{91}$. Apesar dos melhores manuais de terapia poderem evitar estes estereótipos, eles não podem fornecer um meio de escapar deles, porque não têm nenhuma análise integrada de dinâmicas de poder.

Reconhecer o impacto do poder sobre relações reais enfraquece seriamente os "elementos centrais" contidos no tipo ideal da relação pura. Escolhemos focar três deles, mas problemas semelhantes podem ser identificados com os outros elementos que Giddens identifica - comprometimento, intimidade, e solução significativa de problemas $^{92}$ - todos pressupondo um grau de estatuto igual numa relação que não pode existir sem antes desmantelar os poderes que a definem.

Nos tipos de sociedades complexas e multiculturais que Giddens enfatiza, o poder se intersecciona com as relações de muitas formas diferentes. Grupos diferentes viveram histórias culturais diferentes: a permeabilidade, por exemplo, da literatura romântica ou de manuais terapêuticos é desigual, circulando em agrupamentos culturais específicos e ligados a histórias que são mais parciais do que Giddens admite. O confinamento e regulação destes recursos, e os modos de autocompreensão que eles promovem, podem servir para enfraquecer tanto quanto para favorecer processos de autodesenvolvimento. Divisões entre católicos e protestantes na Irlanda; entre sérvios e muçulmanos na antiga Iugoslávia; hindus e muçulmanos na Grã-Bretanha; e colonos e aborígenes na Austrália, no Canadá e nos EUA são divisões de recursos e de posição política e econômica, assim como modos de engajamento cultural. A inserção de conceitos liberais ocidentalizados do eu em culturas diferentes é uma questão de poder tanto quanto de transformações da intimidade num nível público ou privado.

Na ausência de uma análise do poder, os esquemas da relação pura, crescimento do eu e democratização causados pelas mudanças descritas na obra recente de Giddens

\footnotetext{
${ }^{91}$ Aggleton [1987]; Griffin [1985]; Willis [1990].

92 Giddens [1991:94-97]. Mais uma vez, Giddens reconhece a existência do poder, mas rejeita uma abordagem que coloque o poder e a diferença no núcleo de sua análise. Ver Giddens [1992a:173] sobre a afirmação que "o poder, enquanto tal, não faz nada"; ver a afirmação ainda mais estranha de que a política da vida se refere a uma forma de poder que é gerativa e não-hierárquica, girando em torno de uma política de escolha (Giddens [1991:214]). Se a ordenação de escolhas pessoais (e, portanto, sua política) no mundo moderno é hierárquica, por que o poder associado com ela não é ordenado de forma semelhante?
} 
se decompõem numa versão de voluntarismo que enfatiza decisões pessoais, motivações subjetivas e ações privadas ${ }^{93}$. Nos reinos da sexualidade, emoções e da relação pura em geral, o problema político se volta ao desenvolvimento de um esquema ético para a conduta e para a avaliação e justificação de comprometimentos e valores ${ }^{94}$. Este voluntarismo tem ramificações para a política da vida. Elas são derivadas da afirmação de Giddens que a transformação da intimidade sintetiza a relação entre o local e o global: a relação pura - enquanto tipo ideal - denota esta transformação causada por e dentro da modernidade. O que falta nesta formulação é algum reconhecimento de quem, afinal, está fazendo a transformação e como eles a fazem. Giddens propõe que a transformação ocorre através de divisões sociopolíticas e econômicas - não é uma transformação apenas das classes sociais privilegiadas. Mas tal noção vaga de "transformação" é claramente inadequada como a base de uma sociologia da mudança social. Ela evita todas as perguntas interessantes sobre a intimidade e mudanças (ou estase) em relações hetero e homossexuais, propondo uma psicologia social livre de quaisquer variáveis sociais, econômicas ou culturais. Como afirmamos acima em relação à desigualdade entre os sexos, todos os "elementos" centrais da relação pura são banhados pelo poder. Certamente. investigar o impacto do poder e da diferença sobre a conduta, forma e progresso de todos os tipos de relação, "puras" ou não. é uma tarefa para uma sociologia crítica.

Em vez de se engajar nesta atividade complexa mas sociologicamente sofisticada, Giddens prefere se concentrar nas propriedades abstratas de relações potenciais criadas voluntariamente no contexto de uma diversidade de possibilidades. Ele ignora o fato que a diversidade de escolha e a possibilidade de seu exercício são distribuídas desigualmente através das redes institucionais e interpessoais que modelam os contornos da vida social moderna (alta ou baixa). Se, como afirmamos, o poder e a diferença são intrínsecos a relações heterossexuais, e se as possibilidades de desenvolver e controlar essas relações são divididas desigualmente, então qualquer “política da vida" emergente precisa exibir tais características. Assim, a ligação entre a transformação da intimidade, o ethos do crescimento do eu e os movimentos políticos

\footnotetext{
93 "[Esta política da vida] só pode ser obtida se as pessoas forem capazes de desenvolver uma autenticidade interna - um esquema de confiança básica através do qual o período da vida pode ser entendido como uma unidade contra o pano de fundo de eventos sociais em transformação" [Giddens, 1991:215].

${ }^{94}$ Ver Giddens [1992a:181, 188, 201, passim]. Nós não discordamos da afirmação de que esquemas éticos democratizados sejam desejáveis, mas acreditamos que o desenvolvimento de tais esquemas não substitui a análise sociológica rigorosa de diferenças políticas.
} 
na (alta) modernidade não pode ser mantida. Em nossa análise, mostramos como a sensibilidade a questões empíricas - divisões socioeconômicas reais, convenções culturais existentes, divisões políticas entre grupos sexualizados e racializados - dirige a análise sociológica das experiências modernas na direção de questões de poder, desigualdade e estratificação. Apesar de Giddens mencionar todas estas questões de passagem, ele sistematicamente as exclui do programa teórico que desenvolve em Modernidade e identidade do eu e A transformação da intimidade.

\section{Conclusão: ação política e modernidade}

Pode ser que o fin de siècle vindouro precise de uma nova psicologia social crítica capaz de forjar novas conexões entre ações subjetivas e movimentos políticos globais. Pode ser que seja hora da sociologia transcender seu passado; extrapolar uma nova sistemática, embutida em tradições diferentes e orientada para um futuro incerto. Porquanto tais desafios são sempre encorajados por sociólogos que buscam compreender a construção atual e direção futura de sua disciplina, precisamos receber bem a publicação de Modernidade e identidade do eu e A transformação da intimidade. Entretanto, nossa exploração da estrutura temática e trajetória política destes livros nos leva a concluir que, como a própria modernidade, sua contribuição é ambivalente.

Esta ambivalência está enraizada numa fusão de proposições empíricas e teóricas, e numa ausência relacionada de conceitos mediadores - como "poder", "desigualdade" ou mesmo "prática" - com os quais possamos ligar o local e o global, o pessoal e o estrutural, e o eu e a sociedade. Nós achamos que a consequência disto não é tanto uma repolitização, e sim uma despolitização da vida social. No capítulo final de Modernidade e identidade do eu, Giddens propõe que é difícil analisar as várias características da política da vida e as transformações que elas anunciam. Mas ele apenas piora as dificuldades ao não especificar precisamente que conexões entre o eu e a modernidade indicam sua substância política. Nós concordamos fortemente com o objetivo de Giddens de reter um lugar central para o ator social na criação e sustentação da mudança. Mas sem uma separação apropriada entre o teórico e o empírico, sem uma definição substancial de termos chave na análise, e sem um exame completo de efeitos diferenciais, não podemos ver como seu programa teórico poderia cumprir o que promete. 
O que Giddens oferece é uma análise da experiência individualizada do eu em relação aos "pilares" abstratos da modernidade. Ele não consegue dar conta da mediação da experiência através dos contextos diferenciados em que tais processos são vividos, nem mesmo de expressões locais e formas coletivas de resistência. Como uma consequência da ausência de conceitos teoricamente integrados como aqueles que discutimos acima (desigualdade, poder e estratificação), que podem situar a experiência da modernidade em contextos sociais e culturais, a resposta política a tal experiência se torna, para Giddens, ligada integralmente não a identidades coletivas, mas ao projeto reflexivo do eu. A política da emancipação passa a confiar na política da vida individualizada da realização do eu na modernidade tardia. Apesar da noção do projeto reflexivo do eu parecer ligar a ação e a estrutura num esquema analítico coerente, na verdade esta ligação não pode ser mantida. Assim, as possibilidades de ação na política da vida e o poder gerador através do qual tal ação é constituída têm um potencial muito mais limitado do que a obra recente de Giddens implica. Resumindo, achamos que é um exagero afirmar que o ethos do crescimento do eu associado com este projeto do eu sinaliza grandes transições na modernidade tardia. Não há apoio suficiente para tal afirmação, com a consequência que o esquema conceitual estabelece atores como eus individualizados encontrando uma modernidade institucional abstrata. É neste sentido que caracterizamos o programa de Giddens como um "esvaziamento" da teoria social.

O mundo moderno é certamente um mundo de possibilidades, mas estas possibilidades não circulam de forma igual e não-problemática ao redor do globo. Há possibilidades para crescimento do eu, e reorientação pessoal, e liberdade para partes da população, mais especialmente, agrupamentos etnicamente dominantes de classe média. Para os outros, há a possibilidade distinta de uma intensificação da exploração, com a insegurança política, econômica e pessoal subsequentes. O subemprego estrutural, o uso inescrupuloso de trabalho migrante, a favelização das cidades, a política neofascista e a criação de fortalezas econômicas e políticas contra populações imigrantes - todas estas são condições em que muitas pessoas vivem. Em vez de ter pouca importância na globalização de uma ordem "moderna”, a divisão e a exclusão são processos políticoeconômicos cada vez mais importantes, que qualquer análise da ação pessoal e política precisa abordar. 


\section{Bibliografia}

AGGLETON, P. [1987] Rebels Without a Cause: Middle Class Youth and the Transition from School to Work. London: Falmer.

ANTHIAS, F. \& YUVAL-DAVIS, N. [1993] Racialized Boundaries: Race, Nation, Gender, Colour and Class and the Anti-Racist Struggle. London: Routledge.

BALLARD, R. [1982] "South Asian Families”, in Rapaport, R. N., Fogarty, M. \& Rapaport, R. (eds.) Families in Britain. London: Routledge.

BAUMAN, Z. [1990] "Modernity and Ambivalence", in Featherstone, M. (ed.) Global Culture. London: TCS/Sage.

BERG, M. [1993] "What Difference Did Women's Work Make to the Industrial Revolution”, in History Workshop Journal, v. 35.

BRAHAM, P., RATTANSI, A. \& SKELLINGTON, R. (eds.) [1992] Racism and Anti-Racism. London: Sage.

BUTLER, J. [1990] Gender Trouble. London: Routledge.

CCCS [1980] Culture, Media, Language. London: Hutchinson.

CERNY, P. G. [1989] The Changing Architecture of Politics. London: Sage.

COCKS, J. [1989] The Oppositional Imagination: Feminism, Critique and Political Theory. London: Routledge.

DAVIS, M. [1986] Prisoners of the American Dream. London: Verso.

DAVIS, M. [1993] "The Dead West: Ecocide in Marlboro Country”, in New Left Review, n. 200.

DELPHY, C. [1984] Close to Home: A Materialist Analysis of Women's Oppression. London: Hutchinson.

DELPHY, C. \& LEONARD, D. [1992] Familiar Exploitation: A New Analysis of Marriage in Contemporary Western Societies. Cambridge: Polity.

DESSLER, D. [1989] "What's at Stake in the Agent/Structure Debate", in International Organization, v. 41, n. 3.

DOBASH, R. E. \& DOBASH, R. P. [1992] Women, Violence and Social Change. London: Routledge.

ENLOE, C. [1989] Bananas, Beaches and Bases: Making Feminist Sense of International Relations. London: Pandora.

GIDDENS, A. [1976] New Rules of Sociological Method. London: Hutchinson.

GIDDENS, A. [1984] The Constitution of Society. Cambridge: Polity.

GIDDENS, A. [1985] The Nation-State and Violence. Cambridge: Polity.

GIDDENS, A. [1990] The Consequences of Modernity. Cambridge: Polity.

GIDDENS, A. [1991] Modernity and Self-Identity. Cambridge: Polity.

GIDDENS, A. [1992a] The Transformation of Intimacy. Cambridge: Polity. 
GIDDENS, A. [1992b] Sociology. Cambridge: Polity.

GILROY, P. [1987] There Ain't No Black in the Union Jack. London: Hutchinson.

GLENDINNING, C. \& MILlAR, J. (eds.) [1992] Women and Poverty in Britain: the 1990s. Hempstead: Harvester.

GREGORY, D. [1990] "Grand Maps of History: Structuration Theory and Social Change”, in Clark, J., Modgil, C. \& MODGIL, S. (eds.), Anthony Giddens: Consensus and Controversy. London: Falmer.

GRIFFIN, C. [1985] Typical Girls: Young Women from School to Work. London: Routledge.

GUREVITCH, M., BENNETT, T., CURRAN, J. \& WOOLACOTT, J. [1982] Culture, Society $\&$ the Media. London: Methuen.

HALL, S. [1990] "Cultural Identity and the Diaspora", in Rutherford, J. (ed.) Identity: Community, Culture, Difference. London: Lawrence and Wishart.

HALL, S. [1992] "The West and the Rest: Discourse and Power", in Hall, S. \& Gieben, B. (eds.) Formation of Modernity. Cambridge: Polity.

HAY, C. [1995] "Structure and Agency: Holding the Whip Hand", in Marsh, D. \& Stoker, G. (eds.), Theories and Methods of Political Science. London: Macmillan.

HAYEK, F. [1979] Law, Legislation and Liberty, v. 1. London: Routledge.

HAYES, B. \& MILLER, R. C. [1993] "The Silenced Voice: Female Social Mobility Patterns with Particular Reference to the British Isles", in British Journal of Sociology, v. 44, n. 4.

HUMBOLDT, W. [1903] Ideen zu einen Versuch, die Grenzen der Wirksamkeit des Staates zu bestimmen. Berlin.

KOPINAK, K. [1993] "The Maquiladorization of the Mexican Economy", in Grinspuri, R. \& Cameron, M. A. (eds.) The Political Economy of North American Free Trade. Montreal: McGill Queens University Press.

LULL, J. [1990] Inside Family Viewing: Ethnographic Research and Television's Audiences. London: Comedia/Routledge.

MAMA, A. [1992] "Black Women and the British State", in Braham, P., Rattansi, A. \& Skellington, R. (eds.) [1992] Racism and Anti-Racism. London: Sage.

MILES, R. [1993] Racism after "Race Relations”. London: Routledge.

OAKLEY, R. [1982] “Cypriot Families”, in Rapaport, R. N., Fogarty, M. \& Rapaport, R. (eds.) Families in Britain. London: Routledge.

PEARSON, G. [1975] The Deviant Imagination. London: Macmillan.

PERElBerG, R. J. \& MILleR, A. C. (eds.) [1990] Gender and Power in Families. London: Routledge.

RISMAN, B. J. \& SCHWARZ, P. (eds.) [1989] Gender in Intimate Relationships: A MicroStructural Approach. Wadsworth: Belmont.

ROJEK, C., PEACOCK, G. \& COLLINS, S. [1988] Social Work and Received Ideas. London: Routledge.

SAID, E. [1985] Orientalism. Harmondsworth: Penguin. 
SASSOON, A. [1987] Women and the State. London: Hutchinson.

SAVAGE, M. [1988] "Women and work in the Lancashire Cotton Industry, 1890-1939", in Jowett, J. A. \& McIver, A. J. (eds.) Employers and Labour in the English Textile Industries. London: Routledge.

SCHNEIDER, B. [1991] "Put up and Shut up: Workplace Sexual Assaults", in Gender \& Society, v. 5, n. 4.

SHARPE, P. [1991] "Literally Spinsters: A New Interpretation of Local Economy and Demography in Colymore in the Seventeenth and Eighteenth Century", in Economic History Review, v. 44.

SMART, C. [1984] The Ties that Bind: Law, Marriage and the Reproduction of Patriarchal Relations. London: Routledge.

SMART, C. \& SMART, C. (eds.) [1978] Women, Sexuality and Social Control. London: Routledge.

SOLOMOS, J. [1991] Black Youth, Racism and the State. Cambridge: Cambridge University Press.

SPIVAK, G. C. [1987] In Other Words: Essays in Cultural Politics. London: Methuen.

STONES, R. [1991] "Strategic Conduct Analysis: A New Research Strategy for Structuration Theory", in Sociology, v. 25., n. 4.

STUART MILL, J. [1962] On Liberty. London: Everyman's Library.

THOMPSON, J. B. [1991] Ideology and Modern Culture. Cambridge: Polity.

THOMPSON, N. [1990] Anti-Discriminatory Practice. Basingstoke: Macmillan.

TROYNA, B. [1981] Public Awareness and the Media: A Study of Reporting on Race. London: Commission for Racial Equality.

TROYNA, B. [1987] "Reporting Racism: The 'British Way of Life' Observed", in Husband, C. "Race" in Britain: Continuity and Change. London: Hutchinson.

WALBY, S. [1986] Patriarchy at Work. Cambridge: Polity.

WHARTON, A. S. [1991] "Structure and Agency in Socialist-Feminist Theory", in Gender and Society, v. 5, n. 3 .

WILLIS, P. [1990] Common Culture: Symbolic Work at Play in the Everyday Cultures of the Young. Milton Keynes: Open University Press.

YOUNG, R. [1990] White Mythologies: Writing History and the West. London: Routledge.

ZOLA, I. K. [1975] "In the Name of Health and Illness: On Some Sociopolitical Consequences of Medical Influence", in Social Science and Medicine, v. 9. 


\section{Tony Spybey - A constituição da sociedade global}

Apesar de não haver nenhum livro ou artigo substancial de Anthony Giddens especificamente sobre o assunto da globalização, através de sua reformulação extensa da teoria social e da modernização há um vasto material relevante para este termo, que é utilizado de forma notoriamente frouxa e ainda mal compreendido. Nas palavras de David Jary, “o escopo das aspirações de Giddens para sua teoria da estruturação é totalmente global" [Bryant e Jary, 1991:116]. Como um esquema que pretende corrigir as deficiências do materialismo histórico e da teoria da modernização, grande parte da teoria da estruturação trata do "distanciamento" das relações sociais na cultura ocidental, através do qual ela veio a constituir "a primeira cultura verdadeiramente global do mundo". O princípio fundamental da abordagem de Giddens se baseia no "desencaixe" e na "interconexão" da política e da economia resultantes do desenvolvimento da Europa como um sistema de Estados sem um centro imperial, e nas vantagens que tal arranjo ofereceu para o desenvolvimento da economia capitalista supranacionalmente. Como ele afirma, isto representa uma "descontinuidade" fundamental e decisiva em comparação com o desenvolvimento de outras civilizações, nas quais as formas de progresso eram restritas pela hierarquia imperial.

Entretanto, em referência ao uso disseminado do termo "globalização" atualmente, Giddens se preocupa mais com desenvolvimentos próximos do final do século XX. Quer dizer, com a definição de globalização como um fenômeno das últimas décadas envolvendo a "revolução eletrônica" nas comunicações. Ele enfatiza que a comunicação intensificada tornou necessário abordar a globalização como uma coisa "aqui dentro", parte de todas as nossas vidas, em contraste com a abordagem "lá fora" das relações internacionais no estudo do sistema global de Estados, ou da análise dos sistemas mundiais de Immanuel Wallerstein sobre o desenvolvimento da economia capitalista mundial. Evitando as tendências respectivamente políticas e econômicas destas duas abordagens, Giddens pressupõe que, intrinsecamente, a palavra "globalização" deve implicar na intensificação da comunicação e da reflexividade sobre seus receptores. Sem isto, a globalização não tem nenhum significado no mundo contemporâneo. Isto criou uma espécie de relação dialética entre o global e o local. Fluxos dominantes globais de influência cultural invadem a cultura local e vice-versa. 
Continuando o tema da teoria da estruturação, acima de tudo são pessoas que reproduzem o processo da globalização, e elas o fazem em seu próprio meio cultural local. É precisamente isto que faz da globalização uma coisa "aqui dentro", parte da vida cotidiana, mas que constitui o processo de globalização contínuo. A visão de Giddens está próxima de Roland Robertson [1992], que se refere à “interpenetração" do global e do local resultando num efeito continuamente "à disposição de qualquer um" ["up for grabs"]. Entre outras coisas, isto implica que, apesar do ocidente ter criado a primeira cultura verdadeiramente global do mundo, é pouco provável que o resultado seja puramente, ou mesmo dominantemente, ocidental. Quando o mundo é cada vez mais atraído para a cultura globalizante do ocidente, essa cultura passa a pertencer ao mundo, e não ao ocidente.

Grande parte da obra mais recente de Giddens se dedica aos dilemas do indivíduo na reflexividade da "alta modernidade", e podemos supor que a dialética global-local abrange a dialética global-individual. Uma parte do desabrochar extremo da comunicação durante as últimas décadas resultou na reprodução do eu como aquilo a que Giddens se refere como um "projeto reflexivo". Nós somos os receptores de comunicações cuja escala de penetração é tão global, que fica difícil para o indivíduo pensar em qualquer coisa, ou entrar em qualquer interação social, sem ter anteriormente entrado em contato de alguma forma com suas conotações globais. Isto "desencaixa" a situação da fixidez de normas e padrões de autoridade tradicionais que só pode ser mantida em formas de sociedade que sejam, de alguma forma, limitadas, e, assim, isoladas dos tipos de influências carregadas pelo processo de globalização.

Todos estes temas são familiares aos escritos de Giddens depois de 1990, mas, antes de continuar, quero primeiro olhar referências à globalização em seus escritos pré1990.

\section{O aparecimento do global na teoria social de Giddens}

Noções de presença, ausência e convergência no espaço-tempo foram introduzidas substancialmente em Uma crítica contemporânea do materialismo histórico: volume 1 - poder, propriedade e o Estado [Giddens, 1981]. No capítulo 4, Giddens se concentrou na explicação do distanciamento espaço-temporal na geração do 
poder. O impacto de sociedades tribais no mundo era severamente limitado por sua incapacidade de comunicação e locomoção. Em oposição, a sociedade contemporânea desenvolveu capacidades enormes quanto a estes fatores, e as pessoas não apenas viajam através do mundo em questão de horas, mas também o têm rotineiramente nas telas de seus televisores e computadores. Giddens chamou a atenção ao desprezo dos sociólogos pelo tempo, e em particular ao conceito de presença e ausência [Giddens, 1981:189], que é essencial para a globalização. O indivíduo na sociedade contemporânea tem condições de saber muito sobre o mundo e suas mudanças contínuas, embora ainda seja fisicamente impossível estar em mais de um lugar ao mesmo tempo.

A constituição da sociedade [Giddens, 1984] dedicou-se à exposição da teoria da estruturação, elaborando toda a obra anterior de Giddens. Ela incluiu uma dimensão espaço-temporal substantiva, abrangendo questões tão diversas quanto o "descentramento do sujeito" na filosofia e o desenvolvimento da dimensão do tempo na geografia. Acima de tudo, talvez, questiona-se a amplitude da sociedade a ser tratada pela sociologia. Não deve ser apenas a sociedade do Estado-nação, como foi geralmente pressuposto até agora, mas algo muito mais amplo, em suas palavras, "o primeiro tipo genuinamente global de organização social na história" [Giddens, 1984:183]. Esta é a sociedade que as pessoas rotineiramente reproduzem na teoria da estruturação - a sociedade global.

O Estado-nação e a violência [Giddens, 1985] é na realidade o segundo volume de Uma crítica contemporânea do materialismo histórico, apesar do título do volume receber mais destaque do que o do conjunto da obra. Ele trata especificamente do desenvolvimento do Estado-nação em um sistema de Estados-nação global e do desaparecimento do Estado imperialista tradicional, com tudo que isto implica em termos da gestão do poder político-militar. Ele examina, por exemplo, como "a doutrina do equilíbrio do poder foi transferida de forma mais ou menos intocada do sistema de Estados europeu para o sistema de Estados global" [Giddens, 1985:258]. Giddens chama a atenção a um fator importante, mas muitas vezes negligenciado, o papel da Organização das Nações Unidas na confirmação da normatividade do Estado moderno e do sistema de Estados global. A ONU tende a ser desconsiderada em meio a inúmeras descrições de suas ineficácias na mediação e policiamento do sistema de Estados. Sua importância está na ordenação formal do mundo durante o século XX. Mas um dos 
efeitos da comunicação global intensificada foi chamar a atenção ao problema aparentemente intratável de alinhar as noções populares de nação com o Estado organizado constitucionalmente, no qual o sistema decretou que ela habita. Esta é uma ponta afiada da dialética entre o global e o local. Muitas vezes se considera que a globalização simplesmente deixa as coisas parecidas, mas sua reprodução local envolve graus de transformação, de forma que o resultado está, como diz Robertson, "à disposição de qualquer um". As várias lutas do nacionalismo periférico no mundo são testemunha disto.

A ONU foi um resultado da Segunda Guerra Mundial, mas as origens da ideia estão no "wilsonismo" norte-americano depois da Primeira Guerra Mundial:

“A noção do equilíbrio de poder [é] substituída pela noção da unidade independente de cada Estado, aceita consensualmente pela comunidade global de Estados. (...) Nem mesmo o Estado mais forte poderia, a princípio, prevalecer contra a oposição de múltiplos Estados agindo colaborativamente" [Giddens, 1985:260]

Este é o ideal para o sistema de Estados global em sua organização como as Nações Unidas. $\mathrm{O}$ artigo $2^{\circ}$ da Carta das Nações Unidas afirma "o princípio da igualdade soberana”. Isto pode valer no que tange à Assembleia Geral da ONU, mas além disso, o Conselho de Segurança serviu para reintroduzir as realidades do equilíbrio de poder. A justaposição destes dois é talvez um exemplo perfeito de duas dimensões de Giddens, o sistema de Estados-nação contra a ordem militar global. Giddens, na verdade, vê quatro dimensões da globalização que correspondem às suas dimensões da teoria da estruturação:

- O sistema de informação global é a rede de ordens simbólicas e modos de discurso;

- O sistema de Estados-nação global constitui as instituições políticas, os recursos de autoridade da sociedade global;

- A economia capitalista global consiste das instituições econômicas, os recursos de alocação da sociedade global;

- A ordem militar global é a arena do normativo e dos modos de sanção na sociedade global. 


\section{O fim do projeto socialista}

O Estado-nação e a violência menciona um terceiro livro planejado na sequência para tratar da situação "entre o capitalismo e o socialismo". Mas, tendo em vista os desenvolvimentos políticos no Ocidente depois de 1979, e o colapso subsequente da União Soviética em 1991, ele nunca apareceu. Em vez disso, numa data muito posterior e com a agenda transformada dramaticamente, o título Para além da esquerda e da direita [Giddens, 1994] mais ou menos dispensa explicações. Aqui, a globalização é tratada diretamente como "uma noção arremessada de um lado para outro, mas até agora mal compreendida". Ela na verdade não é vista como um fenômeno econômico, nem mesmo como primariamente econômico, mas "de fato, sobre a transformação do espaço e do tempo" definida como "ação à distância" com "sua intensificação em anos recentes [relacionada] ao surgimento dos meios de comunicação global instantânea e do transporte de massa" [Giddens, 1994:4].

Giddens agora usa o princípio da dualidade da estrutura da teoria da estruturação para acentuar a relação entre o global e o local (ou individual), chamando a atenção à "transformação dos conteúdos de experiência social locais, mesmo pessoais" [Giddens, 1994:5]. Aqui, a globalização trata essencialmente do social enquanto experimentado. Ele usa exemplos de consumo e identidade:

“Assim, minha decisão de comprar uma certa peça de vestuário tem implicações não apenas para a divisão do trabalho internacional, mas também para os ecossistemas da Terra. (...) Assim, por exemplo, o renascimento de nacionalismos locais, e uma ênfase em identidades locais, estão diretamente ligados a influências globalizadoras, às quais eles se colocam em oposição" [ibid.].

Nesta obra, como uma alternativa ao pós-moderno, o termo "pós-tradicional" aparece em relação à ordem social produzida pela globalização. A tradição mudou de estatuto, mas não desapareceu totalmente porque exemplos daquilo que ele chama de "grandes tradições" são inventados e reinventados, como, notavelmente na história dos conflitos do final do século XX, nacionalismos e religiões. O fundamentalismo é visto como "nada mais do que a tradição defendida de forma tradicional", já que um modo de defesa tradicional se encontrou amplamente questionado [Giddens, 1994:6]. Tradições reconstruídas de natureza mais doméstica incluem a família, o sexo e a sexualidade, mas com a reflexividade aumentada da globalização elas são vistas como "um processo de 
filtragem”. Para Giddens, "o eu se torna um projeto reflexivo, e, cada vez mais, também o corpo" [Giddens, 1994:82].

Outra preocupação familiar da obra recente de Giddens que deve ser mencionada neste ponto é a fuga do conhecimento especializado e o declínio da autoridade. A proposição é que anteriormente a ciência se tornara uma autoridade mais ou menos universal, "à qual podíamos apelar de forma relativamente inquestionável para confrontar dilemas ou lidar com problemas" [Giddens, 1994:5]. Esta era a essência do projeto iluminista com fé positivista no progresso linear e na habilidade da humanidade de usar a ciência de forma relativamente não-problemática para superar seus problemas. Em contraste, Giddens diz, "não devemos pensar a globalização como um processo unitário tendendo a uma única direção, mas como um conjunto de mudanças complexas com resultados mistos e muitas vezes contraditórios (...) influências globalizadoras são tão fragmentadoras quanto unificadoras, criam novas formas de estratificação, e muitas vezes produzem consequências opostas em diferentes regiões ou localidades" [Giddens, 1994:81]. Além do mais, conexões globais podem atuar através do mundo ou em vizinhanças, como no caso de fábricas clandestinas que ficam lado a lado com centros financeiros nas capitais mundiais. A globalização traz diásporas culturais na forma de estilos e modas, mas também "a renovação de nacionalismos e etnicidades locais" [Giddens, 1994:81]. Há outros exemplos de conflitos que surgem da globalização e que criam a noção de Robertson de resultados “disponíveis para qualquer um”.

No lado otimista sobre o futuro, de acordo com Giddens, "influências globalizadoras tendem a quebrar a formação de monopólios ou oligopólios, como aqueles frequentemente encontrados em economias nacionais" [Giddens, 1994:89]. A globalização tende a produzir corporações transnacionais (CTNs) cada vez maiores, mas elas estão competindo na arena global. A importância disto é negada por Hirst e Thompson [1992], que afirmam que a globalização só existirá de fato, e não como especulação, quando a economia global for acessível a todos, e não apenas às corporações transnacionais gigantes, que, apesar do alcance de suas operações, têm seus quartéis-generais em alguns poucos Estados-nação. Neste ponto, Giddens reconhece que Estados-nação têm mais poder que CTNs, porque eles controlam territórios e exercem força militar legítima. Ele defende a regulação da economia global através da visão de David Held da "democracia cosmopolita", a ser alcançada através de parlamentos regionais globais modelados numa versão desenvolvida do Parlamento Europeu 
existente e ligados à Organização da Nações Unidas [Giddens, 1994:123]. Isto pretende garantir a globalização vinda de baixo através de grupos organizados na sociedade civil, ou, de forma mais coloquial, o "poder das pessoas", que é visto como o salvador da União Soviética e do leste europeu, da África do Sul, etc.

Isto chama a atenção a alguns dos dilemas fundamentais do giro de Giddens da teoria social per se para a teoria social enquanto ideologia política. Como a sociedade global deve ser regulada? Aquilo que poderíamos chamar de instituições globais "oficiais" têm suas origens no estabelecimento da Organização das Nações Unidas em 1945, e a estrutura dela tende a ser obscurecida hoje em dia, embora suas consequências ainda estejam conosco:

- a Assembleia Geral - supostamente democrática, com um voto para cada Estado-nação;

- o Conselho de Segurança - não-democrático, com assentos permanentes para seis "grandes potências" contrabalançados por um número igual de assentos eleitos entre as outras nações - onde o mecanismo de veto muitas vezes causa impasses;

- o Conselho Econômico e Social - a agência superior para o Banco Mundial, o Fundo Monetário Internacional e, agora, a Organização Internacional do Comércio:

o presidente do Banco Mundial é, costumeiramente, americano - os EUA fornecem a maior parte dos recursos, e consequentemente têm a maioria dos votos.

o presidente do FMI é, costumeiramente, europeu, mas os EUA ainda fornecem a maior parte dos recursos, e consequentemente têm a maioria dos votos.

o estabelecimento da Organização Internacional do Comércio foi atrasado extensivamente até os anos 1990, e ela ainda está encontrando o seu espaço.

- o Conselho de Tutela - para a administração temporária de nações sem Estado, por exemplo, o Kosovo atualmente.

- o Secretariado Internacional, com o cargo de Secretário Geral - que vem de uma nação pequena ou de um "país menos desenvolvido" - útil em disputas 
internacionais, mas cuja ação depende dos recursos dos Estados-membros, especialmente as "grandes potências".

- a Corte Internacional de Justiça em Haia - entre outras coisas, a corte para criminosos de guerra, atualmente lidando com casos contra ruandeses, croatas e sérvios.

A ONU realizou mais do que ela normalmente recebe crédito, mas, ainda assim, ela não tem muitos poderes que possam ser separados das relações internacionais de seus Estados-membros. Na economia global, o Banco Mundial e o FMI, apesar de terem seus papéis modificados com o passar do tempo, foram consistentemente acusados, com justiça, de operar baseados em princípios capitalistas ortodoxos garantidos pelo voto majoritário dos EUA. Em relação às possibilidades atuais para o governo global, Giddens [1994:97-103] lista quatro "ambientes de risco globais" que devem ser enfrentados, com suas soluções possíveis, contra as quais reações prováveis foram adicionadas aqui:

- ecossistemas - resolvidos pela "natureza humanizada". Mas o que a ONU pode fazer (além de organizar encontros internacionais, como o do Rio de Janeiro em 1992)?

- o "holocausto da pobreza" - resolvido pela "economia da pós-escassez". $O$ Banco Mundial e o FMI? A ironia é que estes dois tendem a seguir, e não controlar, as maquinações da economia global que, por sua vez, tendem a ser dominadas pelas corporações transacionais.

- $\quad$ armas de destruição em massa - resolvidas pelo "poder negociado". O Conselho de Segurança?

- a repressão em larga escala de direitos democráticos - resolvida pela “democracia dialógica”. A Assembleia Geral da ONU (ou os supostos parlamentos regionais eleitos da ONU propostos por Held e Giddens)?

Para sermos justos, estas quatro categorias pretendem assumir a forma de algo como um conjunto fundamental e geral de dispositivos sensibilizadores para a política global contemporânea. Mas, se é improvável que a organização formal da ONU forneça uma iniciativa verdadeira, então quem o fará? Supostamente, ONGs transnacionais são as candidatas mais prováveis, como o Greenpeace na área ambiental. Em 1950, existiam apenas duzentas ou trezentas delas, mas agora estima-se que seu número seja mais de 
10.000. Alguns observadores as interpretam em termos de uma forma de sociedade civil global contribuindo para o governo global [ver, por exemplo, Held et al., 1999]. Mas, contra isto, uma organização como o Greenpeace, apesar de toda a coragem de seus voluntários que se arremessam entre poluidores e o meio ambiente, não constitui uma autoridade ambiental global em nenhum sentido formal, e ocasionalmente sofre de forma fatal nas mãos de Estados-nação.

\section{O indivíduo nos escritos pós-1990}

Entre 1990 e 1992, Giddens publicou três livros em que voltou sua atenção para o dilema do indivíduo na modernidade tardia. Eles foram As consequências da modernidade [1990], Modernidade e identidade do eu [1991] e A transformação da intimidade [1992]. Neste ponto, o termo "globalização" já era utilizado amplamente, e por isso precisava de uma definição substantiva:

"A globalização pode então ser definida como a intensificação de relações sociais mundiais que ligam localidades distantes de tal forma que acontecimentos locais são moldados por eventos ocorrendo a muitos quilômetros de distância e vice-versa. Este é um processo dialético porque tais acontecimentos locais podem se mover numa direção inversa das próprias relações distanciadas que os moldam. A 'transformação local' é tanto uma parte da globalização quanto a extensão lateral de conexões sociais através do tempo e do espaço. Assim, quem quer que estude cidades hoje em dia, em qualquer parte do mundo, sabe que aquilo que acontece numa vizinhança local provavelmente é influenciado por fatores - como dinheiro mundial e mercados de matéria-prima operando numa distância indefinida dessa própria vizinhança. O resultado não é necessariamente, ou mesmo frequentemente, um conjunto generalizado de mudanças atuando numa direção uniforme, consistindo, pelo contrário, de tendências mutuamente opostas. A prosperidade crescente de uma Cingapura urbana pode estar causalmente relacionada, através de uma rede complicada de laços econômicos globais, ao empobrecimento de um bairro de Pittsburgh, cujos produtos locais não são competitivos nos mercados mundiais" [Giddens, 1990:64].

As consequências da modernidade foi uma consideração dos resultados daqueles processos de mudança social aos quais Giddens dedicara uma grande parte de sua obra anterior. Como mencionado anteriormente, sua abordagem da globalização é de um fenômeno das últimas décadas resultante, em grande parte, da intensificação da 
comunicação eletrônica. O importante é que as mudanças alarmantes na transmissão do conhecimento das últimas poucas décadas encorajaram as pessoas a refletir muito mais sobre sua situação pessoal, e a relacionar isso a um regime contínuo de informação sobre todos os tipos de pessoas em todos os tipos de situação através de todo o mundo. Por exemplo, é muito provável que um passeio no supermercado, com sua oferta de quatro estações simultâneas de vegetais globais, evoque uma reflexão sobre as implicações políticas, econômicas e ambientais relacionadas àquilo que é apresentado. Mas e daí? Não há muitas dúvidas sobre o aumento da consciência, mas será que isso faz com que a maioria das pessoas consuma de forma mais esclarecida? Os resultados benéficos de qualquer reflexão dos consumidores tendem a ser direcionados pessoalmente, como no suprimento de alimentos orgânicos, e estes são apenas anexados ao lado dos alimentos comuns - sem prejudicar o agribusiness global, mas, sem dúvida, um bom exercício de relações públicas para a cadeia de supermercados.

Tais exemplos demonstram convincentemente que o tempo e o espaço foram atenuados. O mundo efetivamente se tornou menor. As pessoas não existem mais em comunidades fechadas, sendo agora expostas constantemente a trocas globais. Isto teve o efeito de, como diz Giddens, "desencaixar" instituições sociais de todos os tipos de suas formas tradicionais e as "interconectou" em novos esquemas de relações espaçotemporais. As relações sociais se tornam "distanciadas" no tempo e no espaço, o que, para Giddens, é a essência da globalização.

A ênfase de Giddens no caráter recente da globalização separa sua especificação até da abordagem orientada culturalmente de Roland Robertson, que se refere à sua existência por pelo menos 2000 anos, o período do ecúmeno cristão. Entretanto, ambos concordam com a proposição de que a interpretação e reprodução local do global é efetivamente a substância da globalização contínua. Neste respeito, Giddens não diverge de Robertson, que explica o processo numa peça convoluta de sociologia parsoniana:

"Meu argumento envolve a tentativa de preservar a atenção direta tanto à particularidade e diferença quanto à universalidade e homogeneidade. Ele se baseia em grande parte na tese de que somos, no final do século XX, testemunhas - e participantes de um processo duplo e imenso, envolvendo a interpenetração da universalização do particularismo e a particularização do universalismo" [Robertson, 1992:100]. 
Como Giddens, Robertson enfatiza a relação entre o global e o local, e ele amplifica mais o princípio em outra parte de seu livro Globalização: teoria social e cultura global [1992]. Isto chama a atenção ao contraste com obras de análise do sistema mundial ou de relações internacionais, como se segue:

"em vez de enfatizar a estrutura cristalizada do sistema mundial, uma teoria voluntarista permanece sensível a desenvolvimentos empíricos, e assim realça os processos de globalização e a litigiosidade contínua da ordem global. Um dos meus argumentos básicos é que respostas variadas à globalização influenciam este mesmo processo, de forma que sua direção e resultado, e assim a própria forma do campo global, ainda estão 'à disposição de qualquer um”" [Robertson, 1992:62].

O termo "globalização", tomado literalmente, implica o envolvimento de todos no planeta. A realidade pode não chegar a este ponto, mas é muito difícil negar a penetração extrema de fluxos culturais globais. A implicação espacial é que não pode haver uma globalização sem a penetração global do local. A penetração do local é o que faz a globalização global. A globalização, na verdade, é a interconexão do local através do tempo e do espaço globais.

Muito do que Giddens afirma sobre a globalização em As consequências da modernidade trata da globalização do risco [Giddens, 1990:125] e isto afirma a importância que a obra de Ulrich Beck tem para ele. Nos volumes da Crítica contemporânea do materialismo histórico mencionados anteriormente, Giddens enfatiza que a modernidade trouxe consigo a transformação do ambiente em que as pessoas vivem, de tal forma que ele se tornou em grande parte um "ambiente criado". A espécie humana é a única que adquiriu o poder de fazer isto, mas as consequências são os perigos inerentes à própria posse de tal poder, e eles afetam todas as pessoas e todas as espécies. Desastres nucleares como o de Chernobil, e modificações do ambiente como o aquecimento global têm implicações diretas para todos nós. Os riscos são globais. Ainda assim, a indústria de reprocessamento nuclear não foi exceção à privatização e ao enxugamento do Estado, com algumas consequências assustadoras, como os resultados recentes da British Nuclear Fuels demonstraram. Ainda há contradições no capitalismo.

Além de riscos como este, há uma incerteza quanto à extensão dos perigos; por exemplo, enquanto um conjunto de cientistas proclama o aquecimento global, outro defende a visão oposta. E ainda outros afirmam que as mudanças detectadas podem ser 
explicadas em termos de causas naturais, e as consequências das ações humanas teriam um papel menor. Assim, o aquecimento global seria parte da mudança climática inerente à Terra. Em face de tal controvérsia, Giddens chama nossa atenção ao outro lado do risco, que é a confiança. O declínio da autoridade já foi mencionado, e aqui a confiança na ciência é questionada. A abordagem positivista da ciência foi, obviamente, uma característica do século XIX, mas ela foi enfraquecida progressivamente durante o século XX. Guerras mundiais, o Holocausto, armas nucleares, danos ambientais são alguns dos fatores de larga escala que influenciaram esta tendência. Mesmo na luta contra doenças, onde a ciência pode reivindicar sucessos relativamente claros, ultimamente há um movimento forte na direção de terapias alternativas. Também há o retorno de algumas doenças, como a malária, agora resistentes às formas existentes de tratamento. O papel do perito não é mais o foco de autoridade que outrora foi. Este é outro caso do global e do local interagindo entre si. A ciência global encontra o Greenpeace, que é de fato uma reação popular organizada globalmente. Nesta questão, e em outros exemplos comparáveis, tende-se a recorrer às ONGs em vez das organizações globais formais como as Nações Unidas.

A questão da modernidade como um projeto ocidental está relacionada a estes perigos e incertezas, como Giddens afirma [1990:174], com a cultura ocidental como a primeira cultura verdadeiramente global do mundo. Mas o sucesso do ocidente como uma civilização dominante cria ao mesmo tempo a possibilidade de seu declínio. Existe a dificuldade de limitar o crescimento econômico por razões ambientais, mas ao mesmo tempo a percepção de que mesmo formas de produção ocidentais se tornam transpostas no processo de globalização. Notavelmente, há o caso em que o Japão, por assim dizer, venceu o Ocidente em seu próprio jogo na produção de veículos automotivos e no desenvolvimento de produtos eletrônicos para consumo. $\mathrm{O}$ fordismo inflexível abriu caminho para o pós-fordismo flexível através da reprodução da produção em linha de montagem no Japão, mas com a adição crucial de características culturais locais, o global e o local. Emanam de tais desenvolvimentos as enormes mudanças globais no emprego que ocorreram em décadas recentes, com suas implicações para as políticas trabalhistas dos governos, e, na ausência do trabalho, a reforma aparentemente necessária do Estado de bem-estar social. A mudança no emprego é, na verdade, um termo mais correto do que o muito usado "desindustrialização", e uma consequência disto é que, como André Gunder Frank [1998] agora afirma, pode ser que o oriente, e 
não o ocidente, domine no futuro as instituições econômicas globais. A primazia contínua do ocidente está aberta a dúvida também de outras formas. Há pedidos contínuos por uma "nova ordem mundial", e frente a isto a única superpotência remanescente, os EUA, está se precavendo. Apesar deles gostarem de se imaginarem como tendo um assento invisível na União Europeia, eles também têm um papel de protagonista nos encontros econômicos anuais do anel do Pacífico. A visão de Kenichi Ohmae [1985] de uma "tríade" econômica global pode se tornar apenas uma díade se a longo prazo os EUA se moverem apenas para um lado. Afinal, a parte economicamente mais dinâmica dos EUA, a Califórnia, faz parte do anel do Pacífico.

Em Modernidade e identidade do eu [Giddens, 1991], Giddens reforça alguns dos temas desenvolvidos aqui em termos de seu impacto sobre o indivíduo. Logo no começo, há uma afirmação de que "a globalização significa que ninguém pode escolher ficar de fora" [Giddens, 1991:22] e princípios introduzidos nas obras anteriores de Giddens são reunidos, como por exemplo:

"A reorganização do espaço-tempo, mecanismos de desencaixe e a reflexividade da modernidade pressupõem propriedades universalizadoras que explicam a natureza expansionista e coruscante da vida social moderna, em seus encontros com práticas estabelecidas tradicionalmente" [Giddens, 1991:21].

A relação entre o global e o local é desenvolvida ainda mais:

"Eu quero propor que transformações na identidade do eu e a globalização são os dois polos da dialética entre o local e o global em condições de alta modernidade" [Giddens, 1991:32].

As políticas de emancipação do século XIX, neste cenário, já são consideradas como dadas, e o indivíduo busca muito mais. A "política da vida" do final do século XX enxerga o indivíduo perseguindo a sociedade permissiva e o enfraquecimento da autoridade, a transparência do Estado e a disponibilidade geral de informação e conhecimento. Acima de tudo, há o objetivo da individualidade em vez do papel uniforme do cidadão. Esta é a imagem do consumidor no pós-fordismo, e ela tende a ignorar as preocupações da esquerda antiga. A participação em sindicatos de operários diminuiu, e as indústrias tendem a não ser mais defendidas por causa de empregos. 
Em obras subsequentes de Giddens, a globalização aparece principalmente em conexão com o conceito de "modernização reflexiva", o estágio da modernidade em que o indivíduo é soberano. Quando tantos aspectos de nossas vidas são conectados através dos fluxos da cultura global, algumas das estruturas sociais que antigamente dominavam as vidas das pessoas ficam abertas a questões. Formas de autoridade perdem sua gravitas. Acima de tudo, a globalização foi associada com a decadência do Estado-nação. Os princípios fundamentais do Estado-nação são direitos de cidadania equilibrados com deveres, especialmente aqueles expressos através do nacionalismo. Numa obra anterior, Giddens chamou atenção à natureza "de Janus" do nacionalismo, por um lado benéfica e por outro draconiana em sua defesa [Giddens, 1981:192]. A globalização ao mesmo tempo enfraquece e fornece munição para nacionalismos separatistas exatamente porque o indivíduo é instigado a conceber a existência além das prescrições do Estado-nação. A sociedade se torna não a sociedade do Estado-nação, mas, com efeito, a sociedade global.

\section{A Terceira Via (e seus críticos)}

Na última fase dos escritos de Giddens, A Terceira Via [1998] e A Terceira Via e seus críticos [2000b], vemos as referências da globalização dirigidas a uma plateia mais ampla. Neste ponto, o papel de Giddens se expandiu através de sua associação com o novo trabalhismo inglês e a administração de Tony Blair ${ }^{1}$. Ele ainda se refere à globalização como um termo antipático, mas enfatiza a abordagem equivocada a ele no que tem sido escrito a seu respeito [Giddens, 1998:28-29]. Ela é vista, por um lado, como quase um mito, ou no máximo a continuação de uma tendência estabelecida há muito tempo enquanto, por outro lado, ela é algo não apenas real mas também muito avançado. Hirst e Thompson [1992] defendem a primeira posição, e nos lembram que a maior parte do comércio ainda é regional. A questão aqui é de interpretação de estatísticas comerciais, e qual aspecto delas indica mudanças substantivas na forma em que seres humanos interagem uns com os outros. Giddens chama atenção ao aumento da exportação dos países da OCDE de 7\% do seu PIB em 1950 para 17\% em 1997, com um conjunto muito maior de mercadorias e serviços comercializados. O PIB, é claro, é um índice de atividade econômica agregada ao grau mais alto, por isso, o fato de que

\footnotetext{
${ }^{1}$ Primeiro-ministro da Grã-Bretanha de 1997 a 2007 (N.T).
} 
$17 \%$ do total é resultado do comércio mundial é mais significativo do que a estatística inicialmente parece transmitir.

Também há o papel expandido dos mercados financeiros mundiais. Esta é uma área em que podemos ver decisões individuais adquirirem dramaticamente implicações globais. Os mercados financeiros, cada vez mais, seguem tendências de decisões de investimento per se, às vezes às custas da performance de firmas de negócios. George Soros [1987; 1998] estendeu esta posição em seus argumentos afirmando que flutuações de negócios cambiais não são consequências de um mercado, e sim das construções reflexivas dos próprios negociantes cambiais. Ele atribui seu próprio sucesso financeiro extraordinário à habilidade de reconhecer os padrões de especulação, e não à performance das moedas. Neste contexto, a transformação do espaço-tempo ganha vida quando ela é interpretada através de mercados financeiros que nunca fecham. Quando Londres fecha, Nova Iorque está aberta. Quando Nova Iorque fecha, Tóquio está aberta, e assim por diante. Frank [1998] é mais mordaz quando se refere a isto como o "cassino global”, seguindo as descrições de Susan Strange em Capitalismo de cassino [1996].

Neste contexto, Giddens [1998] levanta a pergunta da restrição e do governo, apontando para a estatística reveladora de que apenas 5\% das transações financeiras norte-americanas têm a ver com o comércio. Uma pedra de toque do governo global seria dirigida aos negócios crescentes naquilo que ele chama de "especulações e arbítrios" [Giddens, 1998:149]. Ele discute as possibilidades de transformar a ONU numa estrutura com instituições revitalizadas, incluindo um conselho de segurança econômica para complementar o conselho político-militar que já existe. Tais instituições seriam algo como aquilo que a UE aspira ser em seu papel regional, como David Held [1987] e outros afirmam. Voltamos aqui à questão da regulação dos efeitos da globalização, mas nem Giddens nem Held são muito claros sobre como isto poderia operar, especialmente em termos de fazer o sistema capitalista global mudar de forma efetiva. Isto afeta não apenas a regulação, mas também o ressarcimento na forma do bem-estar social. Quando ocorreu a negociação para o estabelecimento das instituições das Nações Unidas em 1945, o negociador chefe para a Grã-Bretanha foi o economista arqui-intervencionista John Maynard Keynes, mas ele enfrentou o economista antiintervencionista americano Harry Dexter White, que, como na época os EUA possuíam $70 \%$ das reservas de ouro e espécie mundiais, tinha as melhores cartas. Os EUA tiveram resultados irregulares desde então, e Wallerstein afirma que esse país perdeu a 
hegemonia em torno de 1970, mas em termos de influência sobre o Banco Mundial e o FMI, as coisas não mudaram muito.

Giddens aprofunda suas projeções sobre instituições globais futuras em $A$ Terceira Via e seus críticos [2000b]. Com o processo de globalização visto como "em más condições", os "ambientes de risco global" citados anteriormente são redesenhados como uma agenda de intenções, como se segue:

- Governo econômico global: a vigilância de transações financeiras, o fornecimento oficial de liquidez financeira e canais oficiais para a solução de dívidas são todos mencionados. Uma Autoridade Financeira Mundial, um Banco Central Mundial e a cooperação fiscal entre o G7, estendendo-se a ponto de fundir o dólar, o iene e o euro em uma única moeda mundial, são propostos, mas não está claro como tudo isto se relacionaria com o Banco Mundial e o FMI existentes. O financiamento poderia ser derivado de um imposto global sobre negócios externos acompanhado da remoção de paraísos fiscais.

- Gerenciamento ecológico global: o papel melhorado do Greenpeace em relação ao desenvolvimento de melhores agentes refrigeradores para geladeiras, em contraste ao declínio da Monsanto em relação a alimentos transgênicos, são citados como resultados positivos, mas enfatiza-se que é preciso estabelecer com antecedência formas de autoridade "vigilantes", talvez através da democratização da ciência, quando pudermos exercer a prevenção em vez da recuperação.

- Regulação do poder corporativo: a competição global deve ser forçada (mas este deve ser o propósito da OMC!). Governos precisam colaborar com ONGs. A responsabilidade corporativa deve ser alimentada. Espaços públicos, incluindo espaços de comunicação, devem ser mantidos abertos. Formas de capitalismo acionista e interveniente devem ser encorajadas.

- Controle da guerra: conflitos abertos hoje tendem a ser uma questão de legitimidade do Estado, como em Kosovo ou no Timor Leste, e não conflitos entre Estados. Isto gera o problema de refugiados e asilados.

- Democracia global: A UE é vista como um experimento novo, especialmente na geração de provisões como a Carta Social, que transcendem governos nacionais. Parlamentos regionais são propostos, que enviariam delegados a 
uma assembleia mundial que formaria "uma segunda câmara eleita da Nações Unidas".

Em conexão com este último ponto, podemos notar que o Conselho da Europa tem há algum tempo o Tribunal de Justiça da União Europeia, como de certa forma um equivalente regional da Corte Internacional de Justiça das Nações Unidas. Se a experiência daqui puder servir de referência, sentimentos nacionais tendem a se insinuar novamente. Alguns dos juízes do Tribunal de Justiça da União Europeia vindos de países do antigo leste europeu foram criticados por refletirem na prática seus sistemas nacionais de justiça que, neste contexto, são vistos como muito deficientes em relação aos países da Europa ocidental. O caminho para a justiça internacional em qualquer arena não será fácil.

$\mathrm{Na}$ economia global, temos evidências até certo ponto de vantagens ocidentais sendo disseminadas para países mais pobres. Giddens aponta que o crescimento da força de trabalho global ultrapassou o crescimento populacional, com reflexos na melhoria das estatísticas de mortalidade infantil e expectativa de vida. Isto não se aplica a todos os países, mas aqueles que avançaram nestes aspectos também avançaram de outras formas. O grupo de elite dos países mais ricos do mundo, G7, gerou o grupo GX que inclui o G7 mais a China, Índia, Brasil, Rússia, México, Coreia do Sul e África do Sul.

Voltando ao assunto do governo, Giddens observa que os países que não se beneficiaram desta forma são caracterizados por governos autoritários, corrupção, conflitos, regulamentação exagerada, e nível baixo de emancipação feminina. Em referência a tantos desastres recentes de partir o coração retratados tão vividamente pela mídia global, ele cita a insistência de Amartya Sem [1999] de que nenhuma democracia completa sofreu com a fome.

\section{As Palestras Reith}

Talvez o ápice da obra de Giddens sobre a globalização até agora tenham sido as Palestras Reith em 1999, transmitidas de locações globais com apresentação e debate simultâneos na internet, e agora publicadas como Runaway World [Mundo em fuga, Giddens, 2000a]. Giddens terminou a primeira Palestra Reith com a observação de que a globalização é a forma em que agora vivemos. Isto tem muitas implicações; por 
exemplo, há o fato de que todas as nossas transações financeiras estão conectadas de alguma forma com as finanças globais mencionadas anteriormente, já que hoje em dia temos negociações contínuas em moedas e mercadorias. Tudo isto aconteceu muito rapidamente e indica a velocidade da adoção de novas tecnologias num mundo em globalização. Já se tornou uma piada, mas também é um truísmo, dizer que pessoas mais velhas precisam pedir ajuda para seus filhos para lidar com tecnologias eletrônicas que se desenvolvem rapidamente, e com inúmeras aplicações. Já que a globalização é uma coisa "aqui dentro", não temos alternativa a não ser aprender a lidar com ela. Se ela fosse uma coisa "lá fora", talvez pudéssemos permanecer como espectadores, mas ela manifestamente não é. Agências bancárias estão fechando porque podemos gerenciar nossos recursos financeiros através de uma combinação de ligações telefônicas e caixas eletrônicos que estão disponíveis 24 horas por dia.

Giddens consistentemente enfatiza que desenvolvimentos como esses enfraquecem a antiga ordem das coisas. Como mencionado anteriormente, há agora muitas e variadas fontes de autoridade na sociedade, e o Estado, em particular, precisa competir com elas. Mesmo no caso de um Estado repressivo como a antiga União Soviética, embora pudesse dar um jeito de competir com o Ocidente em tecnologias antigas, as novas formas estavam além de seu alcance tanto para fornecer quanto para proibir. Não havia modo eficaz de manter fluxos culturais globais fora de suas fronteiras. Ora, uma sociedade que reprimiu a economia e a sociedade civil por tanto tempo tem imensas dificuldades para se ajustar às eclusas que se abriram. A globalização é penetrante, mas ela não é imparcial nem necessariamente benigna. A lacuna entre os ricos e pobres do mundo aumentou, e ainda assim os países menos desenvolvidos podem ter um efeito nos países desenvolvidos. Há os exemplos de "colonização invertida" a que Giddens se refere: a latinização de Los Angeles, o surgimento de um setor de alta tecnologia orientado globalmente na Índia, a venda de programas de TV brasileiros para Portugal. Nada disso foi planejado, e essa é a natureza do processo de globalização. Isto sublinha que o resultado está disponível para qualquer um.

Alguns aspectos da globalização são expressos em uma forma que parece ser simples demais, quase banal. Por exemplo, o uso global de produtos globais causou o aquecimento global. Mas, como Giddens enfatiza em toda sua obra recente, sequências como esta sem dúvida produziram novas formas de risco. Em sociedades tradicionais, 
as pessoas enfrentavam os riscos naturais de fenômenos climáticos extremos e colheitas pobres. Os povos mais pobres da Terra ainda os enfrentam, e sua posição piorou porque a superação de alguns riscos naturais produziu, em vez disso, riscos manufaturados. $\mathrm{O}$ aquecimento global, o enfraquecimento da camada de ozônio, poluição petrolífera em larga escala, a concentração do dióxido de carbono na atmosfera produzido por emissões veiculares; tudo isto representa riscos que nosso desejo coletivo de consumir produziu para nós. Todos eles, de alguma forma, levaram ao declínio da confiança em figuras de autoridade.

Giddens aponta que o próprio conceito de "risco" é relativamente novo, e quase não era usado antes do início da modernidade. Na verdade, a palavra "risco" parece ter entrado na língua inglesa a partir do português e do espanhol, na época das viagens pioneiras "por mares nunca dantes navegados". Com o risco, vem o conceito de se garantir contra ele. Podemos ir mais longe do que Giddens vai e nos referir à aplicação da matemática à atividade humana como uma parte fundamental do desenvolvimento da civilização ocidental. A matemática não foi apenas aplicada à ciência, como na famosa tese de Needham, mas também aos negócios, com o uso da contabilidade, e à indústria de seguros, com o uso de estatísticas atuariais no cálculo do risco.

De qualquer forma, o "fim da natureza" pode ser uma conclusão prematura, porque o catálogo de riscos manufaturados inclui a ressurreição de alguns riscos naturais, como o ressurgimento do mosquito da malária numa nova forma resistente aos tratamentos existentes. No passado, a Organização Mundial da Saúde considerava a malária totalmente erradicada. Os efeitos de longo prazo de todos os desenvolvimentos deste tipo obviamente não são conhecidos, e não se ouve mais o perito com tanta autoridade. Várias alternativas à ciência ocidental emergiram no mundo globalizado, e isto é realmente uma ilustração da interpenetração do local e do global.

O que ocorre com o risco e o risco manufaturado também ocorre com a tradição e a reprodução da tradição. Sociólogos consistentemente usam a sociedade tradicional para contrastar a sociedade moderna, mas a tradição não desapareceu; ela é reproduzida como parte da sociedade moderna. Muitas coisas hoje alardeadas como tradicionais são na verdade criações modernas. Giddens aponta que mesmo o próprio termo "tradição" é uma criação dos últimos 200 anos, e ele muitas vezes é usado no contexto de práticas bastante recentes. Uma tradição pode crescer muito rapidamente porque, na verdade, 
todas as instituições sociais podem ser encaradas como tradições. Tudo que é "institucionalizado" na sociedade pode entrar no parâmetro da tradição. Se negarmos o estatuto de tradições a reconstruções modernas, como o exemplo de Giddens do kilt escocês, podemos causar ofensas generalizadas. Entretanto, em sua forma mais perigosa, a tradição aparece, ou reaparece, como fundamentalismo, e a globalização pode fortalecer isto. Giddens oferece o caso do uso de vídeos e cassetes pelo Aiatolá Khomeini para propagar o seu caminho verdadeiro do Islã na época da Revolução Islâmica de 1979 no Irã.

A modernização reflexiva aumenta a consciência das pessoas da tradição neste sentido, numa época em que elas têm acesso às facilidades da modernidade. Mas ela também permite que o indivíduo enxergue além das formas tradicionais em suas formas originais ou reconstruídas. Giddens aponta para aquela que talvez seja a instituição social mais fundamental, a família, que através da história foi submetida a tendências sociais, das quais a globalização não é exceção. A modernização reflexiva é derivada de formas de comunicação global, e ela projeta o individualismo acima de tudo. Ela é tremendamente fortalecedora para o indivíduo. O individualismo, entretanto, define relações sociais em suas formas mais puras, e destrói formas mais idealizadas ligadas a princípios não-individualistas como lealdade, dever e responsabilidade. Estes requerem abstenção pessoal, enquanto o individualismo exige igualdade e diálogo. Na família contemporânea, parceiros abandonam o casal e filhos respondem aos pais.

Giddens vê o indivíduo fortalecido vivendo numa sociedade onde existe a capacidade do "poder popular". A década em que a palavra "globalização" passou a ser usada também é a década em que a democracia teve uma espécie de renascimento, e há aqui uma conexão. É mais difícil manter uma ditadura quando sua existência em relação a outras formas de governo fica transparente. O papel da televisão ganhou uma nova forma com o desenvolvimento de ligações por satélite, que são globais por natureza. A capacidade de gerar transmissões de televisão por satélite se tornou extremamente portátil, como os boletins de notícias que mostraram mísseis de cruzeiro atingindo Bagdá durante a Guerra do Golfo ilustraram dramaticamente. Giddens usa os exemplos do poder popular na antiga União Soviética, em seus Estados-satélite no leste europeu, e na África do Sul, onde a televisão por satélite teve um papel significativo. Como ele diz, o ambiente de informação envolve tanto os governantes quanto os governados. Quanto ao futuro, na era globalizada do "Estado indistinto", com suas fronteiras embaçadas de 
todas as formas, ele defende um futuro de democracia cosmopolita. Aqui ele continua a seguir a linha de pensamento de David Held [1987]. ao citar a União Europeia com seu Parlamento Europeu, numa forma fortalecida, como um modelo possível para as Nações Unidas com uma série de parlamentos regionais globais. Os EUA, a última superpotência remanescente, já tentam consistentemente passar seu papel de "polícia global" para a ONU.

Então, como uma palavra final, Giddens enxerga o futuro global como um jogo entre a sociedade civil fortalecida, a economia globalizada e novas formas imaginativas do Estado. Entretanto, tirando o colapso da União Soviética e a queda de outros sistemas ditatoriais, talvez o exemplo mais atraente de poder popular que vimos recentemente tenha sido a manifestação de Seattle contra a Organização Mundial do Comércio em 1999. O veterano esquerdista do Partido Trabalhista inglês, Tony Benn, numa entrevista de rádio para a $\mathrm{BBC}$, chegou ao ponto de descrevê-la como uma nova encarnação da classe trabalhadora do velho espírito do sindicalismo operário. Isto pode ser otimista demais, mas é irônico que um novo movimento de oposição "com crédito nas ruas" seja dirigido contra a mais tortuosa das instituições "Bretton Woods" das Nações Unidas. A discórdia de 1945 entre a Grã-Bretanha intervencionista e os EUA em prol do livre mercado foi de tal ponto que a "Organização Comercial Internacional" proposta nunca saiu do papel para assumir seu lugar ao lado do Banco Mundial e do FMI. Em vez disso, tivemos as rodadas do Acordo Geral de Tarifas e Comércio (GATT) que só emergiram como a Organização Mundial do Comércio nos anos 1990. O objetivo da manifestação de Seattle foi claramente uma mudança decisiva na economia global, que Keynes não conseguiu obter em 1945. A pergunta agora é o que a Terceira Via realmente promete.

\section{Bibliografia}

BRYANT, C. G. A. \& JARY, D. (eds.) [1991] Giddens' Theory of Structuration: A Critical Appreciation. London: Routledge.

FRANK, A. G. [1998] ReOrient: Global Economy in the Asian Age. Berkeley: University of California Press.

GIDDENS, A. [1981] A Contemporary Critique of Historical Materialism. London, Macmillan.

GIDDENS, A. [1984] The Constitution of Society. Cambridge: Polity. 
GIDDENS, A. [1985] The Nation State and Violence. Cambridge: Polity.

GIDDENS, A. [1990] The Consequences of Modernity. Cambridge: Polity.

GIDDENS, A. [1991] Modernity and Self-Identity. Cambridge: Polity.

GIDDENS, A. [1992] The Transformation of Intimacy. Cambridge: Polity.

GIDDENS, A. [1994] Beyond Left and Right. Cambridge: Polity.

GIDDENS, A. [1998] The Third Way. Cambridge: Polity.

GIDDENS, A. [2000a] Runaway World. Cambridge: Polity.

GIDDENS, A. [2000b] The Third Way and Its Critics. Cambridge: Polity.

HELD, D. [1987] Models of Democracy. Cambridge: Polity.

HELD, D. [1995] Democracy and Global Order: From the Modern State to Cosmopolitan Governance. Cambridge: Polity.

HELD, D., McGREW, A., GOLDBLATT, D. \& PERRATON, J. [1999] Global Transformations: Politics, Economics and Culture. Cambridge: Polity.

HIRST, P. \& THOMPSON, G. [1992] Globalization in Question. Cambridge: Polity.

OHMAE, K. [1985] Triad Power: The Coming Shape of Global Competition. New York: Free Press.

ROBERTSON, R. [1992] Globalization: Social Theory and Global Culture. London: Sage.

SEN, A. [1999] Development as Freedom. Oxford: Oxford University Press.

SOROS, G. [1987] The Alchemy of Finance: Reading the Mind of the Market. New York: Wiley.

SOROS, G. [1998] The Crisis of Global Capitalism: Open Society Endangered. London: Little Brown.

STRANGE, S. [1996] Casino Capitalism. Oxford: Blackwell. 